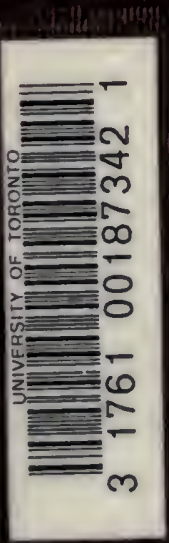




\section{Digitized by the Internet Archive}

in 2007 with funding from Microsoft Corporation 

READINGS IN RURAL SOCIOLOGY 


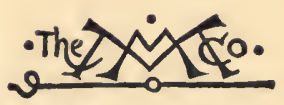

THE MACMILLAN COMPANY

NEW YORK - BOSTON - CHICAGO - DALLAS

ATLANTA - SAN FRANCISCO

MACMILLAN \& CO., LIMITED

LONDON - BOMBAY - CALCUTTA

MELBOURNE

THE MACMILLAN CO. OF CANADA, LTD.

TORONTO 
Professor of Rural Sociology and Director of Short Courses at Massachusetts Agricultural College

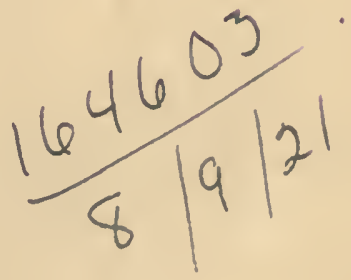

Jew 苗ork

THE MACMILLAN COMPANY

1920

All rights reserved 


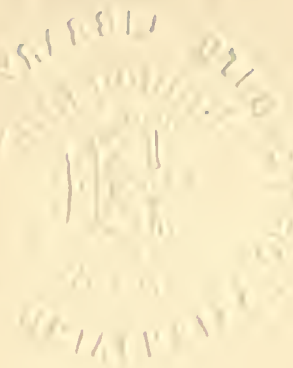

COPYRIGHT, 1920.

BY THE MACMILLAN COMPANY

Set up and electrotyped. Published September, s920. 


\section{PREFACE}

The rapid introduetion during the past ten years of eourses in rural sociology in universities, eolleges, normal sehools and other institutions engaged in the preparation of young men and women for the rural field has prepared the way for a book of readings in this subjeet that may be used as a text for an introduetory eourse.

Mueh of the material ineluded in this book has been used with eollege elasses in this institution and with elasses of teachers in normal sehools and in university summer eourses. In the seleetion of the material it has seemed best to draw upon the writings of men and women whose long experienee or professional standing entitles them to speak with some degree of authority.

I have assumed that an introduetory eourse in rural soeiology should endeavor: first, to develop a broad, sympathetie understanding of the real needs and aetual eonditions of farm and eommunity life in the United States; seeond, to lead students to appreciate the relationship between life and labor, wealth and welfare on the farm, sinee farming is not only an oeeupation but also a mode of life; third, to show as eoneretely as possible the unity of interest of rural and urban groups based on the faet that the farm supplies the eity not only with food but also with a large proportion of its population, thus making neeessary a sound rural life as the eondition for the development of a permanent industrial demoeraey; fourth, to interest students in taking an aetive part in the work of those ageneies that make for better eonditions on Ameriean farms and in Ameriean rural eommunition; fifth, to endeavor to prevent students from making that most eommon of all errors-the undervaluation of the farmer's own judgment of what is best for himself.

Grateful aeknowledgment is here made to the authors and publishers for their generous eontributions and unfailing eourtesy. Their names appear from page to page. My thanks are 
due to many eolleagues and friends for suggestions and eritieisms eoncerning the organization or seleetion of the material, and to President Kenyon L. Butterfield for his interest and eneouragement in its publieation. To my wife, Ida Densmore Phelan, I am indebted for assistance in the abridgement of seleetions, the reading of the proof and the preparation of the index.

Massachusetts Agrieultural College,

JOHN PHELIN.

Amherst, Massachusetts,

1920. 


\section{TABLE OF CON'TENTS}

\section{CHAPTER I}

Country Life in New England . . . . . . . . . . 1

Farm Life a Century Ago . . . . Ethel Stanwood Bolton . 1

Intemperance in Colonial Days . . Percy Wells Biduell . . 13

What Awaits Rural New England . Thomas Nixon Carver . 16

Facts New England Faces . . . Hampden County Improvement League . 20

Agriculture in New England . . . Kenyon L. Butterfield . 20

Bibliography . . . . . . . . . . . . . 25

\section{CHAPTER II}

The Development of Country Life in the West . . . . 27

The Middle West-The Fiber of the

People . . . . . . . . Edward Alsworth Ross . 27

The Significance of the Frontier in

American History . . . . Frederick Jackson Turner 29

The Spirit of the Pioneer . . . . Ray Stannard Baker . . 34

The Passing of the Frontier . . . James Bryce . . . . 35

The Great Southwest . . . . . Ray Stannard Baker . . 36

Life in the Corn Belt . . . . Thomas Nixon Carver . 38

Bibliography . . . . . . . . . . . . . . . 44

\section{CHAPTER III}

The Old Soutri and the New . . . . . . . . . 46

Social Conditions of the Old and the

New South . . . . . . Philip Alexander Bruce . 46

Our Carolina Highlanders . . . . E. C. Branson . . . 58

The Rural Negro and the South . . Booker T. Washington . 65

Following the Color Line . . . . Ray Stannard Balier . 69

Bibliograplyy . . . . . . . . . . . . . 72

CHAPTER IV

The Imimigrant in Agriculture . . . . . . . . 75

Immigration in Agriculture.$_{\text {vii }}^{.}$John Olsen . . . 75 
PACE

Why Immigrants Go to Cities . . Henry Pratt Fairchild . S6 Immigration as a Source of Farm

Laborers . . . . . . John Lee Coulter . . . 88

Bibliograply . • • • • • • • • • • • • • 93

\section{CHAPTER V}

Present Problejs of Country Life .

Wanted-A National Poliey in Agri-

culture . . . . . . . . Eugene Davenport . 95

Who Is the Farmer? . . . . . A. M. Simons . . . 110

The Point of View in Comparisons of

City and Country Conditions . . Kenyon L. Butterfield . 111

Soldier Settlements in Englisl-Speak-

ing Countries . . . . . . . Elwood Mead . . . 114

The Farmer in Relation to the Wel-

fare of the Whole Country . . . Theodore Roosevelt . . 116

Bibliography . . . . . . . . . . . . . . . 117

\section{CHAPTER VI}

SOMe ECONOMic INTERESTS :

A. COOPERATION

The Moral Basis of Coöperation . . Thomas Nixon Carver . 119

Farmers' Coöperative Exclranges . Alexander E. Cance. . 120

Social Effects of Coöperation in Europe . . . . . . . . C. O. Gill .

B. OWNERSHIP AND TENANCY

Tenant Farming . . . . . . Jolın M. Gillette. . . 137

Some Advantages of Tenancy . . W. O. Hedrick . . . 142

Agrarian Aristocracy and Population

Pressure . . . . . . . E. C. Hayes . . . . 145

C. ADULT LABOR

The Influence of Machinery on the

Economic and Social Conditions of

the Agricultural People . . . H.W. Quaintance . . 147

The Agricultural Element in the Pop-

ulation . . . . . . . . Eugene Merritt . . . 150

$\Lambda$ Point of View on the Labor ${ }^{\circ}$ Prob-

lem

L. H. Bailey .

D. CHILD LABOR

Rural Child Labor. . . . . . John M. Gillette . . 155

Colorado Beet Workers . . . Dr. E. N. Clopper . . 156 
PAGE

Strawberry Pickers of Maryland . . Harry H. Bremer . . 157

Children or Cotton . . . . . . Lewis H. Hine . . . 158

Bibliography . . . . . . . . . . . . . . . 160

\section{CHAPTER VII}

Mental and Moral Aspects of Rural Life . . . . . . . 162

Characteristies of the Farmer . . . James Bryce . . . . 162

The Influence of Farm Life on Child-

hood . . . . . . . . Charles W. Elliot . . 164

An Appreciation of Rural People . T. N. Carver . . . . 165

The Rural Environment and Great

Men . . . . . . . . W. J. Spillman . . . 168

Suggestion and City-Drift . . . Ernest R. Groves . . 172

The Mind of the Farmer . . . . Ernest R. Groves . . 175

The Need of Ideals in Rural Life . Kenyon L. Butterfield . 181

Bibliography . . . . . . . . . . . . . . 183

\section{CHAPTER VIII}

Rural Health-Physical and Mental . . . . . . . . 185

A. RURAL HEALTH-PIYSICAL

A Sociologist's Healtl l'rogram for the Rural Community . . . . L. L. Bernard . . . 185

City is Healthier for Children than the Country . . . . . . . Thomas D. Wood . . 193

Rural Sanitation: Definition, Field,

Principles, Methods, and Costs . W. S. Rankin, M.D. . . 197

B. RURAL HEALTH-MENTAL

Feeble-mindedness Defined . . . E. J. Emerick . . . 203 Fundamental Facts in Regard to

Feeble-mindedness . . . . Va. Board of Charities . 204

The Hill Folk . . . . . . Danielson and Davenport 206

The Extent of Feeble-mindedness in

Rural and Urban Communities in

New Hampshire . . . . . Report of the Children's

Commission . . . 213

Feeble-minded Citizens in Pennsylvania . . . . . . . . Dr. W. E. Key . . . 214

Amentia in Rural England . . A. F. Tredgold . . . 217

Urban and Rural Insanity . . U. S. Bureau of Census . 218

What is Practicable in the Way of

Prevention of Mental Defect . W. E. Fernald . . . 219

Bibliography . . . . . . . . . . . . . . . 223 
Rural Recreation, Drama, Art

Extract from the Will of Charles

Lounsbury . . . . . . . . . . . . . . 226

- The Need of Play in Rural Life . . IIenry S. Curtis . . . 226

Pliysical Education in Rural Selools . Laurence S. Hill . . 229

What the People Like . . . . Warren H. Wilson . . 235

The Farm Playground . . . . W. II. Jenkins . . . 236

Drama for Rural Communities . . Alfred G. Arvold . . 236

The Miracle Play at Pomfret, Con-

necticut . . . . . . . Ella M. Boult . . . 241

What the Pageant Can Do for the

Town . . . . . . . . George P. Baker . . 243

Rural Art . . . . . . . Frank A. Waugh . . 248

Bibliography . . . . . . . . . . . . 253

\section{CHAPTER $X$}

Communication and Transportation .

The Future of Good Roads in State and Nation . . . . . . Eduin A. Stevens . . 255

Mitigating Rural Isolation . . . John M. Gillette . . . 266

Social Significance of the Agricultural Press

$J$. Clyde Mlarquis . . 275

Social Value of the Telephone . . G. Walter Fislie . . . 280

Bibliography . . . . . . . . . . . . . 281

\section{CHAPTER XI}

Correctional Agriculture and Rural Police . . . . . . 283

A. CORRECTIONAL AGRICULTURE

The Outdoor Treatment of Crime . . IIarris R. Cooley . . . 283

Outdoor Work for Prisoners . . . Thomas J. Tynan . . 288

The Prison Farm . . . . . W. J. Homer. . . 289

Health on Prison Farms . . . W. O. Murray . . . 289

In the Healing Lap of Mother Eartlı . W. D. Lane . . . . 290

Farming as a Cure for the Insane . W. E. Taylor . . . . 295

Juvenile Delinquency in Rural New

York

Kate H. Claghorn . . 297

B. RURAL POLICE

Rural Police. . . . . . . C.R.Hendersoni . . 303

A Land of Law and Order . . . . Elmer E. Ferris . . . 306

Peunsylvania State Police . . . . Theodore Roosevelt . . 305

Canada's Royal Nortli-West Mounted

Police . . . . . . . . 1. D. Cameron . . 310

Bibliography . . . . . . . . . . . . . . 311 
A. THE HOME

Women on the Farms . . . . Herbert Quick . . . 313

An Open Letter to Secretary Houston Mary Doane Shelby . . 319

Women in Rural Life . . . . . Sir Horace Plunkett . 323

The Problem of the Changing Rural

Home . . . . . . . Georgia L. White . . 324

B. RÜRAL HOUSING

Rural Housing . . . . . . '. Elmer S. Forbes . . . 327

Overcrowding and Defective Housing Harvey Bashore . . . 329

Housing Conditions on Farms in New

York State . . . . . . . L. H. Bailey . . . .331

Bibliography . . . . . . . . . . . . . . 334

\section{CHAPTER XIII}

THE COUNTRY SćHOOL . . . . . . . . . . . 337

An Epigram . . . . . . . T. J. C'oales . . . . 337

The Status of the Rural School . . Ernest Burnham . . . 337

Rehabilitating the Rural School . . L. L. Bernard . . . 340

The County as a Unit of $\Lambda$ dministration . . . . . . . . .

The Change from $\Lambda$ mateur to Professional Teaching . . . . . H. W. Foght . . . . 347

The Rural High School . . . George H. Betts and Otis

E. Hall . . . . . 348

The Spread of the School Manse Idea George E. Vincent . . 351

Agriculture and the Curriculum . . Evelyn Dewey . . . 352

The Moonlight Schools of Kentucky . Cora Wilson Stewart . 356

A National Program for Edueation . Natl. Edn. Assn. . . . 363

The Consolidated School as a Com-

munity Center . . . . . . John H. Cook . . . 371

Bibliography . . . . . . . . . . . . . 374

\section{CHAPTER XIV}

Other Educational Agencies .

Edueation Through Farm Demonstra-

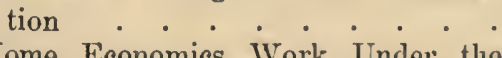

Home Economies Work Under the

Smith-Lever $\Lambda$ et .

Bradford Knapp .

Boys' and Girls' Contest Clubs . .

A. C. True . . . 389

L. II. Bailey • • . 391

The Rural Book Hunger . . . . M. S. Dudgeon . . 394 
The Community Fair . . . . . J. Sterling Moran . . 402

The Smitl-Huglies $\Lambda$ ct . . . . . . . , . . . . . 407

Bibliography . . . . . . . . . . . . . . 407

\section{CHAPTER $\mathrm{XV}$}

The Country Church . . . . . . . . . . . . . 411

Ten Years in a Country Church . . Matthew B. McNutt . . 411

Land Tenure and the Rural Churel . IIenry Wallace . . . 421

Rural Economy as a Factor in the

Success of the Church . . . . T. N. Carver . . . . 426

The Church Situation in Ohip . . C. O. Gill . . . .441

The Genoa Parish . . . . . . Rev. A. Ph. Kremer. . 435

Rural Work of the Y.M. C. A. . . A. E. Roberts and Henry

Israel . . . . 437

County Work of the Y. W. C. A. . . Jessie Field . . . . 440

Ten Years' Progress in County Y.M.

C. A. Work in Michigan . . . C. L. Rame . . . . 411

The Call of the Country Parish . . Kemyon L. Butterfield . 442

Sectarianism . . . . . . . Warrer H. Wilson . . 443

Report of Committee on Country

Church Function, Policy, and Pro-

gram . . . . . . . Kenyon L. Butterfield,

Miss Jessie Ficld,

Charles O. Gill,

Albert E. Roberts,

Henry Wallace. . . 444

Bibliography . . . . . . . . . . . . . 452

\section{CHAPTER XVI}

The Village . . . . . . . . . . . . . . . 455

The History of Village Improvement

in the United States . . . . W. II. Manning . . . 455

Social Privileges of Village or Simall

City . . . . . . . . C. J. Galpin . . . 464

The Town's Moral Plan . . . . II arlan P. Douglass . . 467

Civic Improvement in Village and

Country . . . . . . . . Frank A. Wangh . . . 471

Bibliography . . . . . . . . . . . . . . .476

\section{CHAPTER XVII}

The Survey . . . . . . . . . . . . . . . . 478

The Survey Idea in Country Life

Work . . . . . . . . L. H. Bailey . . . 478

Five Principles of Surveys . . . Paul U. Kellogg . . . 481 
A Method of Making a Social Survey of a Rural Community . . . . C. J. Galpin . . . . 484 , The Social Anatomy of an Agricultural Community . C. J. Galpin . . . . 490 Bibliography

\section{CHAPTER XVIII}

The Organization of Rural Interests

A. RURAL ORGANIZATION

Rural Organization . . . . . Kenyon L. Butterfield . 500

B. INTERNATIONAL ORGANIZATION

The International Institute of Agri-

culture . . . . . . . Official .

C. National ORGANiZATION

Work of the Office of Markets and Rural Organization . : : : C. J. Brand .

The Place of Government in Agricul-

tural Coöperation and Rural Or-

ganization . . . . . . . . . . . . 516

The County Farm Bureau . . . . L. R. Simons . . . . 518

Farmers' Clubs . . . . . . Kenyon L. Buitterfield . 536

Farmers' Social Organizations . . A. D. Wilson . . . . 541

D. VOLUNTARY ORGANIZATION

Declaration of Purposes of the $\mathrm{Pa}$ -

trons of Husbandry . . . . Preamble . . . . 552

E. POLITICAL ORGANIZATION

The National Non-Partisan League . . . . . . . . 557

F. COMMUNity ORGANization.

How to Organize a Community . . E. L.Morgan . . . . 567

Definition of a Rural Community . . C. W. Thompson . . 576

Bibliography . . . . . . . . . . . 576

\section{CHIAPTER XIX}

LEADERSHIP

Leadership or Personal Ascendency . Charles R. Cooley . . 581

Leadership . . . . . . . E. C. Hayes . . . 583

Rural Leadership . . . . . L. H. Bailey . . . 584

The Secret of Influence . . . . James Bryce . . . . 584

Training for Rural Leadership . . John M. Gillette . . . 585

The Sourees of Leadership . . . John R. Boardman . . 587

The Derelopment of Rural Leadership G. Walter Fiske . . . 589 
Seaman A. Knapp . . . . . Pub. U. S. Bur. of Ed. . 601 Henry Wallace . . . . . . Herbert Quick . . . 604 Bibliography. . . . . . . . . . . . . . . . 609

\section{CHAPTER XX}

The Field of Rural Sociology . . . . . . . . . 611 The Sociology of Rural Life . . . A. R. Mann . . . . 611 The Scope of Rural Sociology . John M. Gillette . . 615 The Teaching of Rural Sociology . . Dwight Sanderson . . 620 Definitions of Rural Sociology . . . . . . . . . 62.2 Bibliography . . . . . . . . . . . . . . $6_{2}^{\circ} 3$ 


\title{
READINGS IN RURAL SOCIOLOGY
}

\author{
CHAPTER I \\ COUNTRY LIFE IN NEW ENGLAND
}

FARM LIFE A CENTURY AGO ${ }^{1}$

ETHEL STANWOOD BOLTON

Is the old days, when methods of work about the house and farm were prized for their hoary antiquity rather than, as now, for their novelty, and all farmers did as their ancestors had done, there was hardly a man in the New England towns who was not engaged in the pleasant occupation of farming. The storekeeper and the miller plowed, harrowed, and cultivated in the intervals of their other work, and the minister himself hung up his gown after the last service on Sumday, and, like the rest of the community, worked his land on Monday morning. A century ago each town owned a farm, the use of which was allowed the minister, rent free, as a part of his salary.

The struggle in modern times is for the money to buy the neeessities of life; then there was less to buy, and cach man was dependent on his own exertions to get the necessities themselves from the soil or from the stock which he could afford to keep.

In those days, aside from the work which the miller or the itinerant cobbler performed, each farm was a nearly self-supporting entity, both for food and clothing. In modern times the great English artist, printer, and socialist, William Morris, founded a settlement whieh tried to be independent of the outside world, growing and making all its own neeessities and luxuries. The expcriment was 110 more of a success than Mr. Alcott's similar scheme at Fruitlands, in the town of Harvard.

1 Adapted from a paper read upon several occasions, privately printed. 
In our great-grandfathers' time, however, this was no experiment, eurious and interesting, but a fact to be reckoned with from day to day throughout their lives.

The village store sold the few luxuries of life-white and brown sugar, salt, West Indian goods, such as molasses and spices, and, most of all, New England rum.

Nearly every town boasted a foundry, where artieles were made by hand, which would be far berond the ability of our modern blacksmith. Here were made the plows and seythes, if the foundry was equipped with a trip hammer; shovels and hoes for outside work, nails for the earpenter, from the great iron spike to the shingle nail. The tools the carpenter used also eame from the hands of the local blacksmith. In many country towns, old garrets will yield great chiscls, primitive axes, and wrought iron bit-stocks, all made by hand and testifying to the excellenee of workmanship by their age and condition. The household utensils, too, were his work, the fire dogs, toasting racks, hobs, iron.kettles, skillets, and an endless array of less eommon things; and all this in addition to the shoeing of horses and oxen.

From 1799 to 1853, without a break, a good man of a Massachusetts town kept a line-a-day diary, and from that I am going to quote, from the four seasons of the year, to show the dull routine of work in which the lives of our grandfathers and great-grandfathers were passed; how it lacked the diversified interests which we consider necessary to our happiness to-day, and yet how little the unrest of modern times enters into any of its spirit.

Take these short sketehes of the life of James Parker, known as "Captain James," a young and newly married man in 1806:

"April 1st. I eut Hop-poles at the South End.

2nd. I wrought for Ivory Longley, cart wood. Mr. Edgarton Departed this life.

3d. Fast Day. I and Ruthy (his wife) went to $\mathrm{MI}$ : Harkness (his wife's father). James eame home with us.

4th. I and Ruthy went to the Funeral of Mr. Edgarton. Buryed in Mason order. The day was pleasant. A great collection of People. 
5th. I split staves, mortised posts. Ruthy went to Groton.

6th. I and Ruthy went to meeting $1 / 2$ the day $1 / 2$ went to funeral of Joel Willard's Child that was drowneded.

7th. I made a Curb to the well. Went to town Meeting.

8th. I partly made a yoak and it stormed."

Later on, in the summer, his work changed, and was that of a tiller of the soil about his business:

“July 28th. I mow'd 1/2 the day, 1/2 plow'd hops. Abner mow'd all day.

29th. I plow'd and how'd hops $1 / 2$ the day. I went and plow'd Abner's Corn. Abner helpt me 1/2 the day.

30th. I sow'd some turnips, it rain'd. I went to Davids (his brother).

31st. I helpt Father plow with my oxen and Vene helpt Drive.

August 1st. I was haying. Abner helpt me $1 / 2$ the day. I carted my $\mathrm{N}$ to Capt. Edgarton's.

2nd. I was plowing my stubble, it rain'd and Clowdy. 3. I went to mecting. Esq. Tom (the minister's son) red the Discourse.

And so it is a eonstant reitcration of plowing, mowing, raking, hoeing, all done by hand or with the slow-paced oxen. How many lessons in patience the farmer learned in those days, and what a dignified ease there was about it all! There were no complaints when the hay was all eut and the weather turned bad, but a calm acceptance. In October preparations for the winter were being made.

"Oetober 1 I began to draw and hew the timber for my hogpen.

2nd. I drew and hew'd timber for the same $\Lambda$ bner helpt me. 
3rd. I hew'd timber, Abwer helpt me. I dug some potatoes.

4th. I kiled my Bull. Abner helpt me.

5th. I and Ruthy went to meeting $1 / 2$ went to Mr. Harkness's.

6th. I helpt my father $1 / 2$ the day made cider at Capt. Hazen's. 1/2 dug Potatoes at the Pond.

7th. I and Ruthy went to Laneaster. I went to muster."

A little later, after frost had set in, more animals were killed - cattle, sheep, and pigs-and frozen. The ereatures were hung whole in the attie or in some eonvenient shed, and represented the winter's supply. Apples were dried or turned into eider, for few were kept in barrels for the winter's use, as we now keep them.

Most towns had eider mills in which the neighbors had rights. The mills were usually stone-walled and sometimes were cut into a hillside, like a cellar open in front. Inside was the great press, whieh was worked by a horse going round and round, harnessed to a great bar overhead. The size of the press is evidenee of the universal use of eider.

There is one note which is dominant throughout the diary, and that is one of mutual helpfulness. When haying time came, it was not each man for himself, but all the men of a small neighborhood worked together, and harvested the hay from each farm until it was all well housed. Even then the harvest was slow in eomparison with what our modern machinery will aecomplish. If any were in trouble, help was immediate and praetieal. If a man were siek and the burden fell on the woman alone, the eattle were tended and the work done by the neighbors.

Throughout Deeember Captain Parker sledded wood for himself and for others with his pair of oxen, and doubtless got some of the ready money which all men like to have. One entry on Christmas Day, less than ten years later, shows how muel our forefathers laeked appreciation of the joys of a holiday. Captain James writes: 
"December 25th. I helpt clean the sehool-house. The sehool kept $1 / 2$ the day."

There was one great industry which brought mueh money to New England towns for many years; that was hop growing. Disease and eompetition from more Western States finally put an end to one of the great money-making employments of the New England farm of those days. In the middle of one Massaehusetts town there ean still be seen a field plowed and hilled for the hops that were never planted. Why they were not, no one ean tell now, but there the furrows are, in the midst of a great wood, with sixty-year-old pine trees reaching far over your heads, growing in that forsaken field. On many of the farms one ean see the old hop kilns in a more or less advaneed state of ruin adding their pieturesque touch to the landseape.

A hundred years ago the voeation of a husbandman or farmer was as truly a trade to be learned as that of eobler, miller, blacksmith, or the rest. So young boys were apprenticed to this trade, as to the others. This eustom, also, in large measure, solved the problem of help for the farmers of that day. The low wages paid these apprentices for their services gives some explanation of the reasons for the aequisition of a comfortable living by many farmers.

Among the Parker papers in Shirley I found an indenture of about one hundred years ago, which gives a vivid picture of the duties of the apprentice and his master. The father's eaution in demanding edueation "if the said apprentice is eapable to learn," shows how meager the learning was in those days among the poorer elasses.

"This Indenture Witnesseth, that David Atherton of Shirley in the County of Middlesex and Commonwealth of Massaehusetts, Yeoman, hath put and plaeed and by these presents doth put and bind out his son David Atherton Jun -and the said David Atherton Jun doth hereby put, place and bind out himself as an Apprentice to James Parker Escl ${ }^{r}$ of Shirley in the County and Commonwealth aforesaid to learn the art or trade of an husbandman; the said David Atherton Jun ${ }^{r}$ after the mamner of an Apprentiee to dwell with and serve the said James Parker Esq from the day of the date 
hereof untill the eighth of January one thousand, eight hundred and twenty four, at which time the said apprentice if he should be living will be twenty one years of age. During which time or term the said apprentiee his said master well and faithfully shall serve, his seerets keep, and his lawful eommands everywhere at all times readily obey, he shall do no damage to his said master, nor wilfully suffer any to be done by others, and if any to his knowledge be intended, he shall give his master seasonable notice thereof. He shall not waste the goods of his said master, nor lend them unlawfully to any; at eards, diee or any unlawful game he shall not play, fornieation he shall not eommit, nor matrimony eontraet during the said term; taverus, ale-houses or plaees of gaming he shall not haunt or frequent; from the service of his said master he shall not absent himself, but in all things and at all times he shall earry himself and beliave as a good and faithful Apprentice ought, during the whoie time or term aforesaid-and the said James Parker Esq ${ }^{5}$ on his part doth hereby promise, eovenant and agree to teacl and instruet the said apprentice or eause him to be instrueted in the art or trade of husbandman by the best way and means he ean, and also to teach and instruct the said apprentice or eause him to be taught and instrueted to read and write and eypher to the Rule of Three if said apprentice is capable to learn and shall faithfully find and provide for the said apprentice good and suffieient meat, drink, elothing, lodging and other neessaries fit and eonvenient for such an apprentice during the term aforesaid, and at the Expiration thereof shall give unto the said apprentice two good suits of wearing apparel, one for Lord's Day and the other for working days and also Eighty Dollars in good eurant money of this Commonwealth at the end of said term. In testimony whereof the said parties have hereunto interehangeably set their hands and seals this sixteenth day of Oetober in the year of our Lord one thousand eight hundred and twenty."

The food of our forefathers has always had a eertain enchantment. Who ean read of the ehicken roasting on the spit before the open fire without wanting a taste; or who ean listen to tales of one's grandmother of the great baking of those days without a feeling of longing? In hunting over dry deeds in the Court House in Cambridge, I eame across one which interested me very 
much, as it gave an enlightening touch to the question which to all housekeepers is a most vivid one-the food problem.

In 1823, Hezekiah Patterson, who lived in the eastern part of Shirley, being old and tired of the responsibility of farming, sold his forty-eight acres of land and his house to Thomas Hazen Clark, in exchange for the support of himself and his wife, Jane, for the rest of their lives. They reserved room enough for their horse and its hay in the barn, and room enough in the house for themselves, and then gave an itemized account of what they called "support" for one year.

" 6 bushels of rye

6 bushels of indian Corn

1 bbl. white flour

200 lbs. Shoat pork

100 lbs. beef.

$1 / 2$ quintal of Cod-fish

60 lbs. of butter

$60 \mathrm{lbs}$. of eheese

2 lbs. of SouChong tea

2 lbs. chocolate

$1 \mathrm{lb}$. Coffec

5 lbs. loaf sugar

30 lbs. of brown sugar

10 gals. New England Rum

1 gal. West Indian Rum

6 gal. Molasses

2 bushels of Salt

$1 / 2$ bushel of white beans

15 bushels potatoes

$1 / 2$ of all the eider and enough wood for the fire."

This yearly menu hardly suggests variety, but it was at least sweet and substantial.

While the men worked in the fields and tended the eattle, the women had their many duties, too. Their energies were demanded for so many things that a housekeeper in those days need be an expert along many lines. Men in those days ate simple things, and simple eooking, like very simple elothes, must 
be so much the better intrinsieally. The food that is simple must be well seasoned or well eooked to tempt, while a eomplieated dish disguises its poor cooking by its'high seasoning, as a badly eut dress may be made to look well by its many furbelows. Baking in a briek oven was an art. The oven was filled with wood, lighted and burned out, making the bricks of the right degree of heat. Then the oven must be eleaned. At the farthest end were put the beans, followed by the brown bread, Indian pudding, white bread, pies, and cake. They were allowed to stay, and were taken out in the reverse order from that in which I have named them. All other eooking must be done over the eoals of a great wood fire, or in a tin kitehen plaeed on the hearth. We may imagine that the table serviee in a eountry farmhouse was not complieated. It was etiquette to eat with the knife, as forks had not eome into use. Pewter and old blue iron ware abounded; eopper, also, was mueh used, and must have added color to the kitchen. After the inner man was satisfied, the wife must still elothe her husband, herself, and her ehildren. Cloth eould, of course, be bought, but as a rule was far too expensive for anything but a farmer's very best. Homespun was the general wear, and to make homespun the wool had to be taken from their own sheep oftentimes to make their elothes, and all the proeess after the shearing and washing fell to the woman's share. I believe that there were itinerant tailoresses later on, but of eourse only the well-to-do could afford sueh luxuries. The flax, too, had to be spun and woven. Many houses throughout the eountry still show the old loom room, where the loom stood for generations. Many parts of old looms ean still be found, reeds, shuttles, needles, and heddles.

Stoekings had to be knit and many endless tasks performed to keep the family warm arid dry. Often the man of the family did part of the eobbling of his ehildren's shoes and his own.

Candles must be made for light, and eandle dipping was a hard and dirty task. It took skill to make them round and even. Later molds came in fashion and made the task easier and less dirty. Soap had to be made for the family use. These were tasks in addition to the ordinary sweeping, eooking, and housework whieh every louse demands. Floors were serubbed 
with soap and sand until they were white-and they were kept so by the thrifty housekeeper.

Nearly every town had a man whose oeeupation must have been pieturesque-the hatter-who made those enormous beaver hats that looked almost like fur, that men wore years ago. It took him a long time to make a hat, and when it was done the owner wore it proportionately long.

We New Englanders are all familiar with the eostumes of a hundred years ago. The Shakers still wear them when they dress in their uniform. When Mother Ann Lee founded the order, about 1793, the elothes as you see them now were the ordinary elothes in vogue then. They have never ehanged the style, unless of late years some of them have grown more worldly and have adopted modern dress. And now, after a hundred years of disuse, the stylish eloak of a former eentury is again in demand.

And when all the work was done, they gathered around the great fireplaee, in the eandle-light. The light, even until kerosene eame to be used, was very poor, and in those days one read with the paper or book in one hand and the eandle in the other, so that it might be moved baek and forth before the print. The pieture that one has is the eoziest in the world, but eontemporaries tell us that the reality was often far from the ideal. The great ehimneys, with their huge fires, ereated a draught which brought the outer eold into the room, and fires really warmed but a small area. Yet here, around this kitehen fire, eentered all the life of the home, all its eomfort and its homeliness.

Life was not all a grind to these good people, for they had their soeial gatherings, and varied ones, too. First and foremost stood the ehureh with its serviees, the soeial eenter of the town. But when we remember that eountry towns were nearly isolated from the outer world; that the only travel was by the slow method of stage-eoaeh or private earriage, and was seldom indulged in; it seems natural that the people should have turned to the ehureh, where all were weleome-in faet, where all must go, or be labored with by the minister and deacons. So it eame to pass that this was the one thing in which all were interested, in whieh all had a share. When we remember, too, how large a part religion played in the minds and hearts of our aneestors, 
it is inevitable that the ehureh should stand as the most important and the unifying factor of their lives.

On Sundays nearly every one went to meeting and stayed all day. No one eooked on Sunday, and all the food for that day was cold. The women were expected to go to church all day, as well as the men, so that the Saturday baking, whieh tradition still holds many a modern household to regard, was then a matter of urgent need as well as a matter of eonscienee. The man who had relatives living near the ehureh, or who lived near by, was indeed lueky, because a warm fire at noon might then bc his. Otherwise the dinner was earried and eaten in the church in winter, or outside in summer. How many of us would submit to the diseomfort of sitting all day in an unheated building, regaling ourselves at noon with cold food, with the thermometer many times in the neighborhood of zero? Yet duty led them and personal comfort did not enter into their eonsideration. We may hope that the dish of gossip, taken with their dinner, compensated for much whieh might otherwise have been unbearable. Perhaps this human companionship softencd the denunciations and threats of the two sermons. The church, aside from its spiritual teaehings, furnished a place in which all the town met onee a weck. It was more or less political in a broader sense, for there matters of national politics, state politics, and even those of loeal importance were discussed by the ministcr. As he was the best edueated man, his opinion and its expression very often formed that of the majority of those of the other men in town.

In the chureh, also, were held the town meetings, with their serious and sometimes humorous debates, which furnished a means of growth and expression to others. It was this training which enabled the colonies to withstand the mother country. Men had learned to think in a logical way, and to express their thoughts. They were keen to find the weak plaees in an argument and to seareh out sophistrics. When England attempted to cheat their sense of justiee, she found a eommunity made up of citizens, not of peasants.

The town was divided into districts; the center of each was the school. Each district met and decided its own edueational problems as best suited it; each engaged its own teachers, and 
disbursed its own share of the sehool appropriations. Bitter and often sanguinary were the fights over this important question; many and hard were the debates as to whether it should be a "writing sehool" or a "reading sehool," and how they could make their share of the funds hold out.

These distriets also took eare of their own roads, and most men, rather than pay their taxes in eash, "worked out" their taxes on the roads. So far as one ean gather from the reeords the roads were treated a good deal like a plowed field, and must have been exeeedingly poor. They were plowed every spring and heaped up into the middle, with the intention of making a watershed.

The roads were a eonstant annoyanee at all seasons-mud spring and fall, dust in the summer, and drifting snow in winter. Complaint was made in a nearby town that a eertain man named Hildreth had put his stone wall so far into the road that the drifting snow made it impassable. The road eommissioner warned Hildreth to remove the wall, whieh he refused to do. So the wall was moved baek by those working on the road. Hildreth tore it down in the night and rebuilt it on the former site. The wall was torn down again by the road eommissioner, and replaeed where it belonged. It was then guarded by men until the town met and voted that Hildreth leave his wall where it should be, and write a letter of apology to the eommissioner. All this Hildretl did with a bad graee.

A domestic amusement was a house or barn raising. To this about every one in the town went, the men to do the aetual raising, the women and girls to prepare and serve the feast whieh followed. Their hospitality was generally lavish. To one who has never partaken of the delights which ean be baked in a briek oven, the tales of those so blessed seem more or less like those of the "Arabian Nights." A halo, formed of the reminiscenees of gay good times and the appetite of youth, is put around these pleasures of a bygone day, making them shine with a preternatural light. And at these raisings, besides the baking and the roast meats, was there not cider and Medford rum to make glad the heart of man?

Fumerals and weddings were also legitimate soeial times, the former to afford the luxury of woe, the latter of unalloyed joy. 
Then there were the kitchen danees in the winter, and each man took his turn at entertaining, and showed with pride the good things that his wife eould make. The good times, as we look back upon them, seem so simple and wholesome, they were entered into with sueh a spirit of enthusiasin and expectaney, that it makes one wish tliat one eould now have so whole-hearted a good time from so little. It seems almost as if the hard work and drudgery of daily life gave a fine zest to their amusements.

Later on the Lyecum came to try the sinews of men in debate, came to prove the literary ability of their wives and daughters. They debated on everything under the sun-huge philosophieal subjects jostled trivialities; questions of morals, religion, and polities followed diseussions of farming and eattle raising. The reeords of such a Lyeeum lie before me. The members began their work by this debate, "Resolved, that a seolding wife is a greater evil than a smoking house." They decided in the affirmative, and then passed to this, "Resolved, that the old man in the story in Webster's spelling book was justified in throwing stones at the boy." They next discussed the morality of giving prizes in the schools. Exeitement often waxed high, and personalities were dealt in, but the end of the evening brought ealm. It was devoted to the literary efforts of the women of the Iyeeum. These consisted of recitations, readings, and original essays.

So our fathers on the farm varied their hard work with fun in much smaller quantities than we enjoy to-day. But in those days the actual struggle was less; a man toiled for his daily bread itself with no competitors but the soil, the weather, and his own temperament. Now a man works at his specialty to outdo his eompetitors, to get his goods to the market quieker and in better condition, to sell that he may buy, not to grow and tend that he may eat and be warm.

Through all their life there is a note of eontentment, and I think that deep in the heart of most modern farmers that same note eould be struck. For after all is said, the actnal ownership of a large pieec of mother earth is a continual souree of peaee; and the freedom from the oversight and eommands of otliers, to be at no man's beek and eall, lends a dignity to the farmer, and enhanees his self-respect, until he feels himself and is the equal of any in the land. 
A rhyme on an old English piteher shows that this feeling has been through many, many years the underlying one of the AngloSaxon farmers :

Let the mighty and great

Roll in splendor and state,

I envy them not, I deelare it.

I eat my own lamb,

My own chicken and ham,

I shear my own sheep and wear it.

I have lawns, I have bowers,

I have fruits, I have flowers,

The lark is my morning charmer;

So you jolly dogs now,

Here's God bless the plow-

Long life and eontent to the farmer.

\section{INTEMPERANCE IN COLONIAL DAYS ${ }^{1}$}

\section{PERCY WELLS BIDWELL}

"THe intemperanec of the colonial period," says Charles Franeis Adams, "is a thing now diffieult to realize; and it secms to have pervaded all elasses from the elergy to the pauper." We have already remarked the large consumption of eider in the farmers' families and have commented upon the importanee of the retail sale of stronger liquors in the business of the country stores and taverns. Every important occasion in home or church life, every rural festivity was utilized as an opportunity for generous indulgenee in intoxicants. Neitler the haying-scason in early summer, nor the hog-killing season at the end of autumn could be successfully managed without the aid of liberal potations of "black-strap" and "stone-wall." Husking bees, houseraisings, training days, and even christenings, burials and or-

1 Adapted from "Rural Economy in New Eugland at the 13egiming of the Nineteenth Century." Publication of the Comnecticut Academy of Social Science, 1916, pp. 374-77. 
dinations were often disgraeed by the drunkenness of partieipants.

The craving for stimulants with its disastrous results on the fortunes of individuals and on the general moral tone of the community proceeded partly from the eoarse and unvaried diet of the farming population, and probably to a larger extent, from a desire to relieve at least temporarily the dreary monotony of village life. There are always two opposing views eurrent among the older generation eoneerning the relative virtues of their early days as compared with the conditions which they see about them in their deelining years. Some look baek to a sort of Golden Age and view all the features of the past through rose-eolored speetaeles. Others with a more optimistie frame of mind are quite willing to admit that the passage of the years has brought improvement along many lines and do not hesitate to glory in the progress that has been achieved under their eyes during a long life.

There are probably elements of truth in both views, but as far as the general features of social life are eoneerned and their effeet in stimulating or in depressing the individual, the latter view seems to be more in aeeord with the facts as we know them.

The Rev. Mr. Storrs, in reviewing a pastorate of fifty years in the town of Braintree, Mass., said: "And when it is remembered that fifty years ago, and for many after years, no post office blessed the town, nor public eonveyanee for letters, papers, or persons, was to be had, even seini-weekly, except through villages two miles distant; that but for the oeeasional rumbling of a buteher's cart, or a tradesman's wagon, the fall of the hammer on the lap-stone, or the eall of the plowman to his refractory team, our streets had well nigh rivaled the graveyard in silenee, it ean scareely surprise one, that our knowledge of the outer world was imperfeet, nor that general intelligenee and enterprise was held at a diseount; and if powder, kettle drums, and eonehshells, proelaimed the eelebration of a wedding; or if wine, and spirits more dangerous than any from the vasty deep, were imbibed at funerals to quiet the nerves and move the laehrymals of attendants; or if rowdyism and fisticuffs triumphed over law and order on town meeting, muster and eleetion days, . . . it was but the legitimate overflow of eombined ignorance and heaven- 
daring recklessness. Those days are passed and shame throws its thick mantle over them."

An isolated community always tends toward social degeneration, and the drunkenness, rowdyism, and general coarseness of manners of the inland towns at this time were but premonitions of the more disastrous results which might be expected from economic and social stagnation. At no time in these communities was there a distinct criminal class, of the type now technically known as degencrate; but petty crimes, stealing, assaults and disturbances were of frequent oceurrence. There are many indications that the influence of the church was decadent. Up to the beginning of the nincteenth century, the ecclesiastical organization had secured, by means of a censorship of the private life of its members so inquisitorial as to seem nowadays intolerable, fairly submissive adherence to a rigid code of morality. With the deeline in the authority of the ehurch in matters of doctrine came also a weakening in its control over the conduct of its adherents.

Another eause of laxity in morals, of probably greater importanee, was the general spirit of lawlessness spreading over the country after the Revolution, which seems especially to have affected the country districts. The soldiers returning from the war found it hard to settle down and get their living honestly in the previous humdrum routine. They brought back with them new and often vicious habits which the rest of the eommunity imitated. Then, in the interval between the overturn of the regularly eonstituted colonial authorities and the establishment of the national government under the new federal constitution, there was a period of semi-anarchy, when obedience to any sort of law was difficult to enforce. The disrespect for authority in both ehurch and statc which arose from these conditions could not fail to have a distinctly bad influence on the moral eonditions in inland towns. In the disturbanees of those days the inland farmer was generally to be found on the side of rebellion, and active in opposing a reëstablishment of law and order.

Too much emphasis must not be laid upon the dark features of the community life of these times. Undoubtedly there were mally advantages arising from the homogeneous eonstruction of soeicty, from the uniformity of the inhabitants in race, religion 
and manners and from the absence of class distinctions based on difierences in wealth. The inland villages were by no means entirely lacking the opportunities for helpful and stimulating soeial intereourse; but it was from the home rather than from the community life that the principal virtues of the agricultural population, of which their descendants have been so justly proud, were chicfly derived.

\section{WIIAT AWAITS RURAL NEW ENGLAND ${ }^{1}$}

\section{THOMAS NIXON CARVER}

Mr most salient impression was that agriculture as an independent industry able in itself to maintain a community does not exist in the hilly parts of New England. Outside of such exceptionally fertile sections as the Conncetieut Valley, the farmers engage in such occupations as lumbering and keeping summer-boarders, often carrying on farming merely to supply their own tables with vegetables and their horses and cows with forage. I found few farmers who eould sceure sufficient revenue even from sales of hay and milk, the most profitable of New England farm products.

These facts, however, do not indieate a deeline in agriculture. Farming never was a sclf-sufficing industry in New England. In the days of so-called prosperity domestic manufactures were carried on in farm-houses. The transfer of manufacturing from the farms to the towns accounts as much for the decline of rural prosperity as anything else-the rise of agriculture in the West, for example. Morcover, the development of farming, dairying, and market gardening near the eitics offsets the deeline in the remote districts.

Now, domestie manufactures ean never be revived in New England, though an attempt is being made to revive them at Deerfield, Mass. Summer boarders cannot support the whole country, nor can lumbering. But, why should not northern New England become a great stock-raising country? The land has become so eheap, and the grazing lands of the far West have

1 Adapted from World's Tork, 9; 5748-52, Jan., 1905. 
beeome relatively so dear, that New England offers advantages to sheep-and eattle-breeders. One aere of New Hampshire hillside pasture is worth three acres of grazing lands of western Kansas, Colorado or Montana. There is plenty of water, so that one western problem does not exist. Fifty men with whom I talked on my journey agreed that New England is a good eattle country, but no one knew why more eattle are not raised. I believe that the two ehicf obstacles are: first, the diffieulties of providing winter forage, and, second, the small size of the average farm.

When a man owns a farm of from fifty to one hundred acres, he must plow some of it if he expects to make a living from it, but plowing these steep and roeky hillsides is ruinous, for the rains wash away more fertility than the erops extraet. But no farmers' family can live from the produee of so small a farm if it is used only for pasturing. If the farms ran from 400 to 600 acres each, enough stock eould be pastured on each one to support in eomfort the average farmer's family. There would still remain, however, the question of winter forage, for these lillsides can not even produce hay to advantage - that is, hay-making machinery ean not be used. Profitable stoek-raising on a farm of this kind would therefore be limited by the amount of level land, relatively free from stones, upon which hay-making machinery could be used.

But there is another possibility. In Europe, wherever stoekbreeding has developed on a large seale, eattle are driven from the hills to the valleys in the fall and from the valleys to the hills in the spring. The owners of pasture lands in the hills and mountains buy their stock in the spring, pasture them during the summers, and sell them in the fall to the feeders in the valleys; or the feeders in the valleys drive their stoek in the spring to the hills and mountains for summer pasturage and bring them back in the fall to be wintered on the forage grown on the valley land. The next fifty years may see the development of a eonsiderable industry of this kind in New England. Some experiments are already being made. Mr. J. W. Clark, of Wilmot, N. II., was formerly a sheep-rancher in Montana. He recently sold his interests there and returned to New Hampshire to start a sheep-raneh. He has aequired about one thousand aeres of the 
ordinary rocky, lillside pasture land, which, he holds, is much more productive than the Montana land, and about as cheap.

Almost universally, the prosperity of western agriculture and the poverty of New England farming are explained by the difference in the fertility of the soil. Yet this difference is offset in part by the better markets in the East. If a western farmer should try to make a living at ordinary staple farming on so small a farm as the average one in New England, using the primitive New England methods, he would have as hard a time as the New England farmer to make a living. On the other hand, if the New Englander would use as much land as the western farmer, and have modern labor-saving machinery, he would probably be able to make as good a living. A young unan wishing to start out as a farmer would do better to invest in New England land than in western land. A good Iowa farm will cost from $\$ 75$ to $\$ 100$ an acre; good New England pasture land from $\$ 10$ to $\$ 25$ an acre.

New England writers on agriculture have made the mistake of looking to Europe ratler than to the West for their models. They have held up as examples to the New England farmers European peasants who cultivate a few acres to a high degree of intensity to yield larger crops per acre. But they forget that these mean small erops per man. Where labor is cheap and land dear, as in the Netherlands or in the valley of the Po, it is economical to raise crops with much labor and little land. In the United States, where land is cheap and labor dear, the opposite method is better. And it is to be hoped that conditions will never arise in the United States where labor is so cheap and land correspondingly so dear, as in densely populated Europe. Since the price of labor in New England conforms pretty closely to the price in the West, and general social conditions are much the same, prosperous parts of the West ought to be the New England models rather than Europe. With this idea in view, the managers of New England agricultural colleges have begun to draw on the West for teachers.

The nearness of castern markets, too, is a very appreciable advantage to New England. On the railroads covering the section, run the milk-trains which enter Boston every morning. The farmers along any of these railroads deliver cans of milk 
at the nearest station every morning, and receive the cans there again in the evening, receiving from twenty to thirty eents for each eight-and-one-half-quart ean, though Boston consumers pay a considerable advanee on that priee. A western farmer who could seeure such a priee would regard himself as opulent. Again, Boston is one of the best apple markets in the country, but the market is supplied largely from New York and Miehigan. Yet New England is an excellent apple country. Every year seedling apple-trees grow without planting and flourish without care. Even where grafting is done, it has been the custom to graft only such trees as eome up themselves along old stone walls and other such places. Apple-growing, then, is a New England possibility.

In the Connectieut River Valley, where extensive cultivation is possible, the agrieultural prospeets are very hopeful. I saw many fields of eorn which would astonish a Kansas farmer. The eensus returns show a larger yield of eorn per aere in New England than in a great part of the Corn Belt itself. It is grown, however, in small fields highly fertilized and intensively cultivated, whereas the western farmer never'even hoes his corn, yet he grows the largest crop per man in the world.

On the whole there is every reason to believe that the decline in New England agrieulture is at an end. With the praetical exhaustion of free publie land in the far West, the rise in the price of land in the middle West, and the development of cities for their markets, the consequent rise in the priee of agricultural products will give a value to New England farms which they have not had for many years. It is to be hoped, however, that the proeess of "abandoning farms" will continue, if this simply means that several small farms are to be used in one fair-sized farm upon which the farmer ean economically use superior draft animals and labor-saving machines; for New England methods of agriculture are fifty years behind the times. 


\section{FACTS NEW ENGLAND FACES ${ }^{1}$}

From 1860 to 1910,828 New England towns lost in population 337,086 .

From 1860 to 1910, New England's improved farm lands under eultivation decreased from $12,215,771$ to $7,112,698$ acres, a loss of 42 per cent.

From 1860 to 1909, New England wage-earners increased from 391,836 to $1,101,290$, a gain of 359 per cent.

From 1860 to 1909 New England's popukation inereased from $3,110,572$ to $6,552,681$.

New England is now producing less than 25 per cent. of her food supplies, the other 75 per eent. and over coming from without her borders.

\section{AGRICULTURE IN NEW ENGLAND ${ }^{2}$}

\section{KENYON L. BUTTERFIELD}

New England as a whole is distinetively an urban region. While northern New England, comprising Maine, New Hampshire, and Vermont, has few large eities, populous southern New England, which includes Massachusetts, Rhode Island and Conneetieut, is dominantly urban. For example, the pereentage of rural population in Massachusetts is less than ten. Metropolitan Boston, an urban eenter of perhaps 1,250,000 people, is the great eonsuming center of the region, and it is supplemented by a large group of important residenee and manufacturing eities of lesser size not far away from this eenter, as well as seattered all over New England. At least 5,000,000 of the 6,000,000 people in New England are eonsumers rather than producers of food.

New England grows only a fraction of its food supply. Aeeurate figures are not available, but it has been estimated that probably this region has to purehase at least seventy-five per eent. of its food supply from ontside its borders. Furthermore,

1 Adapted from "Real Preparedness at its Vital Point-The Food Supply." Publislied by Hampden County Improvement League, Springfield, Mass.

2 Adapted from Breeder's Gazette, 72: 1154, December, 1917. - Chieago. 
New England never will grow all its food. Wheat does well enough in New England, but it does not pay to grow it. New England's bread will always be dependent upon outside sources for the supply of flour. Unquestionably the supply of New England-grown meat can be profitably very greatly increased, partieularly pork, mutton, and fish. It is quite eoneeivable that New England will in time supply a very large proportion of these meats from within its own borders. The beef supply ean also be inereased, but it is doubtful whether any large pereentage of the eonsumptive demand will ever be grown in New England.

It seems reasonable to expeet that New England may grow a large share of eertain other items among its food needs. It is an ideal region for both orchard and small fruits, and the same is true of. most vegetables. Apparently it will be possible, at least from the standpoint of production, for New England to take eare of itself in these respeets. The same is true of poultry and eggs. The most serious diffieulty in New England agrieulture is eonneeted with the supply of market milk; we ean hardly expect New England to supply its own butter and eheese. New England has excellent meadow lands, probably none better in Ameriea. Corn does extremely fvell in the valleys, with good yields of both stalk and ear. There is an abundanee of natural grazing on the hills. It would seem as if New England should be an ideal dairying region. Yet the dairy business for twenty years has been, to an inereasing degree, preearious. The zone of market milk supply for the Boston area, for example, has been pushed eonstantly farther away fl:om the eity, so that the largest proportion of the supply eomes from a distanee of more than seventy-five miles. Some milk is sent to Boston from eastern New York, and before the war a eonsiderable quantity was imported from Canada.

The low priee of milk to producers has not met the inereasing cost of such grain as apparently eannot be easily grown in New England, nor the high wages for labor, due to the eompetition of urban industries for the labor supply. The highly eentralized methods of milk distributors in some plaees, and the completely disorganized condition in others, as well as the popnlar idea that milk is drink and not a food, have also contributed to make the situation extremely diffieult for dairymen. 
The dairyman himself must lave some share in the blame for the situation. There has been very little attempt among the smaller dairymen to improve their herds, or in other way's to reduce production costs for a superior grade of milk. The number of dairy cows is decreasing, dairymen are going out of business, and at present there is no apparent relief in sight, execpt that under war conditions the price of milk lias gone up rapidly, as it lias in other parts of the country. But the emergency situation is too uncertain to warrant predicting anything for the future.

This brief survey of the agricultural situation perhaps better than anything else indicates the probable future of New England agriculture after the war, the one factor most uncertain being the great market milk industry.

Some of the hopeful considerations may here be mentioned. There is more to New England agriculture than most people suppose. If a comparison be made between New England agriculture as a unit and that of, say, an average agricultural statc of substantially similar area (about 65,000 square miles), I am confident from some study of statisties that New England would not suffer in comparison, if such factors were considered as the total value of farm property, the total value of farm products, and particularly the value of farm products per acre of improved land. In the latter respect, New England probably holds the record for the country.

Moreover, some of the very best farming in America, if not in the world, will be found in New England. The Aroostook potato region has justly achieved world-wide fame, not only for quality of product but for average yield and for intelligent methods of production. The Champlain Valley in Vermont is one of the rich dairy regions of the country. When former Dean Henry of Wisconsin wanted a fruit farm for his son fifteen years ago, out of the fullness of his knowledge of agricultural conditions, he selected a farm in Connecticut, and the results have justified his choice. The large specialist poultry farms of Rhode Island and Cape Cod are models of their kind. The market gardening area about Boston is one of the most intensive agricultural regions in the country. The tobaceo and onion growers of the Connecticut Valley are highly skilled; the 
town of Hatfield has been called the "high-water mark of American agriculture." The average yield of onions per acre in the valley is greater than in any other part of the country. The net return for shade-grown tobacco is sometimes as high as $\$ 800$ or $\$ 1,000$ per acre.

Of course, there are abandoned farms in New England, statements to the contrary notwithstanding, and there are also "abandoned farmers." But a very large proportion of the land thus abandoned never could be farmed under modern conditions. When the farm home was self-sustaining these lands answered very well for a combination of vegetable-growing, cattle and shecp husbandry, and lumbering; but they were never adapted to a commercial agriculture, and when commercial agriculture appeared these lands had to be given up for profitable farming. Some of these hill lands can well be used for shecp and goats, some for cattle grazing, some for orcharding, but most of them, let us hope, for intelligent forestry. One thing in favor of New England agriculture is the rainfall, averaging approximately forty-two inches per year, and generally fairly well distributed. The markets are excellent. A good system of highways is rapidly evolving, and the motor truck will undoubtcdly play a large part in the marketing of the future. Some day the trolley companies will awaken to the possibilitics of a trollcy freight service.

Another asset of New England agriculture is the large number of organized agencies working in bchalf of agriculture. The Grange is stronger in New England than in any other similar arca in the country, with more granges and more members. Within this area, which is about the size of the average state outside of New England, there are six agricultural colleges, six experiment stations and six boards of agriculture. At present New England is far better organized than any other similar arca in the United States with respect to farm bureaus, practically every county in the whole region now having a farm bureau or similar organization. Probably more attention is given to country life matters in New England than in any otler part of the United States, with many kinds of effort and agencies for the improvement of the home, the school, the health and play life and the moral and religious life of the country people. 
As to the speeifie question, what about New England agrieulture after the war? I suppose that what I have thus far said answers the question in the main. We are not to expect revolutionary changes at once, although unquestionably great changes will eome as the result of the war. The interest of the people of the eities in the quality and eheapness of their food supply has been aroused as never before. Alongside of this new interest has come the more active participation of representative urban ageneies, such as business organizations and women's assoeiations. People have learned their dependenee upon the farmer.

The participation by thousands of eity and village people, old and young, in the garden work has given a new respect for agrieulture, and the toil and rights of farmers. People who heretofore supposed that cabbages came from the groeery new know that they eome from the ground. People who had never given a thought to the farmer's difficulties now understand some of the uneertainties of the weather as the farmer has to faee them.

The whole problem of food supply in all its aspects has been given a new unity. The production of food, the transportation and distribution of food, and the wise use of food have all been brought together into one common problem, and the rights and obligations of all the different groups particularly interested in this common problem have also been brought together-producers, distributors and eonsumers. The part which each must play is more elear. The dependenee of one group upon the other stands out prominently. The need of close eoöperation among them all has been emphasized. The power and possibility of the principles of organization, as applied to the food supply problem, have been demonstrated as never before. What has been done in Massaehusetts has probably been done with equal thoroughness in other states. All over the eountry the food supply problem has been brought to a degree of organization that has often been dreamed of but never before attained. All this has been done by eoöperation, not by eompulsion. There has never been anything like it in the history of Ameriea. All this leads to my last point :

The state and the nation are learning that no man liveth 
unto himself. They are learning that under a great call old animosities can be buried and new relationships established.

I believe that all these results will be permanent-not completely, but relatively so. I believe that in every one of the results that I have suggested we shall find-after the war closes - a permanent addition to our New England farm life as well as a general gain. Nobody can tell what percentage, so to speak, of each of these gains will carry over, but I am certain that it will be high. It means the writing of an entirely new chapter in New England agriculture.

\section{BibLIOGRAPHY}

Anderson, T. F. Old Home Week in New England. New England Magazine, 34: 673-85, August, 1906.

Bailey, Wm. B. Urban and Rural New England. Amer. Statistical Assn., 8: 345-338, Marel, 1903.

Bidwell, Perey Wells. Rural Economy at the Beginning of the Nineteentll Century. Transactions of the Connecticut Academy of Arts and Science, New Haven, 1916.

Bolton, Mrs. Ethel Stanwood. Shirley Uplands and Intervales. Littlefield, Boston, 1914.

Boutwell, George. The Decadence of New England, Forum, 10:142151 , October, 1890.

Butterfield, Kenyon L. The Relationship of New England Agriculture to Manufacturing. The National Association of Cotton Manufactures. Boston, Mass. April, 1916.

Cance, Alexander E. The Decline of the Rural Population in New England. American Statistical Association, 13:96-101, May, 1912.

Crawford, Mary C. Social Life in Old New England. Little, Boston, 1914.

Drake, Samuel $\Lambda . \Lambda$ Book of New England Legends and Folk Lore. Little, Boston, 1910.

Dwight, Timothy. Travels in New England and New York. New Haven, 1821.

Earle, Alice Morse. Customs and Fashions in Old New'England. Seribner's, New York, 1894.

Fiske, Joln. The Begiunings of New Fungland. Houghton, Boston, 1859.

Freneh, George. New Eugland: What It Is and What It Is To Be. Bost on Chamber of Commerce, 1911.

Hartt, Roland L. $\Lambda$ New England Hill Town. Atlantic, 83:561-74; 712-20, $\Lambda$ pril and May, 1899.

Hartt, Roland L. The Regeneration of Rural New Engrand. Ontlook 64:504-63:- March 3, 1900 .

IIoward, J. R. Social Problems of Rural New Englaul. Conference Charities and Corrections, 416-421, 1911. 
Jolnnson, Clifton. New England and its Neighbors. Macmillan, New York, 1902.

Jolnson, Clifton. The New England Country. Lee, Boston, 1897.

Mattliews, Mrs. Lois Kimball. The Expansion of New England, Hougl1ton, Boston, 1909.

Mayo, A. D. New England's Gift to the Republie, New England Magazine, $1: 221-8$, October, 188?.

MacGill, C. E. The New England Type, New England Magazine, 40: 667-75, August, 1909.

MeSweeney, Ed. F. The Food Supply in New England, the situation we are facing and what we can and sloould do. The New England Federatiou for Rural Progress, March, 1917.

Sanborn, Alvan F. Future of Rural New England. Atlantic, 80:7483, July, 1897.

Sanborn, Alvan F. The Problems of Rural New England. Atlantic, $79: 577-598$, May, 1897.

Stone, Mason S. The Restoration of Country Life in New England. Education, 36:630-634. No. 10, June, 1916.

Vallandigham, E. What Ails New England? Putnam's Monthly, 6: 719-24, September, 1909.

Weeden, Wm. B. Economic and Social History of New England 1620-1789 (2 volumes), Houghton, Boston, 1890 .

Wells, George F. Rural Life. Tlie Status of Rural Vermont. Vt. Agric. Report, pp. 61-91, 1903.

Winslow, Helen M. Child-life on a New England Farm, Education, 9 : 466-73, March, 1889. 


\section{CHAPTER II}

\section{THE DEVELOPMENT OF COUNTRY LIFE IN THE WEST}

\section{THE MIDDLE WEST-THE FIBER OF THE PEOPLE ${ }^{1}$}

\section{EDWARD ALSWORTH ROSS}

A IUUNDRed years ago the Rev. Timothy Dwight eommented eomplacently or the benefit to Conneetieut from the draining away to the frontier-then western New York-of the restless spirits who ehafed under the rule of the old families and the Congregational elergy. It never oeeurred to him that these insurgent spirits were earrying with them to the wilderness a precious energy and initiative.

The unprosperous, the shiftless, and the migratory sought the frontier, to be sure; but the enterprising, too, were attraeted by it. The timorous and the eautious stayed and aceepted the eramping eonditions of an old soeiety; but those who dared take chanees, to "place a bet on themselves," were likely to eateh the western fever. Among the sons and grandsons of such risk takers, the venturesome tempers eropped out much oftener than among the sons and grandsons of the stay-at-homes. Henee, the strange fact that it was the roomy West that settled the farther West. On each new fronticr have swarmed men from what was itself a frontier only a generation earlier.

By the time some impression about the West has sunk deep into the eastern mind, the West has swept onward and falsified it. The Yankee thinks of the Middle West as a land of privation and hardship; it is, in faet, a seene of eomfort and plenty. He regards it as peopled by a hodge-podge of aliens, whereas the hodge-podge is at his own door. He looks upon New England as the refuge of the primal Ameriean spirit, when, in sooth, Iowa and Kansas are more evenly Ameriean in tone than any like

1 Adapted from "Changing America," pp. 145-146 and 137-140. Century Co., 1912. 
population in the East. The Back Bay may think of the Illinois farmer as raising more corn to feed hogs, which he will sell in order to buy more land on whieh to raise more corn to feed more hogs with which to buy more land, and so on. But the grandson of the man of whom this was said, sends his daughter to college, taxes himsclf for a public library, and is patron of the loeal art-loan cxhibit.

Nor is the Middle West without its delusions. It imagines it is growing faster than the East, because the drift from the crowd toward the edge of things, and from the wearied land to the virgin soils, has been constant in Ameriean history. That the center of population, which has traveled westward at the average rate of fifty miles a deeade, should halt or even retreat would be deemed a marvel, likc the sun standing still in the vale of Ajalon. Yet that very portent impends. The ecnter, which migrated fifty-eight miles in the seventies, and forty-cight miles in the eighties, shifted only fourteen miles in the nineties. That it then moved on thirty-one miles was due to the rush to the Pacifie slope, where one family being at the long arm of the lever, balances half a dozen Slovak families shantied in Pittsburg.

The truth is that the East grew faster than the Middle West through the nineties, and in the last ten years it has been gaining nearly twicc as rapidly, having added a quarter to its people while the West was adding a seventh. While in the East one county out of four lost in population, more than two counties out of five in the Middle West showed a decrease. One reason is that the Western farmer resents eramping eonditions more strongly, and responds sooner to the lure of fresh acres, than the Eastern farmer. The West it is that peoples the newer West, while the enterprising spirits of the older eommonwealths seek their ehance in the near cities. $\Lambda$ lifetime ago the old Yankee stoek was faring overland to settle the wilderness. Today only a sprinkling of the native Americans west of the Great Lakes claim an Eastern state as their birthplaee. If in Iowa seventy-onc counties out of nincty-nine have gone back in population during the last deeade, and an equal number in Missouri, it is assuredly not from bad times, but from the call of eheap land in Texas or the Canadian Northwest. 


\section{THE SIGNIFICANCE OF THE FRONTIER IN AMERICAN HISTORY ${ }^{1}$}

\section{FREDERICK JACKSON TURNER}

TuE Atlantic frontier was compounded of fisherman, fur trader, miner, cattle raiser, and farmer. Exeepting the fisherman, each type of industry was on the march toward the West, impelled by an irresistible attraction. Each passed in suecessive waves across the eontinent. Stand at the Cumberland Gap and wateh the procession of eivilization, marehing single filethe buffalo following the trail to the salt springs, the Indian, the fur trader and hunter, the cattle-raiser, the pioneer farmer-and the frontier has passed by. Stand at the South Pass in the Rockies a century later and see the same procession with wider intervals between. The uncqual rate of advance compels us to distinguish the frontier into the trader's frontier, the rancleer's frontier, or the miner's frontier, and the farmer's fronticr. When the mines and the eow pens were still near the fall line, the trader's pack trains were tinkling across the Alleghanies, and the French on the Great Lakes were fortifying their posts, alarmed by the British trader's bireh eanoe. When the trappers scaled the Rockies the farmer was still near the mouth of the Missouri.

And yet, in spite of the opposition of the interests of the trader and the farmer, the Indian trade pioneered the way for civilization. The buffalo trail beeame the Indian trail, and this became the trader's "trace"; the trails widened into roads, and the roads into turnpikes, and these in turn were transformed into railroads. The same origin ean be slown for the railroads of the South, the Far West, and the Dominion of Canada. The trading posts reached by these trails were on the sites of Indian villages which had been placed in positions suggested by nature; and these trading posts, situated so as to command the water systems of the country, have grown into sucl cities as Albany, Pittsburg, Detroit, Chicago, St. Louis, Council Bluffs, and Kansas City.

1 Adapted from Amcrican Historical Association Report, pp. 109-227, Boston, 1893. 
Generally, in all the Western settlements, three elasses, like the waves of the ocean, have rolled one after the other. First eomes the pioneer, who depends for the subsistence of his family chicfly upon the natural growth of vegetation ealled the "range," and the proceeds of hunting. His implements of agrieulture are rude, ehiefly of his own make, and his efforts dirceted mainly to a crop of corn and a "truek patch." The last is a rude garden for growing cabbages, beans, eorn for roasting ears, cucumbers and potatoes. A log eabin, and, oceasionally, a stable and a corn crib, and a field of a dozen aeres, the timber girdled or "deadened," and feneed, are enough for his occupancy. It is quite immaterial whether he crer becomes the owner of the soil. He is the occupant for the time being, pays no rent, and feels as independent as the "lord of the manor." With a horse and a cow, and one or two breeders of swine, he strikes into the woods with his family, and becomes the founder of a new country, or perhaps a state. He builds his eabin, gathers round him a few other families of similar tastes and habits, and occupies until the range is somewhat subdued, and hunting a little preearious, or, which is more frequently the ease, till the neighbors crowd around, roads, bridges and fields annoy him, and he lacks elbow room. The preëmption law enables him to dispose of his eabin and corn fields to the next elass of emigrants; and, to employ his own figure, he "breaks for high timber," "clears out for the New Purchase" or migrates to Arkansas or Texas, to work the same process over.

The next class of emigrants purchase the lands, add field to field, elcar out the roads, throw rough bridges over the streams, put up hewn log houses with glass windows and brick or stone ehimneys, oceasionally plant orehards, build mills, school houses, court-houses, and exhibit the picture and forms of plain frugal, eivilized life.

Another wave rolls on. The men of eapital and enterprise come. The settler is ready to sell out and take advantage of the rise in property, push farther into the interior, and become himself a man of eapital and enterprise in turn. The small village rises to a spacious town or eity; substantial edifices of briek, extensive fields, orehards, and gardens, colleges and 
ehurehes are seen. Broadeloth, silks, leghorns, erapes, and all the refinements, luxuries, eleganeies, frivolities, and fashions are in vogue. Thus wave after wave is rolling westward; the real El Dorado is still farther on.

A portion of the two first elasses remain stationary amidst the general movement, improve their habits and eondition, and rise in the seale of soeiety. The writer has traveled much amongst the first elass, the real pioneers. He has lived for many years in eonneetion with the seeond grade; and now the third wave is sweeping over large distriets of Indiana, Illinois, and Missouri. Migration has beeome almost a habit in the West. Hundreds of men ean be found, not over fifty years of age, who have settled for the fourth, fifth, or sixth time on a new spot. To sell out and remove only a few hundred miles makes up a portion of the variety of baekwoods life and manners.

First, we note that the frontier promoted the formation of a eomposite nationality for the Ameriean people. The eoast was preponderantly English, but the later tides of eontinental immigration flowed aeross to the free lands. This was the ease from the early eolonial days. The Seoteh-Irish and the Palatine Germans, or "Pennsylvania Duteh," furnished the dominant element in the stoek of the eolonial frontier. With these people were also the freed indentured servants, or redemptioners, who, at the expiration of their term of serviee, passed to the frontier. Very generally these redemptioners were of non-English stoek. In the erueible of the frontier the immigrants were Americanized, liberated, and fused into a mixed raee, English in neither nationality nor eharaeteristies. The proeess has gone on from the early days to our own. The advanee of the frontier deereased our dependenee on England. The eoast, partieularly of the South, laeked diversified industries, and was dependent on England for the bulk of its supplies. In the South there was even a dependenee upon the Northern eolonies for artieles of food. Before long the frontier ereated a demand for merehants. As it retreated from the eoast it beeame less and less possible for England to bring her supplies direetly to the eonsumers' wharfs, and earry away staple erops, and staple erops began to give way to diversified agrieulture for a time. 
The legislation which most developed the powers of the national government, and played the largest part in its activity, was conditioned on the frontier. The growth of nationalism and the evolution of American political institutions were dependent on the advance of the fronticr. The pioneer necded the goods of the coast, and so the grand series of internal improvement and railroad legislation began, with potent nationalizing effects. Over internal improvements occurred great debates, in which grave constitutional questions were discussed. Sectional groupings appear in the votes, profoundly significant for the historian. Loose construction increased as the nation marched westward. But the West was not content with bringing the farm to the factory. Under the lead of Clay- "Harry of the West," - protective tariffs were passed, with the ery of bringing the factory to the farm. The disposition of the public lands was a third important subject of national lcgislation influenced by the frontier. "No subject," said Henry Clay, "which has presented itsclf to the present, or perhaps any preceding, Congress, is of greater magnitude than that of the public lands." When we consider the far-reacling eflects of the government's land policy upon political, cconomic, and social aspects of American life, we are disposed to agree with him. But this legislation was framed under frontier influences, and under the lead of western statesmen like Benton and Jackson. Said Senator Scott, of Indiana, in 1841: "I consider the precmption law merely declaratory of the custom of common law of the settlers."

But it was not merely in legislative action that the fronticr worked against the sectionalism of the coast. The economic and social characteristics of the fronticr worked against scetionalism. The men of the frontier had closer resemblances to the middle region than to eitler of the other sections. Pennsylvania had becil the sced plot of frontier cmigration, and, although she passed on her settlers along the Great Valley into the west of Virginia and the Carolinas, yet the industrial society of these southern frontiersmen was always more like that of the Middle region than like that of the tidewater portions of the South, which later came to spread the industrial type throughout the South. 
But the most important effeet of the frontier has been in the promotion of demoeraey here and in Europe. As has been indieated, the frontier is productive of individualism. Complex soeiety is preeipitated by the wilderness into a kind of primitive organization based on the family. The tendeney is anti-soeial. It produees antipathy to eontrol, and partieularly to any direet eontrol. The taxgatherer is viewed as the representative of oppression. Professor Osgood, in an able artiele, has pointed out that the frontier eonditions prevalent in the colonies are important factors in the explanation of the Ameriean Revolution, where individual liberty was somewhat eonfused with the absence of all effeetive government. The same conditions aid in explaining the diffieulty of instituting a strong government in the period of the Confederaey. The frontier individualism has from the beginning promoted demoeraey.

So long as free land exists, the opportunity for a eompeteney exists, and eeonomie power seeures politieal power. But the democraey born of free land, strong in selfishness and individualism, intolerant of administrative experience and edueation, and pressing individual liberty beyond its proper bounds, has its dangers as well as its benefits. Individualism in Ameriea has allowed a laxity in regard to governmental affairs which has rendered possible the spoils system and all the manifest evils that follow from the laek of a highly developed eivie spirit.

The most effective efforts of the East to regulate the frontier came through its edueational and religious aetivity, exerted by interstate migration and by organized soeieties. The New England preaeher and the sehool-teaeher left their marks on the West. The dread of western emaneipation from New England's politieal and economie eontrol was paralleled by her fears lest the West eut loose from her religion. Commenting, in 1850 , on reports that settlement was rapidly extending northward in Wiseonsin, the editor of the IIome Missionary writes: "We scarcely know whether to rejoiee or mourn over tlis extension of our settlements. While we sympathize in whatever tends to inerease the plysieal resourees and prosperity of our eountry, we eannot forget that with all these dispersions into remote and still remoter eorners of the land the supply of the means of grace is beeoming relatively less and less." Aeting in aeeord- 
anee with such ideas, home missions were established and western eolleges were erected. Thus an intelleetual stream from New England sourees fertilized the West. Other seetions sent their missionaries; but the real struggle was between seets. The eontest for power and the expansive tendeney furnished to the various seets by the existence of a moving frontier must have had important results on the eharaeter of religious organizations in the United States. The multiplieation of rival ehurehes in the little frontier towns had deep and lasting soeial effeets. The effeets of western freedom and newness in produeing religious isms is notewortly. Illustrations of this tendeney may be seen in the development of the Millerites, Spiritualists, and Mormons of western New York in its frontier days.

To the frontier the Ameriean intelleet owes its striking eharaeteristics. That eoarseness and strength eombined with aeuteness and inquisitiveness; that praetieal, inventive turn of mind, quick to find expedients; that masterful grasp of material things, laeking in the artistie, but powerful to effeet great ends; that restless, nervous energy; that dominant individualism, working for good and for evil; and, withal, that buoyaney and exuberanee which eomes with freedom,-these are traits of the frontier, or traits ealled out elsewhere beeause of the existenee of the frontier. We are not easily aware of the deep influenee of this individualistie way of thinking upon our present conditions. It persists in the midst of a soeiety that has passed away from the eollditions that oeeasioned it. It makes it diffieult to seeure soeial regulation of business enterprises that are essentially publie, it is a stumbling-bloek in the way of eivil-serviee reform; it permeates our doetrines of edueation; but with the passing of the free lands a vast extension of the soeial tendeney may be expeeted in Ameriea.

\section{THE SPIRIT OF THE PIONEER ${ }^{1}$}

\section{RAY STANNARD BAKER}

Tre peopling of the eountry makes one of the most interesting and signifieant stories in the history of the nation. For many

1 Adapted from "The Great Southwest," Century, 64:9, May, 1902. (Copyright by Century Company, 1902.) 
years it was the unknown land, the land of possibilities and wonders, as well as of danger and death. Therefore it has attracted the hardy pioneer, and here, for laek of any other frontier on the eontinent, the pioneer, though with the germ of westward ho! still lingering in his blood, has been eompelled at last to settle down. I shall not soon forget the sorrowful desert-dweller whom I met in what seemed the ends of the earth in Arizona. His nearest neighbor was fifteen miles away, his post-offiee twenty-five miles, and yet he was bemoaning the faet that the eountry was beeoming erowded. "If there were any more frontier," he said, "I'd go to it."

It is hardy blood, that of the pioneer, good stoek on whieh to found the development of a eountry. For years the West has been the lodestone for those adventurous spirits who love the outdoor and exeiting life of the mining prospeetor, the eow-boy, the hunter-a healthy, rugged lot, virtually all pure Amerieans.

\section{THE PASSING OF TIIE FRONTIER ${ }^{1}$}

\section{JAMES BRYCE}

So Ameriea, in her swift onward progress, sees, looming on the horizon and now no longer distant, a time of mists and shadows, wherein dangers may lie eoneealed whose form and magnitude she ean scareely yet eonjeeture. $\Lambda$ s she fills up her western regions with inhabitants, she sees the time approaeh when all the best land, even that whieh the extension of irrigation has made available, will have been oeeupied, and when the land now under eultivation will have been so far exhausted as to yield seantier erops even to more expensive eulture. Although transportation may also have then beeome eheaper, the priee of food will rise; farms will be less easily obtained and will need more eapital to work them with profit; the struggle for existenee will beeome more severe. And while the outlet whieh the West now provides for the overflow of the great eities will have beeome less available, the eities will have grown immensely more populous;

1 Adapted from "The American Commonwealth, II," New Edition, (1916), p. 913. Macmillan, N. Y. 
pauperism, now confined to some six or seven of the greatest, may be more widely spread; and even if wages do not sink work may be less abundant. In faet the chronie evils and problems of old socicties and erowded countries, such as we sec them to-day in Europe, will have reappeared on this new soil.

\section{THE GREAT SOUTHWEST ${ }^{1}$}

\section{R.IY STANNARD BAKER}

ONE of the first teachings of the arid land is that the individual must subscrve his interest to that of the eommunity, and that is a hard matter for many an American to do. In the East a farmer may settle on his quarter-scetion, build a home, raise what he pleases or let the weeds grow, keep up his fences or let them fall down, and no onc says a word in objection; he is the most independent of men. But in the desert, where the struggle for existence is more intense, men must march in lockstep : if one wastes water, allows water to run out on another's field, does not keep up his ditehes, does not eoöperate with his neighbors in the work of cleaning or repairing ditches, he injures the entire community, and the community must foree him sternly into the line of duty. Moreover, he must join with his neighbors in the protection of the water-supply, in ease some other eommunity seeks to divert more than its share from the river above; and in many cases of drought and low water he must suffer equally with his neighbors, sharing what little water there is to be lad, even though his own orehards are dying. All this serves to build up such a community spirit in the irrigated eountries as the Easterner cannot appreeiate. There are human biekerings here as everywhere else, but a man soon learns that the eommunity interest is, after all, greater than that of the individual, and upon every important subject he submits his will to that of the eommunity. From this spirit have arisen those peeuliar and powerful coöperative assoeiations of farmers, which all but control the marketing of crops in parts of the West. Instead of trusting to avarieious commission men and engaging

1 Adapted from Century, 64: 369-371, July, 1902. 
in disastrous eompetition, the orange-growers, the raisin-growers, the bec-kecpers, and other elasses of farmers, have formed unions and associations which control the whole matter of packing, shipping, and sclling the farmers' products. These associations further eurtail the rights of the individual, hindering him, for instance, from shipping poor fruit, or poorly packed fruit, lest it injure the reputation of the eommunity in the Eastern markets; and if there are losses, each man must stand his share. So powerful, indeed, are these assoeiations that they can even venture to fight the railroad companies in the matter of freight rates, as they have done morc than onee in California. Farming in the East is a sort of guerilla warfare, every man for himself; in the arid West, it is a highly organized and diseiplined struggle.

It is interesting to speeulate as to the effeet which these new conditions of life will have on the American character. Irrigation requires a greater degree of skill than ordinary agriculture; it is more a matter of exact seience, less of chance. The Easterner sows his erops and depends on the will of Heaven for his rain; the Westerner goes out to his head-gate and lets in the rain, in just such amounts and at just such times as he pleases. He knows how mueh water he is entitled to, and its distribution is a simple matter of calculation. But he must be a carcful student of his erops; he eannot water his strawberries and his sugar-beets at the same time and in the same amount, for the strawberries are alway's thirsty, while the bects require only a few waterings in the season. He must also know his own peeuliar climate, for fields require much more water in the descrt air of Arizona than in the moister elimate of southern California, and he must have a care that the water leaves no alkali in his soil. In other words, he must be an intelligent, reading, seientifie farmer if he would outwit the desert and eompete with the cnergy of his neighbors. Men in the irrigated lands live eloser together than in the East, and farms are smaller. Some valleys, indeed, seem like villages, each resident of which lives in the midst of handsome grounds; whole districts in southern California are veritable parks for beauty. This brings neighbors closer together, breaks up the deadly isolation of the Niddle States farmers, enables a community to have better schools, 
churches, and places of amusement, tempts the mercurial young man to stay on the farm.

\section{LIFE IN THE CORN BELT ${ }^{1}$}

T. N. CARVER

THE average Western farmer is as well informed upon the questions of the day as the average business or professional man of our Eastern cities, though he lacks acquaintance with many things which some regard as essential to culture. He takes a deep interest in polities, and he is better informed about what goes on in our legislative lialls than any other class.

The corn belt is probably the most prosperous agricultural region of any considerable size in the world, but success requires great industry and a degree of knowledge that comes only from experience. In the East, especially in New England, where farming is not prosperous and the cities furnish better opportunities for men of capacity, it happens that the best men are drawn from the country to the city, leaving, as a rule, only the less competent to people the country districts. That is why there has been so much discussion during the last year or two over the degeneracy of the farming regions. But in the corn bclt the conditions are quite reversed; the best opportunties are furnished by the farms, and one of the most striking facts that one observes on a tour of this kind is the manifest superiority of the average farmer, physically, intellectually, and morally, to the average dweller in the towns of that region. With the exception of the retired farmers, who make up a fair proportion of the population of the country towns and small cities of the West, the bulk of the population seems to be made up of people who are not fit to make good farmers.

Even some of the so-called retired farmers have retired, not because they have accumulated a competence, but because they were unable to make farming pay or because they have found work too hard. They have moved to town, where their wives keep boarders while they loaf around the stores. For this

1 Adapted from World's Work, 7 : 4232-9, Dec., 1903. 
reason there is a sharp distinction made between "tired" and "rotired" farmers. The hotels and livery stables also are generally kept by this class of tired farmers.

It seems that every line of business carried on in the towns and small eities in the corn belt is largely in the hands of inferior men, though of eourse there are numerous brilliant exeeptions. Almost every town or eity will have one or two newspapers, whieh elaim to be the organs of the leading political parties, but which really seem to be published for the purpose of apologizing for their own existenee. The manual labor which is done about sueh towns is almost invariably done by men who are not fit for farm hands. Some are so profane and obseene in their language that a deeent farmer would not have them around, but they will work as section hands on the railroad for less wages than farm hands get, and loaf about the depot and the streets at night, play Sunday baseball, and have other similar enjoyments not open to the farm hand. Even a good deal of the mercantile business is earried on by men who do not show a degree of intelligence at all eomparable to that of the average farmer.

One hears a great deal of shockingly bad grammar in the eorn country, but correet speech is really a matter of eonventionality, and a farmer's success does not depend upon his observance of conventionalities. On the other hand, there are certain things whieh he must know, and which no amount of suavity or grace or good form will enable him to dispense with. He is dealing with nature rather than with men, and nature can not be deIuded by a pleasant front nor a smooth tongue. One must not be liasty in forming conclusions as to the farmer's intelligence on the basis of his clothes, his knowledge of the forms of polite soeicty, nor even his use of grammar.

Though the average family is somewhat larger than that of the well-to-do urbanite, there is a manifest decline even in the eountry distriets. Families of four or five ehildren among the native Amerieans are quite common, but one almost never finds such patriarehal families of ten and twelve children as were common in the days of our grandfathers. The most conspicuous case of this kind that I saw was a family of eight ehildren belonging to an Iowa farmer. The mother, who is still slightly on 
the sunny side of forty, was a daughter of a well-to-do farmer and had execllent "schooling" for the time and place. She was a country schoolma'am at the age of eighteen, and also gave music lessons to a few children in the community. She spent one year at a small Western college, but was married at the age of twenty-two to a young farmer who was living on a rented farm and whose only capital consisted of a team and farming implements. She has raised or is raising her cight children; they have bought a farm of 160 acres, which is now paid for; they have a comfortable house; and they arc just beginning to feel in easy circumstanees. The long, hard struggle through wlieh they have gone has in no way embittered their dispositions. They arc active in church work; the mother teaches a elass in Sunday-school; and the eldest daughter, seventecn ycars of age, is the organist. The children were unusually bright and healthy, and the mother insists that some way must be found to send them all through college, and I have little doubt that they will succecd. The husband is a hard working man of kindly disposition, but considerably her inferior in mental and social endowments, of which fact, however, both secmed utterly oblivious.

One form of social diversion common throughout the corn belt is what is known as the "basket-mecting." A basket-mecting is nothing more nor less than a regular church service turned into a pienic. Some grove near the country cluurch is selected, and on Saturday afternoon the men gather and crect an outdoor pulpit, with a sufficient number of benches for the congregation, and on the following Sunday, at the regular hour, the church service is held here instead of in the church. After the service the members of the congregation, having come supplied with baskets of provisions, spread them upon the benehes and partake of a bountiful dinner.

But such a minor festivity pales into insignificanee in comparison with such annual events as the Fourth of July, Old Settlers' Day, and the County Fair, thougl the latter has sadly degenerated sinee it fell into the hands of city sports, who make it simply an occasion for horse-racing, accompanicd by all the devices for scparating a fool from his money which usually surround a circus. 
The farmer in the corn belt has lis labor problem, too, though I have never licard any one predicting the doom of the corn belt on that ground. The fact is that while the existence of the labor problem is recognized, it is of such minor signifieance as to be almost negligible. Fortunately for Western agrieulture and American socicty in general, there is no proletariat of agricultural laborers. There are practically no farm laborers of the European type-that is, men who expect always to work for wages as farm hands. The typical farm hand is a young unmarried man, usually the son of a farmer living in the neighborhood-though frequently a forcign immigrant-who "works out" for a few years merely to get money enough to begin farming on his own responsibility on a rented farm.

The scareity of farm labor, however, in no way interferes with the suecess of corn-growing. In the first place, the corn-grower works with his own hands, and so do the other members of his family. Riding plows and eultivators, disk harrows and eorn harvesters, as well as twine binders and hay stackers, so reduce the amount of museular strength necded that a boy of ten years of age will frequently render almost as mueh service as a grown man.

Another factor which contributes to the solution of the labor problem is the distribution of the work of the farm over the year. On a typical eorn farm there is no season which is preeminently the busy scason, unless the eorn-plowing has fallen behind beeause of wet weather. Though farmers with whom I talked universally agreed that corn was by far their most profitable crop, there were very few farms where eorn was grown exelusively. With a given labor force, only a certain amount of eorn can be cultivated, anyway, and it requires no more labor force to grow a certain amount of other erops in addition. Wheat and oats are sown before eorn-planting time, and are liarvested after the corn has been "laid by" - that is, after the plowing is finished. The hay harvest also comes in this interval, and the threshing is usually done before the eorn-husking begins. Moreover, the stubble ficlds can usually be plowed in the interval between the harvesting of the small grain (wheat and oats) and the lusking of the corn. Thus the farmer in the corn 
belt has praetically eliminated the labor problem, so that even the limited supply of farm hands is no serious handieap upon the eorn-growing industry.

As to the problem of domestie serviee, there is practieally none. Hired girls are almost non-existent. Every farmer's wife expeets to do her own work, and if in time of siekness or of speeial stress of work she can induee some girl from the neighborhood to eome in and help her, she eonsiders herself fortunate.

Like other parts of the West, the eorn belt was settled by people from a great variety of sourees, and has not been without its share of tough communities; but the land was too valuable, and there was too high a premiun on thrift and industry for such eommunities long to remain.

Everywhere in the eorn belt, and indeed wherever farming is prosperous, one meets with the interesting phenomenon of the retired farmer. In general, he is a man eonsiderably past middle age, who has by hard work and eareful management beeome the owner of a fair-sized farm, with perhaps a moderate bank aecount besides, and who has either sold or rented his farm and moved to town to spend his deelining years in rest. From the number of sueh eases one might almost eonelude that the average farmer's idea of paradise was a eountry town where he could live eomfortably, supplying his daily needs without denying himself rest or sleep, and where he would be free from the wear and tear of continually guessing at the weather, earing for his live-stoek, battling with weeds and the thousand-and-one other relentless enemies of the farmer. But when he reaches this paradise, unless he has retired on aceount of old age, he is almost invariably disappointed, if not demoralized. The life soon grows monotonous. Having always been aeeustomed to an aetive outdoor life, he beeomes restive and diseontented. Sometimes he takes up some other line of business-goes into a store, starts a hotel or a livery stable, or goes into the real estate business; and again he sometimes degenerates into an ordinary town loafer. He frequently makes a poor urbanite, for his ideas of living were developed under rural eonditions. He is somewhat slow to appreeiate the value of good sewage, generally opposes levying taxes for street improvements, and is almost invariably disliked by the merehants beeause of his parsimonious way of buying 
goods. The habits of his early life stay with him and dominate all his business transaetions. The effect of town life upon the retired farmer is, however, by no means to be eompared with its demoralizing effeet upon his minor ehildren, espeeially his boys, if he happens to have any.

As a traveler moves westward, if he keeps his eyes, or rather his ears, open, he becomes more and more impressed at the roughness and even profanity of the language which he hears in public places. This impression, however, is due partly to the faet that the ordinary traveler only sees and hears what goes on about the railway stations, lotel eorridors, and similar places, and the elass of people who infest such places are by no means representative. When he gets away from beaten lines of travel, out into the rural distriets, this impression is by no means so vivid. Nevertheless, it remains, and it is undoubtedly true that there is more rough language in the West than in the East. At the same time, if lie takes the trouble to attend country ehurehes and to form some idea of the popular interest in religious matters, he is impressed with the piety of the people. It will usually take him some time to reeoncile these two apparently contradictory impressions, but the explanation is that as one moves westward through the agrieultural districts he meets fewer and fewer of that elass whieh is so numerous in eities and also in the rural districts of the East, who are neither pious nor wiekedsimply indifferent. In other words, it seems that throughout the West, especially beyond the Missouri River, every man is either pious or profane, and the prevailing type of piety is of the Methodistic sort, just as the prevailing type of impiety is of the turbulent, swearing sort.

Politically, the West is rapidly settling down to more fixed habits of thought, though it had its period of unrest. In the early seventies, and again in the early nineties, the Western farmer beeame the spoiled elild of American politics. He has been flattcred and cajoled by demagogues until he came to think limself the most important factor in our social system. This position he lias now been deprived of by the wage-worker, who is to-day laying the flattering unetion to his soul that he is the most important personage in the universe. To be sure, neitler the Grange nor the Farmers' Allianee in their wildest days ap- 
proached in arroganee the labor organizations of the present; nor did they ever, either direetly or indireetly, eountenance violenee or lawlessness of any kind. This is probably due to the faet that the farmers, as a elass, are vastly more intelligent and law-abiding than the rank and file of the wage-workers, though they are more numerous and politieally more powerful.

The eorn belt is the most considerable area in the world where agrieulture is uniformly prosperous. This prosperity is, moreover, healthful and natural, and not artificial, like the sugarbeet industry, for example, which has never in any eountry shown its ability to stand alone unaided by government favors, nor, like much of our manufacturing prosperity, based upon government protection. The people engaged in the eorn-growing industry are an independent, progressive elass, drawing their sustenanee from the soil, and not from other people.

\section{BIBLIOGRAPIIY}

Baker, Ray Stannard. Destiny and the Western Railroad. Century, 75: 892-94, April, 1908 .

The Vitality of Mormonism, a Study of an Irrigated Valley in Utah and Idaho. Century, 68:165-17 7 , June, 1904.

The Great Northwest. Century, 66: 85-97; 643-55, May and September, 1903.

The Great Southwest. Century, 64:5-15; 213-25; 361-73; 635-45; May, June, July, August, 1902.

Bryce, James. The American Commonwealth, Macmillan, N. Y., 1889. Bentley, Arthur F. The Condition of the Western Farmer as illustrated by the economic history of a Nebraska township. Jolins Hopkins University Studies, Series $7-S$, The Johns Hopkins Press, Baltimore, 1893 .

Canfield, Dorothy. The Westerner. Scribner, 49:158-165, Feb., 1911. Cannon, Frank J. and O'Higgins, Harvey J. Under the Prophet in Utah, Clark, Boston, 1911.

Cannon, Frank J. and Knapp, George L. Brigham Young and his Mormon Empire, Revell, Chicago, 1913.

Coman, Katherine. Economic Beginnings of the Far West. Macmillan, N. Y., 1912.

Fite, E. D. Social and Industrial Conditions in the North during the Civil War. Macmillan, N. Y., 1910.

Garland, Hamlin. A Son of the Middle Border. Macmillan, N. Y., 1917 .

Gleed, Chas. S. True Significance of Western Unrest. Forum, 16: 251-260, Sept., 18 :3.

Harger, C. M. The West at Home-in the Country. Outlook, S6: 32-36, MГay $4,1907$. 
Hartt, Rollin L. Middle Westerners and that Sort of People. Century, N. Y., December, 1916.

Hinsdale, B. A. Old Nortliwest. Silver, N. Y., new ed.

Howells, William C. Recollections of Life in Ohio, 1813-1840. Stewart \& Kidd Co., Cincinnati, 1907.

Lummis, Charles F. Pueblo Indian Folk-Stories. Century, N. Y., 1916.

Norris, Frank. The Pit. Doubleday, Garden City, 1903.

Page, Walter H. The Land and the People. World's Work, $10: 6459$ 65, July, 1905.

Paxson, Frederick Logan. The Cow Country. Amer. Hist. Assoc. Review, 22: 65-S2, October, 1916.

The Pacifie Railroads and the Disappearance of the Frontier in Ameriea. Amer. Hist. Assoc. Rept., 1907, 1:105-122.

The Last American Frontier, Macmillan, N. Y., 1910.

Plillips, Ulrich B. Documentary History of American Industrial Society, Vols. I and II. (Plantation and Frontier.) Clark, Cleveland, 1910.

Pinchot, Gifforl. The New Hope for the West. Century, 68: 309-13, June, 1904 .

Robinson, Edward V. Early Economic Conditions and the Development of Agriculture in Minnesota. Univ. of Minnesota, (Studies in the Social Sciences, No. 3), St. Paul.

Roosevelt, Theodore. Winning of the West. R. of Rev., N. Y., 1904.

Ross, J. B. Agrarian Revolution in the Middle West. N. Amer. Rev., $190: 376-91$, July-December, 1909 .

Ross, Edward $\Lambda$. The Middle West. Century, 83:609-15; 686-92; 874-80; Feb., Mar., A pr., 1912; 84: 142-8, May, 1912.

Showerman, Grant. A Country Chronicle. Century, N. Y., 1916.

Small, A. W. and Vineent, G. E. The Rural Group, An Introduction to the Study of Society. Pp. 112-127, American, N. Y., 1894.

Turner, Frederiek Jackson. Rise of the New West. Harper, N. Y., 1906.

Significance of the Frontier in American History. Univ. of Chieago, 1899. (Nat. Herbart Soc., 5th Yearbook.)

Contribution of the West to American Democracy. Atlantic Monthly, 91: 83-96, Ja1., 1903.

Colonization of the West, 1820-1830. Amer. Hist. Rev., 11: 303-27, Jan., 1906.

Thwaites, R. G. Early Western Travels. Clark, Cleveland, 1904-7.

Cyrus H. McCormick and Reaper. Wis. Hist. Soc., Madison, 1909.

Stories of the Badger State. American, N. Y., 1900.

Van Dyke, Jolın Charles. The Desert. C. Scribner's Sons, N. Y., 1901.

White, Stewart Edward. Riverman. Grosset, N. Y., n. d. Blazed Trail. Grosset, N. Y., 1913. Westerners. Doubleday, Garden City, N. Y., n. d.

Winsor, Justin. Westward Movement. Houghton, Boston. 


\section{CHAPTER III}

\section{THE OLD SOUTH AND THE NEW \\ SOCIAL CONDITION OF THE OLD AND THE NEW SOUTH ${ }^{1}$}

\section{PHILIP ALEXANDER BRUCE}

BroADLY speaking, no institutions of the South were so profoundly affected by the failure of secession as the social. It is true that it was a great economic revolution to pass from slave labor to free labor, but the ground is still chicfly tilled by the hand of the Negro. The large plantation has been eut up into numerous estates, but the same staples continue to be cultivated. There has been a radical alteration in political conditions, but, on the whole, the representatives of the Southern States in their local legislatures and in the national Congress are drawn from the same general class as they were in times of slavery. The economic and political life of the South has been transformed, but transformed to a degrec that falls short of the change that has taken place in its social life; here the change has been complete so far as the rural districts, in which the overwhelming mass of the Southern people reside, are involved. The Frencl Revolution, witl its drastic laws touching the ownership of land, did not sweep away the aristocracy of France one-half as thoroughly as the abolition of slavery swept away the old rural aristocracy of the South. The social condition of this part of the Union is llow the reverse of what it was before the War of the Secession; then all that was best in the social life of the people was to be found in the country; now all that is best is to be found in the city.

The close of the great war marked the end of a society that had safely passed through all the vicissitudes of several hundred

1 Adapted from "The Rise of the New South," pp. 421-435, Barrie, Philadelphia, 1905. 
years. The peeuliar soeial life of the Southern States, as a body, in eonsequenee of its being coineident with the very existence of these States, had permeated with its spirit the genius of the Southern people from generation to generation, until it had beeome the most powerful of all the influenees in molding their eharaeter and destiny. This social life rested primarily on the system of large plantations. In the early part of the history of the older Southern eommunities-Virginia and Maryland, for instanee-when the plantation system, as it existed before the war, was founded, this system derived its strength, not from slavery, but from indentured white service,-which, however, was not unlike slavery in spirit and influenee,-but as time went on, its prineipal support beeame the institution of slavery itself. As the number of Negroes inereased, which they did very rapidly after the beginning of the seventeenth eentury both by natural addition and importation, the individual plantation grew larger and larger in order to ereate room for the employment of superabundant labor. Not even the opening up of new territory eould earry off the surplus slaves. The tendeney toward the engrossment of the soil in a few hands was just as remarkable in Virginia, the oldest of the Southern States, as it was in Texas and Mississippi anong the youngest, and it was just as strong in 1861, when the war began, as it was two hundred years earlier.

What did this engrossment of land through so many generations mean from a soeial point of view? It meant that from 1624, when the plantation system beeame firmly established in Colonial Virginia, down to 1861 , when it prevailed in the most extreme form from one end of the South to the other, there existed a elass in every Southern eommunity, whose soeial preeminenee rested as distinetly upon vast landed possessions as the like preëminenee of the English aristoeraey. The South illustrated anew a faet that had been strikingly illustrated in the history of England: namely that there is sometling in the ownership of the soil, eonfined to a eomparatively small number, that gives peeuliar soeial distinetion to the elass possessing it. The soeial prestige of great landed property was rendered the more impressive in the Southern States by the large retinues of slaves; there was, for that reason, a more baronial importanee about sueh an estate than about the like estate of the English 
nobleman of the same day, whose dependents and retainers were at liberty, if they chose, to transfer their serviees to another employer. 'The slave belonged to the master absolutely; the tie eould only be severed by the latter's will. 'The eomplete subservieney of the relation gave a eertain barbarie aspeet to the condition of the great Southern landed proprietor, but the soeial life which eentered in him was on that aceount not the less truly distinguished.

In possession of a great estate in a comparatively thinly settled eountry, stoeked up with liundreds of slaves, who were in the habit of looking to him for everything in life, the Southern landowner, under the old system, was, naturally enough, remarkable for a prond and aristoeratie spirit. This was the general tone which men of his elass gave to the lighest social life of the Soutl. There were, of eourse, no legally determined and fixed ranks in that life, but the line of separation was as elearly defined, and as firmly drawn as if the hereditary prineiple of easte had a distinet recognition, as in France under the ancient monarehy. The opportunities for aceumulating large estates by the exereise of great talent for heaping up money were very few. The eity shop and the eountry store of the South were narrow fields of operation for this purpose. The highest rank in society was not receiving uneeasing additions in great numbers from the lower, in eonsequenee of sueeess in gathering together fortunes, as has always been the ease at the North, where trade has ever been an unfailing means of building up new families. There were, it is true, many aeessions in the Southern States, but it required a full generation at least to envelop the intruder in the odor of soeial sanetity, unless he had seeured an exeeptional eonnection by marriage. Pride of aneestry was one of the most powerful of all social influenees in the South, and the ability to prove a long and distinguished deseent one of the most valued of possessions.

Unlike the soeiety of England, that of the Sonth possessed no eommon eenter resembling London to direet general taste and govern fashion.

The social life of every large plantation eommunity was restricted to the bounds of the community ; it was the soeial life of neighborhoods, whieh might have a radius of as much as twenty 
miles; in this eireuit everywhere in the older States of the South was to be found a soeial life refleeting a high degree of culture, refinement, and intelligence. The direet effeet of the plantation life was to foster all the influenees giving strength and permanence to the family. The love of home was inereased, not only by long personal association with the spot, but also by traditions running back many generations into the past. Around it gathered the memories of a family life as old, in many eases, as the first settlement of the eountry. The house in which the planter resided had been ereeted perhaps a hundred or more years before, and was hallowed by innumerable events in the family history.

The ties of family were strengthened, not only by long transmitted influenees of this eharaeter, but also by the faet that, under that system, sons, as a rule, settled on lands which had been given them by their fathers in the neighborhood of the paternal estates. In time, there sprang up a eommunity united by the bonds of elosest kinship; and as the years passed, and brothers and sisters had ehildren of their own, these bonds were knit more elosely together still by the intermarriage of cousins. A whole eountryside was frequently deseended from the same aneestors, and the most skillful genealogist often found it impossible to follow the ramifieations of the eommon strain. It needed but the law of primogeniture to make the state of Southern society preeisely similar in spirit to the society of England in the previous eentury.

That society was even more given to hospitality than English society in the eountry. There was praetically an unlimited supply of servants; the abundanee of provisions of all kinds was inexhaustible; and there was no effort at display imposing expense and ineonvenienee. The seelusion of the planter's life threw around the visitor an unusual degree of interest; hospitality, at first a pleasure, took on very shortly a saered eharaeter -it beeame a duty which it was always delightful to perform. The guest, as often a stranger as a kinsman, was rarely absent from the plantation residenee.

Below the highest elass of planters there was praetieally only one great elass among the whites, a elass whieh the general elanges following the war have brought into the greatest promi- 
nenee, but whieh, under the system prevailing before 1860 , oeeupied a position of small soeial importanee. The elass made up of the small landowners always formed the body of the white population. Its members, as a rule, owned from fifty to two hundred aeres of land, whieh they worked themselves, with the assistanee, at the most, of a few slaves.

When the first patents were sued out, it was deemed all-important to take up the most fertile soil as, in the absenee of artifieial manures, the best fitted for the eulture of eotton or tobaceo, and sueh as was least likely to be exhausted by prolonged tillage. The lands preferred were those situated on the rivers and larger streams which furnished an alluvial deposit. The eonstant aim of the wealthy planter was to engross as extensive an area of these lands as he eould aequire; broad reaches of upland were patented or purehased as a means of obtaining wood for fuel and timber for building, and as affording a wide range for the browsing of eattle. The mass of the white population, the true yeomanry of the eountry, were confinęd to the ridges and narrow low grounds of the small streams, the soil of which was inferior in productive eapacity as eompared with the grounds lying around the large streams held by the wealthy planters.

The elass of small landowners represented, in many instanees, a high degree of thrift, but in some eases an extreme degree of poverty, aeeording to the eharaeter of the different holdings. Many of the small estates were eultivated with great eare and enabled the owners to live in eomfort and abundanee. The tables were set forth with a eonsiderable variety of food; there was a slave to furnish the household serviee; the residenee though plain was substantially built and suffieiently spaeious; to it were attached small gardens for both flowers and vegetables; also an orehard of fruit trees enelosed as a pen for the hogs; and there were several mileh eows, and a horse and vehicle for eonveying the family to ehureh. During the week, the owner with his sons and a Negro or two hoed and plowed in his tobaceo and eorn fields. When the end of the year eame, he had perhaps several hundred dollars in his ehest. If ambitious of improving his eonditions, he expended his savings in the purehase of more land, by which he was enabled to plant eotton or tobaceo over a larger area of ground. The increase from one eouple of slaves made a con- 
siderable addition to his small fortune. Even when he had no oeeasion himself for the labor of the young Negroes as soon as they were strong enough to work, he eould hire them at a profit; many small landowners derived a good ineome from this letting of slaves who had been trained by them for some meehanieal trade.

The landowner whose entire holding eonsisted of soil on the ridge was by no means so well off as the members of his own elass who owned land on the small streams. The expression " "po' white," so freely used by the slaves as a term of opprobrium, was applied espeeially to these inhabitants of the highlands. The narrowness of their fortunes was diselosed in many waysin the sallowness of their eomplexions, resulting ehiefly from insuffieient and unwholesome food-in the raggedness of the elothing-in the bareness and diseomfort of their eabins, which were mere hovels with the most slovenly surroundings-and in the thinness and weakness of the few eattle they possessed. Nowhere eould there be found a population more wretehed in some respeets than this seetion of the Southern whites, the inhabitants of the ridge and pine barrens, men and women who had no interest in the institution of slavery and whose eondition of extreme poverty was partly due to the system of large plantations. The abundanee of Negroes diminished the ealls for the labor of white men, which might have been furnished by this elass, and the engrossment of land into great states shut them off from the most produetive soil.

The poor white man of energy and intelligenee eould look forward to but one eareer whieh gave him a eertain opportunity to improve his eondition. He eould not hope to get anything but a bare livelihood out of his impoverished aeres; the slave meehanies stood in the way of his seeuring work in any loeal handieraft, and there were no manufaeturing towns where he eould obtain a position in a faetory; but throughout the South there was a eonstant need of faithful and resolute overseers. From the point of view of the indigent elass of whites, the overseerships were most desirable, not only as indieating a soeial advanee in life, but as offering a very sure prospeet of aeenmulating a eompeteney. This was the beginning of many eonsiderable fortunes in lands and slaves. 
The relations of the small landowners with their neighbor, the large planter, were marked by a spirit of kindness, goodwill and estcem. They looked to him as their natural leader. The line of soeial difference was never crossed, but there was no barrier to the display of the warmest regard in their personal assoeiation with him. The society which they formed among themselves was noted for its homcly respectability, but was not remarkable for any features of general interest. The simplicity distinguishing the social life of the leading planters took, in the case of that of the lower, the form of extreme plainness. The cxistenee led by this seetion of the pcople was onc of unusual seclusion; indeed, their only places for general meeting were the churchyard, the courthouse, and the store, while the furthest point to which they traveled was the town in which they found a market for the sale of their cotton or tobacco. Their entire witlidrawal from the world produeed a marked primitiveness of cliaracter which was transmitted from generation to generation.

There were two influenees to maintain great pride of spirit in persons of this social rank even when they had to endure cxtreme poverty. First, they followed the independent life of the plantation; it is true that their estates were small, but they were absolute masters of their own property. Secondly, the presenee of the slave, a standing objeet of soeial degradation, inspired the plainest white man with a sense of his superiority of race, a eonviction tending to strengthen his self-esteem as an individual. These influences gave a prouder tone to the whole social life of the eommon people of the South than would otherwise have distinguished it. On the other hand, the absence of edueational advantages had a considerable effect in sinking this soeial life below the point which has been reached by the same grade of population elsewhere. Illiteracy, as we liave already pointed out, was very prevalent; it was one of the unfortunate results of the old plantation system that it curtailed" all educational facilities, by its tendeney to reduce the number of inlabitants oceupying a given area of country.

Taken as a wholc, the common peoplc of the Southern States, during the existence of slavery, werc an unusually intelligent, eonservative, and sturdy population. The rank and file of the armies of the Confederacy in the War of Secession were chiefly 
drawn from this class, and surely the world never saw a body of soldiers more distinguished for the qualities that win the respeet and admiration of mankind.

The higher planting elass of the South staked everything on the issue of the war-their lives, their fortunes, the framework of their social life, their political supremacy, their all. When the more violent influences which the destruction caused by the eonfliet set in motion had practically finished their work, and this was done in a very few years after the close of the eontest, the society in the rural distriets of the South was like a vast field of grain over which a reaper had passed, eutting off the heads of the tallest stalks only, while it left practically untouched those of less height. The great planters were, with hardly an exeeption, ruined in the end, even though they sueceeded for a short time in holding on to their estates. But as a body, the small planters, who had few slaves and who were eultivators of their own ground, remained upon as good a footing as they oceupied before the War of the Seeession began; indeed, the general position of the lower whites of the South to-day is, from an economic point of view, far more advantageous than it was previous to 1860 .

This is due to several eauses. First, in the breaking up of the large estates, which, as we have seen, were for the most part made up of the most fertile and most eligibly situated lands in the eountry, the small proprietors, who, before the war, had been eonfined to the ridges and ereek bottoms, were able to purehase ground of the finest quality, beeause offered for sale in sinall tracts, without competition on the part of the former great and wealthy proprietors. This elass, of old, always overbid the wonld-be buyers of small means. Many of the riehest aeres to be found in the Southern States are now owned by sueh men, who, had slavery been prolonged, would have spent their whole lives in eultivating a poor soil with very small returns.

Seeondly, the complete alteration in the eeonomie system of the Southern States has direeted the attention of their most enterprising business men to manufactures of all kinds, but espeeially to the manufaeture of eotton. The development of this branch of industry, which, before the war, was earried on in a very limited way, has given employment to many thousands of operatives, drawn entirely from among those persons of the rural 
population who carned a livelihood by eultivating the ground in small traets with their own hands. IIad slavery not been abolished and the large plantation system destroyed, the manufaeturing interests would doubtless have continued to languish; and the opportunities now open in this rapidly expanding department of industry would perhaps never have arisen to improve the eondition of the poorer elasses of the Southern whites.

Thirdly, during the existenee of slavery, it was to the interest of the large landed proprietors, who eontrolled the industrial affairs of every rural community, to train their own Negroes in the different handicrafts; there were blacksmiths, earpenters, wheelwrights, masons, bricklayers, shoemakers, and saddlers conneeted with all the most extensive plantations, and, with hardly an exception, they were the slaves of the owners. The only white mechanies to be found in those parts of the South where the black population was very numerous were residents of the scattered villages and towns. The Negro under the new system shows in the country a marked distaste for every braneh of mechanics, and the handicrafts there have in consequenee steadily gravitated to white tradesmen. Thus the poorer class of whitc persons have a means of earning a livelihood and even a eompetence, of which they were practically deprived before the abolition of slavery; employment in this department of activity is now afforded to tens of thousands of men of their race where, during the existence of the large plantation, employment was afforded to hundreds only, bccause in reality almost the entire work in his line was done by slaves.

These are three most important ways in which the old elass of small landed proprietors have benefited by the change in the eeonomic system of the Southern States. With inereased opportunity for improving their pecuniary standing, it has followed that their general social condition is better than it used to be, but in no social particular as yet has the new order in the Southern rural districts become a satisfactory substitute for that. old order which gave the South its soeial charm under slave institutions. The characteristics of the ruling class of small landowners in the country to-day-whieh before the war was the class occupying an entirely subordinate social rank-are essentially what they have always been. The prosperity of this class has 
not been sufficient as yet to allow them to make any real advance in social attractiveness; the life which they lead still removes them from the general currents of the world; they are still the primitive people, as in former times, with social qualities commanding respect, but with none to produce a society so notable as that which passed away. Education is more general, on account of the establishment of free schools; some social advantages are enjoyed, which, under the old system, werc beyond the reach of all except the rich, but in its principal features, the social condition of the rural population remains as it was when subordinated to that of the higher planting class during the existence of slavery. How entirely this latter class has vanished and how wholly the country is given over to the former lower rank in society is nowhere more conspicuous than in the rural churches. Owing to the increase of the white population, these churches are more fully attended than they ever werc, but the families belonging to the old rural gentry are no longer to be scen there.

A gencral social equality prevails among the whites in all the rural districts. In the agricultural regions, outside of the towns, there are, as yet, no means of accumulating sufficient fortune to give superiority to new families possessing talent for getting moncy; the old rural gentry has not been succeeded, even in a comparatively remote degrec, by a new gentry which rests its claims to social distinction upon large estates acquired in recent years. In the rural district, all the tendencies arc toward a further consolidation of the existing social equality among the whites, because the subdivision of the land means a further progress toward the reduction of the whole number of white inhabitants to the condition of the men who work the soil with their own hands. There are no substantial social distinctions anong manual laborers of the same racc. The small farmer and the small planter who are making up to an increasing extent every year the entirc body of the rural white inhabitants may loold themselves a little above their white assistants who are without property, but there is no real difference in their social level. We see in the South to-day a vast rural white population, which, as a whole, stands upon the same footing, a footing of great respectability, but entirely devoid of those charms which made the 
social life of the rural gentry, during the existence of slavery, one of the most attractive in the world.

What has become of the descendants of this rural gentry? As a body they are no longer to be found in the country. While many have emigrated to other parts of the Union, the far greater number have settled in the towns of the South. All the influences of the old system, as we have seen, tended directly to the discouragement of the growth of cities; all the currents ran toward a dispersion of the population over an ever widening extent of space. It is now precisely the reverse. The drift toward the subdivision of land signifies a drift toward the concentration of population. The inability of the petty landholders to produce on their own estates the artificial supplies they require, has increased the importance of the local distributing and manufacturing eenters, both great and small; the towns liave become steadily larger each year, partly in consequence of the rising rural demand for manufaetured supplies; while the villages have grown beeause they have drawn to themselves a greater number of tradesmen working in different departments.

The eomparative unprofitableness of agriculture under the present system, unless the land is cultivated by the owner with his own hands, thus cutting the expenses down to the smallest point, prompted the descendants of the old higher planting elass to remove to the Southern eities as offering a better opportunity for the improvement of their fortunes. In addition, they expeeted to find there the best soeial advantages which the new order afforded.

If we go to some Southern county, which, in times of slavery was the seat of an intelligent, refined, and eultivated gentry, we shall discover that the only society there possessing any distinction is centered in the courthouse town; and this society is generally made up of families of professional men whose names are amongst the most ancient and honorable in the history of their State. The gentry of the South, from having been associated only with life in the country, have become now thoroughly identified with life in the city. The energy and ability that have built up so many Southern towns in so short a time, have been drawn, in largest measure, from a elass that, before the War of Secession, visited the eity only in winter and looked upon the 
country as offering all that was highest and most interesting in life to people of birth and culture. In the course of the last quarter of a century many fortunes have been made by representatives of the old rural gentry who have emigrated to the towns, but there has been no disposition in these representatives to return to the life of their ancestors; some have purchased rural estates, but it has been for pleasure and recreation during the summer, and not for oceupation throughout the year.

The social life of the South now rests upon the same general foundation as the social life of the North, and as time passes the eharacter of the one will be wholly indistinguishable from the character of the other. The country districts will be oceupied exelusively by a great body of small farmers, planters, and their assistants in the field. The whole extent of the soil will become, in less than a century, so subdivided that two or threc liundred acres will form the average estate. The owners of the land, by the vast increase in the rural population which will follow this subdivision, will enjoy to a far greater degree than they do at the present time all the advantages springing from a teeming community - a more frequent and more diversified social intercourse, more varied and refined amusements, a larger number of public schools, and a more thoroughly organized and more efficient system of public education. The towns and cities of the South, on the other hand, will become, as they have done in the North, the centers of the greatest accumulations of wealth and the seats of the highest culture and refinement. Here, as in the Northern towns and eities, society will be eontrolled, to an ever inereasing degree, by families whose rise to social prominence has been brought about by the extraordinary talents of the men at their head for building up great fortunes. The influenee of mere anecstry going back many generations, perhaps several hundred years, will grow less socially powerful in the Southern eenters of population, where the ability to aceumulate money already gives the highest personal consideration, just as it does in the like Northern communities to-day. The material spirit will govern the forees in Southern urban soeiety precisely as it has always done in urban soeiety of the North. Indeed, time will only slow more elearly that the defeat of the South in the War of Secession meant the eomplete social unifieation of the United 
States as the incvitable result of the economic unification that followed almost immediately upon the destruction of the institution of slavery.

\section{OUR CAROLINA HIGHLANDERS ${ }^{1}$}

E. C. BRANSON

Wirst I shall say or try to say concerns the seventeen Highland counties of North Carolina, and the 243,000 people who dwell in this land-locked area. This is the region and these are the people I best know in our Southern mountain country. I assume to speak for no others.

First of all I want to claim for the whole of North Carolina an identity with our mountain people. They are our very own kith, kin, and kind. They are not a peculiar people-in illiteracy, poverty, degree of isolation, fiery individualism, or organizable qualities. They differ in no essential particular from the democratic mass in North Carolina in mood, humor, temper, and attitudes. Their economic and social problems are not regional; they are state-wide. There are no differences in kind, and few in degree, between the civilization of our hill country and that of the State as a whole. Its virtues and its deficiencies are ours, and I claim them as our own.

Our civilization in North Carolina is primarily rural. Both the strength and the weakness of our democracy lie in this fact. We are saturated with a sense of equality. We stand unabashed in kingly presences. We revel in assured freedom. We have a fierce passion for self-government. We have always held high the spirit of revolt against centralized power, and we have been quick to wrest from tyranny its crown and scepter. All of which is magnificent. But we are learning that untaught and unrestrained individualism needs to develop into the wisdom and power of safe self-government. The civic and social mind supplants the personal and individual view of life all too slowly everywhere.

1 Adapted from "Extension Bureau Circular, No. 2," University of North Carolina. 
Our dwellers in the open eountry number $1,700,000$, and they average only thirty-nine to the square mile.

The ills attendant upon sparsity of population in rural regions are soeial isolation and insulation, raueous individualism, illiteraey, suspicion, soeial aloofness, lack of organization and eooperative enterprise; but our mountain people suffer from these deficiencies not a whit more than the people in definite areas of the tide-water eountry and in the State at large.

Everywhere in thinly settled eountry regions we find people here and there who are suspicious, seeretive, apathetie, and unapproaehable; who live in the eighteenth eentury and preserve the language, manners, and eustoms of a past long dead elsewhere, who prefer their primitive, aneient ways, who are ghettoed in the midst of present-day eivilization, to borrow a phrase from President Frost. They are the erab-like souls deseribed by Vietor Hugo in "Les Miserables," who before advaneing light steadily retreat into the fringe of darkness. People like these abound in Clinton and Franklin eounties (New York) where an eighth of the native white voters are illiterate, in Aroostook County (Maine) where nearly a fifth of the native white voters eannot read their ballots or write their names; in Windham County (Connectieut), where an eighth of the white males of voting age are illiterate. Windham, by the way, lies midway between the academic effulgence of Yale on the one hand and of Harvard on the other. You ean find within the sound of eollege bells anywhere what we found the other day in a field survey that took us into every home in a mid-state eounty in North Carolina - a family of whites all illiterate, half the ehildren dead in infaney, and never a doetor in the louse in the whole history of the family.

All the ages of raee history and every level of eivilization ean be found in any county or eommunity, even in our erowded eenters of wealth and culture. We need not hunt for eighteenth century survivals in mountain coves alone.

We shall not make headway in well-meant work in the mountains unless we ean bring to it what Giddings calls a conseiousness of kind. We need to be less aware of pieturesque, amusing, or distressing differences, and more keenly eonscious of the kinship of the mountain people with their kind elsewhere and 
everywhere. Otherwise we shall bring to noble effort in the mountains a certain disabling attitude that is fatal to sucecss.

And so over against the types we find in the pages of Craddock, Fox, Kcphart, and the rest, let us sct the mountain people as thcy are related to the civilization of which they are a part. I therefore urge upon your attention the fact that they are not more poverty-stricken, nor more lawless and violent, nor more unorganizable than the democratic mass in rural North Carolina.

1. In the first place and quite contrary to popular notions, our mountains are not a region of wide-spread poverty. In per capita rural wealth Alleghany is the richest county in North Carolina. Among our 100 counties, five highland counties rank 1st, 5th, 6th, 13th, and 14th in the order named, in the per capita farm wealth of country populations; and two more arc just below the state average in this particular. The people of these counties are not poor, as country wcalth is reckoned in North Carolina. They dwell in a land of vegetables and fruits, grain crops, hay and forage, flocks and herds. It is a land of overflowing abundance. It is not easy for such peoplc to fecl that they are fit subjects for missionary school enterprises. As a matter of fact, they need our money far less than they need appreciative understanding and homebred leadership. Their wealth is greater than their willingness to convert it into social advantages. They need to be shown how to realize the possibilities of their own soils and souls. Mountain civilization, likc every other, will rise to higher levels when the pcople themselves tug at their own boot-straps; and there is no other way.

Approaching the poverty of our mountain pcople from another angle, let is consider indoor pauperism in 11 mountain counties that maintain county homes or poor houscs. The 1910 Census discloses an average rate for the United States of 190 almshouse paupers per 100,000 inhabitants. In North Carolina the rate was 96 ; in these 11 highland countics it was only 79. Six of the mountain counties make a far better showing than the State at large.

But we may make still another and better approach to the subject of poverty in our mountains by examining the outside pauper rates; better, because outside help is less repugnant to the feelings than residence in the poor house. In 1914 the state 
rate for outside pauperism was 234 per 100,000 inliabitants. In 12 highland eountics the average rate was 205 . Seven of the eounties have rates far smaller than the state average, ranging from 35 in Mitchell to 184 in Cherokee; three are just below the state average; and only two are near the bottom.

It ought to be elear that poverty in the mountains of North Carolina is actually and relatively less than elsewhere in the State. Here both indoor and outside paupers in 12 eounties in 1914 numbered only 559 in a population of 209,000 souls.

2. In the seeond plaee, illiteraey among native whites in our mountains is not more distressing than white illiteraey elsewhere in the State. The average rate for the mountain region is 15.1 per eent., due to exeessive white illiteraey rates in eight eounties. More than one-seventh or $\mathbf{1 5 . 1}$ per eent. of all the white people ten years old and older in 17 mountain eounties are illitcrate. It is appalling; but the fact that nearly oneeighth of all the white people of these ages the whole State over are illiterate is also appalling. But nearly one-fifth or 18.5 per eent. of all our people, both races eounted, are illiterate; and this faet is still more appalling. There is eomfort, however, in the further fact that with a single exception North Carolina led the Union in inroads upon illiteraey during the last eensus period, and we are running Kentueky a elose seeond in Moonlight Schools.

Our mountain people are not peeuliar, even in their illiteraey: Sparsely settled rural people are everywhere apt to be fiercely individualistic, ineapable of coneerted effort, and unduly illiterate; both behind and beyond mountain walls, in New York State, Maine, Connecticut, and North Carolina alike. The problems of developing democraey in our highlands, I repeat, are state-wide, not merely regional. They eoneern a sparsely settled rural population, socially insulated, fiereely individualistie, unduly illiterate, unorganized, and non-soeial, both in the mountains and in the State at large.

3. For instanee, the bad eminenee held by North Carolina in lomieide rates among the 24 states of the registration area is due to the slow soeialization of a population that is still nearly fourfifths rural. In 1913, we led the registration states with an urban rate of 274 homicides per million inlıabitants, and a rural 
rate of 173, against a general rate of 72 in the registration area. I may say in passing that Virginia, Kentueky, and North Carolina are the only southern states in the registration area, and that 24 states are all told still on the outside.

Town rates are higher than eountry rates in twenty-one states, largely beeause the steady eityward drift of eountry people introduees into the organized life of Ameriean towns an element that is slow to learn the lessons of soeial adjustment. On the other hand, the high spirited retreat into inaeeessible eoves before advaneing eivilization. They elimb into the high levels of the Great Smokies in Haywood, Swain, and Graham, where they settle personal diffieulties in the highland style of primitive times. These eounties lead the mountain region in homicide rates. These are the people, by the way, among whom Kephart dwelt and who eolored his impressions of our entire mountain eivilization. But just as might be expeeted, three of our lowland eounties have just as fearful reeords. No, our Highlanders are not peeuliar even in their fieree and fiery individualism. II uman life is just as safe west of the Ridge as east of it.

4. Kephart urges that the mountain people eannot pull together, exeept as kinsmen or partisans. "Speak to them of eommunity interests, try to show them the advantages of coöperation," says he, "and you might just as well be proffering adviee to the North Star. They will not work together zealously even to improve their neighborhood roads." But these are the faults of sparsely settled rural populations in the mountains and on the plains alike. Nothing eould be worse, for instanee, than the country roads of southern Illinois in the bad winter seasons. Failure to organize and eoöperate is the eardinal weakness of eountry people everywhere.

True, there were no improved eountry roads in four eounties west of the Ridge on January 1, 1915; but also, four neighboring eounties in the Albemarle eountry fall into the same category. Thirty-one of our eounties in 1914 had ten per eent. or less of their publie road mileage improved. Seven of these were west and twenty-four were east of the Blue Ridge. Five mountain counties are among the forty eounties that made the best showing in the State in improved publie road mileage in 1914. Avery, a mountain eounty with no improved roads in the last 
report, is now spending $\$ 150,000$ in road construction. Our mountain eounties are falling into line about as rapidly as other sections of the State. And North Carolina is doing well in highway building. In 1914 she stood ahead of twenty-nine states in per cent. of surfaced roads, and outranked thirty-two in the expenditure of road funds locally raised.

5. As a last word in my attempt to show that our mountain conditions and problems are state-wide conditions and problems, let us consider the investment made by our Highlanders in their sehools and children; say, their per capita investment in country sehool property in the eensus year. In 1910 it was only $\$ 1.86$ per rural inhabitant. But then, it was only $\$ 2.08$ the whole State over. Seven mountain counties were well above the state average with per eapita investments ranging from $\$ 2.56$ in Swain, one of the threc poorest eountics in the State, to $\$ 4.56$ in Transylvania.

Our mountain counties are moving forward in rural school property about as rapidly as the rest of the Statc. Bctwcen 1900 and 1914 the value of such property in seventeen highland counties rose from $\$ 408,000$ to $\$ 637,000$, an increase of 56 per cent., against an increase of 45 per cent. in the State at large. Ashe and Yancey more than doubled their investments in rural school property during these four years. In Cherokee the investment was more than trebled. And it is proper to add that under the superb leadership of Hon. J. Y. Joyner, the State Sehool Superintendent, our State as a whole has made marvelous gains during the last ten years in the education of all our people. As a matter of fact, these gains make a story of unparalleled achicvement.

The mountain people I know are democratic by nature, high spirited, self-reliant, and proudly independent. They scorn charities, and secnt patronage afar. They are not a weakling people. They are sturdy and strong in character, keenly responsive to fair treatment, kind hearted and loyal to friends, quiek to lend help in distress; and salted unto salvation by a kcen sense of humor.

They are not a submerged race. They are not down and out, after a hand to hand struggle with advaneing civilization. They are not vietims of soeial mal-adjustment. They are, as yet, the 
unadjusted. They are not decadents like the country people in the densely populated industrial areas of the North and East. They are a eoming, not a vanishing race. Their thews and sinews are strong, their brains are nimble and eapable, and at bottom they are sane and sound, healthsome and wholesome, in wind and limb, body and soul. They are a hopeful element in developing democraey in North Carolina. There is immense lifting power in the people of our hill eountry. They need, to be sure, to be organized for eeonomie, civie, and soeial effieiency; but this need is state-wide, not merely regional.

The Highlanders have long been a segregated, unmixed ethnie group-a homogeneous mass without organic unity. Miss Emma Miles, lerself a mountaineer, says in "The Spirit of the Mountains," "There is no sueh thing as a eommunity of mountaineers. Our people are almost incapable of eoneerted action. We are a people yet asleep, a race without conseiousness of its own existcnee." All of which means that herc is a social mass that laeks soeial solidarity. It lacks the unity in variety and the variety in unity that soeial development demands in any group of people.

A fundamental need in the mountains is an influx of new people with new ideas and cnterprises. The homogeneity of our Highlanders has long been a liability, not an asset. Appalaehia needs the mingling of raee types. The English Midlands offer an illustration in point. Here is where the Cymric, Pictish, and Irish tribes of Celts struggled for long eenturies witl the AngloSaxons, Danes, and Seandinavians. Here they fillally coaleseed, and here is the seed-bed of national supremacy in intellect. Here is the England of Shakespeare, Maeaulay, Ruskin, and George Eliot, Hogartl, Turner and Burne-Jones, Watt, Hamilton, and Farraday.

But a new era is at hand in our hill eountry. Industrialism is rapidly invading and oceupying this region. The timber, mineral, and water power treasures of the mountains have at last challenged the attention of organized big business. The blare of steam whistles, the boom of dymamite, the whir of maehinery, the miracle of electrie lights and telephones, the bustle of business in growing cities announee an eeonomic revolution in our mountain eountry. Industrial enterprises will introduee the 
needed elements of population. They demand railway connections with the outside world. Automobiles in increasing numbers demand improved public highways. This economic revolution will mean better schools, stronger newspapers, another type of religious consciousncss, and a more liberal social life. The industrial transformation of Appalachia has begun, and the next generation of Highlanders will be well in the middle of this new era.

We ought to keep clearly in mind a concern of primary importance to the mountain people. The question, says President Frost, is whether the mountain people can bc enlightened and guided so that they can have a part in the development of their own country, or whether they must give place to aliens and melt away like the Indians of an earlier day.

That is to say, both the church and the school problems are fundamentally economic and social. The highest values, of course, are spiritual. As invading industrialism turns into gold the natural resources of these mountains, will it enhance the value of their largest asset-the men and women of the hill country?

\section{THE RURAL NEGRO AND THE SOUTH ${ }^{1}$}

\section{BOOKER T. WASHINGTON}

OF the nine million Negroes, or nearly that number, in the South, about seven million are in the rural districts. They are on the farm, the plantation, and in the small town. - They include 80 per cent. of the whole Negro population in the South, the great bulk of the Negro population in $\Lambda$ merica, in fact. Of this seven million it is safe to say that $2,200,000$ persons are actually working, either as hired liands, tenant farmers, croppers, or renters and independent owners, upon the land. This number includes women and elildren, for, on the farm and the plantation, the unit of labor is not the individual but the family, and in the South to-day Negro women still do a large part of the work in the fields.

1 Adapted from "Proceedings of the National Conference of Charities and Corrections," Memphis, Teun., May, 1914, pp. 121-127. 
People who live in the cotton growing States know that a very large part of the business of those states is based on the Negro and the mule.

In the South, when a planter wants to borrow money, he finds his credit at the bank is usually determined by the number of reliable Negro tenants he can control; business is based on labor. In other words, the value of the land and of all that goes with it and depends upon it, is determined very largely, more largely, perhaps, than is true of any other part of the country, by the character and quantity of the labor supply.

The two million and more Negroes who are cmployed in agriculture in the Southern States have in their hands, either as renters or as owners, 40 per cent. of the tillable land. Something like $100,000,000$ of the $150,000,000$ acres of improved land is cultivated by Negro labor, and of every eleven bales of ectton produced in the South, seven are raised by Negroes.

The Negro is here and he is likely to remain. First, because after something like three hundred years he has adapted himself to the country and the people; because experience has taught him that, on the whole, the vast majority of the Negroes are more at home and better off in the agricultural regions of the South than they are likely to be in any other part of the world; and finally because the Southern white man does not want him to go away. You may say what you please about segregation of the races, but when there is work to be done about the plantation, when it comes time to plant and pick the cotton, the white man does not want the Negro so far away that he cannot reach him by the sound of his roice.

At the present time Negroes in the rural districts represent, in some respects, the best portion of the Negro race. They are for the most part a vigorous, wholesome, simple-minded people. They are, as yet, almost untouched by the vices of city life, and still maintain, on the whole, their confidence in the good will of the white people by whom they are surrounded.

These seven million people represent, therefore, tremendous possibilities for good and for evil to themselves, and the community in which they live. From an economic view alone, this large actual and potential labor force represents a vast store of undeveloped wealth, a gold mine of productive energy, in fact. 
Imported to this country at an enormous cost in suffering and in money; trained and disciplined during two hundred and fifty years of slavery, and now waiting to be developed, under the influences of free institutions, the Negro is one of the great natural resources of this southern community. This being so, the prospcrity of the South is very largely bound up with the latent possibilities of the Negro. Just in proportion as he beeomes an cfficient farmer and a dependable laborer, just to that extent will the whole country move forward and prosperity be multiplied.

If Negro labor is to become more efficient, every effort should be made to eneourage rather than to discourage the Negro in his ambition to go forward, to buy land and plant himself permanently on the soil. In the long run the planter will not suffer from the existenee in his neighborhood of Negro farmers who offer an example of thrift and industry to their neighbors. For example, Maeon County, in which I live, was the only one of the Blaek Belt counties of Alabama which showed an increase of Negro population in the decade from 1900 to 1910 . The reason was that a speeial effort had becn made in that county to improve the publie schools and this brought into the county a large number of progressive farmers who were anxious to own homes in the neighborhood of a good school.

G. W. MeLeod, who owns a large traet of land in Maeon County, Alabama, is a good example of the white planter who treats his tenants well. Mr. MeLcod belicves in having a good school in the community, so he gave an aere of ground upon which the school house was built and $\$ 100$ in addition to help put up the $\$ 700$ school house. He deeded the land to a set of colored trustees. Mr. MeLeod also offers annual prizes for the best kept stock, best kept houses, best cared for children, best attendance at Sunday school and church. The man or woman guilty of taking intoxieating liquors or engaging in family quarrels is not eligible to prizes and must go at the end of the year.

Mr. MeLeod by this method of dealing with his tenants has little if any trouble in finding profitable tenants for his lands. Not only does he find that this poliey pays in eash, but he has the satisfaction of sceing around him people who are prosperous 
and contented, who are every year making progress, who are growing in intelligence, ambition and the knowledge of all those things which make life worth living.

From direct investigation I find that many valuable colored laborers leave the farm for the reason that they scldom see or handle eash. The Negro laborer likes to put his hands on real money as often as possible. In the city, while he is not so well off in the long run, as I have said, he is usually paid off in eash every Saturday night. In the country he scldom gets cash oftener than once a month, or once a year. Not a few of the best colored laborers leave the farms because of the poor houses furnished by the owners. The condition of some of the oneroom cabins is miserable almost beyond description. In the towns and cities, while he may have a harder time in other respects, the colored man can usually find a reasonably comfortable house with two or threc rooms.

No matter how ignorant a colored man may be himself, he almost always wants his children to have education. A very large number of colored laborers leave the farm bccause they can not get an education for their children. In a large section of the farming district of the South, Negro schools run only from two to five months in the year. In many eases children have to walk miles to reach these schools. The school houses are, in most cases, wretched little hovels with no light or warmth or comfort of any kind. The teacher receives perliaps not more than $\$ 18$ or $\$ 25$ a month, and as every school supcrintendent knows, poor pay means a poor teacher.

In saying this, I do not overlook the fact that conditions are changing for the better in all parts of the South. White people are manifesting more interest cach year in the training of colored people, and what is equally important, colored people are beginning to learn to use their education in sensible ways; they are learning that it is no disgrace for an educated person to work on the farm. They are learning that education which does not somehow touch life is not cducation at all. More and more we are all learning that the school is not simply a place where boys and girls learn to read and cipher; but a place where they learn to live. We are all learning that education which does not somehow or other improve the farm and the home, which 
does not make a return to the eommunity in some form or other, has no justifieation for its existenee.

The possibilities of the Negro farmer are indieated by the progress that he has made in fifty years. In 1863 there were in all the United States only a few farms owned by Negroes. They now (1910) operate in the South 890,140 farms which are 217,800 more than there were in this seetion in 1863 .

Negro farm laborers and Negro farmers in the South now eultivate approximately $100,000,000$ aeres of land, of which 42 ,500,000 acres are under the control of Negro farmers. The inerease of Negro farm owners in the past fifty years eompares favorably with the increase of white farm owners. The Negroes of this country now own $20,000,000$ aeres or 31,000 square miles of land. If all the land they own were placed in one body, its area would be greater than that of the state of South Carolina.

The Negro has made his greatest progress in agrieulture during the past ten years. From 1900 to 1910 the total value of farm property owned by the eolored farmers of the South inereased from $\$ 177,404,688$ to $\$ 492,898,218$, or 177 per cent.

In view of all this it seems to me that it is the part of wisdom to take hold of this problem in a broad, statesmanlike way. Instead of striving to keep the Negro down, we should devote the time and money and effort that is now used for the purpose of punishing the Negro for erimes,-eommitted in many instanees beeause he has been negleeted and allowed to grow up in ignoranee without ambition and without hope-and use it for the purpose of making the Negro a better and more useful eitizen.

\section{FOLLOWING TIIF COLOR LINE ${ }^{1}$}

\section{RAY STANNARD BAKER}

Generaldy speaking, the sharpest raee prejudiee in the South is exhibited by the poorer elass of white people, whether farmers, artisans or unskilled workers, who come into active eompetition with the Negroes, or from politieians who are seeking

1 Adapted from "Following the Color Line," American Magazine, 04: 381-393, July, 1907. 
the votes of this elass of people. It is this element which has driven the Negroes out of more than one eommunity in the Soutl and it eommonly forms the lynching mobs. A similar antagonism of the working elasses exists in the North wherever the Negro has appeared in large numbers.

On the other hand, the larger land owners and employers of the South, and all professional and business men who hire servants, while they dislike and fear the Negro as a race (though often loving and proteeting individual Negroes), want the blaek man to work for them. More than that, they must have him: for he has a praetieal monopoly on labor in the South. White men of the employing elass will do almost anything to keep the Negro on the land and his wife in the kitehen-so long as they are obedient and unambitious workers.

But I had not been very long in the black belt before I began to see that the large planters-the big employers of labor-often pursued very different methods in dealing with the Negro. In the feudal Middle Ages there were good and bad barons; so in the South to-day there are "good" and "bad" landlords (for laek of better designation) and every gradation between them.

The good landlord, generally speaking, is the one who knows by inheritanee how a feudal system should be operated. In other words, he is the old slave-owner or his deseendant, who not only feels the aneient responsibility of slavery times, but believes that the good treatment of tenants, as a poliey, will produce better results than harshness and force.

The bad landlord represents the degeneration of the feudal system: he is in farming to make all he can out of it this year and next, without referenee to human life.

Conditions in the blaek belt are in one respeet mueh as they were in slavery times, or as they would be under any feudal system: if the master or lord is "good," the Negro prospers: if he is harsh, grasping, unkind, the Negro suffers bitterly. It gets baek finally to the white man. In assuming supreme rights in the South, politieal and industrial, the white man also assumes tremendous duties and responsibilities; he eannot have the one without the other; and he takes to himself the pain and suffering which goes with power and responsibility.

Of eourse, seareity of labor and high wages have given the 
really ambitious and industrious Negro his opportunity, and many thousands of them are becoming more and more independent of the favor or the ill-will of the whites. And therein lies a profound danger, not only to the Negro, but to the South. Gradually losing the support and advice of the best type of white man, the independent Negro finds himself in eompetition with the poorer types of white man, whose jealousy he must meet. He takes the penalties of bcing really free. Eseaping the exactions of a feudal life, he finds he must meet the sharper diffieulties of a frce industrial system. And being without the political rights of his poor white competitor and wholly without social recognition, discredited by the bestial erimes of the lower class of his own race, he has, indeed, a hard struggle before him. In many neighborhoods he is peeuliarly at the mercy of this lower class white electorate, and the self-seeking politicians whose stock in trade consists in playing upon the passions of race-hatred.

When the Negro tenant takes up land or hires out to the landlord, he ordinarily signs a contraet, or if he eannot sign (about half the Negro tenants of the black belt are wholly illiterate) he makes his mark. He often has no way of knowing certainly what is in the eontract, though the arrangement is usually elearly understood, and he must depend on the landlord to keep both the rent and the supply-store aecounts. In other words, he is wholly at the planter's merey - a temptation as dangerous for the landlord as the possibilitics which it presents are for the tenant. It is so easy to make large profits by eharging immense interest pereentages or outrageous prices for supplies to tenants who are too ignorant or too weak to protect themselves, that the stories of the oppressive landlord in the South are scarcely surprising. It is casy, when the tenant brings in his eotton in the fall not only to underweigh it, but to eredit it at the lowest priees of the week; and this dealing of the strong with the weak is not Southern, it is human. Such a system has encouraged dishonesty, and wastefulness; it has made many landlords eruel and greedy, it has inereased the helplessness, hopelessness and shiftlessness of the Negro. In many eases it has meant downright degeneration, not only to the Negro, but to the white man. These are strong words, but no one ean travel 
in the blaek belt without seeing enough to eonvinee him of the terrible eonsequences growing out of these relationships.

I made inquiries as to why the Negroes wanted to leave the farms and go to eities. The answer I got from all sorts of sourees was, first, the laek of sehooling in the eountry; and, seeond, the laek of proteetion.

And I heard also many stories of ill-treatment of various sorts, the distrust of the tenant of the landlord in keeping his aeeounts-all of whieh, dimly reeognized, tends to make many Negroes escape the eountry, if they ean. Indeed, it is growing harder and harder on the great plantations, espeeially where the management is by overseers, to keep a suffieient labor supply. In some places the white landlords have begun to break up their plantations, selling small farms to ambitious Negroes-a signifieant sign, indeed, of the passing of the feudal system. Commenting on this tendeney, the Thomaston Post says :

"This is, in part, a solution of the so-ealled Negro problem, for those of the race who have property interests at stake eannot afford to antagonize their white neighbors or transgress the laws. The ownership of land tends to make them better eitizens in every way, more thoughtful of the rights of others, and more ambitious for their own advaneement. The tendeney towards eutting up the large plantations is beginning to show itself, and when all of them are so divided, there will be no agricultural labor problem, exeept, perhaps, in the gathering of an espeeially large erop."

\section{BIBLIOGRAPHY}

\section{THE SOUTH}

Branson, E. C. Farm Life Conditions in the South. Chapel Hill,

N. C. The Churcli as a Country Life Defense.

Branson, E. C. Rural Life in the South. Am. Statistical Ass'n., Pub. 13: 71-75, March, 1912.

Brooks, Robert P. The Agrarian Revolution in Georgia, 1865-1912. Univ. Wis., Madison, Hist. Series, Vol. 3, No. 3.

Bruce, P. A. Economic History of Virginia, in the Seventeenth Century. Macmillan, N. Y., 1896.

Bruce, P. A. The Rise of the New South. Barrie, Philadelphia. The Hist. of North America, V. 17, 1905.

Bogart, E. L. The Economic History of the United States. Longmans, N. Y., 1907.

Cable, George W. Old Creole Days. Scribner, N. Y., 1907.

Cable, George W. The Creoles of Louisiana. Scribner, N. Y., 1834. 
Coulter, John Lee. The Rural South. Am. Statistical Ass'n., 13:4558, March, 1912.

DuBois, W. E. The Rural South. Am. Statistical Ass'n., 13:80-4, March, 1912.

Dunning, W. A. Essays on the Civil War and Reconstruction. Macmillan, N. Y., 1898.

Dyer, G. W. Southern Problems that Challenge our Thonght. Southern Sociological Congress Proceedings, pp. 25-37, Nashville, Tenn., 1912.

Frissell, H. B. Southern Agrieulture and the Negro Farmer. Am. Statistical Ass'n., 13: 65-70, March, 1912.

Glasson, Wm. H. Rural Conditions in the South. Am. Statistical Ass'n., 13: 76-79, March, 1.912.

Gray, Lewis. Southern Agriculture, Plantation System and the Negro Problem. Annals, 40:90-99, March, 1912.

Hale, Louise Closser. We Discover the Old Dominion. Dodd, N. Y., 1916.

Haney, Lewis H., and Wehrwein, George S. A Social and Economic Survey of Southern Travis County. Univ. of Texas Bul., 65, Austin, 1916.

MacClintock, S. S. The Kentucky Mountains and Their Feuds. Amer. Jour. of Soc., $7: 171-187$. September, 1901.

Page, Walter H. Journey Through the Southern States. World's Work, 14:9003-9028, June, 1907.

Kephart, Horace. Our Southem Highlanders. Macmillan, N. Y., 1913.

Olmstead, Frederick L. The Cotton Kingdom. Mason, N. Y., 1862.

Olmstead, Frederick L. Journey in the Seaboard Slave States. Putnam, N. Y., 1904.

Page, Thomas Nelson. Red Rock. 'Seribner, N. Y., 1898.

Southern Agrieulture, its Conditions and Needs. Pop. Sei. Mo., 64: 245-261, Jalluary, 1904.

Southern Soc. Congress. Proceedings. Nashville, Tenn.

Stone, A. II. Studies in the American Race Problem. Doubleday, Garden City, 1908.

Vincent, George E. A Retarded Frontier. Amer. Journal Sociology, $4: 1-20$, July, 1898.

Waldo, Frank. Among the Southern Appalachians. New England Mag., 14:231-247, n. s., May, 1901.

\section{THE NEGRO}

Baker, Ray Stannard. Following the Color Line. Doubleday, Page \& Co., Garden City, 1908.

Commons, John R. Races and Immigrants in America. The Macmillan Company, N. Y., 1908.

DuBois, W. E. B. The Souls of Black Folk. A. C. MeClurg \& Co., Chicago, 1907.

Douglass, H. Paul. Christian Reconstruetion in the South. The Pilgrim Press, Boston, 1909.

Dunbar, Paul Laurenee. Lyries of Lowly Life. Dodd, Mead \& Co., N. Y., 1896. 
Hart, Albert Bushnell. The Southern South. Appleton, N. Y., 1910. Haynes, George Edmund. The Negro at Work in New York City, a Study in Economic Progress. Columbia Univ. Studies in History, Economies, and Public Law, Vol. 49, No. 3 (Whole No. 124), N. Y., 1912.

Horwill, Herbert W. Negro Exodus. Contemporary Review, 114: 299-305, Sept., 1918.

Miller, Kelly. The Negro's Part in Racial Coöperation in the Community. Conf. Social Work, 1918, pp. 4S1-S5.

Negro Education. U. S. Bur. of Ed. Bul., 1916, Nos. 38 and 39, Vols. I and II.

Negro Migration in 1916-17. Bul. U. S. Dept. of Labor, Div. of Negro Economies, Gov't. Printing Of., Washington, 1919.

Negro Rural School and its Relation to the Community. The Extension Department, Tuskegee Normal and Industrial Institute, Tuskegee, Ala., 1915.

Wolfe, Albert B. The Negro Problem in the United States. In Readings in Social Problems, Book V. Grim \& Co., Boston, 1916. 


\section{CHAPTER IV \\ THE IMMIGRANT IN AGRICULTURE}

\section{IMMIGRATION IN AGRICULTURE ${ }^{1}$}

\section{JOHN OLSEN}

AT the beginning of the nineteenth century the United States found itself in possession of vast undeveloped resources, which . were tremendously increased by successful purchases and annexations in the course of the century. To secure the rapid development of these resources the government not only threw them open to unrestricted development by private enterprise but even encouraged such development by public assistance. As a result of such a policy public lands of apparently unlimited extent and enormous fertility were offered to any one at a nominal expense. Later the land acts were multiplied so that any individual could obtain 480 acres of virgin territory. Furthermore this policy of cncouraging private enterprise led to the extension of the means of communication so that these not only accompanied but in many cases preceded the growth of the settlement. Thus access to the splendid public demesne was assured.

The temptation to enter premises so promising could not be suppressed by the unfavorable attitude at first assumed by forcign governments. Consequently a steady stream of immigrants commeneed flowing into this country. Even thougl separated by political boundaries the English, Scotch, Wclsh, and Irish still felt that the states were peculiarly their own. Soon the wanderlust of the Germans, the Dancs, the Swedes, and the Norwegians led them to the same destination. There were also some Swiss and Dutcli and a few from southern and eastern Europe in this first wave which we shall designate the Old Immigration.

1 Adapted from a paper prepared lyy a graduate student in the Editor's Class in the University of Minnesota, summer 1917. 
Of the motives whieh aetuated this immigration, the religious and politieal, which liad been very important, were rapidly diminishing in influcnee. In gencral, hard times in their own eountry, duc to erop failures and fluctuations in industry preeeded the great waves of emigrants. This statement applies principally to Ireland and Scandinavia although there were serious erop failures in Germany, for example the one in Baden in 1825. The famines in Ireland, however, surpassed all. The first one oceurred in 1826. Far more serious was the one duc to potato rot in 1846-7. As a result emigration and death reduced the population 50 per eent.

At the same time the gencral prosperity, whieh, with the exeeption of brief periods designated as panies, eontinued uninterruptedly throughout the century in this country, presented an attractive antithesis. The liberality of our land laws invited any foreigner to become a partaker of our prosperity sinee they afforded him the opportunity either of securing a farm of his own or of employment at good wages. The tariff, the invention of new machinery, and the rapid development of new industries were auxiliary forces tending at least temporarily to the betterment of the conditions of the laborers. The increasing facilities of eommunication enabled the foreigner to compare the opportunities of the New World with those of the Old. Advertising campaigns by the states and especially by private enterprises, such as steamship companies, railways, and other American industrial organizations, which previous to the passage of the Anti-Contraet Immigration Law were absolutcly unrestricted, tended to ereate a favorable impression. Most influential of all were letters from countrymen already in America.

Of course there were also a number of other auxiliary causes. Such were the improved facilitics of reaching our country, the financial assistance which forcigners settled liere could render ill enabling relatives to eome, and the dread eaused by wars and epidemies in the densely populated communities of Europe. Back of all these, however, lay the prime psychological instinct which has been baek of all Teutonic migrations in historieal times, the desire for adventure-the Tcutonic wanderlust.

Of these immigrants a relatively: large percentage engaged in agrieulture. Of the total number of males of foreign origin 
about 30 per eent. belong to the English-speaking raees. They are distributed fairly equitably throughout the North Central, Eastern, and Western states although their main strength is in the first group. This distribution is also true of the Germans. They are the most important people belonging to this group, ineluding 775,175 males or 28 per cent. out of a total of 2,105,766. In direet contrast. are the Seandinavians, of whom a far greater pereentage, 44 per eent. of the Dalles and 50 per eent. of the Norwegians, are engaged in agrieulture. Although found throughout all of the above-mentioned seetions, by far the greatest pereentage of those engaged in agrieulture are found in the North Central states. This eoneentration is most marked in the ease of the Norwegians, of whom 97 per eent. of those in agrieulture are found in that seetion and Washington. Their total number is only 140,000 . Nevertheless by further eoneentration in Wiseonsin, Minnesota, North Dakota, South Dakota, Illinois, and Iowa within the North Central seetion they transform those states into a veritable Norway in Ameriea. The Danes, on the other hand, seatter so that it is diffieult to point out a single large and well-defined Danish settlement, while the Swedes may be termed the eompromisers, neitlier seattering as mueh as the Danes nor conecntrating as mueh as the Norwegians. These settlers were further reinforeed by a few Ieelanders. The natives assumed a by no means favarable attitude towards those who were entering into eompetition with them; but the neweomers were on a quest for homes which nothing exeept absolute prohibition could prevent. In this seareh the similarity of conditions in the various seetions of Ameriea to those of their former habitats was their prineipal guide. Thus the Germans seleeted the timber lands of the Northwest; the Norwegians the rough and hilly lands; the Irish the well-watered meadows. This eoneeption that agrieulture in Ameriea must necessarily resemble their own in Europe was not always fortunate. Sinee agrieultural eonditions in Ireland were wretehed, it deterred a large number of the Irish from going on the land. As a result only 354 out of every 10,000 Irish own farm homes while 611 of the Germans, 717 of the Seandinavians, and 721 of the British do. The immigrants were, of course, influeneed by other considerations also. Some lad 
friends or relatives in certain localities. Industrious land agents were always portraying the splendid advantages of the sections in which they were interested. The building of the railways facilitated immigration both by providing better markets and also by familiarizing laborers with the conditions in the unsettled sections. Sometimes events which ought to be condemned had fortunate results. During the canal mania Illinois became virtually bankrupt. As a result it paid its Irish laborers with so-called canal scrip. The only thing for which this was acceptable was land. Consequently a number of the Irish invested in land and became permanent settlers.

The presence of the Negro in the South caused the foreigners to avoid that section. It is only in recent years that the increasing demand for labor in order that the South may develop its resources has met with any distinct response. Of those that are testing the possible opportunities there the Swedes, Germans, and Irish are foremost. The exhaustion of the public demesne forces the immigrants into such new channels. Thus the neglected and abandoned lands of the Middle Atlantic and New England states are now being put into cultivation. Among those who utilize this opportunity the Irish, Swedes, Finns, Norwegians, Dutch, Germans and Poles are the leaders.

The success of these settlers has depended largely on the type of settlement formed. The joint stock company proved a failure in promoting settling. Money-making and colonization would not go together. Communistic enterprises also proved ephemeral. More promising were the religious, philanthropic, and national enterprises, especially when they were provided with ample funds. In the case of the Irish, the Catholic church tried to promote colonization. A priest was the first sent so as to secure effective religions services. The Germans tried to dircet their emigrants to definite sections so that they might be Germanized. In case the expectation that the United States would break up had been realized those settlements would then have become independent states. The chief of these attempts centered in Wisconsin and Texas. All of these attempts failed, principally on account of mismanagement. Nor was it advisable in the earliest period for an immigrant to start out alone. Great suffering frequently resulted. The best plan was for the 
settlers to settle in groups, but each one independent of all the others. Germans and Scandinavians often did this following the instructions either of friends already settled in that locality or of an agent sent in advance to ascertain conditions there.

These settlers came from the agricultural sections of Europe. Consequently their success depended on their ability to adapt themsclves to American methods. That such success has been attained will be questioned by no one who has compared the rude conditions of the pioneer with those of to-day. Since the great majority settled in the North Central States, they engaged in general farming. In this type of farming the Scandinavians and Germans are leaders. The Danes are noted for their success in butter-making and dairying. The Scandinavians are more likely to waste the fertility of the land than the Germans, who maintain it through the rotation of crops and the application of fertilizers. Wisconsin is the example of German success just as Utah is of English. The fortunate choice of land contributed to German success while the Welsh suceeded in spite of an unfortunate choice. The success of the immigrant is by no means confined to general farming. The Germans raise grapes in California and carry on truck-raising and dairying in Georgia. Together with the Irish they raise rice and other southern products in Louisiana, Florida, and Alabama. The Scandinavians raise grapes in Alabama and truek and fruits in New Jersey. The German-Russians are especially successful in the bect sugar sections of Nebraska and the Swiss in the cheesc industry in Wisconsin. Those whom we ought to praise the most are the Dutch who undertake the reclamation of our lowlands. The best proof of the superiority of the foreign to the native farmer is that the latter is yielding. The Germans and Irisl are securing control of the farm lands of New Jcrsey, the Scandinavians are replacing the natives in Vermont, the Germans are replacing them in New York, and the Poles in Massachusetts.

The desirability of the immigrant does not, however, depend principally on his ability to aceumulate wealth. If such accumulation is accompanied by a lowering of the Amcrican standard of living, he is undesirable. Among our forcign settlers we find the food simple, the clothes cheap and coarse. These features seem incvitable in a frontier community. If, 
lowever, they are retained after the community passes the frontier stage, the settlers are undesirable. As soon, however, as the immigrants from northwestern Europe passed that stage, they eommenced imitating American customs. During the pioneer days any make-shift for a housc had to be satisfactory. Now substantial houses are found almost everywhere. The early settlers had to work exeessively hard to attain suecess. With the inerease of prosperity they have ceased to do this. A very influential reason that the Germans, Seandinavians, and certain minor groups of foreigners outdistanced the natives was that among the former the women and children did a great deal of outdoor labor. The generation born in this eountry do not put the women and ehildren in the fields. Thus in general the earlicr immigrants are conforming to Ameriean standards.

Foreigners on the farms are easily assimilated. The main faetor against assimilation is religion. This statement does not, of eourse, apply to the English-speaking peoples who belong in general to the same churcl as the natives. Other uationalities eouple their language very closely with their forms of worship. They therefore try to maintain sehools in their own language. Such attempts fail beeause of the preference on the part of the young for the English schools and also beeause a large number of the older people realize the paramount importanee of English. Attempts were made by the eonservatives to introduce their languages into the publie schools. With the exeeption of Ohio and Pennsylvania where the Germans succeeded in introdueing German such efforts have been failures everywhere. In the schools these peoples rank high. In fact the literaey of the Scandinavian immigrant has been higher than that of the Northerners as a whole. Their inclination is indicated by the-large number of Germans and Scandinavians who engage in edueational work. To obtain public land they liad to beeome naturalized. Later the questions of local government naturally aroused interest in politics. The Fnglish on aecount of their previous aequaintanee with our political eustoms exeelled. The others, however, were also used to fairly democratie institutions so that they were not at such a great disadvantage. But they have been rather indifferent in this respeet exeept where they have composed practically the entire population and therefore 
have been foreed to participate. The Germans, as a matter of faet, looked on polities as a burdensome duty. Many thought abstinenee from Ameriean polities ereditable on aeeount of the questionable charaeter of the methods employed. The one exeeption is the Norwegian. He is a natural politieian. He insists on his right to be reeognized, and where due reeognition is not voluntarily given he organizes to seeure it. The most ereditable feature of the engagement in polities of any of these foreigners is that they have generally worked for eleaner polities. Although with the exeeption of the Irish they are generally Republieans, they are by no means bound to the party. Exereising their right of independent thinking they make their vote depend on the issues.

The final eriterion of the desirability of the immigrant is his charaeter. The earlier immigrants were noted for their industry, ceonomy, and frugality. Upon their arrival in this eountry they frequently developed an initiative and self-relianee whieh had previously been entirely unsuspeeted. Even the Irish, although those of them who sought the eities have been denouneed severely, have proven very desirable on the farm. Furthermore ethnically nearly all of the earlier immigrants belonged to the same Teutonie stoek as the natives. The wearing off of the elannishness of the foreigner and the appreeiation by the Ameriean of his sterling qualities was followed by rapid assimilation.

During the greater part of the nineteenth eentury inadequate transportation facilities prevented a eonsiderable number of immigrants from southern and eastern Europe from entering the United States. Towards the elose of the eentury, these faeilities were improved so as to equal those from northwestern Europe. As a result, a vast number of inmigrants from the former seetions began to arrive. Simultaneously immigration from nortlwestern Europe deereased both beeause of the severe strain of the eompetition with the newer immigration and also beeause the settling of the United States and the industrial improvements of northwestern Europe had eliminated the advantages of the former. The turning point in immigration was about 1890. Sinee that time the bulk of the immigrants have been Jews, Italians, Portuguese, Poles, Boliemians, and Slovaks. 
With the exception of the Jew all of these are laboring under the most undesirable economic eireumstanees at home. Outof-date industrial organization together with the dense population makes the United States seem the Isle of Bliss. The Jew, on the other hand, although able through his innate shrewdness to attain an independent economic status, is prevented from doing so by the raeial and religious prejudices of the people. This is especially true of Russia and Rumania, from whieh we obtain the mass of our Jewish immigrants. That such emigration is not due to eeonomic hardships is perfectly elear in the case of the latter country, from which practically only Jews emigrate while the Rumanians remain at home.

That the Teutonie Americans would not look with as much pleasure upon the Slavs, Latins, and Jews as they did upon the entrance of the earlier immigrants who were of their own race ean be explained as being due to unconseiots race prejudiee. It can not be said that the reeent immigrant is very inferior morally. It is true that petty thefts oceur frequently in Italian settlements and that the number of lawsuits in Polish settlements is extraordinarily large. The latter faet is largely due to the preferenee on the part of the Poles to settle personal differenee involving trifling amounts in court rather than out of court as Amerieans do. None of the exeessive eriminal tendeneies which exist among these peoples in the eities extend to the rural eommunities. In these communities the Italians and Slavs utilize all their time and in the ease of farm owners and tenants every available inch of land. They are very frugal. The opposition they meet from business men may be largely due to their hesitation to spend. That they do not devote the land around their houses to trees and flowers, whieh is often explained as indieating a laek of the appreciation of beauty, may probably be just as much due to this characteristic whether we eall it frugality or parsimony. The Jew, on the other hand, meets a much heartier welcome from the business world on aceount of his inelination to spend. He is not as industrious as the Slavs or Italians. Even in the rural communities his trading propensity often causes him to devote a part of his time to it.

The deerease in the number of immigrants that engage in agrieulture may not be entirely due to the change in the type of im- 
migrants but also to economic changes in the United States in connection witl the exhaustion of the public demesne and the more intense industrial development. In fact this change had already commenced in the case of the earlier immigrants. For example a lower percentage of the Scandinavians engaged in agriculture after 1880 than before. To a large extent it is due to the foreigners' ignorance of the opportunities in agriculture, the uncertainty of the returns, and the isolated condition of American farm life. The friends and relatives of the recent immigrant are in the cities and thither he goes. With the exception of a few in Wisconsin we find the Italian farmers in New England, Middle Atlantic and Southern states, the Slavs are found in New England, Pennsylvania, and the East North Central and the West South Central states; the Jews in New England, New York, and New Jersey; and the Portuguese in Massachusetts and Rhode Island.

Most of these peoples have been in America too short a time to enable us to make definite conclusions as to their ability to conform to our customs. The third generation secms almost Americanized. Upon their entrance here they retain their typical food and clothes. Soon they find Old World styles and customs inconvenient and commence imitating the Americans. They seem content, however, with the cheapest and coarsest food and care little about its preparation. In selecting clothes they often retain their predilection for gaudy colors. Of course, the custom depcnds on the people. In general the Latins represent the lowest type, the Slavs the middle, and the Jews the highest. The Portuguese are considerably lower than the Italians. The Bohemians stand foremost among the Slavs, showing a distinct preferenec for good living and good clothes whenever they are financially able to afford them. The same general tendeneies are observed in the case of houses. The Portuguese, Italians, and a number of the Slavic peoples manage in shacks with gardens right up to the walls. The Bohemians and Jews are eager for more substantial dwellings. Many of these peoples eare for cleanliness and neatness neither outside or nor within their houses. Nevertheless the Portuguese on Martha's Vineyard, who are considered one of the lowest races in social standards, have wcll-kept gardens and even some flower's around their houses. 
One reason for the ill-prepared food and the lack of tidiness is undoubtedly that the women and children must work so mueh in the fields. The entire family spends all the available time outdoors. Their poverty compels this, consequently these eonditions are bound to continue until these peoples have aceumulated a surplus sufficient to afford them some leisure.

Another result of this hard work is the neglect of education, a tendeney furthered by an inclination to under-estimate its value. In their own eountries the educational facilities are very defieient, thus aecounting for the ligh pereentage of illiteraey among them. Since religion and education are very elosely assoeiated among them they prefer sending their ehildren to the Catholic parochial sehools in which a minimum emplasis is placed on English edueation. Furthermore they are not aecustomed to democratic institutions. Therefore it is not surprising that they take little interest in polities. No free public lands aet as a spur. Gradually but very slowly they are eommeneing to take interest in local affairs. Participation in these will undoubtedly broaden their eonecption until they extend their attention to state and national affairs. IIcre again lies a danger. Hitlıerto they have generally acted as a group,-following eertain leaders. If these leaders should liappen to be unserupulous, the result would be detrimental. The cxception is again the Jew. IIe realized the value of education, and sueeeds well in edueational lines. In polities he aets independently although goverued by a strong race-conseiousness.

On aceount of their poverty and the absence of free public lands, a large number of these immigrants become tenants and laborers. Practically all tlie Portuguese labor in the eranberry bogs where they have become almost indispensable. The Slavic laborer is very subservient while the Italian is inclined to shirk if he is not elosely supervised. Their type of agrieulture differs from that of the earlier immigrant with respect to the average aereage. A large number have five aeres or less while very few have eiglity which may be considered the minimum lolding of the earlier immigrant. On aecount of the smaller looldings there are also fewer general farmers. The agrieultural conditions of their own countries would lead us to expeet small seale farming. The products raised depend, of course, on the section in which 
they are loeated. They raise tobaceo, eotton, truek, and fruit. The Italian especially may be ealled the truek and fruit-grower. Their bank aeeounts are small beeause they invest their surplus in additional land. Consequently the steady growth in their aereage is an aecurate index to their prosperity. Suel prosperity is, however, due to lower standards of living rather than to improved methods of farming. They still prefer hand-labor to machinery. They make only slight use of fertilizers. Again the Jew is the exeeption. He is a farm owner and does not hesitate to invest in machinery and fertilizers. In fact he tends to go to the other extreme. His outlays are often unwise. Moreover, he likes to undertake side oecupations. As a result it frequently happens that he does not prosper on the farm. This eondition is the more surprising beeause he has had more outside assistance than any of the others. The best managed effort for that purpose has been the one finaneed by the Baron de Hirseh fund. In faet the Jew would probably never have attempted agrieulture to any eonsiderable extent if it had not been for these efforts. The result has been a few eolonies of rather impractieal farmers. Colonization efforts in the ease of the other immigrants have frequently been misinanaged and have failed unless eaeh one has been given sole possession of his property. Sueh settlements differ considerably from the group settlements of the earlier immigrants in that eaeh one is far more dependent on the others soeially.

Reeently the impression has been growing that too many undesirable immigrants are being admitted. To remedy this defeet a literaey test has been provided. The proteetion whieh such restrietive legislation will afford Ameriean eapital and labor will undoubtedly be temporary. Far more important is the question whether we ean assimilate the hordes whieh are entering. As indicated above, the nmmber entering has illereased so rapidly in the last few years that the result is doubtful. Nevertheless a literaey test does not seem the proper method of seeuring the result desired. It exeludes individuals who have not had an opportunity rather than those who laek ability. What is needed is a publieity burean to inform the immigrants of the best opportunities in this country. If any one is admitted without the neessary means to betake himself to the 
proper locality it is our moral duty to aid him. This publicity and distribution bureau would find no lack of opportunities for the immigrants. The density of the population of the Southern States to-day is very low compared with that of the Northern:
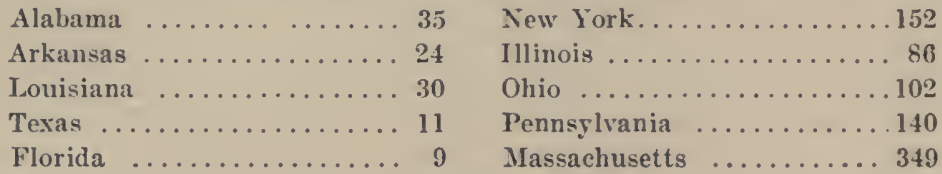

The wonderful resources of those States are almost untouclicd.

The forcigners are very welcome there. It would be unfair to the South to deprive her of these immigrants who would develop her agricultural resources merely because the North is more fully developed. In the West there are still $485,000,000$ acres of idle land. The East has its abandoned farms. If the results of a policy of internal distribution of the immigrant should prove unsatisfactory then it would be time to pass laws restricting immigration. In the meantime we should not forget America's great debt to the immigrant.

\section{WHY IMMIGRANTS GO TO CITIES ${ }^{1}$}

\section{H. P. FAIRCHILD}

IT is apparent that our foreign-born residents tend irresistibly to congregate in the most densely settled portions of the country, and in the most densely populated states. But this is not all. They also tend to congregate in the largest eities, and in the most congested scetions of those cities. In 1890, 61.4 per cent. of the foreign-born population of the United States were living in cities of at least 2500 population. In 1900 the percentage had increased to 66.3 , while 38.8 per cent. of the entire foreignborn population were huddled into the few great cities having a population of over 100,000 . In the same year only 36.1 per cent of the native-born population were living in cities of over 2500. This tendency appears to be increasing in strength, and

1 Adapted from "Immigration," pp. 229-231. Macmillan, New York, 1913. 
is more marked among the members of the new immigration than among the older immigrants. Thus in 1910 the percentage of foreign-born living in eities of the specified size had risen to 72.2.

The reasons for this tendeney of the foreign-born to eongregate in the most densely settled distriets may be briefly summarized as follows. (1) They land, almost without exception, in eities, and it is often the easiest thing for them to stay there. It takes some eapital, knowledge, and enterprise to earry the immigrant any distance from the port of arrival, unless he has a definite connection in some other place. Yet it is elaimed that, land them where you would, about the same number of immigrants would find their way to New York within a few weeks. (2) Eeonomie opportunities are mueh more abundant and varied in the eities than in the eountry. (3) Sueh oeeupations as are obtainable in the eity require mueh less eapital than the eharacteristie eountry oeeupations. With a few dollars, an immigrant in the eity ean set himself up in some independent business, depending on turning over his eapital rapidly to make a living. There are so many people in the eity, that if one can manage to serve the most trivial want satisfactorily, he ean get along. But any independent business in the country requires a larger outlay of eapital than the average immigrant ean hope for. The only eountry oceupation open to him is common farm labor, and there are other reasons which make him ill adapted for this. (4) In the eities, the newly arrived immigrant ean keep in elose touch with others of his own race and tongue. In the eompact colony of his fellow-eountrymen, he may be sure of eompanionship, eneouragement, and assistanee when needed. It is the most natural thing in the world for an immigrant to want to settle where there are numbers of others of his immediate kind. (5) Knowledge of the English language is muel less essential in the eity than in the eountry. The presenee of others who ean speak the same tongue makes it possible for an immigrant to make a living without knowing a word of the language of lis adopted country, as many of them do for year after year. In the rural districts, however, it is impossible for a newly arrived immigrant to get along at all without a kuowledge of the English language, either in independent business, or as an employee, unless he settles in a farm eolony of people of his own 
race, of which there are, of course, many to be found. (6) Not only is there more chance of fricndly relicf from fellow-countrymen, in case of necessity, in the eities, but public relicf agencies and private benesolenees are much more available there than in the country. (7) The excitement and novelty of American eity life is very attractive to many immigrants-just as it is to natives. Trolley ears, skyscrapers, and moving pieture shows are wonderfully alluring features. In fact, in addition to the considerations which are peculiar to limself, the immigrant has all the general incentives to scek the eity, which operate upon the gencral population, and which have produced so decided a cliange in the distribution of population within the last few decades.

\section{IMMIGRATION AS A SOURCE OF FARM LABORERS ${ }^{1}$ JOHN LEE COULTER}

Agriculture has so long been looked upon as the dumpingground of all surplus labor in ease of eity industries, of all poverty-stricken persons in ease of famines, and all revolutionary individuals in case of disruption in European countries, that it is hard to realize that we have reached the state where farming in practically all of its branches requires a very high order of intelligence and the capacity to grasp and use a great varicty of scientific facts. We may, therefore, say that, although it is truc that we need farm labor very much, as a relief for current immigration agricultural distribution is not promising.

There are two great classes of inmigrants that can find room in various branches of the agricultural industry. The first class is composed of those from overerowded agricultural communities in their home countries. On account of the high state of development of their industry they can teach us much which we have failed to take advantage of and which would result in the uplift of many of the sub-industries in agriculture in this country. These should be urged to bring with them their home industries and introduce new phases of agriculture into this country. The United States has been spending millions of

1 Adapted from Annals 33: 373-379, Jan.-June, 1909. 
dollars in introducing new plants, animals, and methods of farming from other countries. At the same time little groups of foreigners, such as the Swiss of Wisconsin or later the Italians in some Southern districts, formerly thought of as the least desirable immigrants, have settled in our midst and put into practice their home training, which has resulted in the establishing of great industries, such as the Swiss cheese industry. The class of immigrants most desired is, therefore, those who will add most to the industry they enter. But it is not necessary that the immigrants should introduce some new sub-industry or be in advance of us in their methods in order to make them eligible to enter the agricultural industries. We may say as a general proposition that farmers from nearly any agricultural community in Europe would be acceptable in some of the agricultural industries of this country. If reasonable precautions are taken the immigrants referred to, even though they bring no new industry, will not become public eharges, but will add to the general prosperity of the country. The class objected to, the refuse from other industries, not only adds nothing new but is apt either to lower the standard of the agricultural industry or to become a public charge.

But it is not enough to encourage one class of immigrants and discourage or prolibit others. The immigrants must not only come from rural districts in their mother-country; if they are to suceced, they must be properly located herc. Probably the most important single eondition is that immigrants should be directed toward and urged to locate where their physical environment will correspond as nearly as may be to that of their mother-country. By that I mean that not only should the climate be nearly the same, but the precipitation, the soils, and the topography should approach that of their former lome, if possible. Failure to satisfy these preliminary requirements has resulted in almost complete failure or a long period of suffering, while attention to these factors lias produced unpredicted successes.

The next consideration of singular importanee is that the social environment should be acceptable. If the agricultural operations are not close to a city where others of the same nationality are employed in other industries, it is desirable- 
almost neeessary-that a eonsiderable number be allowed, even indueed, if need be, to settle in a eommunity. At first, they will live as in a world apart, but they give off ideas and take on others and at the end of a generation or two a few intermarriages will have broken down the hard-and-fast wall between settlements. Common markets, interehange of labor supply, eontests between settlements, political and other eonfliets, and baek of it all the eommon-sehool system, soon result in an amalgamated, assimilated race.

The next consideration which should be held in mind in determining upon the distribution of immigrants among the different branches of the agricultural industry is the economic status of the people to be distributed and their plans or ambitions for the future. Thus, some are independent laborers, others ready to beeome tenants, and still others to be landowners. Some plan to be employees as long as they stay; some of these would plan to save a snug fortune in a few years and return to the mother-country, others to earn and use the returns from year to year. Some plan to step up to the position of tenant and employer, others are ready to enter that state at once. Some are ready to become landowners and independent farmers by purchase of land in settled distriets, others with less eapital would go to the frontier with poorer markets and grow up with the eountry, enduring hardships but accumulating wealth. There is room for all of these elasses of people in nearly all parts of the eountry.

The extended suecesses aeeompanied by individual failures of the English-speaking peoples who early entered the agrieultural industry of this country need not be expanded upon here. Neither will any detailed treatment of the extensive settlement by Germans in the North Central States during the last half-eentury be made. We may place the general influx of Scandinavians into Minnesota and the Dakotas in the same elass and pass by all of these-whieh means the great bulk of immigrants of agricultural peoples-with the statement that they represent suecess and with the assumption that students of economics know of these elasses and know of their successes. It is beeause we are too apt to stop at this point and say that other nationalities as a rule have little or nothing to offer that this paper is presented. The 
writer would emphasize the fact that we have room for farmers from many lands, assuming that we act intelligently in our choice and properly distribute those wlio come.

The large Swiss settlement in Green County, Wisconsin, illustrates success in the introduction of a new sub-industry of great importance. Having struggled for years trying to farm in the American way, these immigrants finally turned to the great industry of their home country. They had settled in a physical enviroment wlich was very much like what they had left abroad. Now several hundred chcese factories are prospering and millions of pounds of cheese arc annually placed upon our markets. Most of it is the famous Swiss cheese. It should also be noted that nearly all of those engaged in making this cheese and in buying and selling it are Swiss or of Swiss origin. The writer feels that this colony is a great success, is the kind of thing this country wants, is the basis of prosperity in our agriculture, and must not be condemned because of the fact that broad Swiss is sometimes spoken or because the thousands of members of the district are not assimilated during the first generation. The writer has found individuals and small groups of settlers from this colouy and from "the old eountry" moving far up into the Northwest carrying with them the information and ambition to start other colonies as prosperous as the old one. The acquisition of such an industry is as valuable to this country as the introduction of a new plant that may have required the expenditure of a hundred thousand dollars.

Turning from this prospcrous Swiss district, we may direet our attention to a Bohemian center in northwestern Minnesota. The Swiss had sent explorers alsead to find a desirable loeation before coming to this country and settling down. The Bohemians were in no greater financial straits in their home country than the Swiss had beeu, but they were brought in and located by great transportation companies. The soil where the Boliemians were "dumped" is very good; but the country needs an expensive drainage system. The poor immigrants are not in a position to establish it. The result is that for some fiftecu years we have had before our eyes a Bohemian colony unmbering hundreds of people, unable to establish a prosperous community because of unfavorable natural conditions. These pcople 
will succeed in time, despite obstacles, but some common-sense assistanee would lasten the day of their prosperity.

In other parts of the United States large settlements of Bohemians of no higher standard are prospcrous and happy. As an illustration of the status that should obtain the writer would refer to some of the very prosperous eommunities of Poles and Ieelanders in North Dakota and elsewhere. No class of citizens, whether immigrants or descended from immigrants half a dozen steps removed, could ask for greater material progress, better buildings-homes, churches, sehools, and town buildings-than the Polish settlements around Warsaw, Poland, Minto, and Ardoek in Walsh County, North Dakota. The writer's knowledge of this and other communities of like character leads him to say that to eneourage sueh settlements is to foster prosperity and frugality as well as to place the stanp of approval upon a home-loving, land-loving elass of farmers. If we pass on to settlements of Russians we may say nearly the same as above. With a love for land and home which is almost beyond our understanding, these people are too often frugal to a fault. They come with a low standard of living and during the first generation the standard does not rise much. But the change soon comes. The children, or at least the grandchildren, become thoroughly Ameriean unless the immigrants have been located in an enviroment where suecess is impossible. In this connection we might refer to such eonerete eases as the settlements in ecntral and western North Dakota, or the large prosperous colony in Ellis County, Kansas, or the newer settlements in the Southwest.

Nor need we stop with the Swiss, Bohemians, Polanders, Icelanders, and Russians. If we turn our attention to the Italians coming into the South we find them filling the various places demanding attention. There is a large demand for white labor, and the mass of Italians who do not intend to make this their life-home more and more fill a long-felt need. With the great numbers of Mexicans eoming across the line for part of a season this demand may gradually be better and better satisfied. There is also a large demand for teuants, and this ery is being answered by Italians. These neweomers are not only fitting into the cotton-growing industry in competition with the colored people, 
but are proving their efficieney in vegetable and fruit farming. Of late years sucl settlements as that of Italians at Tontitown, Arkansas, in the Ozark Mountains, show also that Italians can bring their home industry with them and sueceed here. They not only settle down as dignified farmers, but aetually teach our farmers many things. Vegetables, apples, plums, grapes, and other fruits are sueeessfully grown. If the colony located at Sunnyside, Arkansas, at an earlier date was a failure at first, it is no sign that Italians eannot sueeced in agriculturc. Immigrants, largely from other industries, placed in competition with Negrocs in produetion of a erop that they kuew absolutely nothing about, under foremen accustomed to drive slaves, in a swamp country-hot and siekly to neweomers-attacked by malarial fever and losing a large number of the first scttlers, it is not to be wondered at that failure was threatened. But suceess has eome even in that ease, wherc failure at first starcd all in the faee.

With eolonies like the Brandsville Swiss settlement in Missouri, with the Italians and Russians eoming cven into old New England, with Mexicans pushing up into the Southwest, and with other nationalities gradually finding their own, we may indeed turn our attention toward the agrienltural industry as a much-negleeted ficld. The ery of "back to the land" will not go unleeded by immigrants who have come from farms in their mother-country if any reasonable amount of effort is put forth to "assist them to find themselves."

Referenee might also be made to the Jewish farm problems of the Middle Atlantie States, problems whieh liave importanee as far West as Wiseonsin; and to the Japanese and Clinese agrieultural labor problems of the far West and Southwest. There arc poscibilities here which few people have yet appreeiated. The question of demand for seasonal agrieultural labor and the possibilitics of eontinual labor by passing from one industry to another in neighboring distriets or following the same industry from one part of the eountry to another are left untouched.

\section{BibLiography}

Balch, Emily G. The Peasant Background of Our Slavic Fellow Citizens. Survey 24:667-77. August, 1910. 
Cance, Alexander E. Recent Immigrants in Agriculture. Senate Document, 633, 61 Cong. 3rd Session, Vol. II, 1911.

Cance, Alexander E. Immigrant Rural Communities, Annals 40:69S0. Marel, 1912.

Commr. Gen. of Immigration. Annual Report, year ending June 30, 1919. Supt. of Documents, Washington, D. C.

Coulter, John Lee. The Influence of Immigration on Agrieultural Development, Annals, 33: 373-379, March, 1909.

Connor, Ralph. The Foreigner. Doran, New York, 1909.

Elkinton, Joseph. The Doukhobors. Charities, 13: 252-6, 1904.

Flom, George T. History of Norwegian Immigration to the United States from the Earliest Beginning Down to the Year 1848. Toreh Press, Cedar Rapids, Ia., 1909.

Hall, Prescott F. Immigration and Its Effect Upon the United States. Holt, N. Y., 1906.

Hoverstad, T. A. The Norwegian Farmers in the United States. Hans Jervell Publishing Co., Fargo, N. D., 1915.

Jenks, Jeremiah W., and Lauck, W. Jett. The Immigration Problem. Funk \& Wagnalls, N. Y., 1917.

Joseph, Samuel. Jewish Immigration to the United States. Columbia Univ. studies. Longmans, N. Y., 1914.

Mashek, Nan. The Immigrant and the Farm. World To-day, 20: 206-9, Feb., 1911.

Mathews, Joln L. Tontitown. Everybody's, 20:3-13, Jan., 1909.

Morse, W. N. Earning a Valley. Outlook, 96:80-86, Sept. 10, 1910.

Morse, W. N. Black Dirt People. Outlook, 93:949-57, December, 1909.

Robinson, Leonard G. The Agricultural Activities of the Jews in America. American Jewish Committee, N. Y., 1912.

Ross, E. A. The Germans in America. Century, 85:9S-104, May, 1914.

Ross, E. A. The Seandinavians in America. Century, 88: 291-8, June, 1914.

Shaler, Nathaniel S. European Peasants as Immigrants. Atlantic, 7:646-655, May, 1893.

Steiner, E. A. On the Trail of the Immigrant. Revell, N. Y., 1906.

Steiner, Lajos. Our Recent Immigrants as Farmers. Review of Reviews, $29: 342-345$, Mareh, 1914.

Thomas, Wm. I., and Znaniecki, Florian. The Polish Peasant in Europe and America, Vols. I-III, University of Chicago Press, 1918. Vols. IV and V, to appear.

Titus, E. K. Pole in Land of Puritan. New England Mag., 29:1626, October, 1903. 


\section{CHAPTER V}

\section{PRESENT PROBLEMS OF COUNTRY LIFE}

\section{WANTED: A NATIONAL POLICY IN AGRICULTURE ${ }^{1}$}

\section{EUGENE DAVENPORT}

THE purpose of this paper is to invite attention to the very great need at the present time of a more definite policy regarding agrieulture; a poliey that shall be national in its seope, universal in its interests, and eomprehensive in its procedures.

The term national policy is not intended to mean a policy of the Federal Government as over against the States, nor indeed a governmental policy of any kind as distinct from the convictions and the ideals of the people from which and from whom our democratie government proceeds.

What is meant is rather such consensus of intelligent opinion and such a deliberate judgment about agriculture as shall represent the constructive purpose of the Ameriean people whether farmers, laborers, or business men, and whether operating in their private or their governmental capacities. What is meant is sueh a common recognition of certain facts and principles to be established by investigation and conference as shall amount at any given time to a national policy about farms and farmers and farming as over against the policy which assumes a struggle of each separate interest to maintain its place in a constantly slifting balance of power in which all are frankly antagonistic and each prospers or suffers in proportion to the forec it is able to cxcrt and the advantage it is able to sceurc.

This policy is not ealled a program beeause programs are made to earry out fixed and predetermined purposes, while the thing in the mind of the speaker is rather a status and a procedurc

1 Adapted from "Proceedings of 32 nd Annual Convention of the Assn. of Am. Agricultural Colleges and Experiment Stations," pp. 52-68. 
under shifting eonditions, with the intent always to promote the prosperity of the farmer, not as a favored elass but as a typieal and component part of soeiety, produeing the food of the people and in potential control of the land policies of the commonwealth.

My general thesis is this: That eonsiderations of fairness and of public safety both demand a higher regard for the affarrs and interests of the open country and for the welfare of the farmer and his family; that in a real demoeraey the farmer must stand higher than hitherto in publie esteem, not because of demands he may make upon soeiety but by reason of his worth and his service; and that he should count for more in the management of publie affairs not administratively, in which he has little skill, but in matters requiring counsel, in which he is eomparatively wise and relatively unprejudiced.

Agriculture, whether eonsidered as a profession or as a mode of life, has never figured adequately in world affairs, being regarded by publieists mainly as the source of eheap food for cheap labor and of raw materials good for eommerce and for manufacture, both eonvenient for holding the balance of trade upon the right side of the ledger. The farmer limself has been generally considered as an unskilled laborer, a humble produeer rather than a typical citizen.

Outside the technical journals, the publie press is almost as silent about farmers and agriculture-except for an oecasional poor joke, the annual crop statisties, or the market report-as if our farming were done upon Mars. The eolumns are full of the struggles between labor and eapital, of society notes and of business schemes, but in general a murder trial with a mystery, or the love letters in a triangular divoree suit are good for more space than the greatest livestock exposition in the world. Our magazines and the publie mind are full of modern scientifie achievements and of art, but how much does the world know or care about the farmer and his phenomenal suceess in animal and plant improvement or the pietures he paints every year upon the landseape? Clearly our public press is animated almost exelusively by urban interests even in cities that owe their very eommereial cxistenee and financial support to the agrieultural aetivity of the immediate environs. To be sure, the statistician and the speeulator know something about farming but not about 
the farmer, for their interest is limited to the mass results in the form of millions of bushels and does not extend to the matter of their production, the welfare of the produeer, or the effeet upon the land.

Everybody agrees that this is to be a different world after the war, but no thoughtful man ean fail to be struck with the character of the economic and social questions that begin to loom large in conncetion with reconstruction: trade routes, the new merchant marine, raw materials, improved faeilities for extending credit, coöperative business, public ownership of public utilities, government oversight of private enterprises, execss profits, inheritance taxes, prohibition, woman suffrage, the perennial problems of the relations between capital and labor, the minimum wage, the maximum day, and time and a half for overtime. Not an item, not a suggestion, of anything agricultural cither as a business or as a modc of life, if we may exeept the oceasional mention of the word "land" and eertain plans for providing homesteads for the returning soldiers, which is an army, not an agrieultural, proposition.

For the most part our considerable list of reconstruction problems may be redueed to the two great questions that mainly coneern the public mind to-day; namely, foreign and domestic trade, and the perennial contest between eapital and labor. TWe forget the eitizen because we have learned to think politically and soeially mainly in terms of commerce based upon manufaeture, under eonditions requiring vast combinations of eapital, coneentration of population, and division of labor-the very eonditions that inspire not only greed of gain and social unrest, but international war. Yet our interest lies here rather than with the peaeeful pursuits of the open eountry.

It may well be said that if there is a dearth of live problems in the public mind regarding agriculture, it is the fault of the farmers themselves inasinuch as each interest is assumed to be responsible for promoting its own affairs. Granted, but even so the eonclusion is irresistible that people generally do not regard agrieultural problems as of public coneerı, while my chicf eontention is that the public even more than the farmer is interested in the diseovery and the proper solution of every problem eonneeted with the public domain, with the produetion of food, and 
with the charaeter and condition of that portion of our population that shall live upon the land.

I say that the public is more interested than the farmer in these matters because "The Farmer" is actually a collection of individuals who ean for the most part extricate themselves from any intolerable situation that may develop; while the country as a whole eannot extricate itsclf from the consequenees of bad agricultural policies that easily develop when matters of fundamental character intimately connected with food production, home-building, and land ownership are left to shift for themselves.

But we are not without a start in the right direction. More than half a century ago we began to think nationally about agriculture. The impulse had its origin in our consular scrvice and in the primitive collecting instinct whereby seeds and roots of promising foreign plants were sent to America for trial. Out of this grew the Department of Agriculture, representing the offieial determination of America to do whatevęr could be done administratively to promote agricultural welfare at home and marketing facilities abroad.

Again, in the darkest days of our Civil War the United States established the most unique educational șistem which the world has ever known; hence this association and the colleges it represents. Aiming at increased production though it does, and national in scope though it is, yet after all, the basis of the system is the education and the initiative of the individual, for it is founded upon instruction of collegiate grade and based upon scientific investigation of the highest order. We eould not have a better foundation for the edifice that shall one day stand as emblematical of our national aims and purposes in agriculture than is the education system represented by this Assoeiation of American Agricultural Colleges, and there could be no better eorner-stone for the strueture than the work of the experiment stations connected therewith.

But this is only a beginning of a national policy for agriculture; there yct exists a wide gulf between what these public agencies are doing or ean do and what the individual is accomplishing or able to aceomplish under auything like present or prospective conditions. If agrieulture is to figure as it must 
figure in a successful demoeracy, then this gulf must somehow be bridged.

It must never be forgotten in this connection that in a suceessful demoeracy oecuping territory of continental proportions, approximately one-third of all the people will live upon the land. Moreover, it is this third and not the mass representing organized industry or the fraction representing "business," through which the line of descent will mainly run. Who these people are, therefore, that live upon the land, which third of our population they represent, and what they are thinking about day by day and year by year as the generations come and go, may easily make all the difference between success and failure in the experiment of demoeratic government, to which all the world now stands eommitted and in which experiment the United States occupies a position of associated leadership as conspicuous as it was inevitable.

Specifically, then, what is it that agrieulture needs and does not have but that is essential to the highest sueeess and the greatest safety both of the farming people and of the nation as a whole? What are some of the things that must be provided from the national end after the individual, by his edueation, his industry, and his thrift, has done all that may fairly be expected of him, and the State he lives in has done what it can?

If agrieulture were solely an individual enterprise we should simply eonsult the farmer about his needs and desires. But agrieulture is more than farming and the publie must be party to any polieies affecting the production of its food, the management of its lands, or the soeial and politieal welfare of its people. The question, therefore, what does agrieulture need? must be divided and eonsidered both from the point of view of the farmer and from that of the public in its largest eapacitythat is to say, the nation, present and prospeetive.

First of all, then, what more does the farmer need? If this question slould be put to the observer from the parlor ear or to the publicist, he would likely say that the farmer needs to work to a better purpose and to be more eareful of his equipment; that lie doubtless needs more eapital as he certainly needs to organize his affairs aecording to modern business methods, and to know better than he does what things eost him. 
But if the same question be asked the farmer, he will have a different answer. He will say that the farmer needs many things whieh he is powerless to provide but without whieh the business is beeoming less and less desirable from a relative point of - view, therefore declining.

He will probably say first of all that he wants better educational opportunities for his children, for as matters stand now they must leave the parental roof at a tender age or else he must uproot his home, abandon his business, and go to town if his ehildren are not to fall behind those of the buteher, the baker, and the eandlestick maker-to be more speeific, of the earpenter, the plumber, and the day laborer.

But we have the Smith-Hughes bill which in itself is evidenee that the public has not only reegnized but aeknowledged the eonditions and begun to eorrect them-in a wise way too, for in a democraey the people must take the lead or at least carry a part of the burden of all progress. This plan which we have begun is a logieal extension of the land-grant idea into the domain of secondary edueation.

We are evidently headed in the right direetion at this point, but our progress will be insuffieient until we suceed in providing for the ehildren of the farm as wholesome, as adequate, and as eultural if not as varied, edueational opportunities as are provided in the most favored cities. There are obstaeles to be overcome of eourse, ehief of which are the low tax-paying ability of the open country as compared with the congested city, and the high per capita cost of education.

But if we are to remain a demoeracy and be safe, this burden must in some way be assumed by the public and not remain a permanent handicap upon the profession of farming. If it is not so assumed as a national policy and as a part of a national plan, even to the extent of heavily subsidizing rural edueation, it is inevitable that we shall ultimately have a peasant population on the farms, and colleges sueh as ours will have no students of collegiate grade exeept from among land-holding eity residents. It requires no prophet to foresee that when such a time comes demoeratie institutions will begin to crumble at their foundations.

Next to the laek of educational opportunities for his ehildren eomparable with those of the eity, the farmer will insist that the 
ineome from his business is inadequate to enable him to maintain the same seale of living as that provided through other oeeupations requiring equal or even less preparation, industry, or investment.

Pushed for proof, he will reason substantially as follows: All studies in eost aecounting show a labor ineome from farming which in the vast majority of eases is ridieulously small, failing oftener than not to require more than three figures for its expression and reeognized by the publie as a joke. We are not now eonsidering the exeeptional man, or what might be done, but we are to study deliberately what the great mass of farmers, our hardest working people, are aecomplishing or indeed ean aceomplish in earning power through the production of staple foods under eonditions that have prevailed and that are likely to obtain at the elose of the war and afterwards.

The farmer will eonfess that he has long been eritieized for tight-fistedness in refusing to pay "decent wages" and that he has thereby lost the bulk of his best labor, even his own sons. He will point out that a Federal milk eommission very reeently after six weels' deliberation refused to allow a priee that would net him thirty eents an hour for the labor involved in milk produetion, even though the same milk was delivered by drivers getting a hundred or more dollars a month with no risks and no expenses.

He will point out how severely he has been criticized in the press and from the platform for failure to provide bathrooms in his home and modern eonvenienees for his wife, whom he loves as other men love their wives; but he will also point out that the poliey whieh refused him thirty eents an hour for his own labor, permits the plumber in a country town to eharge eighty eents (by the latest information, to be exaet, eighty-one and onequarter) with fifty eents for a boy helper, who for the most part does little work, and the like of whom would not be "worth his salt" upon the farm.

This farmer will be able to show also that if he should attempt to pay the minimum wage of Mr. Ford or of the labor unions with an eight-hour day and time and a half for overtime now reeognized by the Federal Government, he would either speedily lose his farm or else the eost of food would run to a level un- 
approached by the present war priees. Speeifieally, this would mean that milk would have retailed in Chicago last winter at some seventeen eents a quart instead of twelve, as allowed by a Federal eommission, or the thirteen that would have satisfied the farmers, and that present priees of meat and butter would expand some twenty or twenty-five per eent.

If he reads the daily papers, as he probably does, this farmer will also point out that under Federal management of the railways, his loeal station agent (not a telegrapher) has just been granted a minimum wage of ninety-five dollars a month on the basis of an eight-hour day, pro-rata addition for two days overtime and time and a half for further exeess. Any good farm laborer ean do this work; how, therefore, shall the farmer eompete at less than thirty eents an hour and with what arguments shall he preserve the independenee and initiative of his own son over against a government job, proteeted by the eivil serviee, baeked by a powerful union, and guaranteeing with no investment and no risk a minimum wage far in exeess of what the father has ever made upon the farm, with an eiglit-hour day and time and a half for overtime, spent wholly under shelter and mostly in an armehair?

The situation is illustrated by my own experience within a fortnight wherein a farm laborer protested against his wage of seventy-seven dollars per month upon the ground that his son of seventeen was making one hundred and sixty-five dollars a month in the railroad yards a mile away.

There are vast wheat growing regions in this country underlain by eoal deposits. Here farming and mining eome together. Here the farmer's income from wheat growing and the miner's wage may be direetly compared. When this is done, it will be found that the farmer is unable with the most modern machinery and methods to eultivate with his own liands land enough to produee a labor ineome equal to that of the soft eoal miner, working and living in the same neighborhood, trading at the same stores, attending the same ehurclies, and sending his ehildren to the same schools.

Here we have a elass of artisans largely of alien birth and not yet eitizens, but proteeted in their earning eapacity ly a powerful organization whose existenee and demands are now reeognized 
as a part of our national policy. No preparation is required for their business, nothing is invested, no taxes paid, and no risks assumed except perhaps a slightly, a very slightly, increased hazard of life offset to a considerable degree by easier hours and healthier eonditions of work.

But the citizen farmer who lives in the same eommunity with the miner, whose ehildren grow up with his own, and who is a manager in a small way, competing in the labor market, must invest in land and buildings, tools and livestoek. He must pay taxes and insurance and repairs and veterinary fees. He must work often sixtcen hours, seldom less than ten, and he must be on duty day and night, ready always to care for his independent plant-all this, and yet in order to receive a labor income equal to that of the soft coal miner, whether eitizen or alien, with no preparation, with nothing invested but a pick and shovel, and with no risk involved, the farmer must not only work himself as no professional laborer ever works, but he must also work his children without pay.

The ultimate eonsequenee of this eondition needs no exposition here. By as mueh as this eountry could not permanently remain half free and half slave, no more can our demoeracy endure without a national poliey and plan that will equalize to some degree at least the ineome from the land and investment in the most perishable of all equipment on the one hand and the rewards of unskilled labor upon the other.

But if the profits of farming are so meager, how ean we have so many "rich farmers" here and there as to make the term proverbial? The situation to which this question refers will bear analysis. There are many rich farmers, as riches go among common people, but it will be found upon investigation that they belong to one of four classes, mostly unique or temporary:

First. Exceptional men on large farms or else engaged in some branch of speeialized farming which by its nature is limited in its applieation.

Seeond. Men who have inherited their farms and to whom these farms therefore represent a eapital investment that cost them nothing.

Third. Men who have deliberately raised large families in order to have at hand an alundanee of umpaid labor, brutalizing 
womanhood from no higher motives than aetuated thousands in raising soldiers for the Kaiser.

Fourtl. Men who have obtained their lands in an early day at a nominal rate, often as low as fifty cents an acre, and who have worked the land "for all that's in it," mining out fertility as the operator mines out eoal. Here is where most of the rich farmers will be found-a erop that ean be produeed once and only onee in any country.

Whoever knows the eonditions that aetually obtain in respeet to home-building will understand the deep-seated unrest that is beeoming wide-spread in this eountry beeause of the increasing diffieulty in seeuring ownership to land. To the publie generally this is a sealed chapter in the notes of an unwritten history, but to those of us who can remember when there was no "Great West," when Cineinnati was called Porkoplis, and when steers were fed from the open ranges across the prairies to the eentral market, this is no mystery. We understand perfeetly well what the mass of Americans do not know, that until about the opening of the present century, men, women and ehildren worked willingly and often eruelly without money and without priee for the sake of developing out of nature's raw material "a liome of their own." That opportunity has now gone and with it the impulse to labor for something better than money. Hereafter the farmer, like other people, will have to reckon his ineome in terms of cash.

The wave of land hunger now going up over this country is but the premonition of what is eoming if it is to remain as difficult as now for eountry-minded young families to obtain, within a reasonable period, homes of their own. Here within our midst almost unnotieed and for the most part unknown is growing up a situation of vastly more import to publie welfare than are all the questions of merchant marine, trade routes, raw materials, and preferential tariffs combined. The faets are that as matters are going now, land is slipping away from the typical farmer, and his children will soon be disappearing from our colleges.

But why be so solieitous about a elass of people who eannot or will not take eare of themselves? That is exactly the point. We have now reached a time in world development when we reeognize the fact that many very good things eannot take care 
of themselves but must be eared for, even fought for, and that the policy of laissez faire is often fatal to peaeeful progress.

If the farmer is not satisfied and thinks he ean better himself then let lim change his profession. Exaetly, and that is what he is doing in an alarming proportion of instances, but what about the rest of us, and wherewithal shall we be fed? If farming were a profession engaging but a few thousand people, we might afford to let it alone, but it is our largest industry, engaging millions of some kind of eitizens. It is a matter of public eoneern, therefore, both ways, that they be prosperous and gradually evolving with the rest of the world.

It is beeause the farmer as such eannot take eare of himself; beeause we are drifting rapidly away from eonditions that promote a stable demoeraey and toward agrarian revolution, that a national poliey about agrieulture must be one of the major and not the minor eonsiderations in readjusting the affairs of this disturbed country, which is now, in eommon with the rest of the world, in a lighly fluid eondition and ready for the hand of the molder.

Whatever is true of farmers as individuals or of farming as a profession, the ehief eoneern about agriculture after all, and the considerations that demand a national poliey and plan, fall well within the domain of public welfare.

The eountry as a whole, even more than the average farmer, is eoneerned about the housing, the sanitary surroundings, and the health of that third of our population which lives upon the farm under what ought to be and what can well be ideal plyysieal and moral conditions for raising the eitizens of a democraey. Yet no man will admit that even in this great, new, rieh eountry, with its high pereentage of literaey, are these eonditions anywhere near ideal.

Again, the eountry as a whole is more interested than the average man is likely to be in the kind and amount of edueation which is to be eombined with the wholesome industry that naturally attends upon life in the eountry, and in so far as either of these eonsiderations is hampered from laek of funds or ideals, the publie is bound to supply botli, for the elass of people is too numerous, its power for good or evil too great, to justify negleet. 
The home-building instinet is not only the greatest known ineentive to work but it is also the safety eluteh for demoeratic institutions. We have elloyed a half eentury of unexampled prosperity, largely beeause it has been based upon elieap foodfood so eheap as not to repay the labor bestowed upon it, to say nothing of eapital, of which there was little, or the extraetion of fertility, of which there was much. There is nothing that will get so mueh work out of a man and his family as the desire to own the home that shelters them, and we have eapitalized this instinet to the limit, together with an almost total disregard of virgin fertility. This latter eomponent of eleap food is gone; it bchooves us now to make the most of the former even though it may somewhat inerease the priee of food.

Under existing conditions farmers will do one of two things: require finaneial returns eomparable with those of other people, or settle baek upon the primitive self-suffieing system, produeing not a supply but a simple surplus over their own needs. In either ease more expensive food is inevitable-in the one instanee from an inereased initial eost of produetion and in the other from a redueed supply.

From the standpoint, therefore, both of the amount and the price of food it is in every way to the advantage of the publie to stimulate the home-building as against the money-making motive among farmers. That way too lies safety for our demoeraey. To this end it must be made easier for the young people of each and every generation to aequire the ownership of land with such betterments and such opportunities for living and rearing families as may produce ideal Amerieans. As the land must ehange operators every generation, it must not be too difficult also to ehange ownership.

And we must go on further in our national plan than to make it easy to aequire ownership in land. We must eare for this land as a national asset and as a perpetual obligation, in the interest of future Amerieans. Ownership means at best but temporary eontrol, and whoever earries in his poeket a deed to a portion of the national domain is in reality a tenant at will, and the conditions of his tellantry should be sucl deeent regard to the fertility of the land he oeeupies as shall insure inereasing, not deereasing, productivity. In 110 other way ean the lives and the 
fortunes, in no other way can the domestie peace of the millions of coming Amerieans be guaranteed. This too must go into the policy.

After all, who is The Farmer? And where is the land whieh he wants? The attcinpt to answer these questions brings us very near to the crux of the situation. Not far from half the aereage of our better lands is owned by one group and operated by another. Who then is The Farmer? When two families are attempting to live off the same farm, one of them in idleness, or when eleven families are living off ten farms, with whose interests do those of the publie lie?

In one county of Illinois, twenty per eent. of the farm lands are said to be owned by men who have never secn their properties because they live with other interests on the Atlantic seaboard, eolleeting rent through agents as they clip coupons from stoek certificates.

It is said that the estate of Lord Scully is just now raising the rents of some hundreds of thousands of acres of our best prairie land to ten dollars an acre, or about two thousand per cent. annually of the original eost. Investments and betterments? Not a dollar! For the agent is instructed that if the renter wants a house or a pig pen, let him build it. No investments exeept in additional land. Here is a mare's nest for hatching trouble, and the tenants are already reported as organizing for resistance.

Nobody eares how large is the farm that one man operatesceonomic limitations will control, and the larger the better so far as the public is concerned. But when a man deliberately acquires not one farm but ten farms, not with the intention of oecupying any of them or of produeing anything, then the public will one day have something to say about the matter. It dare not do otherwise. We shall always have renters, but shall renting and landlordism beeome typieal in the country as it is now in the cities? If so, in that direction lies trouble.

Specifically the publie wants to know and it will one day inquire whetleer eapital is invested in land from a desire to operate it or merely from a wish to live without labor and at the same time by speculation to grow rieh upon the rise of real estatc. In no other form are investments of moderate amounts of eapital 
so influential for weal or woe, not only to men and families, but to the public at large, as are investments in land. For this reason, therefore, in one way or another, investments in land will one day be limited as to amount and preseribed as to eonditions. In no other way ean private ownership be preserved from the general wreek of Bolshevism certain to follow a bad land poliey.

We all know what has been done in Russia and what is being done in Hungary. We know that England has been foreed to control land ownership by limiting the eonditions of inheritance, by progressive taxation, and by applying the prineiple of excess profits. Even so, one of the points insisted upon now by the British Labor Party is the nationalization of land.

Among the achievements neeessary to insure the proper development of American agrieulture whether from a private or a public point of view, the following at least are of suffieient significanee to be eonsidered as fundamental in a national poliey.

First. Subsidization of eountry schools to an extent that will insure to every child born upon the farm the opportunity. of a good high sehool education admitting to eollege, with ehoiee of differentiation along agrieultural, meehanical, eommereial, seientifie, or literary lines-and this without leaving the father's roof or breaking up the home and the business.

Seeond. Public reeognition of the fact that the farmer is neither a eapitalist nor a laborer, as the terms are understood in the commercial world, but a managing operator of a small business of which the home and the family are integral parts, and therefore entitled to stand in the public esteem as a typieal democrat, not as a "rube," or even as an eminently useful laborer that should be contented with his lot.

Third. Recognition of the fact that the Ameriean farmer, as a typical eitizen representing our largest and most fundamental industry, and as our greatest home-builder, is entitled to an ineome eomparable with his labor, his investment, and his managerial skill.

Fourth. The assurance of this income, not by arbitrary priee fixing in defiance of the economie law of supply and demand, not by force, but by eonference between produeer, distributor, and consumer. 
Fifth. Requirement by law of minimum housing eonditions upon rented farms, such eonditions to be maintained under a system of adequate inspeetion.

Sixth. The obligation not only to maintain but to inerease the fertility of land, this obligation to be equally binding upon landlord and tenant and enforeed by public lieense.

Seventl. Reeognition of the fact that as between the owner and the operator of the land, the sympathy and support of the publie should be with the operator.

Eighth. Reeognition of the fact that as between the owneroperator, the tenant, and the speeulator, the sympathy and support of the publie should be with the owner-operator as the typical farmer.

Ninth. The elimination from the public mind of the idea that tenantry is to be regarded in Ameriea as typieal land oceupaney or as the ideal road to ownership, theories for nationalization and mutualization of land to the eontrary notwithstanding.

Tenth. The appropriation of public funds for finaneing young men in prospeetive ownership as soon as they shall have fully established a reputation for thrift and shall have aeeumulated say ten per eent. of the purehase price of produetive lands.

Eleventh. The establishment of interest rates on funds loaned upon land for home-building purposes that shall be based upon those of the most favorable bond issues, not upon eurrent banking rates for short term loans-rates that eannot be generally realized in farming and that ought not to be realized in the business of produeing the staple foods.

Twelfth. Diseouragement of speeulation in land, by means of graduated taxation and if neessary by prohibiting the aeeumulation of large numbers of farms or other aequisition of land with no intention of oceupaney; in other words, the absolute dissociation of real estate speeulation from farming and from the production of the food of the people. If we are to retain the prineiple and praetice of private ownership, we must not abuse the privilege.

Thirteenth. Recognition of agrienlture in all its phases as a matter of deep publie eoneern, whether regarded as the ma- 
chinery for the production of the food of the people, or as the means of providing ideal conditions for the rearing of children.

Fourtcenth. Finally, the determination to maintain upon the land the same class of people as are those who constitute the prevailing type among the mass of American citizens.

Granted that these or some similar principles are not only right but desirable, how may we best set about their realization in the form of a working National Policy? Upon this point there is interesting material for reflection in the methods by which we have arrived at other convictions that may fairly be called national.

Sccond only to the need of a new national policy regarding any important matter is the method by which in a democracy such new policy may be elevated from the plane of discussion into the realm of conviction and finally established as a permanent part of our national habit of thought. In this connection it is both interesting and profitable to note with some care the various and diverse processes by which our own particular and characteristic national policies have not only come into being but have developed sufficient strength to determine and to dominate the everyday life of the people.

For example, our fundamental doctrine that all men are equal in respect to their right of life and the pursuit of happiness, was declared and formally adopted in a document published to the world.

\section{WHO IS THE FARMER ${ }^{1}$}

\section{A. M. SIMONS}

If we are to select any particular section or type, which shall it be? Shall it be the New England Yankee wresting from his stumpy and rocky soil a niggard subsistence and swapping produets with his neighbors? If so, when we seek him in his native states we shall find him displaced by French Canadians, Italians and Irish immigrants. If we follow up his children we shall hardly recognize them in the tillers of the broad prairies of the

1 Adapted from "The American Farmer," p. 15, Kerr, Chicago. (Copyright holder A. M. Simons.) 
West with a mind and hospitality as wide and as fertile as the teeming soil beneath their feet. Or is the American farmer best typified by the early pioneer,-that strange combination of hunter, fisher, lumberman, farmer, trapper and scout, now wellnigh extinct, but to whom we owe Lincoln, the best and most typical American citizen? Or shall we find him in the South, anid the cotton, rice and sugar plantations? And if here, is he white or black-a member of ante-bellum aristocracy or "poor white trash"'? If purity of American blood is to be the test, the latter will demand first consideration, for in few places is the foreign strain less present than among the moonshining, feudfighting mountaincers of Kentucky and the Carolinas. Is he cowboy, rancher or sheep farmer on the' Western plains? Or is the typical American farmer the resident of the great arid irrigated belt, a dependent upon a great water company, raising almost fabulous crops and receiving a beggarly return? Or is he the Slav, or Italian, or Dutch truck farmer of the city suburb, working beneath glass and aided by steam and electricity? Or shall we find him upon the dairy and stock farms of Illinois, Iowa and Wisconsin? Or is he a fruit farmer, and if so is he in tropic or temperate climes? Is it all of these, or none, or part of each, or a composite picture of the whole that makes up the American farmer?

\section{THE POINT OF VIEW IN COMPARISONS OF CITY AND COUNTRY CONDITIONS ${ }^{1}$}

\section{KENYON L. BUTTERFIELD}

IN vicw of this apparent cliange in the attitude of people toward the farm problem, it may not be idle to suggest some possible errors that should be avoided when we are thinking of rural socicty. The student will doubtless approach his problem fortified against some misconceptions-he probably has thoughtfully established his view point. But the average person in the city is likely to eall up the image of his ancestral home

1 Adapted from "Chupters in Rural Progress," pp. 4-5. (Copyright by University Chicago Press, 1907.) 
of a generation ago, if he were born in the country, or, if not, to draw upon his observation made upon some summer vacation or on casual business trips into the interior. Or he takes his picture from "Shore Acres" and the "Old IIomestead." In any case it is not improbable that the image may be faulty and as a consequence his appreciation of present conditions wholly inadequate. Let us consider some of these possible sources of misconception.

In the first place it is not fair to compare the country life as a whole with the best city conditions. This is often done. The observer usually has education, culturc, lcisure, the experience of travel, more or less wealth; his acquaintance is mostly with people of like attainments. When he fails to find a rural environment that corresponds in some degree to his own and that of his friends, he is quick to conclude that the country has nothing to offer him, that only the city ministers to the higher wants of man. He forgets that he is one of a thousand in the city, and does not represent average eity life. He fails to compare the average country conditions with the average city conditions, manifestly the only fair basis for comparison. Or he may err still more grievously. He may set opposite each other the worst country conditions and the better city conditions. He ought in all justice to balance country slum with the city slum; and certainly so if he insists on trying to find palaces, great libraries, eloquent preachers, theaters, and rapid transit in rural communities. City life goes to extrcmes; country life, while varied, is more even. In the country there is little of large wealth, luxury, and ease; little also of extreme poverty, reeking crime, unutterable filth, moral sewage. Farmers are essentially a middle class and no comparison is fair that does not kcep this fact ever in mind.

We sometimes hear the cxpression, "Country life is so barren ; that to me is its most discouraging aspect." Much country life is barren; but much more of it is only relatively and not essentially so. We must admit that civilization is at least partially vencer; polish does wonders for the appearance of folks as well as of furniture. But while the beauty" of "heart of oak" is enhanced by its "finish," its utility is not destroyed by a failure 
to polish it. Now, mueh of the so-called barrenness of eountry life is the oak minus the polish. We come to regard polish as essential; it is only relative. And not only may we apply the wrong standard to our situation, but our eyes may deceive us. To the uninitiated a clod of dry earth is the most unpromising of objects-it is cousin to the stone and the type of barrenness. But to the eleet it is pregnant with the possibilities of seed-time and harvest, of a full fruitage, of abundanee and eontent for man and beast. And there is many a farm home, plain to the extreme, devoid of the veneer, a home that to the man of the town seems laeking in all the things that season life, but a home whieh virtue, intelligenee, thrift, and eourage transform into a garden of roses and a type of heaven. I do not justify negleet of the finer material things of life, nor plead for drab and homespun as passports to the eourts of exeellence; but I insist that plainness, simple living, absenee of luxury, lack of polish that may be met with in the eountry, do not neeessarily aeeompany a eondition barren of the essentials of the higher life.

Sometimes rural eommunities are ridiculed beeause of the trivial nature of their gossip, interests and ambitions. There may be some justiee in the eritieism, though the situation is pathetie rather than humorous. But is the charge wholly just? In comparing eountry with town we are eomparing two environments; neessarily, therefore, objeets of gossip, interests, and ambitions differ therein. We expect that. It is no critieism to assert that faet. The test is not that of an existing differenee, but of an essential quality. Is not Ben Bolt's new top buggy as legitimate a topie for diseussion as is John Arthur Smythe's new automobile? Does not the priee of wheat mean as mueh to the hard-working grower as to the banker who may never sce a grain of it? May not the grove at Turtle Lake yield as keen enjoyment as do the eontinental forests? Is the ambition to own a fine farm more ignoble than the desire to own shares in a eopper mine? It really does not matter so mueh what one gossips about or what one's delights are or what the earvings on the rungs of ambition's ladder; the vital question is the effeet of these things on charaeter. Do they stunt or eneourage the inner life? It must be admitted that eountry people do not al- 
ways accept their environing opportunities for enjoying the higher life of mind and heart. But do they differ in this respect from their cousins of the town?

\section{SOLDIER SETTLEMENTS IN ENGLISH-SPEAKING COUNTRIES ${ }^{1}$}

\section{ELWOOD MEAD}

ALL English-speaking countries except the United States have passed special soldier settlement legislation and made appropriations therefor. Where good free land exists he is usually given assistance in the individual purchase of private land, or such private land is purchased by the State in blocks. In countries like England, New Zealand, Victoria, and New South Wales it is largely a question of resuming land.

When land-settlement boards do not already exist they have had to be created, except in the case of Ontario and some of the other Canadian Provinces, which are using their minister of lands, their agricultural, and forestry departments for this purpose.

Handling applications and placing soldiers is largely decentralized and in the hands of voluntary local committees.

The English and Canadian method of settlement is to establish central farms on which to try out crops, to employ and train settlers, stock them with animals and implements for the use of the settlers, and about these farms to lay out farm blocks of varying dimensions. The Australian plan is to follow the policy of closer settlement already laid down and so successfully prosecuted.

Explicit data concerning total appropriations are not available. The usual method is to start the work with a small appropriation and to add to it as required. In the case of Canadian Provinces and the Dominion, funds come from an appropriation for general development, probably derived from taxation; in England it is a disbursement from the treasury; in New Zealand and Australia the funds are derived wholly from the sale of bonds in the London market.

1 Adapted from Bulletin, Department of the Interior, U. S. Reclamation Service (1919). 
In the two eountries where a Federal Government exists, namely, Canada and Australia, tentative steps have been taken toward working out a eoöperative plan the general nature of whieh is for the general Government to supply the land and to supervise its division, and maybe eontrol. A general board has been appointed in eael ease and on which each of the states or provinees is represented. Undoubtedly when the period of demobilization approaehes this plan in the ease of Canada and Australia will be carried out in great detail.

Aid to the soldier takes a variety of forms. There are, first, the allowanees which are given a soldier for himself and family in the probationary period of working and beginning of experienee; under this head might be mentioned transportation which all of the countries offer the soldiers when they are traveling to training stations or to the land; second, either the giving of land or the pricing it to the soldier at the cost of purehase and subdivision; third, the supplying of advice, guidance and instructions by all countries; fourth, the supply of grading, farm tools and sometimes farm animals free or at cost (under this head may be mentioned the supply of seeds and fertilizers); fiftl, eredit advances for the taking up of mortgages and incumbrances, for clcaring, leveling, and ditehing of lands, for ereetion of fences, buildings, barns and houses, for the building of homes; sixtl, assistance in the organization of eoöperative buying and selling associations and the giving of whatever aid the State Governments ought to give in this direetion.

In every instance the payments for the purehase of the land or for the reimbursement to the State for advanees are stretched over a long period of time. The period of payment varies from 20 years, as in the case of Ontario, to $36 \frac{1}{2}$ years, whiel is the case in the Australian States. Advances for stoek and developments are repayable in from 10 to 25 years. The intercst. eharged is seldom more than $1 / 2$ ecnt more than the interest paid on publie securitics.

In Canada freehold rights prevail. In England the perpetual lease predominates. In New Zealand both the lease and the freehold are given. In Australia some of the States, such as New South Wales, South Australia, and Queensland, do not give a frechold title. The oceupier pays a rent of about $11 / 2$ per 
eent. of the eapital value of the land and reeeives a perpetual lease which is inheritable and, under eertain restrietions, transferable. The other States offer a freehold title or a lease. The governments of all these eountries are not inelined to part with their grazing lands or lands that are suitable for further subdivisions. They are usually leased for short or long terms.

In nearly all eases, while the soldier is not legally required to naintain a residenee, he can not lease his land or transfer it within a stated period and he ean not meet his payments on the advanees reeeived unless he is giving his whole attention to his land. Residenee, therefore, is praetieally assured.

The seleetion of soldiers and the adviee they reeeive is largely in the hands of loeal eommittees in the ease of Canada, England, and Australia. Sueh loeal eommittees are usually expeeted to give their adviee in the seleetion of lands to be purehased by the State.

Some training of the soldier in agrieulture, and some practieal farm experience is always expeeted. Sueh training and experienee are obtainable from three sourees: Employment on farms, from agrieultural eolleges, or from farms associated with the eolony enterprise.

The legislative aets in all countries are practieally eomplete. The organization for the administration of the acts is largely completed. Some private lands have been purehased and publie lands set aside by all the English-speaking eountries.

It is not possible at this time to give a table of the amount of land so aequired.

\section{THE FARMER IN RELATION T'O THE WELFARE OF THE WHOLE COUNTRY ${ }^{1}$}

\section{THEODORE ROOSEVELT}

THERE is but one person whose welfare is as vital to the welfare of the whole county as is that of the wage-worker who does manual labor; and that is the tiller of the soil-the farmer. If there is one lesson taught by history it is that the permanent

1 From "The Man Who Works With His Hands," U. S. D. A., Office of Secretary, Circ. 24. 1912. 
greatness of any State must ultimately depend more upon the character of its country population than upon anything else. No growth of cities, no growth of wealth, can make up for a loss in either the number or the character of the farming population. In the United States more than in almost any other country we should realize this and should prize our country population. When this Nation began its independent existence it was as a Nation of farmers. The towns were small and were for the most part mere sea-coast trading and fishing ports. The chief industry of the country was agriculture, and the ordinary citizen was in some way connected with it. In every great crisis of the past a peculiar dependence has had to be placed upon the farming population; and this dependence has hitherto been justified. But it can not be justified in the future if agriculture is permitted to sink in the scale as compared with other employments. We can not afford to lose that preëminently typical American, the farmer who owns his own farm.

\section{BIBLIOGRAPHY}

Antrim, Ernest I. Fifty Million Strong. Pioneer Press, Van Wert, O., 1916.

Anderson, W. L. The Country Town. Baker, N. Y., 1906.

Annals of American Academy of Political and Social Science, Vol. 40, March, 1912.

Bailey, L. H. The Country Life Movement. Maemillan, N. Y., 1911. Cyclopedia of American Agric., Vol. IV. . Farm and Community, Macmillan, N. Y., 1909.

The State and the Farmer, Maemillan, N. Y., 1908.

Bookwalter, J. W. Rural vs. Urban, Knickerbocker, N. Y., 1910.

Buck, S. J. The Granger Movement. Harvard Univ. Press, Cambridge, 1913.

Butterficld, K. I. Chapters in Rural Progress. University of Chieago Press, Chicago, 1907.

Farmer and the New Day, Macmillan, N. Y., 1919.

Carver, T. N. Principles of Rural Economies, Ginn, Boston, 1911.

Carver, T. N. Selected Readings in Rural Economies. Ginn, Boston, 1916.

Country Life Commission (Report). Sturgis, N. Y., 1909.

Davenport, E. Edueation for Effieieney. Heatl, Boston, 1909.

Douglass, Harlan Paul. The Little Town. Maemillan, N. Y., 1919.

Fiske, G. W. The Challenge of the Country. Association Press, N. Y., 1912.

Gillette, John M. Construetive Rural Sociology. Sturgis, N. Y., 1912.

Groves, Eriest R. Rural Problems of 'To-day. Association Press, N. Y., 1918. 
Hart, J. K. Educational Resources of Village and Rural Communities. Maemillan, N. Y., 1913.

Herrick, M. T. Rural Credits, Land and Coöperative. Appleton, N. Y., 1914 .

Howe, Fred. The Land and the Soldier. Chas. Scribner's Sons, 1919.

Morman, J. B. Rural Credits. Macmillan, N. Y., 1915.

Nourse, E. G. Agricultural Economies. The Univ. Chicago Press, 1916.

Plunkett, Sir Horace. The Rural Life Problem of the United States. Macmillan, N. Y., 1910.

Proceedings of the First National Country Life Conference. Baltimore, 1919. Pub. by Secy. Natl. Country Life Association, Itlaca, N. Y.

Proceedings of the Natl. Conference of Social Work, Pittsburgh, 1917, 315 Plymouth Court, Chieago, Ill.

Roberston, J. W. .Conservation of Life in Rural Districts. Assoc. Press, N. Y., 1911.

Ross, E. A. Folk Depletion as a Cause of Rural Decline. Pub. Am. Sociological Society 11:21-30, 1916.

Sociology of Rural Life. American Sociological Society, Vol. XI, 1916.

Taylor, H. C. Agricultural Economies. Macmillan, N. Y., 1912.

Vincent, Geo. E. Countryside and Nation. Pub. Am. Sociologieal - Society, $11: 1-11,1916$.

Vogt, Paul L. Introduction to Rural Sociology. Appleton, N. Y., 1917.

Weld, L. D. H. Marketing of Farm Products. Macmillan, N. Y., 1916.

Wilson, W. H. Evolution of the Country Community. Pilgrim, Boston, 1912.

Country versus City. Pub. Am. Sociological Soc., 11: 12-20, 1916. 


\section{CHAPTER VI}

\section{SOME ECONOMIC INTERESTS}

\section{A. COÖPERATION}

\section{THE MORAL BASIS OF COÖPERATION ${ }^{1}$}

THOMAS N. CARVER

So far as I know, everybody agrees that coöperation would be a good thing. Nevertheless, there is little coöperation as yet. If we all agree that it is a good thing, why do we not eoöperate? This is a question which has puzzled many of us. I believe I have one or two suggestions which go pretty nearly to the root of the matter. The eauses of this laek of eoöperation are fundamentally moral, and we must attaek the problem at this point before we ean make mueh progress. All problems hang in elusters. You ean't separate from our moral problems the eeonomic problems that all hang on the same stem. I believe if you will look about your own neighborhood you will find that if you have a neighbor who is very eareful about his own rights and your obligations, he is not an easy neighbor to work witl. These two things mean the same. His rights are your obligations, his obligations are your rights. They are different names for the same thing, different sides for the same shield. Suppose you are the same way. You two will never get along together and work together in this world. A whole eommunity made up of people of this kind will never eoöperate. On the other hand, if your neighbor is very careful of his obligations and your rights, he is easy to get along with. And if you are very eareful of your obligations and his rights, you are also easy to get along with. You two can work together peaeeably and amieably. $\Lambda$ whole neighborhood made up of people of that kind ean work together and eoöperate. Here is some work for the moral and religious ageneies.

1 Adapted from "Proceedings of National Farmers' Congress," p. 191. 
There is a story of an aged savage who, after having lived in civilized communities most of his life, returned in his old age to lis native tribe, saying that he lad tricd civilization for forty years and it wasu't worth the trouble. Much of the philosophy of civilization is summed up in that remark. Civilization consists largely in making trouble. Genius, in the individual, has been said to consist in the capacity for taking pains in one's work. It is this capacity which marks the supcrior race as well as the superior individual. They who find the taking of pains too burdensome to be borne, will naturally decide that civilization is not worth the trouble. They who do not find it so very burdensome to take pains, will naturally decide that civilization is worth the trouble, and will therefore become civilized.

This principle applies to every stage of civilization and progress. The greatest advanecment is made by those who are capable of taking the greatest pains. It applies especially to agricultural progress. It is more trouble to select than not to select seed, and to select it in the field than in the bin. It is more trouble to test cows than to not test them, to kcep accounts than not to keep them, to diversify or rotate crops than not to diversify or rotate, to mix fertilizers intelligently than to buy them already mixed, to coöperate with one's pig-headed neighbors, especially if he himself is a little pig-headed, than to go to it alone. It is also more profitable. In all these and a multitude of other cases it is found that it pays to take trouble.

Suppose we can secure a higher development of these two moral qualities : first, the deep sense of loyalty and obligation to the neighborhood; and second, the willingness and capacity for taking trouble. Then I believe the coöperative movement among farmers would make rapid headway.

\section{FARMERS' COOPERATIVE EXCHANGES ${ }^{1}$}

\section{ALEXANDER E. CANCE}

WiтHis the past few years very much has been said and written about the unprofitableness of agriculture, and on the other

1 Adapted from Bulletin of the Extension Service, Massachusetts Agricultural College, Amherst, 1914. 
hand mueh complaint has been made of the high cost of living and the desperate straits of the consumer. Many eauses have been advaneed to aeeount for this state of affairs, but probably none more frequently than the somewhat vague aceusation that the middlemen take all the profits.

It is asserted that the farmer must take what he is offered for his products and pay what he is asked for his supplies and equipment-that he fixes the priee neither of what he sells nor what he buys. In a general way and eonsidering farmers individually, this is undoubtedly true. When it is said that this is due to the maelinations of predatory middlemen the statement needs some qualifieations.

In the main, the system of middlemen has arisen and developed with the growth of farming for the market. As soon as farmers began to give up produeing solely for themselves and to raise erops to sell, the question of means of disposal of crops beeame very important. One of the first middlemen was the loeal buyer, often the storekeeper, who took the farmer's produce, sold him dry goods, groceries and supplies, and in his turn passed the corn and eggs, feathers and honey, on to the user or manufacturer.

But division of oeeupations and industries resulting in the growth of eities and the eoneentration of population on the one hand and the eall for more raw materials of agrieulture on the other, gradually separated the countryman from the urban dweller geographically, commereially and socially. Commercially the division meant that the farmer must devote himself to growing crops and produeing raw materials of food and clothing, that the manufacturer and artisan give themselves up to their vocations; henec of necessity there grew up a lot of marketmen, transporters, storage men, purveyors and the like, who made a business of getting goods from the farmer to the eonsumer and from the manufaeturer to the farmer.

This body of men holds a strategie position which has becn strengthened by eombination, eapital investments, natural and trade monopolies, and a beneficent Congress. It is not diffieult to understand that they are powerful because they have by organization and superior bargaining ability eome to dominate 
almost the entire trade in raw materials and manufactured products.

It is only natural that the middlemen should endeavor to increase their gains by buying cheap and selling dear, that they should specialize and multiply as the wants of consumers grow and the sources of supplics become more and more distant. The widening gap between the farmer and the users of the farmer's product makes a place for a large number of go-betweens.

Aside from the fact that these men are specialists in their warious activities, that they furnish the money to store and distribute the products of producers, to find markets and facilitate trade, they have in many instances taken over all the marketing activities of the farmer. They often purchase apples upon the tree, pick them, grade them, pack them and ship them, severing all connection between the farmer and lis product before his fruit is harvested. Differing somewhat in degree, the same may in many instances be said of tobacco, live stock, poul-, try, eggs, potatoes, grain, etc. The farmer buys his fertilizer and feed prepared, mixed, bagged, labeled, delivered by the retail dealer into his wragon and paid for by the dealer, wlo gives the farmer credit. The farmer is a producer of goods, nothing more. Possibly that is sufficient, but if so, le should be an intelligent producer, purchasing shrewdly and sclling lis produce at a reasonable margin of profit.

Now it is very evident that farm methods are improving; the farmer is a better producer than he was years ago. But it is also evident that much of the advantage he lias gained through education, applied science, government aid, better equipment and more intelligent practice, has been altogether lost because he has not been able to dispose of his crop or to buy his supplies and equipments advantageously.

In some agricultural industries in the United States and almost everywhere in Europe, farmers have secured great financial advantages and acquired a kecn sense of business by combining their interests, by buying and selling together. In some countries the results of coöperative business methods are marvelous. Denmark has become rich and world-famous, and little Ireland, for years known as the very poorest agricultural country in Europe, lias made remarkable progress, simply because the farmers 
of these eountries have learned to sell their produets in a businesslike way and buy their agrieultural requirements together. They give their attention to produetion but they also see to it that their produets are sold intelligently and wisely by their own paid agents. The farmer eannot very well learn all there is to know about any market but a hundred farmers ean hire a marketing expert to handle their produets and ean afford to pay him a good salary out of inereased returns that otherwise would go to a host of middlemen.

The market of to-day demands two or three very simple things of the produeer. One of the first and simplest is that the quality of the produet be dependable. The market desires sueh produets as are of known quality, whether this quality be first, seeond or third. One great reason why farmers do not reeeive the highest price for their erops is that they have not learned to ship to the market uniform grades or qualities. When, for example, a barrel of apples is paeked it is likely to eontain apples of the first grade, seeond grade and eulls; perhaps a large part of the barrel eannot be used at all. The seeond barrel may be just like the first or it may be something very different.

In the seeond place, the market demands a neat and uniform paekage. Every marketman in the eountry eomplains of the faet that farmers have little real business sense in the matter of putting up their produets in paekages. One finds potatoes eoming into the market some in barrels, some in boxes, some in bags, some in other paekages of every deseription and degree of deerepitude. A uniform, neat and tasty paekage suited to the eommodity whieh it eontains is a great faetor in inereasing the priee of the produet.

In the third plaee, the market wants produets shipped regularly in quantities suffieient to supply the demand. It is no little matter to the marketman that he ean get all the potatoes he wants one week and eannot get any the next. What he desires is, perhaps, a earload of potatoes every other day for six months and a earload every three days for the other six months. At any rate, it is essential that he reeive his shipments regularly from the shipper.

These simple essentials-dependable goods, paeked uniformly and neatly, well graded, shipped regularly in suffieient dyuantities 
to mect the demand, ean hardly be supplied by the small individual farmer; and because they cannot be supplicd in that way, the marketman and eonsumer naturally go to the jobber to get their goods. The jobber pays the farmer as small a price us he ean and charges the consumer as high a priee as he can for his eostly serviees of packing, grading and distributing the product uniformly.

European farmers in England, Ircland, Denmark and other countrics found themselves confronted with the same marketing eonditions which the farmers of the United States have found. They struggled with it just as the farmers of the United States are struggling, but unlike the majority of the farmers of the United States, they struggled to some effect. The farmers of the Old World are small farmers. Not many of them produce more than a mere handful of products of any one sort. Some of them found themselves with no home market and were obliged to ship their produets across the seas into forcign countries. Some of them found an organized opposition to the sale of their goods in other countries. Nevertheless, the-European farmers in the countries mentioned found the way out by organizing themsclves into small coöperative selling associations. By pooling their products they were able to facilitate their marketing because, in the first place, they were able to pack uniformly, supply the market sufficiently and regularly, and beeause of the supply which they controlled, they were able to meet successfully organized opposition to their interests.

No other poultry in the world is packed as well as Danish poultry; no other eggs are graded as well as Danish eggs; therc is no bacon that eommands a higher price than Danish bacon. This is true chiefly bccause Danish poultry, Danish eggs, and Danish bacon are skillfully packed, uniformly graded and shipped regularly under the guarantec of the shipper. It is known the world over that this coöperation has been the salvation of Danish agriculture, that the farmer of Denmark is to-day the most important man in his eountry and is important chiefly beeause he has known how to organize. It is said that the number of coöperative organizations in Denmark is four times the number of farmers; that is to say, on the average, each farmer in Denmark belongs to four coöperative organizations, 
In Ireland and England coöperative buying and selling have not yet reached the perfection they have in Denmark. Nevertheless, the Irish farmer has for some years been selling his bacon, eggs and poultry on the markets of the world very successfully because he has been shipping them through his local coöpcrative socicties.

The United States has lagged somewhat behind in the matter of coöperative endeavor among farmers; nevertheless, there are some examples of very successful coöperation even in our own country. Perhaps nowhere in the world is there a stronger selling organization than the California Fruit Growers' Exchange. The Exchange has passed through various vicissitudes and has met successfully the most serious opposition from railroads, commission men and other opposing interests. It is now so strongly entrenched in handling the citrus fruit of the Far West that it is a mere truism to say that without it citrus fruit growing on the Pacific Coast would be an utter failure.

The Hood River and other northwestern apple-shipping associations have been almost as successful in marketing apples as the citrus fruit men have in handling their California oranges. The Hood River apple growers have a world-wide reputation for ucat and uniform packages of thoroughly dependable apples which are absolutely guaranteed to the consumer. These apples are packed by authorized inspectors and shipped by experts. They are sold on the markets of the world by agents of the fruit growers' association and all the returns for the apples go to the grower after deducting the charges of transportation and the scrvices of agents employed by the association itself.

Moreover, the truek growers of the Atlantic Coast and the Gulf region have made use of associated selling for some years. The example of the Eastern Shore of Virginia Produce Exchange is most worthy of imitation. Beginning a few years ago with a number of disgruntled farmers who had been shipping their perishable products individually to the markets of Philadelphia and other eities, it has grown to be one of the strongest marketing associations in the United States, doing millions of dollars worth of business and putting upon the market products guaranteed by the Exchange in which the commission men and retailers have the utmost confidenee. 
Thesc coöperative associations, in fact, are becoming more and more numcrous wherever specialized products, usually of a perishable nature, must be put upon a market at some distance. Wherever they have been established successfully they have succecded in bringing to the producer a higher price for his product, a chcaper charge for transportation, a more dependable and a wider market, and consequently an increased prosperity. On the other hand, the consumer has been able to get a product of standard and dependable grade at a price not exceeding very greatly, if at all, the price which he paid for a poorly graded product unreliable in quality.

Nowhere is it more truc that "In union there is strength" than in the shipment of perishable products to commission men. The united farmers have been able to protect themselves in a way the isolated individual farmer could never hope to do, against commission men, transportation agencies, and other allied interests. The fact that they were able to choose between twenty or thirty different markets during the season gave them an added advantage in selling their products.

Coöperation among farmers in New England has never been very enthusiastically received although it must be said that several very successful farmers' coöperative societies, both for purchase and for sale of products, have been formed in our east. ern states. Some of the alleged reasons for the lack of entluusiasm on the part of our New England farmers are first, the individualism of the farmer, his desirc to do his own marketing and to make his own bargains, and perhaps his dislike of interfering in his neighbor's business or to permit his neighbor to interfere in what he considers private matters. As a matter of fact, the old independent farmer about whom so much has bcen said has practically gone out of existence. The farmer of to-day depends upon his market quite as much as the grocer does. His products are frequently prepared for markct, shipped to market, handled by marketmen in precisely the same way as are the products of the manufacturer. Consequently the farmer is interested in the amount his neighbor sells and in the quantity the consumer in his marketing town purchases. Hc is interested in railroads, transportation, banking, and all means of exchange, and the markets of the world measurably affect him. 
In the second plaee, it is said that the farmer has not sufficient business ability to eonduet a eoöperative organization. While this is true in a number of instances, it should not be true of the farmers of New England who are said to be as shrewd bargainers as any farmers in the world. The farmers of New England are intelligent and should be as enterprising and as capable of handling the coopperative assoeiations as the farmers of Ireland, the farmers of Denmark or the farmers of Texas.

Another legitimate reason for the failure of eoöperative organizations among farmers has been the fact that most organizations of farmers have had so many purposes that the real object of the association has beeome obseured. This has been one diffieulty in the formation of business eoöperative assoeiations by the Grange. Again, too, a good many of these eoöperative soeieties have failed because the members of them have had no common interest; a coöperative organization is a very simple thing but each should be eomposed of men who are bound together by some common interest. A large number of purposes or objeets is likely to defeat the whole end and aim of a business enterprise.

One of the first essentials to suceessful coöperation is sufficient matcrial in a given eommunity with which to do a coöperative business.

On the other hand, for purposes of eoöperation, it is altogether best that the coöperating area be rather small. It is much easier for a number of farmers in a small eommunity to organize for purposes of purchase or sale than it is for the farmers seattered over a county or two eounties to organize. Consequently intending eoöperators might well consider the growing of one or two speeial crops by all the members of the coöperative assoeiation.

The third great essential to eoöperation is loyalty. There is no use eonsidering a coöperative society unless the members are loyal to the association even to the point of suffering some loss for the sake of keeping the assoeiation alive and prosperous. This loyalty is one of the most noticeable features of eoopperative soeieties abroad and of sueeessful eoöperative soeietics in the United States. The members uphold their soeicties against all charges, furnish the required raw material even when the coöp- 
crative society pays them less than they could receive outside, and sometimes even when coöperative selling is not always as suceessful as individual selling.

The fourth essential is singleness of purpose. It is true that a great many of the coöpcrative soeicties in the United States both buy and sell but it is also true that most of these successful societics are organized cither for buying or for selling only. A coöpcrative socicty should be organized to sell apples, or to buy feeds, fertilizers or other agricultural requirements, or to store cabbages or onions, and if these same farmers desire to coöperate with others for some other purpose they should form a second association.

The fifth essential is incorporation. Nearly every successful coöperative society in the United States and many abroad are incorporated under state laws. The incorporation of a society is a simple matter but very many fine results accompany it. In the first place, the management is a board of directors definitely provided for in the articles of incorporation. In the second place, an incorporated society cannot go out of business during the limit of time fixed by the articles of incorporation, whereas, a society organized otherwise may stop business at any time, frequently with disastrous results. In the third place, the members of an incorporated socicty are liable for the debts of the society only in proportion to the number of shares which they have taken; and finally, the incorporated socicty is subject to the inspection of the state and all its business must be conducted on approved business lines.

The sixth essential is paid, efficient management. A great many of our eoöperative socicties have gone to the wall because the management was inferior or because the management was in too many hands. The best societies in the United States, in fact almost the only societies that are successful, are those that have a single manager. Moreover, if this manager does any business at all and is at all capable he should be paid and well paid. Managers of some of the larger coöperative societies are paid remarkably good salaries. For example, the manager of one of the vegetable exchanges is receiving $\$ 10,000$ a year.

The seventh essential is absolute publicity regarding the affairs of the soeiety; this ineludes a full and complete oversight 
of the books, papers, and policies of the exehange by its members and, in addition, a eareful supervision of the accounts at stated intervals.

Another essential to suecessful eoöperation is that the business be done as far as possible on a cash basis. Extension of credit has been a rock on which a good many otherwise suecessful organizations have been wreeked beyond repair. The temptation to extend eredit to members or to outside interests is very great, and though sometimes a eredit business may be earried on very sueeessfully, in general it is decidedly safer to make all business cash business. A corollary to this is that sufficient cash should be provided to carry on the work of the exehange effeetively.

Finally, every coöperative association should be organized on strictly coöperative principles. A number of coöpcrative societies, both in this eountry and abroad, are merely joint stock companies, and some of them are operating more or less suecessfully. Nevertheless, there are some principles which are esscntial to the true spirit of eoöperative endeavor and which, in the long run, give better financial and social results than others.

\section{THE FUNDAMENTAL PRINCIPLES OF COÖPERATION}

The essential differenee between a coöperative soeiety and a joint stoek eompany is this: A joint stock company is a eombination of capital or shares. Capital is invested in the business and all the profits are supposed to acerue from the use of eapital, eonsequently all profits are returned as dividends to the shareholders. It makes no differenee whether the dividend be 2 per eent. or 20 per cent. or 200 per eent., it is distributed among the men who hold the shares.

Again, the men who hold the eapital stoek in a joint stock eompany are the men who do the voting. They do not vote as men, they vote as shares; the inan who has ten shares has ten votes; he who has but two shares has two votes; the thought being that the more shares a man has the more powerful he should be in determining the policy of the eompany.

Now the principlc of a coöperative society is fundamentally different. A coöperative soeiety reeognizes the need of capital but it also reeognizes the fact that a reputable eoneern may obtain capital anywhere at the ruling rate of interest. The ruling 
rate of interest is now between 5 and 6 per eent. Why should a man who invests only his money in any business receive more than the 5 or 6 per ecut. that is recognized as legitimate payment for eapital, the rate that a bank will cliarge? So in a strictly coöperative socicty it is agreed that capital shall be paid merely the ruling rate of interest, say 6 per cent., and that all further profits shall be returned to the men who have supplied the business of the coöperative socicty, on the basis of the amount of business they have furnished. That is to say, in the coöpcrative ereamery, the profits will be distributed among the members who have furnished milk to the creamery, in proportion to the amount of milk they have furnished. The man who lias purchased shares will draw 6 per cent. on his capital investment, but the men who have been responsible for the success of the exchange will receive whatever profits there are in accordance with the amount of business they lave done.

In the next place, the coöperative society is democratic; it is a union not of shares, but a union of individuals. Instead of allowing each share to have a vote, each man is given one votc. The principle is this: It is believed that each member, no matter what his contribution to the capital of the association, has as much right to vote concerning its policies as any other shareholder; just as a citizen, no matter low many children he has or whether he has any children at all, has a right to vote for school officers. In a democracy every man has a vote; so it is in a coöperative society. One man, one vote.

Further than this, the coöperative socicty recognizes that there should be a limitation on the amount of eapital stock any man may control. Surely, in a coöperative soriety the capital should be contributed by members approximately according to the amount of business which each man expects to do with the society. If a coöperative socicty is established with 200 shares, it is quite legitimate to say that no member shall hold more than one-tenth of the total number or twenty shares. This keeps the shares well distributed and makes for democracy.

Another point of importance is the transfer of shares. It is ordinarily unwise to have men investing money in a coöperative concern in which they are not interested. A coöperative society, in the first place, should be formed of men who are inter- 
ested in a partieular line of coöperation. Consequently, when any member drops out and wishes to dispose of his shares, he sliould not be permitted to sell them to any person he pleases for, in that ease, he might sell them to some person opposed to the interests of the eoöperative soeiety. Henee, the proviso that a nember may not make a transfer of his shares that is not first approved by the board of direetors.

These are the fundamentals upon which a eoöperative soeiety should be founded. If placed on this foundation, and the members remain loyal, suceess is reasonably assured.

\section{SOCIAL EFFECTS OF COÖPERATION IN EUROPE ${ }^{1}$}

\section{CHARLES O. GILL}

Tile expansion and magnitude of the eoöperative movement are no more impressive than are its soeial effeets. In mentioning these it is not intended to give the impression that in every eommunity where there is a eoöperative soeiety all the good results are observable which are eommonly attributed to eooperation. Doubtless large numbers of eoöperators think ehiefly of the redueed eost of their purehases, of the higher prices they lave reeeived for their produets, or of other material benefits. But it is none the less true that in this eeonomie movement the applieation to business of eertain ethieal prineiples of a high eharaeter lias produeed a variety of other good results which also are well worth eonsideration.

The good results of eoöperation among the poor farmers in Europe are inealeulably great. It has emaneipated them from the usurer. In many places small farmers had never known freedom from oppressive creditors unt il the founding of rural eooperative institutions. By these they have been released from this bondage. Whole eommunities of people have been emancipated. By eapitalizing the eommon honesty of the poor, eoöperation las secured for the small farmer at the lowest rates of interest, money to be used by him for produetive purposes while

1 Adapted from Report of Commissions, pp. 127-143. Federal Council of the Churches of Christ in America. Missionary Education Movement of the U. S. and Canada, N. Y., 1916. 
the time fixed for payment is well suited to his convenience and to the needs of his oceupation. Agricultural coöperation in distribution has enabled the farmer to work for his own support instead of for the support of a large number of superfluous distributors who constituted an enormous burden resting upon his shoulders. Before the introduction of the coöperative system the small farmer in all business operations had been discriminated against. He had been forced to buy inferior goods at high prices and to sell his products at prices unreasonably low. Probably the farmer's business was the only one where products were sold at wholesale while its requirements were purchased at retail prices. But coöperation has changed all this. It has enabled the small farmer to place himself on a level with the large farmer in producing articles of good quality as well as in the matter of prices received for them. It has cnabled the smallest holders to obtain at moderate prices goods of guaranteed quality. Thus while it promotes efficiency on the farm, coöperation secures freedom in the market and so contributes to the highest life in the home.

Agricultural coöperative societies engage in many benevolent enterprises for their members. The Raiffeisen banks in Germany, for example, support infant and continuation schools. They furnish the ordinary seliools with maps, musical instruments and other equipment. They make grants to village libraries, organize circles for reading and acting and establish cvening clubs and clubs for jurenile nembers. They eonduct village institutes, build meeting halls and establish children's savings banks, telephone services and arbitration courts. They appoint local cattle shows and hold regular mectings at which instructive lectures on coöperation and agriculture and other topies are delivered. They form gymustic societies and bathing establishments, eattle and poultry breeding societies, singing societies, local nursing centers, infant aid associations and anticonsumption leagues, and engage in other good works of great variety.

Not only does the increased prosperity of coöperators secure for them better education through the ordinary channels but the special facilities provided by the society, the training in doing coöperative business, together with mutual association 
under these favorable eonditions, the elose eontaet and assoeiation with the larger world which eoöperation always assures, all result in intelleetual development and help to inerease the intelligenee and add to the fund of general information of the eooperators.

It has been observed both in eountry and in eity that eoöperation has a most marked effect on the promotion of thrift. The eoöperative soeiety provides the farmer with the means of pursuing produetive enterprises and eonsequently he engages in them. IIe gets out of debt and as a rule begins to save. In the urban movement it is often the ease that the hard drinking laborer who is head of a wretehed family is indueed to trade with the eoöperative society and finds in a few montlis that he has money to his eredit drawing interest. It is likely that he has never had in his possession money enough to supply his family with food for a week in advance. But his aeeumulated savings give him hope and he is eneouraged to save further. Many a man of this sort, whose original investment had been only a dollar and twenty-five eents, eventually lias aequired as mueh as five hundred dollars. The eondition of his family of course beeomes greatly improved.

When a man begins to save, his money, instead of going into the dram shop, is invested in the eoöperative institution. In the eountry as well as in the eity the wastefulness and the evil effeets of aleoholie intemperance beeome reeognized and the influenee of the eoöperative soeiety is thrown against it. In Dungloe, Ireland, the coöperative store is the only one in the village which does not sell spirituous liquors, thougl it is doing a larger business than any other drug store. In another place where the people wished to form a coöperative soeiety and run a store for household goods the Irish $\Lambda$ grieultural Organization Society refused assistanee beeause the people who desired to eooperate thought it neeessary to sell whiskey in order to hold their business in competition with the otler stores, all of whieh engaged in the liquor traffie. In Austriamand Hungary the priests are the more aetive in the promotion of the eoöperative movement beeause the members spend their evenings in the eooperative soeiety rooms instead of in the publie houses. In Belgium the influenee of the eoöperative soeieties is strongly used 
in favor of abstinenee from strong drinks. In nearly all the eafés and restaurants eonnected witl the eoöperative institutions spirits are not sold while eustomers are eneouraged to drink light beer or non-aleoholie beverages. Thus the coöperative movement has beeome one of the strongest movements in the old world both in eity and in eountry for the promotion of temperanee.

One of the most marked effeets of the movement is the promotion of business integrity. This is a matter of eommon observation and experienee and is well known throughout the eooperative world. For example where there is a small rural coöperative eredit soeiety, a person ordinarily cannot borrow from it unless he has aequired a reputation for reliability. $\Lambda$ s a eonsequence a loan eomes as a eertifieate of eharaeter, while a refusal of one may well be a eause of serious reflection on the part of the would-be borrower. As a result, people learn to eare more for their eharacter and reputation in their dealings with one another. It beeomes manifest to all that honesty is an essential quality for business effieieney.

In agrieultural eoöperation high priees are seeured only beeause the good quality of the produee is guaranteed by the soeiety. Any member who fails to eonform to the standard will be fined or exeluded from its privileges. The eonsumer and the eareful produeer therefore are protected from loss resulting from the misrepresentation of the eareless or dishonest produeer. By making the produeer more eareful, muel waste and injustiee is avoided, while it is eontinually being demonstrated that a high standard of business morality in the individual is an asset both for himself and for his eommunity.

The promotion of honesty by the coöperative movement eomes also more direetly through the atmosphere it ereates. Coöperative business promotes what is ealled the eoüperative spirit. It is a conseiousness of brotherhood. Under its influence one does not wish to injure one's neighbor. Cheating and sharp praetiee are so out of plaee and altogether diseordant with the eoöperative spirit as to insure their infrequeney.

The independenee, eourage and self-respeet, inclueed by freedom from debt, material prosperity, thrift, and temperanee are also inereased by reason of membership in a firmly knitted self- 
help association of responsibility and power. In one community visited it was remarked to the investigator that you ean tell a coüperator by his independent bearing. In more than one loeality attention was called to the faet that on the part of the bankers and business men in their dealings with the small farmers and the poor people, there has been a marked disappearanee of condeseension and the air of favor and patronage. In parts of Ireland visited the respectful treatment on the part of others is keenly appreeiated by the eoöperators, while the system has eaused a greater fellowship and better mutual understanding between the elasses. There is a soeial and industrial leveling up whieh is satisfaetory to all eoncerner.

All this points to the powerful influenee of eoöperation in the promotion of democracy. The eoöperative movement was essentially democratic in origin. Both the original founders and the prime movers were mainly from the class most directly benefited. That the democratie prineiple is the basis of success in agricultural eoöperation is proved by the faet that attempts of farmers to eombine on other principles almost invariably have failed, while in eities no other industrial system has been attended with soeial results which are so satisfactory. True eoöperation which alone ean hope for enduring prosperity is founded on the principle of pure democracy.

The educational effect of the coöperative system is sueh as to give the wage earners a keen interest in public affairs and to eause them to realize their own power and responsibility in them. That the eoöperators use this power intelligently may be seen in the large number of their representatives in the publie bodies and the creditable manner in whieh they acquit themselves. It is confidently asserted that 70 per cent. of the coöperators are on the side of political progress. Coöperation is becoming one of the strongest aids to efficieney in political democracy.

It is the hope of most leaders in the coöperative movement that it will do much to make war less frequent. The eoöperative alliances of different eountries will undoubtedly increase their trade with one another. $\Lambda$ lready reference has been made to an international alliance of eoöperators. The members of a great intemational business organization will understand the folly of going to war with one allother. Among eoöperators there is a 
minimum of unutual suspicion. With them the recognition of brotherhood and community of interest is a habit of mind. Add to this their increased intelligence, larger information, broader outlook, and increased politieal efficency, and we must recognize that the bonds which hold the people of the earth together in peace will be strengthened as the eoöperative movement advanees throughout the world.

The experienee of the coöperative movement indieates that the application of right ethics to business results well, not only to business itself but to the charaeter of those engaged in it and to all parts of the social fabric.

It was observed by members of the Ameriean Commission that in nearly all the European eountries from Italy to Ireland "the great body of coöperators, especially among the leaders, think of agrieultural eoöperation as a sort of social reform and in some eases almost as a religion."' The admirable moral and social results are reeognized nearly everywhere. Not only has it taught illiterate men to read, made "dissipated men sober, eareless men thrifty, and dishonest men square" but it lias made friends out of neighbors who had always been enemies, while estrangements among men through religious antipathies and the inheritance of ancient feuds have yielded to its influence and have disappeared.

It is natural that sound prineiples of economie justice and the spirit of brotherhood should create enthusiasm in those who are engaged in the movement. In the coöperative enterprises therefore laborers are more contented, enjoy their work better and labor and live with more zest. Large numbers of eapable exeeutives are engaged in the movement at great personal saerifiee to themselves of time and money. Many men, beeause of the sane spirit, are living in great frugality though rendering invaluable service. Frequently organizers of coöperative societies in whole hearted devotion live on the lowest possible salaries, suffering hardships and prolonged absence from congenial homes. The Agricultural Organization Society in Ireland impressed the investigator as a Christian institution quite as really as did the churehes in that eountry. The movement in the vicinity of Dungloe, Ireland, has an atmosphere like that of a Christian missionary enterprise in its pioneer stage of development. In two 
other plaees in Donegal, Ireland, two meetings attended were like religious services. The eö̈perative movement in the vicinity of the Temple Cronc Society is regarded by the people as divinely inaugurated, inspired, direeted and sustained.

It could scareely be expected that a movement with sueh beneficial results could have been inaugurated and sucecssfully furthered apart from close assoeiation with the Christian ehurehes. In many of the coöperative enterprises it was found that the elergymen have played an important part.

\title{
B. OWNERSHIP AND TENANCY
}

\section{TENANT FARMING ${ }^{1}$}

\author{
JOHN M. GILLETTE
}

THERE is a tendency somewhat pronouneed toward the operation of farms by tenants rather than by the owners. The owners ceased opcration to the extent of almost ten per eent., in the twenty years between 1880 and 1900 , and tenantry was substituted. The results appear to ensue ehiefly from three causes. First, the investment in farm lands by eity residents-generally in proximity to their municipality, and second, from the retirement of well-to-do farmers into the neighboring eity or village. Third, a larger period is required to save money with whieh to buy a farm than was previously the case. As a eonsequenee, eaeh suecessive generation of farmers must remain longer in the tenant elass.

The tendeneies in the United States are not decisively toward extended eonsolidation and enlarged holdings, In the regions where the enlargement is most noteworthy, it is apparently due to the operation of causes other than the advantage in produetion which arises from large holdings. Quick and large rises in land values, as in Iowa and Illinois, have induced multitudes of

1 Adapted from "Coustructive Rural Sociology," pp. 130-137, hy permission, copyright 1913, 1916, by Sturgis \& Waltou Company, N. Y. Copyright now held by The Maemillan Company. 
owners to sell out and go to newer regions in the United States and Canada where several times the amount they owned ean be purehased for what they reeeived. In the Southeastern States it is the onteome of the dependeney of agrieulture on an ignorant, colored, labor population.

Further, it is likely that when the possibility of proeuring eheap land in the United States and Canada has passed farmers in the improved agrieultural regions will eease to sell to neighboring farmers. When this point is reaehed, and when, also, estates begin to be divided among the deseendants of present farmers, we may expeet to see the eessation of the eonsolidation tendeney and the development of small and intensive farming.

Farms are almost always leased in Great Britain. In France 77.6 per eent., and in Germany 83.6 per eent. of the farmers own all or a part of their farms, while in the United States 35.3 per eent. are tenants.

There are two opposing views as to the effeets of tenant farming and small proprietorship.

1. Young and Mill held that small proprietors form the basis of individual prosperity, independenee, and well being. Young, who traveled through Europe in 1787-8, and who believed in large agrieulture, testified that while there was mueh poor farming on small properties, "yet the industry of the possessors was so eonspieuous and meritorious that no eommendation would be too great for it. It was sufficient to prove that property in land is, of all others, the most aetive instigator to severe and ineessant labor." He thinks the way to get mountains farmed to the very top is to let them out as property to small owners.

Mill reviewed the faets and literature of the eontinental method of small holdings as opposed to the English praetice of large estates in his attempt to get England to see the mistake and loss ineident to its praetice. He believed the evidenee proved that peasant properties eondueed to the moral and soeial welfare of the laboring elass by inereasing their industry to what a Swiss statistieal writer deseribed as "almost superhuman industry"; that territorial arrangement is "an instrument of popular edueation." "The mental faculties will be most developed where they are most exercised; and what gives more exercise to them than the having multitudes of interests, none of which ean be 
negleeted, and which ean be provided for only by varied efforts of will and intelligence?"

Small proprietorship is "propitious to the moral virtues of prudenee, temperanee, and self-eontrol." Laborers are liable to spend their entire wagc. "The tendeney of peasant proprietors, and of those who hope to beeome proprietors, is to the eontrary extreme; to take even too much 'thought for the morrow' "' to be penurious. Even among the pleasure-loving French people of the agricultural sort "the spirit of thrift is diffused through the rural population in a manner most gratifying as a whole, and which in individual instanees errs rather on the side of excess than defeet."

Mr. Mill further holds that small holdings would not interfere with the desirable and much needed purpose on the part of the workers to exereise prudence and restraint in the inerease of population. Some writers had held that peasant proprietors would be likely to multiply up to the limits of food produetion and thus force a minutc subdivision of land. Mr. Mill believes that without education and habituation into the exercise of prudenee the land proprietors, like other workers, would increase in number up to the food limits. But that if indoctrinated-like their urban brothers-they would excreise due restraint. Furthermore, he marshals facts from Switzerland, Norway, Prussia, and other continental countries to demonstrate that peasant proprictorship not only did not evole over-population but rather ehecked it.

Coneluding his chapters on peasant proprietors lic says:

"As a result of this inquiry into the direct operation and indirect influences of peasant properties, I eonceive it to be established that there is no neeessary eonneetion between this form of landed property and an imperfeet state of the arts of production; that it is favorable in quite as many respects as it is unfavorable, to the most effective use of the powers of the soil; that no other existing state of agricultural ceonomy has so beneficial an effect on the industry, the intelligenee, the frugality, and prudenec of the population, nor tends on the whole so much to discourage an improvident inerease of their numbers; and that no existing state, therefore, is on the whole so favorable, both to their rural and their physical welfare. Compared with the 
English system of eultivation by lired labor, it must be regarded as eminently benefieial to the laboring elass. Freneh history strikingly eonfirms these eonelusions. Three times during the eourse of ages the peasantry have been purehasers of land; and these times immediately preeeded the three prineipal eras of French agricultural prosperity."

2. The other view is that effective farming in the future ean only be done by a system of large properties and tenant renters whose rights are proteeted by legal provision. It is held that the eapital whieh needs to be invested in machinery and equipment in order to make farming eompetitively profitable and possible eannot be provided by small owners. They will be foreed to sell to eapitalistie owners who ean make the large investments needed. Moreover, the fall in priees plaees a shoek on the landlords and farmers which is not felt by other eallings in the same manner. Small proprietors have nothing to shield them from the shoek and must give way to men of larger resourees.

It would seem that reeent events and the spirit of present times is in favor of the position leld by Mill. The progress that is being made in agrieultural development in Europe and Great Britain is most eonspieuous just where the larger estates are being broken up, pareeled out, and vested in numerous small proprietors. This is notably the ease in Ireland and in Denmark and in both eountries farming and dairying have made prodigious progress, and in both the eonsequenees have been of the best for the charaeter and intelligenee of the citizenslip. New interest in life, renewed industry, progressive and eoöperative undertakings, enriehed soeial and moral life, have been the results.

Of mueh importanee to rural soeiology is the effeet on rural soeial life of absentee landlordism and of tenant farming. The eeonomie effeets of absentee landlordism with its attendant abuses lias had historic examples. Perhaps the most notable reeent one has been that of Ireland. The profits of the large estates were spent abroad, draining Ireland of its produetive eapital; the best land of large estates was turned into pasture land; and when tenants made improvements on farms to enlarge the produetion the rents were systematieally raised to absorb the reward of initiative and industry. Consequently a premium 
was plaeed on negleet, shiftlessness, drunkenness, and soeial squalor, and agrieultural Ireland was emigrant as to its best and most vigorous element, deeadent eeonomieally and soeially, and rapidly inereasing in pauperism and insanity. The various Land Purehase Acts passed by Parliament revolutionized Irish society, for it was mostly agrieultural and rural. Small estates eould be purehased on one hundred year payments. Buildings and sanitation were fostered. Agrieulture and edueation were promoted. Coöperative undertakings took root. As a eonsequenee the inhabitants are beeming thrifty, industrious, interested in their own community affairs, temperate, and a larger life is full of promise.

In Ameriea soeial degeneration due to tenaney has been noted. Absentee landlordism visits on the given region heavy eeonomic injuries. The tenant who keeps up the buildings, grounds, fenees, and fertility of a farm as he would were he owner is rare indeed. No doubt juster laws and more progress in seientifie agrieulture would form a basis for the eorreetion of some of these matters. Now the tenant sees no profit in the upkeep of the farm. He believes he obtains the greatest advantage in getting the largest returns with the least effort. Could just returns for his efforts be seeured the results would be better.

But the economie phase is less important than the soeial. The eommunity interests are at stake, and are put in jeopardy wherever a neighborhood is given up to renters dominantly. This faet has been observed frequently. Strong spoke of it in his "New Era" many years ago. It has reeeived passing attention now and then sinee that time. Near Syraeuse, New York, (1894), life in eertain tenant eommunities seemed pathetie. Chureh, sehool; and home indieated systematie negleet. In north eentral Kansas (1895) renters exereised neither interest nor influence in eommunity matters. Observations in Montgomery County, Illinois, (1901-1903), resulted in the belief that sehools and ehurehes were deelining under tenant eonditions. Resident owners reeognized and deplored the faet. Olservers in North Dakota report similar eonditions wherever renting predominates.

As an aecompaniment of the neglect of ehurch and sehool the moral and eultural tone of the neighborhood sink low. Coöpera- 
tive ethical activities of country districts usually reside with the church. The larger eultural and social outlook associate themsclves with ehurch and school and are products of their life. Immorality, vulgarity, low cthical ideals, insufficiency of informational and esthetic agencies and outlets result from irresponsibility and transiency.

\section{SOME ADVANTAGES OF TENANCY ${ }^{1}$}

\section{W. O. HEDRICK}

THE public has become interested only recently in the size of businesses generally, but since 1890 our census burcau has collected statistics relative to the size of farms. Spcaking generally, the public cares not at all whether factories and stores and railroads are rented or are owned by their operators, but it has given much attention to the ownership and rental tenures of land since 1880 .

The curious fact is revealed by the last census enumeration (1910) that it is the very large farm which has been notable during the past ten years. The farms of from 500 to 999 acres have had second place in growth of numbers, have execeded all others in absorbing total farm area, have exceeded all others in enlarging improved acreage per farm, have shown the biggest increase in value of total farm property of any class, were sccond greatest in increased building valuation, have had greatest increase in machincry valuation and third greatest in livestock inercase. The relatively small number of these farms, however, robs this record of much significance in characterizing American farm sizes.

With regard to landlordism and tenantry, the samc motive which is relied upon by society to sccure effective farm handling, that is, "self interest," is the very one which stimulates tenants to rent farms. The farm business requires a combination of several factors-notably land, labor, and equipment - for its best success. The extremely high price of all these clements renders it sometimes necessary that two enterprisers should combine their

I Adapted from Publications American Sociological Society, Vol. 11 : 94-96, Dec., 1916. 
factors, one furnishing land, the other labor and equipment, and we have, therefore, the landlord and tenant relation. Farmmanagement studies show almost invariably that tenant farmers make good labor incomes, and no little care should be taken in disturbing a system not adverse to public policy which with all its faults is distinetly profitable to the farmer.

Country-life improvement may indeed be hindered in its coöperative aspect by the presenee of the shifting tenant, but an even more fundamental.wrong may be done by striking at the produetivity of agrieulture itself in the attempt to eliminate this sort of farmer. Commonly it is assumed that tenancy is a stepping-stone to ultimate land ownership. The young farmer or the needy farmer may come to own a farm through a preliminary period spent as a tenant farmer, or he may attain full ownership through the mortgage-indebtedness route. Comparing only the more superficial features of these two methods of reaching the same end and we have the following results. Through having the stimulus to industry which eomes from ownership and through directing his business at will, the mortgagor is advantaged, but he is limited in his farm operations through having invested his eapital in land. On the other hand, the tenant leaves to the landlord the burden of carrying all the unproductive farm parts, such as buildings, fences, lanes, wood lot, etc. $\mathrm{He}$ is further advantaged through putting all his eapital into livestock and equipment, thus being enabled to operate to the maximum of profitableness. He gains nothing, however, by the appreeiation in value of land.

The suppression of tellancy restricts the young farmer or the impeeunious farmer to alternatives which may prove hurtful from the business standpoint. The going in debt for a full-sized farm, as we have seen, is likely to leave the farmer short-handed in the means for the operation of this farm. Another alternative is the little farm-one which he is able to pay for and yet have some means left over-but every study of the little farm has convineed the student of the utter unprofitableness of this style of farming. Farm machinery is standardized in size to the needs of the full-sized farm; a profitable number of labor hours for man or team can be found only upon the full-sized farm. Insufficient variations of enterprises and too high costs in overhead expenses 
are only a few of the many reasons given for the unprofitableness of the small farm.

The sliaring of the expenses of earrying on a farm business between two parties, one furnishing the land factor and the other the labor and equipment, has afforded a sueeessful farm business in the past and still has merits for the future. We find nothing to justify the belief that the landlord's share is to grow larger to the disadvantage of the tenant through the income-absorbing power of land. Landlords will doubtless always secure the returns which are possible to them through owning advantageous differentials in land. The differentials tend to become aecentuated with the inerease in price of farm products, but the means have not yet been shown whereby the landlord may wrest away from the renter any share to which this renter is properly entitled.

Tenancy, it may be said in eonclusion, has stood the test of experience. We do not mean by this every tenaney systemabsentee landlordism, or rack renting, for example-but good systems have survived. The greatest system of farming in the world measured by the test of enduranee is a tenant system. English farming, where all but 4 or 5 per eent. are tenants, has given us our leading types of livestock, our best farm practices, such as marling, drainage and rotations and the measure in aeres of our eustomary farm. On the other hand, among the farmowning peasants of Continental Europe (other than the extremely reeent notion of eoöperation) seareely a single fruitful farm notion has developed. Few farm animals or praetices lave been originated. Women customarily do the farm work and the peasant himself is frequently unable to speak the language of the country in which he lives. The test of a system of agrieulture is the character of its professional representatives, and without doubt the British farmer, though a tenant, ranks high among farmers everywhere. The constantly enlarging growth in numbers of population in this country makes everinereasing demands upon the output from the farms. This inevitably leads to intensive cultivation with all its expensiveness in land, equipment, and labor. It seems almost unthinkable under these circumstanees that a normal tenaney system should . not develop here as in England. 


\section{AGRARIAN ARISTOCRACY AND POPULATION PRESSURE ${ }^{1}$}

\section{E. C. HAYES}

THE agricultural sections of Amcrica have in general by no means reached that balance between population and resources which tends ultimately to establish itself. They are in a period of transition. The coming changes will offer opportunity for great improvements, but they will bring with them one great danger, namely, that of too rigid social stratification.

At first sight such stratification seems incvitable. Omitting qualifications, this tendency may be thus stated: when land becomes worth hundreds of dollars per acre, as it already has in certain scetions, the landless youth can scldom, if ever, succeed in buying a farm, and if he remains in the country must be a tenant or a hired laborer. On the other hand, those who own land will be in a position to buy more. Thus ownership of laind may be expected to concentrate and the number of landless dwellers in the country to increase. This tendency will be strongest where land is inost productive and most valuable, and therefore hardest for the landless to purchase, and at the same time requiring the employment of a large number of hands to tend its heavy crops. The application of scientific metlods to agriculture which will be necessary to make the best lands.pay for their cost requires capital, and this will put an additional obstacle in the way of the landless youtl and add to the tendency created by the high cost of land to devclop a small body of wealthy agrarian aristocrats with a large body of tenants or paid farm liands.

There are, however, three connteracting tendeneies. First, the more intensive the agriculture, the smaller the number of acres which the landless youth must buy in order to become independent and to support a family. The inereased price of good land and the demand for fine fruits, vegetables and meats may be expected to foree a more intensive cultivation, which makes fewer acres suffice for the maintenanec of a louschold. So long

1 Adapted from "Introduction to the Study of Sociology," Appleton, N. Y., pp. $47-50$. 
as wasteful, extcusive modes of eultivation prevail, the growth of eities clamoring for food and raw materials powerfully tends to increase both "the eost of living" and the monopoly of land. It is true that intensive agriculture by increasing the produetivity of the land tends to increase its price. But in intensive agriculture the part played by labor is greater and the proportional part played by land is less, so that the land values do not increase as rapidly as does the product, and there is a gain in position to those who eontribute the labor required for produetion.

Whether the rural population is made up of independent farmers or of tenants and hired laborers, inerease in the number of those who dwell in the eountry and maintain a high standard of living there, is dependent upon the inerease of manufaeturing cities, either of the same nation or abroad, to absorb their preduct of food and raw materials. Thus the high rate of urban increase is favorable to intensive agriculture, and to the inerease of rural population in numbers and prosperity.

A second and more important qualification of the tendency to form an agrarian aristocracy and proletariat is found in the absence of laws of primogeniture and the wish of parents, as testators, to divide their holdings among their children.

A third counteracting tendency is in the fact that in the long run farming land is worth more to the man who cultivates it than to any one else, beeause it gives him a steady job, independent of the will of any employer. The priec of farming land contains at least three elements: first, a sum whieh if invested at interest would yield annually an amount equal to the rental of the land; seeond, a price paid for the expeeted unearned increment ; third, a sum paid by the purchaser for the opportunity of independent self-employment. In time the seeond element will dwindle, for there will no longer be so great an expeetation of unearned increment; indeed, that expectation might largely be extinguished by taxation, as the next paragraph will show. Then, unless land be valued as a basis of soeial prestige, or for some other extraneous consideration, the third element will tend to become the decisive factor in its ownership, for it will raise the price of land above the capitalized value of its rental, and only he who values it as an opportunity for independent self- 
employment can afford to pay this third element in the price of land.

An artificial barrier to the conecntration of land in large holdings would be the heavy taxing of unearned increments. The motive for land purchases by the wealthy who do not farm is largely the hope of enjoying the unearned increment which is resulting from population increasc, improvements in transportation and general progress. Deeds might be required to state the true price paid, and the proof of fraud in the statement might invalidate the deed. The purcliasers would then have two strong motives for having the price correctly recorded, first, in order to get a valid title, and second, because whenever in the future the purchaser became a scller it would be advantageous to him to have liad the full price recorded, since it would be the only amount which he could receive untaxed. On the other hand, he would not overstate the price lest he invalidate the title, and the seller would not allow it to be overstated, if there had been an increment since the previous transfer, because the scller is taxed on that increment. If the actual price at successive sales were recorded the unearned increment could readily be taxed.

To cheapen land by taxing the unearned increment, and rendering it unattractive to speculators, would tend to make it more valuable to the man who would labor on it than to any one else, and so to distribute it among independent farmers in holdings no larger than they could properly cultivate.

\section{ADULT LABOR}

THE INFLUENCE OF MACHINERY ON THE ECONOIIC AND SOCIAL CONDITIONS OF THE AGRICULTURAL PEOPLE ${ }^{1}$

\section{H. W. QUAINTANCE}

THe social conditions resulting from the use of machinery are even more difficult to trace than are the economic. Yet, even

1 Adapted from Cyclopedia of Ameriean Agriculture, Vol. IV: 110-113. (Copyright, 1909, by The Macmillan Company.) 
here, some measure of the truth may be indicated with approximate eertainty. Whatever the soeial eonditions of a people may be at any given time, they are largely the produet of wealth and intelligenee. That the farmers of the United States have advaneed in material welfare has already been shown, and this advanee has been, and is, a prerequisite to intelleetual growth and soeial attainment. For, "as long as every man is engaged in eolleeting the materials neeessary for his own subsistenee, there will be neither leisure nor taste for the higher pursuits." That the use of machine power stimulates mental growth and aetivity, even in the operator himself, is too elear to require demonstration, for the men who work most with machines are among those properly elassed as the most intelligent.

It has been noted that, prineipally as a result of the introduetion of farm machinery, the agrieultural population of the United States deereased from 47.6 per eent. of the total population in 1879 , to 35.7 per cent. in 1900 . The urban population elasses have inereased, of course, by the same amount.

Among those wlo have eontinued on the farms, soeialization has beeome a struggle for place against greater and eonstantly inereasing odds; and this, too, in spite of the fact that not only the general level but also that of the lower classes is mueh higher than before. If we look to the proprietor, or independent class of farm workers, we shall find a great differenee between the farmers of the period just before the introduction of maehinery and the farmer of to-day. The life of the farmer was eharacterized by isolation. Coöperation was largely limited to houseraisings and husking-bees, and these were so infrequent as to be real soeial events.

Self-sufficiency is no longer the ideal. The farmer has beeome a speeialist, devoting himself to partieular branehes of farm work, as stoek-raising: dairying; potato-, corn-, or wheatculture; or to the raising of fruits, vegetables, eotton, or tobaceo, having in mind to seeure the other things for which he has need by means of exchange. The farmhouse is no longer isolated. Good roads, the free delivery of mails, the telephone and the eleetrie ear lines bring the farmhouse into the very suburbs of the eity.

The home is supplied with eonveniences undreamed of by 
farmers of fifty years ago. The farmer and his wife are no longer to be set aside as "from the eountry." They are people of eonsequence, and their voices are heard in institutes, in elubs, federation meetings, and at the polls-the man everywhere and the woman also in some states. What they say is listened to with respeet due to one who knows whereof he speaks. The farmers are eoming forward also as members of the state legislature and as governors of states; and many of those who lead in the national affairs are proud to elaim some farmstead as the place of their early training. They are practieal politicians, and if less erafty, are less unserupulous than their associates from the citics.

But there is another phase of farm life the social import of which must not be overlooked. Along with the increasing wealth, home comforts and influenee of the proprietor class, there has been an inerease also in the material welfare and general intelligenee of farm laborers. But where machine power is used, the laborers have not advaneed as rapidly as have the proprietors.

During the twenty-year period, from 1880 to 1900, the farmlaborer elass, in all the states, inereased 35 per eent. The farmproprietor class inereased 34.2 per cent. Taking the eountry as a whole, these classes were evidently keeping a fairly equal pace. But, turning to the seven leading eereal-producing states, -those especially using complex and expensive machinery,-we find the population was distributed as follows:

\begin{tabular}{|c|c|c|}
\hline & 1900 & 1880 \\
\hline$\ldots \ldots \ldots \ldots \ldots$ & $1,073,911$ & 836,969 \\
\hline Agricultural laborers.......... & 631,740 & 363,233 \\
\hline
\end{tabular}

The farm-proprietor class here increased 28 per cent., but the farm-laborer class inereased 74 per eent. In 1880, the laborer class eonstituted only 30.3 per eent. of the total pupulation engaged in agriculture in these seven states; but, in 1900, this class constituted 37.1 per eent, of the population. The difference, 6.8 per cent.. represents a loss of 115,984 persons from the farmproprietor elass and an addition of that number to the farmlaborer class.

The reasons for unequal growth of these two classes of the agricultural population is not deeply hidden. It is the greater advantage that the possessor of a maehine has over another who 
has only his hands. The farm laborers of to-day, like the workmen in the factories, are being more and more separated from the proprietors whom they serve. These elasses understand eaeh other less and tend more and more to beeome as lords and proletariat. The larger farms, moreover, are passing out of the lıands of resident owners and, like faetories, are being run by managers whose primary duty is to return profits.

The more intelligent of the farm laborers, those who must be depended upon to operate the maehines, fare very well; but the ignorant and the unckilled are probably as ill-eonditioned now as before the introduetion of machinery.

The deeadence, or disintegration of the agrieultural population due to the use of machinery, is evident even in the proprietor elass itself. The group (of states) showing the highest pereentage of deerease (from farm ownership to tenaney) is eomposed of those states in whieh large farms and eostly maehinery are plainly the elaraeteristic feature. It eontains, in faet, the seven leading eereal-produeing states of the eountry. The rate of decline from ownership to tenaney is nearly four times as rapid in the states where much maehinery is used as in the states where eomparatively little machinery is used.

\section{THE AGRICULTURAL ELEMENT IN THE POPULATION ${ }^{1}$}

\section{EUGENE MERRITT}

Is praetieally all eountries where the number dependent upon agrieulture is known, they form a deereasing proportion of the total population. Wherever a eomparison of the male agrieultural worker's with the total males gainfully employed is available, the agrieultural workers form a deereasing proportion of the total. Thus is released to engage in other oeeupations a eorresponding pereentage of the total workers. Apparently the prineipal reasons for this decreasing pereentage are that the agrieultural element in the population is beeoming more effieient and that in the readjustment or ehanges in the methods of pro-

1 Adapted from Publications of the American Statistical Association, March, 1916 , pp. 50-65. 
ducing and distributing agricultural produets, the agricultural people now perform a smaller part of the complete operations than was the case formerly. For example, checse was manufactured in the home; now it is a factory product. There is a smaller proportion of meat slaughtered and cured on the farm than formerly. Farmers perform a smaller part of the hauling of farm produce to market beeause the railroads more thoroughly cover the country.

Many persons, in calling attention to the decreasing proportion of the population living in rural districts, feel that this is a national calamity. Indecd if it should happen that an increasing proportion of our people were found on farms it would be a sure sign that our agrieultural people were losing their efficiency and should be eause for alarm. If eonditions in the United States were similar to those in China there would be between 70 and 75 per cent. of the population engaged in agrieulture or dependent on it for their subsistence, whereas in the United States in 1910, only 35 per cent. were so engaged. In other words, the agricultural element in the population of the United States is twiec as effieient as the agricultural element in the population of China, to say nothing of the differenee in the standards of living of the population of China and that of the United States.

The evidence of the faet that the agricultural element in the population of the United States is becoming more effieient is abundant. The per capita crop production based on total population increased 30 per eent. between 1856 and 1915, while the percentage that the males engaged in agriculture formed of those engaged in all oceupations deereased from 50 to 35 per eent. in the last 30 years. In other words, we are produeing more erops per eapita and use a smaller percentage of our total population for the purpose.

Thus it is evident that the reason for the deereasing perecntage of all peoples found in rural distriets and the migration of young men and women from our farms, is that as the agricultural clement in the population beeomes more efficient, a smaller percentage of them is needed on farms and they have to scek employment in the non-agricultural industrics.

The higher death rate, age for age, in urban districts depletes 
the ranks of the workers so that the rural peoples are called upon not only to furnish raw naterial to feed and elothe the nations, but to fill up the ranks of the eity workers and to eontribute to the supply of labor demanded by our growing industries.

\section{A POIN'T OF VIEW ON THE IAABOR PROBLEII ${ }^{1}$}

\section{H. BAILEY}

I $\mathrm{T}$ is a general eomplaint in the United States that there is seareity of good labor. I have found the same eomplaint in parts of Europe, and Europeans lay mueh of the blame of it on Ameriea beeause their working elasses migrate so mueh to this eountry; and they seem to think we must now be well supplied with labor. Labor seareity is felt in the eities and trades, in eountry distriets, in mines, and on the sea. It seems to be serious in regions in which there is mueh unemployed population. It is a real problem in the Southern States.

While farmers seem now to eomplain most of the labor shortage, the diffieulty is not peeuliarly rural. Good farmers feel it least; they have mastered this problem along with other problems. As a matter of faet, it is doubtful whether there is a real labor. shortage as measured by previous periods; but it is very diffieult to seeure good labor on the previous terms and eonditions.

The supposed short labor supply is not a temporary condition. It is one of the results of the readjustment and movement of society. A few of the immediate eauses may be stated, to illustrate the nature of the situation.

1. In a large way, the labor problem is the result of the passing out of the people from slavery and serfdom-the rise of the working elasses out of subjugation. Peoples tend always to rise out of the laboring-man phase. We would not have it otherwise if we desire soeial democraey.

2. It is due in part to the great amount and variety of construetive work that is now being done in the world, with the consequent urgent eall for human hands. The engineering and

1 Adapted from "The Country Life Movement in the United States," pp. 134-148. Macmillan, 1911. 
building trades have extended enormously. We are doing kinds of work that we had not dreamed of a half-hundred years ago.

3. In some places the labor difficulty is due to the working-men being drawn off to other places, through the perfecting of industrial organization. The organization of labor means eompanionship and social attraetion. Labor was formerly solitary; it is now becoming gregarious.

4. In general, men and women go where things are "doing." Things have not been doing on the farms. 'There has bcen a gradual passing out from backward or stationary occupations into the moving oceupatious. Labor has felt this movement along with the rest. It has been natural and inevitable that farms should have lost their labor. Cities and great industrialism could not develop without them; and they have made the stronger bid.

5. In farming regions, the outward movement of labor has been specially faeilitated by lack of organization there, by the introduction of farm maehinery, by the moving up of tenants into the elass of renters and owners, by laek of continuous employment, by relatively low pay, by absenee of eongenial assoeiation as eompared with the town. Much of the hired farm labor is the sons of farmers and of others, who "work out" only until they ean purehase a farm. Some of it is derived from the class of owners who drift downward to tenants, to laboring men, and sometimes to shifters. We are now sceuring more or less foreign-born labor on the farms. Much of this is merely seasonal; and when it is not seasonal, the immigrant desires to become a farm owner himself. If the labor is seasonal, the man may return to his native lome or to the eity, and in either ease he is likely to be lost to the open eountry.

There is really no "solution" for the labor diffieulty. 'The problem is inlerent in the economic and soeial situation. It may be relieved here and there by the introduction of immigrants or by transportation of laborers at certain times from the city; but the only real relief lies in the general working out of the whole cconomic situation. The situation will gradually eorreet itself; but the readjustment will come much more quiekly if we understand the conditions.

As new interest arises in the open eountry and as additional 
values acerue, persons will remain in the country or will return to it; and the labor will remain or return with the rest. As the open country fills up, we probably shall develop a farm artisan class, comprised of persons who will be skilled workmen in ecrtain lines of farming as other persons are skilled workmen in manufactures and the trades. These persons will have class pride. We now have practically no farm artisans, but solitary and more or less migratory workingmen who possess no high-class manual skill. Farm labor must be able to earn as much as other labor of equal grade, and it must develop as much skill as other labor, if it is to loold its own. This means, of course, that the farming scheme may necd to be reorganized.

Specifically, the farm must provide more continuous employment if it is to hold good labor. The farmer replics that he does not have employment for the whole year; to which the answer is that the business should be so reorganized as to make it a twelve montlis' enterprise. The introduction of crafts and local manufactures will aid to some extent, but it cannot take care of the situation. In some way the farm laborer must be reached educationally, either by winter schools, night schools, or other means. Every farm should itself be a school to train more than one laborer. The larger part of the farm labor must be country born. With the reorganization of country life and its increased earning power, we ought to see an increase in the size of country families.

The rcal country workingmen must constitutc a group quite by themsclves. They cannot be organized on the basis on which some other folk are organized. There can be no rigid sliort-hour system on a farm. The farm laborer cannot drop his reins or leave his pitchfork in the air when the whistle blows. He must remain until his piece of work is completed; this is the natural responsibility of a farm laborer, and it is in meeting this responsibility that he is able to rise to the upper grade and to devclop his usefulness as a citizen.

It is a large question whetler we are to have a distinct working-class in the country as distinguished from the land-owning farmer. The old order is one of perfect democracy, in which the laboring-man is a part of the farmer's family. It is not to be expected that this condition can continue in its old form, but the 
probability is that there will always be a different relation between workingman and employer in the eountry from that which obtains in the eity. The relation will be more direet and personal. The employer will always feel his sense of obligation and responsibility to the man whom he employs and to the man's family. Persons do not starve to death in the open eountry.

Some persons think that the farming of the future is still to be performed on the family-plan, by which all members of the family perform the labor, and whatever ineidental help is employed will beeome for the time a part of the family. This will probably continue to be the rule. But we must face the fact, however, that a necessary result of the organization of eountry life and the speeialization of its industries, that is now so mueh urged, will be the produetion of a laboring elass by itself.

\section{CHILD LABOR}

\section{RURAL CHILD LABOR ${ }^{1}$}

JOHN M. GILLETTE

IT has been the eustomary assumption that the ehild labor evil is confined to our eities and manufaeturing villages. Undoubtedly the more vigorous and unwarrantable eonditions relative to youthful workers do entreneh themselves in those plaees. Another familiar assumption is that the ehild labor performed on the farm is entirely wholesome and is therefore to be eneouraged. But it is largely the produet of those who are ignorant of farm life, or of those who have seen agrieulture at a distanee or in eertain favored regions.

It ean hardly be questioned that mueh of the work whieh farm children do is a distinet advantage to them. Work which is suited to the growing boy and girl is eondueive to a better development of body and mind. The ehores about the house and barn and the lighter forms of labor whieh may be engaged in outside of sehool hours are distinetly favorable to the estab-

1 Adapted from Child Labor Bulletin, No. I, p. 154. National Child Labor Committee, New lork. 
lisliment of a disciplined ability to carry on useful activities, which is deadly lacking in urban children. It is one of the recognized defects of eity life that there is nothing at which to set the boys and girls outside of school hours and in vacation periods. Idleness and idle habits, bad associations, and irregular wayward tendencies are often dircetly traceable to this void in the city boy life. It is not the adjusted, timcly work of children in the country which is the question. There is far more labor of an excessive nature placed on children, particularly boys, who live on farms than we would suspect.

\section{COLORADO BEET WORKERS ${ }^{1}$}

DR. E. N. CLOPPER

WE have been undertaking some isolated investigations of child labor in agriculture because it is a subject about which we know very little although the 1910 census reports that almost 72 per cent. of all the children betwcen ten and fifteen years of age engaged in gainful occupations in the United States are in agricultural pursuits and that 18 per cent. of them or 260,000 are farm laborers working for other than their own parents.

In a recent study of the employment of children in the cultivation of sugar beets in Colorado we found an interesting situation. There are about 5,000 children between six and fifteen working in the beet fields, practically all of them with their own parents. These children of course are under the compulsory education law of Colorado which requires them to attend school nine months, but as the local system is organized on the district plan the local truant officer does not always enforce the law because he would be required to prosccute his own inmediate friends and neighbors. The remedy seems to lie in a large unit of organization that would remove enforcement outside the immediate locality.

We found that the best working children were kept out of school about three months in the fall and lost about three and a half times as many days of school as the non-beet workers. This makes it impossible for the teachers to do the same work with

1 Adapted from Cliild Labor Bulletin. May, 1916. P. 38. National Child Labor Committee, New York. 
them as the other children and henee the beet-workers were found to be very mueh retarded.

\section{STRAWBERRY PICKERS OF MARYLAND ${ }^{1}$}

\section{IIARRY I. BREMER}

TWENTY-EIGHT farms were visited in a brief investigation last spring. On none of these was provision for family privaey made. In one or two eases only one family was foum oceupying a single house but this was not from any desire of the farmer to meet the lowest possible standard of deeney, but simply beeause only about half of the usual number of pickers had been taken out, owing to the poor erops. On one farm the farmer pointed with pride to his piekers' shanty and elaimed it was the best on all the farms. He boasted that in its eonstruction he had paid espeeial eare to ventilation and the general well-being of the pickers. What I saw was a two story building I would have taken for a barn, with four windows and two doors on the first floor, and two windows and one door on the seeond. The building eontained but a single large room on each floor, and showed absolutely no provision for comfort or privaey. In this he housed his piekers, men, women, and ehildren, without regard to age, sex, or relationship. And as a sort of explanation of such meager provision, he went on to expatiate on the low standard of morals and the promisenous living he thought eharacterized the lives of the people when in the eity. "In the eity," said he, "they live like eattle. Go into any house in Bond Street and you will find them erowded in worse than they are here." The other farmers, I found, held the same mistaken idea. This is a base libel on these people. Preeding the investigation of the farms nearly four hundred families were visited in their homes. In not one instanee was more than one family living together and most families had three or four rooms. For the most part these homes were elean and showed care.

1 Adapted from Child Jalıor Bulletin, No. 4. P. 71. National Child Labor Committee, New York. 


\section{CHILDREN OR COTTON ${ }^{1}$}

\section{LEWIS H. IINE}

No wonder a sehool superintendent told me: "Cotton is a eurse to the Texas ehildren." I was then just beginning a detailed investigation of conditions on Texas farms. For two months I went from farm to farm through forty eounties from the "Panhandle" to the Gulf, where I saw Mellie and Millie and Edith and Ruby and other tiny bits of humanity picking cotton in every field.

We have long assailed (and justly) the cotton industry as the Herod of the mills. The sunshine in the eotton fields has blinded our eyes to the faet that the eotton pieker suffers quite as mueh as the mill-hand from monotony, overwork and the hopelessness of his life. It is ligh time for us to face the truth and add to our indietment of King Cotton, a new charge-the Herod of the fields.

Why? What is it that is aetually happening to these ehildren? Come out with me at "sun-up" and see them trooping into the fields with their parents and neighbors. At first the morning will be fresh, and nature full of beauty. You will see kiddies four or five years old pieking as though it were a game of imitation and considering it great fun, and you will think (perhaps) that it is a wholesome task, a manifestation of a kind Providence. But watch them picking through all the length of a hot summer day, and the mere sight of their monotonous repetition of a simple task will tire you out long before they stop. Their working day follows the sun and not until sundown do they leave the fields for the night. Then turn to the "older" children of six or seven, who are eonsidered steady workers, and responsible for a share of the output, and you will realize that for them even in the beauty of the early morning the fun las quite lost its savor.

Here and there a strong voiee is raised in protest. Such a one was Clarenee Ousley, who addressed the Southern Commercial Congress. He said :

"We all are exereised about the hours of labor, the wages and the living conditions, of the women and ehildren who work in the

1 Adapted from the Survey, Vol. 31, pp. 589-592. 1913-14. 
mills, stores and offices, but we take little or no thought of the hours of labor, the wages and the living eonditions of the women and children who furnish the raw material of the looms. It is for the comfort and happiness of these primarily, for the greater prosperity of the South secondarily, and finally for the social and political blessings to come to the republic through a thriving yeomanry, through the strength and virtue of a contented and cultured rural population, that I beg your patience."

It is quite possible that the Texas farmer is not so indifferent to the exploitation of his children as he appears to be, for he is litcrally "up against it," and he may be applying the eommon anodyne of accepting and even justifying that which appears to him to be inevitable. It is obviously casicr for outside observers to tell him that child labor is only making matters worse and that there is no way out until he abolishes it, that it is for him to appreciate and act upon such a long plan.

More than half of the farmers in Texas are transient renters, moving oll every two or three ycars in a hopcless search for better things. They are weighed down with debt; mortgages are high and climbing higher; illiteracy and dependence upon the one crop keep them treading a vicious eircle. The eotton picker's bag hanging about the neck of every child, bending his head with its weight and tripping him as he walks, is a symbol of the life his father lcads and the life to which the ehild himself will come. He may be just on the verge of better things when the boll-wecvil will blight his entire erop and reduce him again to hopeless ruin. Years, deeades, of such expericnces have broken many a spirit. They have lost the little interest they had in edueation and the younger generation has been growing up in ignorance.

Therefore it is that I plaee first and foremost in any program of ehange the restriction of child labor. Children must be left frec to go to school. The school year must be lengthened and attendance required through the entire term. This is obviously and immediately neecssary. 


\section{Biblograpity}

\section{COÖPERATION}

Austin, C. B. and Wehrwein, G. S. Coöperation in Agriculture, Marketing and Rural Credit, Bulletin 60, Extension Service, University of Texas, Austin, 1914.

Buck, S. J. The Granger Movement. Harvard Uuiversity Press, Cambridge, 1913.

Cance, Alexander. The Farmer's Coöperative Exchange. Mass. Ag. Col. Extension Bul., 1914.

Coulter, John Lee. Coöperation Among Farmers. Sturgis, N. Y., 1914.

Fay, C. R. Coöperation at Home and Abroad. King, London, 1908. Filley, H. C. Coöperation. Bulletin 31. June, 1915, Agrieultural Experiment Station, Lineoln, Nebraska.

Ford, James. Coöperation in New England. Survey Associates, Ine., N. Y., 1913.

Hibbard, B. H. Agricultural Coöperation. Bulletin 238. Jan., 1917. Agrieultural Experiment Station, Madison, Wisconsin.

Jefferson, Lorian P. The Community Market. Massachusetts Agricultural College Extension Service Bul. No. 21, Amherst, April, 1918.

Poe, Clarence. How Farmers Coöperate and Double Profits. Orange Judd, N. Y., 1915.

Powell, G. Harold. Coöperation in Agriculture. Macmillan, N. Y., 1913.

Report of U. S. Am. Comm. to Study Coöperation in Europe. Senate Doc. 214, 63rd Cong., 1st Session, Washington, 1913. Part I.

Sinclair, Jolnn F. Coöperation and Marketing. Report Wisconsin State Board of Public Affairs, Madison, 1912.

Tousley, E. M. Coöperation Among Farmers-Ethical Principles Involved. Minneapolis, Minn., 1910.

Wolff, Henry M. Coöperation in Agriculture. King, London, 1912.

\section{MARKETING}

Holmes, Geo. H. Systems of Marketing Farm Products and Demand for Such Products at Trade Centers, U. S. D. A. Report No. 98, 1913.

Huebner, Grover G. Agricultural Commerce. Appleton, N. Y., 1915.

Miller, Cyrus C.; Miteliel, Joln Purroy, and Medneny, Geo., Report of the Mayor's Market Commission of New York City, Dec., 1913.

Weld, L. D. H. The Marketing of Farm Products. Macmillan, N. Y., 1916.

\section{TENANCY}

Ely, R. T. and Galpin, C. J. Tenaney in an Ideal System of Land Ownership. Am. Econ. Assn. Proc., pp. 180-212, Mareh, 1919.

Ely, R. T. Private Colonization of Land. Am. Econ. Rev., Sept. 1918. 
Haney, Lewis. Studies in the Land Problem in Texas. Bul. Univ. of T'exas, No. 39, 1915.

Hibbard, B. H. Farm Tenancy in the U. S. Int. Rev. of Agri. Economies, Vol. 8, No. 4, pp. 90-99, April, 1917. Found also in Amuls 40:29-39, March, 1912.

Kent, Wm. Land Tenure and Public Policy. Am. Econ: Assn. Proc., pp. 213-225, March, 1919. Found also in Yale Reriew, pp. 564579, April, 1919.

Mead, Elwood. The Tenant Farmer and Land Monopoly. Conf. of Social Work, pp. 37S-382, 1918.

Nourse, E. G. Agricultural Economies. Chapter XII, Lniv. of Chicago Press, 1916.

Putnam, G. E. Tenaney and Land Reform. Univ. of Kansas Bul., Vol. 17, No. 18, pp. 73-91, Dec. 1, 1916.

Spillman, W. J. and Goldenweiser, E. A. Farm Tenantry in the U. S. Yearbook, U. S. D. A., pp. 321-46, 1916.

Stewart, C. L. Tenant Farming in the U. S. with Special Reference to Illinois. Univ. of Ill. Studies in Soc. Sci., Vol. 5, No. 3, Sept., 1916.

Taylor, H. C. Landlordship and Tenancy. In Cyclo. of Ag., Bailey, Vol. IV: 174 .

Vogt, Paul L. The Land Problem and Rural Welfare. Proc. Am. Econ. Soc., pp. 91-114, March, 1917.

Wallace, Henry. Land Tenure and the Rural Cliurch. In Church and Country Life, Vogt, Paul L., pp. 232-242.

\section{LABOR}

Barber, M. A. On the Recollections of a Hired Man. In Readings in Rural Economies, Carver, T. N., pp. 547-557. Ginn, N. Y., 1916. Coulter, Joln Lee. Agricultural Laborers in the U. S. Anuals 40 : 40-44, Marcl, 1912.

Country Life Comnission Report, pp. 2\&, 39, 43. Sturgis, Walton Co., N. Y.

Nourse, E. G. Some Problems of Agricultural Labor. In his Agrieultural Economic, Chap. XVI. Univ. of Chicago Press, 1916.

Powers, G. L. Agrienttural Lahor. Cyclo. of Am. Agri., IV: 198.

Wileox, E. V. The Farm Labor Problem. Am. Econ. Assn. Proc., pp. 158-170, March, 1918.

\section{CHILD LABOR}

Child Labor on English Farms. School and Society, May 5, 1917, p. 525 .

Child Labor Bulletins. National Child Labor Com., 105 East 22nd Street, New York.

Monahan, A. C. Rural Child Labor Problem. Reprint, Child Labor Bull., Vol. VI, No. 1, Nay, 1917. National Child Labor Com., 105 East 22nd Strect, New York. 


\section{CHAPTER VII}

\section{MENTAL AND MORAL ASPECTS OF RURAL LIFE}

\section{CHARACTERISTICS OF THE FARMER ${ }^{1}$}

\section{JAMES BRYCE}

I BEGIN with the farmers because they are, if not numerically the largest class, at least the class whose importance is most widely felt. As a rule they are the owners of their land; and as a rule the farms are small, running from forty or fifty up to three hundred acres. In a few places, espccially in the West, great land owners let farms to tenants, and in some parts of the South one finds large estates cultivated by small tenants, often Negroes. But far more frequently the owner tills the land and the tiller owns it. The proportion of hired laborers to farmers is therefore very much smaller than in England, partly becausc farms are usually of a size permitting the farmer and his family to do much of the work themselves, partly because machinery is much more extensively used, especially in the level regions of the West. The laborers, or as they are ealled "the hired men," do not, taking the country as a whole, form a social stratum distinet from the farmers, and there is so little distinction in education or rank between them that one may practically treat employer and employed as belonging to the same class.

The farmer is a keener and more enterprising man than in Europe, with more of that commercial character which one observes in Americans, far less anchored to a particular spot, and of course subject to no such influences of territorial magnates as prevail in England, Germany, or Italy. He is so far a business man as sometimes to speculate in grain or bacon. Yet lie is not free from the usual defects of agriculturists; he is obstinatc, tenacious of his habits, not readily accessible to argument. His

1 Adapted from "The American Commonwealth," volume II, pp. 293-4. Revised edition. Macmillan, N. Y. 
way of life is plain and simple and he prides himself on its simplieity, holding the elass he belongs to is the mainstay of the country, and regarding city folks and lawyers with a mixture of suspieion and jealousy, because he deems them inferior to himself in virtue as they are superior in adroitness, and likely to outwit him. Sparing rather than stingy in his outlays, and living mainly on the produce of his own fields, he has so little ready money that small sums appear large to him; and he fails to see why everybody can not thrive and be happy on $\$ 1,500$ a year; he thinks that figure a suffieient salary for a eounty or distriet offieial, and regulates his notion of payment for all other officials, judges ineluded, by the same standard. To belong to a party and support it by his vote seems to him part of a eitizen's duty, but his interests in national polities are seeondary to those he feels in agrieulturist's questions, partieularly in the great war against monopolies and eapitalists, which the power and in some eases the tyranny of the railroad eompanies has provoked in the West. Naturally a grumbler, as are his brethren everywhere, and often unable to follow the eauses whieh depress the priee of his produee, he is the more easily persuaded that his grievanees are dne to the eombinations of designing speeulators. The agrieultural newspaper to which he subseribes is of eourse written up to his prejudiees, and its adulation of the farming elass eonfirms his belief that he who makes the wealth of the country is trieked out of his proper share in its prosperity.

Thus lie now and then makes desperate attempts to right himself by legislation, lending too ready an ear to politicians who promise him redress by measures possibly unjust and usually unwise. In his impatienee with the regular parties, he is apt to vote for those who eall themselves a People's party or Farmer's party, and who dangle before him the hope of getting "cheap money," of redueing the expenses of legal proeeedings, and of eompelling the railroads to earry his produce at unremunerative rates. However, after all is said and done, he is an honest, kindly sort of man, hospitable, religious, patriotie, the man whose hard work has made the West what it is. It is eliefly in the West that one must look for the well-marked type I have tried to draw, yet not always in the newer West; for, in regions like northern Minnesota, Wisconsin and Dakota, the farming popula- 
tion is mainly foreign,-Seandinavian and German,-while the native Americans oceupy themselves with trading and railroad management. However, the Seandinavians and Germans acquire in a few years many of the charaeteristies of the native farmer, and follow the political lead given by the latter. In the early days of the Republie, the agriculturists were, espeeially in the iniddle and newer parts of the Southern States, the baekbone of the Democratic party, sturdy supporters of Jefferson, and afterwards of Jaekson. When the opposition of North and South began to develop itself and population grew up beyond the Ohio, the pioneers from New England who settled in that eountry gave their allegiance to the Whig party; and in the famous "logcabin and hard cider" campaign, whieh carried the clection of General Harrison as President, that worthy taken as a type of. hardy backwoodsman made the Western farmer for the first time a noble and poetical figure to the popular imagination. Nowadays he is less romantic, yet still one of the best elements in the country. He stood by the Union during the war, and gave his life freely for it. For many years afterward his vote earried the Western and especially the Northwestern states for the Republican party, which is still to him the party whieh saved the Union and protects the Negro.

\section{THE INFLUENCE OF FARM LIFE ON CHILDHOOD ${ }^{1}$}

\section{CHARLES W. ELLIOT}

CHILDREN brought up in the eountry get a deal of invaluable training from their rural surroundings. They roam the fields and wade in the waters, observe plant and animal life, use and take care of domestie animals, and help their fathers and mothers in the work of the house and the farm, and thereby get invaluable training-first, in observation, seeondly, in attention to the task in hand, and thirdly, in good judgment which prevents waste of strength and distinguishes between the essential or immediately necessary in produetive labor and the unessential and deferable. 290.

1 Adapted from Report of the Board of Education, Connecticut, 1903, p. 
A roaming ehild brought up on a farm, learns from nature what it is almost impossible to impart to a eity ehild. In eity sehools we have been for twenty years past laboriously trying to provide substitutes for this natural training in eountry life. The reeent natural history study from speeimens used indoors, the manual training given in earpentry, forging, filing and turning, the garden plots and roof gardens, the vaeation schools, and the exeursions to parks and museums, are all sineere efforts to replace for urban ehildren the lost training of eye and hand which country life supplied. It is impossible to exaggerate the importance of these substitutes; but after all, these substitutes are inferior to the spontaneous, unenforeed results of living in eontaet with nature, and of taking part with mother and father in the productive labors of a farm, a market garden, a hennery, or a dairy. What ehildren aequire in the spontaneous, intense, selfdireeted use of their faeulties is always more valuable than the results of a less eager though more prolonged attention to enforced tasks. 。

\section{AN APPRECIATION OF RURAL PEOPLE ${ }^{1}$}

\section{T. N. CARVER}

Nothing ean give us a elearer idea of the failure of urban people to appreeiate rural people than the names whiel are sometimes applied to the latter. Saying nothing of sueh reeent slang as "hayseed," "rube," "elod hopper," ete., we have sueh aneient words as heathen, pagan, boor and villain, all of whieh meant originally the same as these modern epithets. Even the modern.word peasant has eome to have, in the ears of the typieal urbanite, a somewhat opprobrious sound. The reason is not diffieult to find.

One charaeteristic differenee between rural and urban industry is that in the former, men get their living out of the soil and in the latter, the dominant element gets its living out of other men. They who eoax their living out of the soil must beeome expert in the knowledge of the soil and the things pertaining to

1 Adapted from Rural Manhood, March, 1910, pp. 7-10. 
it, sueh as crops, implenents, and live stock. But they who eoax their living ont of other men must of neeessity become expert in the knowledge of men and the things which please them, such as fair speceh, manners and dress. It is as mueh a part of their business to become expert in these things as it is of the farmer to beeome expert in his work of subjugating nature and direeting its forees. The dominant element in a eity is always one which makes its living by talking (or writing and picture making, which amount to the same thing). This is the clement which makes the sentiment of the eity, coins its slang and determines its tastes.

Sinee such element has so little in eommon with those whose work eonsists in manipulating things rather than men, who are therefore less adroit in the amenities of social life, and less expert in the complexities of drawing room etiquette, it finds itself unable to appreciate them. That is the reason why urban pcople have always found occasion to reproach rural people with their laek of urbanity.

But to the discriminating mind there are abundant grounds for an appreeiation of those who make their living by tilling the soil. In consequence of the antiquity and universality of the agricultural industry there has developed a body of rural lore and rural teehnique the like of which is found nowhere else. Our attention is sometimes attracted by the peculiar wisdom of the sailor people; but that of the farmer people is vastly greater though less peeuliar and thercfore considered less interesting. But beeause so mueh of it is learned outside of the schools by the actual process of doing rural work-father and son working together generation after generation-it does not commonly go under the name of learning. The marvelous technique of rural work is aequired in such a eommonplace way that we ustially regard it as a matter of course and do not realize that it is a real technique. But there are probably no tools or implements known to any eraft or profession which are more perfect in their adaptation, with more fine points known only to the initiated, upon which excellence in form and structure depends, than some of the eommon implements of modern husbandry. The eommon plow is an example. The shaping of the mold board in such a way to give the maximum effieieney with the minimum of re- 
sistance is a result of generations of experienee and adjustment.

Another significant characteristie of the agrieultural industry is that it is still, and shows no sign of eeasing to be, an industry of small units. A small unit in the agrieultural industry means merely a small number of persons employed on each unit and not a small aereage. This eharaeteristic of agrieulture is of great importanee beeause it signifies that a very large proportion of those engaged in it are self-employed and only a small proportion, as compared with other industries, are employed. This faet of self-employment means, among other things, self direction, initiative, independenee, and responsibility for the suecess of the business. This requires qualities never demanded of the wage earning or salaried employee.

The demand for these qualities is still further heightened by another signifieant eharaeteristie of the agricultural industry, viz, its seasonal character. The farmer's work not only changes from season to season, but from day to day, and even from hour to hour. Besides there are multitudinous, unexpected and unforeseeable changes made neeessary by the instability of the natural forees with which he has to eontend, such as ehanges of the weather, ete. All this means that the farmer must reorganize the work of the farm frequently, sometimes at an lour's notiee. He never knows what it is to earry on a single operation the year round as is often possible in the meehanieal trades. He must always be on the alert and ready to deeide what is to be done next. They to whom this everlasting deeiding what to do next is a painful process must leave the farm and go where that question is decided for them by a boss or manager.

Again it is a fact which edueators still have to lament that no substitute has yet been found for the sehooling which the boy gets on the farm as a matter of eourse. Here is where the boy on the farm has a priceless advantage over his eity eousin. He ean watch his father at work, and, as soon as he is old enough, may help. There is no selooling equal to this; but it is seldom open to the eity boy in these days.

The intimate association of parents and ehildren in the work of the farm and the farm household gives a common interest to the rural family which is not always maintained under urban conditions. The rural family is a stable institution as compared 
with the city family. This is shown by the larger divorce rate in the eities, and the lower rate of multiplieation. This difference in the stability of the rural and urban families explains why it is that city populations have to be eontinually replenished from the country distriets.

It has been said that the greatest soeial distinction is that between those who live in town and those who live in the country. Were it not true that city people are themselves eountry people, not more than three generations removed, there would be some truth in this statement. The differences between country life and city life are so wide as to produce incvitable divergenees of great width in their ideals, their manners and their outlook upon life were it not that nature has a way of exterminating city people when they get too far away from the rural point of view. If we may assume that nature knows what she is about it is safe to conclude that the rural point of view is the correet onc. It therefore behooves us to ponder scriously what seems to be the maturer preference before we affect to despise the homely virtues of rural people.

\section{THE RURAL ENVIRONMENT AND GREAT MEN 1}

\section{WILLIAM J. SPILLMAN}

Dr. Woons has shown that at the time when the average man noted in "Who's Who", was a boy, about 16 per cent. of our population lived in the cities. He further showed that about 30 per cent. of the individuals in "Who's Who" were brought up in the city. He accounts for this cxcess of eity men amongst men of note by the fact that the eity attracts talent, the percentage of ability in the city, therefore being grcater than in the eountry. He would, thercfore, explain the cxcess of eity men mainly as the result of heredity. He may be correct in this position. I am inclined at present, however, to believe that while this excess may be partly due to the fact that talent is attracted to the eity and that, therefore, the eity child has a better chanec of inheri:ing talent, part of it is due to that fact that cities in general hav?

1 Adapted from Science, 30: 405-7, Sept. 24, 1009. 
better school faeilities than the eountry. Most of the men in "Who's Who" are those who had good edueational advantages. I suspect, thercfore, that if an adequate study were made we should find that in this ease environment has had something to do with the fact that 30 per eent. of the men in "Who's Who" are from the eity. But for the sake of argument let us accept Dr. Woods's point of view. It would then follow that 30 per cent. of our leading men should be accredited to the city if their leadership is due entirely to heredity. Now for the facts in the case. It is reeognized that the following statisties are meager and that conclusions can only be drawn from them tentatively, but the fact that the figures are eonsistent with each other confirms their correctness.

The following table gives statisties for the three classes of men who may be, perhaps, placed lighest amongst the list of our leading men:

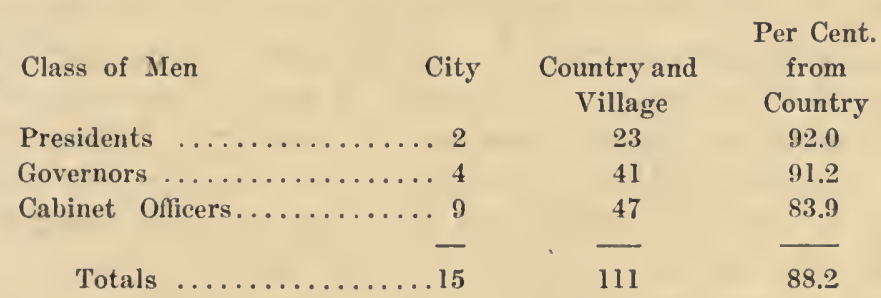

The figures for presidents inelude all the presidents this country has had. Of course in the carly days a smaller proportion of our population lived in the eities. But this critieism ean not be applied to the list of governors. Figures from this class of men relate to the present governors of the states. It is secn that 91.2 per eent. of this class of men are from the eountry or village. The figures for eabinet offieers include members of eabinets between 1869 and 1903. The average of these thrce classes of men shows 88.2 per eent. of them from the country. Now, if we accept Dr. Woods's view that the eities furnish a larger proportion of our leading men for the reason that talent is attracted to the eity, the proportion of these $m \mathrm{en}$ coming from the country should be eonsiderably less than the proportion of our population in the eountry, hut the facts show that the proportion of these men from the comntry is aetually 
greater than the proportion of eountry population. This seems to me to argue strongly for farm life as an edueational foree.

I have reecived replies from forty-seven railway presidents in this eountry. Of these 55.4 per cent. are eredited to the village and eountry. When we remember that preferment in this industry is greatly influeneed by hereditary wealth it seems to me that the fact that so large a pereentage of these men are country bred is somewhat significant. Statisties for members of the house of representatives are of less value for our present purpose than most of the other statisties given here, for the reason that nativity is a distinet foree in polities, and that many representative distriets are wholly eity while others are wholly eountry distriets. Sixty-four per eent. of the present members of the house of representatives are from the country. Figures for members of the senate are of more value in this respect, since senators represent states. Yet the faet that most of our senators are very wealthy men would seem to justify the inference that the eity has more than its share of this elass of men, yet 70.6 per eent. of the eighty-five members of the present senate for whom data could be obtained are from the eountry. Taling all six of these elasses of men, the average per cent. from the country is 69.4. It will be noted that the liigher we go in the seale of leadership in those elasses which are least influeneed by extraneous eonsiderations, the higher is the per eent. of countrybred men. I believe these figures substantiate the elaim made in my original artiele, namely, that eountry life has a distinet edueational value. But what is it in country life that gives this advantage? President Lucius Tuttle, of the Boston and Maine Railroad, in answering my eireular letter answers this question.

He says:

Among other things, the farm boy learns methods of ceonomy and, in. eidentaly, the value of money. He is a part of the business maehinery of the farm and is brought into close contact with all its affairs. He learns methods of trade and how to buy and sell, as well as possible, with. out incurring losses, and, later on when lic leaves the farm and goes into a general business, the education he has aequired during his farm life becomes a fundamental and raluable part of his after business life.

As a general rule, the eity boy has no connection with his father's business and know's notling about it. Ilis father may be eminently suceessful but the boy las nothing to do with making his success and is very seldom 
allowed to be cognizant of the methods of business his father uses. Under modern conditions, school life gives the boy very little business knowledge and, at the end of his school education, when he enters business, he is obliged to begin at the bottom of the ladder without knowledge of many things that the farm boy has learned in connection with his daily home life.

To my mind this is the fundamental reason why boys brought up on the farm appear to make better successes in their after business life than do city boys who have not had the advantages of a similar business training in their earlier days.

President White, of the Richmond, Fredericksburg and Potomac Railroad Company, in discussing the effect of life on the farm, says :

It is preëminently, in my judgment, an experienee which develops independence and self-reliance and, therefore, I think, the spirit of achievement, more than any other I know of.

\section{Another railroad president remarks:}

I believe that farm life lays a good and broad foundation for a healthy, vigorous manhood in both mind and body.

Another noted railway man, who never spent a day on the farm, says :

I am inclined to think boys brought up on the farm have better constitutions and are less liable to temptations.

\section{President L. W. Hill, of the Great Northern Railway, says:}

My present home is on a farm and my principal reason for making my home there, rather than at some of the lakes or in the eity, is that I have three boys of nyy own I am trying to give a fair start in life. I believe there is no end of arguments that living on the farm gives the best elance for a growing boy. While my making the farm my home sometines works an inconvenience to me, I realize that the benefits to iny ehildren are well worth the inconvenience to ne of getting in and out between my offiec and the farm.

I have always contended that the value of farm rearing lies in the fact that on the farm there is a chance to place responsibility on the growing boy. I firmly believe that it is possible to work out a system of edueation that will give our sehools all the advantages of the farm life. This is being done, to a certain extent, in the eities, and I believe that this fact has something to do witl the increasing number of strong men who come from the city. 
But I must admit that the actual data on this subject are very meager.

\section{SUGGESTION AND CITY-DRIFT ${ }^{1}$}

\section{ERNEST R. GROVES}

Tif present morement of population toward urban centers, so strongly expressed in Europe and Ameriea at the present time, deserves study in the light of the modern teaeling of psychology concerning the meaning of childhood experiences as determining adult conduct. It is everywhere admitted that this urban attraction of rural population is socially signifieant, and that its causes are many. It is even feared by many that it represents an unwholesome and dangerous tendency in modern life, and that it should be investigated for the purpose of diseovering a reasonable check upon this drift to the eities.

No study of the mental causes behind this urban entieement can fail to diseover the importance of the suggestions received by country children during their preparation for life. (See "The Mind of the Farmer" - Ed.)

Rural education, of eourse, provides many opportunities for penetrating suggestions, and any one who knows the schools of the country will affirm that their suggestions are not always friendly to rural interests. The character of some studies makes it difficult for the teaeher not to emplasize urban eonditions. In the endeavor for the dramatic and the ideal, the teacher is likely to draw upon urban life.

It is fair to state that a beginning has been made in the effort to utilize the country life possibilities in teaching material. But one usually finds in the ordinary text book an unconseious tendency to emphasize the urban point of view and to accept it as the soeial standard. Many of the striking experiences of morlern life necessarily eulminate amid urban conditions even when caused largely by rural influences. The urban center is the passion spot, and affords more opportunity for the dramatic.

The same fact is true of ideals. The teacher is often tempted to use urban illustrations in lier effort to establish ideals of con-

1 Adapted from Rural Manhood, 7: 47-52, April, 1916. 
duct. The speetacular charaeter of moral struggle and ethical effort in the city makes urban life a source from which to draw interesting moral appeal. This bias in teaehing is magnified not infrequently by the attitude of the teacher toward rural life, eonseiously or unconseiously. The suggestion of the urban minded teacher and the urban inspired school system are bound to provide effective suggestions that will later provide a basis for rural discontent.

The early experience on the farm may leave a suggestion of unreasonable toil. Romantie youth can not rest content with a vision of endless, lengthened hours of work and merely a living. Other opportunities provide a living also, with less toil. Parents have at times been responsible for this coneeption of farming, beeause they have insisted upon having their sons and daughters work unreasonably during vaeation and after school. The parent, who looks baekward upon a generation more given to long toil than this, and uses his own earlier experience as a standard, may the more easily commit this mistake and teaeh his ehildren to hate the farm and rural life.

The boy on the farm finds at times that his holiday and vacation are encroaehed upon by needed labor. Weather and harvest eonditions rob him of the pleasures that his village ehum enjoys. Some definite plan for an outing, or some greatly desired day of sport has to be given up that the erop may not be injured.

Doubtless parents allow these disappointments to happen with little reason, and looking at the matter from an adult point of view, do not regard the boy's feelings as of serious signifieanee; and yet, in the light of modern psyehology, we know that such experienees may build up a very signifieant hostility to the rural environment that appears to be the eause of the agonizing disappointments. The eumulative effeets of a few bitter experiences of this nature may be suffieient to turn the boy away from the eountry in his heart of hearts for all time. In such eases the first opportunity to leave the country for the town will be aceepted gladly, as a way of eseape from a life emotionally intolerable.

The student of rural life is tempted to look too mueh to the eountry and too little to the city for the cause of rural migration. It is not easy to value properly the eonstant and impressive sug- 
gestions of urban opportunity furnished by the eity. It is important to reeognize that the prosperity of the eity requires that it exploit itself in ways that bring people to the eity to live, as well as to trade. Better business is obtained by methods of advertising that naturally lead to more people.

Modern advertising is in itself a supreme illustration of effeetive suggestion, and its development las been for the most part in the hands of urban interests. Such advertising has foreed rural people to eontrast their manner of life witl urban eonditions and often with the result of diseontent. They are drawn to the city on special oeeasions by a luring eity publieity manipulated with seientifie skill by experts, and often return to their eountry homes dissatisfied beeause of false notions regarding the pleasures of the eity. Of eourse this is more largely true of young people as they are more open to suggestion.

Spectacular suecess is largely dependent upon urban eonditions of life, and such success obtains public attention. Even in the country the suecesses talked about are likely to be those made possible by eity life. These are given spaee in the magazines and daily papers edited and published in eities, and so they naturally oеcupy the minds of rural readers of sueh periodieals.

The young man who feels the attraction of such enterprise, who wishes to have a part in big things, even if an insignifieant part, who eraves knowing big business at first hand, reeeives a suggestion that invites him eityward. When a eommunity is itself represented by some former resident in some speetaeular suecess, it is eertain that many young men will question their future on the farm in that loeality. Thus the human produet of a mural community robs it of its personality resourees-and the eareer of the man of fame may continue to act as a tradition long after his death, and still add to the rural migration.

It is not altogether clear what effeet visitors in the summer from eities have upon rural people with reference to eity drift. Althougl a matter of aeeident, perhaps, dependent upon the charaeter of the eity people, and only important in a limited area of the country, summer visitors, nevertheless, must provide suggestions that oecasionally operate powerfully upon some young people in the country in eneouraging their going to the eity. Certain faets in some of our New England eountry towns where 
visitors from the city return summer after summer, appear to. indicate that this condition does encourage young people in going to the eity to live.

\section{THE MIND OF THE FARMER ${ }^{1}$}

ERNEST R. GROVES

Tre difficulty is to find the typical farmer's mind that in the South, in the East, and in the West will be accepted as standard. In our scienec there is perhaps at present no place where generalization needs to move with greater caution than in the statement of the farmer's psychic characteristics. It is human to erave simplicity, and we are never free from the danger of forcing concrete facts into general statements that do violence to the opposing obstacles.

The mind of the farmer is as varied as the members of the agricultural class are significantly different. And how great are these differenecs! The wheat farmer of Washington State who receives for his year's erop $\$ 106,000$ has little understanding of the life outlook of the New Englander who cultivates his small, rocky hillside farm. The difference is not that one does on a small seale what the other does in an immense way. He who knows both men will hardly question that the difference in quantity leads also to differences in quality, and in no respect are the two men more certainly distinguishable than in their mental characteristics.

It appears useless, therefore, to attempt to procure for disscetion a typical rural mind. In this country at present there is no mind that ean be fairly said to represent a group so lacking in substantial unity as the farming class, and any attempt to construct such a mind is bound to fail. This is less truc when the class is separated into sections, for the differences between farmers is in 110 small measure geographical. Indeed, is it not a happy fact that the American farmer is not merely a farmer? Although it complicates a rural problem such as ours, it is fortunate that the individual farmer shares the larger social mind

1 Adapted from Publications of the American Sociological Society, Vol. XI, 47-53. 
to such a degree as to diminish the intellectual influenees born of his oceupation.

The method of proeedure that gires largest promise of substantial fact is to attempt to uncover some of the fundamental influenees that operate upon the psychic life of the farmers of America and to notiee, in so far as opportunity permits, what social clements modify the eomplete working of these influences.

One influence that shows itself in the thinking of farmers of fundamental character is, of course, the oecupation of farming itself. In primitive life we not only see the importanee of agricultural work for social life but we discover also some of the mental clements involved that make this form of industry socially significant. From the first it called for an investment of selfcontrol, a patience, that nature might be coaxed to yicld from her resources a reasonable harvest. We therefore find in primitive agriculture a hazardous undertaking whiel, nevertheless, lacked any large amount of dramatie appeal.

It is by no means otherwise to-day. The farmer lias to be efficient in a peeuliar kind of self-eontrol. He needs to invest labor and foresight in an cnterprise that affords to the usual person little opportunity for quiek returns, a sense of personal achicvement, or the satisfaction of the desire for competitive faceto-face association with other men whieh is offered in the eity. Men who cultivate on a very large scale and men who enjoy unusual soeial insight as to the significance of their oeeupation are exeeptions to the gencral run of farmers. In these days of accessible transportation we have a rapid and highly successful selection which largely eliminates from the farming elass the type that does not naturally possess the power to be satisfied with the slowly acquired property, impersonal success, and non-dramatic activities of farming. This proeess which eliminates the more restless and commercially ambitious from the country has, of course, been at work for generations. This has tended, therefore, to a uniformity of mental characteristies, but it has by no means suceeded in producing a homogeneous rural mind. The inovement has been somewhat modified by the return of people to the eountry from the eity and by the influence on the eountry mind of the more restless and adventurous rural people who, for one reason or another, have not migrated. In the far 
West especially attention has been given to the rural hostility to, or at least misunderstanding of, city movements which attempt ambitious social advances. It is safe to assume that this attitude of rural people is widespread and is noticeable far West merely because of a greater frankncss. The casterner hides his attitude because he has become conscious that it opens him to criticism. This attitude of rural hostility is rooted in the fundamental differences between the thinking of country and of eity people, due largely to the process of social sclection. This mental difference gives constant opportunity for social friction. If the individuals who live most happily in the city and in the country are contrasted, there is reason to supposc that the mental opposition expresses nervous differences. In one we have the more rapid, more changeable, and more consuming thinker, whilc the thought of the other is slower, morc persistent, and less wasteful of nervous energy.

The work of the average farmer brings him into limited association with his fellows as compared with the city worker. This fact also operates upon him mentally. IIc has less sense of social variations and less realization of the need of group solidarity. This results in his having less social passion than his city brother, except when he is caught in a pcriodic outburst of cconomic discontent cxpressed in radical agitation, and also in his having a more feeble class-consciousness and a weaker basis for coöpcration. This last limitation is one from which the farmer scriously suffers.

The farmer's lack of contact with antagonistic groups because lis work keeps him away from the centers where social discontent boils with passion and because it prevents his appreciating class differences makes liim a conservative element in our national life, but one always big with the danger of a blind servitude to traditions and archaic social judgments. The thinking of the farmer may be either substantial from his sense of personal sufficieney or backward from his lack of contact. The decision regarding his attitude is made by the influences that enter his life, in addition to those born of his occupation.

At this point, however, it would be scrious to forget that some of the larger farming enterprises are carricd on so differently that the manager and owner are more like the factory operator than 
the usual farmer. To them the problem is labor-saving machinery, efficient management, labor cost, marketing facilities, and competition. They are not especially influenced by the fact that they happen to handle land products rather than manufactured articles.

Much has been made of the farmer's hand-to-hand grapple with a capricious and at times frustrating Nature. This emphasis is descrved, for the farmer is out upon the frontier of human control of natural forces. Even modern science, great as is its service, cannot protect him from the uncxpected and the disappointing. Insects and weather sport with his purposes and give his efforts the atmosphere of chance. It is not at all strange, therefore, that the farmer fecls drawn to fatalistic interpretations of experience which he carries over to lines of thought other than those connected with his business.

A second important influence that has helped to make the mind of the farmer has been isolation. In times past, without doubt, this has been powerful in its effect upon the mind of the farmer. It is less so now because, as every one knows, the farmer is protected from isolation by modern inventions. It is necessary to recall, however, that isolation is in relation to one's needs and that we too often neglect the fact that the very relief that has removed from country people the more apparent isolation of physical distance has often intensified the craving for closer and more frequent contact with persons than the country usually permits. Whether isolation as a psychic experience has decreased for many in the country is a matter of doubt. Certainly most ninds need the stimulus of human association for both happiness and healthiness, and even yet the minds of farmers disclose the narrowness, suspiciousness, and discontent of place that isolation brings. It makes a difference in social attitude whether the telephoine, automobile, and parcel post draw the people nearer together in a common community life or whether they bring the people under the magic of the city's quantitative life and in this way cause rural discontent.

The isolation from the great business centers which has kept farmers from having a personally wide experience with modern business explains in part the suspicious attitude rural people often take into their commercial relations. This has been ex- 
pressed in a way one ean hardly forget by Tolstoy in his "Resurreetion" when his hero, from moral sympathy with land reform, undertakes to give to his tenants land under eonditions mueh to their advantage and, mueh to his surprise, finds them hostile to the plan. They had been too often trieked in the past and felt too little aequainted with business methods to have any eonfidenee in the new plan which elaimed to have benevolent motives. It is only fair to admit that the farmer differs from others of his soeial rank only in degree and that his experienees in the past appear to him to justify his skeptieal attitude. He has at times suffered exploitation; what he does not realize is that this has been made possible by his laek of knowledge of the ways of modern business and by his failure to organize. The farmer is beginning to appreeiate the signifieanee of marketing. Unfortunately, he too often earries his suspieiousness, which has resulted from business experienees, into many lines of aetion and thinking, and thus robs himself of enthusiasm and soeial confidenee.

A third important element in the making of the farmer's mind may be broadly designated as suggestion. The farmer is like other men in that his mental outlook is largely eolored by the suggestions that enter his life.

It is this faet, perhaps, that explains why the farmer's mind does not express more clearly vocational eharaeter, for no other souree of persistent suggestiolls has upon most men the influenee of the newspaper, and eaeh day, almost everywhere, the daily paper eomes to the farmer with its appealing suggestions. Of eourse the paper represents the urban point of view rather than the rural, but in the deepest sense it may be said to look at life from the human outlook, the way the average man sees things. The newspaper, therefore, feeds the farmer's mind with suggestions and ideas that eounteraet the influenees that speeially emphasize the rural environment. It keeps lim in eontaet with thinking and events that are world-wide, and uneonseiously permeates his motives, at times giving him urban eravings that keep him from utilizing to the full his soeial resourees in the country. Any attempt to understand rural life that minimizes the eommon human fellowship which the newspaper offers the farmer is certain to lead to unfortunate misinterpretation. 
Mentally the farmer is far from being isolated in his experiences, for he no longer is eonfined to the world of local ideas as he once was. This eonstant daily stimulation from the world of business, sports, and publie affairs at times awakens his appetite for urban life and makes him restless or encourages his removal to the city or makes him demand as much as possible of the quantitative pleasures and reereations of eity life. In á greater degree, however, the paper contents his mental need for contaet with life in a more universal way than his particular eommunity allows. The automobile and other modern inventions also serve the farmer, as does the newspaper, by providing mental suggestions from an extended environment.

A very important souree of suggestion, as abnormal psyehology so clearly demonstrates, at present, is the impressions of ehildhood. Rural life tends on the whole to intensify the significant events of rural life because of the limited amount of exeiting experienees received as compared witl city life. Parental influence is more important because it suffers less competition. This fact of the meaning of early suggestions appears, without doubt, in various ways and forbids the scientist's assuming that rural thinking is made uniform by universal and unvaried suggestions.

The discontent of rural parents with reference to their environment or occupation, due either to their natural urban tendeneies or to their failure of success, has some influence in sending rural people to the city. Accidental or incidental suggestion often repeated is especially penetrating in childhood, and no one who knows rural people ean fail to notice parents who are prone to sueh suggestions expressing lural discontent. In the same way suspiciousness or jealousy with reference to partieular neighbors or associates leads, when it is often expressed before children, to general suspiciousness or trivial sensitiveness. The emotional obstacles to the get-together spirit-obstacles which vex the rural worker-in no small degree have their origin in suggestions given in childhood.

The eountry is concerned with another souree of suggestion which has more to do with the effieiency of the rural mind than its content, and that is the matter of sex. Students of rural life apparently give this element less attention than it deserves. As Professor Ross has pointed out in South of Panama, for example, 
the preeocious development of sex tends to enfeeble the intelleet and to prevent the largest kind of mental eapacity. It is unsafe at present to generalize regarding the differenees between country and eity life in matters of sex, but it is eertainly true when rural life is empty of commanding interests and when it is eoarsened by low traditions and the presence of defeetive persons that there is a preeoeious emphasis of sex. This is expressed both by early marrying and by loose sex relations. It is doubtful whether the eommereializing of sex attraction in the eity has equal mental signifieanee, for eertainly science elearly slows that it is the precoeious expression of sex that has largest psyehie dangers. In so far as the environment of a rural eommunity tends to bring to early expression the sexual life, we have every reason to suppose that at this point at least the influenee of the eommunity is such as to lead to a eomparative mental arrest or a limiting of mental ability, for whieh the country later suffers socially. Each student of rural life must, from experience and observation, evaluate for himself the significanee of this sex precociousness. When sex interests become epidemic and the general tendeney is toward precoeious sex maturity, the country community is produeing for itself men and women of inferior resourees as eompared with their natural possibilities. Even the supposed social wholesomeness of earlier marrying in the country must be scrutinized with the value of sex sublimation during the formative years clearly in mind.

\section{THE NEED OF IDEALS IN RURAL LIFE ${ }^{1}$}

\section{KENYON L. BUTTERFIELD}

ONE grave danger to permanent rural progress is the low level of ideals, determined by community standards. It is not that the average ideals are lower than in the eity. I think they are ligher. But they eome perilously elose to a dead level in inmense areas of eountry. There is an absence of that ligh idealism that acts as yeast upon the whole mass, which often pre-

1 From "The Country Church and the Rural Prohlem," pp. 75-78. (Copyright 1911, the University of Chicago Press.) 
vails in eities. It is harder to rise above the conventions in the eountry, simply beeause there are few strata of popular habit. In the eity there are many; the individual ean pass from one to another. Things are redueed to simpler terms in the country. This has its advantages, but it tends to blight budding ideals or to drive them out for development elsewhere-usually in the eity.

As a eonsequence the rural community is in constant danger of stagnation-of settling clown into the easy ehairs of satisfaetion. Rural life needs eonstant stimulus of imported ideas-a stimulus of suggestion apart from its daily routine.

Moreover, rural ideals sometimes lack breadth and variety. Life in the country easily beeomes monotonous, humdrum. It needs broadening, as well as elevating. It needs variety, gaiety. But these ehanges ean find their proper stimulus only in motives that are high and worthy. Hence an appeal must be made for the eultivation of ideals of personal development and neighborhood advancement.

When ideals do come into eountry life, they are apt to be not indigenous, but urban notions transplanted bodily. Urban ideals may often be grafted onto some strong rural stoek. Transplantation is dangerous. Some one must be at work in the country neighborhoods breeding a new speeies of aspirations out of the common hardy varieties that have proved their worth.

Laek of ideals is in a sense responsible for the drift away from the farm. Some people leave the eountry beeause they ean not realize their ideals in the existing rural atmosphere. Others go because they have no thought of the possibilities of eountry life.

In a former chapter attention was called to the faet that rural life is more full of poetry than any other. But rural romance is often stifled in the atmosphere of drudgery and isolation. This high sentiment is of the soul and can come only as the soul expands. It is not merely an enjoyment of trees, erops, and animals. It is in part a sense of exaltation born of contaet with God at work. It has in it an element of triumph beeause great powers are being harnessed for man's bidding. It has in it somewhat of the air of freedom, beeause of dealing with forces free and wild except as they are held in leasl by an unseen Master driver. It has in it much of worship, beeause of all the deep 
mysteries of seed and soil, and because of the everlasting, patient procession of the seasons and their vicissitudes.

\section{BiBLIOGR.PHX}

Anderson, W. L. The Comntry Town. Baker, N. Y., 1906.

The Rural Mlind. Homiletic Review, N. Y., July, 1909.

Bailey, L. H. Countryman and Cityman. In his The Outlook to Nature, pp. 90-97, Macinillan, N. Y., 1905.

The Democratic Basis in Agrieulture. In his The Holy Earth, pp. 139-150, Seribner, N. Y., 1916.

The Farmer's Fatalism. In his Training of Farmers, pp. 71-73, Century, N. Y., 1909.

The Spiritual Contact with Nature. In his The Holy Earth, pp. 75-S0, Seribner, N. Y., 1916.

The Underlying Training of a People. In his The Holy Earth, pp. 39-42, Scribner, N. Y., 1916.

Why Do Some Boys Take to Farıning. In his Training of Farmers, pp. S9-115, Century, N. Y.. 1916.

Bernard, L. L. Theory of Rural Attitudes. American Jour. of Sociolngy, 22: 630-49, March, 1917.

Butterfield, K. L. Culture from the Corn-Lot. In his Chapters in Rural Progress, pp. 66-77, Univ. of Chicago Press, 1908.

Coulter, John B. Marriage and Divorce in North Dakota. Amer. Jour. of Sociology, 12:398-417.

Country the Natural Birthplace of Talent. Harper's Monthly; 106: 649-53, March, 1903.

Davies, George E. Social Environment and Eugenies. In his Social Environment, pp. 82-131, MeClurg, Clicago, 1917.

deCrevecoeur, J. H. St. Jolin. Letters from an American Fanner. Duffield, N. Y., 1904.

Emerson, Ralph W. Society and Solitude. In his Complete Works, 7:9-20, (Riverside Edition), Houghton, N. Y., 1898.

Fairchild, George T. Personal Attaimments. In his Rural Wealth and Welfare, pp. 45-48, Macmillan, N. Y., 1900.

Gold, Guy D. The Psychology of the Country Boy. Rural Manlood $2: 10 \bar{\tau}-109$, April, 1911.

Groves, Ernest R. The Mind of the Farmer. In his Rural Problems of To-day, Chap. 8, pp. 117-33, Assn. Press, N. Y., 1918.

Holmes, Roy IIinman. The Passing of the Farmer. Atlantic $110: 517-23$, October, 1912.

Lewis, O. F. The Tramp Problein, Annals, $40: 217-227$, March, 1912.

Lighton, William R. Letters of an Old Farmer to His Son. Doran, N. Y., 1914 .

Plunkett, Sir Horace. The Human Factor in Rural Life. Outlook, 94: 354-9, Feb., 1910.

Ripley, IV. Z. Ethmic Stratification and Urban Selection. In his Races of Europe, Chapter 20, Appleton, N. Y. Found also in Carver's Sociology and Social Progress, pp. 676-696, Ginn, Boston, 1906.

Ross, Edward $\Lambda$. Folk Depletion as a Cause of Rural Decline. Amer. Sociolngical Society Publications, 11:21-30, December, 1916. 
Sanderson, Dwight. The Farmer and Child Welfare. Conf, of Social Work, 1919, pp. 26-33.

Snith, Asa D. Soil and Mind Culture. 4th Anumal Report of the New Hanpshire Board of Agriculture, pp. 257-265, Coneord, 1874.

Vogt, Paul L. Rural Morality. In his Introduction to Rural Sociology, pp. 203-220. Appleton, N. Y., 1917.

Wallace, Henry. Description of an Ideal Rural Civilization. Men and Religion Messages-Rural Clurch, pp. 14-27, Vol. VI, Association Press, New York, 1912.

Wallace, Henry. Letters to the Farm Boy. Macmillan, N. Y., 1902.

Waters, H. J. The Means at Hand for the Development of an Ideal and Rural Civilization. Men and Religion Messages-Rural Chureh, pp. 27-47, Vol. VI, Association Press, N. Y., 1912.

Where the Great are Born, World's Work, 18: 11645, June, 1909.

Woods, Frederick A. Birthplaces of Leading Americans and the Question of Heredity. Science, N. S. 30:17-21, July 2, 1909; also 205-9, August 13, 1909.

City Boys vs. Country Boys. Science, N. S. 29: 577-9, April 9, 1909. The Share of Vermint in the Production of Distinguisled Men. Ainer. Statistical Assn. Publications, pp. 761-3. Boston, September, 1911.

Woodward, M. Influence of the Summer Resident upon Country Life. Countryside Magazine, 22:320, May, 1916. 


\section{CHAPTER VIII}

\section{RURAL HEALTH-PHYSICAL AND MENTAL}

\section{A. RURAL HEALTH-PHYSICAL}

\section{A SOCIOLOGIST'S HEALTH PROGRAM FOR THE RURAL COMMUNITY ${ }^{1}$}

L. L. BERNARD

Noт the only dangers to human beings come from physical violenee, although in these times of war and international unrest we are too prone to forget or neglect the subtler evils. The menaees to morals and to health have much more disastrous effeets, not alone beeause they claim more victims by aetual eount, even in war time, than does physieal violenee, but -also beeause they are so much more seeretive in their methods, and of all enemies their approaeh is the most unseen. As Professor Carver says, "When people realize elearly that babies ean be killed with fly-infeeted food as well as with an ax, they ought to be as willing to work as hard to exterminate the fly as they would to exterminate a gang of murderers who went about killing babies with axes." But the problem of getting people to realize the dangers of germ diseases and moral pitfalls is a very diffieult one. Merely the relatively unedueated eye ean perceive the dangers of physieal violenee, but it requires a mind educated in at least the rudiments of the theory of germ diseases and sanitation to apprehend the dangers to both young and old from flies, mosquitoes, tuberele, and intestinal bacilli. The one is capable of dramatie presentation, while the other is for most people information of a highly prosaic eharaeter.

Likewise, warfare against the one appeals readily and vividly to the imagination and ean be waged more or less directly, while

1 Adupted from "The New Chivalry-Health," pp. 349-358. (Southern Sociological Congress, May, 1915.) 
war against bad health or bad morals requires mueh more thought and eonstancy of purpose for its planning than most people are willing to give. For these reasons it may be worth while to set forth here a few suggestions for a program which may be of some value both for aequainting the people of the rural community with the hidden menace to their health and for enabling them to overeome these dangers by eradicating their causes. Good health is one of the primary eonditions of a strong and progressive eivilization. Where it is lacking most of the other human ills flourish also. Where it is present there is energy and will for the most difficult tasks of society.

The eountry is behind the eity in both the matter of information regarding sanitary conditions and in the applieation of the methods of sanitation. This is true in spite of the fact that the country has some deeided hygienie and sanitary advantages in the way of an abundance of sunlight and fresh air and, for a large portion of the year, of fresh food in greater quantities than the eity can afford. There is also an abundanee cf physieal exereise in the country, but unfortunately of such a one-sided character that it does not develop the body harmoniously, but tends in many eases to strain and to impair certain tissues and organs. These are largely natural advantages. For the most part the disadvantages of the eountry in a sanitary way are the result of man's own negligence rather than inherent in the nature of the country itself. In the country as yet there is almost everywhere less sanitary inspeetion, and there is eonsequently less sanitary eontrol over such matters as the drainage of mosquitobreeding swamps, the disposal and destruction of noxious refuse and dead animals, the inspection of the water supply and the milk supply, and less control of diseased and poisonous animals, such as the dog infected with rabies and dangerous smakes. This lack of sanitary inspection and control is not alone due to ignorance, but is also in large part traecable to the economic costs of carrying out such programs of sanitation, and perhaps equally as often to the lack of proper social and economic machincry or organization for getting it done.

The country is also less well supplied with many of the sanitary and health aids which are coming to be relatively so plentiful in the eities, such as good physicians within reasonable calling 
distance, the distriet or visiting nurse, hospitals and dispensaries. The country also is too frequently laeking in such other hygienie and health aids as publie and private bathing facilities, regular and well regulated exercise and recreation, protection from sudden changes in temperature and inelement weather. But on the other hand the country does not suffer so extensively from the health-destroying vices which are so common in the cities, especially exeessive aleoholism, drug addiction, and the venereal diseases. Most of the leading diseases, in fact, are recorded in eensus returns as being more prevalent in the eities than in the eountry distriets. There are eertain notable exceptions to this general rule. The rural eommunitics exeeed in malaria, inflnenza, dysentery, peritonitis, and the diseases of the nervous and eirculatory systems, and possibly also in pellagra and hookworm. Some health authoritics have also attributed much of the eities' excess rate of typhoid to rural vacations and an infected milk supply, though the responsibility probably rests more properly upon the cities' infected water supply. The cities' excessive rate in ecrtain of the largely prevalent diseases, such as measles, whooping cough, diphtheria, croup, scarlet fever, and pneumonia, is due primarily to the high contagiousness of these affeetions which operates to advantage in crowded communities. The eountry's excess in the diseases earlicr enumerated above, on the other hand, is not traccable to the contagiousness of the diseases, but to the inferior sanitation which exists there, and in some cases to pliysieal and nervous overstrain.

Thus the comparative statistics of rural and urban health indieate clearly to us the difficulties in each ease. In the country the difficulty is elcarly lack of sanitation and physical and mental hygiene. What then is our program for removing these abnormal conditions? There are a great many things that can and should be done. It will suffiec here perliaps to suggest and outline a few of the more important of these.

Perhaps the primary condition for the establishment of better health in the rural eommunity is the provision of a competent lealth offieer and sanitary inspeetor, one who not only understands the dangers and diffieulties of rural sanitary conditions, but who also has the legal powers and the eourage to enforee the ehanges which are necessary. A number of states already make 
provision for a county health officer, but usually he has iusuffcient powers with which to enforec reforms or he is paid for too small a portion of his time, or his appointment is of too politicala character, to secure the efficiency which so important a function as his requires. The fact remains that rural health inspection is far behind that which is earried on in the eitics, and sanitary enforcement is much more nearly adequate in the eitics than in the country districts. In order to secure the greatest efficiency in this work its administrative dircetion should center in the State Board of IIcalth, which should have adequate powers of control over it.

A closely related need for the protection of rural health is the collection and publication of vital statisties, including statisties of disease as well as of births and deaths. This function may be performed by or under the direction of the rural health officer or by a separate agency. In either case the statisties entire should be made immediately available to all civic and private agencies interested in the health of the rural community. Statistics of health and of births and deaths have the same value for the rural community as for the urban; they point out the weak spots in the community's health and thus indicate where work needs to be done. By the aid of such statisties polluted water supplies, soils polluted with hookworm larva, breeding places for flies and mosquitoes, the need of instruction in dictetics and other matters of household science and management can be indicated. It is therefore absolutely esscutial to proper health administration in the rural community that accurate and adequate vital statisties be collected and published.

It must not be forgotten, of course, that no community, urban or rural, ean be given proper sanitary and hygienic conditions unless there are proper laws prescribing minimum sanitary conditions and giving adequate powers to the officer or officers having the protection of health in charge. Therefore most, if not all, of our states will have to legislate anew for the control of rural sanitation. The large essentials of the health code should be uniform over the state, as uniform in fact as are the licalth needs, while the problems of a purcly local nature may conceivably be left to the administrative diseretion of the county courts or boards of commissioncrs. But whatever body may enact the health laws 
they should be reasonably uniform, and adequate and thorough administrative enforeement should be provided for. But where adequate laws and administrative machinery for rural sanitary proteetion do not exist-and such apparently is everywhere the ease at the present time-mueh may still be aeeomplished through eommunity eoöperation, provided only there is leadership and the dwellers in the eommunity are made to see elearly the eonneetion between sanitary measures and improved health. The health of most of the rural eommunities of the South eould be vastly improved without any eonsiderable visible economie outlay merely through voluntary eoöperative drainage of swamps or wet plaees, oiling, eovering, or filling unused wells, the disposal of all wastes, and the formation of rural improvement soeieties or elubs for the purpose of observing properties for the deteetion and reporting of improperly eared for manure piles, the aceumulation of rain water in bottles and barrels and other reeeptaeles about the liouse, and other nuisanees, and for the ereation of an effective publie opinion regarding these evils. Here the problem is primarily one of edueation and effective leadership rather than of laws, or eoöperative labor rather than of a budget raised through taxation. Valuable as sueh eö̈perative enterprise must always be for the protection of rural health, with or without laws and administration, it can never eompletely take the place of the latter, nor will it work with anything like the uniformity whieh the other provides.

No rural health program ean elaim even approximate adequaey whieh does not provide for the distriet or visiting nurse. The visiting nurse has been an indispensable faetor in the health improvement of the eities and is eoming to be reegnized as one of the first objeetives in rural health campaigus. Where the rural distriet nurse has been employed results have amply justified the expenditure required. Whether the nurse operates over the whole eounty or a smaller division must neeessarily depend primarily upon the density of the population and the value of property for taxation, tlough at least one visiting nurse to the township, or eousolidated sehool district where such exists, should be the ultimate goal. In those States where township divisions do not exist, eommissioner distriets or other similar divisions may well serve as geographic units for her serviees. The function 
of the visiting nurse is normally pretty much the same in rural and in urban communities. She should be available for advice and help wherever there is illness and her serviees should be as mueh educational and preventive as eurative or ministrative. IIer spare time might well be spent in instrueting mothers' elubs and similar organizations, in social eenter or institute and other extension talks, in inspeeting school children, and in giving occasional instructive talks to them regarding the eare of their health and that of the community. No other person perhaps can be of equal help to a eommunity in health protection, for no other comes so intimately into the lives of the people. It is probably desirable that a small fee, of 25 or 50 cents, should be charged for each visit she makes, but this fee slould always be remitted upon the request of the person benefiting from the services. In no ease slionld her salary depend in wlole or in part upon the fees eollected, but it should be met out of the regular funds of the eounty treasury, and the laws of the State should be so modified as to permit of this, where such modifieation is neeessary. Hers is as important a funetion as that of any other public servant in the eounty. Transportation is one of the most diffieult problems to be met in this eonnection, but it is by no means insurmountable.

Another urgent health need for the rural community is that every dweller in the eountry should have easy aceess to a hospital when there is need for such. Most of our larger eities are more or less adequatcly supplied with hospitals and in most of these there is always a limited number of beds which are available even to the very poor. Only the wealthier country people can now afford to make use of the eity hospitals. There is great need of eounty or distriet hospitals in suffieient number and with faeilities adequate for the care of those who cannot receive proper attention at home. In most eases the oversight of the visiting nurse will insure suffieient expert sanitary eare for the person who is ill in his own home, but in a ecrtain number of eases either the gravity of the disease, the laek of home faeilities, or some other consideration makes it highly desirable, if not imperative, that hospital treatment be available. Hospitals are, of course, expensive and rarely pay for themselves, mueh less would they be able to do so if operated on the scale and for the purposes here suggested. But hospitals are not so expensive as 
disease uncheeked or improperly eared for, and this is a fact which should be more generally appreciated. In eonnection with the hospitals there should be provided dispensaries from which medicines may be distributed to the poor, who would not otherwise proeure them, at cost or even in some cases free. Ultimately we may also hope for public physicians, though such does not seem to be immediately realizable. If the other health agencies here deseribed are effective, there should be less need for the physician, and perhaps the fact that his services come high may in some degree help to reënforee the value of the counsels of the visiting nurse.

Already I have mentioned medical inspection of schools as one of the distinetive health needs of the rural eommunity. Its value is now too generally reeognized to require argument by way of reënforeement. To supplement it, however, there should be provided a earefully planned and well exeeuted edueational program for the improvement of rural health. Of primary importanee in this program is the instruetion of sehool ehildren in the essential facts of sanitation and personal hygiene. In many of the better rural schools much has already been aceomplished in this direction. There are now some good text books on the subject which teach in a practical and intelligible way the most neessary facts regarding health. Perhaps the weakest spot in the seheme is the teacher who usually has studied aneient languages or some equally esoterie subject to the negleet of such praetical matters as hygiene. As a eonsequenee she has not the experienee and background to give lier teaching the requisite reality. It is here therefore that oceasional leetures by the visiting nurse ean be most effeetive. There is a very pressing need that we revise the eourse of study in the rural as well as in the urban sehools until they inform us about the lives of our own times and people rather than about the lives and languages of peoples who lived a long while ago and whom we shall never see. It is indeed a poor eulture which does not teach one how to live well in his own day and world.

The teaching of health and hygiene in the schools will reach the young people, whom after all it is most important to reael. But we must not neglect the older people of the community, for their attitudes of encouragement or diseouragement will affect 
profoundly the value of the lessons to the young, as well as hasten or delay the actual application of our program to their lives. Therefore we need an abundance of plain, practical extension teaching on this subject. Most of our state universities are making some efforts in this direction and the State Boards of Ilealth are frequently doing good work and ean do more still. There is no good reason why health extension teaching should not he made available wherever it proves valuable. It can be earried on through local clubs, farmers' institutes, the social center where one has been developed, the rural leeture course, and even the rural chureh. All of the leading facts about health and sanitation ean be easily and elearly presented in public lectures and through bulletins, and people will be interested in them when so offered. Of a more general educational nature, but distinctly valuable in its way, is the rural health survey.

Two diseases from which the rural population suffers more than the urban are nervous and circulatory derangements. Clearly then more than sanitation alone, perhaps more even than health teaching, must be provided for the rural eommunity. There is too much isolation, life is too monotonous, there is too much introspection, too much brooding over problems and diffieulties log the rural dweller and too little self-forgetfulness in the presence of others. For this difficulty we must prescribe a better social life, intercourse which gives to the thought new objects of attention and makes life seem less of a struggle and so little a pleasure. Fal'in women especially are lacking in such contaets. The best remedy here is the social center which coöperates with the home. If eontacts are to be broadened, as they should be, care must be taken that they be made restful rather than competitive and destructive of energy. Another indirect menace to health comes from the excessive severity and duration of labor on the farm at certain times of the year. It may not be possible to abolish seasonal labor altogether, nor to find machines to do all of the exeessively difficult tasks, but a better system of farm management, more coöperation in farm labor, and a better understanding of the dangers of physical and nervous overst rain should do mueh to remove some of the worse evils in this connection.

The various methods of improving rural health here suggested 
will not come of themselves. If we wish to see them realized, we shall have to work for them at least as strenuously as we strive for the other good things of life.

\title{
CITY IS HEALTHIER FOR CHILDREN THAN THE COUNTRY ${ }^{1}$
}

\author{
THOMAS D. WOOD
}

More than half of the $20,000,000$ school children in the United States are attending rural schools.

Country children attending the rural schools are less healthy and are handicapped by more physical defects than are the children of the cities (including all the children of the slums). And this is true, in general, of all parts of the United States.

$\mathrm{My}$ conclusions are based upon all the available official statisties of school children gathered from all parts of the country. As many as 50 or more sources of information were used, and the results compared and collated. These statistics lack uniformity. They contain, doubtless, many errors, but there are probably as many errors in the statisties of the eity school children as in those of children in the rural schools. The comparative result, therefore, is accuratc.

In every health item the country child is more defective than the city child. This is a most surprising reversal of popular opinion. More than twice as many country children suffer from malnutrition as do eity children; the former are also more anemic, have more lung trouble, and include more mental defectives than do the latter.

In an impartial cffort to ascertain the causes of present-day country life, so far as health and welfare are concerned, this fact must not be overlooked: Artificial selection, during the last half century especially, has drawn much of the best human stock from the country to the cities. Before that time the tide in the movement of population apparently carried more good human material to the rural regions than away from them.

Another reason for the physical inferiority of country school

1 Adapted from Philadelphia Public Ledger, April 2, 1916. 
ehildren and of country people in general is that the scienee and art of human living, of conserving and improving human health and general human welfare, have advaneed mucl more rapidly in the eities than in the country distriets. The problems of safety and comfort as affected by eongestion of population and many other eonditious of urban life have thrust themselves upon human attention and have reeeived much eonsideration.

The art of human eare has progressed mueh more slowly in the eountry. The father in the eity spends, on the average, a larger pereentage of his income for the welfare of his children than does the father on the farm. The farmer, relativcly, raises everything else more earefully and, as a rule, more suecessfully, than his ehildren.

Still another condition which helps to cxplain this astonishing inferiority of the country child is the environment. The country home and the country school are, on the average, less sanitary and healthful than the city home and the eity school.

It has been assumed that because the country elild has all the features of the country, he is, of eourse, surrounded by fortunate and wholesome conditions. But the possession of all outdoors is far from enough. The farmer's lome is, as a rule, insanitary in many respects. It is often terribly unventilated, and the dwellers in the house are fed many hours of the day with bad air. Country water and food are less wholesome than water and food in the city. The standards of living on the Ameriean farm, when tested by the aceepted principles of sanitation and hygiene, are alarmingly defective.

The rural school, from the standpoint of health and general fitness for its important use, is the worst type of building in the whole country, including not only all types of buildings used for human buildings, but also those used for livestoek and all domestic animals. Rural schools are, on the average, less adequate for their use than prisons, asylums, almshouses, stables, dairy barns, pig pens, chicken houses, dog kennels are for their uses.

In the eity the best ideas are more readily brought into contaet with all of the people. For many in our cities, deprived through poverty of the material necessities of life-intellectual and social as well as physieul-a bounteous philanthropy frequently sup- 
plies the lack. In the country, on the other hand, the farmers must be persuaded to use their own resources to provide adequately for the welfare of their families, and, most of all, for their children.

To carry this proposal for child betterment directly to the country houschold would be inadvisable and ineffective; would often arouse resentment. In this phase of human education the direct approach to the home is much less feasible in the country than in the eity. The school is, however, the agency endowed by every circumstance for the accomplishment of this great special task of a higher civilization.

After careful consideration of this serious problem of the relatively deficient health of the children in rural schools, the Health Committee of the National Council of Education, in coöperation with the corresponding Health Committee of the American Medical Association, strongly recommend the following measures as a practical program for the solution of the difficulty :

First-Health examination and supervision of all rural school cliildren.

Second-The service of the school or district nurse to provide the practical health scrvice and follow-up work, which (it has been so elearly demonstrated in our cities) ean be best accomplished by the school nurse. The work of the nurse is even more - vitally important in rural than in city schools.

Fourth-Warm school lunches for all children in rural as well as in eity schools. The indirect educational benefits of the sehool lunches upon the children and the homes are even inore important than the immediate health improvement of the children themselves.

Fifth-Correction of physical defects which are interfering with the health, the general development and progress of rural children. For this remedial and constructive liealth service, practical rural equivalents of medical clinies, dental elinies and community health centers of the cities are urgently needed in all parts of the United States. The county unit organization and administration for health as well as other rural interests has already proved successful and promises the best results. Every 
county should have one full time health officer, one or more school and distriet nurses, and one or more community health eenters to provide rational, self-supporting health and medical service for all the people.

Sixth-Coöperation of plysicians, medical organizations, health boards, and all other available organizations in the rural health program.

Seventh-Effective health instruction for the rural schools which shall aim decisively at the following results:

(a) Establishment of health habits and inculcation of lasting ideas and standards of wise and efficient living in pupils.

(b) Extension of health conduct and care to the school, to the homes, and to the entire community.

Eighth-Better trained and better paid teachers for rural schools, who shall be adequate to the health problems as well as to the other phases of the work of rural education.

Ninth-Sanitary and attractive school buildings, which are essential to the health of pupils and teachers.

Tenth-Generous provision of space and facilities for wholesome play and recreation.

Eleventh-Special classes and schools for the physically and mentally deficient, in which children may receive the care and instruction requisite for their exceptional needs.

Better health is to a striking extent a purchasable commodity and bencfit. Vast sums of money ale expended from public and private funds for the amelioration of human suffering and disability in the attcmpt to salvage the wreckage resulting from unfavorable carlier conditions, which with foresight and at very moderate cost might in large measure have been prevented.

Our schools are spending millions in educating, or trying to educate, the children who are kept back by ill-health, when the expenditure of thousands in a judicious health program would produce all extraordinary saving in ceonomy and efficielley. $\Lambda$ dollar saved in a wise, constructive effort to conserve a child's health and general welfare will be more fruitful to the child and for the general good than a thousand times that sum delayed for twenty years. The principle of thrift in education finds its first and most vital application in the conservation and improvement of the health of the children. 


\title{
HEALTH WOIK IN CITY AND RURAL SCHOOLS OF THE UNITED STATES
}

\section{Activity.}

Medical inspection laws in 23 States

Mandatory laws

Permissive laws

M ed i c a 1 inspection practiced

Dental inspeetion by dentists

Dental elinies

Clinies for eye, nose, throat and other defects

Nurses

Open air classes

Athletics and recreation; organized with appropriate facilities and equipment

IV a $\mathrm{r} \mathrm{m}$ lunehes in scliools
For City Curluden

Mandatory for cities only in 12 States

Apply to all citics

Enforeed in most cities

In over 400 eities

In 69 eities

In 50 eities

In cities

750 in 135 citics

In cities only

Virtually all cities and large towns
For Coustry Childrey

Mandatory for rural schools in 7 States

In 7 States

In 6 of the 13 States laving such laws

In 13 States, in parts of 130 counties

Permitted in 2 States, but not yet provided

In one rural eounty (St. Jolın's County, Fla.)

None

In $12-20$ rural distriets

Little provision in rural sehools

\section{RURAL SANITATION: DEFINITION, FIELD, PRIN- CIPLES, METHODS, AND COSTS ${ }^{1}$}

\author{
W. S. RANKIN, M. D.
}

THF word sanitation refers to eivic life; the term rural sanitation refers to rural eivic life; the constituted and the common

1 Adapted from American Journal of Public IIealth, Vol. VI, pp. 5545.58, June, 1916. 
organ through which rural civic life finds expression is the county government; therefore, we may define rural sanitation as the administration of sanitary measures by or through the eounty government. Rural sanitation finds its parallel in urban sanitation, and county sanitation its parallel in municipal sanitation.

The field of rural sanitation includes more than 99 per cent. of the area and more than half of the population of the United States.

Rural sanitation should be initiated by the state, but executed through the rural civic inachinery, the county government. The state should initiate, because the state is the only existing force that can initiate rural or county health work. The county government must carry on the rural sanitation initiated by the state for two reasons: First, should the states undertake to execute, as well as initiate, rural sanitary measures, all of the states, with a few exceptions, would soon realize that their undertaking was far beyoul their means; second, no one, or no ageney should do for oth rs what they ean do for themselves, as such practice leads toward dependence and indifference and away from independence and appreciation. The people are able, when properly shown, to eare for themselves, and it is better for them to do this than to lave it done for them.

The independence of the county as a governmental unit demands a plan of rural health work that will permit the more progressive counties to go forward, liberating such counties from the possible retarding influence of the backward counties-in short, a plan that permits of leadership and healthy rivalry among counties.

The multiplicity of rural governments is a greater rural sanitary asset, affording a corresponding multiplicity of opportunity. There are 2,953 county governments in the United States, an average of 66 to the state. The county governments of the average state hold over a thousand meetings a ycar; at practically all of these meetings the state's representatives are welcome and can get a hearing. If the state health officer has a reasonable proposition, with good argument behind it and not too big a budget in front of it, he ean influence the county to take one, two, or three steps toward a cleaner civic life. Every meeting of the county government is a challenge to the state department 
of health to show the eounty its sanitary needs and how to meet them.

Rural sanitation must be developed on a smaller budget than the budget for urban sanitation. The eountry is poor. What the exact differenee between the urban and rural per eapita wealth is in the United States, no one knows, but we do know that rural per eapita wealth is mueh less than the urban per eapita wealth.

The influenee of epidemieity is weaker in rural than in urban life, and rural quarantine measures need not be as rigid as urban quarantine measures.

Rural sanitation will be influeneed by the individualism of the eountry. The ruralite (a term more expressive than orthodox) is individualistie; the urbanite is eommunistie. The errors of individualism are best treated by edueation; the errors of communism are best treated by legislation; therefore, sanitary edueation is relatively more important in rural sanitation than in urban sanitation, while the reverse is true for sanitary legislation.

There are two general methods by whieh a eounty may have sanitary measures earried out: First, the eounty may do its own work; seeond, the eounty may have its work done by some outside ageney. The whole-time eounty health offieer is usually regarded as the best solution by the first method, while the unit or eontraet system of eounty health work furnishes, probably, the best solution by the seeond method.

The unit system of eounty healtl work assumes, first, the divisibility of eounty health problems into fairly independent units of health work; seeond, that a eounty may get better work for less money by paying the State Board of Health just what it eosts to eomplete a eertain picee of work than by attempting to do the work itself. Several illustrations will make the praetieability of the unit system clear and perhaps better appreeiated.

Illustration No. 1.-The North Carolina State Board of Health proposed to and eontraeted with ten eounties for a eounty appropriation of $\$ 500$ to administer free typhoid immunization to those eitizens of the ten eounties who wished to be immunized. In the first set of five eounties we gave eomplete treatment to 26,537 people; when we eompleted the work in the next five 
eounties, 50,000 people in the ten eounties will have been vaeeinated against typhoid fever. This is about one-eighth of the population of the counties treated. In several eounties about one-third of the population has been treated.

Illustration No. 2.-Our prineipal fall and winter work in rural sanitation will be exeeuting eontraets for the following unit of seliool work: For a eounty appropriation of $\$ 10$ for each sehool in the eounty the State Board of Ilealth agrees to arrange through the county sehonl authorities and with the teachers a program of eonseentive liealth days for each sehool as follows: Two weeks before health day the principal of the school reeeives from the State Board of IIealth a bateh of hand bills anmouneing a date and program for healtl day. The hand bills also earry an invitation to the patrons of the sehool to attend the exereises. The teacher distributes these notiees through the elildren to the scliool eommunity. The representative of the State Board of Health arrives at the sehool at ten A. M. on health day. He makes a fifteen minute talk to the ehildren and visitors on the importance of a knowledge of the laws of health. He then makes a medieal inspection of the pupils and gives eael defeetive ehild a eard to its parents, notifying the parcnts of the nature of the defeet and urging the parents to see the inspeetor after the evening exercises. The inspector mails a report of the inspeetion to the State Board of Health, whieh, througl a system of follow-up letters, keeps in touch with the parents of the defeetive ehildren until they are treated. The inspeetor then questions the ehildren after the manner of the old-time spelling mateh on a health eatechism, which has been supplied to the sehool in suffieient number at least one month prior to health day. The health day exereises then adjourn until 8 P. M., at which time the exereises are resumed. The evening exereises eonsist of from three to four short illustrated leetures by the inspeetor on the more important subjeets of sanitation, interspersed with the reading of seleeted compositions by the sehool ehildren. The last item on the program will be the awarding of prizes, the first for the best knowledge of the eateehism and the seeond for the best eomposition. The inspeetor will grade, seore-card manner, each sehool on the excellenee of its showing, on health day. When this eounty unit is completed, a eounty 
prize will be awarded to that school giving the best eoöperation in the work; a county prize will be awarded for the best eomposition, and another prize for the best knowledge of the health catechism. The inspeetor can handle one rural school a day. It will take two or three days to handle some of the larger village and town schools. In the first eounty to adopt this unit there are fifty-seven schools whieh will require a program of practically three months. The inspeetor will have very hard work for five days in the week, like all school workers, but like them will have Saturday and Sunday to rest. This unit of health work eouples medical inspection of school children with the sanitary instruetions of the entire community, young and old alike-the young through the eateehism, eompositions, and leetures, and the old through the lectures, but most of all through the help the ehildren will demand of their parents in learning the eateehism, and in preparing the eompositions.

This plan of eontract county health work greatly increases the appropriation of the State Board of Ilealth; an appropriation from a eounty is just as uscful in doing health work as an appropriation from the state. This plan has great adaptability, and I might say extensibility in proportion to the ingenuity of the operator; under it a unit of infant hygiene work may be dcveloped; under it a unit of anti-malaria work may be carricd out; under it a unit of anti-pellagra work may be executed; under it many other more or less independent eounty health problems may be sueeessfully attempted.

Comparative Value of Mcthods.-The whole-time eounty health offieer idea proposes a means-an officer; the unit or eontraet system of eounty health work proposes an end-the execution of the plans and spceifications for a definite pieec of work.

The whole-time eounty lealth offieer idea, if carried out by the county authorities, is subjeet to local polities; if administered under state supervision it is in eonflict with the principle of local self-government. The unit system of eounty health work is not subjeet to local politics and does not confliet with the principles of local self-government.

The whole-tine eounty health officer plan eosts the eounty from $\$ 3,000$ to $\$+, 000$ a year, and is available to only a comparatively few countics; the unit system of work eosts the eounty 
from $\$ 500$ to $\$ 2,000$ a year, and is available to nearly all counties.

There are eertain counties that should employ whole-time health offieers, but the contract or unit system of eounty health work is better adapted to a variety of county eonditions, and will be, in all probability, far more effective than the wholetime county health offieer plan in redueing the state's deathrate. The unit system of county health work is important as a stepping stone to the whole-time county health offieer. In leading up to the whole-time eounty health officer, the unit system standardizes county health work, so that, when a wholetime eounty health officer is employed, an effeetive plan of county health work will have been established.

The unit system of work or proposed eontraet submitted by the average state to the county should not call for an appropriation of more than $\$ 1,000 ; \$ 500$ is better. The smaller the eost of the unit, the greater is the probability of securing the funds with which to start county health work. After one appropriation is obtained the responsibility is then largely with the state for making such use of it as to pave the way for easier and more liberal funds. The game of sanitation, like the game of life, to use the other fellow's grammar, "is not in holding a good hand but in playing a bad hand good.." Even the noviee can get results with plenty of money. The intelligent health officer never loses sight of relative values, and the real fun of the game is in getting big results with little budgets. We shall be able to handle the eounty eontagious disease problem for the average county for $\$ 300$ to $\$ 400$ per year. We will carry out the school unit for from $\$ 500$ to $\$ 600$ a year for the average county or for fifteen cents per pupil. We will have vaecinated 50,000 people in ten counties by September 11, for a cost to the counties of about ten cents for each person immunized. 


\section{B. RURAL HEALTH-MENTAL}

\section{FEEBLE-MINDEDNESS DEFINED ${ }^{1}$}

\section{E. J. EMERICK}

Feeble-mindedness is due to an arrested or imperfect cerebral development. By most authorities, a person who is three or more years retarded is considered feeble-minded; for instance, a ehild of twelve years, whose mental development is that of a child of nine, would be feeble-minded.

The feeble-minded have been divided into three classes: the idiot, (2) the imbecile, and (3) the moron.

(1) The idiot has a mentality of less than three years. $\mathrm{He}$ cannot protect himself from common dangers.

(2) The imbecile has a mentality of from three to seven years. $\mathrm{He}$ can protect himself from common dangers, but cannot be made self-sustaining.

(3) The moron has a mentality of from seven to twelve years. $\mathrm{He}$ is "capable of carning his living under favorable cireumstances, but is incapable. ... (a) of competing on equal terms with his normal fellows, or (b) of managing himself and his aftairs with ordinary prudence."

No one needs to be told how to recognize the idiot or imbeeile. Their inability to care for themselves, their physieal stigmata, and obvious mental limitations make them easily distinguished. For this reason, they do not constitute a serions problem; they are recognized for what they are, and disposed of accordingly.

The moron, on the other hand, may present no physieal evidence of deficiency; may be able to perform quite diffieult tasks; may read and write; and may talk fluently, sometimes even with a eertain superficial eleverness.

This is the elass that makes for us our social problems. Here are the individuals who are put down as dull, ignorant or shiftless, or unwilling to exereise their judgment, eommon sense and will-power. Their resemblance to the normal makes it difficnlt

1 Adapted from "The Problem of the Fecble-minded," Publication No 5, Marcl, 1915. Olico Board of Administration, Columbus. 
for many to believe that they eannot be trained to do as normal people do. Bad environment, laek of opportunity, ignoranee, and what not, are given as eauses for their failure to funetion normally. But those who have had these brighter defectives in institutions for the feeble-minded, and have watehed them from childhood, under most careful training and instruetion, know that they never develop beyond a eertain stage: and know that there is in these morons a lack as definite as in any other form of feeble-mindedness; a laek which makes it impossible for them to beeome thoroughly responsible.

At large, the moron may beeome an aleoholie, prostitute, sex offender, thief, or graver eriminal; he is almost sure to be on the very edge of the poverty line, if not an aetual pauper. Dr. Goddard tells us "Every feeble-minded person is a potential eriminal," and this is particularly true of the moron-the highgrade defeetive, who passes for normal, yet who laeks in whole or part the sense of values and the will-power so neeessary to the law-abiding eitizen. He has been misunderstood; he has been eredited with a degree of responsibility he does not and eannot possess; lie has been sent to eorreetional institutions time after time only to eome out unimproved; and he has been left free to perpetuate his irresponsibility, beeause we have not realized:

(1) That the moron is not a normal person mentally.

(2) That he ean never be made normal, and

(3) That feeble-minded invariably produce feeble-minded unless eombined with normal stoek.

\section{FUNDAMENTAL FACTS IN REGARD TO FEEBLE-MINDEDNESS ${ }^{1}$}

SEvERAL important faets regarding mental defeetives have been elearly established:

1. Feeble-mindedness is ineurable.

2. The feeble-minded reproduee twiee as rapidly as normal stoek.

1 Adapted from "Fifth Annual Report Virginia State Board of Charities," pp. 11, 12, Richmond. 
3. Feeble-mindedness is hereditary. There has never been found a normal ehild both of whose parents are feeble-minded.

4. From 25 to 50 per eent. of our law-breakers are feebleminded. They are dominated by an inherited tendeney to erime. The pereentage of commitments for major erimes, sueh as murder, arson and rape, is apparently twiee as great among mental defeetives as among normal people.

5. From feeble-mindedness springs, by inheritanee, insanity, epilepsy and all forms of neurotie degeneraey.

6. A very large pereentage of prostitutes are feeble-minded. In 1911 the Department of Research of the New Jersey Training Sehool for Feeble-minded tested fifty-six delinquent girls, "all of whom laad probably eommitted the worse offense a young girl ean." Fifty-two were found to be mental defectives. A test reeently made of one hundred_girls takell at random from the New York Reformatory for Women at Bedford, by the Bureau of Soeial Hygiene, established by John D. Rockefeller, Jr., showed that all were apparently feeble-ninded. Their average physieal age was twenty years, nine and seven-tenths months; their average mental age, ten and five-tenths years. As shown elsewhere in this report, a test of inmates of our reformatory for delinquent white girls revealed the faet that thirty out of thirty-five were mental defeetives. Out of 300 women examined by the Massaehusetts Viee Commission only six were found to have ordinary intelligenee.

In view of these faets it is apparent that our great problems of erime, insanity and the soeial evil are inseparably intertwined with the problem of feeble-mindedıess. Whatever progress we may make in the treatment of eriminals there ean be no great reduetion of erime so long as we ignore the faet of eriminal inheritanee, and whatever we may do toward the segregation of the insane, or toward the suppression of the soeial evil, we shall eontribute little toward the aetual solution of these problems so long as we make no attempt to stem the appalling tide of feeble-minded offspring that is inereasingly pouring forth from our large and ever-growing elass of mental defeetives. So far as moderu investigation enables us to see, the most pressing soeial need of our time is the segregation of the feeble-minded. 


\section{THE HILL FOLK ${ }^{1}$}

\section{FLORENCE H. DANIELSON AND CHARLES B. DAVENPORT}

Tre following report is the result of an investigation of two family trees in a small Massaehusetts town. It aims to show how mueh erime, misery and expense may result from the union of two defeetive individuals-how a large number of the present eourt frequenters, paupers and town nuisanees are eonneeted by a signifieant network of relationship. It ineludes a diseussion of the undesirable traits in the light of the Mendelian analysis. It presents some observations eoneerning the relation of heredity and environment, based on their effeets upon the children. While it is not an exhaustive study of all the ramifications of even these two families and their eonsorts, it may be suffieient to throw some light on the vexed question of the prevention of feeble-minded, degenerate individuals, as a humane and eeonomieal state poliey.

The town in question lies in a fertile river valley among the New England hills. It is on the direet railway line between two prosperous eities. East and west of it are more hilly, less produetive towns. Its present population is about 2,000. Most of the people are industrious, intelligent farmers. A lime kiln and a marble quarry are the only industries of importanee. In summer the population is nearly doubled by eity boarders.

Into one eorner of this attraetive town there eame, about 1800, a shiftless basket maker. He was possibly of Freneh origin, but migrated more direetly from the western hill region. About the same time an Englishman, also from the western hills, bought a small farm in the least fertile part of the town. The progeny of these two men, old Neil Rasp, ${ }^{2}$ and the Englishman, Nuke, have sifted through the town and beyond it.

1 Adapted from Exeerpts from Report on a Rural Community of Hereditary Defeetives. Eugenies Record Office-Memoir No. 1, Cold Spring Harbor, i. Y.

2 The few names which are used in the deseription of this eommunity are fictitious. The loeal setting and the families and all the other details aetually exist, but for olvious reasons imaginary names are in every ease substituted for the real ones. 
Everywhere they have made desolate, aleoholie homes which have furnished State wards for over fifty years, and have required town aid for a longer time. Enough of the families still live in the original neighborhood so that, although they oceupy tenant houses of respectable farmers, for they own no land now, the distriet of the "Hill" is spoken of slurringly. Where the ehildren have seattered to neighboring towns, they do not remain long enough to seeure a residence and are eonsequently referred baek to the original town when they require outside aid. As the younger generations have grown up, they have, almost without exeeption, married into American families of the same low mental grade, so that the "Hill" people are linkè by their consorts to a similar degenerate family a hundred miles away.

The attitude of the townspeople is that of exasperated neighbors. They have lived beside these troublesome paupers for so long that they are too disgusted with them, and too aceustomed to the situation, to realize the neeessity for aggressive work upon it. A few of them realize that hard eider is a large factor in the eause of their neighbors' poverty, but more of them, apparently ignoring the faet, keep it on tap free or sell it. This poor class of people are left largely to themselves until they need town aid, or some member beeomes so drunk that he disturbs the peace, or some girl becomes pregnant and has to be taken to an institution. About onee every eight or ten years, a state agent is informed of the conditions, and four or five children are removed from the families. Then the father and mother find that their finaneial problems are relieved for the time and settle down to raise another fanily.

A few of the men and some of the women have soldier's or widow's pensions and state aid, but most of them work, when they do work, as wood ehoppers or farm laborers. Mlost of their wages go for hard eider or, if handed to the wives, are spent in other equally foolish ways. They move frequently from one shanty or tumbled down house to another. So long as food and a small amount of elothing are furnished by some means, they live in bovine eontentment.

From the biologieal standpoint, it is interesting to note that mental defeet manifests itself in one branch of the pedigree by 
one trait and in another branch by quite a different one. Thus, in one line alcoholism is universal among the men; their male cousins in another line are fairly temperate, plodding workers, but the women are immoral. Another branch shows all the men to be eriminal along sexual lines, while a cousin who married into a more industrious family has desecndants who are a little more respectable. These people have not been subjected to the social influences of a city or even of a large town, so that the traits which they show have been less modified by a powerful social environment than those of urban dwellers.

The conclusion of this brief survey, then, must be that the second and third generations from a union of mentally defective individuals show an accumulation and multiplication of bad traits, even though a few normal persons also appear from such unions. It is also evident that certain traits tend to follow certain lines of descent, so that after one generation, related families may cach have a different characteristic trait. Fecblemindedness is due to the absence, now of one set of traits, now of quite a different set. Only when both parents lack one or more of the same traits do the children all lack the traits. So, if the traits lacking in both parents are socially important the children all lack socially important traits, i.e., are feeble-mincled. If, on the other hand, the two parents lack different socially signifieant traits, so that each parent brings into the combination the traits that the other lacks, all of the children may be without serious lack and all pass for "normal." However, inasmuch as many of the traits of such "normals" are derived from one side of the house only (are simplex), that may, on mating persons of like origin with themselves, produce obviously defective offspring.

The large majority of the matings which are represented in this report are of defectives with defectives. A few of those who have drifted into a different part of the country have married persons of a higher degree of intelligence, but the most of such wanderer's liave, even in a new location, found mates who were about their equal in intelligence and ambition.

In a rural district which supports such a class of semi-paupers as has been described the social advantages which come to them are meager and narrow. After a long day's work on the farm 
or in the kitehen, the farm laborer and kitehen girl find their reereation in an evening of gossip, for they know every one in the neighborhood. They may live near enough to their homes to go there at night. If sueh is the ease, one dirty kitehen may hold half a dozen men and the women of the house. They smoke and drink eider and pass rude jests together and in the end sometines fight. Away from home, they are ostracized by the other soeial elasses. They oeeasionally have a danee whieh will bring together many of the same elass from neighboring towns.

Under these eireumstanees it is not surprising that early marriages are the rule. After the legal age is passed, sehool work is dropped and, for a girl, the servant's life often begins, unless she is married at onee. At any rate she antieipates marriage and works with that as a goal, not to eseape work, but to gain a eertain independence and that end of all effort, "to be married." Nor is it surprising that eousin marriages are frequent. In faet, even where no known relationship exists between the eontraeting parties, it is probable that they are from the same strains. The early marriage is usually followed by a large family of children. Some die in infaney in nearly every home, but most of them survive a trying babyhood and develop fairly robust physieal eonstitutions. They are born into the same narrow eirele that their parents were, and unless some powerful faetor ehanges the routine, they are apt to follow the same path until past middle age. For, exeept where tubereulosis has ravaged, lisease has spared these people. So it is that the meager social life, the eustoms of their parents, the llatural ostraeism of the higher elasses, and the individual's preference for a eongenial mate induee endogamy, or in-marriage, anong the mentally defieient.

It has been maintained that the dispersion of such communities of feeble-minded persons would stimulate out-marriage and that this wonld inerease the ehanee of marriage with different and perhaps better blood and thus diminish the frecpueney of appearanee of defeets in the next generation. The instanees of two daughters who married eomparatively normal men supports this view. Their progeny are, as a whole, a better elass of eitizens than the progeny of their sisters who mated with feeble- 
minded men. Nevertheless, the $50 \mathrm{pcr}$ eent. of the offspring who were feeble-minded or criminal, even in these cases, eonstitute a menaee which should be eonsidered. Another ease was from a eriminal, aleoholic family and possessed both of these traits. He' migrated to another state and married a woman who had more intelligenee than cither of the normal husbands (beforc mentioned). Only one of their children shows the criminal tendencies of the father, though the two youngest are neurotie, and backward in school. After the mother found out the real eharacter of her husband and his family, she left him. While such repression of defective traits in the progeny by marriage into normal strains is beneficial to the community, it involves a great sacrifice on the part of the normal consort. Howcver, the eonsort is only one; the progeny many. The more frequent result of the migration of a feeble-minded individual is his marriage into another defeetive strain in a different part of the eountry. The change in locality usually means that two different kinds of fceble-mindedness are united instead of two similar types.

Looking at the rclation of the Hill families to society on the financial side, we see the three ehief ways in which they have becn an expense to the public are through town relief, eourt and prison eharges, and their maintenance as the State wards. The town of about 2,000 inhabitants in which the original ancestors settled has had to bear most the burden of the petty bills for relief. The poor records of this one town have been used to get an estimate of the cost of these families to the town, and these reeords run back only to war time. From 1863-64 to the present time, some families of the Hill have had partial or entire public support. In the first deeade 9.3 per eent. of the town's bill for paupers was paid for the Hill families. In the seeond dceade, 29.1 per eent of the total bill was paid for the same families or their deseendants. During the thirty years eovered by these decades, the total aid given to paupers increased 69.4 per ecnt., but that given to the Hill families inereased 430 per ecnt. It is probable that more than 9.3 per eent. of the $\$ 15,964$ cxpended from 1879-89 went to these people, for in some instanees the names of those aided were not reeorded. Besides the usual bills for rent, provisions, fuel, and medieal attendanee, the last deeade 
contains the item of partial support of thrce children in the State Sehool for Feeble-minded. The births, minus the deaths, during this same period eaused an increase of about 59 per eent. in the number of individuals eonneeted with the Hill families. This means, then, that for 59 per eent. inerease in numbers, their expense to the public has inereased 430 per eent.

Turning to the eourt and prison reeords for the last thirty years, we find that at least sixteen persons from the IIill families have been senteneed to prison for serious crimes during that time. A majority of these erimes were against sex, and the sentences varied from ten years to two months, or were indeterminate. The eost of these sixteen persons to the eounty and State through the eourts and institutions has been at least $\$ 10$,763.43. The arrests for drunkenness and disorder have not been included. They are very frequent and the eases are usually disposed of by a fine or thirty days' imprisonment. About a third of the business of the district court eomes from these families.

The third large item of expense which falls upon the publie, through the State treasury, is the maintenance of the wards which have been taken from their homes.

Of the 1hirty-five, twenty-one are still under the control of the State as institutional eases or beeause they are uncler twentyone years. The expenses of commitment, board, clothing, school tuition and officer's' salaries is difficult to eompute, but as accurately as ean be estimated, these children, during the last twenty-three years, have cost the State $\$ 45,888.57$. This means that for nine families about $\$ 2,000$ each year has been expended to maintain ehildren whose parents were unfit to eare for them.

The finaneial burden, then, whieh the Hill people entail is eonstantly increasing, and that far beyond the proportion of their increase in numbers. This burden rests especially upon the town in which they live. The 400 per eent. increase in the finacial aid which they have required in the last decade presents this fact in a startling manner. The large pereentage of the erimes whieh were against sex inclieate that the influence which such persons exert in a community is of far more importance than the 10,700 odd dollars spent in punishing the eriminals after the influenee has been established. The money 
expended on the State wards is well spent where even half of them are trained for useful eitizenship, but the imposition upon soeiety of an equal number of undesirable eitizens ealls for a policy of prevention which will work land in hand with the present one of partial alleviation.

Most of the previous diseussion has been in regard to the first four generations,--those individuals who are old enough to have their traits fully developed and their habits firmly established. There is, however, a eomparatively large number of children between the ages of six and sixteen years who are growing up to form the fifth generation of the Hill people. $\Lambda$ brief study of the school record of seventy-five of these ehildren may give one an idea of the prospeet for the next generation.

The sehool reeord of seven of them is not known. The others have been divided into two elasses, those who are up to grade and those who are below the grade they should be in. Brief deseriptions of the mental traits which they have exhibited in school serve as an index of the eharaeteristies whieh are developing. Glaneing down the list of thirty-eight ehildren who are below grade, two eauses for their backwardness stand out most prominently. Either tliey are unable to fix their attention upon one thing long enough to grasp it, or else they require so much more time to comprehend ideas upon which they have eoneentrated, that they progress only half as fast as the average ehild. They are frequently irregular in attendanee so that they even lose the stimulus of regular systematic work. All of these ehildren attend rural sehools where no speeial provision is made for the backward elild. Beeause the sehools are so small, this elass of ehildren not only eonstitute a drain upon the teacher's time and resourees, but retard the progress of the entire elass in which they are studying. Oeeasionally they develop inisehievous qualities, but usually they are quiet, stupid laggards. They will leave sehool as soon as the law will allow and go to form the lower strata in the industrial world as they have in the aeademie. Five of these thirty-eight have one parent who is approximately normal.

Thirty elildren from similar families have kept up to their grade. Most of them do as well as ehildren of ordinary parentage, though only eleven of them have one or both parents who 
are not feeble-minded. A few of them are the slow ones in their classes.

This brief survey, then, indicates that before adolescence half of the ehildren from the Hill families show evidences of their mental handicap. The detrimental influenee which such ehildren may exert upon the rural schools which they attend is an important matter for consideration. How many of the other half, who have held their own with ehildren of average parcntage, up to adoleseence, will be able to kcep up to the same standard from sixtcen to twenty-five is an open questioll. Its solution depends largely upon the comparative weight of hereditary and environmental influences during that period.

\section{THE EXTENT OF FEEBLE-MINDFDNESS IN RURAL AND URBAN COMMUNITIES IN NEW HAMPSIIIRE ${ }^{1}$}

ONE of the most signifieant studies that ean be made in the survey of these countics is the geographie distribution of the feeble-minded and the proportion of the entire state population that falls within this defeetive class. Since there has been a report from every town in the State, either by questionnaire or personal canvass, this proportion may be eonsidered fairly eorrect evell though many eases have not been reported.

One of the most signifieant revelations of this table is the range of feeble-mindedness gradually ascending from the smallest pereentage, in the most populous county of the State, to the largest pereentages, in the two most remote and thinly populated eounties. It speaks volumes for the need of improving rural conditions, of bringing the people in the remote farm and hill districts into eloser toueh with the eurrents of healthy, aetive life in the great centers. It shows that a eampaign should begin at once,-this very month,--for the improvement of rural living conditions, and especially for the improvement of the rural sehools, so that the elildren now growing up may receive the edueation that is their birthright. Let us have eompulsory supervision of sehools all over the State, as well as eompulsory school attendanee.

1 Adapted from Report of the Children's Commission, Coneord, N. H. 
'The feeble-minded population of the State does not appear to be a shifting one. Of the 8.9 per ecnt. of eases born in New Hampshire, but outside the town of present residence, the majority were born within the county as well, often in an adjacent town, and the majority of those born in the United States, but outside of New IIampshire, were born in one of the other New England states.

\section{FEEBLE-MINDED CITIZENS IN PENNSYLVANIA ${ }^{1}$}

DR. WILHELMINE E. KEY

Dr. KEY's report is based upon a four months' intensive study of a rural community in northeastem Pennsylvania, containing about 700 square miles and a population of 16,000 .

The purpose of the study was to determine the number of mentally defective persons in this community, and their cost to the people of Penusylvania, as well as to discover possible remedies for a condition that cxperts agree becomes rapidly worse wherever left unchecked.

Dr. Key found in this district 508 persons, ranging in age from six years upward, who were feeble-minded-that is, who were either clearly mentally defective, or who, being members of the family of such a defective, have been so affected by their associations and environment as to be indistinguisliable from mental defectives in their conduct and social and family relations.

In other words, more than three defectives not in institutions were found for every 100 of the population of this Pemsylvania community. This enumeration did not include a considerable number of shiftless, indolent, inefficient persons, who had no clear mental or physical defect, but who, in a stricter classification, might be classed with the defectives, so far as their effect upon the community is concerned. Nor did it include children under six, unless they were obviously and unmistakably defective.

A careful house-to-house study, oft-repeated, rerified and amplified by examination of official records and family historics and by consultation with well-informed neighbors and social workers, devcloped several striking conclusions :

1 Adapted from Report of The Public Charities Association of Pennsylvania, pp. S-9; 36-46; 61-62. Publication No. 16. Phila., 1915. 
(1) Certain centers of mental and moral degeneraey and defeet were found, which eorresponded elosely with the distribution of certain well-known mentally tainted family stoeks. In two little settlements, for instance, on the edge of the area studied, it was found that 57.7 per eent. and 26.6 per cent. of the population were mentally defeetive, in the sense above indicated. Examination revealed the fact that these settlements were the original seats of two families that were notably defective. By inbreeding and inter-breeding, the original small groups, after several generations had brought forth hundreds of their own kind, and other hundreds who werc on the borderline of inefficieney and mental defectiveness.

Not only by drawing together representatives of their own and other bad strains, but by attraeting weak members of better and normal families, these settlements beeame eenters of constantly widening and contaminating influenee, the more aggressive members going out to found other centers of contamination.

(2) From figures supplied by the officers of the county most direetly coneerned, Dr. Key shows that the aetual financial eost to the county, for caring for and protecting against these defective groups during the last twenty-five years, has been at least $\$ 265,000$, of which $\$ 125,000$ was aetually spent for maintenance of representatives of these families in the eounty home for varying periods; $\$ 30,000$ for eare of orphans; $\$ 75,000$ for settlement of criminal cases outside of court; $\$ 15,000$ for settlement of criminal cases in court, and $\$ 20,000$ for outdoor or home relief. This takes no aeeount of the eost of their private depredations, nor of private charity, nor frec medical attendance, nor necessary extra police service, nor drink bill, ete.

In this conneetion Dr. Key says:

"Could this sum have beels applied to the segregation of its feeble-minded women, it would have suffieed to rid the county of the whole of its younger generation of undesirables. We must bear in mind, however, that at present the State has 10 institution for the carc of such women .. The training-schools for the feeble-minded are overerowded and have long waiting lists ... Our short-sighted policy ... has not even the merit of being incxpensive. It costs a great deal of money and then serves only to aggravate the evils which it is designed to cure... The 
eounty has done the best it could with the means at hand. Surely it is ligh time that the State inangurate a more intelligent and far-reaching poliey which shall forever rid these seetions of their unequal and undeserved burden."

(3) There is a very distinet tendeney for mental defect to run in eertain families, indieating the strong hereditary influenee, which ean only be ehecked by steps to prevent marriage and eontinued propagation of the kind.

(4) Comparisons between groups of forty-five defeetive women, and forty-five normal women in the same area, showed that the average birth-rate for defeetives was seven ehildren to each mother, while that of the normal women was two and ninetenths ehildren for each mother. This exeess of defeetive birtlis was not offset by higher mortality rate among defeetives, the actual survivals of ehildren of defeetive mothers being twice as great as in normal families.

While it is reeognized that this narrow inquiry, eovering so few eases, is not to be aecepted as eonelusive, it seems elear that in this partieular area, the tendeney to multiplieation is eonsiderably greater among defeetives than among normals, thus intensifying and emphasizing the problem of earing for and preventing the unlimited propagation of mentally tainted ehildren.

(5) Centers of defeetiveness have flourisled where remedial ageneies liave been most aetive for relief of exterual eonditions. The lightening of the struggle for existenee which this relief brings only makes it easier for the defeetive to live on, proereate and multiply his kind. The root of the evil lies not primarily in external conditions, but in the failure to separate and restrain inherently defeetive individuals from propagation.

An interesting sidelight on the situation is eontained in Dr. Key's study of the rural school, in relation to the defeetive. This diselosed 160 pupils whose inability to advanee eould be laid primarily to hereditary defeet. The detailed histories of fifty such ehildren are given in the report. An instance is eited, where, of forty ehildren in a eertain sehool, ten were defeetive, or retarded in their revelopment from two to four years. The effeet of these ehildren upon the normal ehildren, and the waste effort expended by and for the defeetives is one of the sound arguments for wider State supervision and eare of defeetives. 
In eonclusion, Dr. Key remarks :

"No sensible person to-day questions the State's authority to cleanse a polluted water supply or take any measures deemed neeessary to stop the spread of disease. . . Why should it not exereise the same jurisdiction with regard to these plague spots, the sources of moral eontagion?" .

She strongly urges the need of loeating the worst eenters of degeneracy and defect; registration of notoriously bad strains; marriage laws to restrain marriage into these strains; establishment of adequate institutions immediately, for the eustodial care of those whose eontinued multiplication cannot be prevented by these means.

\section{AMENTIA IN RURAL ENGLAND ${ }^{1}$}

\section{A. W. TREDGOLD}

Showing ture total. Nimber of AMExts, AxD idiots, iMbeciles, AND. FEFIBLE-MINDED, RESPECTIVELY, PER 1,000 POPULATION, IX CERTAIX DISTRICTS OF tire Uxited Kixgdom, accordrig to tre investigatrox of tile Royal Commission, 1904.

\begin{tabular}{|c|c|c|c|c|c|c|}
\hline & & & & Feels & inded & $\stackrel{\infty}{+}$ \\
\hline & & $\underset{\stackrel{0}{0}}{\stackrel{\infty}{0}}$ & 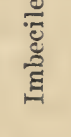 & $\frac{\stackrel{\infty}{\Xi}}{\Xi}$ & 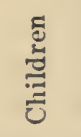 & 离 \\
\hline & Maneliester & 0.05 & 0.32 & 1.20 & 2.10 & 3.74 \\
\hline & Birmingham ... & 0.09 & 0.27 & 1.70 & 1.60 & 3.76 \\
\hline & IIull $\ldots . . \ldots \ldots$ & 0.02 & 0.20 & 0.55 & 0.58 & 1.35 \\
\hline Urban & Glasgow ..... & 0.07 & 0.23 & 0.32 & 1.00 & 1.68 \\
\hline 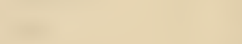 & Dublin ....... & 0.19 & 0.57 & 1.20 & 2.10 & 4.14 \\
\hline & Belfast ....... & 0.13 & 0.63 & 0.70 & 0.97 & 2.45 \\
\hline & Stroke-on-Trent.. & 0.21 & 0.45 & 2.10 & 1.10 & 3.96 \\
\hline Industrial & $\{$ Durham ....... & 0.02 & 0.34 & 0.56 & 0.56 & 1.48 \\
\hline & Cork .......... & 0.07 & 0.32 & 0.16 & 0.54 & 1.10 \\
\hline Mixed Industrial & $\int$ Nottinghamshire & 0.30 & 0.66 & 1.50 & 1.20 & 3.81 \\
\hline and Agrieultural & Carmarthenshire & 0.59 & 0.6 .5 & 0.51 & 1.20 & 3.05 \\
\hline & SSomersetshire .. & 0.18 & 1.00 & 2.10 & 1.10 & $4.5 t$ \\
\hline & Wiltshire .... & 0.35 & 0.69 & 2.20 & 0.90 & 4.25 \\
\hline Agrieultural & $\{$ Lincolnshire ... & 0.44 & 0.98 & 1.40 & 1.70 & 4.68 \\
\hline & Carnarvonshire. & 0.24 & 0.58 & 2.10 & 0.94 & 3.96 \\
\hline & Galway ...... & 0.13 & 1.00 & 1.00 & 2.20 & 4.49 \\
\hline
\end{tabular}

1 Adapted from "Mental Deficieney," p. 12, Wood, N. Y., 1908. 


\section{URBAN AND RURAI, INSANITY ${ }^{1}$}

IN general the statisties indicate that there is relatively more insanity in cities than in country districts and in large cities than in small cities, although to some extent the difference may be accounted for by difference between eity and country as regards the tendency to place eases of insanity under institutional eare. The figures may also be affected in some degree by the accident of the loeation of the hospitals for the insane. Studies made in New York State slow that the proportion of admissions from a county in which a hospital is loeated is always greater than from other counties and that the proportion decreases with the distance from the hospital. The influence of this factor upon the comparison between eity and country, however, would not everywhere be uniform. Whether it tended to increase the ratio of admissions from country districts or that from city districts would depend entirely upon the loeation of the hospitals. Probably it does not go very far toward explaining the higher ratio of admissions from the urban population.

The ratio of admission to hospitals for the insane is higher for urban than for rural communities for both males and females, and the difference is about as marked for one sex as for the other. It follows that the difference between the sexes with regard to this ratio is about as marked in urban communities as it is in rural, the one statement being a corollary of the other.

One difficulty, however, about all comparisons of this kind as applied to the United States as a whole is that the urban population and the rural are very differently distributed over the territory of the United States. New England and the Middle Atlantie divisions together inelude 45 per cent. of the total urban population of the United States, as compared with only 13.5 per cent. of the rural population. If to these two divisions is added the East North Central the combined area includes 67.6 per cent., or about two-thirds, of the urban population, but only 31 per cent., or less than one-third, of the rural population. The three southern divisions, on the other hand, contain a much smaller

1 Adapted from "Insane and Feeble-minded in Institutions, 1910." Dept. of Commerce, U. S. Bur. of Census, pp. 49-5̃l. Published 1914. 
proportion of the urban population than of the rural-15.5 per eent. of the one as eompared with 46.1 per eent. of the other. The eharaeteristies of the rural population of the United States, therefore, are affected to a large degree by conditions peeuliar to the South, while those of the urban population largely reflect eonditions in the North and East; and, in general, any comparison between urban and rural population is to a considerable extent a eomparison between the North and East on the one hand and the South and West on the other.

\section{WHAT IS PRACTICABLE IN THE WAY OF PREVENTION OF MENTAL DEFECT ${ }^{1}$}

\section{WALTER E. FERNALD}

DURING the last deeade four factors have materially ehanged the professional and popular eoneeption of the problem of the feeble-minded.

1. The widespread use of mental tests has greatly simplified the preliminary recognition of ordinary eases of mental defeet and done mueh to popularize the knowledge of the cxtent and importanee of feeble-mindedness.

2. The intensive studies of the family histories of large numbers of the feeble-minded by Goddard, Davenport and Tredgold have demonstrated what had hitherto only been suspeeted, that the great majority of these persons are feeble-minded because they come from family stoeks which transmit feeble-mindedness from generation to generation in aceordanee with the laws of leredity. Many of the members of these families are not defeetive themselves, but these normal members of tainted families are liable to have a eertain number of defeetives among their own deseendants. The number of persons who are fecbleminded as a result of injury, disease or other cuvironmental conditions without hereditary predisposition is muel smaller than had been suspeeted, and these aeeidental cases do not transinit their defect to their progeny.

1 Read before the National Conference of Charities and Correetion, Baltimore, 1915, being the report of the Conference Committee on State Care of the Insane, Feeble-minded and Epileptie. Reprinted from the Proeeedings of the Conference. 
3. The cumulative evidence furnished by surveys, community studies, and intensive group inquiries has now definitely proved that feeble-mindedness is an important factor as a cause of juvenile vice and delinquency, adult crime, sex immorality, the spread of venereal disease, prostitution, illegitimacy, vagrancy, pauperism, and other forms of social evil and social diseasc.

4. Our estimates of the extent and the prevalcnce of feeblemindedness have been greatly inereased by the application of mental tests, the public school classes for defectives, the interpretation of the above mentioned anti-social cxpressions of feeble-mindedness, and the intensive community studies.

It is becoming evident that some central governmental authority should be made responsible for the supervision, assistance and control of the feeble-minded at large in the community who are not properly cared for by their friends. This proposal is not so revolutionary as it seems, for a large proportion of feebleminded people at some time in their lives now come under the jurisdiction of public authorities or private socictics as dependents or as irresponsible law-breakers. Many feeble-minded persons eventually become permanent public charges. Many run the gauntlet of the police, the courts, the penal institutions, the almshouses, the tramp shelters, the lying-in hospitals, and often many private socicties and agencies, perhaps, eventually to turn up in the institutions for the feeble-minded. At any given time, it is a matter of chance as to what state or local or private organization or institution is bcing perplexed by the problems they present. They are shifted from one organization or institution to another as soon as possiblc. At present there is no bureau or officer with the knowledge and the authority to advise and compel proper care and protection for this numerous and dangerous class.

This state supervision of the feeble-minded might be done successfully by some existing organization like a properly constituted state board of health, or statc board of charities, or by a special board or official; but the responsible official should be a physician trained in psychiatry, with especial knowledge of all phases of mental deficiency and its many social expressions. The local administration of this plan could be carried out by the use of cxisting loeal health boards, or other especially quali- 
fied local officials or, perhaps better, by the utilization of properly qualified volunteer soeial workers, or existing local private organizations and soeieties, already dealing with dependents or delinquents. This systematic supervision and control, could easily be made to eover an cntire State, and would obviate the present ncedless, eostly and futile reduplication of effort.

The most immediately praetieal method of prevention is that of intelligent segregation. The average family is entirely free from mental defeet. It is possible that a real eugenie survey of a given loeality might show that 90 per eent. of the feeblemindedness in that loeality was eontributed by 5 per cent. of the families in that eommunity. The proposed governmental supervision of the fecble-minded, with its sequence of registration, extra-institutional visitation, aeeumulation of personal and family histories, coöperation with private organizations, publie school elasses for defectives, and mental clinies, would soon indieate the individuals most likely to breed other defcetives. The families with strong potentiality of defect would be recognized and located. We know that if both parents are hereditarily feeble-minded, all the ehildren will be defeetive, and that if one parent is feeble-minded, on an average half of the elildren will be defective. Families and settlements of the Kallikak, Nam or IIill-folk class, the so-ealled hovel type, ean be broken up and terminated by segregation of the members of the ehild-bearing age. Every feeble-minded girl or woman of the hereditary type, espeeially of the moron elass, not adequately proteeted, should be segregated during the reproductive period. Otherwise she is almost certain to bear defeetive ehildren, who, in turn, breed other defeetives. The male defeetives are probably less likely to beeome parents, but many male morons also should be segregated. This segregation carried out thoroughly for cven one generation would largely reduee the number of the feebleminded.

The eost of segregation will be large, but not so large as the present eost of earing for these same persons, to say nothing of their progeny in future generations. These people are seldom sclf-supporting and most of them are eventually supported by the public in some way. From the eeonomie standpoint, alone, no other investment could be so profitable. The present genera- 
tion is the trustee for the inherent quality as well as for the material welfare of future generations. In a few ycars the expense of institutions and farm colonics for the fecble-minded will be counterbalaneed by the reduction in the population of almshouses, prisons and other expensive institutions. When the fccble-minded are recognized in ehildhood and trained properly, many of them are eapable of being supported at low cost under institution supervision.

The State will never be called upon to place all the fecbleminded in institutions. Many eases will never need segregation - small ehildren of both sexes, cases properly cared for at home with or without supervision, many adult males and adult females past the child-bearing period. Eugenic study will recognize the non-hereditary cases who cannot transmit their defect, and who do not need segregation for this reason. The one great obstacle to effective prevention of feeble-mindedness is the laek of definite, precise knowledge. This knowledge ean only be supplied by long-continued scientific research along many lines of inquiry. We do not cven know the exact number of the fecbleminded. This fact will be supplied by the future community surveys and other extensive and intensive studies.

And, after all, the meaning of this report is that in the long run education in the broadest sense will be the most effective method in a rational movement for the diminution of fceblcmindedness. One of the prineipal advantages of the proposed plan for state registration and supervision of the feeble-minded is the opportunity it gives for the general education of the people of the State upon this subjeet. The public generally should be persistently informed as to its cxtent, causes and results by means of suitable literature, popular lectures, and other means. This field offers a great and useful opportunity to mental hygiene societies and other similar organizations for disseminating knowledge on this subject, for, under present eonditions, it will be many years before local eommunities have an equal realization of the nature of the problem, or are prepared to deal with it.

The principles of heredity as they are unfolded, and espeeially of morbid heredity, should be taught in the eolleges, the normal schools, and, indeed, in the high schools. The adolescent has a right to be informed upon a subjeet whieh is of supreme im- 
portance to himself, to his family and to his deseendants. The great majority of these young people will later marry and become parents. The dangers of marriage with persons of discased stock should be presented plainly. The most important point is that fceble-mindedness is highly hereditary, and that eaeh feebleminded person is a potential sourec of an endless progeny of defeet. No fceble-minded person should be allowed to marry or to become a parent.

Even the normal members of a definitely tainted family may transmit defect to their own ehildren, especially if they mate with one with similar hereditary tendencies. If the hereditary tendency is marked and persistent, the normal members of the family should not marry. Certain families should become extinet. Parenthood is not for all. Persons of good heredity run a risk of entailing defeet upon their descendants when they marry into a family with this hereditary taint. Intelligent people are usually willing to forcgo a proposed marriage if the possibilities of defective heredity in that mating are fully understood. The immediate sacrifice is less painful than the future devoted to the hopeless care of fecble-minded children. The class of people who are not amenable to reason in respect to this question must be dealt with through the general educational influences whieh have been outlined in this report.

When the natural leaders of thought in the community-the teachers, physicians, lawyers and elergymen-are fully informed on this subject they will help to create the strong public sentiment which will demand the passage of necessary laws, and will secure sufficient appropriations to eventually cusure the intelligent protection and control of the fecble-minded persons in that cominunity.

\section{BibLiography}

\section{HEALTH-PHYSICAL,}

Allen, W. H. Civies and Health, Gimn, N. Y., 1909.

Annual Report American Red Cross Town and Country Nursing Service, Washington, 1916.

Bashore, H. D. Overerowding and Defective Housing in the Rural Districts, Wiley, N. Y., 1915.

Brewer, I. W. Rural Hygiene. Lippincott, Plila., 1909.

Clement, F. F. District Nurses in Rural Work. Conference Charities 
and Corrections, 1914, pp. 279-88. 315 Plymouth Court, Cliceno, Ill.

Crumbine, S. J. Sumner County Sanitary and Social Survey, Bul. 4, 1915, Kansas State Board of Health, Topeka, Kansas.

Dyer, W. A. New Kind of County Hospital. World's Work, 30 : 60j-9, September, 1915.

Flannigan, R. K. Sanitary Survey of the Scliools of Orange County, Virginia. Bul. 590, U. S. Bureau of Edue., 1914.

Foster, I. A., and Fulmer, Harriet. White County, Illinois, Health Survey, State Board of Health, Springfield, Illinois.

Gerhard, Wm. P. The Sanitation, Water Supply and Sewage Disposal of Country Homes, Van Nostrand, N. Y., 1909.

Gillette, Joln M. Construetive Rural Sociology, pp. 147-167. Sturgis, N. Y., 1915.

Gulick, Luther H. and Ayers, Leonard P. Medical Inspection of Schools. Survey Associates, N. Y., 1914, (Russell Sage Foundation Pub.).

Harris, H. F. Health on the Farm. Sturgis, N. Y., 1911.

Health in the Open Country, Report of the Commission on Country Life, pp. 100-103, Sturgis, N. Y., 1911.

Howard, C. O. How Inseets Affect Healtl in Rural Districts. U. S. Farmers' Bulletin, 155 .

Hurty, Jolın N. A Rural Sanitary Survey of Five Counties in Indiana, State Board of Healtl, Iudiana, Indianapolis, 1914.

Lumsden, L. L. Rural Sanitation: A Report made on special studies made in 15 counties in 1914, 15, and 16. Public Health Bul. No. 94 , Oct., 1918.

Monalıan, A. C. Rural School Sanitation. In Edueation Hygiene, 355-380 by L. W. Rapeer, Scribner, N. Y., 1915.

Medical inspection of 469,000 selool clildren in Penusylvania. Health Bul. No. 71, State Dept. of Health, Harrisburg, Pa., 1915.

Minimum Health Requirements for Rural Scliools. Report of the Joint Comm. on Health Problems in Edueation of the National Council of the National Educ. Assn. and of the Council of Health and Public Instruction of the Amer. Med. Assn. Prepared by Thomas D. Wood.

Ogden, Henry W. Rural Hygiene. Maenillan, N. Y., 1911.

Ruediger, G. F. Program of Public Health for Towns, Villages, and Rural Communities; with discussion. Amer. Jour. Publie Health $7: 235-47$, March, 1917. Concord, N. H.

Rural Selıool Hygiene, Medical Inspection, etc. Surveys made by U. S. Public Health Service in Virginia, Florida, West Virginia, Indiana, Kentucky, North and South Carolina, Tennessee. Public Health Reports, Bulletins: No. 23, Vol. 29 ; No. 6, Vol. 29; No. 37 , Vol. 29; No. 102, Vol. 30.

Rural Sclıool Nurses. (1) Report of Kent Co. (Mich.) Nurse. (2) The Story of a Red Cross Visiting Nurse on her Round of Visits, ete. American Red Cross Town and Country Nursing Service, Waslington, D. C.

Stiles, C. IV. The Rural Health Movement. Annals, 37:367-70, Marcli, 1911.

Terman, L. M. Hygiene of the Seliool Cliild. Houghton, Boston, 1913. 
Vogt, Paul L. Introduction to Rural Sociology, pp. 150-169, Appleton, N. Y., 1917.

Van Duzor, Charlotte E. County Nursing. Town and Country Nursing Service, May 15, 1917.

Waters, Yssabella. Visiting Nursing in the U. S. Charities Publication Committee, N. Y., 1909.

\section{HEALTH-MENTAL}

Baldwin, B. F. Psychology of Mental Deficiency. Popular Science Monthly, 76: 82-94, July; 1911.

Burnham, Wm. H. Success and Failure as Conditions of Mental Health. Pub. No. 37, Mass. Soc. for Mental Hygiene, Boston, 1919.

Burr, R. H. A Statistical Study of Patients Admitted at the Conn. Hospital for Insane from the years 1868 to 1901. Amer. Statistical Assn, 8: 305-343, June, 1903.

Clark, T.; Collins, G. L., and Treadway, W. L. Rural School Sanitation. U. S. Public Health Bulletin, 77, 1916.

Danielson, Florence and Davenport, Charles B. The Hill Folk. Cold Spring Harbor, Long Island, N. Y., Eugenies Record Office, 1912.

Dendy, Mary. Feeble-minded. Economic Review, 13:257-279, July, 1903.

Dugdale, Robert L. The Jukes, A Study in Crime, Pauperism, Disease, and Heredity. Putman, N. Y., 1910.

Estabrook, $\Lambda$. H. and Davenport, C. B. The Nam Family. Eugenic Record Office, Cold Spring Harbor, N. Y., 1912.

Estabrook, A. H. The Jukes in 1915. Carnegie Institution, Washington, D. C., 1916.

Gillin, Joln L. Some $\Lambda$ spects of Feeble-Mindedness in Wisconsin. U. of Wis. Extension Div. Bul., Serial No. 940, Gen. Ser. No. 727, June, 1918.

Goddard, H. H. The Kallikak Fanily. Macmillan, N. Y., 1912.

Johnson, Alexander. Concerning a Form of Degeneracy. Amer. Jour. of Sociology, 4:326-334; 463-473; November, 1S9S; January, 1899.

Key, W. E. Feebleminded Citizens in Pennsylvania. Publication No. 16, Public Charities Assn. of Pennsylvania, Pliladelphia, 1915.

Kite, Elizabeth S. The Binet-Simon Measuring Scale for Intelligenee. Bulletin No. 1, Committee on Provision for Feeble-minded, Plila.

Lundberg, Einma O. $\Lambda$ Social Study of Mental Defectives in New Castle Co., Del. U. S. Dept. of Labor, Children's Bureau, Pub. No. 24, Washington, D. C., 1917.

Mental Defectives in Indiana. A Survey of Ten Connties. Second Report of the Indiana Comınittee on Mental Defectives, Indianapolis, Ind., 1919.

Surveys in Mental Deviation in Prisons, Public Schools and Orplanages in California. Cal. State Bd. of Charities and Corrections, Sacramento, 1918.

Tredgold, A. F. Mental Deficiency. Wood, N. Y., 1908.

Winslip, A. E. Jukes-Edwards, $\dot{\Lambda}$ Study in Education and Heredity. Myers, Harrishurg, Pa., 1900. 


\title{
CHAPTER IX
}

\section{RURAL RECREATION, DRAMA, ART}

\author{
EXTRACT FROM THE WILL OF \\ CHARLES LOUNSBURY
}

"Iтем: I devise to boys jointly all the useful fields and commons where ball may be played: all pleasant waters where one may swim; all snow-clad hills where one may coast; and all streams and ponds where one may fish, or where, when grim winter comes, one may skate; to have and to hold the same for the period of their boyhood.

"Item: To young men jointly I devise and bequeath all boisterous, inspiring sports of rivalry, and I give to them the disdain of weakness and undaunted confidence in their own strength, though they be rude; I give them the power to make lasting friendships, and of possessing companions, and to them exclusively I give all merry songs and brave choruses, to sing with lusty voices."

\section{THE NEED OF PLAY IN RURAL LIFE ${ }^{1}$}

\section{HENRY S. CURTIS}

Is the early days there was plenty of hunting and fishing, and there was an occasional scalping party, conducted by the Indians, which gave variety to life and prevented it from being dull. Such conditions brought out the manhood in boys and awoke the heroic in girls. There was not the time or energy or often the opportunity for vice. Men and women living under such conditions did not see the need of play. Life itself was a desperate game of engrossing interest. The farmer has been too

1 Adapted from Introduction, "Play and Recreation," pp. 13-16, Ginn, Boston, 1914. 
busy improving his farm to take thought of soeial eonditions or to notice the change. In his haste to be rich, he has forgotten to live. He has not learned to love nature or his work. $\mathrm{He}$ and his wife are working too long hours themselves, and working their sons and daughters too long. Following a plow or a drag over a eultivated field is not as interesting as felling the trees in the forest and burning the elearing. Mueh farm machinery has been introdueed and the work and hardships have become less. Perhaps the farm is not less interesting to the adult farmer who is trained to handle machinery and to understand the problems with which he has to deal, but eountry life is vastly less interesting to ehildren and young people, because its danger and romance are gone. The nature appeal of great forests, and wild animals and a wild life is gone. The adventure and romance and exploration are gone. The opportunities of taking up new land and becoming a proprietor have largely gone. The eoöperation and sociability of the pioncer have been replaced by the independenee that has come with safety and labor-saving devices. The rural sehool is no more a social center. The results of these conditions are upon us. Forty-three per eent. of Ameriean farms are now held by tenants. It is very diffieult if not impossible to get either a hired girl or a hired man in most seetions. The more eapable members of the population are drifting toward the eity, and there is a vague but general unrest and dissatisfaetion among the younger generation, which is the outward expression of this hunger for a larger life.

The eountry must take seriously this problem of readjustment. It must provide some substitute for the adventure and romanee and soeiability that have disappeared. It must break the isolation and spirit of self-sufficieney of the modern farm that has replaced the interdependenee and soeiability of the pioneer. It must restore to the eountry school at least as mueh of social value as it had in the old days of spelling matehes and debates. It must appropriate for itself the message of the modern gospel of play. This should not eome to the eountry as something wholly new, but rather as a restoration and a readjustment. It is essentially an eflort to give baek to life those fundamental soeial values of which ehanging conditions have deprived it. 
Rural life has become over-serious and over-sordid. It must perceive that life and love and happiness, not wealth, are the objects of living. There must be injected into it the spirit of play. The isolation of the farm home must be broken by establishing some place where farm people will frequently meet together, and the colder and freer months must be more largely utilized for education, recreation, and the public good. The hours of work must be reduced, and the half holiday must be brought in. The country must discover again in its daily life the adventure and romance and beauty that have passed.

All too often in these years of earnest struggle for success, the children have been only a by-product of the farm. The farmer has loved and earcd for them, but the rearing and training of a worthy family has not been one of his objects in life. He has cared for his corn and potatoes, but his children have "just growed." Play" he has often confounded either with idleness or exercise, deeming it only a useless waste of encrgy, better devoted to pulling weeds or washing dishes. Yet playfulness is almost synonymous with childhood; it is the deepest expression of the child soul, and nature's instrument for fashioning him to the human plan. Play is needed by the country child no less than by the city child; but, with decreasing families and enlarging farms, it is becoming increasingly difficult. The equipment that is necessary must be introduced into the home and the yard. Play must be organized at the country school, as it is coming to be at the city school. The social center, the Boy Scouts, and the Camp Fire Girls must bring back the adventure and romance that the country has lost. The rural school must train the child to perceive and love the beauty of the open country, to hear the thousand voices in which Nature speaks to her true worshipers. 


\section{PHYSICAL EDUCATION IN RURAL SCHOOLS ${ }^{2}$}

\section{LAURENCE S. HILL}

Physical education in rural scliools is a problem that has not yet been satisfactorily solved. It is a problem that presents sevcral angles. We must determine the needs not alone of the boys and girls of the rural schools but also the needs of the rural communities in a physical, moral and social way. We must determine what physical education should include and how to inaugurate and organize its various phases.

There has been rather consistent opposition to physical education in the rural communities. Judging from the testimony of several district superintendents and many teachers of rural schools and from our own cxperience in New York State, we must conclude that opposition to this so-called "fad" has its beginning in several facts. First, it involves the expenditure of money. This has been our experience in the solution of most problems as well as in the accomplishment of most aims. The problem is indeed difficult of solution when communities come to value money more highly than they do activities that make for greater social, moral and physical efficiency. It is easy to measure the value of tangible things, but difficult to estimate the growth in education, refinement and culture on the part of the child. This is the reason why pcople generally are willing to spend money in those things the results of which are apparent at once and incasurable in dollars and cents, but hesitate and often refuse to give to their own community those things which are necessary for the fullest development of the boys and girls.

Another reason for opposition to physical education in the rural schools is that the people of these communities do not realize the value of this phase of education. They do not appreciate the need for a well-organized health program. They haven't the right conception of what it is, what it includes and what it should accomplish. The feeling is general that they are getting all the physical education they need in their daily labors. They point with complacency to the fact that they liave all the

1 Adapted from American Physical Education Revier, Jan., 1919, pp. 2732. Read before the Plysical Education Dept., N. F. A., Pittshurgh, Pa., July 2, 1918 
fresh air there is; the eity people may need plysieal edueation, -not they. They do not know tlic eorreetions neeessary for oeeupational defeets, the physieal need of soeial life, and of that type of activity whiels will diminish the exaggerated awkwardness of the eountry lad. IIere, too, the rural selool-teacher is apparently lost. She is apt to know nothing or very little about physieal edueation and liealtl edueation. She takes a very small part in the affairs of the eommunity. She has not made herself felt in the life of the child out of the sehool. The teaching of physical training seems but to add one more burden to the many she is already earrying. She is not capable of giving a good aecount of herself in the health edueation of the ehild. She therefore is opposed to it. Not the least of all eauses for opposition is that in many of those distriets where physieal training has already been inaugurated the instruetors supervising the work have not been properly trained. Their knowledge of physieal edueation is limited. Is it not just possible tlat this last-mentioned faet may in some degree be attributed to the systems of physieal training common in various institutions of learning throughout the country in whieh the supervisor, perehance, has learned gymnasties but missed the mark in physieal edueation? From some of these institutions one gets the notion that athletics is physieal training, or calisthenics is plyysieal training, and that these activities eomprise all there is to physieal training. The institutions themselves seem to have the idea that they are promoting physieal training, for upon investigation we find published in their catalogs the statement that they have eourses in physical culture and naturally we find the students going out from these institutions to promote the same type of edueation. Witl sueh conditions it is little wonder that we find opposition to physical training as a part of the sehool eurrieulum.

Now what ean we do to overeome this opposition? We must go slowly. We may give entertainments, play and athletie festivals with as many ehildren taking part as is possible. This is the best means of popularizing the work I know of. At these festivals offer games or events suitable for adults, especially those aetivitics that bring back fond memories. Don't lose an opportunity of getting the parents to the sehool or playground to inspeet the work. 
I have received many reports from rural school supervisors of physieal training coneerning the diffieult task of winning the support of teachers, parents, and trustees. In every instanee where festivals or physical training demonstrations have been given these supervisors and their superintendents have been enthusiastic over the support of the eommunity won for the work as a direet result of these demonstrations. People will listen to talks on various health topies and become enthusiastie supporters of a health program onee they are won over to what physical education means. You must show them what they are getting for their molley.

The most vital factor in the physieal edueation program is after all the teacher and the supervisor. People of proper training, of faculty for the work, with entluusiastic interest, and with a vision of the possibilities of the work and opportunity for serviee will do more to develop wholesome recreational and eivic aetivities than any other possible ageney. They will popularize this training in the rural eommunities and wipe out the opposition to it.

And now we must determine the needs of the boys and girls of the rural sehools and of the rural eommunities. These must neecssarily be stated in general terms. In the first plaee healthful and attraetive surroundings are essential to the physieal, mental, social and moral welfare of the children and to the life of the community. Instruction in personal hygiene and sanitation of the sehoolroom and yard is needed, and in order not to blush with embarrassment and to teaeh effectively, hygienic and sanitary eonditions must cxist, beginning with the teacher and the buildings. It is useless to preaeh if preaehing is all we do. It is absolutely necessary for the boys and girls to learn these laws of health through observation and practice. Attention must be ealled to them of course. Morning inspeetion of pupils' room, buildings and yard must be condueted. These must be followed up by visits to the lome to see that instructions are carried out.

School life is a severe nervous strain if the ehild is expected to always observe proper decorum and to sit still for long periods. We are fighting nature if we compel the child to do this. On the other hand school life will not become a nervous strain if suffieient periods arc given for relaxation and physical exercisc. In- 
hibition is one of the needs of the ehild, but all inhibition and no relaxation makes of the ehild a nerrous wreck. It is not a question of whether the selool program affords time for this relaxation throngh aetivity, it is a matter of ehanging our sehool program if neeessary to meet the needs of the child. We are beginning to get away from the obsolete idea of fitting the ehild to our system of edueation. In the rural eommunities, this idea makes way very slowly. In making our edueation satisfy the needs of the ehild the first need which appears is his physieal need.

Traditional sehool life has a'harmful effeet upon the normal posture of the body, and poor posture in turn works great havoe with the health of the elild beeause of the erowding of the vital organs of the body. Museular weakness, fatigue and the oceupations of rural life are eommon factors of bad posture. The rapid growth of ehildren which saps the power and efficiency of the museles, the exeessive fatigue of supporting museles which results from hard labor, and long periods of sitting and standing are other eommon causes of bad posture. The need of postural exereise is apparent. The natural tendeney to avoid the fatigue of holding one fixed position is one eause of the restlessness of children.

Rhythm and grace of movement is a need of the child. Observe how one moves, walks, and talks and you will learn a great deal about him. The habitual rhythm of motion is fundamental for full intelleetual development. There is a profound and elose relationship between our musele habits and thinking. The rural ehild is eonspieuously wanting in spontaneous graeeful movements. We know, now, enough about the developments of ehildren and adoleseents to know that the powers of aetivity are always developed before the powers of eontrol. A great many people live and die undeveloped. They have no control. No phase of our edueation ean train the individual in this respect quite as well as ean games, athletics, rhythmie exereises, exereises to response eommands, and other branehes of physical training. Nowhere will boys and girls receive this type of training if not during the years of sehool life.

The ehildren of the soil need physieal, mental and moral eourage. Exereises and games which require nerve, daring, eourage and skill should be given. Through the appointment of leaders 
the individuals aequire confidence in themselves and the ability to lead others. They will aequire the ability to stand defeat as graeefully as victory, reeognition of the rights of others, coöperation, self-subordination for the good of the majority, and leadership through teain games and athletics. These rural children need, perhaps more than any other one thing, the soeial aspeet of these games and eontests. Rural communities must have more wholesome social life. There is a dire need for social centers in the country. Entertainments, festivals, and community "sings" will do more to bring our eountry brothers out of their shells than any type of aetivity yet observed, and the vehicle for inaugurating these soeial gatherings is the supervisor of physical training, who must act as a general eommunity leader.

We must give these elildren something they ean use when through sehool as well as develop them while in school. We must develop the habit of wholesome exereise for after sehool life.

Aetivities that develop health, strength, intelligenee and charaeter must be given in order to give the rural ehildren the fullest measure of physieal edueation. Those activities are manifold. They should be utilized during frequent periods in the school program during reeess and after sehool. Directed play is needed for the rural ehildren far more than for their eity eousins.

To sum up these needs we may say that the rural child requires a special type of aetivity. It is useless to preach morality, selfcontrol, recognition of the rights of others, altruism, self-confidenee, determination, loyalty, coöperation, courage, skill, and a host of other attributes which the individual should aequire in sehool, if mere preaching is all that is attempted. It is neeessary to give the individual opportunity to learn these valuable lessons for himself, and this he ean do through normal direeted aetivity better than he ean in any other way. Children need aetivity intended to promote health, and body as well as moral diseipline; aetivities for the liealth and happiness of all boys and girls at the same time as the mental and moral training. They need to realize the obligations to the soeiety in which they live, and to have a readiness of spirit and body to meet those obligations in daily life. They need to be made eonseious of the faet that it is not for themselves alone that they sing patriotie songs, perform daily drills, play games and undergo licalth examinations, but for 
themselves as happier, healthier, more effieient members of the eommunity in which they live.

Space should bo provided to serve not only for the drills, plays, games, competitions and the like but also for entertaimments and community gatherings.

In order to inaugurate a program of this character it is necessary that eacl community should have a general community leader. Whatever the future may develop in bringing this need to a practical realization in terms of specifie organization, for the present, at least, this work must be done by the loeal leader of physical education. Now the usual instruetion afforded by the majority of eourses in physical education fails properly to equip its product with the necessary training. The physical director in a rural community, to be able properly to work out this program, must have a very definite and concrete notion of personal and school hygiene, health and sanitary inspections, inspection for signs of abnormality, and injury or illness, for conditions which call for immediate attention on the part of the teacher, and for signs of disordered health for which children should be kept at home ; for conditions productive of bodily deformity, posture, and the like; of the detection of defective sight and hearing; of the organization and duties of health officers and pupil sanitary inspectors; she must have a very definite and conerete notion of physical training, including calisthenies, athleties, games, dancing, swimming, ete., and all those terms imply, and the practieal conduct and organization of these various phases of physieal training into a rational health program; she must have a very definite and conerete notion of the nature and function of play, of child nature, of festivals and entertainments for old and young, of the social center or community eenter; and she must have a vision of the service and duties of a general community leader as well as a technical knowledge of her subject.

I wish I had time to elaborate on the training of a so-ealled general community leader. At Cornell University we have made a special study of the needs of the rural boys and girls and of the rural communities. A Division of Physical Education in the Rural Education Department of the Summer Session of the College of Agriculture lias been organized for the purpose of training teachers of physieal education as gencral community leaders 
for the rural districts. Besides the general training courses for physical directorships, special emphasis is made on personal lyygiene and school hygiene and school inspection, plyysical diagnosis, first aid and lome nursing, with opportunities for hospital practice for the training in the duties of the rural school nurse; games, athleties and folk dancing with special reference to organized, directed rural recreation; psychology and child study, rural leadership and administration and rural sociology; and the practical organization and conduet of a department of entertainments, demonstrations, festivals and pageants. We fecl that teachers with faculty for the work, with enthusiastic interest and such training will solve the health problem in the rural districts of New York State.

The oft-repcated assertion-that the rural communities are the basic social organization upon which rests the stability of the nation-still holds true. A proper conception, therefore, of rural plyysical education, is a fundamental educational necessity if a definite program of development is needed. An adequately trained personnel to put this program in operation is the first step in this direction. In some of the states, this idea is already taking definite form in legislation and in edueational organizations. A nation-wide movement to this end is indicated for the near future. This body can do no more constructive service for the gencral advancement of physical edueation in America than by a sane and enthusiastic support of that important phase of physical edueation so urgently needed in rural communities.

\section{WHAT THE PEOPLE LIKE ${ }^{1}$}

\section{Communities in Pennsyluania}

WARREN II. WILSON

Baseball .......29 per eent. Skating ...... 3 per cent. Social and pienies..18 per eent. Daneing ...... 3 per eent. Pool and Billiards..13 per eent. Cards ....... 3 per ecnt. Moving pieture Basketball ..... 3 per cent. shows .......11 per cent. Football ..... 3 per cent.

Adapted from "RuraI Survey in Penna.," p. 17. Department of the Church and Country Life, Pres. Board of Home Missions. 
Gymnasium athletics 5 per cent. Tennis ...... 3 per cent. Concerts and lectures ..... 3 per cent. Bowling .....2 2 per cent. Golf ........ 1 per cent.

\section{THE FARM PLAYGROUND ${ }^{1}$}

\section{W. H. JENKINS}

THE following words were spoken by a very suceessful farmer, who brought up a fine family of boys on the farm:

I brought up seven boys on the farm. Every one wanted to stay on the farm until they grew to manhood. They are successful business men with good habits of life. Some are farmers, and some in other occupations for which their gifts best fitted them. The boys stayed at home and worked with me, because there were more attractions and enjoyments for them there than in any other place. We all worked together. We paid for one farm and then bought another and paid for it, and when one of the loys went into business for himself, lis training, habits of life, and a little capital we had for him, assured his success. One of the main reasons why my boys loved the farm life and lome so well that they never wanted any of the dissipations that are demoralizing, and which the young people on the farm engage in because there is nothing that satisfies their natural love for play and recreation, was that I spent $\$ 30$ to build a playground where they could play baseball, tennis or croquet, and I played with thein. I lave stopped work right in haying time to play with the boys and then we all worked better for the change.

The above is the testimony of a man who was successful both in making the farm pay, and in bringing out the best qualities of manhood in boys, so that they made men of such intelligence and vitality and character that they were prepared to overeome difficulties and win the battle in the struggle of life.

\section{DRAMA FOR RURAL COMMUNITIES ${ }^{2}$}

\section{ALFRED G. ARVOLD}

Trie United States Department of Agriculture recently sent out hundreds of letters to farmers' wives asking them what would make life on the farm more attractive. Hundreds of the

1 Adapted from the Rural New Yorker, N. Y., June 29, 1912.

2 Adapted from American Reriew of Revieus, 54: 309-311, 1916. 
replies, which were reeeived from practieally every seetion, told the story of social starvation. They wanted some place to go. They wanted to be entertained. Moral degeneraey in the eountry, like the eity, is usually due to lack of proper social reereation. When people have something healthful with which to oeeupy their minds they rarely think of wrongdoing.

The impulse of building up a eommunity spirit in a rural neighborhood may eome from without, but the real work of socialization must eome from within. The eountry people themselves must work out their own eivilization.

With a knowledge of these basie facts in the mind the idea of the Little Country Theater was eoneeived. The theater became a reality when a dingy old ehapel on the second floor of the administration building at the North Dakota Agrieultural College, loeated at Fargo, was remodeled into what is now known as the Little Country Theater. It is simply a large playhouse placed under a reducing-glass, and is just the size of the average eountry town hall. The decorations are plain and simple, the eolor seheme being a green and gold.

Simplieity is the keynote of the theater, for it was not meant for the institution alone, but for every rural eommunity in Nortl Dakota and the rest of Ameriea as well. It is an example of what ean be done with hundreds of village halls, unused portions of sehool-houses, and garrets and basements of country homes and eountry ehurehes.

The objeet of the Little Country Theater movement is to produee such plays and eommunity programs as ean be easily staged in just sueh plaees, or, in faet, in any place where people assemble for soeial betterment. Its prineipal funetion is to stimulate an interest for good, elean drama and original entertaimment among the people living in the open eountry and villages, in order to help them find themselves and beeome better satisfied with the eommunity in whieh they live. In other words, its real purpose is to use the drama, and all tlit goes with the drama, as a sociologieal foree in getting people together and aequainted with each other, so that they may find out the hidden life forees of nature itself. Instead of making the drama a luxury for the elasses, its aim is to make it an instrument for the enlightenment and enjoyment of the masses. 
The work of the Little Country Theater has more than justified its cxistenec. It las produced scores of plays and community programs. The people who have participated in them seem to have caught the spirit. One group of young people from various scctions of the State represented five different nationalities-Scotch, Irish, English, Norwegian and Swedishsuecessfully staging "The Fatal Message," a one-act eomedy by John Kendrick Bangs. In order to depict Russian life, one of the dramatic clubs in the institution gave "A Russian Honeymoon." Another east of eharaeters from the eountry presented "Cherry Tree Farm," an Englisl comedy, in a most aeeeptable manner. "Lconarda," a play by Björnsterne Björnson, was presented by the Edwin Booth Dramatic Club and was undoubtedly one of the best plays ever staged in the Little Country Theater. An orehestra played Norwegian music between the aets.

An illustration to demonstrate that a home-talent play is a dynamic forec in helping people to find themselves is afforded in the presentation of "The Country Life Minstrels" by the Agrieultural Club, an organization of young men coming entirely from country districts. The story reads like a romanee. The elub decided to give a minstrel show. At the first rehearsal, nobody exhibited any talent except one young man. He could elog. At the second rehearsal a tenor and a mandolin player were discovered; at the third, several good voices were found; whereupon a quartet and a twelve-piece band were organized. When the play was presented, twenty-cight young men furnished an exeellent entertainment. During the last three years nearly twenty young ladies, the majority from eountry distriets, liave presented short plays. Each of them lias also sclected the production, but they have promoted the play and trained the cast of claracters as well. When Pcrey MaeKaye, the well-known dramatist, visited the Little Country Theater, four young men presented "Sam Average." "The Traveling Man," a miraele play, was presented in honor of Lady Gregory, of Ireland, on her last tour of America. Many other standard plays have also been presented by these rural amateurs as well as a number of original productions. 
Several original plays have been presented to large erowds. Three of these, "For the Cause," "A New Liberator" and "Bridging the Chasm," made an unusually fine impression upon the audienees. They were written under the direetion of Abbie Simmons, writer of plays and a splendid student of the drama.

Perhaps the most interesting ineidents which have oeeurred in eonneetion with the work of the Little Country Theater were the presentation of "A Farm Home Seene in Ieeland Thirty Years Ago," "The Prairie Wolf," "Baek to the Farm" and "A Bee in a Drone's Hive." All of these produetions have eome out of the eountry people themselves. Standing room was at a premium. The Little Country Theater eould not hold the erowds, 80 per eent. of the people being farmers who were eager to see the drama of their ereation.

"A Farm Home Seene in Ieeland Thirty Years Ago" was staged by twenty young men and women of Ieelandic deseent whose homes are in the eountry distriets of North Dakota. The tableau was very effeetive. The seene represented an interior sitting-room of an Ieelandie home. The walls were whitewashed; in the rear of the room was a fireplaee; the old grandfather was seated in an arm-ehair near the fireplace reading a story in the Ieelandie language. About the room were several young ladies in native eostumes, busily engaged in spinning yarn and knitting, a favorite pastime of an Ieelandie home. On a ehair at the right was a young man with a violin playing seleetions from an Ieelandie eomposer. Through the small window rays of light were thrown, representing the midnight sun and the northern lights. Just before the eurtain fell, twenty young people, all Ieelanders, joined in singing their national song, whieh has the same tune as "Ameriea." The effeet of the tableau was farreaehing. The two hundred people who saw it will never forget it.

"The Prairie Wolf," a play written by a young man named John Lange, was staged in the Little Country Theater before an audience representing more than thirty rural eommunities in the State. The play was not only written by a young farmer, but it was staged and rehearsed by country poople. It was a tre- 
mendous sueeess. Dozens of communities in the State have already asked for permission to present it. The aetion throughout the play was superb.

"Baek to the Farm," written by a student of the Minnesota Agrieultural College, was presented on three sueeessive nights during the Tri-State Grain-Growers' Convention, which is held every year in the eity of Fargo. Seven hundred and fifty persons, 90 per eent. of them eountry people, witnessed this produetion. Inndreds were turned away from the theater. The east of charaeters in the play was made up entirely of young people from the eountry.

Last fall, Ceeil Baker, a young farmer from Edmunds, N. D., who has eaught the soeial vision of the soil, eame to my office with a manuseript of a play which he had written entitled " $\mathrm{A}$ Bee in a Drone's Hive, or a A Farmer in the City." Mr. Baker wanted his friends to present it, and they did. Two hundred and fifty people saw the produetion. Some said it was the greatest argument in favor of eountry life that had ever been presented. Others were astounded at the naturalness of the make-up and the eostuming of the eharaeters. Everybody was more than satisfied.

The influence of the Little Country Theater in the State as well as the Nation has been far-reaehing. Seareely a day passes but somebody writes asking for data in regard to it, or for eopies of plays, and matter for presentation on publie programs. These letters tell an intensely interesting story of the soeial eondition of the eommunity. During the past few years in North Dakota, hundreds of people young and old have partieipated in home-talent produetions and eommunity programs. Thousands of pieees of play-matter and pamphlets have been loaned to individuals, literary societies, farmers' elubs, eivic elubs, and other organizations. While the Little Country Theater is loeated in North Dakota, it nevertheless stands ready to assist other eommunities in every way possible to develop eommunity life. 


\section{THE MUACLE PLAY A'T POMFRET, CONNECTICUT ${ }^{1}$}

\section{ELLA M. BOULT}

Two months earlier our Neighborhood Association had been organized, and had already proved itself responsible to evcry eall upon it. We had not believed that its varying elements would make eommon eause so readily. It had developed a surprising unity of interests, and a sympathetié and hearty eoöperation in developing those interests. And now Christmas was approaching, supreme season of festival and eelebration. What should we do to eommemorate it-we, whose very foundation stone was brotherhood, community of interests, fellowship, goodwill?

Back of us were three ehureh soeieties: the Congregational, sentinel and saint of every New England village; the Episeopal, always proudly assured in its sense of power; and the far-reaching, never flagging Roman Catholie. All three are generous in their response to the material demands of Christmas, as they are devout in spiritual ministrations at this and all seasons of the year. From all three, and from without the ehureh, we draw our membership. Not only are we of many ereeds but of many voeations, and especially of many nations. Our Irish and Swedish membership equals our native Puritan elements; we have a number of English and Seoteh members, and a few Swiss, Italian, Portuguese, Canadians and Negroes.

As to voeation we are largely working people, and are of all trades-domestie workers, day-laborers, earpenters and builders, preaehers, teachers, painters, plumbers, merehants, farmers. It is true that in our community we have a large number of the leisure elass, so ealled. Who shall say that they are not the busiest of all elasses? Certainly from them we may draw a sympathetie and helpful portion of our nembership.

Above all it (the festival) must be expressive of the great event that it eommemorates. Throughout the ages Christmas has never weakened in its tremendous signifieanee. Bells ring, eandles glow, greetings and gifts and good cheer abound; but always, below these surfaee manifestations, there is the Manger at Bethle-

1 Adapted from Country Life in America, 25: 49-56, December, 1913. 
liem, the transfigured Mother, the pondering Joseph, the dumb brutes, the night, the stars, the shepherds keeping wateh over their flocks by night, the glory of the Lord, the leavenly hosts, the miracle of miracles. Our impulse was toward the wonderful reality. We did not approach the undertaking without trepidation. With material so heterogeneous eould we maintain the solemnity of our subject, sacred in itsclf and wrapt round witl ecnturies of mystical beauty?

Our shepherds were boys from the farms; our angelie hosts were made up of girls in their teens; our wise men were, one a Frenehman, one a Moor, and one a native of New England stock; by trade they were a plumber, a day laborer and the village storekeeper and postmaster; the retinues of the Magi were scliool boys as full of life and spirit and mischief as the average boy; Joseph was an Italian laborer, Mary a young Irish girl. The only representative of the brute world was Laddie, our beantiful collie, typieal of the shepherd's calling. Laddie had had no more dramatic training than the others, but his instinct proved like theirs, perfeet. When, a few months later, he died, he was mourned far and wide as the "dog that came with the shepherds to see the Babe in the manger."

The event proved that faith in our people, however great, was still less than their due. Nothing more beautiful came of our miracle play than the devout spirit of our young aetors. It seemed to our Italian workman an astounding thing that he should take the rôle of San Giuscppc but no art could have tanght him the profound gravity that he assumed. It came from within, from the solemn realization of the verities. There is sometimes in human nature a eertain simplicity that responds like the heart of a child to the elemental without. This quality nurtured beyond any doubt by eountry life, has shown itself more and more to be a eharaeteristic of our people.

When the curtain fell upon the last scene of our little drama there was silenee-a silenee of deep emotion. The lights came on with an incongruous glare, thrusting us with a rude jolt forward into the twentieth ecntury. They disclosed an audience unable to speak. The "Silent Night" melody that still filled the air resolved itself again into words in an effort to make artieulate the spell that kept us dumb. Haydn, even in his great- 
est masterpieees, never surpassed this theme in its elemental, pastoral quality, so touehingly eloquent of the open eountry, the starlight, the rudeness and homeliness of the stable, the peaee, the ealm, the vastness of the event.

\section{WHAT THE PAGEANT CAN DO FOR THE TOWN ${ }^{1}$}

\section{GEORGE P. BAKER}

Houddys, which should be of interest to all, and not a mere excuse for idleness that leads to drinking or other vice, are in far too many eases ill used. The growth of eompetitive outdoor sports in fitting season is a move in the right direetion, for they employ many and entertain more; they are demoeratic and healthful. Clearly the desideratum for our holidays is something whieh interests and oeeupies, as partieipants or audienee, as many people as possible, whieh does not emphasize soeial or money distinetions, and which produees something more than momentary pleasure. This is just what the modern pageant, as to some extent already developed in the United States and widely sueeessful in England, provides.

What is a pageant then? "Something between a play and a proeession." It is not merely proeessioning by people in faney eostumes, nor tableaux on fixed or movable stages, nor daneing, nor instrumental or voeal musie, nor dramatie seenes in prose or verse. It may be all of these, or some of these, eombined. It is a eomposite for'm that stands between a proeession like that of the trades or of the Antiques and Horribles and a regular play. As to plaee or seene it is not limited, but may be given indoors or outdoors, though outdoor performanees are usually more pieturesque, make it possible to use more performers and provide eomfortably for a larger audienee. Its aims in setting are pieturesqueness and spaee suffieient for free movement by the inany people taking part.

Nor is the pageant limited as to subjeet. It may revivify the listory of state, eity, town, village, eollege, selool or individual. It may be all allegory eonveying some stimulating idea or moral

1 Adapted from Ladies' Home Journal, April, 1914, p. 44. 
lesson, or a pageant of edueation, of beauty or of poetry. It may re-ereate the past, explain the present, suggest the future. In a word the pageant is what our enthusiasm, imagination and intelligent eöperation ean make it; it is, and should be, the plaything and the playtime of the masses. A small pageant, to be sure, may employ only two hundred or three hundred people, though a large pageant requires the eoöperation of several thousand. But evell a small pageant, espeeially if given outdoors, may eaeh time be played to from three thousand to five thousand people.

Some of the most sueeessful pageants here and abroad have been given in the smaller plaees. Even fifty people may give a ereditable pageant. Nor is it true that only plaees rieh in history should attempt pageantry. Different eonditions demand different pageants; that is all. There is the Pageant of the River, for the river town whieh is laeking in beauty or seanty in history; there is the Pageant of the Woods for the lumbering town; there is the Pageant of Grain for the farming eommunity, the Pageant of Steel for the manufaeturing town, and the Pageant of the Mountains for the village among the hills. Given imagination and eonstruetive skill on the part of the maker of the text, with hearty eoöperation by all eoneerued in the work, and any town not far distant from railroads or with roads not too bad for automobiles may have a pageant without fear of going into debt.

It is not true, then, that only rieh and large eommunities, or those eontaining a few eitizens able to be large guarantors, may attempt a pageant. The great desideratum is time-not in which to prepare the aetors, but in whieh to make ready a finished text, to provide appropriate eostumes and to foresee all the details whieh provide for the eomfort and artistie satisfaetion of the publie. If possible some eight to twelve months before a pageant begins, plans for it should be roughed out and eommittees organized.

The text, whieh has been gone over again and again for the largest dramatie effeetiveness in the smallest spaee, the greatest elearness of meaning as a whole and the largest effeet of beauty, should be ready in proof at least a month before rehearsals begin. Thus the parts may be learned without too great'a strain, and ehanges whieh are first seen to be neeessary in the rehearsals 
may be made in time to allow an early final printing of the text.

Costumes should be made slowly and systematieally, either by the persons taking part or by seamstresses direeted by some Mistress of the Robes. Time in this provides inexpensively eostumes which, hurriedly prepared or rented in quantities, would be both less artistie and very expensive. A book ealled "Festivals and Plays," by P. Chubb, eontains many valuable suggestions as to eeonomies in such preparations.

Time means, too, a chance to work up wide enthusiasm among the townspeople and to spread far and wide a knowledge of the eoming pageant. In the first days of many a pageant townspeople have said that loeal history, eostumes of the past, old firearms and domestie utensils were laeking. In the last days of preparation, however, eostumes, souvenirs, relics have eome flowing in from all sides, resurreeted from garrets and eellars. In one instance a town that had been strangely lethargie, when urged by an enterprising eitizen to found a historieal museum, took hold of the plan with vigor after its pageant, placing in the museum many of the eostumes, implements and firearms which the pageant had brought together.

On one other aeeount people of small eommunities are sometimes kept away from pageantry. "We are not an artistie eommunity," they say. "They are four or five among us who have aeted a little as amateurs, and still more who sing well, but there is no widespread, marked artistie ability. Who is to prepare our text and rehearse the pageant? Who are to aet, sing and danee in it?', At first any pageant master must be prepared to meet in the native Ameriean man an ill-eoneealed feeling that artmusie, aeting, painting, even singing, and, above all, daneingis for women, not for inen. It was eertaiuly evident at first in Peterboro, New Hampshire; but as the pageant shaped itself before those who eame somewhat timidly to wateh rehearsals, those who at the outset lacked the interest or the eourage to take part eame in one by one. In the beginning it was hard to find men enough for the neeessary parts. But in the final rehearsals there were enough, and among the most enthusiastie partieipants were men who had at first stood aloof. Nc eommunity that has eooperated-men, women and children of all ages-in produeing a local pageant will ever again look down on art as effeminate. 
They will foster the artistie power any one of them may possess and will weleome art of all kinds, grateful for the uplifting pleasure and the beauty it brings into their lives. Again and again Ameriean pageants, large and small, have proved this true.

And the artistry revealed in those who never suspeeted that they even possessed it! I remember one quiet, self-eontained farmer of nearly seventy who, though willinguess itself to help in every way, bewailed his inexperienee and probable laek of all ability. Even in the first rehearsal of a seene arranged to illustrate MaeDowell's "Deserted Farm" he eaught exaetly the required spirit of delieate, wistful pathos. He "lived his part," though it had to be expressed in the art most diffieult for the inexpressive New Englander, the art of pantomime. A hint, a suggestion, he took instantly and developed with keen intelligenee. At the end of the first rehearsal, when he eame for some direetions, I said: "How did you know so quiekly exaetly what that man should do?"

"Ah," he said sadly, "years ago it was no uneommon thing for me to be saying 'Good-by' to old friends that were going westward to the Middle States or California, and so I just remembered and let go."

Day by day, filled with growing enthusiasm, he eame to me with illuminating suggestions of business whieh ellaraeterized his part. My task was merely helping him to express largely ellough for an audience of a thousand people what he felt perfeetly and even at the outset expressed adequately for those within short range. And his is the story of many men, women and ehildren in all these pageants.

$\mathrm{He}$ is a foolish pageant master, indeed, who does not eneourage his aetors to suggest business and even lines for the seenes in whieh they take part. What will come to them, absorbed as they are in their work, is often far more vivid and right than the lines of the author, no matter how earefully seleeted. One of the most effeetive details in a Revolutionary scene was entirely rephrased and infinitely bettered by an old man of eighty-seven playing a part. He had never aeted before. At first he looked on the whole experiment a little doubtfully; but, onee stirred by what had meant so mueh to his forebears, he quiekened in imagination. Enthusiastieally living the seene over and over both at 
rehearsal and away from it, lo! one day he thought of lines far more eharacterizing than those he had originally been given. Moreover the pageant that docs not reveal unexpected powers in more than one youth, and perhaps determine a later eareer, is unusual. A pageant is to the artistic youth of the community a great opportunity for self-revelation.

The most essential matters in preparing for a pageant are text and trainer. To handle a mixed erowd of several hundred men, women and ehildren so as to diseover and reveal to them any artistie power they may possess, so as to keep them contented and even happy when working hard, and so as to get ultimate order out of original chaos, may require the trained hand. It is probably safer, therefore, to call on somebody experienced in this work, and to pay him or her well. If, however, there is any man or woman in the eommunity who feels eompetent to provide the text don't put that person aside until an outline of what he or she wishes to do has bcen_considered by the eommittee, or, better still, passed on by some person experienecd in pagcantry. If scveral people prepare the text, rather than have it ineffective let the pagcant master deeide whether the seenes may stand as written or should be simply the basis of a reworking by him or some other skilled hand.

Indeed writing pageants is not so easy as many seem to think. Given outdoors or in large halls the pageant eannot depend to the extent the play ean on the spoken word. Pantomime of a large, free sort, ehoral effcets and processioning must in many instances replace the spoken word.

A pageant should as far as possible have some unity of idea, to bind part with part and to give it meaning as a whole. Audienees do not like evenings of onc-aet plays. Nor, in a pageant, do they like a dozen one-aet episodes of singing, dancing or acting. Let the early parts of the pageant ereate interest for later parts, arouse query. Carry some characters over from episode to episode or division to division; contrast similar conditions in different periods. In brief, bind the parts together all you can. But it is meaning as a whole that a pageant most needs, for onc of the great dangers of Ameriean pageantry to-day is eommercialism. Commereialism means that instead of writing a pageant for each plaee growing out of its peculiar history, interests 
and traditions, some one stands ready with a seheme of pageantry whiel, if slight adaptations are made in the seenes, may be used almost anywhere. With this plan all that is most desirable instantly disappears, for in pageantry of the right sort a eommunity not altogether understanding itself seeks to know itself better, and tries in self-expressive, artistie aetion to review its past, know the meaning of its present and appreeiate rightly the latent beauty of its life.

An auditor leaving the pageant field or liall should feel that he understands as never before the speeial signifieanee of the past and present life of that town. The eommon share of all workers in the inspiration of dreams, that is what the hearer should have brought away. Individuality, a speeial meaning that grows out of right interpretation of the life of a partieular eommunitythat, then, is the great desideratum of the best type of pageant.

Is not, then, the pageant worth while? It spreads widely the name and reputation of a town. It brings trade to it. It rouses and sustains civic pride. "It reveals and develops artistry. It gives the fine arts their right position in the life of the people. Above all, it is to the people who share in it a pleasure in the doing, and a proud and delightful memory. When our young people, indeed the people of the country at large, have by popular rote ehosen the drama as our ehief interest in the fine arts, when the great essential for our proper growth in drama is to give our people right standards, ean there be any question that it is wise to foster pageantry in this eountry?

\section{RURAL ART 1}

\section{FRANK $\Lambda$. WAUGH}

TuE term is one whieh is eoming into use in eertain eireles. Some of the universities now offer eourses in rural art. The present artiele ean hardly do more than survey the field and indieate the seope of the subjeet.

Art is, of eourse, universal, and its prineiples are the same in the eountry as in the eity. All we ean mean therefore by rural

1 Adapted from Business America, Feb., 1914, pp. 164-167. 
art is the applieation of art prineiples to rural problems. When we reach this ground, no one ean doubt that art is able to render a service to the eountry as much as to the eity. Its purpose is to bring order and beauty in place of disorder and ugliness. Beauty seems to be more natural to the country than to the eity, and more indispensable. Perhaps it would be wise therefore to make a stronger effort to preserve and enhanee the beauty of the eountry districts.

But the country needs also to be orderly. An orderly arrangement of roads, farms, fields, publie grounds, buildings and of the whole landseape will have considerable practical value. Indeed, order, heaven's first law and the foundation of art, has also great praetical value. The ministrations of art may be justified, therefore, on wholly praetical grounds. It is wise to present this argument in most eases, though it would be wrong to make the final test of the service which art would render to the eountry.

It will be worth while to point out in beginning that rural art in America is entirely different from "peasant art" in the old eountry. The artists of the Old World reeognize and value very highly what they know as bauer-kunst. Perhaps nothings would differentiate more elearly the spirit of American country life from the spirit of Bavarian peasant life than this very difference between Ameriean rural art and bauer-kunst.

It seems to me that rural art in Ameriea onght to deal first with rural arehiteeture. Farmhouses ought to be essentially and typieally rural. In the past twenty-five years we have seen many horrible examples of town houses built in the eountry. The arehiteets have been designing eity houses almost exelusively and the only new ideas in eireulation have been developed to meet urban eonditions. In most instances they are wholly unadapted to rural eonditions and the results are often genuinely grotesque.

It should be remembered distinetly in this conneetion that some of the best Ameriean domestie arehiteeture las been developed in the eountry. The old-fashioned New England farmhouse and the good old Southern ante-bellum plantation house were fine types. The modern bungalow in its pristine purity is essentially a eountry house and suited to eertain types of rural seen- 
ery. Unfortunately it is being badly misused by unskillful designers and badly misplaced on eity streets amidst incongruous surroundings so that one lias to be very eareful of his admiration for bungalows.

It ought to be plain, however, that what we want in the country, and especially on the farms, is good country houses, native to their surroundings and suited in all respeets to the life which goes on in them. The same desire may be freely expressed in referenee to all other rural and semi-rural buildings, sueh as sehoollouses, eountry ehurehes, eountry libraries, village stores, ete. For the most part these buildings also are eopied from city models and the results are depressing. There have been built in all parts of the eountry a number of fine examples in reeent times to show what ean be done in the way of country banks, schoolhouses, stores, ete., and these models ought to be followed.

The improvement of farmyards is always spoken of in eonneetion with rural art, and frequently as thougl it were the main issue. Farmyards ought, doubtless, to be embellislied and made attraetive everywhere, but it seems preposterous to be planting IIydrangea paniculata grandiflora in the front yard while the kitehen sink drains into the well. In other words, the problems of mere ornamentation ought to be the last to be taken up, rather than the first. In this work simple, elean arrangement, tidiness and good order, are worth a great deal more than flower beds and shrubbery. The special value of good shade trees, however, should not be overlooked.

The proper applieation of art to the planning of the farm would reach far beyond the front yard. Every farm needs to be planned as a whole. Different fields and buildings should be arranged in a logieal system, in proper relation to one another. This is essentially an art problem, and unless rural art ean help in its solution, it has failed at an important point.

Landseape gardening, which deals with all these subjeets, lias in reent years developed on a large seale a speeial branch of study known as eivie art. Like every other line of lumman endeavor this has been earried farthest in urban eivilization,--in its application to eities; but it has its equally important applications in the eountry. Rural eivie art simply means the applieation of art prineiples to all the publie affairs in the eountry. The most 
important of these are (a) roads and streets, ineluding bridges, street railways and street trees; (b) all publie grounds such as parks, pienic grounds, eommons, lakes, water fronts, school grounds, eemeteries; (e) all publie and semi-publie buildings sueh as sehoolhouses, libraries, ehurehes; (d) publie reereation facilities, espeeially playgrounds; (e) all publie service utilities, sueh as telephone lines, eleetric light lines, railway stations and station grounds. All these items of the material equipment of the eountry should be improved in beauty and in usefulness. Such eivie improvement is greatly to be desired in the eountry as well as in the eity and eonstitutes one of the large fields of rural art.

As art deals essentially with what is beautiful, rural art strives to eonserve and inerease the stoek of rural beauty on every hand. It is easy to see that there is a great deal of beauty in the country and to determine what some of the main features are. For example, the eountry roads are extremely beautiful. They are in a good and important sense the best kind of publie parks. Everybody enjoys them whether a-foot or driving, or even touring in an automobile (though this last is the poorest way of all). Mueh ean be done to preserve and even develop the beauty of the country roads. It hardly needs to be added that very little has thus far been done. Any loeal improvement organization eould hardly attempt a better line of work or one in which suceess is more likely than in this line of preserving the beauties of the eountry lanes. These eountry roads are beautiful for their trees and for the wild shrubbery and ferns and flowers whieh border them. Such native growth, within reason, ought to be preserved; and it would be an exeellent plan to use favorable strips of eountry road as speeial preserves for wild plants. There are many parts of the eountry, especially where agrieulture is highly sueeessful, where the wild plants are in imminent danger of extinetion. Hundreds of the native speeies are already almost eradieated. No better publie place eould be found for making a eolleetion of these for general instruetion and enjoyment than along suitable strips of eountry road.

Many persons are also giving serious thought to the preservation of native birds, fish and small animals. To some extent these objeets ean be accomplished, espeeially the protection of the birds, in eonneetion with these roadside plant preserves. 
One of the crying evils of modern country life is the rapid removal from general use of all streams, stream banks, lakes, lake shores, forests and hills. Within the memory of all elderly people such sources of recreation were open frcely to the world. Every boy could hunt, swim and fish where he liked; and all people, old and young, held their pienics on the river banks or went boating on the lakes as they pleased. All this property is now being rapidly taken up by private owners and eommon people stringently excluded. The only way to preserve any of these ancient and highly valuable rights to future generations is to have them taken very soon under publie eontrol. All these ponds, lakes, streams, hills, forests, or at least the best of them, ought to be free for the publie use forever; and it is the most immediate and important work of rural civic art to seeure these reservations. Of course after the public has secured title to sueh properties, their various beauties and utilities remain to be dcveloped. Such development will be the natural field before long of rural art.

Aside from these park reservations to which the public should hold a legal title there is a much larger sum total of beautiful rural secnery whieh the public does not need to own, but whieh everybody ean enjoy. This scencry does not need to be neglected simply because it is owned by private individuals and exploited as farms or forests. Every wise community will appreciate its resources of beautifnl landscape and will make the most of them.

The final test of rural art must be a love of rural beauty. If people will not see the beauty of the eountry, especially those people who live in it, it is uscless to talk to them of art in any other form. There are many ways in which this appreciation of the eountry beautiful may be developed. It may even be taught in the sehools. It is quite as easy to convinee one of the beauty of native trees or of the neighborly hills or the local lake as of the Sistine Madonna, or the Hermes of Praxiteles, whieh most of us never saw. Genuine, thoroughly organized campaigns for the appreciation of local seenery would do more for many communities than organized efforts to produee more eorn. 


\section{BiBLIOGRAPHY}

Arvold, Alfred G. Soul and the Soil. Playground, 10 : 324-33, December, 1916.

Bailey, L. H. The Playground in Farming Communities. In his York State Rural Problems, 1:70-7S, Lyon, Albany, N. Y., 1913.

Bancroft, Jessie H. Games for the Playground, Horne, School, and Gymnasium. Macmillan, N. Y., 1909.

Children's Games and Rules for Playing. (With Crampton, C. W. and others) Amer. Sports Pub. Co., N. Y., 1916.

Butterfield, K. L. Play and Recreation in Our Country Life. Rural Manlood, 3:147-150, May, 1912. Intl. Committee Y. M. C. A., N. Y.

Clarke, Ida Clyde. The Community Drana. In The Little Democracy, Chapter 13, and Community Music, Chapter 12. D. Appleton \& Co., N. Y., 1918.

Community Nusic. The Playground, Vol. 8; 139-142,; 1914-1915.

Curtis, Henry S. Play and Recreation. Ginn, N. Y., 1914.

Dykema, Peter W. Community Music and the Spirit of Democracy, The Playground, 10:368-376, Jan., 1919.

Spread of Community Music Idea. Annals, 67: 218-223, Sept., 1916.

Farwell, Arthur. Community Music Drama. Craftsman, 26:41S-424, 1914.

Gillin, J. L. The Sociology of Recreation. Amer. Jour. of Soc., 19 : 825-834, May, 1914.

Groves, E. R. Using the Resources of the Country Church. Assn. Press, N. Y., 1917.

Hetherington, Clark W. Play for the Country Boy. Rural Manhood, 2:139-142, May, 1911.

Johnson, George Ellsworth. Education by Plays and Games. Ginn, N. Y., 1907.

Scudder, Myron T. Play Days for Country Scliools. Outlook, $92: 1031-8,4$ ugust 28, 1909.

Organized Play in the Country and Country Village. Journal of Education, 66: 59-63, July 11, 1907.

Rural Recreation, A Socializing Factor. Annals, 40:175-190, March, 1912.

Sharp, Cecil J. The Country Dance Book. Novello, London, (in three parts), 1909, 1912, 1913.

Stern, Renee B. Neighborhood Entertainments. Sturgis, N. Y., 1910.

Suretle, Thos. W. Community Music. Atlantic Monthly, 117:658667.

The High School as a Center for Community Music. U. S. Bureau of Education Bul. No. 49, pp. 36-37, 1917.

The Playground, Vol. 6, No. 8, November, 1912. Special number on Rural Recreation. Published by the Playground and Recreation Association of American, 1 Madison Ave., N. Y.

The Playground, Vol 6, No. 7, Octoher, 1912. Speeial number on Rural Recreation and the Church. Published by the Playground and Recreation $\Lambda$ ssociation of $\Lambda$ merica, 1 Madison Ave., N. Y. 
The Playground, Vol. 8. The Rural World at Play, pp. 379-393, $1914-1915$.

Waugh, F. A. Rural Improvement. Orange Judd Co., N. Y., 1914. Watrous, Richard B. Civic Art and Country Life. Annals, 40:191200.

Wilson, Mrs. E. B. Iowa's Children and Communities at Play. Dept. of Public Instruction, Des Moines, 1916. 


\section{CHAPTER X \\ COMMUNICATION AND TRANSPORTATION}

\section{THE FUTURE OF GOOD ROADS IN STATE AND NATION ${ }^{1}$}

\section{EDWHN A. STEVENS}

In no country has the growth of the highway problem in importance and in difficulties been greater than in the United States, and in none does it seem likely to be greater in the future. Our motor-vehicle registry is already the largest in the world.

The effect of these industrial phenomena on our roads is worthy of most careful thought. The problem in its most simple and general statement is one of transportation. The cost of transporting one ton a mile at any given speed will divide itself naturally into two parts : first, the cost of providing and running the vehicle, including up-keep, fuel, and lubricants; second, the cost of providing and maintaining the roadway in such shape that the sum of both parts of the cost of transportation shall be a minimum. The latter is the special provinee of highway administration. To discharge this duty, provision must be made for the future traffic.

To do this intelligently we must form some idea of the traffic of to-day and of its past growtl. The horse-drawn traffic is practically unlinown; it will probably not show any matcrial increase, though, in the minds of many authorities, it is not likely to decrease. It is also less trying on our road surfaces. The following statistics as to automobile registration in ten States that have undertaken the systematic improvement of their roads affords us a means of foretelling what is to be expected within the next few years for the nation:

1 Adapted from Seribner's magazine 59:181-190, Feb., 1916, copyright, 1916, by Charles Scribner's Sons. 
MOTOR-VEHICLE REGISTRATION. AND POPULATION

\begin{tabular}{|c|c|c|c|c|c|c|c|c|c|}
\hline State & 1911 & 1914 & $\begin{array}{c}\text { Esti- } \\
\text { mated. } \\
1915\end{array}$ & $\begin{array}{c}\text { Popula- } \\
\text { tion, } \\
1915\end{array}$ & $\begin{array}{l}\text { Inhabit. } \\
\text { ants per } \\
\text { motor } \\
\text { velicle. } \\
1915\end{array}$ & $\begin{array}{c}\text { Motor } \\
\text { vehicles } \\
1918\end{array}$ & $\begin{array}{c}\text { Motor } \\
\text { velicles } \\
1919\end{array}$ & $\begin{array}{c}\text { Popula- } \\
\text { tion, } \\
1919\end{array}$ & $\begin{array}{c}\text { Inhabit- } \\
\text { ants per } \\
\text { motor } \\
\text { vehicle, } \\
1919\end{array}$ \\
\hline $\begin{array}{l}\text { Mass. } \ldots . \\
\text { R. I. .... } \\
\text { Conn. } \ldots . . \\
\text { New York } \\
\text { N. J. .... } \\
\text { Penn. .... } \\
\text { Mdd. ...... } \\
\text { Virginia . } \\
\text { Ohio ..... } \\
\text { Illinois .. }\end{array}$ & $\begin{array}{r}38,907 \\
7.262 \\
16.372 \\
83.968 \\
55.913 \\
48.108 \\
7.273 \\
4,020 \\
45,788 \\
42.615\end{array}$ & $\begin{array}{r}77,246 \\
13,530 \\
32,790 \\
168.428 \\
76.910 \\
125.189 \\
20.238 \\
13,984 \\
122.504 \\
145.992\end{array}$ & $\begin{array}{r}99,000 \\
15,600 \\
39,000 \\
222,000 \\
91,500 \\
180,000 \\
33,000 \\
22,000 \\
184.000 \\
190,000\end{array}$ & $\begin{array}{r}3,700,000 \\
618.000 \\
1,235,000 \\
10,300,000 \\
2.960,000 \\
8,500,000 \\
1.350,000 \\
2.180 .000 \\
5.100,000 \\
6.100 .000\end{array}$ & $\begin{array}{l}37.4 \\
39.6 \\
31.6 \\
46.4 \\
32.4 \\
47.2 \\
40.9 \\
99 . \\
27.7 \\
32.1\end{array}$ & $\begin{array}{r}193,497 \\
30,595 \\
84,902 \\
457.924 \\
154.870 \\
393.972 \\
78.146 \\
72.228 \\
417,400 \\
399.135\end{array}$ & $\begin{array}{r}250,800 \\
42,000 \\
105,419 \\
600,000 \\
192,000 \\
414,485 \\
104,353 \\
94,100 \\
511,500 \\
478.450\end{array}$ & $\begin{array}{r}3.889 .607 \\
618.964 \\
1.307 .163 \\
10.833,795 \\
3.936,091 \\
8.936,091 \\
1.395 .405 \\
2.255 .036 \\
5.335,543 \\
6.400 .473\end{array}$ & $\begin{array}{l}15.5 \\
15.5 \\
12.4 \\
18 . \\
16.4 \\
21.7 \\
13.3 \\
23.9 \\
10.4 \\
13.3\end{array}$ \\
\hline Totale & 350.227 & 790.811 & $|1,076.1 \mathrm{~m}|$ & $42,043,000 \mid$ & $\$ 39$ & $|2,272,669|$ & $|2,793.10 \%|$ & $41,937,16 \mathrm{~S}$ & $\neq 161$ \\
\hline
\end{tabular}

(Mr. Sterens' table brought the firures to 1915 only. The motor-vehicle registration for 1918 and 1919 is added from a recent eount by the $B, F$. Goodrich Rubber Co., hased on offieial figures from every State. It excludes dealer and motorcycle registrations. The population hy States is taken from the World Almanac for 1920. According to the Coodrich count the total motor-rehicle registrations for the United States for 1919 was $7,555,269$, or onc for every 14.2 inhabitants. This greatly exceeds Mr. Stevens' estimate.-ED.)

If the average life of a ear be three years, it seems possible that by 1920 we shall have on our lighways a total of not less than $6,000,000$ motor-vehieles, or one for every twenty inhabitants. This is about three times our present registration.

To eare for this traffie we have in the United States about $2,125,000$ miles of eountry roads, not eounting streets. What mileage has been "improved" it is impossible to say, for the word has no standard meaning. We are probably safe in assuming that for a satisfaetory system not less than $1,250,000$ miles of road must still be improved. With the ever-growing traffie and with the eonsequent demand for better construetion, the ultimate eost of this system will not fall short of $\$ 10,000,000,000$, and its eonstruetion will probably eover a period of not less than forty years. These figures do not overstate the ease. Many roads have been and will be built too narrow, too erooked, with exeessive grades and inadequate pavements. These should be widened, straightened, regraded, and repaved. They will also have to be provided with bridges designed for the inereasing weight of vehieles. However this may be, it seems safe to say that we have 
a big job on our hands, and that if we are to plan for its exeeution we must do so in a big way.

Let us eonsider the full extent of the problem-what we are now doing to solve it and what is needed to obtain good roads.

Assuming for a moment that in 1920 we shall have $6,000,000$ motor-vehieles and $6,000,000$ teams using our roads, that the motors will average 200 days at thirty miles and the teams 180 days at fifteen miles, we have totals of $36,000,000,000$ motorvehiele miles and $16,200,000,000$ team miles. The differenee in eost of operation on an improved as against an unimproved road may be safely put at not less than six eents per mile for both motor and teams. On this basis we would have $52,200,000,000$ vehiele miles at six eents, or $\$ 3,120,000,000$ - the total yearly saving.

I need only allude to the other gains due to good roadsthe opening up of the eountry, the development of industries, the improvement of the eonditions of agrieultural life. These cannot be readily estimated in figures, but the value is eertainly not less than the reduction in eost of haulage and probably exeeeds it manyfold.

The importanee of the interests involved would seem to warrant the expense of scientific and businesslike administration. Sueh administration we laek; we seem to have formed but a faint idea of our woful state of unpreparedness and of the seriousness of the results. Our present methods of road administration are inadequate.

While most of the States have preserved the eommon-law doetrine of the king's higliway, the treatment aeeorded to our roads has not matehed the dignity of their title. Generally, the roads, exeept in the ease of eity streets, are in the hands of some loeal body or of a turnpike eompany. The eare they have reeeived is sueh as might have been expeeted in a eommunity deseended from pioneer ancestry. The traditions still survive of the days when each man raised his own food, built his own house, and looked to no polieeman to enforee his rights. Any man, in those days, was supposed to be able to build and keep a road, and this belief is by no means dead. It shows itself in the underlying idea of our road administration, the turning over to township committees, seleetmen, or by whatever name they nay be known, 
the management of the greater part of our road systems. In most of our States we have plaeed bridges under the eare of somebody other than that in eliarge of the road.

On this substrueture many of the States have built, eaeh in its own way to provide for our inereasing highway traffie. The laws passed for this object may be grouped into two general elasses, following the lead set by the two States that first took up road improvement as a field for State activity, namely, New Jersey and Massaehusetts. The former undertook to aid counties in the building of improved roads, leaving the eare of the roads thus built to the county authorities; Massachusetts, on the other hand, set herself to building and maintaining a system of State roads made up of the most important through lines of traffie. Both of these represent eorreet prineiples. The State should care for the important through lines. Loeal bodies should be eneouraged to improve roads of seeondary importanee. Neither of these States, however, undertook to thoroughly provide for the proper eare of all of its eountry roads, nor, as far as I know, has any other State. Nothing less than this will meet the need. Every public road should be insured sueh intelligent eare as to furnish the best service of whieh it is eapable.

My own experienee as a road official may be enlightening. A meehanieal engineer by training, with seanty knowledge of roadwork and even less experience in public office, I was appointed five years ago head of the New Jersey Road Department. The appointment, I believe, was eonsidered a good one.

I expeeted to find very simple engineering, an ill-organized repair system, and more or less "graft." I found the engineering by no means simple, that proper reorganization of the repair system would require voluntary eoöperation and aeeptanee of State eontrol by the counties, many of whieh were jealous of each other and of the influenee of the department. I found no legal evidenee of "graft" and no reason for suspieion against the foree under my eontrol. This foree had been formed and had worked under department heads not one of whom had any previous engineering experience; it was personally well fitted for its work, but hardly large enough for its statutory duties and utterly insuffieient for the work neeessary to insure thoroughness. There was much duplication of work between the State and 
county forees and ill-loeated responsibility. While I eannot eomplain of any laek of good will, the work has been and is being done under eonditions that exelude any high standard of attainment and with the knowledge that no one expeets results to measure up to any sueh standard.

I may be slow-witted. I have had to waste mueh time in planning how to get the work done under legislation both unreasonably restrictive and often inconsistent and in learning to tie the red tape thereby required into the regulation bow-knots.

During my term of office almost every one of our neighboring States has ehanged the head of its road department. This brings us to a most serious defeet of our road administration, namely, that the head, whether a eommissioner or a board, is a politieal appointee, usually unskilled in road-work and frequently without any engineering training. Holding offiee for a term of years, subjected to great politieal pressure, and intrusted with wide powers, it would, indeed, be wonderful if these men did not frequently yield to considerations other than the best interests of our roads and err by dabbling in engineering matters.

Instead of appreciation of the seriousness and the needs of the situation, one generally finds in our legislatures a faith in the effieacy of eertain pet remedies and a leaning to numerous eheeks, safeguards, and investigations, the outgrowth of laek of eonfidenee in the road administration, fruitful sourees of delay, red tape, and waste, and godsends for the muekraker.

I have said that European experienee is of but limited value to us in the solution of our problem. The weight given in Europe to the administration of their roads is, however, instruetive. The Freneh Republie las been the elassie example of road administration. It compares with our ten States as follows, the Freneh motor-vehiele figures being for the period before the great war :

\begin{tabular}{|c|c|c|c|c|}
\hline & $\begin{array}{c}\text { Road } \\
\text { mileage }\end{array}$ & Area & Population & $\begin{array}{l}\text { Motor- } \\
\text { velicles }\end{array}$ \\
\hline France & 357,000 & 207,000 & $40,000,000$ & 122,000 \\
\hline Ten States ............ & 457,000 & 261,000 & $42,000,000$ & $1,076,000$ \\
\hline
\end{tabular}

In Franee all national roads and most of the departmental roads are under the eare of the celebrated "Ponts et Chausées" 
corps. This corps is the best and most thoroughly trained body of eivil engincers in the world. Their men are especially trained for the work from boyhood, as are cadets and midshipmen. Their life-work is in the corps. Their instruction covers the enginecring, the administrative detail, and the law referring to the subject. The standing of the corps personally and professionally is of the highest.

Contrast for a moment our conditions. There is no legal standard of qualifieations for an engineer, least of all a highway engineer. The job is seldom permanent. There is but little confidenec in the ability and but too often in the integrity of lighway officials. This is hardly to be wondered at when we recall that we are trying to carc for a fast-growing motor traffic, to-day sixteen times that of the French Republic, under the leadership of political appointees lolding office for limited terms and working under raws that make efficiency impossiblc.

To avoid any misunderstanding as to our highway engineers, let $\mathrm{me}$, in this connection, bear witness to the devotion and ability of those with whom I have been thrown in eontact. There are, of course, lamentable exceptions, but as a whole they are morally and technically of higher class than one would expect under the conditions. There is, however, little organization, no recognized standard of qualifications, and practically no interstate coöperation. Road societies there are, but these are organized to "boost" the cause of roads and only incidentally to afford technical training and interchange of data.

The very evident cure for our present evils and the best provision for the future is such legislation as will establish in cach State a highway force that will command respect and confidence in its ability. We must then state our problem, and this, too, will generally require legislation. Even in the smallest and in the sparsely settled States the cost and importance of the work will warrant thorough preparatory study. But little of this has been done. Te have tackled the job of improving our roads with an insouciance that would be almost laughable if its results were less ominous. Few, if any, States have any accurate idea of their country-road mileage, much less of its proper and economical development, and, I may add, practically none at all of the ultimate cost nor of the duration of the period of improve- 
ment. Yet all these can at least be approximately ascertained, and the public which pays the bill is entitled to the information.

For this purpose we should lay out a road system for eaeh State. Such a system will include roads of all elasses. If national roads become a fact they will form a separate class. There will also be the main lines of intra-State traffie, then roads of secondary importance furnishing the prineipal feeder lines for the State highways and connecting towns of secondary importance, and, lastly, the lesser roads corresponding to the capillaries in the system of blood circulation. Each of these elasses will call for different features of design and for different types of paving. For our greatest roads it would scem that the best will be none too good, for the smallest our means will demand that we adopt the most cconomical construetion. Without thorough preliminary study and planning we shall, beyond doubt, build roads, some insuffieient for their loads and others more eostly than their traffie will warrant. I may here point out that the permanent investment in a road is made up of the cost of the right of way and of grading. Drainage works and foundation courses may be or may not be permanent; the same is true of bridges; but surfaees are never permanent. If, however, we secure enough land and grade it properly at the outset, our investment to that extent is secure.

Our legislation should extend to all country roads. Streets present another problem. Just as physically and commereially all roads in a State form part of one system, so the State must provide that they be administered under uniform laws and in coördination. The public has a right to expect and the State should provide that every road be so kept as to give the best service of which it is capable.

There must be a strict, uniform, and scientific system of accounting and audit, including an accurate census of road traffic. The resulting data must be carefully analyzed to enable those in charge not only to make comparisons but also elcarly to account for the discharge of the trust imposed on them.

We must, in all cases, have sueh elasticity in statutory provisions as will eut the red tape down to a minimum.

The importance of the work to be done will justify provisions that will make highway engineering a eareer that will attract 
and hold young men of ability and energy. Material of this charaeter cau be trained to high effieieney if politics be exeluded, if promotion follow on proven fitness and diseipline be rigidly enforeed.

Road-work calls for analytieal study requiring the combination of expericnce, eommon sense, and teehnical training. It involves also, in the higher grades, difficult administrative work, whieh cannot be readily separated from the engineering and exeeutive ability of no inean order. This always demands and must rceeive good pay. A high professional standard for such a foree gives the members a pride in their organization and a eonfidence in its ability to do its work, without which it is uselcss to expect any full measure of sueeess or of public trust. This latter, I repeat again, is essential to any satisfaetory solution of our problem. Without it the public will not insist on the exclusion of politics from road-work, and before they will so insist the people must know that their business is being handled by experts and honest men.

The teehnical work to be performed by such a body should consist, in addition to the preliminary study needed for the laying out of road systems, of design, construction, and maintenance.

"Safety first," of whieh we have heard much of late, nceded but little consideration in the road design of the ante-automobile age. Any road was safe enough if it was good enough. Guardrails on higl embankments, avoidance of sharp turus at the foot of stcep grades, and a little eare at approaehes to bridges were cnough to makc a road reasonably safc at the speed and weights for which they were designed, say ten miles an hour and about three tons. It is no wonder that they have beeome "death-traps" when called on to earry traffic at forty miles with maximum loads of from twelve to fifteen tons. The solution of the guard-rail question is yet open. Any obstruction to the view within a distanec of from 350 to 400 feet is highly dangerous. Curves on or at the lower end of steep grades, narrowness, execssive crown, unproteeted ditches, badly placed trees or poles, and even the pipes often used to earry water aeross entrances, have become dangers that are taking a heavy toll of human life.

The most apparent dangers on our highways are the crossings over railroad and trolley tracks at grade. The elimination of 
these death-traps should never be overlooked. The cost of this work will form no small part of our future highway disbursements. Even when elimination is impossible, much may be done to deerease danger at erossings.

As to pavements, for minor roads this will always depend on the relative costs of locally available materials. Gravel, oystershells, and maeadam will probably always be able to provide for a considerable mileage of the lesser roads. Macadam with a blanket eoat of tar or asphalt, well maintained, will carry a eonsiderable traffic, but only at a fairly high maintenanee eost. For more important roads Portland cement eonerete and bituminous coneretes seem the most promising solution. Bloek pavements, briek, wood, asphalt bloek, and granite on a eonerete base will be required for the heaviest traffie and for sueh grades on bituminous concrete roads as may be found too steep for that material.

Roads must be designed for the speed and weights that will be used on them. Whether there be a statutory speed limit or not, it is not seriously regarded and will in time probably disappear. Any prudent designer to-day will eount on not less than forty miles. There is little use in providing a surface suited for such a specd without giving the corresponding widths and curvatures. Without knowledge of weiglits to be earried, bridge design is but guesswork. Pavements and foundation courses must be suited to the weights to be earried. Thesc should be regulated by legislation uniform in all the States. The paved way for important roads should not be less than eighteen fect on tangents; eurves should have radii of not less than 1,000 fect with inereased widths of paved surfaee.

Grades are a matter of both economy and safety; with bituminous surfaces anything in excess of five per ecnt. becomes too slippery for horses; automobiles also skid dangerously thereon.

Many of the minor appurtenances of our roads deserve and should receive more thorough study than has gencrally been given them. Road signs, for example, should be legible from whatever side approaehed. Rumning beyond a sign before being able to read it destroys, to a great extent, its uscfulness and is a souree of actual danger. Dust in exeessive quantities is not only a nuisance, but has beeme a serious danger. 
The correct plaeing of shade-trees and the selection of the species used are matters of importance. Trees must not be placed so near the driveway as to be dangerous. The same is true of telegraph-poles, sign-posts, ete.

The military features of our roads have been all but entirely overlooked. A few years ago a request for the views and advice of the War Department met with a polite but entircly unenlightening answer. Strategieally, roads must connect points of military importance. Tactically, they must be designed to earry necessary military traffic. In the light of the experience of the great war, this means that very heavy loads, guns of six and eight inch caliber, heavy motor-trucks, high-speed cars, cavalry and infantry must be accommodated. Less than three lines of traffic will hardly meet the requirements. Nothing less than thirty feet of graded width will do. Bridges must also be strengthened. It may well be that sereening will be required.

The designer must also carefully weigh the advantages of any proposed feature of design against its eost. He must bear in mind that the total road eost is divided into three parts: interest on the first cost; depreciation and up-keep, including the overhead charges due to administration, use of machinery, and, what is usually ealled the repair cliarge, the eost of the aetual labor and materials used in repair. What he now has in most cases is the repair charge only and that without traffic data. This eharge may be easily kept low by an expensive construction. It may well be that a low-priced road with eomparatively high repair charge will be the cheapest solution. Yet, on the other hand, too eheap a construction is sure to prove wasteful. It ean easily be imagined that the designer has ample field in which to show his ability.

We have generally built good roads as far as construetion work is coneerned. We have probably been a little too impatient for results and too casy-going to obtain all the accuraey in following a speeification that we find abroad. Our inspection, too, in many eases, may have lacked in intelligence and thoroughness, but on the whole we lave not done badly in this respect.

The up-keep of our roads has, on the whole, been disappointing. There are, of course, brilliant exeeptions. If we are to have good roads we must provide a system that will make good minute 
defeets as soon as they appear. This eannot be done without eonstant and competent inspection. The best way to provide this serviee will vary with roads of different materials and subject to different traffic intensities. Whatever method, however, is adopted, the importance of aceurate aceounting for all maintenanec expenditures will remain undiminished.

Our task is such a huge one that for suceess we must have teamwork. Our federal seheme of government is a hindrance in seeuring the interstate eoöperation that the situation demands. It is not only in the planning of interstate lines of traffie and in seeuring uniform laws as to elassification of vehicles and regulation of traffie that this need exists. We should have standardization of nomenelature so that, for instance, "improved road" will mean the same thing in Indiana and in New Jersey; standard system of road signs, standard methods of accounting, standard units of traffie and wear, and, in general, eoöperation and eoordination between our forty-eight State-road forces and the federal government.

That this coördination and the leadership needed for any teamwork can be supplied only by the general government is, to my mind, the unanswerable argument for federal aid. The gain by united and eoneerted effort will be greater than that due to any federal appropriation.

The finaneial problem involved is by no means the least of the many road questions that we must settle.

While building and after having finished the work, we shall have to keep up the roads already built. This will involve a tremendous outlay. The present total road repair eharge in this country is unknown, but we do know that much of it is wasted on unintelligent work.

We must evidently look to our sources of revenue. Benefits are conferred by road improvement on both the land-owner and the user of the road. The former pays through the ordinary tax levy. The latter pays a so-ealled lieense fee for his autoniobile only and nothing for his horses. It secms rational to look to the business on the roads for part of the cost of building and maintaining them.

Enough has been said to outline roughly, indeed, the many and very serious problems suggested by a foreeast of our road-work. 
The lesson to be drawn therefrom is the need of thorough organization of our road forces and of careful preliminary study. The interests affected are among the most important to the welfare of the nation. The investment will be gigantic in size, but can be made to return a benefit far beyond its cost if we will handle it as a business proposition. If, on the other hand, we rush into work of unparalleled magnitude without adequate preparation, if we continue to intrust its exceution to men unskilled in the work, closen mainly on account of past political scrvices and lacking public confidence, and if we kecp changing them as various partics may command popular pluralities, we shall pay the price of our folly.

\section{MITIGATING RURAL ISOLATION ${ }^{1}$}

\section{JOHN MORRIS GILLETTE}

THE statement is often made that the great urban problem is that of congestion of population while the chief drawback to rural life consists in the isolation of families and people. It is leld that life in cities is too compact while that in the country is characterized by too great an aloofness. Isolation is not solely a matter of spatial separation: the greater the distance persons are removed from one another the more intense the consequent social aloofness. On the contrary, isolation is in part a state of mind, one of the chief factors of which is a feeling of loneliness, and such a state frequently occurs among persons living amid dense urban populations. Perlaps the greatest hunger for luman association and friendship is often to be found in the midst of the tlurongs of great cities. Neighboring in cities is not always or mostly with those who live next door or in the same block. The urbanite's closest friends may be blocks or miles removed, necessitating the occurrence of social exchanges at infrequent intervals. Similarly the church and other institutions that are attended, the theater, the recreation place and the like, may be far distant, requiring a considerable journey to attend them.

1 Adapted from a Reprint from the Quarterly Journal of the University of North Dakota, Vol. VII, No. 2, University, January, 1917. 
Nevertheless, although there is danger of exaggerating the isolation obtaining in the country, the social aloofness that exists there is real, considerable, and serious. Grant to individuals living in cities friends and a standing in some circle or set of persons, and unquestionably opportunities for intercourse and amusement, culture and social service are not only much more numerous in cities than in country but in general the distance travelcd to reach them is less; and perhaps it should be added that transportation and communication facilities are better.

There are three proximate conditions which account for the rural social isolation existing in the United States; namely, spatial separation of families, fewness of social institutions, and what may be called the rural state of mind. These will be considered for the purpose of evaluating the difficulty of overcoming or mitigating them.

A fairly approximate perception of the degrec of separation obtaining among persons and families in each of the nine geographical divisions of the nation may be gained by dividing the rural population by the appropriate division area. This is only approximately correct for rural density since, besides the rural territory, the total division area contains the urban area; and further the rural population includes that of towns and villages, or all segregated populations of less than 2,500 inhabitants eacl. The latter statement is undoubtedly of greater import than the former, ereating the likelihood that the rural population density is somewhat, though not greatly, less than the accompanying figures indicate. The following table sums up the data:

\begin{tabular}{|c|c|c|c|c|}
\hline Division & $\begin{array}{c}\text { Division } \\
\text { Area }\end{array}$ & $\begin{array}{c}\text { Rural } \\
\text { Population }\end{array}$ & $\begin{array}{c}\text { Population } \\
\text { Per Square } \\
\text { Mile }\end{array}$ & $\begin{array}{c}\text { Families } \\
\text { Per Square } \\
\text { Miles }\end{array}$ \\
\hline New England. . & 62,000 & $1,097,000$ & 16 & 4 \\
\hline Middle Atlantic ...... & 100,000 & $5,593,000$ & 56 & 12.7 \\
\hline l.. N. Central ....... & 246,000 & $8,633,000$ & 35 & 8.1 \\
\hline W. N. Central ........ & 511,000 & $7,764,000$ & 15 & 3.3 \\
\hline South Atlautic....... & 269,000 & $9,103,000$ & 34 & 6.8 \\
\hline E. S. Central......... & $17: 0,000$ & $6,8.36,000$ & 38 & 7.9 \\
\hline W. S. Central ...... & 430,000 & $6,827,000$ & 16 & 3.2 \\
\hline Mountain $\ldots . . . \ldots$ & $\left.S_{5}\right) ! 9,000$ & $1,686,000$ & 2 & 0.47 \\
\hline Pacific & $31 \leqslant, 000$ & $1,810,000$ & 6 & 1.4 \\
\hline
\end{tabular}

(Abstract 13tl census, pp. 29) and 60.) 
Aeeording to this table, four of the divisions have thirty-four or more persons or practically seven or more families per square mile, the Middle Atlantie lıaving fifty-six persons and alınost thirteen families per such area. Where there are cight familics to the square mile they might be so located in that space that the lomes need be only about onc-fourth of a mile apart. What really oceurs is that the homes are placed along adjaeent lines of travel and lie eomparatively near cael other. In the ease of three divisions, eontaining over three-tenths of the total rural population of the nation, there are from threc to four families to the square mile, requiring a separation of homes of perhaps one-half mile or more. The Mountain and Pacific divisions contain about onc-twelfth of the rural population and in these divisions the fainilies must be on the average from a mile to over two miles removed from one another.

In the typieal rural community are to be found chureh and sehool generally, although there are many neighborhoods without clunrehes. Farmers' elubs arc developing rapidly but are not yet suffieiently numerous and universal to be eonsidered typical of farm eommunities. But perlıaps Grange, Society of Equity, the Union, or some sueh organization might well be included. This list which is liberal practically exhausts the list of institutions which rural neighborhoods eommonly possess and enjoy. In the town-country communitics (villages with the elosely assoeiated surrounding agrieultural region) no doubt should also be ineluded the lodge. The typieal eity community supports sehool, church, saloon (save in prohibition territory), lodge, play houses, danee halls, movies, pool halls, and kindred plaees. Besides these the shops, stores, fuetories, and streets bring individuals into frequent eontact. Certainly institutional faeilities for soeial interehange in the typieal urban neighborhood are far more abundant than in the typieal farm eommunity.

Relative to their quality for purposes of soeial intcrehange the institutions of the eity eommunities are likely to be superior. The avcrage rural church is an anaehronistic, semi-deeadent affair. It typically eomprises a one-room building where all aetivities must be aecommodated. It praetiecs what aptly has been ealled "ministerial vivisection," the distribution of a minister's services between two or more eluurehes, with the prob- 
able eonsequenee of being ministered to by a man of inferior training or ability. In eonsequenee of these conditions, not to speak of others, its aetivities are few and listless.

The typieal country sehool is likewise a backward institution. It, too, is a small one-room affair, without facilities for diversified instruetion, sustaining an ill-adapted course of study, with too few pupils to ereate competitive interest in elass work or to sustain organized play. It is ungraded, demands a multiplieity of brief elasses daily, and is taught by a poorly paid, poorly trained pedagog. In eontrast with these the average eity ehureh and sehool appear to be very progressive and effieient institutions, and the other ageneies found in urban neighborhoods but not in rural are of equally prepossessing eharacter.

Rural eonsciousness, or the form the rural social mind takes, is a large faetor in the produetion of rural isolation. What may be phrased "passive rural-mindedness" operates as an effieient but indircet cause of such isolation. This form of eonsciousness eonsists in being satisfied with aloofness, paueity of social organizations, dearth of eontact and eommunity activities, with the eonsequenee that the individuals so eonditioned do nothing and want to do nothing toward improvement. Of eourse those who are so minded are not aware of it any more than do the mass of people take eognizanee of the soeial eustoms and modes of proeedure of the national, elass, or loeal groups.

Not all inhabitants of eountry districts are possessed by passive rural-mindedness. Some there are who are "urban minded," being diseontented with rural life and having a strong desire to dwell in the eity. Probably only the powerlessness to seeure the finaneial means to earry out a suecessful removal stands in their way of joining the urban ranks.

Again there is a state of eonseiousness which may be ealled "aetive rural-mindedness." Those who are aetively rural minded dwell in the eountry beeause they wish to do so. Nevertheless, they are intelligent regarding the defieieneies in rural eommunity matter's and positively desire and strive to remedy them. This body of eitizens eonstitute the hope of the eountryside. However it is likely that the passively-minded individuals are in the majority, thus making ehanges toward a better situation diffieult and slow. 
That rural soeial isolation is regarded as undesirable by country people is attested by several sets of events to be mentioned without discussion: the flow of large numbers of persons from country to eity; the settlement of retired farmers in neighboring towns and villages; the frequent testimony of intelligent ruralites to the irksomeness and the undesirability of the eustomary social poverty; and the response to the introduetion of social facilities by practieally every elass of non-urban residents, including the group we have alluded to as the passively ruralminded. That the latter elass respond is not ineonsistent with ealling them passively rural-minded, sinee they may take advantage of privileges without participating in their establishment.

Perhaps the most severe strain arising out of this situation is suffered by the women of the farm homestead, espceially by the mother. IIer sphere of practical aetion is within the confines of the house, she cannot meet the neighbors at the borders of the adjoining fields as eity women may talk across lots, nor in the exchange of tools and work does she have the opportunity to eonverse as do the men of the farm, and her field of coöperative exehange is limited. Neither does she go to the neighboring town for marketing and repair purposes as often as the men. Further, her work is of a routine naturc, lacking the variety and the occurrence of new situations that call for inventive talent which the activities of the outdoor workers involve. That farm women age mueh earlier in life than do the men is no doubt partly due to the greater absence of intelleetual incitement.

The problem of rural isolation has attracted much attention and naturally has brought forth a number of proposals for solutions and panaceas. One of the most short-sighted and brutal suggestions is what may be called "familism." It is asserted that the social activities and satisfactions of rural inhabitants inevitably must be limited to the sphere of the family, sinee that institution represents the scope of normal human association possible to country distriets. This proposal flics in the face of aceomplished faets and is only a dogmatic generalization from a narrow range of data. It is doubtless true that the majority of rural inhabitants realize the larger portion of their associational life within the family and that many will do so for some time to comc. But notwithstanding the fact that the fanily is a most 
worthy and indispensable institution and that it is destined to furnish much of the soeial eontaet for both rural and urban inhabitants in future, it must be said that it is too small, unresoureeful, and monotonous to supply eomplete assoeiational satisfaetion. Moreover, multitudes of eountry neighborhoods have established and now enjoy larger eommunity organizations. The trend of the rural movement without question is toward the creation and the adaptation of varied reereational and social faeilities.

Another proposition is that Ameriean farmers shall abandon their present system of widely distributed, separate homesteads and segregate themselves in some kind of eentral farm village. Various aetual and ideal types of sueh eommunities present themselves, some of whieh deserve attention.

The European form of farm village is generally thought of when the proposal in question is eonsidered. European farmers almost universally live in small segregated communities, proceeding from these during the daytime to proseeute their agrieulture on the outlying farms. In Ameriea, also, are to be found a few types of agrieultural village. In various seetions of the United States immigrant Mennonites have established themselves in such eommunities, very largely reprodueing here the eustomary European prototype. The most indigenously Ameriean farm village is to be found among the Mormon settlements of the western portion of the United States and Canada. When the Mormons settled Utah they designated an agrieultural eommunity somewhat peculiar to themselves. The Mormon settlers and reeruits were to settle in eenters, all of which were built from a common plant. Eaeh village resident had a eonsiderable plot of land surrounding his house, another plot of a few aeres just outside the eenter, a still larger pieee still farther removed, and might have more land still farther distant. The dwellings are eharaeteristically arranged relative to each other to seeure family privaey. A further important eharaeteristie is that the chureh is the eenter of community interest and lies at the foundation of the Mormon farm village plan.

Besides these existent types of agrienltural villages, a strictly eoöperative farm village eommunity has been urged. It is proposed that not only dairies and ereameries, but also laundries, 
kitehens, dining halls, and all pliases of domestic and distributive economie busiuess should be eoöperative.

These plans of and proposals for farm villages possess both interest and value, nevertheless they are eonfronted by several obstaeles and objections. First, the great majority of Ameriean farmers have mueh eapital invested in louses, barns, other buildings, orehards, and other home equipment on their separate allotments of land. To make a change to sueh a eompletely different system of living as the farm village represents would involve the destruetion of muel of the capital so invested and the ineurring a large removal expense. The eeonomie loss involved in the proposal is so heavy that we cannot expect seriously to see it exeented.

Seeond, to the average farmer it would seem a eostly ineonvenienee to drive daily several miles to earry on his farm work. Where farms are small, as most of them are in Europe and to a less extent in the irrigable seetions of the United States, the distanees to the outlying land are not great. But the average size of farms in the United States is 138 aeres. Were the farm village large enough to be of any great soeial advantage it should eontain probably 100 families. This being so, in a distriet eomposed of average sized farms, the more remote farms would be about four or five miles removed from a eentrally loeated village. This would mean a daily drive of eight or ten miles, whieh is praetieally prohibitive beeause of the eeonomie loss involved.

Third, a small village of the usual type possesses questionable advantages, soeially, when eompared with open eountry communities. Without the fuller soeial life, intelleetual interests, ideals, and resourees of the larger urban aggregations, the petty gossip, jealousies, and biekerings are not eondueive to inereased satisfaetion or a higher existenee. The paueity of recreational and amusement faeilities, the almost entire absenee of those of a wholesome kind, espeeially for boys from ten to sixteen ycars of age, engenders idleness and the resorting to vieious gangs and forms of sport which are demoralizing. The average small village in the United States represents one of the most deadening and disheartening forms of eommunity, and, as a problem, ehallenges the serious attention of the Ameriean nation.

The siggestion of a eoöperative form of farm village is worthy 
of consideration. That the scheme is Utopian should not condemn it in advance. Its real test is, can it overcome the diffculties just presented relative to farm villages in gencral?

In the case of the establishment of new agricultural communities, especially in irrigation districts where farms are small, the coöperative proposal is most deserving of attention. Aside from these relatively infrequent situations, the heavy investment in separate farm plants and the remoteness of the majority of farms from the central villages would appear to make the proposal impracticable.

In view of these considerations we may regard our present system of distributed and separate farm homesteads as permanent, and are forced to conclude that the initigation of rural isolation must come from other directions. In this connection it is worthy of note that in agricultural Utah there is an observed tendency toward independent farm homes. From the top of the divide between Cache and Salt Lake valleys in Northern Utah it is seen that in the former valley, which was settled very early, there is an occasional homestead in the open country while in the northern portion of the former, a region settled more recently, scparate farm homes appear to be the rule.

Considerable may be expected from the improvement and extension of the rural communicating system, including under this caption roads, rural delivery, automobiles, interurban trolleys, telephones, and periodical literature. Fach of these agencies is making its contribution toward the establishment of a more effective rural solidarity and also toward bringing country and urban districts into eloser touch.

Improved and extended roads are essential to the development of the economic interests of agriculture and are the indispensable foundation for all larger community organizations and activities. The larger organizations which the improved rural church, the consolidated school, farmers' clubs, and recreational and community centers are demanding can matcrialize only as the highways are built to permit rapid and comfortable transit.

The automobile and rural delivery are serviccable in creating larger contacts and in stimulating the building of a better lighway system. Where population density warrants the establishment of rural free dclivery of mail, rural routes are assigned by 
the national government on eondition that the routes to be used in earrying the mail should be put and kept in passable shape. Organizations and individuals interested in the extended use of the automobile are promoting both local and inter-community highway improvement. Since so many farmers have become owners of ears, they have the more heartily joined the movement for the establishment of good roads.

The automobile quickens rural life by bringing families and communities into closer and more frequent contact. Distances which once took hours or days to compass by horse or horsedrawn vchicle, now are covered in a few minutes or hours. Could every farmer possess an automobile, the problem of establishing larger and better rural institutions in considerable measure would be solved because transit would be speedy and easy and because the care of teams involved in travel by horsedrawn vehicles would be obviated.

Rural frce mail delivery and the circulating library are effective agencies for reducing isolation. The former places within reach of out-of-town residents the possibility of daily contact with the world of events by means of the daily press; makes possible more frequent correspondence with friends and relatives; and helps cultivate a habitual perusal of periodical and library literature. In its turn the circulating library brings to neighborhoods which command its services the enlivening store of fiction, the inspiration of good literature, and the practical knowledge of the whole range of natural and social science.

A definite local communitization of rural districts constitutes a further method of mitigating rural isolation. Communitization takes place to the degree to which the inhabitants of a particular locality think and act together, the alternative, individualization, being most often obscrved in the country, in that residents of such locality think and act as if they were only individuals. It is highly desirable that people generally, and rural inhabitants especially, should cultivate a neighborhood outlook, appreciate the good results which flow from increased coöperation, and set about establishing the agencies for realizing the community spirit. 


\section{SOCIAL SIGNIFICANCE OF THE AGRICULTURAL PRESS ${ }^{1}$}

\section{J. CLYDE MARQUIS}

THE influence which the printed page has had upon agriculture eannot be definitely measured. The idea has been generally aeeepted that praetieal and, especially, suceessful farming has until reeently been conducted apart from the direetions given in books. The disfavor with whieh the eountryman who eonsiders himself espeeially praetieal has regarded those who eonsult the written experiences of others in books has been too generally dwelt upon in discussions of the literature of agrieulture.

The influenee of the printed page is particularly snbtle. The easual reader often believes that he has reeeived no benefit from an aeademie treatment of a topie, yet his subsequent methods are indisputable evidenee that he has absorbed an idea and adopted the suggestions, even though he believes he has not. To say that the most important single influence for the improvement of agrieulture has been the periodieal press would be both trite and unneeessary, yet no discussion of the influence of the printed page upon agricultural methods would be complete did it not begin with this premise.

A sketeh of the development of agricultural literature is necessary to seeure an adequate appreciation of its importanee. Its beginnings are unknown, and there were probably treatises on practieal agrienlture in early periods of Chinese history of which we now have no record. There are only oceasional glimpses of the development of the art of husbandry in the early history of man. These appear in Biblical literature and in Egyptian reeords and later become more evident in the writings of the Greeks and Romans.

The first foundations of the literature of husbandry which may be said to support the present structure were laid by the Roman writers, and many of the fundamental propositions presented by them may still be accepted with trifling modifications. The husbandmen of to-day would be benefited greatly by a thoughtful perusal of the adviee of Cato and Cohmella.

1 Adapted from Annals of the Amer. Aead., 40: 158-162, March, 1912. 
Following the Roman period there is a stretch of centuries until the time when the early English writers appear. Arthur Young has been mentioned as the forcrunner of our modern agricultural writers, and lie unquestionably set a standard which has been seldom equaled and rarely surpassed in deseriptive and helpful writing on rural topies. The awakening which resulted from the entertaining works by Young was the beginning of the agrienltural revival in England, and was also coineident with the beginning of modern agriculture in America. The friendly relations between Yonng and George Washington unquestionably had eonsiderable to do with the popularity of the writings by the former in America.

Among American pioneers were a few eapable, foresighted men who appreciated the importance of permanent records in agriculture, and their work is principally to be found in the procecdings of the various agricultural societies then in the forefront of the agricultural advance. Even before the opening of the nineteenth century there was a considerable volume of helpful agricultural literature not only in proeeedings of societies but in a few periodicals and in a number of cxecllent books. Following the opening of the new century tle inerease in printed matter relating to the farm and the field was steady but slow. Periodicals appeared and after more or less successful eareers were absorbed, transformed or abandoned until the end of the first quarter of thic century found very little substantial advancement. Beginning about 1830 the quantity and the character of books and journals on agriculture received a considerable impetus. Capable men began to realize that an interchange of ideas was necessary. Boolis for farmers could no longer satisfy those who were interested in a given subject because of the distribution of the people over a wider area and the growing complexity of rural problems. The earlier journals were published and edited by men of ideals, backed by the courage of aecomplishment, who looked upon their journals as ageneies for progress rather than merc commercial enterprises. They stc od for certain reforms and improvements, and though sometim $\mathrm{s}$ radical and extreme in their methods, their purpose was on the whole to improve agriculture, which they unquestionably did.

The three prime divisions of agrieultural literature then, as 
to-day, were: First, the periodical; seeond, the public and semipublic document, and third, the book, the three standing in this order as to numbers distributed. Periodicals reach a larger audience than cither the proceedings of soeietics, some of which are private and others semi-publie documents, or books which have a more limited eireulation but perhaps a greater influenee upon those who are actually reached.

As a eonelusion of this hasty glanee at the development of agrieultural literature, we find at the beginning of a new eentury that periodical literature is most higlly developed and speeialized, and, in the opinion of many, commereialized to all extreme degree which must sooner or later result in the eonsolidation or transformation of many journals. With approximately five hundred periodieals devoted to one or many of the phases of agriculture and related topies, the field of periodieal literature may be said to be erowded. These numerous periodieals send out literally millions of copies each week, and while a large proportion of the rank and file of rural people do not read a periodieal regularly, all are touehed direetly or indireetly by the ideas thus distributed. Were they properly distributed, there would be several eopies eaeh month for eaeh person engaged in agriculture in the entire eountry. This eonsistent dissemination of literature, going on as it does without eeasing and with growing foree, eonstitutes the greatest ageney for agrieultural improvement.

Next in order of importanee must be placed the publie doenments. They have inereased in numbers within the last deeade with great rapidity, and within the past five years the quantity of reliable free literature for the man on the farm has been almost doubled. There is little doubt that this inerease will eontinue for some time to come. The reeognition by the daily newspaper of the importance of agrieulture, and eonsequently the regular appearanee of departments eoneerning suel matters is one of the newest and most signifieant phases of this rapid inerease of printed matter on farm topies.

For the books on agrieulture there is less to be said. The most valuable works now found in our libraries are the produet of the last deeade. The tendeney for more popular and attraetive literature has unquestionably brought down the average 
quality of the books produeed. The new book that will remain authentic for a decade is the exception, yet there are many books now near the end of their second decade of popularity that continne to meet with a large demand. The character of the new works on agriculture is on the whole entirely helpful, since a new type of literature which is both interesting and instructive is certain to be evolved through the experience of the publishers.

To pass to the social significance of this literature, its improvement in quality and its increase in distribution and in influence are due to the appearance of a generation that is prepared to be benefited by it. As soon as men are trained to put human experience in rural affairs into forceful, convineing writing, the reader will be able to secure more material aid from such writings. The facility with which reliable matter may be secured is the greatest point in favor of its development. We receive our new agricultural thoughts in our daily press along with the news of progress in other industries. The organization of press bureaus within the last few wccks by the agricultural colleges, state experiment stations, boards of agriculture and federal organizations is an important advance step in this direction. Few items of particular significance in agriculture now escape the daily press, and whereas such news was previously written in a form designed to be of general interest, it is now prepared by a special writer often trained in agriculture, so that it is both interesting and accurate.

Plans are in operation in several state experiment stations to send regularly to the local newspapers carefully prepared matter designed to meet local needs. This newspaper matter on agriculture is closely followed by the dissemination of clcarly written and attractive circulars and bulletins dealing with special topics. These appear either as reading courses or as separate publications just as the subjects are timely. Bulletins of this character are now being issued regularly by a large number of the leading experiment stations and boards of agriculture, and are being distributed through the mails, at farmers' mcetings, banks, etc., until the numbers that are actually placed in the hands of working farmers aggregate millions of copies each year. The printed proceedings of state and local associations of stockmen, horticulturists, grain-growers, etc., are distributed to $\mathrm{mcm}$ - 
bers and others at praetically no eost to the reeipient. A library eomprising literally tons of material, most of it trustworthy, is being assembled by many farmers at absolutely no eost beyond the postage on their letters of request. The eonsumption of agrieultural books has inereased markedly during reent years. The extension of leeture eourses into outlying distriets has gained the attention of several people who as a eonsequenee beeome interested in following up these addresses by a eareful study of the books written by the same men. Onee the working farmer has a taste of the benefits whieh he ean seeure from a eareful study of sueh literature he demands large quantities of printed matter.

Mueh of the agrieultural literature of the.past deeade has been loeal and speeifie in that it has dealt with partieular problems as they exist in a partieular eommunity, and has not been designed to broaden the farmer's soeial relations. It is noteworthy that a large pereentage of the newer literature deals with lis soeial relations; the periodieal press as well as books and publie doeuments now deal with soeial questions. The traveling library, whieh is growing rapidly in favor in rural eommunities in many states, now has its quota of good books and bulletins dealing with agrieulture. The shelves of the reading-rooms of all kinds of gathering plaees for eountry people now bear their burden of the new literature. While much of it falls far below the standards established by the best writers, the influenee whieh it has is on the whole benefieial. Agrieultural literature is on the average of as high a quality as the teehnieal literature of any industry, and if judged with eonsideration of its quantity it perhaps exeeeds in interest and helpfulness the average of the printed page of other industries.

The present need is not so mueh more literature as a better interpretation of farm problems, both eeonomie and soeial. There is a vast amount of repetition and generalization in present-day writings. New ideas and details are growing less frequent from day to day. In the mass of literature a signboard is needed to point the way for the uninitiated. This interpretation of the printed page is expeeted to be the next important advanee in the field of the literature of the farm. 


\section{THE SOCIAL VALUE OF THE TELEPHONE ${ }^{1}$}

\section{G. WALTER FISKE}

Amovg these modern blessings in the country home, one of the most significant is the telephone. $\Lambda$ business necessity in the city, it is a great social asset in the rural home, like an additional member of the family circle. It used to be said, though often questioned, that farmers' wives on western farms furnished the largest quota of insane asylum inmates, because of the monotony and loneliness of their life. The tendeney was especially noticeable in the case of Scandinavian immigrant women, aceustomed in the old home to the farm hamlet with its community life.

To-day the farmer's wife suffers no such isolation. To be sure the wizards of invention have not yet given us the teleblephone, by which the faces of distant friends can be made visible; but the telephone brings to us that wonderfully personal element, the human voice, the best possible substitute for the personal presence. Socially, the telephone is a priceless boon to the country home, especially for the women, who have been most affected by isolation in the past. They can now lighten the lonely hours by a chat with neighbors over household matters, or even have a ncighborhood council, with five on the line, to settle some question of village scandal! All sorts of community doings are speedily passed from ear to ear. Details of social plans for church or grange are conveniently arranged by wirc. Symptoms are deseribed by an anxious mother to a resourceful grandmother and a remedy prescribed which will cure the baby before the horse could even be harnessed. Or at any hour of the day or night the doctor in the village can be quickly summoned and a eritical hour saved, which means the saving of a precious life.

On some country lines a general ring at six o'cloek calls all who eare to hear the daily market quotations; and at noon the weather report for the day is issued. If the weather is not right, the gang of men coming from the village ean be intercepted by 'phone. Or if the quotations are not satisfactory, a distant city can be called on the wire and the day's shipment

1 Adapted from "The Challenge of the Country," pp. 66-68. Association Press, New York, 1912. 
sent to the highest bidder-saving money, time, and miles of travel.

All things considered the telephone is fully as valuable in the eountry as in the eity and its development has been just as remarkable, especially in the Middle West where thousands of independent rural lines have been extended in recent years, at very low expense.

\section{BibLiography}

\section{COMMUNICATION AND TRANSPORTATION}

Bing, Phil. Country Weekly. Appleton, N. Y., 1917.

Morton, M. B. Agric. Press. Relation of the Press to Agrieulture, in Proceedings 12th Annual Session, Middle Tenn. Farmers' Institute, Nashville, 1913.

Thorpe, Merle. The Coming Newspaper, Holt, N. Y., 1915.

University of Missouri Bul., Journalism Series, Columbia.

The County Newspaper, No. 2, pp. 22-34, May, 1912.

The Ideal Country Paper, July, 1914.

Building a Cireulation-Methods and Ideals for Small Town Newspapers, Powell, J. B., No. 6, Feb., 1914.

The News in the County Paper, Ross, C. G., No. 4, Mareh, 1913.

Women in Country News Work, Dutter, Mrs. C. E., No. 5, pp. 21-22, May, 1913.

Writing for Farmers, Shamel, C. A., No. 5, pp. 29-33, May, 1913.

Circulating the Newspaper Among the Farmers, Rueker, Frank W., No. 20, pp. 3-9, Sept., 1919.

Reminders for the Country Editor, Finn, Bernard, No. 11, pp. 31-33, May, 1915.

Current Agricultural Journals. Cyclopedia Am. Agriculture, Bailey, IV : 78-87.

Wallace, J. P. Journalism, How the Farm Paper Helps the Implement Dealer, Wallace's Farmer, 41; 234, 235, Feb. 11, 1916.

\section{ROADS}

Campbell, A. W. System of road building in Canada. Modern Road Building, First Report of Congress of $\Lambda$ meriean Road Builders, Seattle, Wash., 1909 , p. 55.

Carney, Mabel. Roads and the Road Problem. Country Life and the Country Sehool, pp. 108-133. Row, Chicago, 1912.

Flagg, Ernest. Road Building and Maintenanee and Examples of Frencl 1 and English methods. Century 79:139-144. November, 190 9.

Gillette, Joln M. The Inprovement of Transportation and Communieation. In his Constructive Rural Sociology, pp. 110-116. Sturgis, N. Y., 1912.

Gross, H. H. Highways and Civilization. Modern Road Builders. Report of 1st ('ongress of Ameriean Road Builders. Seattle, Wash., 1909, p. 210. 
Laut, Agnes C. Price We Pay for Bad Roads. Collier's, 42:14-15, July 17, 1909.

Moore, W. H. The Social, Commercial and Economic Importance of the Road Subject. Cireular 34, Office of Good Roads, Washington.

Official Good Roads. Yearbook of the United States, 1912.

Page, Logan Waller. Good Roals-the Way to Progress. World's Work, 18: 11807-19, July, 1909.

Roads and Canals, Cyelopedia of $\Lambda$ merican $\Lambda$ griculture, IV : 320-8. Roads, Patlis and Bridges. Sturgis, N. Y., 1912.

Parker, Harold. The Good Roads Movement, Annals, 40:51-8, March 1912.

Pennypacker, J. E. State Management of Public Roads; its Development and Trend. United States Department of $A$ griculture Yearbook, pp. 211-26, 1914.

Pope, Jessie E. Rural Communication, Bailey, Cyclopedia of American Agriculture, IV : $312-320$.

Powers, E. L. History of Road Building in the United States. Modem Road Building. Report of 1st Congress of American Road Builders, Seattle, 1909 .

Pratt, J. H. Good Roads Movement in the South. Annals, 35: 105-13, January, 1910.

Ravenel, S. WT. Ravenel's Road Primer for School Children. McClurg, Chicago, 1912.

Shaler, Nathaniel S. American Highways. Century, N. Y., 1896.

Sipe, Susan B. Good Roads Arbor Day. Suggestions for Its Observance. U. S. Bureau of Education, Bulletin No. 26, 1913.

Streets and Highways in Foreign Countries. Special Consular Reports, 1891, Vol. 3. U. S. Bureau of Foreign Commerce.

Vogt, Paul L. Means of Communication and Rural Welfare. In his Introduction to Rural Sociology, Chapter IV. Appleton, N. Y., 1917.

Waugh, F. A. Rural Improvement, pp. 36-58. Judd, N. Y., 1914. 


\section{CHAPTER XI}

\section{CORRECTIONAL AGRICULTURE AND RURAL POLICE}

\section{A. CORRECTIONAL AGRICULTURE}

\section{THE OUTDOOR TREATMENT OF CRIME ${ }^{1}$}

HARRIS R. COOLEY

THere is no distinct outcast class of offenders. The establishment of the outdoor or farm prison is one expression of this new attitude. It is a long step from the gloom and depression of the felon's cell to the sunlight and fresh air of the open field. The normal environment of the country tends quickly to reëstablish a normal life. The open-air treatment is as helpful to the vietim of vice and erime as to the vietim of tubereulosis.

In a number of the institutions of our eountry the outdoor methods have been tried with marked suceess. Dr. Lconard, Superintendent of the Ohio State Reformatory at Mansfield, has the spirit and attitude toward his young men wlich arouse in them a surprising sense of honor and fidclity. There are nearly a thousand prisoners, many of them eommitted for most scrious offenses. A school of conduct or of cthies helps to maintain the moral atmosphere of the institutions. The trusted men enter into a formal bond with the superintendent. Out of eighteen hundred young, vigorous fellows who have been trusted to work out on the six-hundred-aerc farm, only nine have violated their trust and run away. As one sees these men in the open, sunny ficlds, many of them without guards, doing faithfully their daily tasks under normal conditions, it is diffieult to rcalize that a few ycar's ago they would have toiled inside erowded, gloomy prisons with heavily barred windows. They themselves liave construeted their shop buildings within the wall for the employ-

1 Adapted from the Outlook, Vol. 97:403-8, Feb. 25, 1911. 
ment for winter months and stormy days, but these are as full of light and fresh air as a model factory. The institution impresses you as a training-school with a helpful, hopeful attitude toward life.

The Province of Ontario, under the direction of the Provincial Scerctary, W. J. Hanna, is developing an outdoor prison at Guclph. The spirit of fellowship, coöperation, and confidence prevails. Some temporary buildings shelter the prisoners who work under the open sky, cultivating the soil, ditching, grading, and making roads. One of the Canadian pastors, who perhaps lad been skeptical about the project, walked over the farm and saw the groups of men laboring in the ficlds. He said to me, "I was so moved by it that I went off by myself and cried." In his cnthusiasm the liead officer declares that "the prisoners have done a grcat work." With this attitude the Guclph Prison Farm will do much for the imprisoned, and still more for the citizenship of Ontario.

In Cleveland we began the outdoor treatment by purchasing a group of farms ten miles from the city, and before any permanent buildings could be erected we tested the plan by taking "trusties" and other prisoners from the City Workhouse and lodging them in the old scattered farm-houses. Our farmer neighbors were frightened. Our friends prophesied that the prisoners would all run away. The plan worked. Most of the men completed their sentences, giving faithful and willing scrvice. We ourselves have been surprised at times at the results of some of our ventures with these men. The confidence placed in them, the useful work in garden and field, the tonic of the sky and trees, developed a new sense of honor and a common sentiment that it is a mean and cowardly thing to "take a sncak from the farm."

In four years five thousand prisoners served time on the Correction Farm. These men have worked at excavating for our buildings, quarrying and crushing stone, grading, road-making, under-draining the land, clearing dead timber from the forest, and doing gencral farm labor. They have had better food, for they liave raised it themselves. The officers in charge of the working groups of laborers have becn really foremen rather than typical prison guards, The purpose has been not 
simply to locate the institution in the conntry, but to have a great estate as a basis for unlimited useful employment, and also as a means of controlling and shaping a large environment. The Correction Farm is part of a great tract of nearly two thousand acres, or more than three square miles, on which are the Tuberculosis group, the Almshouse group, and also an extensive municipal cemetery to be graded and developed by prison labor. The arca is so large and diversified that the Almshouse group is a mile and a half from the Correction group, and two hundred feet higher. Each of the four divisions is distinct on its own five hundred acres, yet out on the broad fields and in the light, airy shops of the Correction buildings every prisoner can be used at his best in the raising of food and the making of all those things which will add to the life and comfort of themselves and the other unfortunates who are the residents of the Farms.

A visiting judge said to me, "It is so fine out here, I should be afraid some of these prisoners would want to stay." Near by a group of men were shoveling dirt into a grading wagon. I said to him: "Judge, you see those men at work; they are drinking an abundance of pure water, they eat heartily, they sleep well. They say to themselves, "This is not "made work," this is real, genuine work. Free men right over there are getting a dollar and a half a day for doing this.' The old prison cell, the food, the confinement of their labor, tended to depress them and to make them hopeless. This treatment quickly brings them to themselves and arouses the normal man. There is a psychological clcment, which you have not thought of and which we did not fully foresee, which makes these men more anxions to go back and again take their places in society and industry. At the expiration of their sentenees they go out withont the prison pallor, stronger in the face of temptation, and ready at once to do a full day's work."

For the friendless prisoners when released a Brotherhood Home Club grew up in the city, largely througl the efforts and support of the men themselves. The purpose of the Brotherhood is to find them employment and to provide for them a comfortable place in which to live until their first pay day.

That the colony movement is the outgrowth of a common feel- 
ing and attitude is manifest from the fact of its springing up under varying conditions in different countries. In 1892 the Belgian Government began the organization of Merxplas in a barren and desolate region twenty-five miles from Antwerp. This is a penal colony established primarily for vagrants, but which receives offenders with sentenees as long as scven years. There are at present about five thousand prisoners. The grounds are laid out on a broad, general plan. The men liave constructed the buildings, including a finc church. They take pride in earing for the surrounding lawns, the trees and flowers, the gardens and orchards. The group is in the midst of a great tract of cultivated fields, green pastures, and planted pine forests. Director Stroobant estimates the present value of the estate at a million dollars. To develop all of this out of the naked, barren land must awaken interest and hope in the hearts of many of the laborers. Those who had special tasks in the care of the stock seemed to feel an ownership in the horses and cattle. One prodigal son showed us a young pig which he had in his arms.

With a small military guard as a rescrve, these five thousand irregulars and unfortunates arc controlled and directed by a staff of only eighty wardens. Some of the better prisoners assist in the supervision of the work. The most serious offenders are confined in buildings with large interior courts. They are thus held more securely, and also kept from direct association with the others. Their open courts, however, furnish opportunity for much outdoor life and labor.

In addition to work on the farm, other industries are carried on, such as brick and tile making, wood-working, mat, boot and shoe making, weaving, and tailoring. The men receive small wages, a part of which is paid in colony money, which they can spend. The balance is paid to them on their discharge. As one sees the multitude of men, quiet and orderly, going to their vaious places of employment, he is convineed that it is possible to conduct even a great centralized prison on the general colony plan.

In many ways the model prison farm of Europe is Witzwill. It is on a mountain-girt plain about thirty miles west of Berne, Switzerland. The great tract of two tlousand acres, which for- 
merly was wet, boggy, and known as the great Moss, has been, by draining and eultivation, transformed into a beautiful and valuable estate. There are two hundred and fifty prisoners, with sentenees of from two montlis to five years. The men themselves have eonstrueted the Swiss buildings, the barns, workshops, dormitories, and dwellings. They seem fond of working with the animals. With the oxen and heavy wagons, they eame trudging in from the harvest-fields for their noonday rest. They have fifty horses and seven hundred head of eattle. Aeeompanied by twelve of the prisoners, the young stoek had been sent for the summer months to the pastures of the higher mountains. They sell butter, eheese, and vegetables, but all manufaetured goods are for the institution or the State.

The spirit of eonfidenee and demoeraey is manifest. The guards or foremen were washing up for dinner along with the other men. The ehildren of the employees were playing about. The Superintendent, Mr. Kellerhals, who has been with the farm from the beginning, said to us, "Yes, these men, when well dressed, look just like the people outside." About one-half tmm ont well, one-fourth are doubtful, and one-fourth eome baek. In a year only three had lun away.

In the hospital we found elean beds with outlook on the garden and pastures. The windows were open and the fresh mountain air was blowing in, but there were no patients in this outdoor prison ward. It stood out in marked eontrast to many of our own institutions, whieh by their eonstruetion and environment are the breeding-plaees of tubereulosis and other physieal and moral diseases. Reeent researeh has bronght to light the faet that the mortality from tubereulosis among onr own prisoners is three times as great as in our general population.

Germany is making extensive use of the farm eolony method in dealing with vagraney and ninor misdemeanors. At the Labor House of Rummelsburg, near Berlin, out of two thousand prisoners, one thousand were working outside on the sewage farms owned by the inunieipality. In Franee, Holland, IIungary, and Italy the Government has made sueeessful experiments with the eolony system for the treatment of offenders. The testimony is that it is less expensive for the State and mueh better for the health and reformation of the prisoners. 
The reflex influenee on soeiety of more rational and humane treatment of its erring members is the larger part of this benefieenee. For its own sake soeiety eannot afford to be eruel and brutal to its meanest and most unworthy member. Russia is to reap a more bitter harvest than her exiles. Love your enemies is a good soeial law. If we lift soeiety from the bottom, we all move upward together. We thus rise not to deeline and fall. To be helpful to "one of the least" who is in prison is not simply a religious sentiment; it indieates the only method of soeial development which will eonserve and make permanent the achievements of our civilization.

\section{OUTDOOR WORK FOR PRISONERS ${ }^{1}$}

THOMAS J. TYNAN, WARDEN, COLORADO STATE PENITENTIARY

I THINk the ideal work for eonviets is outdoor work, preferably farm work, which puts them baek on the soil and takes them away from the eities and their temptations. I believe every state should have large farms whereon they might work their prisoners with profit to the state and the men as well. Men who work in the open air beeome strong physieally and it is mueh easier to reform a strong healthy man, than a poor weakling, who has not proper balanee. When men are taught farm work, they ean easily obtain positions on farms after their release, where they are as a rule kindly treated and where they will have some soeial standing, which is an impossibility in the erowded eities. By the use of eonviet labor on the roads the taxpayers have been more than reimbursed by the value of the roads built. This labor does not enter into eompetition with free labor, as these roads eould not otherwise have been built on aeeount of the expense. The eounties pay for the maintenance of the eamps in which the men are worked, but the men are in eharge of overseers from the prison, who thoroughly understand the handling of this elass of labor and the building of roads. Our report will show you the immense saving in this way of road building, and the state is thus aequiring hundreds of miles of good roads, which

1 Adapted from Report of Convict Labor Commission, State of Connecticut, Public Document-Special, Hartford, Conn. 
could not otherwise have been built. We expeet to more than double our mileage during this present period and also to double the value of our farm products.

\title{
THE PRISON FARM ${ }^{1}$
}

\author{
WM. J. HOMER \\ WARDEN, GREAT MEADOW PRISON, COMSTOCK, N. Y.
}

I AM much in favor of the plan in operation here, i.e., a number of farms, or a farm eonnceted with each prison as they are established. I believe there should be some shops maintained in which, perhaps, eertain men, though well behaved and amenable to diseipline and absolutely to be trusted, should be retained throughout the extent of their sentenees, beeause there are a certain number of men in every prison population who have come from the cities, have been in faetory work all their lives, and in order to support their families will have to return to factory life on relcase. 'To take sueh men for a year or two and put them on the farm would not make farmers of them but would spoil a factory hand. But with these exeeptions, I think all those who show themselves fit for it, should be sent to farms where they may gain strength of body and eleanliness of mind which farm work seems to bring to men, that they may be able to go baek to liberty stronger and better men than they were on entering prison.

\section{HEALTH ON PRISON FARMS ${ }^{1}$}

\author{
W. O. MURRAY \\ CHATRMAN, BOAIRD OF PRISON COMMISSION
}

We employ the greater part of our labor on farms. The State owns eight farms, aggregating about 32,000 acres, and we have four plantations rented or leased, aggregating about 18,000 acres,

1 Adapted from Report of Convict Lahor Commission, State of Con. necticut, Public Document-Special, Hartford, Conn. 
making in all about 50,000 acres. The land actnally in cultivation on these farms in the aggregate amounts to ahont 46,000 acres. We employ in the enltivation of these farms forces ranceing from 2,800 to 3,500 conviets. A small farm is located in an isolated section, separate from the male convicts, and it is gratifying to state that they have been nearly self-sustaining. We also have another farm near Huntsville Prison owned by the State where we have segregated the tubercular and traclomatous eonviets. Also upon this farm we have what we eall the "Old Soldiers' Home," where we keep and care for the old and decrepit eonviets of both the Confeclerate and Union forces. This has proven to be rather an expensive department of our Prison System. Ilowever, we have the satisfaction of liaving a remarkable record witl reference to the deaths caused by tuberculosis in this System. Out of a prison popnlation averaging something over 4,000 convicts last year we had only seven deatlis from tuberculosis, and it is my candid opinion that if the jails of the State could be put in a sanitary condition, such that the convicts would not contract tuberculosis before being transferred to the penitentiary, it would be but a few years until we would have eradicated tuberculosis from the Prison System, or at least the ratio of tubereulosis among the convicts would be a negligible quantity in the System.

\section{IN THE HEALING LAP OF MOTHER EARTH ${ }^{1}$}

\section{WINTHROP D. L.INE}

The Indiana Village for Epileptics, opened eight years ago and just coming to full development, comprises 1,246 rich acres about two miles north of Newcastle and forty-five miles from Indianapolis. It lies in a country of rolling farm land that rises and falls through an altitude of 100 feet or more. Old Indian mounds dot the landscape and frequent groves of walnut, ash, maple, oak and poplar help to break the view.

The visitor for the first time will not know when he reaches the village. No walls enclose it, no impressive architecture bor-

1 Adapted from the Survey, Vol. 35: 3־3-380, Jan., 1916. 
rowed from the monasteries of another age stamp it as an "asylum." It is just another farm. Groups of attraetive, twostory briek buildings, where patients live, eat and sleep, lie baek from the road, but even these are more than likely to be passed without notice.

"The seientific treatment, edueation, employment and eustody of epilepties," says the law, shall be the objeet of this "farm eommunity. Translated, this means that here the epilepties of the state may lead as nearly as possible the normal life of farmers. Tliose for whom most ean be done edueationally are given the preferenee; purely eustodial eases and persons violently insane are not reeeived, though the law does not prohibit them.

Inmates do not have to work quite so hard as most farmers, for they are the wards, not the servants of the state. Nor ean they eome and go entirely as they please, for epilepsy is usually aeeompanied by mental defeetiveness and supervision is therefore neeessary. This supervision may amount to no more than being eonstantly within sight, of other inmates, for epilepties display the same fellow-feeling and eare for one another as the deaf. An epileptie who stands by and does nothing while his fellow has a seizure often finds himself an outeast for a time from lis assoeiates.

Two hundred and thirty men and boys are now living in eomfort on this farm. When the land has been fully improved and all buildings have been ereeted the village will be equipped to eare for about 1,000 or 1,200. Women, it is hoped, will be admitted next year. They will live in separate buildings a mile from the men.

The care of epilepties, like that of feeble-minded, is in the main an edueational problem. A sehool is to be ereeted, and shops for various forms of industrial aetivity. The work of the farm also is given an educational value. There is almost no kind of farm labor in which the epilepties do not assist. They help in the growing of erops, the eare of live stoek and poultry, in building fenees, in making and repairing roads, and in keeping the weeds down at the sides of the road. Sixteen epileptie teamsters, whose seizures eome only at night or ean be predieted beforehand, water, feed and bed their own horses. "I do not believe," deelares Dr. W. C. Van Nuys, superintendent of the 
Village, "that I eould get sixteen paid teamsters who would give us as little trouble in their work as these seleeted patients."

The village for epilepties is more than a place in which to keep busy. It is a place in which to enjoy some degree of individual life. The eongregate plan of lousing inmates, which brings them all together under one roof, has been abandoned, and instead patients are seattered about the farm in small groups, carefully selected to be as nearly homogeneous as possible.

When women are received the Blue Rivel will be used as a natural division for the sexes. On each side three separate eolonies will be built : one will be devoted to adults of the better elass, one to ehildren of the better elass, and one to low grade adults and ehildren. The colonies for the men are already partly built and oceupied. The low grade adults and ehildren, while in the same group, live apart from each other.

Each colony has its own orehard, garden and small fruits, its own horses, pigs, ehiekens, dueks and turkeys. The living rooms are provided with phonographs, newspapers and magazines. Some of the inmates reeeive their own home papers. Leslie's Weekly, Judge and Life are the most popular of the magazines taken, and "Robinson Crusoe" is most in demand of the books.

While Indiana is not the first state to make special provision for her epilepties, the movement is eomparatively new. The first speeial public institution for epileptics was establislied in 1867 at Bielefeld, Germany. In 1886 a colony was opened in England by private philanthropy. Ohio opened its institution for both sane and insane epilepties at Gallipolis in 1892. From these begimnings the movement has grown rapidly. There are to-day fifty institutions in Germany having speeial provisions for epilepties, nine in Fngland and several in Switzerland, Holland, Belgium, Australia and Canada.

New York was the seeond state in this country to found an epileptic eolony, her institution for sane epileptics at Sonyea being open in 1894. Massachusetts, New Jersey, Kansas, Missouri, Texas, Pennsylvania, Virginia, Connectient, Illinois, Iowa, Miehigan and Wiseousin have sinee been added to the list of states making special provision. 
Some of these states have been quiek to see the advantage of the true farm village type of institution. Mieligan acknowledges her debt to Indiana in the plan and arrangements of eottages on her 1,510 aere farm at Wahjamega, Tuseola eounty, bought in 1913. Dormitories, dining-room and day room oeeupy the ground floor, and employees' quarters the seeond. An old two-story hotel on the site was remodeled into a eottage for twenty-four patients. There are now living in eottages provided out of the original appropriation of $\$ 200,000$ for the establishment of the institution, 155 patients.

Illinois is laying out her village of 1,100 acres at Dixon on the small group plan. No buildings for inmates are to be more than two stories high, some of them being limited to one story. All buildings are to be of fireproof eonstruetion. Iowa is distributing groups of eottages about her 1,144 aere farm. The buildings for patients, both hospitals and eottages, are onestory and of fireproof eonstruetion.

The Indiana farm eommunity for misdemeanants is a eity hewn from the wilderness. Already within its first year this farm is aetually emptying the jails of nearby eounties.

Indiana lias long hated her jails. For a seore of years investigations, newspaper exposure, eommission reports and all the artillery of denuneiation availed nothing against these "ageneics of viee and training sehools of erime." Now, by the simple expedient of providing a wholesome, braeing substitute, Indiana is literally starving her jails and work-louses out of existenee. Some that heretofore aspired to a nightly population of eight or ten now find themselves earing for only two or three.

If the besetting evil of jails is idleness, the outstanding virtue of this farm eommunity is industry. Perhaps it was well that the institution got its start when the ground was eovered with snow and there were only tents to live in. To work was the only way to be eomfortable, and the spirit then engendered has been maintained. It is now kept before the minds of the prisoners in many subtle ways. "Positively no loafing" read signs at a seore of points, giving those who pass a sense of ehoiee that ean have but one psyehologieal effeet-a desire not to exereise that ehoiee.

Perhaps it is the frontier eharaeter of the work that gives the 
air of industrious eö̈peration so noticeable in the present stage of the farm's development. Few people eould be put at the task of building a town where none had been before and not be interested. Each prisoner ean see the beginning and end of his own job, and its relation to the work of others. IIe ean see a bustling community taking form before his own eyes and as a result of his own efforts. Work, under eireumstanees like these, is more than a mere means of passing time; it is faseinating, eonstructive, ereative, and it has eanght the slumbering interest of many a roving spirit whose previous aequaintanee with the law was limited to iron bars and walled idleness.

A large part of the work in walled prisons is either not found at all outside of these prisons or is monopolized by women or liandicapped classes like the blind. It is not edueative and adds little to the prisoner's wage-earning eapaeity. Nothing eould be stronger than the eontrast between this and the industrial opportunities on Indiana's penal farm. The buildings, even to the eutting and sawing of mueh of the timber, have been erected by the prisoners. The sewer system is now being installed by prisoners. Prisoners are building two and one-half miles of railway switeh over rough land, doing the grading themselves. They are building their own roads. They are laying thirty miles of fenee. They will install their own power plant. They are now making handles for all their implements and tools. This winter they will make brooms. They not only ereeted, entirely unaided, the toilet faeilities in the dormitories, but installed the plumbing and shower-baths as well.

Indiana is not the first to establish a penal farm. Sueh farms are eommon in Europe. There are three in this eountry besides Indiana's, one at Cleveland, Ohio, one at Kansas City, Kan., and one at Oceoquan, $\mathrm{Va}$.

Indiana has learned that she eannot build eongregate institutions fast enough to take eare of her insane. So she has ehanged her plans. She las deeided to provide the tonic of farm life for all her insane who ean profit by it. When the legislature of 1911 appropriated $\$ 75,000$ for the purehase of such a eolony, Governor Marshall and his advisers seleeted the Eastern Hospital for the parent institution.

Unlike the villages for epilepties and the farm for misde- 
meanants, which are teehnieally "villages," this traet is a real eolony. It draws its population direet from the Eastern IIospital, instead of from the whole state, and it is administered through that institution.

On the rieh acres of Wayne Farms, as the colony has been ehristened, thirty patients of varying degrees of insanity are now living the simple life. Eleven oceupy a remodeled farm dwelling ealled Cedar IIouse; another group a remodeled school building ealled Maple House. An old tavern, built about 1840 for the convenience of immigrants to the West, is being made over and will house twenty-five more patients.

$\Rightarrow$ Patients now at Wayne Farms do teaming, plowing, grasseutting and similar oceupations under little or no supervision. Some are put in eharge of the farm machinery in the fields. On the day of my visit five patients were digging a eellar at Cedar IIouse under an employed foreman. Others were loeing beans. One sturdy workman stopped ehopping wood long enough to urge us to eolleet for him some unpaid bills, fietions of his diseased mind.

In Wiscousin distriets eontaining one or more counties have established small agrieultural eommunities for their insane, only the nost aeute eases being eonsigned to hospitals.

This plan was worked out thirty-three years ago, and for the past eighteen years Wisconsin has kept abreast of the demands of her insane population for institutional eare. The eounties build the farm eomumities (asylums) and each eounty sending patients to one pays one-half the maintenance of its own eharges, the state paying the other lialf. This is the best system of state eare for the insane yet devised in this eountry.

\title{
FARMING AS A CURE FOR TIIE INSANE ${ }^{1}$
}

\author{
W. E. TAYLOR
}

I A fully eonvineed that a thoroughly equipped farm properly eondueted will eontribute more to the cure of the insane

1 Adapted from National Conference of Charities and Corrections, $17: 943-4$, F. $23,07$. 
than any other one thing we may resort to. I base my assertion upon experienee and experiments of tell years and the results obtained are most gratifying.

In order to obtain the best results, farming or gardening should be done in a strietly seientifie manner and the patients should be partiers in the work, and in a manner enjoy a part of the henefits; that is, one or two acres should be attended by a few patients and a preminm offered for the best produets.

The seed should be seleeted to suit the soil or the soil analyzed and fertilized to meet the requirements of the seed planted. The erops should be rotated seientifieally to prevent an exhaustion of the nutriment in the soil. . This should all be done under the direetion of a thoroughly eompetent foreman, and the patients should be taught and made to understand the purpose of analysis, fertilization and rotation, as well as how to plant and eultivate. Experiments in this line are earried on at this institution and we get splendid results. At a small eost for proper fertilizers our soil is made to yield three and four times more than previously raised with no more work or seed required.

Employment of any kind is always good, but when some ineentive is offered, the patient is stimulated to greater aetivity, and the old morbid eoneentration is elianged and the mind undergoes a phenomenal transformation. Drudgery and routine will not aecomplish the desired results any more than a wagon wheel running in the same track for months will obliterate a rut.

Every state institution for the eare of the insane should have at least one half aere of good tillable land for each patient. None but thoroughbred stock should be raised as they eost no more to feed and eare for tlian the ordinary serubs and the profits are much greater.

The plan of allotting stock to patients as well as land, results in a rivalry, which brightens the patient's mind and in a short time restores him to his normal eondition if his case is at all eurable.

Aside from the great eurative benefit the patient reeeives, the institution is provided with an abundance of vegetables, which materially roluees the eost of maintenanee. Again, the state farm should be conducted on a high seientifie plan as an 
example to the eommunity. Reliable and adaptable seed should be provided the neighboring farmers and they should be permitted to purchase at a nominal eost thoroughbred stock.

\section{JUVENILE DELINQUENCY IN RURAL NEW YORK ${ }^{1}$}

\section{KATE HOLLADAY CLIGHORN}

A GENeris impression is abroad that juvenile delinquency is peenliarly a problem of the cities and especially of the foreign population of the cities. In so far as this impression is based upon statisties of arraignments or commitments it must be verified from some other source, beeause of the unfitness of such statistics to give adequate information about the problem. In cities many aets whieh are disregarded in the country districts are punishable by law: and in cities the standard of enforcement of law, espeeially against children, is mueh more rigorous than in the country. The result is that the official reeord of rural juvenile delinqueney is unduly low beeause it fails to inelude much bad conduet that is passed over without eourt aetion and soon forgotten but which, if committed in the eity, would bring the ehildren coneerned to the judgment of the court and add their names to the list of delinquents.

We can say, however, from the facts brought to light, that there is a problem of juvenile delinqueney in rural distriets and that it is a serious onc. During the investigation little communities were found which at first sight appeared to have no problem yct, after study, each yiclded up a quota of "bad" children of various grades. The showing in the pages of the report may well bring doubt into the minds of readers who are under a delusion that their own ncighborhoods are free from taint.

Looking over the case histories and such summary figures as we are able to use, we find emerging distinctly two gencral types of charaeter: The active, enterprising, intelligent ehild-the born leader-and the duller and more stupid child, the natural

1 "Juvenile Delinquency in Rural New York," U.S. Department of Labor, Children's Bureau, Washington, 1). C., Pp. 11, 15, 21-31, 40, 54; Bulletin Pub. No. 32. 
eomplement and aecompliee and victim of the first type. Many instances of such partnerships will be scen in the ease histories. The obviously defective child is in the minority.

What have community influenees to do with produeing juvenile delinquency? First let us look at the general setting-physical and soeial.

Within the bounds of our definition of "rural" the scparate communities studied had a considerable range of variation in eharaeter. One type is the little eountry village- the trading ecnter of a surrounding agricultural district. Its population is made up mainly of the native-born white of native parentagethe old American stock-and is decreasing rather than inereasing beeause its young men and women, as fast as they grow up, are caught in the eurrent flowing to the large towns and cities.

Going out of the village eenter, and "on the hill" pcrhaps, we come upon little aggregations of people, not big enough for a village group nor yet wholly isolated on scattered farms. Such aggregations may gather about some erossroads or straggle along some seeondary highway. Here the conditions described for the village are in most respeets exaggerated for the worse. These little eenters, too, are often the survival of better days, and there has been an even greater drain on the population than on that of the village. And this has resulted even more definitely in a survival of the least fit. As a net result the little isolated settlement is apt to be of a distinetly lower grade. There is less intelligence and activity; the social standard is lower.

Still farther away from the center we eome to the isolated farm where many of our eases are found. This may be a good, pleasant, deeent home, but its owners are so far away from soeial influenees of any kind that they find it hard to take advantage of them. On the other hand, the isolated dwelling may be a tumble-down old shaek to which have withdrawn a family group too inefficient to maintain themselves in an organized eommunity, or too vicious to be tolerated there. Here we reach almost the negation of soeial life. Practieally all good influenees are wanting. This is such an extreme type, and the evil influences so obvious, that it was thought undesirable to devote mueh time to hunting out examples of it. It seemed better to lay emphasis on the normal community, the "country village" that even yet 
holds a large proportion of our native eitizens, rather than on the degenerate "hill peoplc" who are eomparatively few in numbers. But sueh families were not avoided when they eame within the range of our study, and several instances will be found deseribed.

A step was also taken in the other direetion-into villages where there is a background of agrieultural prospcrity in the surrounding farming distriet, and into villages feeling the stimulus of industrial development and either growing into towns or showing the soeial effeets that eome from eontact with such towns. Sometimes being in the neighborhood of the large town emphasizes the "deadness" of the little town. The young people get away more easily to eheap amusements-the moving pictures, the eheap theaters, the garish saloons, the evening promenade along the brightly lighted town thoroughfare-and find their own village the duller by eontrast. And they are more rapidly drained away permanently by the industrial opportunities nearer at hand.

Industrial activity may strike the village itself. Small factories start up, and a factory population is established. Foreignen begin to eome in, and the original social homogeneity of the American country village is lost. It is interesting to note, however, that foreigners appear to have been little involved in the delinqueney found.

Still another type is the eountry village which has felt the stimulus of industry by beeoming the summer or suburban residence of people who have achieved prosperity in the industrial centers. Here a very distinet social stratification is set up, in which "the natives" is a term in common use almost as patronizing as "the foreigners," used in the cities. Sueh activity-better schools, better churches, organized play-for the building up of the soeial ideal. The danger here is that the improvements may not really take root in tle community on which they are superimposed.

Next to take into aeeount is the economic background. In general, in the communities studied it is that of the farm and of agriculture. The usual complaint in the average eountry distriet is that "farming does not pay." This means that the oldfashioned farms and farming of our early ycars are being displaced by the opening of more fertile districts, the introduction 
of more effeetive methods, requiring greater intelligenee and more capital than the old-style farmer had. In one region studied the attempt is made to carry on farming in the old ways. Here a large proportion of the farmers are poor. Two-thirds of those who have records in the farm burcau have labor incomes varying from below $\$ 200$ to $\$ 500$ a year. Of this two-thirds, one-fourth make from $\$ 100$ to $\$ 200$, while one-fifth have no labor income at all. And in the lill distriets the abandoned farms are more numerous than the eultivated.

Such unfavorable ceonomie conditions mean poor and insanitary living eonditions, overwork, lack of recreation, and difficulties in the way of making use of edueational opportunity.

Another region studicd is, as a whole, rieh and flourishing. Its population is inereasing rapidly. Land values are constantly rising everywhere. It is, in faet, a land of milk and honey, of large, imposing farmhouses and enormous barns, of beautiful automobile highways winding their way between miles and miles of apple trces and peach trees and vineyards. Nearly cvery farmer owns an automobile, their boys go to eollege and their girls go to the various normal and training schools. There is high level of comfortable living and progressive Americanism. The village population is largely made up of retired farmers, who have either leased their farms or sold them and eome to the village to live.

Thesc villagers are often wealthy, owning several farms within a radius of five or six miles. There are high sehools in the larger villages and the ehildren of the well to do drive in from their farms in comfortable carriages drawn by sleck horses.

But in this region, too, out from the villages, baek from the fcrtile farms, will be found roeky, infertile districts where poverty-strieken tenant farmers find it hard to make a living.

In all but one of the communities studied the farm and its work are seen to be a powerful influcnee in the child's life, especially that of the boy. The boy living in a farming district is expeeted, as soon as he is big enough to hold a loe, to do his part in the work of either his father's or some one else's farm.

Even where farmers are prosperous and farming pays, the work the boy has to do is hard and lonesome. If the boy is at work on his father's farm, the father is in no hurry to pay him 
wages, wishes to keep up the parental eontrol indefinitely, and the boy gets tired of it and wants to get away.

Then somebody else's boy must bo hired. And the farmer is not always eonsiderate or reasonable in his treatment of him. In the eases studied are a number of instanees where a boy has gone to work for a farmer or has been plaeed with one by some soeiety or institution and has been badly overworked and misused. More than onee the aet of delinqueney eovered under the former eharge "ineorrigible" or "vagrant" consisted in running away from a farmer for whom the boy was working. It must not be eoneluded that in all these eases there was misuse of the boy, but it may be assumed from the evidenee at hand in these instanees and others that usually there was some bad eondition from which the boy wished to get away.

One of the eases was that of an eleven-year-old boy at Industry who, before his eommitment to the institution, had been plaeed with a farmer, but was so abused by these foster parents that he was removed by the truant offieer. An interview with the boy bronght out the faet that the farm where he lived was seven miles from the village. When asked what he did to have a good time he replied that he "used to plow and drag and milk and go to see the boys evenings." The farmer used to whip him for poor work and also refused to buy the neeessary selool boolis for him.

Besides being hard on the boy physieally, farm work eauses truaney, sinee there is a eonstant indueement to keep the boy out at harvest time and at spring planting to work.

Farm work under prevailing eonditions in the rural distriets is, then, not only hard on the ehildren while they are young, but affords little opportunity for the future.

This evil, however, is beeoming more and more elearly reeognized, and plans of one kind and another are already being tried in many plaees for the betterment of farm eonditions.

The une aetive but disavowed rival to the ehureh as a soeial eenter for old and young is the village tavern.

In some eases the village itself is "dry," but any one in seareh of refreshment ean easily find the way to a neighboring town or village where rules are not so striet. The taveru is the eateliall for every sort of amusement proseribed by the elureh and the 
strieter people of the town. Here danees may be given, here there may be a pool ronm or bowling alley, and here sometimes may be found rooms to let for immoral purposes. Here all the gossip of the neighborhood is interehanged; and here, in the bar, pool room, or bowling alley, may be found-legally or illegallynumerous little boys who learn to drink, smoke, swear, steal, tell dirty stories, and amuse the adult erowd thereby.

After so many years of agitation the large part drink plays in all soeial problems hardly needs to be stresser. Perhaps, after all, it should be stressed, beeause with the diseovery of other sourees of evil has eome a tendeney to minimize the one about which we have heard so mueh. But eertainly the present investigation shows anew and deeidedly the great harm done by drink, not only through tavern training of the young but also in making parents and guardians eruel or idle or ineffieient, as found in ease after ease, and ereating those bad home eonditions which are most favorable to the development of juvenile delinqueney.

No aecount of soeial eenters in a eountry distriet would be eomplete without mention of the village store. It is the elubhouse for men and boys who do not like to go to the length of haunting the village tavern; or for all, in "dry" villages where no tavern exists. Here neighborhood matters are diseussed, personal affairs, polities, the latest seandal. Here it may happen that "raey" stories are told and matters of sex held up to indeeent comment and ridicule. The store is to a startling extent the place where social ideals are formed and where the minds of the young are impregnated with the prineiples whieh later will govern their work and play.

Here, too, a taste for gambling may be fostered. This is a form of recreation greatly under the ban of opinion in rural eommunities, but as a matter of faet, quite frequently indulged in. It may be earried on in eonnection with games of various kindspool, poker, and so on-entered into spontaneously. But worthy of special note are eases mentioned in the investigator's report of petty gambling sehemes, devised to play upon and eneourage the gambling instinet, run in eonnection with the store. Such deviees are familiar in eity neiglıborhoods where they are with greater or less severity suppressed by the poliee. They are no doubt introdueed into country distriets in the process of organ- 
ization of trade from some large center which is so characteristic a feature of economic life to-day.

Beyond these main centers of social life there is little in the average rural district. Grange meetings, farmers' pienics, neighborhood parties occur, but they are few and far between. The great complaint of the young people in the country neighborhood is " nothing to do." This gap they try to fill with sex excitement and with riotous mischief that may end in lareeny and burglary.

The politieal unit-the village as a whole-should also be doing some true social work. One task peculiarly appropriate is the improvement of vocational opportunities. Towns and villages are already aetive along this line in the formation of boards of trade and other organizations intended to build up business in the town. For the farmers, greater use of eoöperative methods of marketing and extension of rural eredits will help.

The political unit is also responsible for its share in enacting and enforcing soeial legislation, and civic organization is needed to arouse community feeling along these lines. The evils of child labor, of truaney, of drink can be eured only when the communities themselves want them eured.

Village and town boards and offieials charged with the duty of giving poor relief also have a direct responsibility in the matter of juvenile delinqueney. Laek of judgment in caring for a dependent family may result in the delinqueney of the neglected children. The official who carries on such work as this should not only realize his responsibilities, but have some adequate training in the principle underlying social work.

\section{B. RURAL POLICE}

\section{RURAL POLICE ${ }^{1}$}

\section{CIIARLES RICIIMOND HENDERSON}

THe law is the law of the state. Munieipal eorporations have no original authority to enact legislation; their ordinanees eannot go beyond charter limitations. The enforcement of law, the

1 Adapted from Annals of the American Academy of Political and Social Science, 40: 230-233. March, 1912. 
punishment of erime, the prevention of dangerous acts are all functions of the commonwealth. And this with good reason: it would be intolerable to have an independent law-making authority set up within the territory of a state. No local eommunity can be permitted to become a nursery of criminals, a cave of Adullam serving as a resort for dangerous elements. Horse thieves and burglars will not restrict their malignant activity to the township of their residenec. They may even spare their neighbors and live by spoiling persons at a distanee.

The criminals of a city go out to plunder rural banks and stores. The common interest does not stop at eity lines. The common enemy must be caught where he can be overtaken. The reecnt extension of trolley lines into the country and the introduction of swift automobiles have widened the field for professional burglars of eities. Against these trained villains the thin safes of country merehants and banks are mere tissue paper.

The rural constabulary is no mateh for city bred eriminals, skillful in the use of dynamite and electricity, and shrewd in studying the hours best adapted for their exploits. The sheriff at the county seat is a toy in the hands of a professional sneak thief or burglar. Even if lie can spare time from colleeting the fces which fall to him as spoils of his office, he has no natural or aequired qualifications as a detective; he is both awkward and ignorant. Local agents of peace and justice have only a local knowledge of persons bent on erime, usually those who are most harmless, stupid inebriates, naughty boys whose mothers have neglected to spank them. Rural sheriffs and eonstables know nothing of sleek, well dressed, polite criminals who reside in comfort in the eity and put up at the best inn of the country town while planning to rob a bank or a merchant's cash drawers. The big, burly sheriff is a baby in eunning when pitted against a wily safe-blower who from childhood has lived by his wicked wits and fooled professional detcetives. The rural officials are made cowardly by their liabits of life; they know nothing of the daring which is characteristic of urban firemen and policemen who face death daily and never think of shrinking. A desperatc fellow may dynamite fish, eontrary to law, in a lake near a state university; but farmers and professors are afraid to inform, and county officials are too timid. to arrest. State game wardens, 
just beausc they move about on large areas, seem to have some influence on killing game out of season, but their organization leaves much to be desired.

What is needed may be inferred from the statcment of essential facts in the situation. We need a larger unit of police control; under our political arrangements the governor is the natural head of all the forecs of public safety. It would be a good beginning to clothe the chicf magistrate of every commonwealth with authority to direct county sheriffs and to hold them to striet account. But a more important measure would be to furnish the governor with a completc and thoroughly organized corps of detectives, plain elothes men and mounted police, under a professionally trained chief responsible to the governor for methods and results. In the eentral office would be found an identification bureau, with Bertillon and finger print records, in close and regular correspondence with the federal bureau of identification; and this office would furnish descriptions at a moment's notiec for any point in the state or elsewherc. The state police force of a statc would eoöperate with those of other states in matters of detection, arrest and cxtradition. Suspicious characters in villages and cities would be kept under espionage and plots would be discovered and thwarted. Of the necessary legal adjustments betwecn municipal police, sheriffs and the state force this is not the place to write. Such adjustments could casily be made in aeeordance with precedents already established.

The men of this country owe it to the wives and daughters of farmers to provide for them better protection. Self-appointed patrols are not enough, and the state ought not to leave private eitizcus to guard their own barns and homes. The insolence, the ficree passion and the dangerous brutality of ecrtain types of negroes in the South could be effectually curbed by a guard of mounted poliec. It is the hope of immunity whieh nurses sexual passion into assault. Animal impulses neet with their best counter-stimulus and inhibition in the frequent and unexpected appearanee of alert and omnipresent mounted poliecucn.

Certain results may fairly be expected: In the war with crime it is essential to make the way of the transgressor as hard as possible, and, at the same time, open ways to honest industry. Wild animals disappear before the hunters of eivilization. Gangs 
of criminals are like predatory animals and must be harried and watehed until this mode of living becomes unendurable. Swift and sure justice begins with a trained corps of detectives. All admit that mobs and lynenings are a disgrace and menace to our civilization. They arise out of prolonged neglect and freqeucnt miscarriage of justice. They would diminish and disappear with a well disciplined and effective rural police.

\section{A LAND OF LAW AND ORDER ${ }^{1}$}

ELMER E. FERRIS

THE development of a new, prosperous country attracts the adventurous as well as the enterprising. Young unmarricd men come West in large numbers. The restraints of former home life and social customs are absent. Under such circumstances it is easy to form habits of drinking and gambling and to fall into other forms of moral looseness. Personal safety and property rights are more or less insecure. Society tends toward lawlessness.

Such, lowever, is not the case in Northwest Canada. Quite to the contrary, it is doubtful if there is any country where person and property are better protected. The Albcrtan farmer was right when he said that this is a country of law and order.

One must travel through the country to appreciate it properly. One finds himself in an atmosphere of respect for law. The people feel safe. They assume that the law will be enforced. The amount of crime and disorder that comes under onc's personal notice is so small as to be negligible, and onc sees comparatively little of it in the newspapers-at least crime occupies a relatively insignificant part of their space.

The question then arises, What makes it so? What is there about the social organization and the underlying forces of this young civilization that gives it this distinctive feature? It is evident that in the thought of the farmer it was largely due to the efficiency of two institutions, the Royal Northwest Mounted Police and the courts. "When a man commits a crime herc,"

1 Adapted from the Outlook, Vol. 98, 685-690, July 22, 1911. 
said he, "these mounted police get after him, and they land him." Such is certainly the reputation of the Royal Northwest Mounted Police. It is an organization that is unique among world-famous constabularies. It is a body of men numbering 651 ; composed of 51 officers and 600 men, commissioned officers, and constables, with 558 horses. They police a territory composed of the provinces of Alberta, Saskatchewan, and the extensive districts of Mackenzie and Keewatin, excluding, of course, the larger cities, which have their own constabulary. The most distant detachment is on the Arctic Ocean, 2,500 miles from headquarters at Regina-a distance that requires two months to travel.

The entire force is under the command of Commissioner A. B. Perry, with headquarters at Regina. The whole territory is divided up into eight districts, each of which is under the charge of a superintendent with headquarters respectively at different points in the two provinces. At each divisional point there are barracks, a jail, and complete equipment. There are many duties performed by the force in addition to what may be termed regular police duties. They maintain the common jails, escort all prisoncrs to trial and those who are convicted to the penitentiary, attend upon all criminal courts, scrve all criminal processes, escort lunaties to the asylum, ctc., etc. They also conduct important patrol expeditions through unsettled and unsurveyed regions, visit the settlers once a month in sparsely settled sections, make investigations and report upon the condition of the natives, the state of immigration, the nature of the soil, crops, etc., in all outlying regions that are beginning to be settled up-all this in addition to their regular police duties.

One gets an idea of the nature and amount of work done in the detection and punishment of erime and the preservation of order from the report of Commissioner Perry; it shows for cleven months of the year 1909 that 6,888 cases of crimes, misdemeanors, and petty offenses were liandled by the forec, and that convictions resulted in 5,849 cases, being 86 per cent. of cases tried. The special reports filed by the divisional superintendents, which go into the facts with more or less detail, are full of interesting cases showing the courage and esprit de corps of the force. 


\section{PENNSYLVANIA S'TATE POLICE ${ }^{1}$}

THEODORE ROOSEVELT

The Pennsylvania State Poliee is a model of efficieney, a model of honesty, a model of absolute freedom from political contamination. One of the great diffieulties in our large States has been to secure an effieient polieing of the rural sections. In communities where there are still frontier conditions, sueh as Texas and Arizona, the need has been partially met by establishing bodies of rangers; but there is no other body so emphatically efficient for modern needs as the Pennsylvania State Police. I have seen them at work. I know personally numbers of the men in the ranks. I know some of the officers. I feel so strongly about them that the mere fact that a nan is honorably discharged from this Foree would make me at onee, and without hesitation, employ him for any purpose needing eourage, prowess, good judgment, loyalty, and entire trustworthiness. This is a good deal to say of any organization, and I say it without qualification of the Pennsylvania police.

The forec has been in existence only ten years. It has eooperated efficiently with the local authorities in detecting erime and apprehending eriminals. It has efficiently protected the forests and the wild life of the State. It has been the most powerful instrument in enforeing law and order throughout the State.

All appointments are made after the most careful mental and physical examination, and upon a thorougl investigation of the moral eliaracter, and the past record, of the man. All promotions have been made strictly from the ranks. The drill is both mounted and dismounted. The men are eapital riders, good shots, and as sound and strong in body and mind as in eharacter.

This is the foree which Katherine Mayo deseribes in a volume so interesting, and from the standpoint of sound American citizenship, so valuable that it should be in every public library and

1 Adapted from the Introduction, by Theodore Roosevelt, to "Justiee for All, the Story of the Pennsylvania State Police," by Katherine Mfayo, pp. 8-I1. G. P. Putnam's Sons, New York, (copyright Katherine Mayo, Bedford Hills, N. Y.) 
every sehool library in the land. In the author's foreword the murder of gallant young Howell, and the complete breakdown of justice in reference thereto under our ordinary rural police system, makes one's blood boil with anger at the folly and timidity of our people in tamely submitting to such hideous eonditions, and gives us the keenest gratitude to the founder of the Pennsylvania State Poliee. This was a ease of ordinary erime, in which the sheriff and county constable were paralyzed by fear of a band of gunmen. Other forms of crime are dealt with in eonnection with industrial disturbances. The author shows how until the State Police Foree was established the State, in times of strikes, permitted the eapitalists to furnish their own Coal and Iron Police, thus selling her police power to one of the eontending parties, that of the vested interests.

The author also shows how after the establishment of the Pennsylvania State Police this intolerable eondition was ended; loeal demagogues and foolish or vicious professional labor leaders in their turn attaeked the Pennsylvania State Poliee with the foulest slander and mendaeity, beeause it did impartial justice. The prime lesson for all true friends of labor to learn is that law and order must be impartially preserved by the State as a basis for seeuring justice tlirough the State's action. Justice must be done; but the first-not only the first, but a vital first-step towards realizing it must be aetion by the State, through its own agents, not by authority delegated to others, whereby lawless violence is summarily stopped. The labor leader who attacks the Pennsylvania State Police beeause it enforees the law would, if suecessful in the long run, merely suceeed in reëntrenehing in power the lawless eapitalists who used the law-defying Coal and Iron Police.

No political influenee or other influenee avails to get a single undesirable man on the Force, or to keep a man on the Foree who has proved himself unfit. I am informed and I fully believe, that not a single appointment has ever been made for political reasolis. The efficieney with which the Foree does its duty is extraordinary. Any man who sees the troopers patrolling the country ean tell from the very look of the men what invaluable allies they are to the cause of law and order. In the year 1915 the force made 3,027 arrests and seeured 2,348 eonvietions-80 
per cent. of convietions. The men are so trained and schooled in the eriminal laws of the State that they know just what evidenee is necessary. They deal admirably with riots. Perhaps there is nothing that they do better than the protection of women in sparsely populated neighborhoods. Small wonder that the criminal and disorderly classes dread them and eagerly hope for their disbanding!

Ycar by year the efficieney of the foree has increased and its usefulness has correspondingly increased. All good citizens in Pennsylvania should heartily support the Pennsylvania State Police. The sooner all our other States adopt similar systems, the better it will be for the cause of law and order, and for the upright administration of the laws in the interests of justice throughout the Union.

\section{CANADA'S ROYAL NORTH-WEST MOUNTED POLICE ${ }^{1}$}

\section{AGNES DEAN CAMERON}

The Royal North-West Mounted Police, a handful of men less than a thousand in number, maintain order over an extent of country as large as Continental Europe and do their work so well that life and property are safer on the banks of the Athabasea and on Lesser Slave Lake than they are to-day in many crowded corners of London and Liverpool. How largely looms the individual in this vast land of Canada, this map that is half unrolled! Men, real men, eount for more here than they do in Old World erowded centers.

This is the most wonderful body of mounted men in the world. Surely more individuality goes into the make-up of this force than into any other; it is a combination of all sorts of men drawn together by the winds of heaven. Five years ago the roll-eall of one division disclosed an ex-midshipman; a son of the governor of a British eolony; a medical student from Dublin; a grandson of a eaptain of the line: a Cambridge B.A.; three ex-troopers of the Scots Greys; the brother of a Yorkshire baronet, and a goodly sprinkling of the ubiquitous Scots. For years a son of

1 Adapted from Littell's Living Age, 276: 65̃8,659, March 8, 1913. 
Charles Diekens did valiant service with this foree, and has left behind him a book (as yet unpublished), "Seven Years Without Beer!"

Far back in the year 1670 another body of men dominated Canada, the staunch Seottish servants and offieers of the Aneient and IIonorable Iudson's Bay Company whose charaeter-mark for loyalty and fair dealing remains inclelible on the early pages of the history of this land. The eharter which was granted to them in the reign of Charles II had run for two hundred years and expired in 1870, leaving all Canada west of the Great Lakes in a eondition of readjustment and unrest.

Illieit whisky-dealers, horse-thieves, and smugglers poured into Western Canada from the United States to the south over the invisible and unguarded parallel of forty-nine degrees, and Canadian Indians and Canadian interests needed proteetion. This eondition of affairs was the immediate eause of the formation of the R. N. W. M. P. in the early seventies, the launehing of the project and the forming of the foree being the pet seheme of the then premier, Sir John A. Maedonald.

The 300 eharter-members of the Mounted Poliee had their work eut out for them in the early days on this far frontier where eupidity and lawlessness reigned and no law of God or man had previously been enforeed north or south of this part of the international boundary line. The profit to the Ameriean "wolfers" had been great and was measured not in dollars but largely in buffalo-robes and sometimes in squaws. The traders from the United States brought bad whisky and worse ammunition and fire-arms to the Canadian Indians and for their own gain eneouraged tribal wars and the stealing of horses.

In the forty years of its existence the R. N. W. M. P. has elosely identified itself with the growing history of Western Canada, being the greatest moral ally to every ereative faetor of the eountry's growth.

\section{BibLiography}

\section{CORRECTIONAL AGRICULTURE}

Cooley, H. R. Correetion Farm of Cleveland. Annals, 46:92-96, Mareh, 1913.

Farm Colony: Our Experiment in Cleveland, Proceedings National 
Conference of Charities and Correction, 1912, pp. 191-195, 315 Plymouth Court, Chieago, Ill.

Elwood, Everett S. Mental defeet in relation to alcohol with some notes on colonies for alcoholic offenders. Proceedings National Conference of Clarities and Correction, 1914, pp. 306-314.

Femald, W. E. Massachusetts Farm Colony for the Feebleminded. Proceedings National Conference Charities and Correction, 1902, pp. $457-490$.

Goodyear, Anna F. Deseription of German and other labor Colonies, benefieient and penal, slowing what we ean do with our abundant land. Old Corner Book Store, Boston, 1599.

Jackson, F. J. Farm Treatment of Misdemeanants. Proceedings National Conference of Cliarities and Correction, 1911, pp. $70-72$.

Royaard, A. Farms for the City Poor. Craftsman, 25:168-177, Norember, 1913.

Famous penitentiary sanatorium at Witzwil. Amer. Rer. of Reviews, 54:441-442, October, 1916.

Haggard, Sir H. Rider. The Poor and the Land: being a report on the Salvation Army colonies in the United States and at Had. leigh, England, with scheme of national land settlement and an introduction, p. 15T, Longmans, N. Y., 1905.

Potts, C. S. The State Farm System in Texas. Proceedings National Conference of Charities and Correction, 1914, pp. 5+61.

Scott, E. L. Municipal Correction Farms. American City, 15:623630, December, 1916.

Whittaker, W. H. Industrial Farm. Proceedings National Conference Charities and Correction, 1914, pp. 45-4S.

\section{RURAL POLICE}

Cameron, A. D. Riders of the Plains. Living Age, 276:656-63, Mareh 15, 1913.

Ferriss, E. E. Land of Law and Order. Outlook, 95:655-93, July, 1911.

Haydon, A. L. Riders of the Plains. Nation, 92:425-6, April 27, 1911.

Henderson, C. R. Rural Police. Annals, 40: 228-233, Mareh, 1912.

Lewis, C. F. The Tramp Problem. Annals, 40:21i-2S, Marel, 1912. Mayo, Katherine. Justice to All. The story of the Pennsylvania State Police. Putnam, N. Y., 1917.

Mott, L. Day's Work in the Mounted Police. Outing, 4S:96-100, A pril, 1906.

Ogden, G. W. Watch on the Rio Grande. Everybody's, 25:353-65, September, 1911.

State Constabulary. Nation, 9S: 5-6, Jan., 1914.

State Constabularies Needed. Outlook, 106:145-6, January 24, 1914. Thompson, H. C. Canadian Northwest Mounted Police. Outing, 32: 75-S0, April, $189 \mathrm{~S}$. 


\section{CHAPTER XII}

\section{A. THE RURAL HOME \\ WOMEN ON THE FARMS ${ }^{1}$}

\section{HERBERT QUICK}

MY explorations of the souls of farmers, baeked by my own life on a farm, and the lives my mother, sisters, aunts, cousins, and women neighbors lived, lead me to the eonelusion that the " $\mathrm{drift}$ to the eities" has been largely a woman movement. I have found the men on farms much more eontented and liappy than the women. My mother wanted my father to leave the farm, and move to a college town where the children could have "a better ehanee." He did not aecede to her wishes; and one bit of spiritual drift was cheeked. But just to the degree that farmers have reached the plane of letting the wife and daughter vote on the future of the family, they have been pushed toward the eity. Out on broad eattle-ranges I have found the men and boys filled with the traditional joy of open spaees and the freedom of spirit which goes with it; but in many, many eases, their women were pining for neighbors, for domestie help, for pretty elothes, for sehools, musie, art, and the things tasted when the magazines eame in.

'There is a movement for better things among the farmers' wives of the land. There is a new organization on an international seale. There are questioning and revolt and progress in the rural homes. This idea is finding reeognition among them: that all the prizes of progress are no longer to be allowed to go to the man-life on the farm, while the woman-life is left to vegetate.

I spent a day in a New England neighborhood recently, and at the sight of the old stone walls whieh divide field from field, my prairie-bred baek ached, and my fingers bled in spirit at the

1 Adapted from Good Houschceping. Vol. 57:426-36, Oct., 1913. 
thought of the awful labors of the farmers of old who dug those stones, carried them off the land, and aligned them in those old fences. But progress came along and emancipated the man. He found that it paid to abandon the stoncfields and work the richer, kinder Western lands with machinery. He could make more money by the use of tools on which he rode. It became profitable to thresh by steam, harvest by horse-power, put the corn in the soil by machinery, bind the grain with twine and hoe with a horsedrawn machine. To handle manure with a fork does not pay when it can be spread by means of a machine. Potatoes arc sliced, dropped, dug, cleaned, and elevated into wagons by machines. Tomato plants, cabbage plants, and the like are planted by machines.

The farmer has come to be a man who operates machines, and his life is made more interesting and caseful thereby. There is still a great deal of hard drudgery in his life, but progress and invention have been busy in relieving him of that dreadful burden under which our farming ancestors bowed, grunted, and sweated. The internal-combustion engine, while it has transformed the lives of so many city people through the motor-car, has become the chore-boy and handy-man of the farm.

But all these improvements have come into the life of the man on the farm because they have been profitable. I do not know of onc which the American farmer has generally adopted merely because it gave him ease. He has not spared himself. He has been emancipated in large measure because the easier ways of doing things liave promised better pay for lis labor.

And here is where the farm woman has not received a fair deal in the partnership. Not that she has been entirely without relief from the march of progress. The wind-mill, or the gasengine which pumps water for the live stock, also saves her the back-breaking carry from the spring-house which sent our mothers to town invalids, or made their lives a burden. The invention of the cream-separator and the establishment of the creamery have freed woman from some of the drudgery of the old-fashioned dairy.

The farm woman no longer makes cheese, becausc the cheesefactory can do it better and more cheaply. The introduction of labor-saving machinery lias decreased the number of ravenous 
mouths which she must satiate with food. The steam-tlresher, carrying its own cook and crew, saves her the labors of serving hordes of threshers.

These things helped her because they were introdueed as profitable innovations, and not as woman-saving ones. More amelioraions of woman-life on the farm will come in for the same economic reason. In many parts of the country women milk the eows; but the next development is sure to take the form of the general adoption of mechanical milkers. These machines are being thoroughly tried out, and where twenty or more cows are kept in a herd, the milking-maehines pay. Therefore they will be adopted; and thereby both women and men will be able to lead easier and fuller lives of greater happiness on the farms.

The present woman movement on the farm is toward a higher plane than the economic plane. It is a demand for happiness and case and the fruits of progress in the house, as well as out of it.

In brief, the farm woman is now demanding, and reeeiving, better things in the order of their nearness to her daily life-first, things in the house for her housekecping; seeondly, things in the house for her children's happier and fuller home life; and thirdly, things outside the house, in the neighborhood, for the better and fuller community life of herself, her children, her husband, and her neighbors. This is the outline of the rural uplift which is gathering foree every day.

Millions of farmers' wives do their own housework. The problem of domestie help is more difficult on the farm than in the eity. They care for their elildren-and their families average larger, I am sure, than do the families of eity women. They have been emaneipated to a large degree by the faetory system from the task of making the clothes of their families; but they still make their own elothes, in the main, and mueh of the elothing of their families. They cook, cure meats, make sausages, bake their own bread and pastry, elurn, make butter, tend gardens, and onee in a while lend a liand in the liaying, or other out-door work. The women of the eities eomplain that they have lost their economie usefulness in the household, and demand a share in the produetive work of the world. No sueh wail ever arises from the women of the farm. Their hands are full of necessary and productive work from morning till night. 
In a large measure this work is done witlout the modern aids to housework which eity women possess. If a vote could be taken of the farmers' wives of the nation as to the improvement in the house most generally needed, I think there can be no doubt that the referendum would be overwhelmingly to the effect that the first great need is running water in the house! And this is the first concession to progress that farm women are getting. Millions of them have no eisterns, and the simple first step toward a parity of women's work with men's is to put a eistern of soft water in commission, with a pump plying into a kitchen sink. The next thing is a water-back to the kitchen range, and a faucet of hot water. These lead directly to a washing-machine for the laundry work.

Not in words, but in deeds, and still more in thoughts, the in. sistent need of emancipation from drudgery is making itself felt in rural homes. Not in words, but in spirit, these things are appearing in the current thought of American rural life. It pays to make the women happy. It pays to emancipate slaves, and especially when those slaves are our wives, our mothers, our daughter's. It pays in money, indirectly, if not directly; but whether or not it pays in money, it must be done. Any farm that can afford a silo can afford a bathroom and a septic-tank sewage-disposal system. Any farm that can afford a cream separator can afford a washing machine. Any farm that can support pumping and storage facilities for the live stock can afford running water, hot and cold, in the house. Any farm that can maintain a manure spreader can afford an acetylene, gasoline, blaugas, or electric lighting system. Any farm that can afford self-feeders for the cattle can afford vacuum eleaners and electric labor-saving deviees for the women. Any farm that can justify binders, silage-entters, hay-forks, pumping engines, shredders, side-delivery rakes, corn harvesters, potato planters, and finely equipped barns can afford every modern convenience for making the home a good place for women to live, work, rear children, and develop in them the love for farm life.

A corm-shredder or a silo costs more than an electric lighting sy'stem for the farm lome-a system which will give the women all the things that eity women receive in the way of electric 
serviee. A modern hog-house, a thorouglily good set of poultry buildings, a concrete fecding floor, an improved equipment of stanchions for the dairy barn, or a good bull to head the herd, is not much, if any, less expensive than a system of water-works for the house, which places water under pressure in the bathroom. kitchen, and bedrooms.

Let no one understand from what I say here that the conditions of work and living which weigh down upon millions of farm women, and which aceount for much of the prevailing discontent with farm life, have caused, or will result in, mucl of that sex revolt which is so much talked of in feminist eircles all over the world. The farmer's wife is not diseontented with her husband, nor with his treatment of her. She inay even in many eases throw the weight of her vote against the expenditures necessary to emaneipate her from unnecessary drudgery. To her the mortgage on the farm is a nightmare as baleful as it is to her husband. She knows her husband's business, and is as solicitous as lie is for management which will bring profits.

But there is a woman here and a woman there wlo sees that the whole scheme of family life falls to ruin if the home suffers in eomparison with homes of those friends and relatives who live on wages in the towns. She and her husband begin to realize that it does not pay to build the farm up into a profitable property which is despised by the very children for whom they are giving their lives. And they are stndying statisties, too. They find that such faets as have been eompiled by Dr. Otis, of Wisconsin, establish the faet that farms pay just in proportion to the amount of the farm value which is invested in equipment, rather than in mere land. And myriads of farmers are forewarned by their wives' diseontent with farm life that a erisis is approaehing in which the decision will have to be made between removing the family to town or bringing the things of the town to the family.

When, however, the tired and harassed farm wife eomes to the point of asking herself whether it is worth while to stay on the farm, she thinks sccondarily of the disadvantages of work and living which have frazzled her nerves and depressed her spirits. She thinks first of her children. That is the Eternal 
Mother. She finds that the ehildren are, in most parts of the country, deprived of the school advantages and soeial advantages which the eity gives even to the slum-dweller.

The Ameriean furm women constitute our largest class of economically useful women. This is shown by the fact that marriage is regarded as a burden by the poor man in the eity, but is almost a necessity for the poor man who owns and works a farm. The poultry products of the nation are worth as mueh as the eotton crop, exceed the wheat crop by four hundred millions of dollars yearly, and are worth more than the eombined values of the oat, rye, barley, and potato crops. This enormous product, if lost to us, would be felt ruinously at once in increased eost of living. It must be eredited mainly to the woman of the farm. For she it is who produees nine-tenths of the poultry productsthe fowls and eggs- of the nation. Give her credit also for butter, eheese, vegetables, piekles, preserves, and a thousand other things. Allow her, too, her share in preparing the means for men who grow the rest of the food for us, and for keeping their houses.

Remember also that she bears our sturdiest children while she helps to feed us all. And then ask yourself who has done anything for the farm woman? She has been left to shift for herself, and must still do so. She still bakes her own bread; she still serubs her own floors. She washes her own dishes; she cans and preserves and dries her own fruit and vegetables. She bas bent faithfully, dutifully, uncomplainingly over these appointed tasks while, to the rhythmie swing of its pounding maehinery, the mareh of modernity has borne class after class out beyond her. On her rests the burden of emancipating herself from the things that weigh upon her life; and she is rising nobly to the task.

There are clubs and societies already formed and forming. Thousands of farm women are making up their minds that their sisters who have abandoned the farm and farm life have deserted the field on whieh they should have fought and triumphed. They are studying, where they formerly sueeumbed; and advaneing, where they formerly retreated. There is revolt in the air against eounsels of submission and fatalistie retreat. The twentieth eentury is to see a renaissanee of farm life. And the women 
who formerly led the fight are to head the eounter-eharge for better things on the farms.

\section{AN OPEN LETTER TO SECRETARY HOUSTON ${ }^{1}$}

\section{From a Farmer's Wife}

\section{M.ARY DOANE SHELBY}

I THINk that I must tell you first that eountry living is eomparatively new to me. To my four years of life on a farm I have a baekground of many years of eity life, during which I did the strenuous things which women of leisure are apt to do to-day. In the midst of these activities a great doctor told my husband that he was in a bad way physically and must heneeforward lead . an out-of-doors life. It was decided that we should try farming. Health was the first consideration in the selection of our new home, but we must make the enterprise a paying investment. We ehose a beautiful stock farm in the foothills of the Ozarks, in a sparsely settled neighborhood which had had no neweomers for years.

The roads are poor. When erops fail, our neighbors aecept the situation philosophically and keep their families in food by eutting timber and hewing railway ties. They are a simple people whose wants are easily satisfied. They know little of the outside world save as an adventurous son or daughter has left home to seek employment as a streetear conduetor or domestic servant. Their forebears have lived here for nearly a hundred years. While their opportunities for "book learning" have been incredibly meager, they come of such fine stock that the lack of a formal education serves to emphasize native ability. I feel very modest when I am with them.

Within a radius of ten miles I am familiar with family conditions. Unless the mother is still a young woman, one finds from seven to sixteen clildren in eaeh lousehold. I liave given the two extremes. I humbly confess that I fall below a fair eity average in this regard. With this exception, and the fact that I have more material possessions, my problem and my neighbors

1 Adapted from the Oullonk, Vol. III, 923-5, Dec. 15, 1915. 
as women trying to make a loome in a promising but undeveloped farming community are the same.

What does every home-maker want primarily? Health, and a chanee at the higher life for her family-an edueation for her children.

The farmer's wife should find these things possible to attain. As a matter of fact, they are out of reaeh of most of the women of this neighborhood. The reason for this, I bclieve-and here is a conelusion whieh surprised me-is that the Government does not give the eountry woman the protection whieh the eity woman receives and which she should have if she is to be the economic faetor in the National life whieh she will become if she intelligently follows the path marked out for her by your Department.

Of late, when I have been reading your bulletins on sanitation, - Mr. Sceretary, I have been reminded of Moses. He had probably given the Children of Israel sueh instruetion with regard to matters pertaining to health before he realized the necessity of putting his farm bulletins into law. It is to remind you of this that I am writing you now.

On a neighboring farm, where the barns are not far from the house, there is a large pile of stable manure. It has been standing there for weeks. My neighbor's wife knows why she has so many flies; she also knows the menaee to health. Her husband knows too. Your information has reaehed them. But it secms that at the present time there is no available field for this fertilizer; no man and team to haul it; sometime it will be attended to; just now "he" is busy with other work. The eity man would be prevented by law from thus jeopardizing the health of those around him. The farmer is permitted to dally with the situation.

Why eould there not be rural health departments to insure sanitary eonditions? The farmer and his family are said to be National assets. Why not protect them? The forest has its rangers; eonservation of forees would suggest a like protection for farm folk.

Another neighbor is permitted to let the drainage from his farm buildings pollute his water supply. Why not have building restrietions for the farm?

At our annual "graveyard elcaning," when the valley people meet at the burying-ground next the school-house, every family 
has its little mounds from whieh the father euts the long grass and weeds, and over which the mother allows herself time for the luxury of tears. A eonferenee with our overworked eountry doetors would reveal the many eauses for a high death rate in naturally healthy regions. The eity slogan "save the babies" might well be extended to the eountry.

I will frankly eonfess that I had mueh more reason for eonfidence in the milk which I used to buy in bottles in the eity than I have now that it eomes from our own eows. I have obtained tolerable eonditions through strikes and boyeotts, refusing for days to aeeept milk until the stables were properly eleaned. That I have been sueeessful in these hazardous domestie enterprises is entirely due to my family's sense of humor, which has never yet failed me. I eould not advise my neighbors to resort to my methods, although their need is greater than my own. I am sure the eourse pursued by Moses would be better for family tranquillity.

It is a usual thing, when the summer exodus eomes, for the newspapers and family physicians to warn eity people of the probability of finding eontaminated water and unsanitary eonditions generally in the country. There seems to have been little thought of the helplessness of the women and ehildren who are eompelled to live (or die) in those regions. One must eonelude from the universal warning that the problem is a National one, calling for new legislation and its enforeement.

I have mentioned our roads. In eertain stretehes they are tragically, laughably, hysterieally roeky. In other stretches they are punctuated with stumps. Few women would venture to drive a team over them for any distanee, altlough the men, through practice in driving, are able to eover the rough miles at a remarkably good gait.

It is a matter of record that on the ground of bad roads alone the Government has so far refused our eommunity free rural delivery, although there are many men who eould easily qualify as earriers, eovering the territory in the time required by the Government and serving ninety fanilies three times a week. Don't you think, Mr. Secretary, that bad roads are a very good reason for having a free delivery of mail? Isn't it better for one responsible man to go over the road than that ninety families 
should have to send for their mail or go without? I am not speaking for Big Hawk Valley alone. In these stretehes of eountry where money is not plentiful, and where the farmers and their wives are dependent upon their own physical exertions for everything necessary for living, Governmental and newspaper urging doesn't take us very far on our way toward good roads. When we shall have automobile roads we shall not need rural delivery. In the meantime we are paying our taxes and are really a part of the United States of Ameriea, although we slould hardly realize it save for sentimental attachments.

Since I have been living in Big Hawk Valley, Mr. Seeretary, I have often wished for a vote, although it was far from my intention to express my wish in this letter. But here, more than any region I have known, the ballot seems to be a subtle but insurmountable barrier between me and all questions subject to a vote. Our women take part in the work of men. If neessary, they lielp take eare of the live stoek, gather wood, and work in the fields, but their splere most emphatieally does not inelude "meddling" with questions to be deeided by men alone.

I am reminded of this by a plaeard which is posted upon the door of the sehool-house. It calls attention of parents to the State law which requires six months' yearly sehool attendanee of every ehild of the required age. Owing to a curious knot which no one attempts to cut, the children of this neighborhood are getting only four months' schooling in a year, although we are paying taxes for an eight-month term.

The situation has been brought about through a mistake in distrieting the eounty. Our district includes a near-by mountain and is of illegal length. Sinee the mountain children must be taught as well, or as poorly, as the valley clildren, and sinee neither the mountain fathers nor the valley fathers are inclined to two wagon trips daily to take the ehildren to sehool, two little sehool-houses were built, one in the valley, the other on the heights. One teaeher divides the eight montlis' term between the highlanders and the lowlanders. This year she serves the mountain folk from July through October. The valley children will attend sehool from Oetober through January.

I should be an ingrate, Mr. Seeretary, if I elosed without telling you that I owe my vocational training as a farmer's wife * 
almost entirely to your Departinent. My text-books have been the Government bulletins. I have them bound, indexed, and eatalogued. There is not a day when some one of the household does not refer to them. Yesterday I heard one of my aides, a neighbor's daughter, say to the other: "Marthy, if you take that jelly off now, you will be goin' right against the Government!",

\section{WOMEN IN RURAL LIFE ${ }^{1}$}

\section{SIR HORACE PLUNKETT}

In the more intelligent seheme of the new country life, the economic position of woman is likely to be one of high importanee. She enters largely into all three parts of our program-better farming, better business, better living. In the development of higher farming, for instanee, she is better fitted than the more museular but less patient animal, man, to earry on with eare that work of milk reeords, egg records, ete., which underlies the selection on seientifie lines of the more productive strains of eattle and poultry. And this kind of work is wanted in the study not only of animal, but also of plant life.

Again, in the sphere of better business, the housekeeping faculty of woman is an important asset, since a good system of farm aceounts is one of the most valuable aids to suecessful farming. But it is, of eourse, in the third part of our program, -better living,-that woman's greatest opportunity lies. The woman makes the lome life of the Nation. But she desires also soeial life, and where she has the ehanee she develops it. Here it is that the establishment of the eoöperative soeiety, or union, gives an opening and a range of eonditions in whieh the social usefulness of woman makes itself quiekly felt. I do not think I am laying too much stress on this matter, beeause the pleasures, the interests and duties of society, properly so ealled,-that is, the state of living together on friendly terms with our neighbors,are always more eentral and important in the life of a woman than of a man. The nan needs them, too, for without them he

1 Adapted from "The Rural Life Problem in the United States," p $\bar{p}$. 139-141, Macmillan, N. Y., 1910. 
becomes a mere machine for making money; but the woman, deprived of them, tends to become a mere drudge.

\section{THE PROBLEM OF THE CHANGING RURAL HOME ${ }^{1}$}

\section{GEORGIA L. WIITE}

THE committee on Rural Home Making begs to submit the following report of its plans for work for the coming year. In looking over the available material for a study of the problem of the rural home and its relation to the rural community and rural life, the committee finds little that can be utilized for a careful study of the present problems. There has been much generalization concerning the rural home but this generalization has been based upon material which is inadequate and seemingly contradictory.

This lack of reliable material about the home seems to be due to several causes.

(1) The tendency we all have to take for granted the things with which we are most familiar and to assume that the conditions with which we are acquainted are typical.

(2) The intimacy of home relations which makes a study of the conditions in the home, except possibly of the economic conditions, seem to be an intrusion.

(3) The fact that many of those who in recent years have been interested in studying rural conditions and the rural home have been town or city born and bred and, therefore, when they have attempted to make a survey they have used the town home as the standard and have interpreted the phenomena which they found in terms of the town home.

(4) The fact that many investigators have studied the home with reference to some particular reform which they wished to introduce into rural life or with reference to some social scheme which they wished to justify.

(5) The inability of many of those interested in country life

1 Adapted from Proceedings lst Natl. Country Life Conf., Baltimore, 1919, pp. 117-119. National Country Life Assn., Dwight Sanderson, Ex. Secy., Ithaca, N. Y. 
to realize the ehange in rural home eonditions, and the tendeney they have shown toward assuming that the funetion whieh the rural home should perform and does perform in the eommunity has remained unehanged in spite of the great economie and social ehanges outside the home.

Beeause of this seareity of reliable material on whieh to base attempts to solve some of the problems of the rural home, it seems to the eommittee that the most important pieces of work that it ean undertake for the eoming year will be those of-

(1) Gathering together the few studies whieh have already been made of the rural home and-

(2) Making new studies in different seetions of the country and under different eonditions, in order to secure, if possible, suffieient material for formulating some tentative statements as to the present status of the rural home in the eommunity, its funetion, and its problems.

The eommittee feels that furtler information should be gatliered eoneerning the following points and it expeets, also, to add others to the list:

(1) The funetions that the home is performing in the rural eommunity and the degree to which it is neeessary or desirable at the present time, with our present eommunity organization, for the home to provide food, shelter, elothing, reereation, sanitation, religious life, ete., for the family.

(2) The relative emphasis now plaeed in the rural home upon the satisfaction of the desires of the members of the family for (a) food, (b) shelter, (e) elothing, (d) "higher life."

(3) Tle relationships existing among individuals in a family whieh tend to retard or aeelerate progress in the community. It is felt by the eommittee that the study of the relationships between men and women and between adults and elildren in the family may indicate whether the rural home is tending to retain a form of despotism-even tlough at times benevolent despotism -which is out of harmony with the demoeratie standards being introdueed into the eommunity, beeause of its failure to provide for a division of rights and responsibilities among its members; or whether the retention of the older form of family organization is lending advantageous stability to the community. For example, when the war made it neessary for the food administrator 
to utilize the sehools and the agrieultural extension serviee in all its branehes to edueate the women and the ehildren,-so that food habits eould be changed and food saved without great detriment to health,-it was found that muel of the time, energy and money used in edueating the women and ehildren was wasted and the results postponed beeause of the form of eontrol within the home, and the question arises whether there is a eompensating advantage to the eommunity from this form of organization. It is felt that a careful study of present relationship may not only throw light upon the home eonditions but also bring out some interesting faets eoneerning the relation between the amount of foree exerted in the eommunity for bringing about progress and the aetual results produeed. It may also help to determine whether the relationship that is found to exist is based upon an eeonomic basis or a basis of tradition.

(4) The aetions and reaetions of the home, the sehool, the ehureh, the rural govermment, ete.

(5) The effeet upon the integrity of the home of the new interests whieh are being introdueed into the rural communities: i.e. whether they are tending toward the disintegration of the home or the integration of the home on new lines.

(6) The fundamental, as well as the immediate, effeets upon the rural homes of

(a) The introduetion of automobiles, telephones, better transportation facilities and improved roads, espeeially in so far as they bring the eity and eountry more elosely together.

(b) The organization of the Farm Bureau and the introduetion into the counties of the Home Demonstration Agents and the Boys and Girls Clubs.

(e) The emergeney work whieh the men, women and ehildren of the rural distriets have been doing during the period of the war and the loeal emergency organizations, sueh as those formed by the Red Cross, the Couneil of $\mathrm{Na}$ tional Defense, the Y. W. and Y. MI. C. A., ete.

These indieate some of the lines of inquiry whieh the eommittee would like to follow, though the eommittee realizes the diffieulties attending the seeuring of reliable material along these lines. 


\section{B. RURAL HOỤSING}

\section{RURAL HOUSING ${ }^{1}$}

\section{ELMER S. FORBES}

RURAL housing as a whole exhibits the same differenees, the same degrees of exeellenee as does the housing of the towns. There are numbers of farms where the dwellings are well built and provided with modern systems of heating and lighting and with every eonvenience for the eeonomieal dispateh of the work of the household, where the barns and outhouses are well kept and elean, and where the sanitation is all that ean be desired. At the other end of the seale there are to be found here and there in the country single houses or small groups of houses which exhibit many of the eharacteristie marks of the stum. Not all, for in the open eountry at the worst, there is plenty of fresh air and sunlight and spaee; but there are dirt and filth indeseribable, the most primitive sanitation, serious overerowding and indecent promiseuity. These slum spots exist not only in remote distriets far from the railroads, but elose seareh will find them in many eommunities where they would not be expeeted and where their presence is known to but few, on narrow eountry by-ways and lanes, in wild plaees in the vieinity of the railways, in negleeted woodlands; indeed, there is seareely a hamlet or town within whose limits these disreputable shacks may not be diseovered.

Two or three eases may be instaneed by way of illustration. The family of a small farmer on the outskirts of a eountry village was found living in a one room $\log$ eabin in utter disregard of the ordinary laws of health and deeeney. As a eonsequenee, two of the elildren had been attaeked by tubereulosis, and unless immediate aetion were taken there was every reason to believe that all would beeome affeeted. Another sueh family lived in a dilapidated eombination of dwelling and barn, not fit to be the habitation of either eattle or human beings, where the overerowding was equal to that in the most eongested distriets of the eities and all

1 Adapted from the Annals of American Academy of Political and Social Science, January, 1914, pp. 110-116. 
sanitary eonveuiences were eonspicuous by their absenec. As an example of still lower type there may be instanced a degenerate group of four men, two women and three ehildren who oceupied a shack in a clearing of the woods in the neighborhood of a New England town until they were finally dispersed by the authorities.

Sueh eases can be duplicated almost anywhere. In all of them, with scareely an exeeption, the housing eonditions are vile, the equal of anything in the slums of the towns, and yet in the opinion of the writer the problem which they present is not essentially one of housing reform. In this respect the partieularly bad housing of the rural districts is quite different from that of the towns. City slums are due in large measure to land and business speeulation, utilization of land for dwelling house sites which is too valuable for this purpose, an inequitable system of taxation, the lack of any housing law worth the name, inadequate supervision, and a disposition on the part of some landlords to exploit their tenants. These are eauses which are in no way connected with the eharacter of the families living in the slums, and their operation can be checked by right legislation honestly enforced.

The slum spot in the open country, however, is not so much due to social or eeonomie causes beyond the eontrol of the occupant as it is to his own mental and moral deficieneies. Land speculation, speculative building, metlods of taxation, the greed of landlords, none of these in most eases has anything to do witl it. Such dwellings are the natural expression of the lives of the shiftless, feeble-minded, immoral, drunken or eriminal people who inhabit them. It is not a better housing law which is required here so much as it is the labor colony, the penitentiary, the almshouse, and the home for moral imbeciles. These social plague spots are the eause of enormous publie expense and are a steadily increasing burden upon the industry and thrift of the eommunity. They should be accurately registered, earcfully studied, and each one should be disposed of upon its own merits. All this will cost much effort and money but not a tithe of what it will cost twenty, thirty, or fifty years henee, and incidentally it will wipe out the eountry shm.

Dr. W. C. Stiles, of the U. S. Marine Hospital Service, states that of 3,369 farmhouses in sis different States 57 per cent. have 
no privies of any kind. The better grade of farm house is always provided witl some sort of sanitary convenienee, but the number where it is anything more than the ordinary outdoor privy is eomparatively small. The neglected privy is the greatest danger to the health of the farming community, and a menace to the population of the towns througl the part which it must play in the contamination of milk, vegetables, and fruits sent to eity markets. It defiles the soil all around it, and unless earefully located may pollute the family water supply. The fact is so generally known that it is not necessary to give statisties showing that scrious epidemics have been started by the use of water from eountry wells polluted by the disease-infected privy. It is the breeding place of eountless generations of flies, and when used by persons suffering from any kind of infeetious disease, as fevers, dysentery, diarrhea, and the like, the eontagion may be spread far and wide by their agency. The family cess pool is but one degree less dangerous than the outdoor privy, and together they lave undonbtedly been responsible for a vast amount of siekness and death.

\section{OVERCROWDING AND DEFECTIVE HOUSING ${ }^{1}$}

\section{HARVEY BASIORE}

WHAT is the result of this overerowding and lack of proper housing in the country? Just exaetly the same as in the great cities. Lack of effieieney, disease, and premature deatl to many. We have been talking much lately of our conservative policy of lumber, eoal and wild animals, but in many instanees fail to see the great loss due to luman incficieney brought about by laek of suitable environment. While the great majority of people surbjeeted to overerowding and bad lousing eonditions do not prematurely dic, yet they have lessened physieal and mental vigor, are less able to do properly their daily work, and not only become a loss to themselves and their families, but to the State; and forever stand on the thresloold of that dread disease-tubereulosis; for tubereulosis is the one great disease of the overerowded.

1 Adapted from "Overerowding and Defective Housing," pp. 80-92, John Wiley and Son, N. Y. 
Just how much tuberculosis we have in the rural distriets in proportion to the great cities is pretty hard to say: but every one who has investigated it is positive in the opinion that there is just as much in the country distriets : indeed, some report more in the country than in the adjoining eities. We find it in the farmhouse and the mountain home: habits of carelessness possibly kcep up the infeetion. We do not have "lung blocks," like the large citics, but we do have "lung houses," where case after ease of tubcreulosis has lived and perhaps developed.

The prevalence of tuberculosis in the eountry is so evidently marked that there is a growing interest in the subjeet in many places. The Wisconsin Antitubcreulosis League, a year or so ago, made a very eareful and exaet sanitary survey of a certain rural district in that State, relative to the amount of this disease, and found that in some parts of this district the death-rate from tuberculosis execeded that of Milwaukee, Wiseonsin's largest eity.

Minnesota also discovered that it had mueh tubereulosis in its rural districts. "As serious," says Dr. Daugherty, who investigated the subject, "as that in the congested areas of the eities." Following a rural survey of several townships, under the auspices of the State Antitubereulosis Association, there were found housing conditions much as I have described in the preceding pages as existing in Pennsylvania. "The average number of people sleeping in one room," says the report, "was four." In one house there were eight, in another nine, and it was not at all uncommon to find five or six. This was not due to the fact that there was not cnough room, for in many of the houses the whole family would sleep in onc room, use one for the kitchen, and lcave two, threc, and in some cases four, rooms vacant.

Coineident with this bad housing there was found one township where there were twenty-two deaths from tuberculosis in a population of 500 in ten years: a death rate of 44 per 10,000 . These investigators in Minnesota also found that "eontributing eauses, as overwork and poor food, which play such an important part among the inhabitants of the erowded tenement distriets, do not usually count for much in the eountry. Bad housing and unrestricted exposure to contagion scem to be the great factors." Of course, in certain well-to-do farming distriets, such as were under 
investigation, this would hold good, but in many other plaees, especially in parts of Pennsylvania known to the author, poor food and lack of food are a vast contributing cause of this discase. A poor eonstitution to start with, and insufficient food, soon cngender a eondition whieh quiekly yields to the inroads of the bacillus. As a corollary to this is the rapid improvement of such incipient eases, when put on the food and under the proper environment of a sanitarium.

And now a word, a very short word, about the remedy for overcrowding and bad housing in the eountry. This probably can not be attacked as in the great eities, by legislative enactment or resort to legal measures, but the solution lies, it seems to me, in proper education by the various health authorities, by the schools, and by the press, and the crusade must be kept up until the people understand that it pays-pays in real dollars and cents- to live in sanitary homes. Educate the rural dweller in regard to the penalties for bad housing, show him how tuberculosis follows in the wake of overerowding, poor food, and dissipation: in a great many instanees he will mend his ways. In Pennsylvania this work is earried on by the Tubereulosis Dispensaries of the State Department of Hcalth scattered all through the State, where they have become the foei for spreading sanitary knowledge of just the sort needed in rural communitics. Visiting nurses from these dispensaries go to the homes, and to my personal knowledge do mueh, very mueh, to remedy the defects of bad and improper living, and do it without resort to any legal means. There is no factor so potent for good as the work of the visiting nurses of this great health department; and many other States are taking up the work and earrying it forward on the same lines.

\section{HOUSING CONDITIONS ON FARIS IN NEW YORK STATE ${ }^{1}$}

\section{II. BAILEY}

Housing eonditions in the eountry run all the way from very cheap and poor tenant houses to well-appointed large farm res-

1 Adapted from "York State Rural Problems," Vol. 1:55-59, Lyon, Albany, 1910. 
idenees. Between these two extremes there is every range of eondition. The better elass of farm residenees is all that ean be desired. The poorer elass is, of course, quite the opposite. Fven the better elass of farm residenees does not represent money value as measured by eity and town values. This is largely due to the faet that most of them were built many years ago, when materials were eheap, and also before the addition of waterworks and other modern improvements. A residenee in the farming region that is valued at one thousand dollars may be aetually more roomy and eomfortable than one in the town that is valued at more than twiee that sum. In this letter I am, of eourse, omitting all referenee to the eountry seats of nonresidents or absentees.

I have asked Professor Warren to give me his comment on housing eonditions as found in his surveys; and most of the following statements of faet are his.

Practically all of the farmhouses in New York State, as in the northern states in general, are made of wood. In the northeastern states nearly all of these houses were built at least fifty years ago. Only a small pereentage have been eonstrueted along the newer lines. In Livingston eounty, whieh is one of the riehest agrieultural regions in the eountry, Warren found that the average value of these houses in 1909 was not quite $\$ 1,600$. Of eourse, it would eost mueh more than an average of $\$ 1,600$ to build these houses, but this is the estimated average value of the house as it stands. Perhaps $\$ 1,000$ would be nearer eorreet for the average value of the farm residenee in the State, but it would take over twiee this mueh to build these houses at the present time. The new houses would probably also be worth twiee as mueh, beeause new and better adapted to the needs.

The average number in the family in Livingston eounty is 4.2 persons, and the average of boarders or hired men .8 , making a total of five persons as the size of the average farm family. Of eourse, this gives no suggestion as to the number of children away from home. In Tompkins eounty the average farm family, exchusive of hired help, was found to be 3.55 .

The size of the farmhouse is, of eourse, exeedingly variable, but the average would probably be about six or seven rooms. The farm water-supply is praetieally always situated at some 
distance from the house. On some farms running water is piped to the housc, but these are exceptions. Bathrooms are yet rare in general farming regions. In western New York, along the lake shore, a considerable number of farmers are installing watersupply and bathrooms, but outside of this seetion probably not morc than one in several hundred of the farms has a bathroom. In one county less than one in 500 was found to be thus supplied. The heat is nearly always provided by a kitehen stove, and in colder weather often onc additional stove is used. The chief fucl is wood, but a eonsiderable amount of eoal is used in winter, particularly for the sccond stove. The almost universal system of lighting is with kerosenc lamps, although aeetylene is used by a small number of farmers. Perhaps more persons have aeetylene for lighting than have bathrooms. The privy is loeated largely by chanec, so that it is often near the wells, but in the great majority of cases it is not close enough to be a scrious menace to the water-supply. The fact that it is often left open so as to provide a fceding-place and gathering-place for flies is perhaps the greatest source of danger.

All of the above discussion refers to the main house on the farm. The houses occupicd by hired help are usually smaller and not in so good repair as are the farmhouses diseussed above. Probably tenant houses do not average more than five or six rooms. The differenee between them and the other house is likely to be more striking in questions of repair than in aetual size.

The ehange from old housing eonditions to new is very gradual. Perhaps it ought to be aeeelerated by having more attention given to the subjeet in publie leeture and teaehing work. It is eustomary not to diseuss personal questions so mueh as erops and live-stoek and eommereial situations. If the farmer lacks in some of the meehanical convenicnees of eity dwellers, he gains in spaee to each person, light, outlook, storage place, room to move, and ability to eontrol his premises. If he were to add more freely of mechanieal convenienees and contrivances, his eonditions of housing would be enviable. We need now to have as mueh ingenuity applied to housing conditions as lias been applied to farming praetices. 


\section{Bibliography}

\section{WOMEN IN AGRICULTURE}

Allen, Mrs. M. M. Poultry Culture for Women. N. Y. Dept. of Agriculture, Bu. of Farmers' Institutes, Report 1904, pp. 249-256.

Baldensperger, J. Beekeeping for Women. American Bee Journal, V. 58, pp. 53-54, Feb., 191 .

Beckman, F'. W. Women Testers in Iowa. Hoard's Dairyman, V. 55, p. 807 , May $31,1918$.

Burns, Adelaide. The Truth about Squab Raising for Women. Country Life in America, V. 18, pp. 67-68, 86, 88, May, 1910.

Cypliers Incubator Co. Reports of Successful Poultry Growers $\$ 1000$ A nuual Prize Contest, 1912-1913 edition. Buffalo, N. Y.

Farm Tractors, War and Women. Touchstone, V. 2, pp. 606-611, Mar., 1918.

Farrington, E. H. Women in Dairy Manufacturing. N. Y. Prod. Rev. \& American Creamery, V. 46, pp. 366-36S, July 3, 1918.

Francis, M. S. Opportunities for Profit in Horticulture. California St. Com. of Horticulture, Mo. Bul., V. 5, pp. 434-437, Dec., 1916.

Fraser, Helen. "The Women's Land Army." In Women and War Work, Chapter 8, pp. 155-167, New York, Sliaw, 1918.

Gordon, G. P. War-time Training and Employment of Women in Forestry. Quarterly Journal of Forestry, V. 12, pp. 266-271, Oct., 1918.

Women a Success in Planting Work. Canadian Forestry Journal, V. 14, pp. 1961-1964, Dec., 1918.

Griswold, Beatrice. A Woman's Success in Forest-seed Cultivation. Countryside Magazine, V. 22, pp. 355-356, 357, June, 1916.

Hartt, M. B. Women and the Art of Landscape Gardening. Outlook, V. 88 , pp. $694-704$, Mar. 28, 1908.

Landman, M. V. Women Farmers. Cornell Countryman, V. 14, pp. 479-502, Mar., 1917.

Laut, A. C. Training Recruits for the Farm Game, Especially Girls Who Have Been to the Agricultural Camps. Country Gentleman, V. 82 , No. 44, pp. 6-7, 52, Nov. 3, 1917.

MacKenzie, Cameron. England's Farmerettes. Country Gentleman, V. 83, pp. 6-8, 48, Mar. 2, 1918.

McLean, A. M. The Fruit Industries of California. In Wage-earning Women, pp. 116-129, N. Y., Macm., 1910.

Mahaney, Margaret. Margaret Mahaney Talks about Turkeys. Boston, Park \& Pollard Co., 1915.

Negley, Noel. Wisconsin Has the First Woman Cow Tester. Hoard's Dairyman, V. 53, p. 973, July 13, 1917.

Noel, C. T. My Bees. American Bee Journal, V. 58, pp. 22-23, Jan., 1918.

Ogilvie, I. H. Agriculture, Labor, and Women. Columbia Univ. Quarterly, V. 20, No. 4, pp. 293-300, Oct., 1918. 
Pellett, F. C. How the Women Win. Ameriean Bee Journal, V. 57, pp. 372-373, Nov., 1917.

Preistman, M. T. How One Woman Keeps Bees. Country Life in America, V. 18, pp. 51-52, May, 1910.

Some Real Women Farmers. Wallace's Farmer, V. 43, p. 1159, Aug. $16,1918$.

Stebbing, E. P. The Enployment of Women in Forestry. In British Forestry, Chapter 15, pp. 215-254, London, Murray, 1916.

Stone, J. L. Opportunities for Women in Agriculture. Cornell Countryman, V. 14, pp. 32-34, Oct., 1916.

Warren, G. E. and Livermore, K. C. Women as Farmers. In an agricultural survey. Cornell Agri. Exp. Sta. Bul. 295, pp. 544-548, Ithaca, 1911.

Warwick, Frances Evelyn. Hodge in Petticoats. Fortnightly Review, V. 106, pp. 321-324, Aug. 1, 1916.

Wellesley college training camp and experiment station for the Woman's land army of America. Report: Advanced ed., 1918, p. 32, Second ed., 1919, p. 95.

Wilkins, Roland. The work of educated women in horticulture and agriculture. Journal Bd. of $\Lambda$ gri. Great Britain, V. 22, pp. 544-569, Sept., 1915; pp. 616-642, Oct., 1915. Also published by Women's Farm and Garden Union, London, 1916.

Wilson, E. G. Woman's Work in Greenhouses. Florists' Exchange, V. 45 , p. 434 , Mar. $2,1918$.

Winters, S. R. Miss Hefner-Cheesemaker. Kimball's Dairy Farmer, V. 16, pp. 410-411, May 15, 1918.

Women's Educational and Industrial Union. Agrieultural oceupations ... In Vocations for the Trained Woman, V. 1, pt. 1, pp. 122167, Boston, 1914.

Women's Educational and Industrial Union. Appointment Bureau. Poultry Raising as a Vocation for Women. Vocational serięs Bulletin No. 5, Boston, 1911.

Wolseley, F. G. Gardening for Women. London, Cassell, 1908.

Young Women Can Help. Wallace's Farmer, V. 43, p. 938, June 14, 1918.

\section{THE RURAL HOME}

Andrews, Benj. R. Education for the Home. U. S. B. of Education, 1914.

Bailey, Ilena M. A Study of the Management of the Farm Hoine. Journ. of Home Econ., $\Lambda$ us.-Sept., 1915. $\Lambda \mathrm{m}$. Home Economies Assn., Baltimore, Md.

Buell, Jennie. One Woman's Work for Farm Women. Whiteomb, Boston, 1908.

Crow, Nartha Foote. The American Country Girl. Stokes, N. Y., 1915.

Dixon, S. G. The Rural Home. Annals $40: 168-174$, March, 1912.

Dodd, Helen Chamberlain. The Healthful Farm House. Whiteomb, Boston, 1906. 
Domestic Needs of Farm Woinen. U. S. D. A., Report 104, 1915. Extracts from letters receired from farm women in response to an inquiry.

Economic Needs of Farm Women. U. S. D. A., Report 106, 1915.

Edueational Needs of Farm Women. U. S. D. A., Report 105, 1915.

Forbes, E. S. Rural Housing. Annals 51:110-6, Jan., 1914.

Gillette, Joln M. Making Farm Life More Attractive. In his Constructive Rural Sociology, Sturgis, N. Y., 1915.

Langworthy, C. F. What the Department of Agriculture is Doing for the Housekeeper, U. S. D. A. Yearbook, 1913.

Proceedings of the 30th Annual Convention of the Assn. of Ameriean Agrieultural Colleges and Experiment Stations, Washington, 1916.

Proceedings of the American Assn. of Farmers' Institute Workers, 14th Annual Meeting, 1909. Report of Committee on Women's Institutes.

Richards, Ellen H. The Farm Home a Center of Social Progress. In Bailey's Cyclopedia of American Agriculture, Vol. IV, pp. 280284.

Scott, Rhea Clarke. Home Labor Saving Devices. Lippincott, Plila., 1917.

Small and Vincent. The Family on the Farm. In their Introduction to the Study of Society, Book II, Chap. I, American Book Co., 1894.

Social and Labor Needs of Farm Women. U. S. D. A., Report 103, 1915. Extracts from letters received from farm women in response to an inquiry. 


\title{
CHAPTER XIII \\ THE COUNTRY SCHOOL
}

\author{
AN EPIGRAM ${ }^{1}$
}

T. J. COATES

"THE average farmer and rural tcacher think the rural sehool as a little house, on a little ground, with a little equipment, where a little teaeher at a little salary, for a little while, teaches little ehildren little things."

\section{THE STATUS OF THE RURAL SCHOOL ${ }^{2}$}

\section{ERNEST BURNHIM}

THE value of the school as an integrating agent in rural eommunity life lies primarily in the suceess of its work as a school. No single institution can so eheapen rural community life as a poor sehool, beeause next to the common industry-agriculture - the sehool is the greatest mutual interest. Besides doing what it is speeifieally direeted to do-interpret to ehildren their inheritanees-the sehool may reaet as a unifying agent through the sehool library, the annual meeting, the course of study, the social aetivities of the pupils, coöperation between sehool and home, through being the leader in, or at least the lost for, the intellcetual and asthetic eommunity meetings and through sympathetie, voluntary, eompetent and unostentatious promotion of the best things by the teacher.

The chicf elements of effieieney in the rural schools are: first, individual objective in instruetion; seeond, simple and natural stimulations; third, the inter-aetion of all grades and ages;

1 Adapted from a circular letter issued by United States Bureau of Education.

2 Adapted from Rural School Efliciency in Kalaınazoo County, Michigan, Bulletin. No. 4, 1909, Pp. 22-25. Published by State Superintendent of Public Instruction, Lansing. 
fourth, the constant, though not often eonsciously realized, tuition of nature.

The clice elements of effieiency now absent from the rural sehools are: first, conscious integration of the work by teachers and pupils; second, the best physieal and mechanieal accessories; third, due appreciation of the value of education by many parents and pupils; fourth, adequately qualified and efficiently directed teachers.

The unexliausted resourees of the rural schools are: first, an equalized and proportionate use of local and state funds; seeond, a eomparatively well trained and experienced staff of teacher's, well led and themselves capable of leadership; third, a conseiously intelligent interpretation of nature; fourth, the impetus of awakened community consciousness.

The state cannot afford supinely or ignorantly to neglect fully to develop the unexhausted resources of the public schools. It is truc that the rural schools are less well cared for to-day than the urban scliools. It is historically true that the country bred eitizen lias been the nation's most valuable human asset. He has liad a longer childhood and youth. He has come to maturity with a greater potential of nervous energy. He has, by constant association in work and play, absorbed the wisdom of the parent generation. Nature has had him largely to herself, and-

"Whenever the way seemed long,

Or his heart began to fail,

She sang a more wonderful song,

And told a more marvelous tale."

President Rooscrelt said, "The small farm worked by the owner has been the best place to breed leaders for both eity and eountry."

The conservation of that wholesome country life which produces the greatest human excellenee, is the first public consideration. The rural sehool is the most peculiarly public institution in country life. It is the shortest eut to planned public participation in rural progress. The mural school teacher is the largest factor in the problem. The teacher is the publicly appointed executive partner of the parent generation, of nature, and of God. The small community integrates the elemental 
sourees of life. It is, therefore, an oasis eapable of produeing the richest human fruitage. Selected fertilization, industrial, edueational, social, politieal and spiritual, is the supreme need. Equipped and inspired leaders inearnate and eommunieate seleeted fertilization. The state may, if she will, put such leaders into the life of every rural eommunity.

The four inequalitics in the state's provision for the intellectual uprearing of her youth are:

1. The eollection and use of the public funds.

2. The agencies instituted for the qualifieation of publicly employed teachers.

3. The supervisory control of the schools.

4. The years of instruction offered at publie expense.

Two groups of questions immediately suggest themsclves to the student of rural schools :

First group-

1. To what extent are these inequalities due to defeets in the statutes?

2. What amendments are neeessary?

Seeond group-

1. What inequalities are not due to defeets in the statutes?

2. How may these be reached and remedied?

The answers to these questions, which the facts presented in this report suggest, are:

First group-

1. Inequalities

(a) in the collection and use of the public funds,

(b) in supervision,

(c) in the years of free publie instruction, are due to inadequate statutory provisions.

2. The ancidments suggested are-

(a) the enlargement of the area unit for taxation purposes from an ungraded distriet to a township; this not neessarily to involve the centralization of the schools, ample provision for which, when desired, has already been made;

(b) the provision of suffieient means for securing effieient supervisory direction of all the schools; 
(c) the extension of the privilege of free secondary instruction to pupils in schools not giving such instruction, through the payment of tuition and transportation by the township.

Second group-

1. Inequalities in the qualifieation of publicly employed teachers are human eonsiderations largely not subject to legal control.

However, there is at present a very noticeable differenee in the preparation by the state of teacliers for ungraded rural schools and graded urban schools. This condition is not due to defeetive statutes. It is due largely to an interpretation of the statutes which has permitted a coneentration of the state's appropriations for teacher training, more than five-thirteenths of which has been paid by rural ungraded districts; upon the preparation of teachers for graded urban schools.

2. This condition has come into public attention and in recent years a redirection of part of the normal school activitics to the service of the ungraded rural schools has begun in a small way to make good to these schools the accumulated loss of the years. Further attempts have been made to refund the rural communities that which has been taken from them by the state without practically any direct return, by the remitting of tuition in the normal schools to teachers preparing for country service and by the institution of the county normal training classes, largely supported by the state, for rural teachers.

\section{REHABILITATING THE RURAL SCHOOL ${ }^{1}$}

\section{L. BERNARD}

IT is the contention of the present writer that the heart of the problem of functionalizing the rural school is the question of the eurriculum. Therefore, in the following bricf outline of changes most urgently needed to be wrought in the general organization of the rural school this change is placed first.

1 Adapted from "School and Society," Vol. IV, No. 100, p. 810-16, Nov. $25,1916$. 
We must fall baek upon the rural sehool as the only ageney whieh fulfills all the fundamental eonditions neeessary to equip it for the work of edueating the rural population up to the new requirements of eountry life in our day. The rural school, under proper eonditions as to organization and eurriculum, should be able to give this information most effectively to the largest number and in the shortest time. Therefore all reforms of the rural sehool should aim direetly or indireetly at funetionalizing its eurrieulum. The ehanges whieh might be immediately brought about in the rural sehool's course of study, without arousing unneeessary opposition or disturbanee, are three in number.

1. Certain of the old and well established subjeets, such as arithmetie, grammar (language study), biology (nature study), geography and physiology (sanitation and hygiene), should be brought down to praetieal and loeal applieation. Edueational theory as applied to the rural eommunity has already gone this far. It is only neeessary to infuse the politieal state edueational administrations with the knowledge of the desirability of this ehange to make it fairly effeetive, and there is some eause for eneouragement in believing that this desired end may be attained even before polities is eradieated from these state edueational administrations. Some text-books and teaehing outlines looking in this direetion have already been prepared in each of the subjeets mentioned. The general effeet of such a ehange would be to bring the formal instruetion of many of the standard eourses in the rural sehool into direet and funetional eontaet with the teehniques of the oeeupation of farming. Nor would any general or eultural edueational values adhering to these subjeets be lost, for the general underlying prineiples of knowledge in each would of eourse remain the same. Only the illustrative material would change.

2. The eourses mentioned above ean at their best be made to deal only with the teehniques of produetion and sanitation. They ean not be made to reach over into the eonstruetive eeonomie and soeial aetivities of eountry life.

At present there are no comses in the eountry sehool whieh perform this wide function, and sueh eourses must be introdueed. The knowledge for whieh there is now the most erying need in the rural eommunity is that which will enable the farmer to 
understand the fundamentals of his business, soeial, institutional and eivie life. The modern farmer, regardless of the size of his aeres, must be a business man, whether he wishes it or not. He has at last been eaught in the swirl of the industrial revolution with its emphasis upon division of labor and speeialization; upon markets and eredits; and above all upon seienee and effieieney. For the sake of greater produetivity he has lost his self-suffieiency. A half-hearted teaching of agriculture has been added to the rural eourse of study, but the farmer has not learned to enter the markets to the best advantage nor to proteet hiniself once the requirements of his oceupation have brought him in. His institutions are largely outgrown survivals of pioneer eonditions and have neither the organization nor the grasp neessary for adjusting him to modern life. They are largely inert and parasitie, not virile with the spirit of leadership. The governmental aspeets of rural life are so little in the farmer's eonseionsness that he seareely realizes that he has any sueh eonneetions at all. Although the plan of organization of eounty and rural governments is not beyond the powers of eompreliension of the most ordinary normal intelleet, very few farmers who have no politieal ambitions for themselves really understand it. Goverument means to them national government, and no otler group so eomplaeently takes its politieal opinions ready made or so universally fails to take any opinion on matters of most intimate personal eoncern to it. Organization for independent politieal expression, espeeially on local matters, is extremely exeeptional among farmers.

The explanation of sueh a wholesale abdieation of the privileges of demoeratie eontrol over his destiny ean be explained only in terms 'of the farmer's laek of information regarding his broader soeial and ceonomic needs and the techniques of organizing his interests effeetively. The most hopeful proposition for meeting this need is to introduee just this subjeet-matter into the rural sehool eurriculum. The time has arrived when we ean no longer forbear to add eourses of regular instruetion in matters of sueh intimate eoneern to the farmer's welfare.

3. A third ehange in the rural sehool eurrieulum eapable of aecomplisling mueh good would be to make the sehool readers truly supplementary to the general purposes of edueation. The 
reader should supplement the two types of instruetion outlined above, but particularly the second, the more general economic, social and eivie type of teaching. The readers should be distinctly supplementary, their general funetion being to stimulate interest in more intensive study and to give coloring and emotional content through personal instances and sidelights. Thus a description of coöperation in Denmark or of the work of Pastor Oberlin or the story of the founding of the John Swaney School could not but give the student an impetus to the discovery through his formal courses of the teehniques for bringing about such ehanges in his own eommunity.

Onc of the most frequent objections to proposals to expand the eurriculum on its eivie side is that there is not time for such a modified curriculum in the one-teacher rural sehool. That is true in essentials. It is also true that there is not time for the effieient teaching of any currieulum in a school eonsisting of eight grades and presided over by one teacher only. Where at all possible the old onc-room school must go. It belongs to the age when farming was carried on by means of a single horse and a donble shovel or a "bull tongue" plow and each family was a self-sufficing unit with but few and simple eontacts with the outside world. This is the age of machine farming and it is also the age of efficiency in education. The consolidation movement is so well under way that it searecly needs the support of argument; it is much more in need of guidance. There are three kinds of consolidation, and of these eomplete eonsolidation of enough distriets to make the school really efficient and to provide high-school faeilities is by far the best type where it is at all possible. This sort of consolidation involves transportation, which is at once the most expensive and the most eombated feature of consolidation. But even transportation pays in the long run. Where eomplete consolidation with transportation does not appear to be feasible many districts are eonsolidating for highschool purposes and leaving the district schools intact for the clementary students. Sucl a policy seems of doubtful wisdom. While there is a saving due to the lack of eommunity transportation, the eost in duplieation and inefficiency probably overbalances the saving. The third type of consolidation is to be found where two or three or four districts unite, usually for fiscal 
rather than primarily for educational purposes. Such limited consolidation may be better than none, but it by no means approximates the ideal.

For one reason or another there will probably always be some isolated onc-teacher sehools. What ean we do with these? Surcly we must have a fairly uniform curriculum for eountry sehools. Our revised course of study could probably be adapted to these schools quite as well as the present one is, especially if the great amount of dead matter whieh now exists in the rural school curriculum were eliminated. And the resulting benefits to the community should be much greater.

The best effects from such a ehange in curriculum can not be realized until the rural sehool is bronght into eloser contact with the adult members of the community. Already in certair isolated instances much has been done in the way of rural seliool extension, especially through agrieultural chib work, school fairs, eoöperative instruetion in farm practiee and home cenomics on the farms and in the homes of patrons; and in some eases the sehools have attempted to give some formal instruction to adnlts. The busy teacher of a one-room sehool is necessarily limited by lack of time, and possibly by her sex, in the amount that may be accomplished in these direetions. Both these limitations may, however, be removed if the consolidated school and its cxtension work can be so expanded as to inchde not only agriculture and home economies, but also coöperative endeavor in the wider forms of social and eivic interests.

Along with these more definitely educational modifications in the rural school should eome eertain administrative changes which we need only mention briefly herc. The valuc of medical and dental inspection and supervision in rural schools is now eonceded. It is one of the improvements which will soon come regardless of other ehanges here suggested. And there is also great need of better-state and eounty administration, supervision and inspeetion of rural schools. Likewisc our taxing system as at present applied to eountry schools docs not secure anything like equality of educational opportunity. These and other problens are eoming into the publie eonsciousness.

But the heart of the rural school problem is that of the curriculum. For as it is, so will be in large degree the intellectual, 
eivie and oeeupational outlook of the farmer of to-morrow. It should be repeated that without knowledge the farmer ean not even understand his problems; mueh less will he be able to solve them. It is beeause of the erueial nature of this knowledge problem that the rural sehool is the determinative institution of rural life. If it fails the farmer all else must assuredly fail him.

\section{THE COUNTY AS A UNIT OF ADIINISTRATION ${ }^{1}$}

\section{A. C. MONAHAN}

WE find four units of organization for the administration of the rural sehools in the United States-the district, township, magisterial distriet, and county. The distriet, or the single distriet, as it is sometimes ealled, is the unit in twenty-one states and in parts of four others. The township is the unit in ten states and in parts of three others. The magisterial distriet is the unit in two. The eounty is the unit in eleven states and in part of one other.

On the whole, the eounty unit has most to eommend it. The territory ineluded in a eounty is usually small enough for a eounty board to keep in toueh with the entire eounty, and it is large enough for sehool distriets to be arranged to the best advantage, both for the eonvenienee of the pupils and for eeonomy in management and support. It is the unit of supervision in the great majority of states. For effieieney the supervision and administration must be elosely united. This is possible in the best way only when the unit of supervision and the unit of organization are identieal. Another eonsideration in favor of the eounty unit is the question of support. The eounty is now the unit in most states for the assessment and eolleetion of taxes, the building and eare of roads and bridges, and maintenanee of eriminal and eivil eourts. To make it the unit for school purposes would do away with loeal distriet taxes for edieation, equalize the tax rate for the eounty, and distribute the eost of the support of the schools over the entire eounty, so that equal educa-

1 Alapted from "The Need of a Cominty Unit," U. S. Bur. of Fd., Bulletin No. 30, 1913, pp. 52-54. 
tional opportunities would prevail throughout the county. It must be clearly recognized that education is a matter of concern not only to the local district but also to the county, and to the state and nation as well.

The ideal county system, judging from the most successful elements in various state systems where the county is the unit of organization, is probably as follows: The entire management and control of the schools of the county rests in the hands of a county board of education composed of three, six, or nine members, one-third of whom are elected by the voters of the county at each annual or biennial clcetion. This insures a continuing board. The county board should have the selcetion of a county superintendent of schools, who bccomes the agent of the board in the management of school affairs. In the administration of the course of study, however, the county superintendent should be independent of the county board, as that is a professional task which requires the expert judgment of a professionally trained man. The county superintendent should be a man who has had a good general education, professional education in psychology and pedagogy, and successful experience as a teacher. In the administration of the course of study his only responsibility should be to the state department of education.

The county superintendent should select all teachers for the county, final election being a prerogative of the county board.

The county board of education should divide the county into school districts, for convenience in locating schools and assigning pupils to the various buildings. In each district there should be a trustee or a board of trustees, either appointed by the county board or elected by the people of the district. This local board would have no absolute power, but would have the immediate oversight of the local school and act in a supervisory capacity to the eounty board in all affairs dealing with their school.

School funds should be assessed and expended on the county as a unit. If the county contains independent school distriets, the school tax should be levied on all taxable property in the county including that in the city districts. The funds collected should be divided between the county as a whole and the independent districts, probably on the basis of school population. The basis of division would depend upon local conditions in 
cach state. The independent city districts might raise further funds for the support of their schools, if they so desired. The school distriets in the eounty might also raise an additional sum for the support of their school, although in the ideal system the county funds should be suffieient for all sehool purposes. It is essential that the county board of edueation have power to expend the county funds wherever they are most needed, regardless of the portion of the funds eoming from any particular school distriet.

The average county in the United States is too large an area for adequate supervision of its rural schools by the county superintendent, unless enough assistanee is furnished him so that the schools may be visited and the teachers assisted in their work at regular, frequent periods. In the eighteen larger eities in the United States in 1910 there was one supervisor for every nineteen teachers, devoting half or more than half of his time to supervising. Sueh close supervision is probably not neeessary in the country sehools. The county superintendent, however, should have at least one assistant devoting his entire time to supervising the instruetional work of the sehools for every thirtyfive or forty teachers. Massachusetts and Oregon, both of whieh require all sehools to be under cxpert supervision, have set the maximum as fifty country schools in each supervisory district; that is, fifty schools to onc supervisor. In only a few cases, particularly in Massaeliusetts, do any supervisors have as many as fifty.

\section{THE CHANGE FROM AMATEUR TO PROFESSIONAL TEACHING ${ }^{1}$}

\section{HAROLD W. FOGHT}

TuE ehange from amateur to professional teaehing may be hastened in several ways: (1) Salaries should be increased enough so a teaeher with family may live on his income without worying how to make ends meet. Provision should also be made, by legal enaetment, for a liberal sliding-seale salary, allowing the teacher's incone to increase in direet ratio to

1 Adapted from "lefliciency and Preparation of Rural School Tenchers," Bulletin 49 (1914), U.S. Bureau of Edueation. 
length of service in the same eommunity. This is only frio, since teachers of the right sort will unquestionably grow i value to the community year by year. (2) The entire sc i plant should be reconstrueted to answer present needs and be attractive and sanitary. This would be another inducemest for the teacher to spend his best years in the open eountry. (3) The community should be obliged by legal enaetment to int a teacher's cottage elose by the modern school building and : aferably upon the same grounds. (4) Teachers' eolleges, norinal sehools, and other sehools with teacher-training elasses should be encouraged to organize distinct departments in rural life and rural teaching, from which to draw teaehers prepared and willing to undertake work in the new farm schools.

\section{THE RURAL HIGH SCHOOL ${ }^{1}$}

GEORGE II. BETTS AND OTIS E. HALL

Willingness of the rural eommunity to provicle high sehool edueation for its youth is one of the first tests of its right to the loyalty of the young people. The four years of school privileges above the elementary grades now so generally available to urban ehildren must be similarly open to eountry boys and girls, else we ean not blame them for deserting the farms for the better edueational opportunities afforded by the town. The high sehool must be free and must be acecssible to the boy's and girls of the farm.

The high school is not yet free to the majority of rural children, even if they are willing to go to town for their high sehool training. In many states the rural youth must himself pay a tuition of from three to five dollars a month if he attends the nearest town high sehool. His district disclaims all responsibility for his edueation after he eompletes the elementary sehool. Some states, as Iowa, for example, have reeently provided that graduates of rural schools may attend the nearest high sehool, the distriet to pay the tuition fees. But in the Iowa law, reasonable

1 Adapted from "Better Rural Schools," pp. 25S-262. The Bobbs-Mferrill Company, Indianapolis, 1914. 
as the demand on the distriet is, the liability is limited to three dollars and fifty eents a month, any amount in exeess of this devolving on the pupil.

But even where the rural district freely pays the tuition in the town high school, such a situation is far from satisfactory. The high sehool training afforded rural ehildren should be in rural high schools and not in town and city schools. Not only in currieulum but in spirit and in teaching, the rural high school should represent the life and activities of the farm. If the rural high sehool is to maintain an adequate standard of effieiency, if it is to serve its patronage aright, it must take into its program of studies training in the concrete affairs awaiting its graduates. There are at present more than two thousand publie and private high sehools in the United States teaching agriculture, but eomparatively few of these have aetual eountry environ. ment, most of them being situated in towns and eitics. Such is also truc of the more than onc hundred speeial agricultural sehools of secondary grade located in seventecn different states. While the agrienltural courses tanght in the eity sehool are valuable as educational matcrial and well worth while from the standpoint of general eulture and development, yet of neeessity they lack the vitality and conereteness possessed by similar courses taught with an immediate environment of farm life and conditions. In the reorganization of rural cdueation that is now going on, therefore, there must be definite provision for the installation of high schools as a part of the rural system.

The rural high sehool is a natural outgrowth of the movement toward consolidation. It need hardly be argued that the oneroom school ean never support a high school eourse, nor ought it under any circumstances to undertake the teaching of high school branches, exeept in rare instances where a number of the clementary grades are laeking from want of younger children in attendance. It has been almost uniformly found that the consolidating of a number of elementary sehools into one school has brought about a demand for the introduction of high school subjects. Hence a large majority of the fully consolidated schools are now offering two or even four years of high-sehool work. Not a few of the eonsolidated rural sehools in Indiana, Ohio and many other states, are fully equal in the scope and 
character of the eurriculum and in the quality of teaching to the best town and eity schools. The rural high selools in such communitics are recognized by the colleges and universities, and their graduates are accepted on the same terms as those from urban schools.

It may therefore be concluded that the policy of consolidation ultimately commits to the introduction of rural high schools as a part of the system. This is natural and right, sinec consolidation not only encourages the regularity of attendanee that allows completion of an elementary course preparatory to the high school, but also provides the type of curriculum and teaching necessary for such preparation. Further, the educational standards of communities supporting consolidated schools demand opportunitics for high school education for their clildren.

Certain regions, as in Illinois, have developed the township system of high schools independently of consolidation. Many of these township secondary schools are of higl grade, fully the equal of town and eity schools; indecd, not a few of them are conducted in some convenient town or eity of the township and are in effect not rural high schools at all. They offer the traditional high school course of study, are governed by the typical urban high school spirit, which looks not toward farming but to other lines of occupation, and are therefore not the type of secondary education most useful to rural communities.

In other scetions of the country, county high schools prevail, the county supporting one secondary school open to all qualified residents within the county. The county high school can be approved only as a temporary expedicnt to supply sccondary cducation at a time when the economic ability is not equal to the burden of supporting high schools available to every community. In order to be wholly efficient, the high school must, like the elcmentary school, be brought to the door of those for whom it is intended-and must not require traveling half-way across a county in order to obtain its advantages. Nor must it demand that the pupil leave his home and enter the school as a boardingschool. To be truly a school of the people the rural high school must be connected with the rural clcmentary school, which is equivalent to saying that it will bccome a part of the consolidated school of the future. 


\title{
THE SPREAD OF THE SCHOOL MANSE IDEA ${ }^{1}$
}

\author{
GEORGE E. VINCENT
}

THE older countries of Europe have long recognized that the proper housing of teachers is as much a duty of school authorities as the provision of class rooms, laboratories and gymnasia. In Denmark every rural school has its teachers' house with kitchen garden and flower garden. The schoolmaster and his assistants live on the school grounds. The institution is not a place descrted for all but a few hours in the day; it is rather a permanent residence of community leaders. Little wonder that the Denmark schoolmaster holds his place year after year. It is not unusual for a principal to devote his whole life to one or two eommunities. Throughout Germany practically the same system prevails with the same results in cducational efficiency and community leadership. In France every rural teacher is provided at public expense with living quarters. The same system is well established and is spreading in Sweden, Norway and Finland.

In various parts of the United States significant experiments in providing houses for teachers have been made. In Hawaii one-third of the schools have eottages built at public expense. In the state of Washington notable progress has been made in furnishing living quarters for teachers. North Dakota has twenty-two schools equipped in this way. Mississippi, North Carolina, Illinois, Tennessee and Oklahoma have made promising experiments. In St. Louis County, Minnesota, twenty-five rural school teachers live, in groups of two and threc, in eottages built and completely furnished at public expense.

A teachers' house or school manse is peculiarly necessary to the success of the consolidated rural school which, it is now agreed, is to be the typical country school of the future. There should be built, in connection with the consolidated school on the same grounds with the school building and heated by the same plant, a permanent house for the use of the teaching staft. This building should contain a wholly scparate apartment for the principal and his family, living room and bed-rooms for the

1 Adapted from Annals of the American Academy of L'olitical and Sucial Science, Vol. 67: 167-169, 1!16. 
women teachers, laundry, kitehens, etc. It should be equipped with a view to providing in the community a model of tasteful and economical domestic furnishing and decoration. The rentals and other eharges should be so regulated as to provide for the maintenance, insurance, repairs and renewals of equipment, but not for a sinking-fund. The house should be regarded as a part of the school plant and included in the regular bond issue for construction. $\Lambda$ privately owned manse in Illinois is netting 8 per cent. on an investment of $\$ 10,000$.

The manse has a bearing in several ways upon the educational work of the school. Flowers and vegetable gardens are natural features of school premises which are also residence quarters. The domestic seience work of the school can be connected in valuable ways with the praetieal problems of manse management. The cost accounting offers a capital example of bookkeeping. The use of the school as a community eenter is widened and its value enhanced. The sehool as an institution takes on a more vital character in the eyes of the countryside.

MLst important of all is the effect upon the teacher. Comfortably heated, wcll-lighted quarters, comradeship with colleagues-and at the same time personal privacy-a satisfying, coöperatively managed table, independence of the petty family rivalries of a small eommunity, a reeognized institutional status, combine to attract to the eonsolidated rural school manse teachers of a type which will put the eountry school abreast of the modern edueational movement. It is futile to preach the gospel of sacrifiee for the eause of rural education. There is no reason why rural teachers should be ealled upon to saerifice themselves. They ought not to do it, and they will not do it. The school manse is not a fad, nor a luxury; it is a fundamental necessity.

\section{AGRICULTURE AND THE CURRICULUM ${ }^{1}$}

EVELYN DEWEY

Most states are now reeognizing the necessity for making some effort to promote agricultural stability through the schools.

1 Adapted from "New Schools for Old," pp. 252-259. Dutton, N. Y., 1919. 
Sinee the exodus from farms begins with the young people, legislatures realize that influences which will affeet ehildren direetly may result in eheeking that exodus. They also see that regions where farmers are poor and farm methods baekward are the most seriously depleted by eityward migration. It is natural then to think that equipping the ehildren to earn more money on the farm will tend to keep them there. Therefore, they say country schools ought to teach agrieulture; and they pass laws making so many hours of study of the subject obligatory during the sehool year. They are not teachers and it is not their affair to say how it shall be taught; this important detail is left to the state edueational administrators. They in turn find themselves confronted with the duty of laying out a eourse of study which shall fill up the required number of hours, adopting text-books for the pupils' use and telling every teaeher what lessons they shall give, regardless of varying agrieultural eonditions in the state. If the farmers in the legislature are skeptical of the results of this method of attack, they are still glad to have any attention paid to their profession, and they are usually so vague as to a better way of dealing with the problem that they gladly give their support to such bills. Every country teacher knows the futility of simply going through the required lessons in the agricultural text-book, in order to make better farmers or keep clildren on the farm. The prejudice against book farming is very general in farming regions. This faet alone diseounts unst of the knowledge that pupils might gain from their lessons. Besides this, the same text-book is used for a whole state, regardless of the particular conditions of soil, elimate, markets, ete.; so that it is entirely a matter of chance if the information has any application to the agricultural needs of a partieular distriet. A visitor asked the teacher in a typieal one-room school if she taught any agrieulture or gardening; the reply was: "No, we are not able to manage any at all." Later the teaeher returned to the subjeet, saying: "Of eourse we use the lessons in agrieulture preseribed in the state eurrieulum." This indieates the value the teachers themselves attach to this type of agrieultural teaching if it is not vitalized by the addition of practieal work adapted to loeal eonditions.

Even if it were desirable to teach grade pupils trades, farm- 
ing does not lend itself to the usual state eurriculum, or to any preseribed metlods. It is a profession, not a mechanical trade where praetice in routine acts brings skill, and one set of faets illustrates all its principles. Young children may be able to understand these general principles, but reciting long preseriptions for soil treatment under theoretical conditions for erops they have never seen, has no bearing whatever on their future as farmers, and linders their edueation as it takes time which might be spent in worth-while work.

If there is nothing educational in abstract lessons in agriculture, engaging in agriculture with an open mind is an education in itself. City and country teachers alike are agreed in testifying to the valne of real work in gardens for ehildren of all ages. The work is valuable because through it the ehildren learr so much abont the commonest things about them, plants, earth, water and sunsline, not beeause it teaches them processes which will enable them to earn more money when they grow up. The teaching metlod which looks to the environment of the child to furnish most of the class-room matcrial makes the teaching of agriculture a necessity. When elildren learn to understand the things around them and learn the possibilities and relationships of the local environment, there is no danger of training mere technicians, who arc capable only of mechanical work, nor yet of developing abstract theorists, whose contact with life is confined to books and ideas.

Using the world for a text-book insures the children's being fitted to live in that world efficiently. Since the modern world even in a simple farming district is much too complicated to give one person a grasp of all its phases, the important thing in edueation is to give every person a good working point of view towards life. MIrs. Harvey believes that there are two essential sides to this point of view, and that it is equally important that pupils acpuire them both in their school life. The first is sufficient practical knowledge of the industrial and ceonomic life about them from the side of its underlying prineiples to insure their being able as adults to control their material environment, not to be at its merey. This work should always be taught with seientific principles and social relationships in mind; because it is no part of the duty of the public sehools of a democracy to give 
trade training. It is their duty to teaeh so that every one ean approaeh a trade with general skill and eritical faeulties developed so that he ean learn the trade as a whole, not simply one proeess of it. This involves for a sehool in an agrieultural eommunity, not only theory and praetice in gardening and farming, but general book work which will enable the pupil to understand the business aspeets of farming, its plaee in national life, markets, buying and selling; the relations of the farmer to the rest of the world.

The other side to this point of view is the understanding of the rest of the things in life, whiel is just as important in a demoeraey as the ability to earu a living. Every eliild should have a ehanee to learn how to think for himself; how to understand national and soeial aims, how to appreeiate beauty and wholesome pleasure, how to be healthy, self-reliant and courageous, and how to find out things for limself. Real work presented in the right way promotes both these phases of effieient soeial equipment. It no longer beeomes neeessary to argue the advantages of voeational versus eultural teaehing; the teaeher ean devote her entire time to giving her pupils an edueation. No demonstration is neessary to prove the plaee of agriculture in the eurrieulum of a sehool whieh sets out to edueate farm ehildren. It belongs there just as mueh as an adjustment of the program to the elimate, or of the seating eapaeity to the number of pupils.

The results of a eurrieulum made up and starting from the ehild's environment are sure to be both voeational and eultural. The differenee between teaehing a trade in sehool and using the prevailing industrial eonditions for edueation, ean be demonstrated by a deseription of Mrs. Harvey's methods of using agrieulture in the eurrieulum of Porter, better than by a more theoretieal diseussion. From the very first she saw that the ehildren eould be brought up to adopt the best farm methods as a matter of eourse, if their intelligenee eould be enlisted at the ontset. She selected the vegetable and flower gardens as the best point of attack for the sehool. Owing to eonditions in the eorn belt little attention has been paid to the garden on the individual farms. The farmer, busy with the planting, eultivation and harvesting of the larger erops, lad eome to feel that he 
could spare no time for the garder. The work of gardening fell to the lot of the already overworked woman. Usually, therefore, the plot eultivated was small and the vegetables were few and insuffieient in variety and quantity. By enlisting the children in garden work several purposes were served. The garden serves as a laboratory for teaching the fundamental principles of agrieulture. The ehildren find a healthy summer oceupation, and those who are too young for the heavier farm work are uneonseiously aequiring knowledge and skill which is eertain to make farm life attractive and satisfying to them eventually while it gives them an immediate eonsciousness of and pride in adding to the family comfort and in saving "mother's" strength.

School gardening can be made a valuable adjumet to eountry schools in the corn belt because of its edueative value to the child and its effeet upon the community as well. In truck growing regions some other form of agricultural work should be employed beeause children are pressed into scrvice at home so young that gardens lose their educational value. In using the environment, emphasis must always be put upon the prineiples involved and immediate things should be used as stepping stones to more remote things. The gardening work was in no sense supposed to react immediately upon family incomes by producing vegetables that could be sold; but was expected to react indireetly through the added understanding of agricultural prineiples and through a raised standard of living. Through the school garden the ehild at an age when he is forming tastes and habits for life can learn all the fundamentals of farming in which he is expeeted to take an interest later on.

\section{THE MOONLIGHT SCHOOLS OF KENTUCKY ${ }^{1}$}

\section{CORA WILSON STEWART}

THE various impressions which have prevailed throughout the country in regard to moonlight schools have been amusing indeed. Some have imagined them to be schools where children studied and played and seampered on the green like fairies in the moonlight. Others have believed them to be ideal courting

1 Adapted from Survey, Vol. 35: 429-31, Jan., 1916. 
schools, where lovers strolled arm in arm, quoted poetry, and told the old, old story by the light of a bewitehing nıoon. Others have speculated upon their being schools where moonshiners, youthful and aged, were instructed in the most scientific methods of extracting the juice from the corn, and, at the same time, the most seeretive, to prevent government interference.

When I was superintendent of Rowan county (Kentucky) schools, I served as secretary to a number of illiterate folk-a mistaken kindness. I ought to have been teaching them to read and write. Among these folk was a woman whose children had grown up without education, except one daughter, who had had limited sehcoling. She had gone to Chicago, and there had profited by that one advantage at least which the city possesses over the rural district, the night school. Her letters were the only source of joy that eame into that aged mother's life, and the drafts which they contained were the only means of relieving her necessities.

Often she brought the daughter's letters over the hill, seven miles, to the county seat, for me to read and answer for her. After an absence of some six weeks, she eame in one morning fondling a letter. I anticipated her mission, and said: "A letter from your daughter? Shall I read and answer it for you?"

With dignity and pride, she replied: "I kin answer it fer myself-I've larned to read and write."

In amazement I questioned her, and this is the story she told: "Sometimes I couldn't get over here to see you and the 'cricks' would be up between me and the neighbors, or the neighbors would be away from home, and I could not get a letter read and answered for three or four days; and, anyway, it jist seemed like thar wuz a wall 'twixt Jane and me all the time, and I wanted to read with my own eyes what she had writ with her own hand. So I went to a store and I bought me a speller, and I sot up at nights till midnight, and sometimes till daylightand I learned to read and write.",

And to demonstrate her accomplishment, she slowly spelled out the words of that precious letter, and she sat down and, under my direction, answered it-wrote her first letter, an achievement which pleased her immeasurably, and one which must have pleased the absent Jane still more. 
Shortly after this, therc came into my office one morning a middle-aged man, handsome and intelligent in appearance. While waiting for me to dispateh the business in hand, I gave him two books. He fingered the leaves hurriedly, like a child, turned the books over and looked at the backs, and laid them down with a sigh. Knowing the seareity of interesting reading through the eointry, I proffered him the loan of these two books. He shook his head, and said: "No, I cannot read or write." And then the tears came into the eyes of that stalwart man, and he added: "I would give twenty years of my life if I could."

A few evenings later I attended an entertainment in a rural district school. A stalwart lad of twenty sang a beautiful ballad, mostly original, but partly borrowed from his English ancestors. When lie finished, amid deafening applause, I went over and congratulated him. "Dennis, that was a beautiful ballad-it is worthy of publication. Will you write it down for me?" "I would if I could write," he replied, erestfallen, "but I cannot. I've thought of a hundred of 'em better'n that, but I'd forget 'em before anybody eame along to set 'em down."

These three incidents led directly to the establishment of the moonlight schools. Not merely the eall of three individuals was sounded, but the appeal of three elasses: illiterate mothers separated from their absent children farther than sea or land or any other condition than death; middle-aged men shut out from the world of books and unable to east their ballot with intelligence and in secrecy and security; young people who possess undeveloped talents which might yet be made to contribute mueh to the world of literature, art, seience or invention.

The public school teaehers of the county were ealled together. These specific incidents were related to them, and the fact that there were 1,152 such men and women whom the schools of the past had left behind was dwelt upon. The teachers were asked to voluntecr for night service, to open their scloools on moonlight evenings-to give these people a chance.

This they checrfully agreed to do, and on Labor Day, September 4 , 1911, these teachers celebrated by visiting every farmhouse and every hovel, inviting people of all classes to attend the moonlight sehools which were to open their sessions the next 
evening. They expeeted some response and hoped for from one to three pupils in attendance at each sehool-perhaps one hundred and fifty the eounty over.

These country folk had all the exeuses that any toil-worn people ever had. There were rugged roads to travel, high hills to elimb, streams without bridges to eross, ehildren to lead, and babes to earry; but they were not seeking exeuses, they were seeking knowledge. And so they eame. They eame, some singly and alone; they eame hurrying in groups; they eame traveling for miles; they eame earrying babes in arms; they eame. bent with age and leaning on eanes; they eame 1,200 strong.

The youngest student was eighteen, and the oldest eighty-six. Some learned to write their names the first evening, and some required two evenings for this feat. Their joy in this aehievement, simple though it was, is beyond the power of pen to deseribe. They wrote their names on trees, fenees, posts, barns, barrel-staves, and every available serap of paper. Those who possessed even meager means drew it out of hiding and deposited it in bank, writing their eheeks and signing their names with ehildish pride. Letters soon began to go to loved ones in other eounties and far distant states.

Usually the first of these letters eame to the office of the eounty superintendent. Romantie in the history of this movement is the faet that the first three letters written from the moonlight schools eame in this order: the first from a mother who had ehildren absent in the West; the seeond from the man who had said he would give twenty years of his life if lie eould read and write, and the third from the boy who would forget his ballads before anybody eame along to set them down.

Edueators were skeptieal of the plan, and freely predieted that after the novelty had worn off, the interest would wane. But in the seeond session, the first year's reeord was surpassed in every partieular: 1,600 were enrolled, 350 learned to read and write, and a man eighty-seven years old entered and put to shame the reeord of the proud "sehool-girl" of eighty-six of the year before.

There were many ineidents of really remarkable individual development. A man who had labored for years at $\$ 1.50$ a day enrolled, speeializing in mathematies-in that partieular branch 
in which he was interested, lumbering. At the end of the sixweeks' session he was promoted at a salary double that which he had reeeived before. It was not unusual in traveling over the eounty to find in the day sehools here and there, after the moonlight sehools had elosed, a man or a woman seated at the desk with a clild.

In Mareh, 1913, the teaehers of Rowan eounty met in the offiee of the county superintendent and deelared their determination to wipe illiteraey out of that eounty that year. First, the sehool trustees were indueed to take a eensus of the illiterates. When this was eompleted, an illiteraey reeord was made. On the reeord was not only the name and the age of every illiterate in the county, but his history as well: his home environment, family ties, religious faith, politieal belief, weaknesses, tastes and peculiarities, and the influenee or eombination of influenees through which he might be reached in ease the teacher failed with him.

Each teacher was given a list of the illiterates in her distriet when she opened her day sehool. She ealled on these people and cultivated their aequaintanec before the moonlight sehools began their sessions. The home department of the moonlight schools was established that.year, in whieh the indifferent, the disinclined, the stubborn and the deerepit were taught by the teaeher or by some one under the teacher's direetion at home. "One for every one," was the slogan which brought into serviee doetors, who eould teach their convaleseent patients; ministers who might find a pupil among the members of their flocks; stenographers who could interest waitresses in the small-town hotels, and any others who would seek and teach a pupil. Each distriet was striving to be the first to completely stamp out illiteraey.

We tried, by every means, fair and foul, to get illiteraey out of the county to the last individual. At the close of the third session, we had but a straggling few who could not read and write-twenty-three in all, mainly defeetives, invalids and the blind.

Meanwlile, the moonlight sehools had been extended to twentyfive other counties in the state, and whether it was in distillery seetion or among the teuant class, or in mining region or among the farmers, it was ever with the same results. Men and women 
thronged to the schools, striving to make up for the time they had lost, and they pleaded for a longer term when the session closed.

The Governor of .Kentucky, sceing the determined warfare which was being waged against illiteracy, urged in his messagc to the legislature that an Illiteracy Commission be created to drive illiteracy from the state. The measure creating this commission passed the legislature of 1914 without a dissenting vote, and the scat of the war against illiteracy in Kentucky was transferred from the Court House in the county seat of Rowan to the statc capitol at Frankfort. The commission is directing the state-wide campaign to remove illiteracy from Kentucky by the time the census of 1920 is taken.

One of the first activities of the Illiteracy Commission was to enlist the various organizations in the state to aid the teachers in their warfare on illiteracy. The Kentucky Educational Association was induced to pass a resolution expressing commendation and pledging its support. The Kentucky Press Association was approached for assistance, which was cheerfully given. The Kentucky Federation of Women's Clubs, the Society of Colonial Dames, and other organizations, were among those to early lend their aid.

Governor James B. MaCreery of Kentucky issued, in September, 1914, the first proclamation against illiteracy in the history of the world, urging all classes to join in the fight. Again, in 1915, he issued a similar proclamation. Kentucky has celcbrated "no illiteracy"' Sunday in Octoher, for the past two suecessive years. A galaxy of one hundred and twenty speakers covered the state during the summer of 1915 , condemning the evils of illiteracy and advocating moonlight sclools as a remedy. These speakers consisted of the governor, state officials, United States senators, congressmen, judges of the court of appeals, circuit judges, prominent educators and club women.

Moonlight school graduates have been asked to volunteer to teach at least one to read and write. Individuals and organizations have offered prizes to stimulate teachers in their moonlight schoolwork. A teacher who has taught sixty-two illiterates during a session this year believes that he is very elose to the $\$ 100$ state prize. Yet he, like thousands of other volunteer teachers, 
trudges baek to the sehool at night with no thought of reward, save that of the joy of service and the emancipation of those enslaved in the bondage of illiteracy.

Kentucky will owe her publie sehool teachers a debt that ean never be estimated when they shall have wiped out her illiteracy, whieh they propose to do by 1920 , and in many counties will do even before that time. That eounty in the state which has the largest percentage of illiteracy has taught 1,000 persons in the moonlight schools this year to read and write, while many counties have taught two and three hundred, besides raising the standard of cdueation of many scmi-illiterates and others who hare enrolled.

The moonlight school curriculum embraces more than reading and writing: It includes arithmetic, history, geography, eivies, agriculture, hortieulture, home ceonomies and road building. A speeial method of writing is taught-a moonlight school tablet, with indented letters for acquiring the form, and ruled sheets with wide spaees, designed espeeially for adult pupils. Readers have also been prepared for sueh beginners, dealing with roads, silos, seed-testing, crop rotation, piping water into the house, value of the daily bath, extermination of the fly, ways of cooking, and such problems as the people are facing every day. For example, a lesson on roads reads :

This is a road.

It is a good road.

It will save my time.

It will save my tcam.

It will save my wagon.

The good road is my friend.

I will work for the good road.

The seript lessons follows: "I will work for the good road," which pledge the student writes ten times, and if the law of suggestion works, he beeomes truly a friend and promoter of good roads.

Moonlight sehools are conducted in seventeen states, Oklahoma, Alabama and North Carolina following elosely Kentueky's lead. These schools minister equally to illiterate Indians in 
Oklahoma, illiterate negroes in Alabama, and illiterate whites in North Carolina and other states. California and New Mexico, the last states to adopt the institution, are finding it useful in the edueation of the immigrant population of the one, and the large Mexican population of the other.

'There are 5,516,163 illiterates in this eountry, aeeording to the federal census of 1910-more than the entire population of Denmark, also more than the population of Sweden or Norway, and of several other prosperous eountries. Some eountries thrive, support churches, schools and industries on the number of people that America is permitting to go to waste. Illiteraey in the United States is largely a rural problem; it exists in rural districts in double the proportion found in urban communities. Until the moonlight school was established, there was absolutely no provision for the education of illiterate adults in rural sections, and there is none in urball distriets now, save the eity night school, whieh reeeives illiterate foreigners, but in most eities, at least, does not eoax or compel them to attend.

It is the privilege of Ameriean publie sehool teachers to wipe out America's illiteracy. Back to the sehool-house twenty to twenty-four evenings, and, with proper organization, the deed is done; for experienee has proved that all but abnormal adults can eseape from illiteracy in a month's time, and some in even less.

Could there be more valiant and heroic serviee to humanity than the stamping out of illiteraey, the most insidious foe of the nation?

\section{A NATIONAL PROGRAM FOR EDUCATION ${ }^{1}$}

(A statement issued by the National Edueation Association Commission on the emergency in education and the program for readjustment during and after the war.)

Tue time has clearly eome when we in Ameriea must think and plan for edueation on a seale eommensurate with the magnitude of the task that lies before us and in terms consistent with

1 Adapted from Commission Series No. 1, pp. 10-20; National Edueation Association, Washington, D. C., June, $191 \mathrm{~S}$. 
the obligations that the eoming generations will be called upon to discharge. Heretofore our edueational policies have been confined and cramped by the narrow boundaries of our local units of selrool taxation and control. Our eoneeption of edueation lias been essentially a neighborhood conception. This principle of local responsibility for the support and eontrol of schools has undeniable elements of strengtl. It is an expression of that will to independenee, self-relianee, and individual initiative which eonstitutes so striking a quality of American demoeraey. It must not and need not be saerifieed. But while the interests of the loeal eommunity must still be the determining faetor in school organization and administration, events are rapidly teaching us that our loeal interests are genuine interests only when framed in harmony with our national needs and our international obligations and responsibilities.

There ean, then, be no fundamental antagonism between local and national needs. There are eertain phases of publie edueation with which the federal government may properly concern itself to the immediate and permanent advantage of the sehools, and with an effeet upon loeal initiative and local control that will be stimulating and salutary. Indeed, the outstanding weaknesses and inequities of our public sehools to-day are sueh as to make their reform on a national seale impossible without federal eoöperation, and here as elsewhere in a true demoeracy it is to eoöperation and not to domination that we must look for the solution of our problems.

It is futile to speak of our publie schools as the bulwark of Ameriean demoeraey when tens of thousands of the teaehers in these sehools are only sixteen, seventeen, eighteen, or nineteen years old; when more than one hundred thousand are less than twenty-two years old; when more than a quarter of a million have not passed the age of twenty-five.

There are no fewer than five million ehildren in the United States to-day whose teaeliers have not passed the age of twentyone, and whose teaehers have themselves had as preparation for their responsible work not more than one, two, or rarely three or four years of edueation beyond the eighth grade of the common schools. Every six or seven years these five million elildren are replaced by anotlier group equally numerous, subject to the 
same limited opportunities for instruetion and guidanee. In the eourse of a single generation, these groups now aggregating twenty million men and women will be among the voting eitizens of the nation. The intelligenee that direets their skill and industry will be an important faetor in determining the nation's wealth. The ideas and ideals which were impressed upon them in sehool will form the baekground against which they will interpret and evaluate the nation's polieies. Their judgment, guiding their votes, may make or mar the nation's destiny.

It is in the little sehools of the villages and the rural distriets that the youngest, most experieneed, and least well-trained teachers are to be found. Little sehools they are individually, but large in the aggregate and big with national signifieanee, for in them more than one-half of the nation's ehildren are enrolled. And of all phases of the teaching service that which is represented by these rural and village sehools is the most exacting, the most arduous, and in many ways the most responsible. While the teaeher of the graded eity school instruets a single group of ehildren approximately equal in age and attainment, the rural teacher must eover a wide range of subjeets witl many groups, adapting limself, a seore of times eaeh day, to the varying levels of growth and attainment. While the eity teacher is helped by expert prineipals and supervisors, the rural teaeher is all but absolutely isolated, and must supply through his own initiative, enthusiasm, and resoureefulness many of the elements of good teaehing that one working in an urban eommunity gains through eontaet with his fellows.

And yet the environment of these small and isolated sehools is in many ways the best that eould be provided for the edueation of boys and girls. The equipment of libraries, shops, and laboratories may be laeking, but potential resourees in abundance lie round about. What is needed is the mind to interpret them and translate their lessons. But this is the hardest kind of teaching, far harder than to assign lessons in books and hear reeitations. It is a kind of teaehing that requires knowledge, insiglit, and skill to be obtained only through a broad and thorough training followed by a faithful and earefully supervised apprentieeship.

Nor does this tell the whole story of the possibilities and diffi- 
eulties of rural-sehool teaching. The right man or the right woman in this offiee may beeome a real leader in the eommunity, knowing its people intimately and sympathetieally. Under his or lier tactful direction, the schoolhouse may beeome a true community eenter, enriehing the social life with a round of wholesome activities. It would be hard indeed to overestimate what two hundred thousand mature, well trained, and permanently employed teachers in these small schools would mean both to rural America and to the nation as a whole. They eould do for America and American democracy what the village dominies have done for Scotland and what the rural schoolmasters have done for Denmark and Norway. They could make these lonely outposts of eulture what they should be, strategic eenters of national strengtl and national idealism-for outposts though they may be in one sense, in another and a deeper sense these little schools, of all our educational institutions, are elosest to what is formative and virile and abiding in our national life.

The urban eenters are not wholly blameless for this negleet of the rural sehool. They have required in general higher standards of maturity and preparation for their teachers, but they have fallen far short of recognizing public-school service as a worthy profession or of setting a standard of reeognition and rewards that might well have had a stimulating effeet upon the outlying rural districts. By limiting its teaching-appointments especially in the elementary schools to young women living with their parents in the home community, the typieal Ameriean eity has been able to recruit its teachers at the smallest possible wage. The effeet of this upon the development of a true professional spirit among the teachers can be readily eonjectured. It has lept the standards of professional preparation deplorably low, it has eneouraged young women to enter the work of teaching merely as a temporary oeeupation, and in many eases it has led the public to look upon teaching-appointments, not as positions of trust and honor, but as jobs to be distributed, either to the deserving poor or to those who ean enlist "influence" in their behalf.

Again it is beside the point to say that there are eommunities that have risen far beyond this primitive estimate of the teacher's work. There are many sueh eommunities, it is true, but their 
influence again has been local and circumscribed. It has not sufficed to raise the general level of the teaeher's ealling. It is not, indeed, through individual and loeal advances that the nation's problem is to be solved.

There is, in fact, but one way in which the evils that are inherent in the transient and unprofessional charaeter of the general teaching population ean be remedied, and that is the ereation of conditions that will make teaehing throughout the length and breadth of the land, a permanent oceupation, a real career. Larger appropriations for teachers' salaries are needed, and in view of the alarming shortage in the supply of teachers and the deereasing attendanee upon the normal schools, such appropriations should certainly be made at once if a situation worse than that whieh exists to-day is to be avoided. But higher salaries alone will not solve the problem. What is needed at basis is a different coneeption of the teacher's work, and what is needed first of all is an adequate appreciation of the importanee of a thoroughgoing preparation for its responsibilities.

It eannot be a souree of pride to our people that the United States gives less attention to the training of teachers than does any other great nation. It eannot be a matter of pride to our people that, of all our professional institutions, those who have been intrusted with the preparation of teachers for the publie sehools are the most penuriously supported and the least attraetive to ambitious youth.

Nor ean these normal schools with their inadequate support supply more than a fraetion of the teaehers annually needed for the publie sehools. Their total output each year is seareely enough for the needs of the urban eommunities, leaving the rural and village sehools almost entirely dependent upon untrained recruits. In a typical state-a state that is perhaps midway between the most progressive and the most backward edueationally-80 per eent. of the rural-school teaehers this year are boys and girls fresh from the eighth grade of the eommon schools-and even under these inadequate standards this state reports a shortage in teaehers, so keen is the demand for their services in other oeeupations.

For the national government generously to eoöperate with the states, first in meeting the energency which is drawing so many 
teachers away from the schools, and then in supporting institutions and agencies for the preparation of competent teachers, would be to raice at once the status of the teaching profession and thereby enhance the efficiency of the schools throughout the land. Witlout encroaching upon the autonomy of the several states, such eö̈pcration would recognize in a most effective way the dependence of the nation's welfare upon the public schools and the signifieance of the teacher's serviee to the nation's life.

The eountry child to-day is at a distinct disadvantage edueationally as compared with the city child. Not only are his teachers immature, transient, and untrained, but his term of sehooling in the average of eases is from one to three months shorter each year, and from two to three years shorter in its entirety. Attendance laws are often laxly enforeed or not enforeed at all. The expert supervision, which could do something to offset the immaturity and lack of training upon the part of the teachers, is practically non-existent. The course of study is ill-adjusted to the needs of rural life.

For fifty years and more the difficulties of the rural sehool situation have eonstituted the most serious and perplexing problem of American education. During all of these years courageous cfforts have been made throughout the country to find a solution of this problem. While these efforts have enlisted the scrvice of hundreds of eompetent and devoted leaders, they cannot he said as yet to have done more than tonch the surface. When one remembers that one-half of the nation's ehildren are enrolled in the rural and village sehools it is not diffieult to understand why the largest advanees have been at best only local and sporadic. The problem is of too vast a magnitude to be affected fundamentally by anything short of a great national movement. The time for that movement has clearly eome.

At basis the difficulty is ceonomic and soeial rather than edueational. If the country child is to have opportunities for seliooling equivalent to those provided for the eity ehild, proportionately more money must be spent on the country schools than on the eity schools. The one-room, ungraded sehools are small schools, and the ratio of teachers to pupils is necessarily higl. The consolidation of the onc-room sehools will reduce this ratio and make for economy; but consolidation is impossible in 
some districts, and even where it is practicable, the consolidated sehool, pupil for pupil, will always be more expensive to operate than the eity school. Not only must the cost of transportation be met, but expert teachers for these sehools. must be paid higher salaries than are demanded by teaehers of the same ability and training in the city schools. Indeed, in the few states where a eonsistent effort has been made to furnish the country ehild with teaehers as well qualified as those in the city sehools, it has been found necessary to inerease the rural teachers' salaries from 10 to 20 per cent. above the eity level.

As long as schools are supported entircly or almost entirely by local taxation, then, it is elear that the country ehild cannot have the educational advantages of the eity ehild. The per capita wealth of the rural districts, taking the eountry as a whole, is very far below the per capita wealth of the urban districts. School funds raised by general state taxation and distributed to the local eommunities in proportion to their cducational needs have done something to reduec these inequalities, but except in a very few cases the state funds are so meager that their influenee is almost negligible.

It is again the narrow neighborhood eonception of edueational responsibility that has stood squarcly in the way of progress. In general, each local community has been educationally selfsufficient. The American people have aceepted the principle that it is just and equitable to tax individuals in proportion to their wealth for the education of all the children of the community. They have not as yet followed the course of reasoning to its logical conclusion. They have not thoroughly aceepted the equally sound principle that it is just and equitable to tax communities in proportion to their wealth for the education of all the children of the state.

Combined with the neighborhood conception of educational responsibility as a handicap to progress is a tendeney still to think of the public school as an essentially philanthropic enterprise. In the arguments for increased funds for sehool support, the value of edueation to the individual and the disadvantage under which the individual suffers when he is denied educational privileges have had a preponderant place. The elaims of the state and of the nation for an enlightened eitizenship have been 
reeognized, it is true, but largely in a perfunetory way. At basis the appeal has been to philanthropy and has laid its ehief emphasis upon the injustiee of denying to the children of the poor the advantages that the elildren of the rieh enjoy.

It is in no sense derogatory to our people that they have supported and extended edueational opportunities primarily from this essentially philanthropie motive; but the exelusive appeal to this motive has been unfortunate. It has intensified the loealism of education. It has led the rieher eommunities to selfsatisfaction with their own edueational efforts on the ground that they were doing their best for all the ehildren within their own borders. If ehildren beyond their borders were less well eircumstaneed the rieher eommunities might lament the fact, but they eould hardly be expeeted to divide their wealth and their advantages with their less fortunate neighbors. Thus the fact that American eommunities are interdependent edueationally as well as eommereially and industrially has been obseured. That the wealth and prosperity of a great eity are directly related to the prosperity of its tributary area is elear to all. That the prosperity of this tributary area depends upon the intelligenee of its inhabitants, that the sehools of this area should be matters of eoncern to those who have the eity's prosperity at heart, and that the eity has an obligation to the outlying distriets from whieh its wealth has been derived, these are truths not so readily grasped.

It has indeed taken the experienees of the past year to drive home this basie faet of educational interdependenee. It has taken the erisis of the great war to prove convineingly that there can be no such thing as an Ameriean eommunity that lives to itself alone, whether in industry, in polities, or in edueation. With seven hundred thousand illiterate young men subjeet to the draft, the edueational backwardness of any single district or area beeomes at onee a matter of national eoneern. Modern warfare is a eonfliet in which mental effieieney and physieal effieiency combine to play the leading rôles, and even the kind of physieal effieieney whieh modern warfare demands is the intelligent kind-the counterpart of adequate knowledge and elear thinking.

The war has revealed all this with startling elearness. It is 
for us now to generalize the lesson. If the safety of demoeracy in a time of great crisis is so clearly dependent upon a high level of enlightened intelligence, we may be sure that the passing of the erisis will not change this fundamental eondition.

The rural and village schools are by far the weakest links in the educational chain. There is no way in which these links can be strengthened save through expenditures vastly greater than the loeal communities can supply. General state taxation has already proved itself inadequate to a solution of the problem on a national scale. The welfare of the nation itsclf is more intimately bound up with the intelligence of that majority of its children now enrolled in the rural and village schools than with any other single factor. Federal coöperation in the support and development of rural education is elearly and unequivoeally the only solution of the problem.

\section{THE CONSOLIDATED SCHOOL AS A COMMUNITY CENTER $^{1}$}

\section{JOHN H. COOK}

THE eonsolidated sehool ministers to the educational needs of a larger eommunity than is served by the one-room school. A minimum number of intercsted people are essential to an abiding interest in a social eommunity center. The number of patrons in the sub-distriet sclool is below the minimum, while the eonsolidated sehool may have sufficient numbers to maintain this interest. Many forms of community reereation and aetivity are made possible by the support of this larger number. Among suel activities may be mentioned leeture eourses, interscholastie eontests, both athletic and intellectual, lometalent plays, farmers' institutes and extension sehools, and other entertainments of various sorts.

Talented leadership is indispensable to suecess in making an institution a soeial or eommunity center. There is a dearth of leadership in the onc-room school district unit, owing to small numbers and the lack of interest of the natural leaders of tho

1 Adapted from Publications American Sociological Society, XI: 97-105, 1916. 
community in the one-room school. For the class from which leaders are reeruited is composed partly of those parents who are divided in sehool interests on aceount of ehildren attending forcign ligh schools and partly of those who hold in entire disdain the inferior schools of the eommunity. The funetions held in the onc-room school are not likely even to secure the patronizing presenee of those whose standing and attainments fit them for lcadership. Without the hearty coöperation of the natural lcaders of a community no institution ean be a suecessful social center.

The consolidated or eentralized school offers bountiful opportunity for the extension of mutual aequaintanee among the residents of a rural community. Children from distant portious of the township form friendships which tend to create ties of interest in the parents. One resident of a centralized district describes the results of centralization in extending acquaintanec thus: "Before the schools were centralized my son seemed to know no one when we rode about the towuship. Now as we ride about, a boy or girl will yell, 'Hello, Sammy,' or wave grectings from a distanee. When I inquire, "Who is this?' he often gives names entirely unfamiliar to me. Through my son I have become acquainted with many excellent people whom, otherwise, I would have never known." This is a typical experience.

Another benefieent result, permanent in effect, will be the formation of lasting friendslips among the citizens of the future. This will more than neutralize the disintegrating forces resulting from changed industrial conditions. Not only does the centralized school offer a wider aequaintanceship than is offered by the onc-room school, but in addition a longer period of aequaintance is offered by the consolidated schools. The high school will eontinue the assoeiations of childhood through the adolescent period. These constructive features of the consolidated school do not exist in the one-room school or in any other rural institution except the consolidated sehool.

Another service offered by the consolidated sehool is of farreaching effect in the social life of rural communities. Rural folks have long been characterized by bashfulness and the lack of capacity for social enjoyment. This is caused largely by lack of 
opportunity to play in ehildhood. Sehools should develop the soeial power of pupils as well as their mental power. Social power, like other powers, ean be developed only by its growth through exereise in a favorable enviromment. In the one-room sehool, where a ehild meets witl only one or two of his own age and where wholesome play and social enjoyment are lacking, there ean be no development of the social power. The habits thus formed are diffieult to overeome in after-life; for the social powers of the pupils in sueh an environment are stunted. The consolidated sehool offers a wider aequaintanee and a higher standard of social behavior. Sehool activities stimulated by a eommendab!e sehool spirit will establish the habit of eoöperation. Thus, the inereased social opportunities offered by the consolidated sehool will lay the foundations of a higher type of social aetivities in the rural eommunities of the future, so that the eultured elasses of the eommunity will be glad to eoöperate in the soeial uplift of all.

In the consolidated or centralized sehool there is also a better opportunity to seeure construetive leaderslip from among the teaehers. The consolidated sehool with its high sehool department demands better trained and better prepared teachers than does the typieal one-room sehool which is entent with a teacher who has a modieum of seholarship, training, and initiative. The eollege graduate who teaches in the high sehool and the normal graduate who teaelıes in the grades offer better material for leadership by reason of their selıolarship, their speeial training, and their social experienee.

In the eorps of teachers of the eonsolidated sehool, there is usually one who has specialized in musie and who is eapable of teaehing and drilling ehildren, so that appropriate musie, an essential of all eommunity gatherings, may be furnished by the ehildren of the parents of the community. Under the direetion of the domestie seienee teacher the pupils of the sehool may demonstrate the quality of their work in the enlinary art to the satisfaction and pride of parents and friends. The one-room sehool system is defeetive in providing eapable leadership from among its teachers. The eonsolidated sehool need not be handieapped by this defeet, as it has opportunity to provide fit material from anong its eorps of high-elass teachers. 
Suitable buildings and adequate equipment are necessary for modern comnunity ecuters. $\Lambda$ well-lighted and well-arranged auditorium, a piano, a library and reading-room, a gymnasium for winter functions, and tinaneial backing suffieient for the maintenanee of these essentials are needed in a modern eommunity eenter. A modern consolidated sehool usually provides the requisites mentioned above. If not, because of the union of financial resourecs that obtains in a consolidated school district, these things may usually be provided without fillaneial strain. Conmunity meetings held under favorable eonditions will seeure a larger attendanee and greater enjoyment than when held in buildings poorly arranged, badly lighted, and scantily equipped. When meetings with helpful, interesting, and elevating programs are held in a properly equipped building under competent management in eonncetion with an institution in whieh all are interested, there can be no serious doubt as to the successful future of such efforts.

\section{BibLiograpHY}

Betts, G. H., and Hall, Otis E. Better Rural Selıools. Bobbs-Merrill, Indianapolis, 1914.

Betts, G. H. New Ideals in Rural Schools. Hougliton, Bostou, 1913. Brittain, H. L. Report of the Olio State Seliool Survey Commission. Published by State of Ohio, Columbus, 1914 .

Brown, H. A. The Readjustment of a Rural High School to the Needs of the Community. Bul. 20, U. S. Bureau of Education, 1912.

Burnlıam, Errıest. Rural School Efficiency in Kalamazoo County, Mich. Bul. 4, 1909, published by State Supt. of Public Instruction, Lansing, Mich.

Two Types of Rural Schools with Some Facts Showing Economic and Social Conditions. Teachers College, Columbia Univ., N. Y., 1912.

Rural Teacher Preparation in State Normal Seloonls. U. S. Bur. of Ed. Bul., 1918, No. 27. Government Printing Office, Washington.

Carney, Mabel. Country Life and the Country School. Row, Chicago, 1912.

Cary, C. P. Rural Seliool Board Conventions. National Edueation Assn. Proceedings, 1907, pp. 259-290.

Cook, Katherine M., and Monahan, A. C. Rural Selıool Supervision, U. S. Bureau of Education, Bul. 48, 1916.

Cotton, F. A., and O'Shea, M. V., and Larson, W. E. Consolidation of Scliool Distriets. Bul. 17, Supt. of Public Instruction, Madison, Wis., 1912.

Crocheron, B. H., and others. The Rural School as a Community Center. The Tentli Yearbnok of National Society for the Study of Education, Part II, Univ. of Chicago Press, Chicago, 1911. 
Crosby, Dick J., and Crocheron, B. II. Community Work in the Rural High Selool, U. S. Department of Agriculture, Yearbook, 1910 , pp. $17 \overline{7}-\mathrm{SS}$.

Cubberley, E. P. The Improvement of Rural Schools. Hougliton, Eostun, 1912.

Rural Life and Education. Houghton Mifflin Co., Boston, 1914.

State and County Educational Reorganization. Macmillan, N. Y., 1915.

Cubberley, E. P., and Elliott, E. C. State and County School Administration. Vol. II, Source Book, Macmillan, N. Y., 1915.

Cutler, H. M., and Stone, Julia M. The Rural Sclıool, its Methods and Management. Silver, N. Y., 1913.

Davenport, E. Elucation for Efficiency. Heath, N. Y., 1909.

Davis, E. E. A Stuly of Rural Schools in 'Travis County, Texas. Univ. of 'T'exas, Bul. 67, Austin, 1916.

Dewey, Evelyn. New Schools for Old. Dutton, N. Y., 1919.

Dewey, Jolın. Democracy and Education. Macmillan, N. Y., 1016.

Dresslar, F. B. Rural Selioolhouses and Grounds. U. S. Bureau of Elucation, Bul. 12, 1914.

Egrgleston, J. D., and Bruère, R. IV. The Work of the Rural School. IIarper, N. Y., 1913.

Field, Jessie. The Corn Lady. Flanagan, Chicago, 1911.

Foght, H. IV. The American Rural School. Macmillan, N. Y., 1910. Rulal Denmark and its Schools. Macmillan, N. Y., 1915.

The Ruial Teacher and His Work in Community Leadership. In School Administration, and in Mastery of the School Subjects. Macmillan, N. Y., 1917.

The Rural School System of Minnesota. U. S. Burcau of Education, Bul. 20, 1915.

Frost, N. A Statistical Study of the Public Schools of the Southern Appalachian Mountains. U. S. Bureau of Education, Bul. 11, 1915.

Hainilton, Jolın. The Townslip High School. Pennsylvania Dept. of Agriculture, Bul. 21, Harrisburg, 1897.

Hart, Joseph K. Educational Resources of Village and Rural Communities. Macmillan, N. Y., 1913.

Hart, IV. R. The Work of the Massachisetts Agricultural College for the Selinols of Massachusetts. Mass. Agric. College Extension Service, Facts for Farmers, Vol. 3, No. 6, Amlierst, 1913.

Hockenberry, John C. The Rural School in the United States. Published by author, Westfield, Mass., 1908.

Jolmsou, A. A. County Schools of Agriculture and Domestic Economy in Wisconsin. Bul. 242, Office of Experimental Stations, U. S. D. A., 1911.

Kennedy, Joseph. Rural Life and the Rural Selıol. American, N. Y., 1915 .

Ǩeru, O. J. Among Country Selıools. Ginn, Poston, 1906.

Larson, W. F., and others. Social and Civic Work in Country Commumities. Bul. 18, State Supt. of Public Instruction, Madison, Wis., 1913.

Larson, TV. F. The Wisconsin Comnty Training Schools for Teachers in Rural Schools. U. S. Burean of Education, Bul. 1T, 1!16. 
Lewis, Howard P. The Rural School and the Community. Badger, Buston, 1918.

Miller, James C. Rural Sehools in Camada. Teachers College, Columbia Univ., N. Y., 1913.

Monahan, A. C. Consolidation of the Rural Sehools. Bul. 604, U. S. Bureau of Ellucation, 1915.

The Status of Rural Education in the United States. U. S. Bureau of Education, Bul. 8, 1913.

Monalıan, A. C., and Wright, R. H. Training Courses for Rural Teachers. U. S. Bureau of Education, 2, 1913.

Murpliy, C. R. Country and Town Students in High Schools. (A comparative study of the work done in high schools by pupils who did their first eight years' work in rural schools and those who did it in town schools.) Amer. School Board Journal, 52:25, 26, February, 1916.

Piekard, A. E. Rural Edueation a Complete Course of Study for Modern Rural Schools. Webb, St. Paul, 1915.

Preliminary Report of the Committce of Fifteen Appointed by the State Superintendent of Selinols to Investigate Educational Necds and Conditions in Wisconsin. State Supt. of Public Instruction, Madison, Wis., 1912.

Report of the Committec on Industrial Edueation in Selıools for Rural Communities. National Edueation Assn., Winona, Minn., 1905.

Reynolds, Annie. The Training of Teachers for the Country Sehools of Wisconsin. State Supt. of Public Instruction of Wisconsin, Madison, 1917.

Ryan, Bridget A. A Redireeted Rural School. Mass. Agrie. College Extension Service, Bul. 6, Amlierst, 1916.

Scerley, Homer H. The Country School. Scribner, N. Y., 1913.

Sims, J. F., and Phelan, Jolın. The Normal Sclıools and Rural Education. Normal Schools of Wisconsin Bul., Board of Regents of Normal Schools, Madison, 1912.

Stcrn, Rence B. Neighborhood Entertainments. Sturgis, N. Y., 1910.

The Negro Rural School and Its Relation to the Community. Pamphlct issued by Extension Dept., Tuskegee Normal and Industrial Institute, Tuskegec, $\Lambda$ la., 1915.

Ward, Edward J. The Social Center. Appleton, N. Y., 1913.

Warren, Burton, (edited by Clifton Johnson), The District School as It Was. Lee, Boston, 1897 .

Waugh, F. A. Country Sehool Grounds. Mass. Agric. College Extension Service, Amherst, 1914.

White, E. V., and Davis, E. E. A Study of Rural Schools in Texas. Univ. of Texas, Bul. 364k, Austin, 1914:

Williams, J. H. Reorganizing a County System of Rural Schools. U. S. Bureau of Education, Bul. 16, 1916.

Wilkinson, William Albert. Rural School Management. Silver, N. Y., 1917.

Wray, Angelina W. Jean Mitchell's School. Public-School Publishing Co., Bloomington, Ill., 1915. 


\section{CHAPTER XIV}

\section{OTHER EDUCATIONAL AGENCIES}

\section{EDUCATION THROUGH FARM DEMONSTRATION ${ }^{1}$}

\section{BRADFORD KNAPP}

IN 1903-04 Congress made an appropriation authorizing work to eounteract the ravages of the Mexican eotton boll weevil in Texas and other eotton states. This inseet pest was laying waste the cotton fields of the Southwest, leaving abandoned farms and business failures in its wake. A small portion of the funds so appropriated was devoted to a work eondueted by the late Dr. Seaman A. Knapp to enable him to try out his method of teaching by eondueting a large number of demonstrations on farms as deseribed above. Dr. Knapp was then seventy years of age. He had been a stoek farmer in Iowa in the '70's, and afterwards Professor of Agrienlture and President of the Iowa Agrienltural College. He had eome to the South in 1885 and had devoted a great deal of his time to the development of the rice industry in Louisiana. In that work and in some of his work in Iowa he had used simple, direet methods of reaching farmers through praetical field examples and, out of that experience, had suggested that he be permitted to try his plan of teaching farmers through demonstrations condueted on their own farms.

The work was aetually begun in January, 1904. The main features eonsisted of personal visits of the department's representatives to a large number of farms seattered over the conntry then seriously affeeted. Demonstrations were earried on by these farmers under the eareful instruetion of these representatives. At first the work was devoted mainly to improving the enltural methods of raising cotton in order to minimize the Camage from the weevil. However, it was soon seen that the

1 Adapted from innals of the American Academy of Political and Social Science, Vol. $67: 224-240,1916$. 
diffieulty eould be met only by a general campaign of the same character for the purpose of bringing about a diversification of crops and better ayricultural practices. The purpose was to bring about such a ehange that the farmer would not be dependent entirely upon cotton for both ineome and maintenance. Therefore, demonstrations in eorn and many other crops were instituted in the same way.

The work was almost an immediate suecess. Thousands of examples or "demonstrations" were created by farmers through the instructions of the department's agents under Dr. Knapp's leadership. Meetings were held at the demonstrations and experiences eompared at the end of the season. During the first year or two the work eovered a great deal of territory. The demonstrations were seattered along railroads and main highways where they eould be easily reached and seen. One agent was compelled to eover considerable territory. However, the effect was to restore confidence, and give the people hopc and something to live on while they readjusted their agrieulture to meet the new conditions. Gradually the farmers began to understand that they could raise cotton in spite of the weevil, and the full restoration of prosperity was only a matter of time and the cxtension of the new type of cducation.

The General Education Board of New York was, at that time, engaged in an earnest effort to assist southern cdueation, not only in colleges, but in secondary schools, and even the primary rural schools. Their attention liad been called to the rural problem and to the rural schools and the gencral educational needs of the country. While studying the situation with a view to grcater assistance, they came in contact with the work of the department under Dr. Knapp. Their representatives visited Texas, met Dr. Knapp and studied his work. They were interested and impressed with Dr. Knapp's statement that in meeting an energency he lad found an opportunity to put into praetice an idea he had worked out which he believed to be of universal application. They, therefore, offered to furnish the neeessary funds to permit Dr. Kuapp to try his plan in seetions of the South far removed from the influence of the boll weevil, if arrangements could be made with the department of agriculture for the trial. As a result of their effort the offer was ae- 
eepted and Dr. Knapp was furnished with funds from the General Edueation Board in addition to the funds from Congress. With the federal funds work was done in boll weevil territory and the territory immediately in advanee of the weevil, which was gradually migrating from year to year north and east through the eotton states. With the funds of the General Edueation Board work of the same kind for the general improvement of agrieulture and rural eeonomie eonditions was begun in Mississippi and Virginia in 1906, and was extended to Alabama, South Carolina, Georgia, and North Carolina in 1907. The direet federal funds earried the work in Texas, Louisiana, Oklahoma and Arkansas. As the weevil advaneed eastward, the states were transferred in sueession from the General Edueation Board fund to the federal fund. The funds from both of these sourees inereased from year to year as the work grew in popularity. In 1909 the federal funds amounted to $\$ 102,000$ and those from the General Edueation Board to $\$ 76,500$.

In 1906 and 1907 sueh was the demand for the work that it was impossible to reaeh all who were insisting that they needed the help. When advised that finaneial assistanee was the limiting faetor in spreading the work, business men in some of the eounties offered to assist in the payment of the salary of an agent if his aetivities eould be restrieted to their eounty. This was done. It had been fully realized by Dr. Knapp that the work would be improved by limiting the territory served by each agent. This led to the adoption of the title "County Agent" afterward so well known in the South.

In 1909 the state of Mississippi took the lead in reeognizing the new type of edueation by enaeting a law under whieh the eounty might pay part of the salary of the agent. In the years from 1909 to 1915 , every southern state having power to grant sueh authority to the eounty passed some sort of law permitting the eounty government to eoöperate with the United States Department of $\Lambda$ grieulture in this work and to pay part or all the salary of the eounty agent. State appropriations were made also in a number of eases, the first in 1911 in Alabama.

The growth of the work was phenomenal. It soon beeame the rule rather than the exeeption for the eounty to furnish at least one-half of the money neeessary for the salary and expenses 
of the eounty agent. Of late years the finaneial eoöperation from loeal sourees has praetieally doubled the serviee and met the appropriations dollar for dollar or more. During the early days of the development of the work men often served for tlie love of the serviee, and henee the rule was rather low salaries eonsidering the serviee rendered. The work was always praetieal and direet. As it grew and developed and the men beeame more expert, the whole system gradually took form and eertain. well reeognized methods were followed.

What does a eounty agent do and how does he teach by demonstrations? The eounty agent goes to the farm and gives his instruetion while the farmer is at his everyday duties. The aim of the work was and is to place in every community practical objeet lessons illustrating the best and most profitable method of produeing the standard farm erops, or of animal feeding, ete., and to seeure such aetive participation in the demonstration on the part of the farmers as to prove that they ean make a mueh larger average anmual erop, or feed or produee livestoek more eeonomieally, and secure a greater return for their toil. Dr. Knapp said that it might be regarded as a "system of adult edueation given to the farmer upon his farm by objeet lessons in the soil, prepared under his observation and generally by his own hand."

The teaching was very effeetive beeause at first it was simple in eharaeter, direet, and limited to a few fundamental things, sueh as the preparation of a good seed bed, deep fall plowing, the seleetion of good seed, and shallow and intensive eultivation. In the early stages of the work Dr. Knapp framed what he ealled the "Ten Commandments of Agrieulture," as follows:

1. Prepare a deep and thoroughly pulverized seed bed, well drained; break in the fall to a depth of 8,10 or 12 inehes, aeeording to the soil; with implements that will not bring too much of the sub-soil to the surface; (the foregoing cepths should be reached gradually).

2. Use seed of the best variety, intelligently seleeted and earefully stored.

3. In eultivated erops, give rows and the plants in the rows, a spaee suited to the plant, the soil and the elimate. 
4. Use intensive tillage during the growing period of the erop.

5. Secure a high eontent of humus in the soil by the use of legumes, barnyard manure, farm refuse and eommercial fertilizers.

6. Carry out a system of erop rotation with a winter cover crop on southern farms.

7. Aecomplish morc work in a day by using more horse power and better implements.

8. Increase the farm stock to the extent of utilizing all the waste produets and idle lands on the farm.

9. Produce all the food required for the men and animals on the farm.

10. Keep an aeeount of each farm produet in order to know from whieh the gain or loss arises.

These became very widely known in the South and formed the basis for mueh of the work done by the agents.

The demonstrations were extended from erop to erop. With the fundamental idea that it was necessary to readjust the agrieulture of the South and make it more profitable and to make the country life better, Dr. Knapp tauglit the grcat lesson of diversifieation or a self-sustaining agrieulture. The preservation of the fertility of the soil and the furnishing of the living of the people on the farm from its produets, were two neeessary ehanges if the South was to prosper. With these things taken earc of, that great seetion was wcll supplied with eash crops whieh it eould produee and exehange in the markets of the world for the money with which to improve her life and her industries. The trouble was that the South was produeing these splendid erops of eotton; tobaeeo, riee and sugar and exehanging them for lier living.

One of the problems was to reach as many farmers as possible. The eounty agent eould not possibly carry on a demonstration on every farm in the eounty. Two plans proved effective. The first was to rely upon the faet that farmers, like other people, would imitate what they saw tried with sueess. It became very evident that one good demonstration in a ncighborlood reached more people than the farmer who carried on the demonstration. A varying number of the neighbors copied the practices and 
profited by the lesson beeause it was simple, and elose by where they could see it. But some effort was also made to assist this process. Farmers around the demonstration were notified of the agent's visit and invited to eome to the demonstration farm for a conferenee. These informal meetings were ealled field meetings or field sehools. Neighboring farmers who were sufficiently interested agreed to earry on a demonstration on their own farms and to obtain their instruction from meeting the agent at the demonstration farms. These men who were not visited were ealled "coöperators." Out of these meetings grew neighborhood organizations of farmers or eommunity elubs which now form an important part of the work.

About 1908 Dr. Knapp first began what was known as the Boys' Corn Club Movement in the South. It is true that there had been corn elubs in a number of the northern states and in one or two of the southern states prior to that time. However, Dr. Knapp should reeeive the eredit for systematizing this very important afid excellent picee of work. He established it on an aere eontest basis and arranged ior the giving of prizes, not on the maximum yield alone, but upon the maximum yield at minimum cost, with a written essay deseribing the work done and an exhibit of the produet. The objeets of the Boys' Com Club Work were:

1. To afford the rural teacher a simple and easy method of teaching practical agriculture in the seliools in the way it must be aequired to be of any real service; namely, by aetual work upon the farm.

2. To prove that there is more in the soil than the farmer has ever gotten out of it. To inspiresboys with a love of the land by showing them how they ean get wealth out of it by tilling it in a better way, and thus to be helpful to the family and the neighborhood, and

3. To give the boys a definite, worthy purpose and to stimulate a friendly rivalry among them.

The first effort in this direetion was in Mississippi when Mr. W. H. Smitl, then County Superintendent of Sehools for Holmes County, did the work in eö̈peration with the demonstration 
forces. Results of this work were extended gradually to the other states until the Boys' Corn Club Movement as a part of the general scheme of education through demonstration became a very large factor in southern agricultural work.

The Boys' Club Work was organized mainly through the schools. The county agent was recognized as the agricultural authority and gave the boys instruction. The school teachers generally acted as the organizers of the clubs. The county superintendent was a good coöperator. The state superintendent often assisted materially with the work. Prizes were contributed by local business men; the bankers became interested and often gave eonsiderable money for prizes for these contests. The local contest and the county and state contest soon became very important and interesting events. In 1909 four state prize winners reccived free trips to Washington, D. C. For a number of ycars these annual trips attracted much attention. This plan was abandoned in 1914 for the better system of scholarship prizes. Since then the chief annual prize in the state has been a scholarship at the Agricultural College. Pig Clubs, Baby Becf Clubs, Clover Clubs, ete., are but a natural cvolution which came with the years.

In 1911 the number of county agents had reached 583, the number of demonstrators and coöperators had reached 100,000, and the number of boys approximately 51,000 .

In 1910 Dr. S. A. Knapp began to develop a part of the work for women and girls. It was his belief that he had thus far planned the work for the father and son. He desired to complete the work by doing something for the mother and daughter.

In Oetober, 1910, he wrote:

The Demonstration Work has proven that it is possible to reform, by simple means, the economie life and the personality of the farmer on the farm. The Boys' Corn Clubs have likewise shown how to turn the attention of the boy toward the farm. There remains the lome itself and its women and girls. This problem ean not be approaehed direetly. The reformer who tells the farmer and his wife that their entire home system is wrong will meet with failure. With these faets in view I have gone to work among the girls to teach one simple and straight-forward lesson whieh will open their eyes to the possibilities of adding to the family income through simple work in and alsout the home. 
Beginning in the states of South Carolina, Virginia and Mississippi, there were developed that year a number of Girls' Canning Cubs. This work inereased rapidly.

In the broad development of the work as a whole the county agents, both men and women, naturally divide their activities into three general elasses:

First: Their aetual demonstrations with farmers, their wives, and the boys and girls.

Second: The giving out of general information through speeches, meetings, ete.

Third: Efforts to stimulate organization.

In the South organization work has proeeeded mainly on a community basis. Community interest and aetivity have been often stimulated by the demonstrations, and the collecting of people together at the demonstrations has furnished a ready means of natural organization of eommunities. In many eommunities there were already organizations such as the Farmers' Union. These are assisted by the eounty agents. As a rule the eommunity organization has some definite objeet in view sueh as the improvement of agrieultural praetiees, standardization of produetion, maintenanee of pure varieties of seed and standardizing the production of various kinds of livestoek. Very often, also, they have engaged in the eoöperative purehase of supplies, mainly fertilizers, and in some eoöperative marketing.

In the northern states there has grown up a type of organization known as the County Farm Bureau, whieh is mainly an organization of individual farmers who interest themselves in seeuring a eounty agent and assisting in the general work in the eounty. These organizations have proved quite effective in handling a large anount of business and ereating greater interest in agrieulture.

In many eounties in the South the type of organization for the whole county eonsists in the eonfederation of representatives from the eominunity organizations to form a eounty assoeiation for the general improvement of agrieulture in the whole eounty. It is not possible in this short artiele to diseuss the merits of the two types of organization. Each type has many points of merit and eaeh seems to be meeting the present needs of the people. 
The ultimate type may be a combination of the good features of both plans.

Thus in brief we have the eomplete work involving the service of an educational system for the men, women, boys and girls on the farm. It should be fully understood that the eounty agent, either among the men or the women, is not left to his own fancy or whim in the work. First there are the state agents or leaders who look after the work in an entire state, with assistants, called by that name, or distriet agents in case they are given a portion of the state.

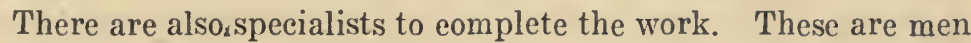
who have been trained especially along some particular branch of agriculture and therefore have studied and prepared themselves to meet special problems or sets of problems. These men are entomologists, agronomists, horliculturists, dairymen, pathologists, ete. A few such speeialists are employed to assist the county agents along these special lines. There are also such men as market experts and farm management experts who assist the eounty agents in their various special problems. All of these together, under a general direetor, constitute what is usually known as the Extension Work or the Extension Service of the state.

Dr. Seaman A. Knapp died in the spring of 1911 at the ripe age of seventy-seven years. After his death the work was eontinued without interruption. In these years it grew as before and its various parts were perfected as the men engaged increased in knowledge and understanding of the work they were doing. In 1911 the work had been extended to all of the southern states with the exeeption of Kentucky, West Virginia and Maryland. In these states it was begun in 1913.

As early as the fall of 1911, an effort was made in South Carolina to bring together all the extension work in the state and to join the federal and the state forces into one organization managed under a coöperative agrecment. The coöperative agreement was actually perfected in Deeember, 1911, and put into operation in January, 1912. Under this plan the College of Agriculture of the State and the Federal Department agreed on a joint representative to administer the work in the state and 
agreed on the details and method under whieh he was to carry the work along. This plan proved an iminediate sueeess and was eopied in Texas in 1912 and in Georgia in 1913. Florida fell in line in the early spring of 1914.

In 1911 some experiments in reaching farmers direetly through a resident instruetor were tried in the northern states under the direetion of the Offiee of Farm Management of the Federal Department of Agrieulture. In the early part of the year 1912 the same office was authorized to begin a systematie effort to extend this praetieal direet work among farmers into the southern states. The problems to be met were different and it required time and experienee to enable the workers to adapt the fundamental principles involved in the demonstration work to the new field. North Dakota began an independent demonstra. tion work early in 1912, afterward uniting with the department's general work of the same eliaraeter. In addition to North $\mathrm{Da}$ kota, New York and Indiana were among the first to develop the work in the northern states. In all the northern and western work the well trained eounty agent was the neeessary part of the plan as in the South.

Beginning in 1862 with the Morrill Aet for the endowment of the state eolleges of agrieulture, the Congress of the United States had passed a series of aets to assist the states in agrieultural edueation and researeh. The Nelson Act inereased the funds for teaehing agrieulture in the eolleges, and the Hateh and Adams Aets ereated and supported the state experiment stations.

It would be impossible to say just when the eolleges had first begun to think about some aet to assist them with the extelssion work or direet work with farmers, but eertainly a number of years before the passage of the Smith-Lever Aet the Association of Ameriean Agrieultural Colleges and Experiment Stations had been interested and aetive in that direetion. Many of the leading agrieultural eolleges of the northern states, and espeeially of the middle western states, had established extension departments of eonsiderable proportions. Their work eonsisted mainly of the sending out of specialists, the conducting of institutes, movable sehools of agrienlture and home eeonomies, short eourses at the eolleges, and boys' and girls' elub work. Some plot work 
and a few demonstration farms of the kind first referred to in the early part of this artiele were also a part of the work. As already stated, the Office of Farm Management of the United States Department of Agrieulture began aetual work in the North in 1912. This work of putting eounty agents into northern counties grew rapidly and appropriations were inereased to meet the expense.

It is not the purpose here to trace the history of the passage of the Smith-Lever Aet. The Act was finally approved by the President May 8, 1914. It provides for the establishment of eooperative extension work in agrieulture and home eeonomies. Each state was to establish a division for sueh work at its land grant eollege, that 'is, the college which had reeeived the benefits of the Morrill, the Nelson, the Hateh and the Adams Aets.

The act provides that the work shall consist of instruction and practical demonstrations in agriculture and home cconomics to persons not attending or resident in said colleges in the several communities, and imparting to such persons information on said subjects througl 'field demonstrations, publications and otherwise; and this work shall be carried on in such manner as may be mutually agreed upon by the Secretary of Agriculture and the State Agricultural College or colleges receiving the benefits of this Act.

The appropriations from the federal treasury, under this aet, began with $\$ 480,000$ for the year ending June 30 , 1915, which was divided equally, $\$ 10,000$ to each of the forty-eight states. For the next year an additional appropriation of $\$ 600,000$ was made and then the amount inereases by $\$ 500,000$ per annum until the amount reaehes $\$ 4,100,000$ in addition to the original $\$ 480,000$, or a total of $\$ 4,580,000$. As to all the additional appropriation above the $\$ 480,000$, it is provided that it shall be divided between the states in the proportion that the rural population of each state bears to the total rural population, on condition that "no parment out of the additional appropriation herein provided shall be made in any year to any state until an equal sum has been appropriated for that year by the Legislature of the State, or provided by state, eounty, eollege, loeal authority, or individual contribution from within the state for the maintenanee of the eoöperative agrieultural extension work provided for in this aet." This means that at the end of the 
year 1922 there will be an annual appropriation from the federal treasury amounting to $\$ 4,580,000$, and annual contributions from within the states amounting to $\$ 4,100,000$ for the support of the work, or a grand total of $\$ 8,680,000$. This will be the annual expenditure in this new and important system of agrieultural edueation.

It should be remembered that the law itself makes this a cooperative work. The enormous annual economic loss in the United States by reason of soil depletion, inseet ravages, diseases of erops and animals, improper cultural methods, and lack of proper marketing systems has been inercasing from year to year. The nation, the states, the eolleges and many publie and private organizations have been attempting to correct these evils, each in its own way and with its own maehinery and independent of the others. The resulting effort could not be otherwise than wasteful, more or less ineffieient and often misdirected. Wrong principles were often advocated or correct ones improperly presented. Fxpensive effort was duplieated many times. Rivalries and competition were more eommon than harmony and coöperation. The result of it all was doubt, eonfusion and laek of eonfidenee on the part of most of the people in agrieultural work. The new aet provides for unity and coopcration. The field foree represents both the United States Department of Agrieulture and the state eolleges of agriculture.

Shortly after the passage of the act the Seeretary of Agrieulture put the aet into effeet by making an agreement with each state whieh brings all the work into harmony and unity through the one state organization representing both the statc and the nation. Within the department he established the States Relations Service, the two divisions of whieh, under the director, handle the relations with the states under this act and also administer all extension work of the department earried out through the state extension divisions.

Under the present plans there will eventually be a county agricultural agent in every county and also a county woman agent, each supported in their work by a trained foree of specialists and a competent administrative staff.

So we have the new system of instruction with its full foree of instruetors and its plans being worked out. A great public 
serviee organization las been ereated. The effeet of this great movement ean not be estimated. In the South, where it has been the longest in operation, the improvement in agrieulture is most noticeable. Thousands of eommunity organizations are drawing together for better rural life, hundreds of thousands of demonstrations are eondueted eaeh year and the aetual number of persons reaehed already mounts into the millions. The wastes are being stopped, the bad practiees remedied, the diseases eradieated, the fertility of the soil eonserved and built up, the marketing systems improved, and eountry life is beginning to take on an air of interest and attraetiveness which will hold its people and draw others to the great life of this foundation ealling of the people.

The work is yet in its infaney. With the years there will be improvements. What are now regarded as experiments will settle into aeeepted praetices. Skill, form, system, all will grow and be developed as they have with the teaching in the sehools. But the fundamental prineiple of having the teaeler go to the une to be taught and to illustrate the lesson by a demonstration eondueted by the one reeeiving the lesson will remain the very foundation of the new edueational system. It has already triumphed where the word of mouth instruetion failed. The dream of the founder has beeome the reality reeognized and established by law.

\section{HOME ECONOMICS WORK UNDER THE SMITH-LEVER $\mathrm{ACT}^{1}$}

THE chief objeetions of women to eountry life are usually (1) the generally small returns in farming, (2) the drudgery of farm work, and (3) the soeial isolation. More money for home eonvenienees and greater effieieney in lousehold management both have in view the lessening of the drudgery of farm work and the seeuring of eertain periods of leisure to farm women whieh may be used in produetive, soeial, and reereational ways.

1 Adapted from Journal of Home Economics. 7: 357-358. The American Home Economies Assn.. Baltimorc, 1015. Oflice of Information, U. S. Dept. of Agriculture. 
Extension work designed to be fundamentally helpful to farm women would seem, therefore, to in elude within its seope eertain matters, as follows:

1. Plans to inerease the net ineome of the farm. Farm women need more money for home purposes. The purehase of home eonvenienees, the installation of water, sewerage, lighting, and heating systems, kitchen and other eonvenienees, and the bringing of literature and musie into the home are, in the majority of eountry hoines, dependent upon greater net profits in farming. Knowledge of these eonvenienees and other desirable things is good, but money to buy these desirable things is a vital neeessity if country life is to be made as aeeptable to women as town life. The eounty agent is giving espeeial attention to this phase of the work.

2. Plans to teach and demonstrate effieieney in farm home management. These inelude sueh matters as wholesome food properly prepared and served in adequate supply and variety throughout the year, the eare of the home and the family linen and wardrobe, the eare and management of ehildren, and sometimes the handling of eertain farm enterprises like poultry and eggs, milk and butter, the garden, small fruits, ete. Effieieney in farm home management eontemplates the maximum of aeeomplishment with the minimum of effort to the end that the farm family may find satisfaction and eontentment in the home, and that the time of the farm woman may be eonserved.

3. Plans for leisure and development. The farm woman needs time for reading, self-development, ehild teaehing, soeial life, and reereation.

In the development of Home Eeonomies demonstration work, there needs to be kept in mind the point of view that the problems of eountry women must ehiefly be solved by country women. The eounty agent movement in some seetions of the North and West started out primarily as a eity man's movement, but it has sueeceded in exaet proportion as the farmers of the eountry have taken hold of the work and made it their own.

City women ean help in the development of the fortheoming demonstration work in Home Eeonomies for eountry women. One of the ways in which eity women ean be of direet help in the movement is through greater social intereourse with farm 
women, through direet purehases of poultry, eggs, butter, fresh and eanned fruits and vegetables, and by eoöperating with them in the maintenanee of rest rooms, nurseries, ete., for farm women when they eome to town. But what farm women need and how to meet these needs are matters whieh must be worked out ehiefly. by farm women themselves. The eritieism sometimes heard with referenee to much of our Home Eeonomies teaching is that such teaehing is done primarily from the standpoint of the town woman. The eountry woman's problems are the problems of the eountry and must be approached from that standpoint.

\section{BOYS' AND GIRLS' CONTEST CLUBS ${ }^{1}$}

\section{II. BAILEY}

Among the many enterprises that are at present undertaken for the betterment of country life and agrieulture, boys' and girls' elubs are holding mueh publie attention. These elubś are in the nature of organized eontests, with emoluments, prizes or publie reeognition standing as rewards. Contests may lie in the growing of prize erops, in the feeding of aninals, in the making of gardens, in the organizing of prize-winning eanningelubs, bread-elubs and others. The organization of these elubs in reent years has undoubtedly constituted a distinet contribution toward the stimulation of interest in rural affairs and the development of pride and ineentive on the part of many of the eountry people.

I have watehed their growth with mueh interest and have had something to do in giving them eneouragement and faeilities. However, there are eertain perils in this kind of effort, and I desire to offer soine suggestions of warning, while at the same time reaffirming my approval of the general idea of organizing boys and girls for mutual emulation and improvement. We are now eoming to a new era in our agrieultural work, eonsequent on the passage by Congress of the great extension bill and the beginning of the organization of many kinds of rural betterment

1 Adapted from "York State Rural Problems," 2: 71-79. J. B. Iyon Co., Allany. 
enterprises on a national basis. It is time, therefore, that we ehallenge all our old practiees and make plans in a new way.

I sec eonsiderable dangers in the boys' and girls' elub work, as some of it is undertaken at the present time or into which it may drift in the future. Perhaps there are other dangers, but four will be suffieient for discnssion at the moment.

(1) These elubs or contests may not represent real effort on the part of the ehild. Work that is eredited to the ehild may be done by father, mother, brother, sister, or by assoeiates. Probably in many eases the ehild's responsibility is only nominal. The boy or girl may receive ereclit for accomplislıments that are not his or hers and that therefore are not real; and if they are not genuine, then, of eourse, they are dishonest. They start the child on a wrong basis and on false pretenses. All sueh work should be under eareful and eontinuous control.

(2) The rewards may be out of all proportion to the effort expended. The prize should have relation to the value of the effort or the earning-power of the work, or it is likely to be damaging to the ehild and to arouse opposition in his community or among his associates. Rewards in agriculture have not come easily, and this has been one of the merits of the oceupation in the training of the race, and it is one of the reasons why agrieulture is a strong and important national asset.

When we make the rewards too casy, we not only cheapen the effort, but we lose the training value of the work. We must be carcful that we do not let the rewards in agrieulture come more cheaply or more easily than in other oceupations. The person must work for what he gets and really earn it, or clse the occupation will lose in dignity and standing with the people. Agrieulture should not aeecpt gratuities.

Some time ago a young woman eame to my office to secure a subseription, saying that if she aeeomplished a eertain number of hundreds, she wonld win a seholarship. She was willing to expend weeks of very hard work, to go to much ineonvenience for the purprese of earning the scholarship. About the same time, certain young boys were brought to my office as one stage in a trip that was given them for relatively unimportant effort in an agrieultural contest. I could not help feeling that the rewards of exertion were unjustly distributed. The travel-prizes 
are speeially likely to be out of keeping with the original effort expended by the ehild.

We should take every pains to let the ehildren feel that the rewards in life eome only with the expenditure of adequate effort.

(3) The effeet of these eontests may be to inflate the ehild and to give him undue and untruthful estimate of his own importanee. A shrewd observer of a boy's prize exeursion remarked that every boy after he got home should be punished; but another observer suggested that the boys in the neighborhood would probably prevent him from getting the bighead. I do not indorse these remarks, but it illustrates the dangers that are likely to aeerue uneonseiously to the ehild. It is a doubtful undertaking to single out eertain ehildren in a eommunity for unusual reeognition or reward.

(4) The children are liable to be exploited, and this is one of the most apparent dangers in the whole situation. They are likely to be used in the making of politieal or other publie reputation, or in aeeomplishing advertising and propaganda for institutions, organizations, publieations, eommereial eoneerns, and other enterprises, or to exploit the resourees of the state or the agrieulture of a region. Children should never be made the means of floating anybody's enterprise.

Every part of the "boom" and "boost" element must be taken out of this work, and all efforts to make a display or a demonstration. Substantial enterprises may stand on their own feet, and the work with ehildren may stand on its ow'l feet and not be tied up to undertakings to whiel it does not belong.

Reeognizing the dangers that may eome from the organization of boys' and girls' elubs, how can we so safeguard them in the new time that these dangers will be eliminated or at least redueed to the minimum? I think that we ean safeginard them if only we reeognize the essential nature and funetion of such eontests.

The fundanental eonsideration is that all this kind of work is edueational. It is not primarily agrieultural work, not undertaken direetly to improve the farming of a region. The primary eonsideration is its effect on the ehild. If we eannot aeeept these propositions, then I should be in favor of giving up the boys' and girls' eontests. 
It is legitimate to use domestie animals and crops for the primary purpose of improving and advertising the agriculture of a region; but we must not use children in this way. Animals and crops are agricultural products; children are not agricultural products.

If these positions are granted, we shall agree that this contest work between children must be put more and more into the hands of those who are trained in education and who carry the responsibility before the public for educational effort. I think that this kind of work should be a part of the public school system. On their own account, schools must take up this and similar work if they are to secure the best results for themselves and to cover their own fields. The organizing or laboratory work at home under the direction of the teacher is one of the most important means of tying the schools and the homes together and making the school a real part and parcel of the community.

When this time shall come, the work with crops and domestic animals and home practices will be a regular part of the school day, incorporated inseverably with the program of education. We must hope for the time when there shall be no necessity for the scparate organization of such clubs, the school having reached and stimulated the situation on every farm and in every home. It is sometimes said that the agricultural agents organize the contest work better than the teachers. Perhaps; but the work is essentially school work, nevertheless, and we should now be looking for results in the long future.

Supervisors and superintendents of schools and teachers will need the demonstration-practice and the subject-matter that the agrieultural agent can give them; they will increasingly call on this agent; and herein will be another effective means of tying all rural work together on a basis of coöperation and coaction.

\section{THE RURAL BOOK HUNGER ${ }^{1}$}

\section{S DUDGEON}

Probably no enterprise for rural betterment has borne more fruit than the traveling library system, and certainly few have

1 Adapted from Rural Manhood, Vol. 6:303-307, April, 1915. County Work Dept., International Com. Y. M. C. A., N. Y. 
more promptly shown results. Begun as a benevolenee, it has grown to be an important part of an edueational system.

The dearth of reading matter in many rural homes is almost beyond the belief of those to whom the daily paper, the weekly, monthly and quarterly magazines, the well-filled private book shelves, and the publie libraries, general and speeial, have always been a matter of course. To one aecustomed to these, they are neeessities, and he little realizes the eonditions which led that ehild of a baekwood eommunity to cherish the eatalogue of a mail-order house as a ehoice possession. In order to show this lack of. reading matter more speeifieally it may be well to eite the ease of a eertain township in the Middle West, where an investigation was earried on to learn just how mueh reading was done. The prineipal of the sehools of a small eity near by, in eooperation with the state library eommission, made a survey of the twenty-one homes in this sparsely settled township. The first important diseovery was that not one adult had read a book during the last year. It is little wonder, for there was not a new or attractive book in the whole three hundred owned in this whole territory, eovering one hundred and fifty square miles.

The investigator found that at four homes there was not even a Bible, which he had wrongly assumed would be in every home, and did not at first eount as a book, while five homes had no other book than the Bible. A little more than half of the books of fietion in the eommunity were of the dime-novel variety. In one Ameriean home, the family eonsisting of father, mother, and ten ehildren under seventeen, the total literary equipment eonsisted of "The Foreman's Bride," "Who is the Creator?" "Twenty Years of IIustling," and a Bible. The boy of thirteen years of age said that "The Foreman's Bride"' was his favorite book and that he had read it several times. Another home, where both father and mother were Indians, eontained about fifty dime novels, with no other books or periodieals of any kind, although both parents were edueated at Carlisle.

In two homes there were no periodieals, and in the others the magazines were ehiefly of the light literature type, Comfort, Good Storics, IIappy Hours, ete. One home had The Woman's Home Companion, the Cosmopolitan, the American IIome, and Extension. Forty weekly papers and eight dailies were taken, 
two of the latter being Bohemian papers with strong Soeialistie tendeneies.

Another investigation made in a seaboard state, not more than three hundred miles from New York City, reveals eonditions even more startling, the data being eollected with the assistanee of the sehool teaehers throughout the eommunity. Great eare was taken and the eonditions found should be fairly representative, as the rural population of the state is almost exelusively native born; there is searcely a distriet in the state more than ten miles from a railroad; the rural free delivery brings mail to every door; there is a eompulsory sehool law; and the state maintains a system of traveling libraries, whereby any sehool, ehureh, or elub might have one free of charge upon applieation.

The eonditions show even greater laek of reading matter than in the West. Nore than 50 per eent. of the families reported owned no books whatever. More than 25 per eent. of the homes reported that they look no periodieals of any kind, not even a loeal newspaper. About 94 per cent. took no periodieal of a general or hiterary eharaeter. Of every thousand ehildren in one eounty, 44 per eent. reported that they read nothing. Nore than 50 per eent. of the households in this same eounty reported that they owned no books.

In a distriet from which thirty-one replies were received, representing nineteen families, not a single pupil reports having read a book. Only two of these families own a book, "The Life of MeKinley" in both eases. In eleven of the nineteen homes there was not a newspaper, a magazine or a book. Only two of seventeen families in another district own books; one has "Robinson Crusoe" and the other has "The War with Spain."

These investigations show the value of traveling libraries. In one sehool from whieh seventeen replies came (representing nine households) three homes were utterly without books, yet sixteen of the seventeen ehildren had read books from the traveling library; four of the sixteen had never read a book from any other souree, and the sixteen pupils had read sixty-one books from this library. While these data indieating a dire need for books are the result of reeent investigations, librarians have for a long time appreeiated the rural need for good literature, and have done much to relieve this book hunger. Before the phrase 
"rural betterment" passed eurrent, if not, indeed, before it liad been eoined, many attempts were made to open to the eountry boy and girl the edueational opportunities found in good books and to relieve the dull monotony of the eountry life by attractive reading matter. In at least thirty-three states efforts are now being made to send good books to eountry distriets.

Sometimes the books are furnished by the publie library of an adjoining eity. Oceasionally a township supplies its own needs with loeal funds. In many eases the eounty is the unit and owns and eireulates the books. Most frequently, however, the work is done by state library eommissions, whieh, by sending out traveling libraries, reach hundreds of eommunities which otherwise would be withont books. In a few instanees the books have been taken to the very door of the farmhouse, as in Delaware and in Maryland, where book wagons make periodieal rounds. There traveling libraries are eolleetions of from thirty-five to one hundred books which are paeked in stout wooden eases and sent out by the state or the eounty, as the ease may be. They are made up of the best popular books in fietion, history, travel, biography, seienee and literature, and are suited to the needs of botl adults and ehildren. Where there is a local need there may be added a seleetion of books printed in German, Norwegian, Bohemian, Danish, Polish or Yiddisl in order that those older rural residents who eannot read the English language may be served. All forms of the traveling library are intended for farming eommunities and for those small villages wlich do not enjoy publie library privileges.

If a few persons in a eommunity are suffieiently interested in any subjeet to make a serious study of it they are furnished a eolleetion of books whieh, with a study outline, enable them to eonstitute themselves a study elub. There is practieally no limit to the number of topies which may be studied in this way. Material of various kinds, books, pamphlets, periodicals, and pietures will be sent upon any subjeet from Egyptian history to the latest phase of the up-to-date soeiologieal problem. The desires of every one are met as nearly as possible, whether he wishes to make a study of Flemish art or to learn the best way of preventing potato seab.

When the people of any eommunity have read a library it is 
returned to the state or county authoritics where the books are cheeked up, a record of their cireulation is taken, and necessary repairs are made, after whieh it is sent to another community. The rural community is at no-expense except that the eost of transportation is generally paid by the local patrons. In no event, however, is even an insignificant finaneial payment on the part of the patrons madc the eondition of obtaining the books from the loeal eustodian.

The rule is that the traveling library shall be kept in the most eentrally loeated and most easily accessible place that can be found. The local postoffice is an ideal plaee, but a general store often serves the purpose well. Frequently the loeal merchant finds that his inereased trade wcll repays him for the time spent in caring for the library, since the presenee of the books attraets the publie to his place of business. Where there is no postoffiee or store, a creamery, a eheese faetory, or a private residenee beeomes the home of the little group of books. Sometimes the library is loeated in a sehoolhouse, but sinee a sehoolhouse is closed evenings, Saturdays, and during long vaeation periods, the books so loeated are not always aeeessible. It is found also that adults do not usually patronize libraries whieh are located in schoolhouses.

Reeords indieate that the tastes of eountry readcrs differ very little from the tastes of eity people. An cxamination of the reeorded eireulation of certain books explodes the theory that the interests of eountry people are peeuliar to eountry distriets. Farmers refuse to read the books whieh theorists think they ought to read. For example, cven the best book on farm topics is rather less popular in the country than in the eity. On the other hand, a book that is popular in the eity is likely to be popular in the eountry. Further, however, a good book sent to the country is more likely to be read there than in the eity, sinee there is in the country little or no competition from the poor, but possible more attraetive, best-seller.

It is an intercsting faet that the eountry boy or girl is very much the same sort of an individual as is the eity youth and likes the same sort of books. Prof. B. A. Heydriek, of the High School of Commeree of New York City, asked six hundred city boys to give him a list of the twenty books which they liked best. 
Care was taken to seeure the independent, individual preferenee of each. At about the same time Mr. O. S. Rice, of the State Superintendent's offiee, in Wiseonsin, made a similar request of the boys and girls in attendanee in one hundred and fifty high schools in the state, many of these being the smaller village and country high schools. The result of the vote among the eity boys was as follows:

Autlior and Title Votes

Stevenson-Treasure Island.............. 222

Dickens-Oliver Twist................ 100

Cooper-Last of the Mohicans............. 81

Dumas_Three Musketeers............... 78

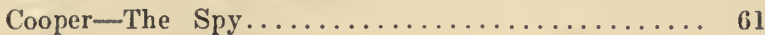

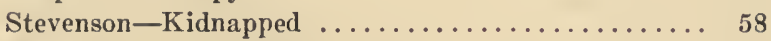

Barbour-Half Back................ 5 ל

Dumas-Count of Monte Cristo............ 55

Barbour-Crimson Sweater............. 51

Doyle-Sherlock Holmes................ 46

Tarkington-Monsieur Beaucaire........... 44

Twain-Tom Sawyer................ 44

Scott-Talisman ................... 43

Dickens-Tale of Two Cities............. 42

Longfellow-Courtship of Miles Standish....... 37

Hughes-Tom Brown's School Day's .......... 35

Longfellow-Evangeline $\ldots \ldots \ldots \ldots \ldots \ldots \ldots \ldots \ldots . \ldots \ldots$

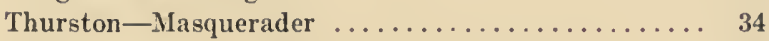

Doyle-Sign of the Four............... 33

London-Call of the Wild.............. 33

The country boys in Wisconsin, some of whom were in smaller villages and cities, chose the following books as their favorites:

Author and Title

Stevenson-Treasure Island.

Scott-Ivanhoe.

London-Call of the Wild.

Cooper-Last of the Molicans.

Churchill-The Crisis.

Twain-Tom Sawyer.

Wallace-Ben-Hur.

Eliot-Silas Marner.

Cooper-Pathfinder.

Cooper-The Spy

Dickens-Tale of Two Cities. 
Cooper-Deerslayer.

IVright-Shepherd of the Hills.

Doubleday-From Cattle Ranch to College.

Egerleston-Hoosier Selioolmaster.

Fox-Trail of the Lonesome l'ine.

Dickens-David Copperfield.

Wister-The Virginian.

Eggleston-Last of the Flatboats.

Dixon-Leopard Spots.

It is to be noted that "Treasure Island" heads both lists and the presenee of the "Last of the Mohicans," "The Spy," "Tom Sawyer," "Tale of 'Two Cities" and "The Call of the Wild" upon both lists indieates that boys are boys in the country and in the eity. It is rather interesting to note also that in addition to these-exeellent books which are indieated upon both lists, the eountry boys seleeted Scott's "Ivanhoe," Diekens' "David Copperfield," Eliot's "Silas Marner," and Wallaee's "BenHur." While some deplore that only fiction is represented upon these lists we suspeet that a perfectly sincere expression from a group of adults would have given mueh the same results in this partieular. On the whole the investigation indieates that the tastes of the Ameriean boys, whether in the eity or country, are clean and wholesome. City and eountry boys alike have an evident fondness for books of violenee and heroism, but the violenee is not lawless and the heroism is genuine.

The vote taken by the boys living in rural Wiseonsin bears evidence that good use will be made of book faeilities when they are offered. The Wisconsin boy's aequaintanee with the best books grows out of the faet that under the Wiseonsin law each sehool distriet is required to expend for books out of the funds eoming to it from the state at least ten eents for each person of sehool age within the distriet. Something over sixty-five thousand dollars is thus spent annually for books in these sehoolhouses. None of this is spent in the large eities, so that this sum goes into the smaller eitics and villages and into the eountry distriets. In addition to this the state expends a eonsiderable sum of money in maintaining a state traveling library system, and during the last year over forty thousand volumes were sent ont to over six hundred different rural communities seattered over the entire state. 
Some time sinee a rather eareful investigation was made of the efficieney of different library systems. It was diseovered that the state traveling library systems eirculated every volume owned with greater frequeney than did the average city library in six representative states chosen at random. The average city library eireulated eaeh volume owned only 2.22 times during the ycar, whereas one state traveling library system, aeeording to its aetual reeorded cireulation, circulated every volume 2.77 times per year. As it is very diffieult to get unpaid eustodians of traveling libraries to record every circulation, it is likely that the aetual eirculation much cxceeded the reeorded eireulation. It is also probably true that each time a book is taken from a traveling library situated in the country it is read by many more persons than is a book taken from a eity library by a resident of the eity. Several members of the farmer's family are likely to read evcry book whieh gets into the farm-house. The records of another state traveling library system showed that each volume owned was eireulated 4.07 times per year.

The average eity library in the six states tested expended 12.6 eents for eaeh time a volume was eirculated, whereas the two state traveling library systems tested spent 7 eents and 7.7 eents respectively for eaeh time a volume was eireulated. Fourteen county traveling library systems in one state expended only 5 eents for eaeh time a volume was eirculated.

We think we may safely assume that the need for books in the country is greater than the need in the eity. If this is eorrect and if the traveling library systems cireulate the books on their shelves more frequently than do eity libraries, and if it costs the traveling library systems less to deliver good books in book hungry rural districts than it eosts to deliver the less needed books to urban dwellers, are not the traveling library systems more efficient than are city libraries?

The data collected seem to indicate clearly four points: first, many rural communities are sadly in need of reading matter; second, country people will read when given the opportunity; third, country people do not differ greatly from city pcople in their ehoiec of books; fourth, money invested in traveling libraries is well invested. 


\section{THE COMMUNITY FAIR ${ }^{1}$}

\section{J. STERLING MORAN}

The Community Fair is a miniature eounty fair eondueted by the people of a community to promote its social and economic life. It arouses interest and pride in local aehievement by affording an opportunity for the exhibition of the best produets of the community, fosters the spirit of coopperation by bringing the people together in friendly rivalry, and affords an opportunity for wholesome eommunity reereation.

These fairs are held quite generally throughout the country and are known in different localities as community fairs, district fairs, township fairs, school fairs, grange fairs, and farmers'-elub fairs. The fall festivals, harvest home festivals, and farm, home, and sehool festivals, which are held in certain localities, are adaptations of the same general idea.

The eommunity, township, or district fair makes its appeal directly to all members of the community, while the fair conducted by the farmers' club appeals especially to the members of the organization eoncerned.

The school fair in its simplest form is an exhibition of the work done and the products grown by the school ehildren. From the school fair, with its community-wide interest, it is an easy step to include the products of the older girls and boys who are not in school, and ultimately the products and work of all the members of the community.

Other types of community fairs vary from the "harvest home thanksgiving festival" of New England, which was originally dominated by the religious motive ard had very few exhibits aside from those brought for decorative purposes, to the "farm, home, and sehool festivals" of the Middle West, where the main feature is the exhibition of produets and where recreation of all kinds forms a prominent part.

A single organization is seldom influential enough to enlist all the elements in a community for the purpose of conducting a

1 Adapted from Farmers' Bulletin 870, United States Department of Agriculture. 
community fair. Every organization in the eommunity ought to feel responsible for the suceess of the enterprise.

The first step is to get together the leaders of the different organizations in the community for the purpose of considering whether or not it is advisable to hold a eommunity fair. It is well to present at this meeting a general outline of the method of procedure for the conduct of the fair. If the plan is approved by this group, a community mecting is called, at which full explanation is made regarding the nature and purposes of a eommunity fair and the methods of condueting it. This meeting should be well advertised by posters, newspaper notices, and post eards addressed to each family, ealling attention to the plaee and date and emphasizing the importance of the meeting. If the community decides to hold a fair, the next step is to form an organization, either temporary or permanent, and eleet officers, eonsisting of a president, a viee-president, and a seeretary-treasurer. Committees should also be cliosen.

The president keeps in close touch with the other officers and the ehairmen of all the committees and is the correlating foree and executive officer of the fair. The other officers perform the duties usually pertaining to their offices. The eommittees should have from three to five members each, ineluding at least one young person of sehool age.

The amusement and entertainment committee has charge of all athletics and field sports, games, folk dances, pageants, and parades, and also arranges for music, motion pietures, speakers, and other attractions.

The arrangements and decorations eommittee arranges for a place to hold the fair and looks after the decorations, using flowers, autumn leaves, evergreens, bunting, flags, and other available material. This committee eoöperates with the several committees having eharge of the different exhibit departments and assigns such tables, shelves, and wall space as are needed.

The publicity eommittee enlists the help of the loeal newspapers and supplies them regularly with articles eoneerning the fair and witl a eomprehensive report after it has been held. Regular notiees are given in schools and churelies and at all publie gatherings for several weeks prior to the holding of the fair. Ilandmade posters are often used, and when well made 
they give individuality and attractiveness to the advertising. Printed handbills or "fliers" giving detailed lists of artieles that may be exhibited in each department are distributed to every family in the eommunity several weeks before the fair. In the preparation of these suggestive lists the publicity eommittee works with the ehairman of the eommittees having charge of the several exhibit departments of the fair.

While it is to be expeeted that the exhibits at a eommunity fair will receive special attention for the purpose of exhibition, nevertheless they should represent as nearly as possible the normal production of the community, for one of the purposes of holding a eommunity fair is to stimulate a desire to inerease the quantity and to improve the quality of the average product. Freak exhibits of all kinds are to be avoided.

Personal solieitation has been found to be a most effective means of indueing people to make exhibits. Each exhihitor should realize that he is in eompetition only with other members of the eommunity and that it will not be possible for some stranger to take all the prizes.

Satisfactory results are usually obtained in community fairs by grouping eertain classes of exhibits. Thus, in the live-stock departinent, horses, eattle, swine, poultry, and pets are exhibited. In the farm-produets department are shown different varieties of grains and seeds, grasses and forage crops, field beans and peas, peanuts and potatoes, together with dairy produets and bee products. The orehard and garden department includes such exhibits as fruits and vegetables, ornamental shrubbery, and flowers.

The woman's-work and fine-arts department includes prepared foods, eanned goods, jellies, preserves, and piekles, and all kinds of needlework, together with such exhibits as paintings, metal work, raffia and reed basket work, pottery, painted ehina, and handmade jewclry.

The sehool and elub department includes all exhibits from organizations in the eominunity whicl wish to bring the results of their work before the community in this way.

The historieal relies department includes firearms, swords, eaps, and other war relies, old looms, spinning wheels, and artieles produced on them, old pietures, drawings, documents, Indian 
relies, family relies, geological speeimens, and objects of interest from other lands.

Besides the eommittees having charge of these departments, there are often others that conduct such activities as a betterbabies contest, a health exhibit, or a pareel-post exhibit.

Judges of ability and experienee should be secured. The state agrieultural colleges and other institutions are usually willing to render such assistance as their force of workers and means will permit. There are often other individuals with exeeptional experience who may be available at little or no expense. When possible, judges should be ehosen from outside the eommunity.

The relatively small number of exhibits at a community fair makes it possible for the judges to explain the basis upon which the awards were made. Besides allaying eritieism, this plan has great edueational value. If standard score eards ean be obtained from reliable sourees, they should be put into the hands of prospective exhibitors several weeks prior to the fair, and all judging should be done on this basis.

It has often been found that community fairs do not appeal to ecrtain persons who have been in the habit of making exhibits at fairs where eash premiums are awarded. The primary aim of an exhibitor at a eommunity fair, however, should not be to win a money prize as compensation for preparing his exhibit. Experience has proved that the awarding of money prizes not only makes the cost of a fair prohibitive, but, by plaeing the emphasis on money instead of on the honor of achievement, defeats the purpose of the fair.

The best results have been obtained where ribbons have been awarded, the color of the ribbon denoting the grade of the prize. If money is available for printing the ribbons, each one should be so printed as to show the oceasion, place, and date. Awards should be made on the basis of the exeellenee of the exhibit, and 110 premium should be awarded to a poor exhibit. Aceordingly, for the information of exhibitors, it is well to publish for each elass of exhibits the requirements that are to be eonsidered by the judges in awarding premiums.

There are numerous instanees where valuable premiums have been given by commereial eoneerns for awards to individuals or organizations that have been sueeessful along the line in which 
the donors were partieularly interested. In a Middle Western State premiums were offered for the best kept farm and home premises and to the farm and home showing the greatest improvement in a given time.

The community fair does not require large sums of money for premiums or other expenses, and for this reason no eharges are made for entry of exhibits or gate admissions. A small amount of money, however, is neeessary to pay for printing and general advertising, lumber for tables, shelves, and live-stock pens, ribbons for premiums, and such decorative material and incidentals as are nceded. This money is raised either by subscription or by selling advertising space in the premium list or fair catalogue.

The managements of county fairs are beginning to realize the value of the community exhibit as a factor in making the county fair serve its purpose as an agrieultural exhibition. Liberal premiums lave been offered for these community exhibits, either in eash or in such form as to be of eommunity use, as, for example, referenee books on agrieultural subjeets to be kept in the community library, a watcring trough conveniently loeated, or a drinking fountain.

One state has recently passed a law providing for the holding of community fairs and appropriating moncy for the purpose of packing community exhibits and transporting them to the larger fairs.

An interesting county fair, made up of seventy-two eommunity exhibits, was recently held in a county in the Middle West. There were no raees or sideshows. The 10,000 people in attendanee spent their time for two days in visiting and inspeeting the exhibits and in wholesome recreation under the supervision of an expert reercational director from a neighboring eity. The exlibits, occupying in all about 15,000 square fcet of floor space and 55,000 square feet of wall space, werc housed in vacant buildings on the business street and in tents. Each eommunity had its booths and the several communities vied with each other in making attractive exhibits of the products of the farm, home, and sehool. 


\section{THE SMITH-HUGHES ACT ${ }^{1}$}

This aet is quite similar in some of its features to the Agrieultural Aet of 1914. There is the same provision for eontinuing and inereasing appropriations, beginning with $\$ 1,700,000$ in 1917 , and rising to $\$ 7,200,000$ in 1925 . The available money will be distributed among all states which agree to eontribute sums equal to their allotments and to eonform to the terms of the aet. The appropriation provides for the ereation of three distinet funds, viz., (1) for paying salaries of teachers, supervisors or direetors of agrieultural subjeets; (2) for paying the salaries of teachers of trade, home eeonomies and industrial subjects, and (3) for training the teaehers and others mentioned under (1) and (2). The basis of distribution among the states is rural population under (1), urban population under (2), and total population under (3). A state may aeept benefits under one or more of these funds, as it prefers.

The aet ereates a Federal Board of Voeational Edueation, eonsisting of the Seeretaries of Agrieulture, Commeree and Labor, the United States Commissioner of Edueation, and three other members, to be appointed by the President, of whom one is to represent manufacturing and eommereial interests, one agrieultural interests, and one labor interests. The board, besides administering the act and supervising the work in the several states, will earry out investigations of various kinds relating to voeational edueation, eoöperating, so far as may be advisable, with the Department of Agrieulture, the Department of Commeree and the Bureau of Edueation.

1 Adapted from "The Smith-Hughes Act for Vocational Education," Scientific American, p. 130, N. Y., Aug. 25, 1917.

\section{Bibliograpily}

CHAUTAUQUA

Flude, G. L. Leaven of Chautauqua. World To-day, 21:1120-2, Sept., 1911.

Chautanqua: Symposium. Independent, 82:497-504, June 21, 1915. MeClure. W. F. Chautauqua of To-day. Review of Reviews, 50:53!), Tu! 1914. 
Pearson, Paul M. The Chautauqua Movenent. The Annals, 40:211216, March, 1912.

Ransom, W. L. Founding of the Chautauqua. Independent, $89: 380$, Feb. $26,1917$.

Strother, F. Great American Forum. World's Work, 24:511-64, Sept., 1912.

Vincent, G. E. What is Chautauqua? Independent, $79: 17-9$, July 6 , 1914.

\section{CLUBS-BOYS AND GIRLS}

Benson, O. H. School Credit for Boys' and Girls' Club Work and Extension Aetivities in Agriculture and Home Economies. Jonrnal of Procedings and Addresses of the National Education Association, August, 1915, pp. 1144-1154.

Creswell, Mary E. Girls' and Boys' Club Work-A Manual for Rural 'Teacher's, Bulletin 101, Vol. 4, No. 11. Georgia State College of Agrienlture, Athens, 1916.

Kereher, O. Boys' $\Lambda$ gricultural Clubs, Kentucky Agricultural Extension Cireular, Vol. 46, pp. 1-51, Lexington, 1917.

Johnson, Stanley. Youth Leads the Way-The Corn Clnb Boys. American Magazine, Vol. S0, pp. 8-13, September, 1915.

Youth Leads the Way-The Canning Girls. Ameriean Magazine, 80: 20-25, October, 1915.

Youth Leads the Way-Pigs and Baby Beef (Boy's Clubs). Ameriean Magazine 80:43-47, November, 1915.

Organization and Instruction in Boys' Corn Club Work. U. S. D. $\Lambda$. Burean of Plant Industry, Cir. \$03, 1915.

Swain, J. E. Hand Book for Boys' Agrieultural Clubs with Suggrestions to Teachers, and Bibliograpliy of Bulletins and Books. Oklahoma Agrienltural Extension Cireular 43, pp. 1-90, 1917.

\section{EXTENSION SERVICE AND VOCATIONAL EDUCATION}

Lapp, John A. Important Federal Laws, pp. 96-106. B. F. Bowen \& Co., Indianapolis, 1917.

National $\Lambda$ id for Vocational Education, School and Society, Vol. I, pp. 649-657, May S, 1915.

Leake, Albert H. Vocational Education for Girls and Women. Chap. I. Macmillan, N. Y., 1918.

Monahan, A. C. Federal Aid for Vocational Training: The SmithLever and Smith-Hughes Bills. Journal of Home Economies 7 : 245-248, May, 1915.

Pearson, R. A. Organization and Administration under the SmithLever Act. Proceedings of the $\Lambda$ ssociation of Ameriean Agricultural Colleges and Experiment Stations, pp. 116-129, 1916.

Seeond Report of the Federal Board for Voeational Education, 1918. Government Printing Office, Washington.

Stimson, Rufus. Vocational Agricultural Education by Home Projects. Macmillan, N. Y., 1019.

True, A. C. Federal Legislation, Regulations, and Rulings Affecting Agrienltural Colleges and Experiment Stations. U. S. Department of $A$ griculture States Relations Seryice, Augnst 25, 1917. 
Home Economies Work Uuder the Smitl-Lever Act. Journal of Home Economies, 7:353-355, August, September, 1915.

Woolman, Mary Schenck. The Smith-Hughes Bill. Journal of Home Economies, 8: 241-245, May, 1916.

\section{FAIRS}

Bailey, L. H. County and Local Fairs. In his The Country Life Movement, pp. 165-177, Macmillan, New York, 1911.

Community Service Week in North Carolina, by the Community Service Week Committee, Superintendent of Public Instruction, Raleigh, N. C., 1914.

Hamilton, Joln. Influenees Exerted by Agricultural Fairs. The Annals, $40: 200-210$, March, 1912.

Jordan, S. M. Agricultural Exhibits and Farmers' Institutes. Missouri State Board of $\Lambda$ griculture, Monthly Bulletin, Vol. 14, January, 1916, Jefferson City.

Meisnest, C. W. Harrest Fairs in County and Township Schools. $\Lambda$ merican City (T. and C. ed.), 15:25\%-S, September, 1916.

Morgan, E. I. The Community Fair. The Massachusetts $\Lambda$ gricultural College Extension Service, Extension Bul. No. 27, Ainherst, May, 1919.

Nelson, W. L. The County Fair in Missouri. Missouri State Board of Agrieulture, Monthly Bulletin, Vol. 14, No. 7, July, 1916.

Rubinow, S. G. Community Fair- $\Lambda$ Factor in Rural Education, Sehool and Society, Vol. 6, pp. 96-101, July 28, 1917.

Vogt, Paul L. The County Fair. In his Introduction to Rural Sociology, Chapter XIX, 331-341, Appleton, N. Y., 1917.

\section{FARM BUREAUS AND FARM DEMONSTRATION WORK}

Bailey, L. H. The Farm Bureau Idea. In his York State Rural Problems, I: 132-146, Lyou, Albany, 1915.

The Farm Bureau Movement. In lis York State Rural Problens, II : 80-102, Lyon, Albany, 1915.

Bronson, W. H. Farı Mauagement Demonstration Work in Massachusetts. Massachusetts $\Lambda$ gricultural College Extension Bul. 9, Amherst, 1916.

Burrit, M. C. The Farm Bureau as an $A$ gent in Local Development. Journal of Proceediugs and Addresses of the National Education Association, 1916, pp. 614-619.

The County Farm Bureau Movement in New York State. Bul. 60, New York Department of $\Lambda$ grieulture, Albany, 1914.

IIurd, W. D. Farm Bureau and County Agent Movement. Anerican City, (Town and County Edlition), Vol. 12, pp. 100-2, February, 1915.

Jolınson, Edward C. The Agricultural $\Lambda$ gent aul Farm Bureau Movement in Kansas. Extension Bul. 2, Kausas State $\Lambda$ gricultural College, Manhattan, 1914 .

Lloyd, W. $\Lambda$. Status and Results of County $\Lambda$ grieullural $\Lambda$ gent Work in the Northern aud Western States, 1915. U. S. D. A. States Relutions Service, Document 32, Cireular 1, Ext. N. 
Knapp, S. A. Farmers' Cö̈perative Demonstration Work, U. S. D. A. Yearbook, 1909 , pp. 153-60.

How the Whole Country Demonstrated. U. S. D. A., Yearbook, 1915, pp. $225-48$.

\section{FARMERS' INSTITUTES}

Carney, Mabel. Farmers' Institutes and the Agricultural Press. In Country Life and the Country Scliool, pp. 90-102, Row, Chicago, 1912.

Hamilton, Jolın. Farmer's' Institute and Agrieultural Extension Work in the United States in 1913, U. S. D. A., Office of Experiment Stations, Bul. 83, 1914.

\section{RURAL LIBRARIES}

Dudgeon, M. S. The Rural Book Hunger, Rural Manhood, Vol. VI, p. 303, September, 1915.

Dyer, Walter A. The Spread of County Libraries, World's Work, 30 : 609-613, September, 1915.

Eddy, Harriet G. California County Free Libraries. Journal of Proceedings and Addresses of the National Edueation Association, 1911 , pp. 1026-1029.

Magill, H. N. W. The Rural Library in Practice. Library Journal, 43: 84-86, Jan., 1918.

Preston, Josephine C. The Country Cliild in the Rural Library. National Education Association, 1914, pp. 796-79S.

Rice, O. S. Rural School Libraries: Their needs and possibilities. National Education Association, pp. 740-774, 1913.

Tarbell, Mary Anna. A Village Library. Massachusetts Civic League, Leaflet No. 3, Boston, 190?.

Utley, George B. The Rural Traveling Library. The Playground 6: $486,487$. 


\section{CHAPTER XV \\ THE COUNTRY CHURCH}

\section{TEN YEARS IN A COUNTRY CHURCH ${ }^{1}$}

\section{MATTHEW B. MC NUTT}

THE simple story of a decade of ministerial work, such as the magazine has requested me to write, is this:

One cold Saturday morning in February, 1900, a seminary fellow-student chanced to mect me.

"Hello, Mac," he said, "don't you want to preach to-morrow, thirty miles out of Chicago? I have two appointments."

I told him that I would go. I boarded the first train and landed about noon in Naperville. III. I was met at the station by an old gentleman whom I took to be a farmer. I was right, and he informed me that his church was six miles in the eountry. This was rather unwelcome news, for the day was disagreeable and I was not clad for such a drive; but I was treated to a good dinner and we made the venture. The good roads attracted my attention at once, and my farmer friend told me that all the roads were thus paved with gravel. And such splendid farm-buildings as we passed I had never before seen on my travels. We saw horses and eattle that looked as if they had just come from a state fair. My expectations had risen high at what I had observed and I was eager to see that country church.

At last it hove in sight-a very plain structure, built half a century before, with a single room and with surroundings that gave a stranger the impression that the chureh was the last thing in the community to receive any consideration. It was altogether incommensurate with its thrifty surronndings. The fenees about the manse and chureh-lots had toppled over, and the old horse-sheds were an eye-sole to every passerby. The

1 Adapted from World's Work, 21 : 13761-13766, December, 1910. 
manse secmed to be about the only house in the community that was void of all eomforts and convenienees. One of the clders, a farmer, had been preaehing for threc years, until le died; and the last regular minister had resigned with $\$ 400$ due on his salary, which the ehurch borrowed to square the account. Six of the nine Sunday-sehool teachers werc members of onc family -and they were good teachers, too. The three elders were also trustces, and cael taught a class in the Sunday-school. One of these elders was also Sunday-school superintendent, Sundayschool treasurer, church treasurer, and trcasurer of benevolenees. A hall had been fitted up in the neighborhood to be the home of an organization that called itself "The New Era Club." But daneing secmed to be the only amusement, though the club's original promoters had hoped for better things. No one had united with the church for five years. The only services were preaehing and Sunday-sehool on the Sabbath, and a meeting of the Women's Missionary Society. Colleetions were taken once a year for missions and ministerial relief, and this was practieally the extent of the benevolcnee.

Herc was a chureh that had lived in a community for sixtyseven years. Its organization had been effected beneath some trecs with a tribe of Indians euriously watching the proceeding from a distanec. Many of the original Seotch, English and Yankec families had moved away or died; and their plaees had been often filled by Germans, who were invariably of a different faith. How to sustain the life of this institution had beeome a scrious problem that worried those who were responsible for its dircction. Some of the people were thinking that the eountry ehureh had outlived its usefulness. None knew better than the leaders that things werc not going well with their kirk, and none were more grieved about it.

I preached that Sunday and was invited to preael again the following Sunday. I did so, and at the elose of the serviee was asked if I would eonsider a call. I replied that I would finish my work in the seminary in May and would then be ready for a job somewhere; and that I saw no good reason why I should not become the pastor of a farmers' ehurch. The salary proposed was $\$ 600$ a year, with a manse and fiva acres of land. In the meantime a letter eame from a presbytery in the West (where 
I had preached during two summer vacations), strongly urging me to go there and take charge of three ehurehes at nearly double the salary offered here. That looked like a mueh larger proposition-finaneially and otherwise-and I was drawn toward it.

The Du Page people were to deeide by vote the following Sunday whether or not they wanted me. Siek from a eold that I had eontracted on the first trip, I had asked a elassmate to go in ny stead-requesting him to wait at his room until I had prepared a message asking the congregation not to eonsider me as a eandidate. For some reason the elassmate did not wait. I hastened downtown, thinking that I eould overtake him at the station, but I reached the gate just in time to see the train disappearing round the bend. The vote was talien and the result came to me two days afterward in a letter from one of the elders, saying that out of forty-eight-ballots there had been only one "no." A letter from the same man eame the next day explaining that the one negative vote had been east by a little 13-yearold girl who had not understood how to prepare lier ballot.

Here was truly a great opportunity, looking me squarely in the faee-a eall from the country! I reeonsidered the matter and eoneluded that I would east ny lot with those eountry-folk - for better or for worse.

Why I eame to this eountry ehureh, six miles from a railroad and without even a village surrounding it, I eannot explain. I had reeeived no speeial training for it other than that I had been born on a farm and brought up in a eountry elureh. The days spent in eollege and in the seminary were so full of lard study that the thought of where my "homiletie bias" should eventually be turned loose never once entered my mind. I simply had a general feeling that in due time there would be some good, hard work for me somewhere, I eared not where.

When I eame to the field the first of May, I was surprised and not a little disappointed to find that these good people would not eonsent to an installation until they lad tried the new minister at least a year. This was the Seoteh eonservatism that was lurking in the eongregation. However, I did not feel so badly when I diseovered that this was their regular enstom.

There was no one to oceupy the manse with me, so I furnished 
two rooms for mysclf and arranged to take my meals with a neighborly farmer. When a year had passed, the pcople werc then willing enough to install; but the pastor, somewhat dissatisfied with this loncly way of living and with no immediate prospeets of anything better, thought it unwise to form a permanent relationship with the church. Another year fled and there was a "better-half" in the manse. The eongregation voted againunanimously as before-and the installation took place.

Onc of the hardest things to overcome was their preconceived notions about the ehureh and about country life. I found it difficult to change the old way of doing things. The only hope of progress seemed to be in training the younger generation. But how to train it and in what, were the great problems to bc solved. One thing was certain: the ehureh society as it was organized and eondueted did not seem to be all that the eommunity needed. Many of the people had grown indifferent to the ehurch, and those who were interested did not seem to know just what was laeking. Where could this country church and pastor look for light? Not to other eountry ehurehes, for they, too, were in the dark. Not to the town and eity, beeause their methods were devised for an environment presenting altogether different eonditions. There was nothing left for us to do, therefore, but to study the situation and work out the solution ourselves. And that is just what we have been doing.

I soon realized that, in order to suceed in a community like this, a country parson must do a great deal more than preaeh and visit his flock. His duties must vary, as mine did, from janitor to head finaneier,--depending upon how much the people have been trained to do, and also upon how much they are able to do.

The first work that we attempted (apart from what is ordinarily eonsidered ehureh work) was to develop systematieally the musical talent of the eommunity. This was done through an oldfashioned singing-school. All the young people were taught to read music and to sing. Quartettes were formed; musieal instruments of various kinds were purehased by individuals; and an orchestra was started. There are few homes in the parish now that do not have music of some kind. A great many of the young men and women have been eneouraged to take private lessons in 
voice and on the piano, violin, and cornet. Some of them had thought that they possessed no talent for music; they got their start in the singing-school.

This musical talent was put to good use. The chorus choir has done finc work-singing around in the different homes one or two evenings every week-for the sick, for the aged, and for those who can not go anywhere to hear music. Our quartettes have been in demand to sing in the surrounding towns on special occasion, such as funerals and farmers' institutes. There are many special entertainments at the church in which our musicians take a prominent part. At our last Children's Day service a chorus of eighty voices sang, accompanied by a number of instruments. Some of our young women are now teaching music in the eommunity.

Parallel with the music, we cultivate the art of public speaking. Even the very sinall children are given places on our programs. Extemporaneous speaking is practiced in all our societics.

These public occasions are a great stimulus to our young folks to do their best in declaiming. In many cases the parents become interested and send their children to some teacher in elocution for more thorough training, especially when the son or the daughter is to read or debate at some big event. Last fall a team from our young men's socicty debated the income tax question with a team of business men from town. $\Lambda$ t different times we have given plays in the church. The last was a story from one of the magazines which a woman of this parish dramatized for the occasion.

These home-talent entertainments have proved to be more popular than the attractions we get from the lyceum bureaus, some of which cost $\$ 100$ a night. We have had audienees of between 400 and 500 people. Many town-folks drive out to their countryneighbors' cntertainments. We have found that to the great majority of our people this kind of work is far more attractive than the cheap amusements which they are apt to get ontside of the community at the public parks and shows in the surrounding towns.

The pride of the community is our band of athletes. It is a sight to see these husky farmer boys in base-ball suits. We have 
a number of teams; and if a stranger were to eome along almost any Saturday afternoon in the base-ball season, he would find a game in progress near some farm-louse. No Sunday base-ball here! It is no less a delight to see a goodly number of eountry "fans" in evidenee, from both sides of the house. The annual field-day is one of the notable events of the year. Hundreds of people assemble to witness the athletie contests and its ballgames.

The young men of the ehureh, prompted by a spirit of patriotism, have undertaken to reseue the Fourth of July from the shameful and degrading way in whieh it is so often eelebrated. They plan to make it first of all a day of patriotie inspiration. A good local program is provided, supplemented by the best publie speaker that ean be seeured from outside. Then it is made a soeial event as well as a day of innoeent sports and pastimes. Some of the folks who went last Fourth to an adjacent eity, to see a flying-machine that didn't fly, eame baek in the afternoon to our eelebration, saying that it was "lots better fun" to watch the eountry sports.

Come with me now to one of our young men's meetings-the young men's Bible-elass. The program for this evening is a mock eourt-trial. The ease in hand is Jones vs. Brown, for assault and battery with intent to do great bodily injury. The judge, very dignified, sits on the bench. Before him are the plaintiff and the defendant, with their favorite attorneys and all the necessary eourt-officers. The jury is earefully seleeted; the witnesses are examined; the ease is tried in due form; the jury is eharged, and the verdiet returned. It is needless to say that there is "a heap of fun" at sueh a trial. Besides, the boys learn a great deal about praetieal affairs, for each is required to look up the duties of his offiee beforehand and explain to his associates. Perhaps a watermelon is devoured at the elose; then the fellows visit and sing for a while and go home feeling that they have lad "a grand time."

Next time it is something else-an old-fashioned spelling-bee, or a story-night, or what-not. They diseuss all sorts of questions and do all sorts of things. There are upward of fifty enrolled in the elass now. It also meets every Sunday morning for Bible-study, and these Sunday sessions are quite as well at- 
tended as the monthly meetings. It is taught by the pastor. These same lads conduet a leeture-eourse-not for peeuniary profit, but for the sole purpose of bringing wholesome entertainment within reaeh of all. Everybody attends, irrespeetive of ereed.

The young men own and operate a small printing-press and (with the assistanee of the pastor) do all the ehureh printing. They hold religious meetings and entertainments in the publie sehool-houses during the winter and in a grove during warm weather. In the pastor's absenee a number of the men speak at the Sunday serviee. This elass and the young women's elass have beeome great powers in the ehureh. From them we seleet teachers and offieers for the ehureh and Sundav-sehool.

If you were to aeeompany me to one of our young women's monthly meetings, you would find thirty or more girls and young women with needles, busily engaged in making little garments for poor ehildren in the eity, ehatting as they sew. Some members of the soeiety, who have eompleted eourses in sewing, instruet the others. Or, if we arrive in time for the beginning of the meeting, we might find them studying "On the Trial of the Immigrants," "The Uplift of China," "Korea in Transition," or some other live book or subjeet. This study is sandwiehed in between musie and devotional exercises. At the proper time, a signal is given and the young ladies arrange their ehairs in groups of four and have plaeed upon their laps lunehboards laden with good things to eat that have been prepared by the member or members of the soeiety at whose home the meeting is held. Then, home they go. These meetings are mueh enjoyed by our young women and it is no task to seeure their attendanee.

You would see similar proeeedings at the monthly women's meetings exeept that (if it were winter) you would find a sprinkling of men in the assembly. The husbands and fathers eome -mostly for the soeiability afforded, though they do diseuss, in a very informal way, the leading topies of the day and the business of farming and stoek-raising. The mothers, in addition to their mission-study, eonsider topies pertaining to houseleeping, the eare and training of ehildren, home-building, and other praetieal subjeets. The soeiety has forty members. 
We are obliged to minimize the number of meetings held, on aeeount of the great diffieulty that eountry people have in getting together. We have few meetings and make each eount for mueh.

$\Lambda$ great deal is made of soeiability and fellowship. In faet, the ehureh is praetieally the soeial eenter of the neighborhood. The best soeials that we have are those attended by all the familythe older people and the ehildren taking part in the games and the frolie. We are, indeed, just like one family. The mothers eome and bring their babies. The little ones romp and play till they grow tired and sleepy; then they are taken to the mothers' room and tueked away in a little bed provided for the purpose - and all goes merrily on.

Perhaps the greatest day in all the year is what we eall our "Annual Meeting," whiel is held on the third Saturday in Mareh. Its prineipal objeets are inspiration and fellowship, and it eertainly does give the dead-level gait a severe jolt. It is an all-day meeting, and the whole eountry-side assembles in full foree. The ladies serve a banquet at noon-sometimes to 250 people. We usually have two or three good speakers from outside, besides the best musie that our home talent ean produee. This is the grand round-up of the year's work. Reports and letters from absent members are read. Some one always speaks ienderly and lovingly of those who have passed away during the year. A blessed day, this!

Other inspirational meetings are held onee in awhile for the various soeieties. One was lield recently for the young men's Bible-class and was attended by 100 young men.

A new feature which we are planning for this winter is a number of study eourses-in Seientifie Farming, Domestie Seienee, Soeiology, and Civil Government. Landseape Gardening will also be taken up with a view to eneourage the eountry people to beautify the environment of their homes.

It is not our intention to make of the ehureh a knowledge-imparting institution, but rather, through it, to foster the spirit of inquiry and to eneourage the investigation of truth by supplying the oeeasion and the opportunity for sueh investigation. The desire for knowledge and development once inspired, the way is found and things get done. 
Symbolieal of this new life in Du Page Chureh and one of our greatest achievements is the new chureh-home reently dedieated. It eost, ineluding furnishings, $\$ 10,000$. This building enterprise was a good test of the eonfidenee and the interest which the eommunity has in the elureh. Everybody gave to the building-fund-Protestants, German-Lutherans, Catholies, and men of no ehurch-and they all helped willingly to haul the materials. A new paee was set in ehurch building by this people when they subscribed all the money before the work of building was begun. No eollection was taken at the dedieation for building or furnishing purposes.

The new church, with a maximum seating-eapaeity of 500 people, is a model of neatness and eomfort. It has a scparate Sunday-sehool apartment (with a number of elass-rooms), pastor's study, ehoir-room, eloak-rooms, mothers' room, and vestibulcall on the first floor. These floors are all covered with eork earpet. In the basement are the dining-room, kitehen, toilet, and furnace-room. The building is equipped with lighting-plant, water-works, and hot-air furnaces. We entertained the Chieago Presbytery last fall, and the eity brethren all said that they had never scen the like of this ehureh in the open eountry. And, by the way, more yellow-legged ehickens entered the ministry that day at Du Page Church than ever before or sinee!

Three doors in the old strueture and twenty-one in the newthat is an intimation of the inereased efficieney and of the greater number of avenues of usefulness whieh this modern country-chureh secks to enter. It aims to be of service to the whole man-body, mind, and spirit. It sceks to surround him with an atmosphere that will stimulate him to live his own life and to cultivate a harmonious development of all his faculties and powers.

With all this practical work, the spiritual has not been neglected nor minimized. In fact, more attention has been given to it-in training the youth and in making the publie worship attractive and helpful. The people have not grown less religious or less reverent. Quite the opposite. The Sunday serviees have never been so largely attended nor the interest so well sustained. The membership of the church has increased from 80 to 163 , and the Sunday-school from 100 to 300 . And, in addition 
to building the ehurch, remodeling the manse, making other repairs, and increasing the pastor's salary 40 per eent., the people have contributed to benevolences in the last decade $\$ 5,270$-as against $\$ 6,407$ contributed during the fifty years preceding.

The effect that this new life is having upon the people of the parish is remarkable. Whole families that formerly had no interest in the church or in the uplift of the eommunity have become active members. Some of them are now officers and leaders. They not only lend their serviec but they give frecly of their means to support the work. Their conception of life is growing larger. They are buying books, pictures and musieal instruments. They are installing in their dwcllings the modern eomforts and conveniences, including the daily newspapers, magazines, and religious weeklies, where formerly there were none of these. Many who once gave nothing to benevolences are now regular contributors. Others that formerly gave but a pittanee have grown generous.

We sec in the young people a growing ambition to get an edueation. They seem to be inspired with a determination to make the most out of their lives. The honor students at a neighboring high school in town for the last five years have been young people from our eommunity. A number of these young men and women have taken honors at our State university. Nor is the studying all done in college and away from home. The fireside university is becoming more and more popular.

There is noticeable in the people an inereased willingness to take part in the various activities of the community's life, which may be attributed to the fact that they are better prepared for service. A new community-spirit and harmony have sprung up, with a wholesome pride. This las been brought about by making the church serve the whole community rather than minister to a particular part of it.

Whether it be the result of a more abundant life in this vicinity or not, farms here are at a premium. Whenever a farm is advertised for rent, half a dozen applicants are after it the next day. Persons living outside the parish have remarked to pastor and people again and again: "How we wish we lived nearer to your church!" And there has not been in our community the tendency for farmers to sell or rent and move to town. 
The greatest achievement of all, however, is the orderly, peaceloving, enterprising community that surrounds the church, and the lot of clean, sturdy, capable young people that are growing up in the church. These are the fruits we covet most and by which we wish to be known and judged.

\section{LAND TENURE AND THE RURAL CHURCH ${ }^{3}$}

\section{HENRY WALLACE}

THE prosperity of the rural church has in all ages and in all countries been determined largely by the tenure by wlich farmers loold their lands. A prosperous country church means a relatively large rural population-large enough to support a minister, to push the work of the church vigorously, to impress its ideals of life and character on the community, and to do its part in extending the gospel to outside sections and to foreign lands.

It requires, second, that farming be on an ceonomic basis; that is, that farmers are making money. For the church is always and everywhere supported, not by capital, but by profits; and if the farmer is not making a comfortable living or is sinking his eapital, he does not have the means of supporting the church. And if he does not have the means, his will to support the church will be incffective.

In the third place, the prosperous rural ehurch requires a reasonably stable population. So much of the Christian life lies in Christian relations with neighbors, with employees, with employers, with the whole community life, that a roving farm population cannot, even if it would, develop Christian graces or impress itsclf favorably on a community of unbelievers. The farm owner who has moved to town and is renting his land cannot be expected to be a real, vital force in the rural church. Nor can the tenant who has a one-ycar lease, or whose tenure is uncertain, be cxpected to cultivate the Christian graces by-intimate fellowship with his neighbors and associates or fellow church-nembers; in other words, to take root in the community and become a part of it.

1 Adapted from "The Church and Country Life," pp. 232-242, Missionary Education Morement of the U. S. and Canada, New York City, 1916. 
One thing more. The prosperous country church requires that there be an agreement among the members as to the big things for which the churcl stands: the sinfulness of men; the possibility of redemption from sinfulness; growth in Christian graees; the efficieney of the gospel to make better liusbands, better wives, better parents, better children, better farmers, better business men, better neighbors, better eitizens. Success need not be expeeted if minor things of which Jesus said nothing and upon which the apostles laid no emphasis, sueh as forms of church government and modes of baptism, are regarded as the essential things for which the church stands. If the ehurch is to be suceessful, there must be toward these matters a body of sentiment which makes hearty eoöperation and Christian fellowship possible.

These, as I see it, are the conditions of the prosperous rura! ehureh. These conditions prevailed when the rural ehureh was in the height of its prosperity in the early part of the last century. There was then a dense population per square mile in the settled portions of the country, because the farmer was then a child of the woods, hewing his way painfully through the forests of the Eastern and Middle States, and requiring a lifetime to clear up a quarter section or even an eighty. He was a man of the ax and eradle and seythe and flail. Rural eongregations were large then; and the spirit of the farmer of that day is refleeted in the names that he gave to his ehureh,--names fragrant of the spirit of piety and devotion and showing elose aequaintance with the Bible,-Bethel, Rehoboth, Mount Zion, Ebenezer.

There was then no pull to the eity, for the cities were small, as they must needs be, since there was not the wherewithal to feed a large eity population, nor adequate means of transportation. Labor was chcap, land was cleap, living was eheap; and the farm was mainly a means of supporting a large family cheaply. There was no landlord, no tenants. While no one was getting rich, all but the ineompetent were getting ahead, and the minister was the outstanding big man in the eommunity - "guide, philosopher, and friend" to all, a consoler in sickness or sorrow, an adviser in trouble. There was unity as to the great doctrines of Christianity. Not that all were agreed; but the various nationalities, witl their forms of worship and religious thought and eustoms, grouped themselves together in loealities-the Pennsyl- 
vania Duteh here, the Scotch and Scotch-Irish there, the Quakers elsewhere, the Yankees in other groups.

All this changed when the farmer emerged from the woods and drew long furrows in the rich, fertile soil of the prairies; and still greater was the change when, at the close of the war, the government gave one hundred and sixty aeres of land at the cost of surveying ( $\$ 1.25$ an acre) to any landless man in the wide world who wanted it and who would become a eitizen of the United States.

Then began the rush for these cheap lands, a rush from New England, from the Middlc States, from the South, and from Europe. The farming population began a game of leap-frog. The church organizations, awakc to the importance of sceuring a foothold in this new land, pushed their missionary enterprises, aiming to oceupy strategic points. The result was a mingling together of men who, while they agreed on fundamentals, gave special importanee to distinetives; and a still further result was the overchurching of the entire prairie country.

Then the rural ehurch began to decline; for the introduction of railroads and of farm machinery and a far greater usc of horse power deereased rural population per square mile. It has eonstantly been decreasing ever sinee from purely economie causes. Still the rural chureh did fairly well, although gradually declining in the size and number of congregations, until the last thirty years, when another set of economic eonditions began to render it less efficient.

When thoughtful men began to sce that there was no more choiec land to be given away; when the great growth of eity population not merely in the United States but in the Old World (the result of eheap food furnished by the farmers of the United States at less than the eost of growing it) began to bring the price of grain up to the eost of produetion and above it, land began to advanec. In the eorn belt, the wheat belt, and the fruit belt land has inereased at the rate of about 10 per eent. per annum.

The country chureh then began to deeline more rapidly. Farmers began to rent their farms and move to town. Capitalists began to invest in lands as soon as the net ineome would equal the interest on savings, and speeulators began to buy land far in advanee of its productive value, on the assumption that this 10 
per eent. per annum increase in priee would continue. One result of this was an enormous inerease in tenancy, until abont $371 / 2$ per eent. of the tillable lands of the United States was farmed by tenants. In the eorn belt from 40 to 50 per ecnt. of the land is farmed by tenants, and in the cotton belt from 50 to 70 per cent.

Meanwhile the use of improved machinery and of horse power instead of man power tended to increase the size of farms and to decrease the population per square mile. $\Lambda$ recent investigation by the Iowa Agricultural Department shows that, while the increase in the size of farms that are farmed by their owners is less than 4 per eent., the inerease in the size of those farmed by tenants is 16 per cent. It shows further that in seetions in which land is bought for speculation tenancy has increased very rapidly. We have three main elasses of landlords: retired farmers, eapitalists, and speculators, or speculating eapitalists; and the lands of all these elasses are necessarily farmed by tenants.

Inasmuch as we have not yet really begun to farm in the West, but are simply mining our soil and sclling its fertility (at present at a profit), the tenure of the tenant is mainly for one year; this eondition makes about 45 per eent. of the population of the open country in Iowa more or less unstable. The tenant who goes into a new eommunity for a ycar does not usually align himself with a chureh unless he is a man of very positive religious convictions. Neither does the church look upon the tenant as anything more than a pilgrim and a stranger, and henee it is apt to think it not worth while to gather lim into the fold.

Another influence is powerfully effeetive. Members of churches who bought land, especially in the eorn belt, at from $\$ 25$ to $\$ 50$ an acre thirty ycars ago, could not resist the temptation to harvest the unearned increment and invest it in the newer lands of the spring wheat belt, or the plains, or the Northwest. They moved to the new country, taking their familics with them. This has decreased the financial ability of the eongregation of the eountry ehurch, has reduecd the salary of the minister to the starvation point, or has perhaps eompelled the congregation to have preaching for but onc-lialf or one-third of the time, and in eertain sections, for only one-fourth of the time. This deprives the eommunity of the pastoral labor and the example of a Chris- 
tian leader and his family; and the result is that the church declines and then dies. In faet, the churches in the towns of the eorn belt arc largely built up by the removal of members of eountry churehes to the towns.

The farms arc beeoming larger, and the population of the rural eommunity smaller and more unstable beeause of tenantry. The population remaining is divided up into various dellominations and sects through difference of opinion about chureh government and baptism and other things, the inheritanee of a past generation.

There are two remedies for this condition, one industrial and the other spiritual. Neither is capable of instant applieation, but eaeh is eertainly applicable in the somewhat distant future. The first is such a system of leasing as will make the tenant a reasonably permanent citizen in the community,-in other words, longer leases. Tenancy is not in itself an evil, but uncertainty of tenure and short leases are evils that vex humanity. Wc cannot expeet to see a prosperous rural church until the tenant can make some arrangement with his landlord by which he can stay on the same farm indefinitely, take root in the community, become an active member of the ehureh, and make of his ehildren real members of the Sunday-sclool and rural school. Economie eauses theimselves will force upon the landowner this system of longer leases. The constant deerease of soil fertility through the bad farming of the short-lease tenant and the faet now beeoming evident that it it more profitable to the enterprising farmer to rent land than to own it, must work for the greater permanency of the tenant. The first will wipe out speculation and reduce land values in the rieher sections until it will be possible for the tenant by renting land to become the owner of the land. This will give us a stable population and greatly increase the efficiency of the rural church.

The second remedy is in the ehange of view of the Christian ideal. We must now get back to the original Christian idea : that salvation is for every man and for every part of the man-body, soul, and spirit; that it involves loving "thy neighbor as thyself," and eoöperation in every good work instead of competition. $\Lambda$ church united on the fundamentals, and with a reasonably permanent temre of lands by ownership or lease, will cnable us in time to build up a eivilization on the prairies and the eleared 
timber lands more satisfying than that whieh ean be found anywhere else on earth.

\title{
RURAL ECONOMY AS A FACTOR IN THE SUCCESS OF THE CHURCH ${ }^{1}$
}

\author{
THOMAS N. CARVER
}

IT may be laid down as a general law of rural economy that the produetive land in any farming eommunity will tend to pass more and more into the hands of those who ean eultivate it most efficiently,- that is, into the hands of the most effieient farmers,unless it is prevented from doing so by some kind of military force exercised by an aristoeratie ruling class. In a democratic eountry, like the United States, where there are so few impediments in the way of the free transfer of land, we need look for nothing else. The men who ean make the land produce the most will be able to pay the most for it, and in the end they will get it and hold it. This looks simple enough, no doubt, and may not at first seem to signify mueh, but it is weighted with consequenees of the most stupendous and far-reaching character,-consequenees which it would be suieidal for the church to ignore.

It means simply and literally that the rural distriets are never to be thoroughly Christianized until Christians become, as a rule, better farmers than non-Christians. If it should happen that Christians should become really better farmers than non-Christians, the land will pass more and more into the possession of Christians, and this will bceome a Christian country, at least so far as the rural districts are concerned. The first result would probably be to paganize the eities, sinee the non-Christians displaced from the rural districts by their superior eompetitors would take refuge in the towns. But since nature has a way of exterminating town populations in three or four generations, and the towns have therefore to be continuously reeruited from the eountry, the Christianizing of the rural distriets would eventually mean the Christianizing of the towns also. But, vice versa, if non-Christians should beeome the better farmers, by reason of

1 Adapted from American Unitarian Association, Social Service Bulletin No. 8., 25 Beacon St., Boston. 
some false philosophy or supereilious attitude toward material wealth and eeonomie aehievement on the part of the ehureh, then this would eventually beeome a non-Christian eountry, for the same reason.

But if, as a third possibility, there should be no pereeptible differenee between. Christians and non-Christians as to their knowledge and adaptability, or as to their general fitness to survive and possess the earth,- - fitness, that is, as determined by nature's standard rather than by some artifieial standard of our own devising,-the result would be that Christians would remain indefinitely a mere seet in the midst of a non-Christian or a nondeseript population. The only way of avoiding this rather unsatisfaetory situation would be to foree the whole population into a nominal Cliristianity by military foree. But, assuming that physieal foree is not to be used, and that the ordinary eeonomie forees are to operate undisturbed by sueh violent means, then the eontention will hold. This is what is likely to happen if certain religious leaders should sueeed in identifying Christianity with millinery, or with abstraet formula respeeting the visible world, or with mere loyalty to an organization, rather than with rational eonduet. By rational eonduet is meant that kind of eonduet which eonserves human energy and enables men to fulfill their mission of subduing the earth and ruling over it, whiel enables them to survive in the struggle with nature, whieh is the essenee of all gemuine morality.

But why eonfine these observations to agrieulture and rural eeonomy? Are not the eonditions of eeonomie sueeess the same in the eity as in the eountry? And must not religion prevail over irreligion in the eity as well as in the eountry, provided religion seeures a greater eonservation of human energy than irreligion seeures? In a eertain very broad sense, or in the long run-with a great deal of emphasis upon the word "long" - that is probably true. But the eonditions of individual eeonomie sueeess in eities are so eomplex, there are so many opportunities . . .

"for ways that are dark

And for tricks that are vain"

as to obscure, if not to obliterate entirely, the working of this law. 
In agriculture one must wrest a living from nature, and nature eaunot be trieked or deluded. But a large element of eity populations,- and generally they are the dominant element,- - get their living out of otler people; and people are easily deeeived. Instead of laboring to make two blades of grass to grow where one had grown before, their business is to make two dollars emerge from other people's poekets where one had emerged before. Neither impudenee, nor a smooth tongue, nor a distinguished manner, nor lurid rhetorie, ever yet made an aere of land to yield a larger erop of grain; but they have frequently made an offiee, a sanetum, a platform, and even a pulpit yield a larger erop of dollars. They who get their living out of other people must, of neeessity, interest those other people, and men are so eonstituted that queer and abnormal things are more interesting to them than the usual and the normal. They will pay money for the privilege of seeing a two-headed ealf, when a normal ealf would not interest them at all. The dime museum freak makes money by showing to our interested gaze his physieal abnormalities. IIe is an eeonomie sueeess in that he makes a good living by it, but it does not follow that he is the type of man who is fitted to survive or that religion ought to try to produee. Other men, going under the names of artists, novelists, or dramatists, of eertain nameless sehools, make very good livings by revealing to interested minds their mental and noral abnormalities. They, like the dime museum freaks, are eeonomie sueeesses in that they make good livings, but it does not follow that they are the type of man fitted to survive or that religion ought to try to produee. This type of eeonomie sueeess is an urban rather than a rural type, and it flourishes under urban rather than rural eonditions. So long as it flourishes there is no reason why religious men who eonserve their energies for produetive serviee should sueceed in erowding them out of existenee. The only ehanee of attaining that end will be for religion to give people a saner appreeiation of things, teach them to be more interested in normal ealves than in twoheaded ealves, in normal men than in dime museum freaks, in sane writers than in eertain degenerate types now holding the attention of the gaping erowd. If this ean be brought about, then it will result that the religious type of man, even in cities, will nore and more prevail over the irreligious, provided the 
religion itself is worth preserving,-that is, provided it beeomes a positive faetor in the conservation of human energy.

As has already been suggested, there is a great deal more involved in making a good farmer tlian in the teaehing of scientifie agrieulture. Mr. Benjamin Kidd has done well to empliasize the importanee of moral qualities as eompared with intelleetual achievements. In the first place, intelleetual aehievements, or their results, ean only be utilized where there is a sane and wholesome morality as a basis. In the seeond plaee, the results of intelleetual aelievement of one race or one man may be borrowed freely by the rest of the world, provided the rest of the world have the moral qualities which will enable them to profit by them; whereas moral qualities can not be borrowed from one race by another. Japan, for example, eould easily borrow from European nations the art of modern warfare, together with its instruments of destruction; but it did not borrow, and eould not borrow, that splendid eourage and diseipline whieh enabled her to utilize so efficiently the inventions whieh she borrowed. So, one nation ean easily borrow farm maehinery and modern methods of agrieulture, but it eannot borrow the moral cualities which will enable it to profit by them. Saying nothing of mental alertness and willingness to learn, whiel might be elassed as mental rather than moral, it eould not borrow that patient spirit of toil, nor that sturdy self-rclianee, nor that forethought whieh saerifiees present enjoyment to future profit, nor ean it borrow that spirit of mutual helpfulness whieh is so essential to any effeetive rural work. Again, a nation eamnot easily borrow a sane and sober reason, a willingness to trust to its own eare in preparing the soil rather than to the blessing of the priest upon the fields, nor ean it borrow a general spirit of enterprise whieh ventures out upon plans and projeets whieh approve themselves to the reason. And, finally, it eaunot borrow that love for the soil, and the great outdoors and the growing erops, and the domestie animals which marks every sueeessful rural people. These things have to be developed in the soil, to be bred into the bone and fiber of the people; and they are the first requisites for good farming. After them eome seientifie knowledge. $I_{n}$ the development of sueh moral qualities as these the ehurch has been, and may beeme again, the most effeetive ageney. 
It is said that the great problem of the country ehurch is that of an adequate support of the ministry. But how ean the ministry be adequately supported? One obvious answer is to reduee the number of eliurehes. This is a good answer, perhaps that is the casiest way; but it is the seeond best way. Another way is to build up the community in order that it may furnish adequate membership and adequate support for all the ehurches. This may be a liarder way, but where it is not impossible, it is the best.

Of course there should be continued emphasis, in the tcaehings of the ehurch and the pulpit, upon the plain economic virtues of industry, sobriety, thrift, praetieal, seientific knowledge, and mutual lielpfulness; but mueh more emhasis than hitherto should be placed on the last two. Praetieal, seientifie knowledge of agriculture, and mutual helpfulness in the promotion of the welfare of the parish are absolutely essential, and unless the churehes ean help in this direction they will remain poor and inadequately supported. For those who think that the ehurch should hold itself above tlic work of preaching the kind of eonduet whieh pays, or the kind of life which succeds, the eeonomie law stated above, is the strongest argument.

Organized efforts in the churches for the study of parish economy, for gaining more and more seientifie knowledge of agrieulture, for the practieal kind of Christian brotherhood whieh shows itself in the form of mutual lielpfulness and coöperation, in the form of decreasing jealousy and suspicion, in the form of greater publie spirit, greater alertness for opportunities for promoting the publie good and building up the parish and the community, in helping young men and young women to get started in productive work and in home building, in helping the ehildren to get the kind of training which will enable them to make a better living in the parish, - - efforts of this kind will eventually result in better support for the churehes themselves, beeause the eommunity will then be able to support the chureh more liberally; and, what is more important, it will then see that the church is worth supporting. 


\section{THE CHURCH SITUATION IN OIIIO ${ }^{1}$}

C. O. GILL

ThE rural church survey of Ohio now complete is the first church survey covering an entire state. The state contains in its area of 40,000 square miles some 1,388 townships. Reports are at hand from every onc of these. If we exclude the townships in which the population is urban, those in which there are villages of more than 2,500 inhabitants and those in which are parts of large town or city parishes, there arc in the state about 1,200 townships which may be classed as rural. In these townships there are more than 6,000 rural churches and more than a million and three quarters persons. In each there is on an average a population of 1,470 , while there are five churches, a church to every 286 persons.

It must not be inferred, however, that there is an even distribution of the churches. As a matter of fact, in many districts, there are not enough of them. How excessive the overchurching is in some regions may be well illustrated by the condition in Morgan County. Meigsville Township with a population of 846 persons has nine churelies or one church to 94 persons. Union, another township in this county with a population of 1,048 persons, also has nine churches. Neither township has a resident pastor. This is true of seven townships in the county. In these seven townships there are 41 eliurehes or one ehurch to 142 persons.

The significance of the excessive number of eliurehes ean only be appreciated by coming into close contact with the communities themselves. Very rarely have I visited an overehurched community in the country without finding a condition of harmful competition often resulting in an anæmic condition of the religious institutions. In most of the communities several churehes are trying to do what one church, if left to itself, could do far more effectively. Under present conditions the churches commonly constitute the greatest obstacle to progress they themselves liave

1 Adapted from a preliminary report of a state wide survey made by the Commission on Chureh and Country Life of the Federal Conneil of Churches of Christ in Ameriea in eoüperation with the Ohio Rural Life Assn. Pub. Missionary Edu. Movement of the U. S. and Cauada, N. Y. 
to encomnter. According to data gathered by the Ohio Rural Life Survey, the churches, as a rule, whose membership is less than 100 do not prosper, while the smaller the membership the greater the proportion of the churches which are dying; yet in rural Ohio it appears that more than 4,000 churches have a membership of 100 or less, more than 3,000 a membership of 75 or less, more than 2,000 a inembership of 50 or less.

Membership must not be eonfused with attendanee. I have personally visited a eonsiderable number of chnrehes on Sundays, have eounted their congregations and have eompared the attendanee with the membership. In this State I have, in no ease, found the attendance as large as the membership. In this respeet the best record in any ehureh I have attended is that of a ehurch whose membership is sixty and the attendanee forty. In one church the nembership was 125 , the attendanee 34 ; in another ehurch the membership 300, the attendance 136.

One of the striking facts brought to light through the survey is the lack of an adequate number of resident ministers. While a reasonable degree of interehurch eoöperation should result in the maintenance of a resident pastor in nearly every inhabited township, at the present time the church falls far short of realizing this possibility. In fact nearly 4,000 or about two-thirds of the churches in rural Ohio are without resident ministers. In 26 per eent. of the townships no church has a resident pastor.

More than 5,000 of the ehmrehes are without the undivided serviee of a minister. More than 2,200 chmrches have only onefourth of a minister's service or less, more than 3,300 have only one-third of a minister's serviee or less, while more than 700 have no part of a minister's serviee. These figures do not take into consideration the fact that a considerable number of the ministers have other occupations than the ministry. I personally have met several ministers who have seeular oecupations and yet are eaeh serving two or more country churches.

One of the most striking features of the sitmation is the faet that whereas there are superintendents who are responsible for the supervision of ehurches of their own denominations, there is no superintendent, or official, who aceepts responsibility for the general moral and spiritual eonditions in any eonsiderable area. However bad eondidtions in a eounty or region may be there is no 
organization or person whose business it is to know about it. Consequently decadence and degeneration may go on in an extensive territory without any responsible body or responsible person beeoming aware of it. The defectiveness of the organization of the ehureh, as a whole, therefore, demands our serious consideration and the application of a remedy. On the other hand the promise in a movement such as is now on foot under the auspices of the Ohio Rural Life Assoeiation and its Committce on Interchurch Coöperation is a cause for congratulation. It may be presumed that in some arcas conditions existing to-day would never have come to pass had the church, itself, as a whole, been aware of what was going on.

Areas of the most pronounced ecclesiastical decline and moral degeneration arc found in some of the eastern, southeastern and southern eounties. A striking illustration of the failure of our present church organization appears in one of these southern eountics. The aim of the typical and most influential religious leaders in this county is to stir up an emotional excitement without regard to its effeet upon eharaeter. These religious leaders apparently are not conscious of an ethical end. By the use of music well adapted to the end sought, by adaptation of the voice, sometimes even by the use of the hypnotie cye and suggestion of cmotional expericnec to be expeeted, an excitement is produeed which is acepted as a substitute for the more worthy aims of religion. They report additions to the membership of the churches and even the organization and building of churches. The so-called evangelist at the end of a period of protracted meetings leaves the loeality having aceomplished no good thing. $\mathrm{He}$ returns period after period, scason after season, year after year and the same aetivities are repeated. This has displaeed a more wholesome type of ehurch life with disastrous results to the eommunity. For at least fifteen ycars this type of religion has been gaining in popular favor, while it is displacing other forms of religious activities.

In the year 1883 there were 96 churehes in this eounty. In the following thirty year's there were 1,500 religious revivals or on an average fifty each year. During that period there was a decline of no less than five hundred in the membership of the ehurches, while thirty-four ehurches were abandoned; the production of 
corn declined from thirty-four to twenty-eight bushels to the acre; a larger proportion of the population are afflicted with tubcrenlosis than in any similar area in the United States; a trained hygienie expert who has made carcful investigations declares that the prevalenec both of infectious disease and fecblemindedness is extreme; politics are corrupt, the sclling of votes common, petty crimes abound, the seliools are badly managed and poorly attended while there is much illiteraey.

The itinerant cvangelists who eome into the county each year are the chicf religious leaders. The ministers who live in the county usually remain but a year. They have several churches each and direct their efforts to increasing the membership of the particular churches they serve. They have no intimate relation with the pcople and cxert very little influence upon them. One minister serves no less than ten ehurches.

The type of religion here described is strongly intrenched in parts of many eounties while its influcnce through the migration of farm laborers is seriously affecting the religious and social life in some of the more prospcrous and progressive counties. In onc of these in an area of sixtcen miles long and from seven to eleven miles wide there are three abandoned but no living churches. One of the eauses of this condition is the fact that the farm laborers, imported by the owners of large tracts of land, have never been made familiar with a normal type of religion. Investigation has disclosed the fact that they come from the regions where the excessively cmotional type of religion prevails.

In no less than nine countics conditions such as we have described may be found in localities. In two of the counties homicides are eommon and frequently go unpunished. In Vinton County there are two Mormon Churches. It has been truly said that in this southeastern section of the State our civilization is not being conserved.

A fairly good community, typical of a considerable arca, may bc found in a certain township in the northwestern section of the statc. In this township one-half of the inhabitants are descendants of the carly settlers who came from New England. The traditions of these people are good, but they are too conservative to cneourage progress in agriculture. The other half of the population consists of farmers coming mostly from the western 
part of the state or from still farther west. These are progressive, but in applying the methods of farming to which they have been aecustomed under different eonditions they sometimes fail. They have a fairly good eentralized sehool and desire to have good edueational facilities. Little is done to eneourage the social life of the eommunity, nothing for the promotion of seientific agriculture or to promote the general welfare of the eommunity outside of what little is done in the sehool. Fornerly it was the eustom to have at least one resident pastor in the eommunity, but for ten years or more they have had nolle. There are three ehurehes, the Methodist Episeopal with forty-eight, the Disciples with forty-three families, represented in their membership, and a Baptist Chureh with a membership of only three, but holding a Sunday School of eonsiderable size. In this township there are forty vaeant houses. Large numbers of the farms are very imperfeetly eultivated, yet it is said by an agrieultural expert that drainage and scientific farming will greatly add to the produetion and the wealth of the township.

\section{THE GENOA PARISH, WALWORTH COUNTY ${ }^{1}$}

REV. A. PH. KREMER

THere ean be no doubt of the faet that a eloser union of the eountry population will not only make life in the eountry more attractive, but will also stimulate mental development and promote Christian eharity.

From the standpoint of mental and moral advaneement, the eountry elureh is the most prominent faetor in uniting people whose homes are often miles apart. By reuniting them, it brings them into eloser eontact with one another, thereby creating soeial life of a high standard and fostering the soeial intereourse so neeessary to the average man.

Let me say now that I eonsider it a great misfortune that the nembers of a parish should be brought together only for the purpose of raising money for ehureh purposes. There should be gatherings whose objeet is not replenishing the ehureh treasury.

1 Arlapted from Third Annual Report of the Wiseonsin Country Life Conference, pp. 46-7, Univ. of IWis., Malison, Jan., 1913. 
The parish has five distinet means of bringing people together. The first of these is the parish school. Children living in various school distriets meet daily in the sehool-room and thereby naturally extend the horizon of their friendships along broader lines. All school festivals bring in the parents of these ehildren, thus one eommon interest unites both parents and ehildren.

After the sehool years are over the boys and girls join the junior divisions of the young people's soeieties. Onee a month they hold regular meetings, listen to eonferenees adanted to their eonditions of life, arrange little soeial affairs, and, when old enough, are admitted into the young men's or young women's sodalities.

The chureh is the real social eenter for these young people. They furnish the material for the ehoir and the dramatic elub. Once a month they meet for the purpose of mental and spiritual eulture; they have a eireulating library of choice books. Every Sunday after Mass the librarian is at hand to give ont books, and as the young people meet here they naturally speak of the merits or shorteomings of the books they have read.

Cineh parties and spreads are arranged at times, when the young people-practieally all of them--meet and spend an afternoon or evening in the most pleasant manner, without any other thought than that of giving and enjoying what they eall a "jolly good time."

The married people meet onee a month for moral improvement, and, at odd times during the year, for soeial pleasure. I remember one oeeasion on which the married ladies were the guests, and the married men the hosts. It would have done your hearts good to have seen these sedate men, deeked in the uniforms of waiters and eooks, reeeive their guests, seat them, and wait on them in the most solemn manner.

Onee a year a pienie is held; the whole eongregation, neighbors and friends meet in the forenoon and spend the whole day in any way they ehoose. The men sit together, smoke, and talk politics and farming; the married women sit in groups with their babies playing around them, exchanging views on every topie. The young people play ball, tennis, bean bag, or any other game their faney suggests, till the deelining day reminds them of the raees. Then old and young assemble to witness or to take part in the 
various tests of strength, swiftness, and athletie ability. No ehanees are sold, no money denanded. Every one spends what he wishes and feels sure that he gets full value for the money lie pays.

One word must be said about the buildings. The sehool has two adjoining rooms separated by a movable partition. The larger room may readily be used as an auditorium, as a movable stage ean be ereeted in the smaller room, the partition removed, the sehool desks taken to the basement of the sehool and ehairs put in their plaees. Thus the sehool is ehanged into an auditorium with a stage eomplete in all its appointments. After the performance is over. the stage is taken down and stored away, and the deslis replaced, the whole not requiring more than two or three hours of work.

The basement of the ehureh has a furnace and fuel room, a large kitehen furnished with everything needed in the line of eooking utensils and desks, a large dining-room with large dining tables and three hundred ehairs. The dining-room and the kitehen are never used for any other purpose, and are therefore always in readiness.

\section{RURAL WORK OF TIIE YOUNG MEN'S CHRISTIAN ASSOCIATION ${ }^{1}$}

ALBERT E. ROBERTS AND HENRY ISRAEL

Tre eounty work, or rural department of the Young Men's Christian Assoeiation seeks to unite in a town, village, rural community, or in the open eountry the vital forees of young manhood for self-improvement, physieally, soeially, mentally, and spiritually, and to give expression to these resourees in community life for the betterment of others.

It eonsiders its legitimate field to include all eommunities that are too small to maintain the eity type of Young Men's Christian Association work, generally eoneeded to include towns of four thousand and under. Experienee has proved that its best work is done, however, in communities in which the rural environment

1 Adapted from Annals of the American Academy of Political and social scicnce, March, 1!12, pl). 140-?. 
dominates the community idcals. It therefore is a movement which must be determined from the standpoint of qualitative rather than quantitative values. There are 45,000 sueh eommunities in the United States and Canada with a eombined population of over $12,000,000$, thus including over 60 per eent. of the boyhood and young manhood in this field. There are 2,000 eounties eonsidered organizable in the United States and 500 in Canada on the present basis of organization and type of work.

The term "eounty work" is applied to this movement beeause the eounty already affords a ready geographieal unit for eonstructive work. Counties have distinetive traditions of their own soeial clements and existing organizations of a eounty-wide eharaeter. As the result of repeated failures in individual communities apart from other eommunities, a eounty-wide organization eommanding the eombined resourees of men and money within the eounty, made possible in community life that which eould not have been aeeomplished independently.

There are two factors that enter into this plan so essential to sueeess-volunteer effort and expert supervision. The voluntary organization, the eounty committee, eonsisting of from fifteen to twenty prominent business and professional men and suceessful farmers, constitute the administrative unit and elearing house for policies and programs for the country-wide aetivities as well as for individual eommunities. These eounty eommitteemen are seleeted with great eare, primarily meeting one of two qualifieations: to be able to eommand resourees of their own to promote this work for a period of years, or to possess sueh influence as to eommand the resourees of others, both in time and money. They all must stand for the best things in eommunity life, be vitally related to the ehureh, to the sehool and other ageneies that make for eommunity progress. They eonstitute a voluntary body not unlike the faeulty of a university at one time, of the health board of the eounty in another instance, as the elearing house for a religious eampaign at another time, as a voluntary body of eommissioners to advanee the specifie interests of a eounty, and in no unecrtain degree to measure out their best judgement frequently along the lines of advaneing the agrieultural or eeonomie interests. Therefore, the eounty committee assigns these various aspeets of its work to sub-emmittees, each of whieh renders its 
report at the quarterly meeting of the eounty eommittee which works in elose contaet with the employed seeretary and trained experts. The eounty committee is responsible for a budget varying from $\$ 2,000$ to $\$ 6,000$ annually secured by voluntary eontributions, which enables it to employ a seeretary who is a trained expert as their exceutive officer. Thus the work is correlated and coördinated and a eentral elearing house is established through whieh any eommunity and every eommunity may find help and counsel in promoting its internal welfare. In many instanees the eounty eommittee has thus saved a eommunity from expensive and painful experienees that have been previously proven impractieable.

The County Seeretary. He is usually the fittest type of the college man, often not only a eollege graduate, but also with some special training. He is a man who likes country life and believes in the eountry and has great faith in the immediate future of the rural distriets. He is usually a man of large eapacity for leadership, with a broad knowledge of human nature and a fine friendliness as well as an carnest Christian purpose and a great longing to help country boys and young men to well developed Christian manhood. He is in a real sense a eommunity builder. As he is employed by a voluntary organization, his serviees and his largest eontribution to a eounty will be in reproducing his expert knowledge and experienee in volunteer service. Therefore, his primary task is to diseover, enlist, train, and utilize leadership. He is also a servant. Pastors, Sunday Sehool superintendents and teaehers, publie sehool superintendents and day school teachers, fathers and mothers, granges, farmers' clubs and institutes, women's elubs and many other organizations seek his coöperation and adviee. In the individual eommunity having diseovered leaders and set them at work, he exeeutes the plans and policies adopted by the eounty committee througl volumtecr leadership. His relationship is with the few men who are the leaders rather than witl the massses. In addition to the eounty seeretaries some of the older and larger eounties are employing assistant seeretaries, physieal direetors, boys' work direetors, ete. There are now fifty sueh seeretaries in forty-nine eounties.

County work is not an attempt to build up a new organization in country eommunities. It reeognizes as the primary institu- 
tions of the community, the home, the sehool, and the ehureh. Many other supplemental organizations are doing splendid work, but the aforementioned are recognized as fundamental. It is also a faet that though these are the primary institutions, they are in many eases funetioning inadequately, or have ceased to perform their function entirely. Again, in supplementary organizations which are found in country life many are overlapping and even working at eross purposes. There seems to be no well defined or unified policy. Furnishing a eommon platform upon which the various interests of the people will find expression and where these interests can come together in a demoeratie spirit is the unifying task of the eounty work in organized counties. It stands for the elimination of waste, for the interpretation of the real needs after surveys have been made, for the assumption of specific tasks by speeifie individuals and communities. It gives itself to the awakening of a social conseiousness, a getting together; it seeks to supplement and not to supplant. If it can persuade a leader to supervise the plan and athleties of a school, or a farmer to give his boy a man's chanec, it has made a eontribution to the community life, and its leaders are as well satisfied as they would be if a new organization were formed.

\section{COUNTY WORK OF THE YOUNG WOMEN'S CHRISTIAN ASSOCIATION ${ }^{1}$}

\section{JESSIE FIELD}

JUST as eountry life is at the very foundation of our national life in many ways, so the young womanhood of the eountry holds a plaee of strategie importance, both in the country, and for serviee to womankind everywhere. The National Board of the Young Women's Christian Association with its plan of service to girls and young women everywhere, realizing this, and thinking of the many girls in eountry communities, began about cight years ago to work dofinitely towards making all the resourees of the Assoeiation available to them.

This has been done through work in the development of leader-

1 From a statement prepared at request of editor. 
ship for eountry eommunities in student eenters and through organized county Assoeiations. Voluntary study eourses in Country Life Leadership, with the text book "College Women and Country Leadership" as a basis, have been taken by thousands of eollege women, the majority of whom have gone baek to lead elubs of girls in their home eommunities during the summer. Such elasses as these have, also, been held in the summer conferenees. These elasses have not only given more knowledge in regard to country conditions but have definitely enlisted a great many strong young women in aetive, saerifieial serviee.

Through the organized County Young Women's Christian Assoeiations, trained leadership is made available through the county seeretary and the volunteer leaders of the eounty with whom she works, for the girls and young women of the eounty. Loeal resourees are made use of ; programs for soeial, edueational, physieal and spiritual growth are planned; reereational features are made a eonstruetive foree; while county Camps, Conferenees, and so forth, bring a chance for a wider community and more friendslips for the girls of the eounty. Through eoöperation with the homes, the schools and the ehurehes, the best things are made available for the girls.

There are now twenty-three such organized eounties in the United States and the number is rapidly growing. Seven field seeretaries are at work on this speeial part of the Assoeiation work in different parts of the United States.

\section{TEN YEARS' PROGRESS IN COUNTY Y. M. C. A. WORK IN MICHIGAN ${ }^{1}$}

.C. L. ROWE

The County Y. M. C. $\Lambda$. has cvolved a policy that is applicable to the field, town, village and rural eommunity. It uses resident forees, makes its appeal on the basis of serviee, eoöperates with existing ageneies and develops the individual through group service. A comparison of the growth in the last ten years is as follows:

1 Publication of Rural School Department of Western State Normal School, Kalamazoo, Michigan. 


\begin{tabular}{|c|c|c|}
\hline & 1905 & 19 \\
\hline Counties organized. . & 1 & 16 \\
\hline Organized communities......... & 8 & 159 \\
\hline Seeretaries employed........... & 1 & 18 \\
\hline Money expended annually... & $\$ 1,500$ & $\$ 36,000$ \\
\hline Members $\ldots \ldots \ldots \ldots \ldots \ldots \ldots$ & 170 & 3.421 \\
\hline 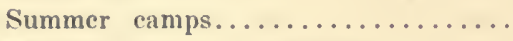 & 20 & 600 \\
\hline Attended Boys' Conferences......... & 40 & 2,300 \\
\hline Agricultural contestants.......... & - & 625 \\
\hline In physical aetivities.......... & 140 & 6,452 \\
\hline
\end{tabular}

\section{THE CALL OF THE COUNTRY PARISH ${ }^{1}$}

KENYON L. BUTTERFIELD

THE country-side is calling, calling for men. Vexing problems of labor and of life disturb our minds in country as in eity. The workers of the land are striving to make a better use of their resources of soil and climate, and are seeking both larger wcalth and a higher welfare. The striving and the seeking raise new questions of great public concern. Social institutions have developed to meet these new issues. But the great need of the present is leadership. Only men can vitalize institutions. We need leaders among the farmers themselves, we need leaders in education, leader's in organization and coöpcration. So the country church is calling for men of God to go forth to war against all the powers of evil that prey upon the hearts of the men who live upon the land, as well as upon the people in palace and tenement.

The country church wants men of vision, who see through the incidental, the small, the transient, to the fundamental, the large, the abiding issues that the countryman must face and conquer.

She wants practical men, who seek the mountain top by the obscure and stecp paths of daily toil and real living, men who can bring things to pass, secure tangible results.

She wants original men, who can enter a human ficld poorly tilled, much grown to brush, some of it of diminished fertility, and by new methods can again secure a harvest that will gladden the heart of the great Husbandman.

1 "The Country Church and the Rural Problem," pp. 13I-133. University of Chieago Press, 1912. 
She wants aggressive men, who do not hesitate to break with tradition, who fear God more than prejudice, who regard institutions as but a means to an end, who grow frequent crops of new ideas and dare to winnow them with the flails of praetical trial.

She wants trained men, who eome to their work with knowledge and with power, who have thought long and deeply upon the problems of rural life, who have hammered out a plan for an aetive eampaign for the rural ehureh.

She wants men with enthusiasms, whose energy ean withstand the frosts of sloth, of habit, of pettiness, of envy, of back-biting, and whose spirit is not quenehed by the waters of adversity, of unrealized lopes, of tottering sehemes.

She wants persistent men, who will stand by their task amid the mysterious ealls from undiseovered lands, the siren voiees of ambition and ease, the withering storms of winters of diseontent.

She wants eonstruetive men, who ean transmute visions into wood and stone, dreams into live institutions, hopes into fruitage.

She wants heroie men, men who possess a "tart, eathartie virtue," men who love adventure and diffieulty, men who can work alone with God and suffer no sense of loneliness.

\section{SECTARIANISM ${ }^{1}$}

TIIE growth of seetarianism is shown by the number of denominations foumd in rural eommunities. The following is taken from a study made under the direetion of Dr. Warren H. Wilson, showing the number of ehurehes in six eounties in Ohio.

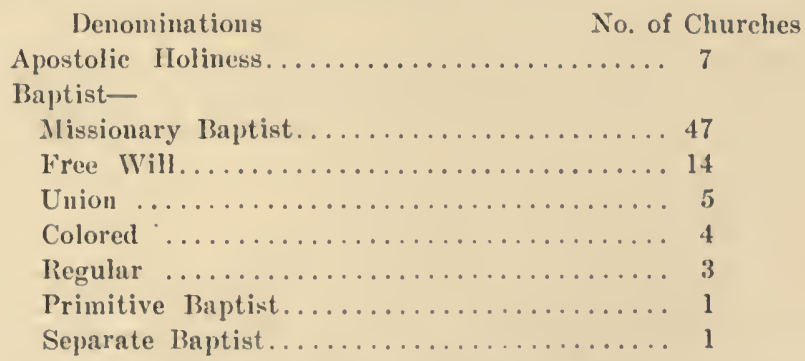

1 From Dept. Church and Country Life, Bd. Ifome Missions, Preshyterian Church, N. Y. 


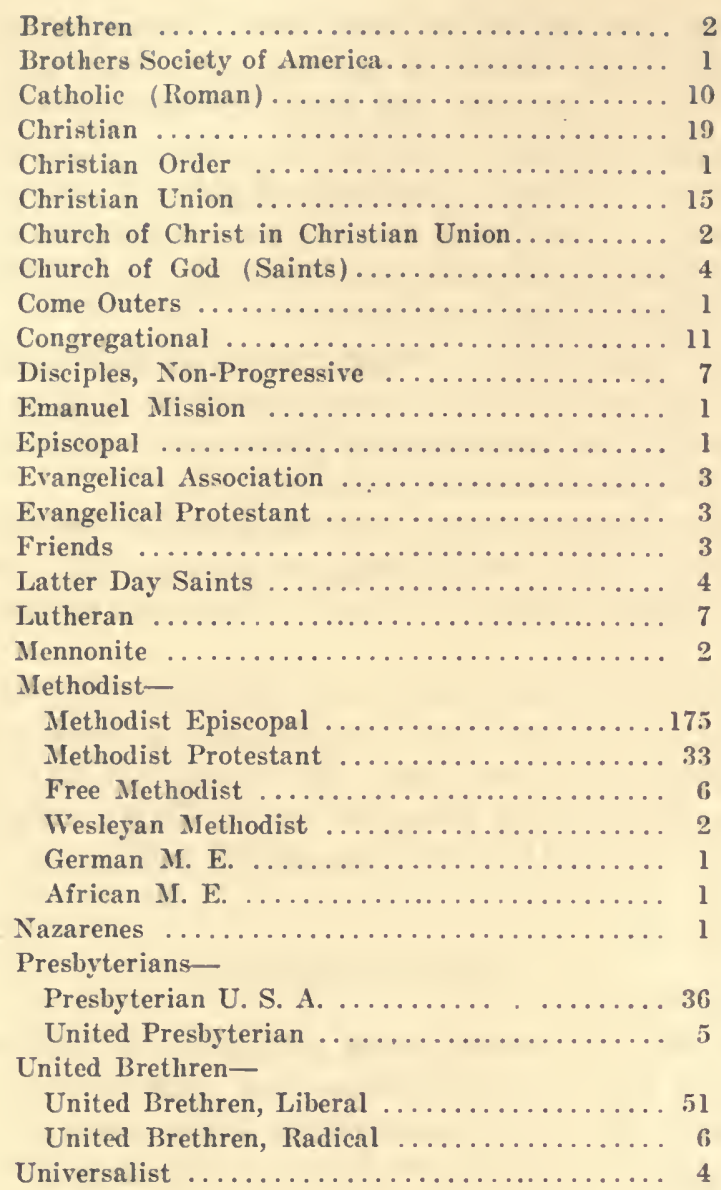

\title{
REPORT OF COMMITTEE ON COUNTRY CHURCH FUNCTION, POLICY AND PROGRAM
}

\author{
Kexyox L. Butterfield, Chairman. \\ Charles O. Gill. \\ Miss Jessie Fietd. \\ Albert E. Roberts.
}

Hevry IVALLACE.

Your Committee began its study on the assumption that there were three aspects of the work of the country church that needed stating: 
1. A definition of the function of the eountry ehureh, in order to gain if possible a elear notion of what the fundamental work of the chureh is, partieularly in relation to the work of other soeial institutions.

2. An outline of a general policy for the country chureh as a whole, in trying to earry out its function.

3. A suggestive program, embodying many conerete plans and suggestions for the work of the loeal ehurch, appropriate to the earrying out of the general poliey.

\section{THE FUNCTION OF THE COUNTRY CHURCH}

God's great purpose for men is the highest possible development of eaeh personality and of the human race as a whole. It is essential to this growth that men shall hold adequate ideals of eharaeter and life. The Christian believes that these ideals must spring from a elear appreeiation of God's purpose, and from a consuming desire to reproduee the spirit and life of Jesus.

Therefore, the function of the eountry ehureh is to ereate, to maintain, and to enlarge both individual and community ideals, under the inspiration and guidanee of the Cliristian motive and teaehing, and to help rural people to inearnate these ideals in personal and family life, in industrial effort, in politieal developnient, and in all soeial relationships.

The ehureh must bring men to God, must lead in the task of building God's Kingdom on Earth.

The mission of the Christian ehureh is that of its Founder: To teach the fatherhood of God and the brotherhood of inan as the ideal of life for the individual, the family, the community, and the nation, and to point out the best way to make the ideal the aetual.

\section{THE WORK OF THE COUNTRY CHURCH}

The Committee has divided the work of the country ehurch into the following heads:

1. Knowledge.

2. Preaehing and worship.

3. Religious edueation.

4. The Chureh ministering to all the people.

5. The Chureh, the servant of the community. 
6. Coöperation among the cliurches.

7. Division of labor.

8. Administration and finance.

9. The preaclier and his lielpers.

10. The preacher, a community builder.

11. The country church circuit.

Under each one of these heads there is:

1. A statement of general policy:

Intended to apply to the church as a whole, or to any church. This poliey is expected to be broad enough on the one hand to malie the church "function," and on the other hand practical enough to serve as a guide for local eluurch work.

2. A program for the local chureh :

This is by no means complete, but is a list of specific things that might be done by the loeal elunrch. Probably no one church will do all of them, but every chureh can do some of them. Each chureh should adapt its program to its own needs and conditions, but should always test the program in the light of a broad policy.

3. Suggestions and examples:

Under this head there is given a list of practieal helps, either indicating literature or mentioning actual instances that slow the practicability of many of the items in the suggested program.

\section{KNOWLEDGE}

\section{Policy}

a. Country church leaders, both preachers and laymen, should have a clear view of the fundamental aspects of the rural problem, and should broadly define the relationship of the church to that problem.

b. The country church should make a survey of its field, to diseover neglected individuals and families, to ascertain the conditions whieh letermine its work, and to learn what movements are entitled to its guidance, interest, and support. 'Two or more churches serving the same commmnity should coöperate in such a survey. The main results should be made public, but the rights of privacy should be duly guarded. 


\section{Program for the Local Church}

a-1. Books, bulletins, and magazines on country life should be put into public libraries and church libraries.

(See lists furnished by Rural Department of Y. M. C. A.)

2. Import lecturers on country life from the agricultural colleges, church societies, Y. M. C. A., ete.

3. Have speakers on the subject of the rural problem, at church coventions, conventions of young people's societies, ctc .

4. Ifold county or district conferences of rural preachers to study the rural problem.

b-1. Promote the community survey. Use some good standard survey such as that furnished by the Federal Council, by the Presbyterian board (Dr. Wilson), by agricultural colleges.

2. Encourage self-study by the community.

3. Chart results in graphic form so that material can be prescrved, and also made available for actual use.

\section{PREACHING AND WORSHIP}

\section{Policy}

The country church should foster private and public worship of God. Through its preaching, it should bring a ringing spiritual message to the community, and interpret the Gospel for the uplift of motive and the transformation and development of character.

\section{Program}

1. Preaching every Sunday in every ficld.

2. Emplasis on congregational singing.

3. Topies and texts witl rural setting.

4. Religious use of special days, like Harvest Home, Rural Life Sundays, Thanksgiving, Farın Mother's Day, Easter,-with reference to rural enviroument.

\section{RELIGIOUS EDUCATION}

\section{P'olicy}

The country clurel should develop definite means of religious education, both of adults and of children, interpreting personal 
and social duty in terms of rural life, and applying what is learned in actual social service. To this end, the pulpit, the home, and the Sunday Sehool should definitely coöperate.

\section{Program}

1. Graded Bible instruetion for children; adapted to the average country Sunday School.

2. Instruction of adults through eonsecutive studies in sermonie material.

3. Mid-week and monthly eonferenees.

4. Rural Bible Study.

IV. THE CHURCH MINISTERING TO ALL THE PEOPLE

\section{Policy}

While the country chureh should minister to the efficient and successful, to the end that it may hold the community throngh competent leadership, it should minister with special zeal to the ineffective, the poor and the degenerate, sinee they also belong to Christ. The rapidly inereasing instability of the rural population lays upon the church the special duty of religious and soeial helpfulness to the tenant farmer and the hired man.

\section{Program}

1. Organize clubs within the church for eommunity serviee projects; bring in outside speakers at club dinners, ete., to discuss community work.

2. Utilize existing women's organizations for larger and more effective service.

3. Encourage use of the church buildings by organizations and soeieties.

4. Give public advoeaey to varions forms of social service, sueh as clean-up days, community pienics, play festivals, town improvement, Arbor day. beautifying cemetery or common, etc.

5. Preach eontentment with rural life and adequaey of country as a life investment.

6. Make ehurch soeiables eommunity affairs, if possible, with all welcome. 


\section{THE CHURCH THE SERVANT OF THE COMMUNITY}

\section{Policy}

The eountry church should regard itself as the servant of the entire community, and should be deeply concerned with all legitimate agencies in the community; it should give them support and promotion as there may be opportunity or need. It should suggest and inspire rather than instigate and supcrvise, but it may undertake any new service for which there is not other provision.

Coöperation with Other Agencies.-The church should recognizc a division of functions in the community, and should cooperate with other institutions and organizations. Such adjustments arc made individually for the most part, but by public advocacy and by its educational methods the church may exert its collective influence for all cnds that may help to upbuild the community.

\section{Program}

Community movements should be instigated or aided by active coöperation, as the need may bc, for such ends as the following:

1. Temperance, wherever the community is suffering from intemperance or lawlessness; a campaign for no license or prohibition; law enforcement; Sabbath observance.

2. Public health and sanitation.

3. Good roads.

4. School cducation for rural life, and ordinarily consolidated schools.

5. Intellectual development by means of libraries, lectures, reading circles, clubs, and similar agencies.

6. Provisions for public recreation, and a Saturday lialf-holiday for agricultural laborers.

7. Promotion of demonstrations of recreation on church grounds if no better place can be had.

8. Better farming and better farm homes, with special stress upon extension work of agricultural colleges.

9. Beauty of village, roadsides and private grounds.

10. Celcbration of religious and patriotic holidays, observance of old home week, and production of historical pageants. 
11. Education of the pcople by preacling on community planning.

12. Establishment of a supcrvised social center or community liouse.

13. Local federation for rural progress and other community programs.

14. In general, promotion of coöperation among farmers in their production, buying, and selling.

\section{COOPERATION AMONG THE CHURCHES Policy}

Groups of country churches, with natural and social affiliations, should unite for the study of their special field and for the more effective use of their resources in meeting its needs, thus forming a church federation. Churches should consolidate where only onc church is necded in a community. In some communities a federated church may be practicable, an arrangement by which all clurelies in a community unite for worship and work but each church socicty prescrves its corporate identity.

\section{Program}

1. Union meetings for religious and patriotic purposes, song service, etc.

2. Community projects for various forms of community welfare, Christmas tree, ctc.

3. Evangelistic campaign on the coöperative basis, preceded by survey and followed by cffective organized work.

4. Union campaigns on moral issues like tempcrance.

5. Coöperative surveys.

6. Coöperaitve Boys' and Girls' clubs.

7. Coöperative play festivals.

8. Coöperative community pageants.

9. Coöperation in athletic contests.

VII. DIVISION OF LABOR

\section{Policy}

Oftentimes the greatest efficiency of the church requires specialized agencies for special tasks. The rural Y. M. C. A. and 
Y. W. C. A., the young people's societies, and other similar organized allies of the country church should therefore be utilized and encouraged where needed, and supported in their work.

\section{Program}

1. Furnishing leaders for special community tasks.

2. Encouraging financial support.

3. Special work with boys and girls.

4. Special work with young people.

5. Athletic league and recreation features.

6. Use of church buildings for these "allies of the country ehurch."

\section{ADMINISTRATION AND FINANCE}

\section{Policy}

A sound business organization and an adequate financial policy are essential to the conduct of the country ehurch. This involves utilizing the available resources of a community, the relation of the local ehurch to the Home Missionary Aid, the matter of minimum salaries for the resident ministers, and proper methods of financial accounting.

\section{Program}

1. Official boards and organizations regularly and completely organized with proper program of work.

2. Carefully kept records and regular reports of work in finances.

3. Systematic, community-wide, and adequate financial plan for local ehurch support and benevolences.

\section{THE PREACIIER AND HIS HELPERS}

\section{Policy}

A resident ministry is essential to the highest efficiency of the country church. It should be adequately trained to meet rural needs. Permaneney of tenure should be souglit by every possible means, including the payment of salaries commensurate with present ceonomie needs and proportionate to ability and service. One of the greatest tasks of the pastor is to inspire, enlist, and train all available leadership on behalf of the full measure of the service of the church to its members and to the community. 


\section{Program \\ The Training of Church Workers}

1. Every effort should be made to train leadership in the local cliurch, such as Sunday School teachers, lay readers, clders, deacons, leaders of young pcople's societies, officers of the various organizations for old and young within the church.

2. Training in young people's mectings.

3. Training in Bible School.

4. Normal class leader and lectures.

5. Conferences and institutes.

6. Reading and correspondence courses.

7. Personal interviews.

8. Practice work for novices, including apprenticeship system.

9. Inter-church visitation.

\section{THE PREACHER A COMMUNITY BUILDER}

\section{Policy}

The immediate work of the pastor is with the loeal church to which he is responsible, but his efforts should by no means be confined to the church. The church should, as it were, lend its pastor to the community for such helpfulness to individuals, agencies, and causes as will definitely contribute to the building up of the community as a wholc.

\section{Program}

The pastor may help in many or all of the tasks of rural community building that have been suggested heretofore in this outline on behalf of "better farming, better business, and better living."

\section{BIBLIOGRAPHY}

\section{THE COUNTRY CHURCH}

Ashenhurst, J. O. The Day of the Country Chureh. Funk, N. Y., 1910.

Beard, A. F. Life of John Frederick Oberlin. Pilgrim, Boston, 1909.

Bemis, C. O. The Chureh in the Country Town. American Baptist Assn., Boston, 1912.

Branson, E. C. The Church as a Country Life Defense. Bul. State Normal School, Athens, Ga., 1911. 
Bricker, G. A. Solving the Country Chureh Problem. Eaton, N. Y., 1913.

Butterfield, K. L. The Country Church and the Rural Problem. Univ. of Chicago Press, 1911.

Carver, T. N. Rural Economy as a Factor in the Success of the Churel. Bul. No. 8, Social Service Series, Ameriean Unitarian Assoc., Boston.

Dubois, Leo L. The Catholic Church and Social Service. The South Mobilizing for Social Service. (Addresses Southern Sociological Congress, 1913), pp. 584-596, Nashville, Tenn.

Earp, E. A. The Rural Chureh Movement. Methodist Book Concern, N. Y., 1914.

Feeman, Harlan L. The Kingdom and the Farm. Revell, Chicago, 1914.

Galpin, C. J. The Country Church an Economic and Social Foree. Bul. 278, Agric. Exper. Sta. of Univ. of Wis., Madison, 1917.

Gill, C. O., and Pinchot, Gifford. The Country Chureh. Macmillan, N. Y., 1913.

Six Thousand Country Churches. Macmillan, 1920.

Groves, E. R. The Cliureh and the Small Community. Rural Manhood, Vol. 6, May, June, Oct., 1915, and Jan., 1916.

Hammond, F. J. The Country Parson. Morehouse, Milwaukee, Wis., 1913.

Hart, J. K. The Religious Life of the Community. In his Educational Resources of Village and Rural Communities, pp. 176-197, Macmillan, N. Y., 1913.

Hayes, E. C. The Churel and the Rural Community. Amer. Journ. of Soc., 16: 693-695, Mareh, 1911.

Israel, Henry. The Country Churels and Community Coöperation. Assoce. Press, N. Y., 1913.

Macfarland, Charles S. The Protestant Church and Social Service. The South Mobilizing for Social Service. (Addresses Southern Sociological Congress, 1913), pp. 596-612.

Masters, V. I. Country Church in the South. Publicity Board of Southern Baptist Convention, Atlanta, 1916.

Miller, G. A. Problems of the Town Church. Revell, Chicago, 1902.

Mills, Harlow S. The Making of a Country Parish. Missionary Edueation Movement of the U. S. and Canada, N. Y., 1914.

Practicing Chureh Unity in Vermont. Conf. of Denominational Superintendents and Secretaries, Rev. C. C. Merrill, Sec., St. Johnsbury, Vt., $\Lambda$ pril, 1919.

Roads, Charles. Rural Christendom. Amer. Sunday School Union, Philadelphia, 1909.

Rural Cliurelı and Community Betterment. Association Press, N. Y., 1911.

Staratt, F. A. The Demands of the Rural Church upon the Theological Curriculum. Amer. Journal of Theology, 22:479-96, October, 1918.

Symposium "The Chureh and the Rural Community." Amer. Jour. of Sociology 16:668-702, Marelı, 1911.

Vogt, Paul L. The Church and Country Life. Miss. Educ. Movement, N. Y., 1916. 
Wallace, Henry. Remarks on Presentation of Report of Commission Upon the Rural Chureh-Men and Religion Movement. Men and Religion Messages-Rural Chureh, VI : 119-137, Association Press, N. Y., 1912.

Wells, George Frederick. The Country Church. In Bailey's Encyelopedia of Amer. Agric., IV : 297.

The Rural Chureh. Annals 40: 131-139, Mareh, 1912.

Wells, H. S. The Making of a Country Parish. Miss. Educ. Movement, N. Y., 1914.

Wilson, W. H. The Chureh of the Open Country. Miss. Edue. Movement, N. Y., 1911.

The Church at the Center. Miss. Edue. Movement, N. Y., 1914.

Surveys of Rural Cliurelies, Departinent of Chureh and Country Life, Presbyterian Board of Home Missions, 156 Fifth Ave., N. Y. 


\title{
CHAPTER XVI
}

\section{THE VILLAGE}

\section{THE HISTORY OF VILLAGE IMPROVEMENT IN THE UNITED STATES ${ }^{1}$}

\author{
WARREN H. MANNING
}

THE precursor of the Ameriean village improvement was the early New England village Common,- the people's forum, the eenter of their'social and industrial life, a place of recreation, and on it, at Lexington, was the opening act of that great drama that led to the American independence. Early, espeeially English, colonists set apart liberal portions of land to be used by louseholders in eommon for public landings, pasturage, and from which to secure timber, sedges, and the like,-all under restrietions imposed by the citizens in town meeting. This Common was at first an irregular plot or a very wide street, around or along whieh the village grew. Many are still retained, sometimes little, sometimes mueh, diminished by mnanthorized encroachments of adjacent property owners or by the town's permitting publie or semi-public buildings to be plaeed upon them. Publie landings have suffered even more from private appropriation, and most of the "eommon lands" lying away from the villages beeame "proprietary land," at an early date, by sneh aets as the following: Malden, Massachusetts, in 1694, voted: "Yt ye Common be divided; bottom and top yt is land and wood," and it ordered that eommissioners making the division "employ an artist to lay out ye lots." While sneh aets were legitimate, they were not always wise, for often the same land has becn re-purehased for publie use at large expense.

The extent of the illegitimate eneroacliment of private individuals upon lands reserved for the common good was not realized in Massachusetts until Mr. J. B. Harrison investigated for The

1 Adapted from the Art World and Craftsman, V:423-432, Feb., 1904. 
Trustees of Publie Reservations the status of sueh lands in the sea-shore towns. A typieal example of his findings will suffiee:

"Marslifield formerly had a Common. In earliest times it was the training field. The town gave a religious soeiety a perpetual lease of a part of it as a site for its ehapel, and then ran a publie road eurving diagonally through what remained. During reeent years various persons liave obtained permission to build sleds on the remnants of the Common, and there is not mueh of it left for future appropriation."

That street trees were appreeiated in the earliest days is evideneed by the aetion of a town meeting in Watertown, Massachusetts, in 1637, which passed a vote "to mark the shade trees by the roadside with a ' $\mathrm{W}$ ' and fineing any person who shall fell one of the trees thus marked 18 shillings." That this interest was continuous is made evident by the age of existing lomestead and roadside trees, very many of whieh are between one hundred and two hundred years old. This appreciation did not, however, extend far beyond the residential distriets, for lumbermen and farmers very generally appropriated to their own use all valuable trees on the publie ways unless elose to their houses. Notwithstanding this, there were always agreeable, if not always stately, woodland drives, for it required from thirty to fifty years for a erop to grow.

To the village eommon outlying roads rambled in by graeeful eurves over lines of least resistance as established by Indians, by eows, and by men of good sense. Later, that man of "mueh skill" and less sense, the turnpike engineer, by projecting his roads on straight lines, regardless of hill, dale, or water, managed, at great eost, to ruin much of beauty and convenienee, just as the road-builders of the West are following section lines with, however, the frequent additional disadvantage of the zig-zag eourse along two sides of each seetion. Such engineers and the surveyor who made his plans of streets and lots on paper from plotted property-lines and angles without levels and with little regard to existing surface conditions or existing streets, were then and are now destroying great beauty at unneeessary eost. In the early days these outlying roads were of liberal width, usually four, often ten, and sometimes more, rods wide. Such roads have also been eneroaelied upon by adjaeent property-owners. 
The first cheeks to the petty local land and timber thieves eame when permanent roads were established over which they dare not reach and, more reently, from the growth of a public sentiment against such eneroaehments which they dare not challenge.

That this early interest in village improvement was more pronounced in the older Eastern States, especially in New England, than elsewhere, was probably due to the more eompact and direct method of local government represented by the New England town mecting, and by the antecedents of the first settlers. Many causes have contributed to the growth of this movement that sprang into being in the earliest days, and struggled for.years in the forests of new movements, and against the weeds of selfish interest, until it is now a sturdy growth with many stout branehes and a promisc of great fruitfulness. There has been a growing recognition of the distinct utility and the continuous growth in beauty of trec and shrub-planted streets and public reservations and of rural roads following lines suggested by nature. This growth in beauty, exercising the refining influenee that such growth always does, brought about sueh a quiekening of publie opinion that unlovely, untidy, and unsafe publie and private grounds and public ways, once passed unnoticed, became so painfully obvious that action was demanded. At the same time the value of beauty, convenienee, and safety as an asset was made obvious by the attraetiveness of towus so favored to persons of eulture and means who were seeking permanent or summer homes.

A first evidenee of organized effort to promote these objects appeared in the $\Lambda$ gricultural Soeieties that grew out of the earlier "Societies for Promoting the Arts." They werc formed in South Carolina, Pennsylvania, and Massachusetts a few years before the end of the cighteenth century. They gave considerable attention to the improvement of home grounds, to street-trec planting, and to the preservation and reproduction of the forest. That of Massachusetts, for example, in 1793, offered prizes to persons who should eut and clear the most land in three years, and for the most cxpeditions method of destroying brush without plowing; but answers to questions sent out at this time showed so alarming a deerease in the forest areas that the policy was reversed and prizes were offered for forest plantations and the management of wood-lots. This same society endowed one of the first botanic 
gardens, and is still engaged in good works. The development in sueh soeieties of the horticultural interest led, in the first lialf of the nineteenth eentury, to the formation in scveral States of hortieultural soeieties that gave much more attention to these objects and oeeasional attention to public reservations.

During and just after the same period, a number of hortieultural magazines eame into being under the direetion of sueh men as A. J. Downing, Thomas Meehan, and C. M. Hovey, and some literary magazines, espeeially Putnam's, gave space to the writers on village improvement. Then eame the group of writers represented by Bryant and Emerson, whose kcen insight into and elose sympathy with nature was transmitted to so many of their readers, and, above all, Thoreau, the Gilbert White of America, with a broader point of view, whose writings did not, however, reeeive their full reeognition until mueh later.

It is very significant that two we'l-marked phases of the "improvement of towns and citics" should have developed at almost the same time. First, in a studied plan of public grounds, at Washington in 1851, to be followed by the acquirement of a publie park and the appointment of a Park Commission in New York in 1857, and second, by the organization of the first village improvement soeiety by Miss Mary G. Hopkins, at Stoekbridge, Mass., in 1853. Equally significant as indieating the impetus the movement is to attain, was the aetion of the national Government a quarter eentury later in aequiring great reservations, first, like the Yellowstone Park, for their natural beauty, then, later, as forest reservations for eeonomie reasons, and sueh battlegrounds as that of Gettysburg, on aecount of their historieal associations.

The first powerful impetus to village improvement was given by B. G. Northrup, Seeretary of the Commeetieut State Board of Edueation, who, in his report of 1869 , wrote upon "How to Beautify and Build up Our Country Towns," an article which he states was received with ridieule. He thereafter for ycars wrote mueh, leetured often. and hefore 1880 had organized not less than one hundred societies in the New England and Middle States. His writings were published by the daily papers, and the New York Tribune republished and offered for sale, in 1891, at three dollars per hundred, his "Rural Improvement Assoeia- 
tions," which he first published in 1880. It is interesting to note some of the objects espeeially touched upon in this pamphlet: "To eultivate publie spirit and foster town pride, quieken intellectual life, promote good fellowship, publie health, improvement of roads, roadsides, and sidewalks, street lights, public parks, improvement of home and home life, ornamental and economic tree planting, improvement of railroad stations, rustic roadside seats for pedestrians, betterment of factory surroundings." Other men aetive in the movement during this period were B. L. Buteher, of West Virginia, and Horaee Bushnell, in California.

That this activity made its impress upon the literature of the day will be evident to those who read "Village and Village Life," by Eggleston, "My Days at Idlewild," by N. P. Willis, and to those who seareh the files of the New York Tribune and Post and the Boston Transcript, The Horticulturist, Hovey's Magazine, Putnam's Magazine, the Atlantic, Marper's, and others. Much of this writing and the few books devoted to the subjeet, such as Downing's "Rural Essays," Seott's "Suburban Home Grounds," and Copeland's "Country Life," had more to do with the improvement of home ground; than with town planning. It was reserved for Mr. Charles Mulford Robinson in his very reeent "Improvement of Towns and Cities" and "Modern Civic Art" to give a permanent place in our literature to that phase of the work of town and eity improvement, although Bushnell, Olmsted, and others contributed to the subjects in reports, magazines and published addresses.

During this same period a broader and deeper interest in forestry and tree-planting was stimulated, espeeially in the Middle West, by such men as Joln A. Warder, of Ohio, and Governor J. Sterling Morton of Nebraska, at whose suggestion Arbor Day was first observed in his state, and there officially recognized in 1872. By the observanee of this day a multitude of sehool ehildren and their parents lave beeome interested in tree-planting on home and sehool grounds. For this, Mr. Morton deserves the same reeognition that belongs to $\mathrm{Mr}$. Clapp and the Massaehusetts Hortieultural Soeiety for the beginning and promoting of the equally important sehool-garden movement.

Little do we appreeiate to what Dr. Warder's forestry move- 
ment has led in the West. It has, by its encouragement of homestead plantations, greatly modified the landscape of the vast central prairic region of our continent. What was an endless and monotonous sea of grass is now a great procession of everchanging vistas between groups of trees. It has resulted in our Government's establishing fifty-three reservations containing sixty-two million acres of public forests managed by an efficient department, in establishing state forest commissions and reservations, in the formation of national, state and local forestry associations, many of which give quite as much attention to the forest as an element of beauty in landseape and to the preservation of roadside growth and encouragement of public and private tree-planting for beauty alone, as they do to the economic problems. In Massachusetts such an association secured laws placing all town roadside growth in charge of a Tree Warden. The importance of a ecntralized, instead of the individual propertyowner's control, of street trees is receiving general recognition. Mr. Wm. F. Gale, the City Forester of Springfield, Mass., by his enlistment of school children as street tree defenders, has shown how centralized control may greatly stimulate individual interests.

A little later in this period there began to flow from the pens of such men as Hamilton Gibson, Bradford Torrey, John Burroughs, John Muir, and Ernest Thompson Scton, a literature that has drawn the people so close to nature that they are sceing and feeling keenly the beauty of the common things right about them, and drawing away from the meagerness, garishness, and conventionality of the lawns and lawn planting of the period that followed the decline of the rich, old-fashioned garden of our grandmothers, and began with the vulgar "bedding-out" craze that followed displays at the Philadelphia Centennial. Then came the World's Fair at Chicago, where many men of many arts worked earnestly in harmony, as they had never done before, to produce an harmonious result. This bringing together of artists in the making of the Fair, gave a tremendous impetus to civic and village improvement activities, in common with all others.

The American Park and Outdoor Art Association, organized in Louisville in 1897 , and giving special attention to the public 
park interests, was the first national association representing the interests under review. In 1900, the American League for Civic Improvement was formed at Springfield to give special attention to improvement associations, in the promotion of which it has been most efficient. The League for Social Service, of New York, is another most efficient association working along similar lines, but giving more attention to sociological subjects. This year the first state association of village improvement societies was organized in Massachusetts. The association, first referred to, invited representatives of all national associations having similar objects in view to attend its Boston Meeting in 1902, where the action taken resulted in the formation of the Civic Alliance, to be general clearing-house for all activities and ideas represented by these various associations. The leaders of the first two associations, feeling that greater efficicncy could be secured by working together, have taken action toward a merger, the following sections being suggested for the new association:

Arts and Crafts.

City Making and Town Improvement.

Civic Art.

Factory Betterment.

Libraries.

Parks and Public Reservations.

Propaganda.

Public Nuisanees.

Public Reereation.

Railroad Improvement.

Rural Improvement.

School Extension.

Social Settlements.

Women's Club Work.

The National Federation of Women's Clubs, with its menbership of over 230,000 , has done mueh to improve towns and citics through its local clubs. How important this woman's work is ean be known only to those who ean appreciate with what moral courage, enthusiasm, and self-denial women will take up new interests, and how often one woman's persisteney 
and persuasiveness is the impelling force behind important inovements for the publie good.

One of the best evidences that beauty and good order pay, is given by the aetion of railroad corporations throughout the country, whieh have, by the improvement of their station grounds and right-of-way, ereated everywhere a sentiment in favor of village improvement.

The United States Government is issuing numerous bulletins that relate to village improvement work, and it reeognized the importanec of the school garden movement by sending a special representative, Mr. Dick J. Crosby, to the Sehool Garden Session of the American Park and Outdoor Art Assoeiation at its Boston meeting. The National Edueational Assoeiation also devoted a session to the same subject at its last meeting. Among universities, Cornell has done great good in establishing courses, and in sending out pamphlets on the improvement of home and school grounds, ehiefly under the direetion of Professor L. H. Bailey. Through this same agency "Uncle Joln"' Spencer has, by letters to and from a multitude of children, brought them to learn much about the objeets in their every-day life, by drawing out their powers of observation, reasoning, and expression. Quite as important are the newspapers and magazines. They are giving much spaee to the movement, and offering prizes for good work. The Chicago Tribune not only offered prizes in 1891, but gave a page or more to improvement work for several montlis in suecession. The Youth's Companion has not only given spacc to the work, but has sent out thousands of pamplılets on village improvement of school grounds. Garden and Forest, during its time, was a powerful agency of the highest order under the direction of Professor Charles S. Sargent, and with Mr. W. A. Stiles as editor. Of the existing publications Country Life in America, Park and Cemetery, American Gardening, The House Beautiful, House and Garden, Home and Flowers, The Chautauquan, and others, give a large share of their spaee to improvement work.

Sinee the appointment of a Park Commission in New York to make and administer a park for the pcople, nearly every large city and many towns have their Park Commission and public parks. States also arc acquiring land to preserve natural beauty, 
sueh as in the Waehusett and Grayloek mountain reservations in Massaehusetts; for their historie value, as at Valley Forge in Pennsylvania; for the protection of the drainage basin to a eity water supply, as in New York and Massachusetts; for a game and forest preserve, as in Minnesota. Two states have eoöperated in the aequirement of a reservation for beauty alone, as at the Dalles of the St. Croix, lying partly in Minnesota and partly in Wiseonsin, and furthermore, eommissions under two governments have eoöperated in aeeomplishing the same purpose at the Niagara Falls Reservation.

As an outeome of all this, we may look for the establishment of State Park Commissions, already suggested in Massachusetts, and for which a bill was introduced into the Minnesota legislature, and ultimately a National Park Commission to tie together the great national, state, eounty, eity and town publie holdings that will inelude such dominating landseape features as mountains, river-banks, steep slopes, and sea and lake shores: land for the most part of little value for eommereial, industrial, or agrieultural purposes, but of great value as elements of beautiful landseapes. The seleetion of such lands will ultimately be governed largely by natural and by eeonomie eonditions as established by sueh bureaus as that of Soil Investigation of the Government, which is engaged in investigating and mapping soil eonditions, as well as by the Forestry Bureau already referred to, and others. At present, large areas of private property, many lakes, rivers, and some sea-shore, now in private hands, are opened to the publie without restrietion: but with an inerease in population and in land values, the publie will be shut out from all points of vantage that are not held for the eommon good, as it is now excluded from many miles of sea-and-lakeshore by private owners, where a few years ago there were no restrietions.

The work of the village improvement soeieties should be direeted toward this movement to make our wlole eountry a park. They should stop the eneroachment of individuals upon publie holdings, urge individuals to add to sueh holdings by gifts of land, fine old trees, or groups of old trees, in prominent positions, in town or eity landseapes. Every assoeiation should secure and adopt a plan for the future development of the town 
as a whole, showing street extensions and public reservations to include sueh features in sueh a way that they may beeome a part of a more extended system, if this should be brought about in the future. These societies should not undertake the legitimate work of town offieials, sueh as street-lighting, street-tree planting, repair of roads and sidewalks. They should eompel the authorities to do such work properly, by gathering information and seeuring illustrations to show how mueh better similar work is being done in other places, very often at less cost. They should inaugurate aetivities of which little is known in their eommunity: sueh as the improvement of sehool and home grounds, and the establishment of sehool-gardens and playgrounds. If the poliey of such a society be not broad enough to admit the active coöperation of the ablest men and women of a town, it ean aceomplish but little. If its methods are not so administered as to instruet up to the highest ideals, its efforts are quite as likely to be as harmful as beneficial.

\section{SOCIAL PRIVILEGES OF VILLAGE OR SMALL CITY ${ }^{1}$}

\section{J. GALPIN}

THE general law has reeognized the village as a eommunity. The visible unity of the village group of houses, stores, and shops has been the main warrant for treating the village or small eity as a eommunity all by itself. The people are elosely related in business and life and come to feel a real solidarity. The legal provision for ineorporation is a presentation of a set of new powers, and new duties to this group of homes as a comprehensive social unit. A village legislature, a village exceutive, the thinkers and actors who individually have sueeeded by foreeast, insight, integrity, and perseveranee, are now banded for the village interests. The president or mayor now begins to have his vision widened from a community pedestal, and a new soeial machine for progress with power is put to work for the common good.

1 Adapted from Rural Life, pp. 92-94, Century Co., 1918, and Bulletin 34, "The Social Anatomy of an Agricultural Community," pp. 24-28. Agricultural Experiment Station, Univ. of Wisconsin, Madison. 
Organizations and institutions spring up instinctively for the village population. It is assumed that there is to be a ehurch or ehurches. A village without this ancient publie ageney at once loses caste. The ehildren of villagers of course must have soeial privilege of instruction in race idealism. Fraternal orders are assumed. Lodges quickly spring up. Human fellowship must have its ritual and mysticism for the villager. The library is assumed. It may wait for a benefaetor, but it is counted on. As soon as there is suffieient taxable property the most important and significant assumption is made-the village will have a high school. It is taken for granted that the children of the village, ehildren whose roofs are near together, should have the privilege of four years' training in idea organization and work acquaintanee. Amusement halls, parks, bands, orchestras, and baseball grounds are soon provided. As the village, following its eity ideal, moves on into small eity government, multiform organized agencies and institutions, voluntary, eommercial; or municipal in the plane of public health, education, business, information, soon follow.

The institutional reënforeement of the village, along with the growing consciousness of village unity, clothes the villager with a seeondary social personality. This is reeognized, even though disparaged by the farmer. Prestige is the outeome. Superiority is inevitable; but here begin the troubles with a neeessary farm population, which the banker, storekecper, and blacksmith know as the goose that lays the golden egg. The problem is one of pleasing the farmer and getting lis trade, without building him and his mind, capaeities, and wishes, into the community fabric. The farmer's money is good and necessary and must be obtained and his good will retained; but how to aeeomplish this objeet is a problem. Thorough-going ineorporation of the farmer into the strean of village activities is frustrated by the fundamental eonception of the self-sufficiency of the village. The farmer is presented outright with a few donations, as privileges in order to hind him. Toll, of course, is to be exacted by villagers sontewhere. Craft sometimes takes the place of open dealing. The farmer does not share in the control and responsibility of eertain things which le oeeasionally enjoys at the village as a speetator. The outlying farm population is 
seldom massed. Its members eome to town by team or automobile or on foot or horseback, do their business withont a resting place of their own, stand on other people's streets, in other penple's shops, and over other people's eounters. They go back after some hours of absence to their own lands, oceupations, and homes. In the village they are aliens, but aliens with a possible title to be coneiliated. The embarrassment is on both sides. The farmer pays in so much in trade he feels that he ought to have consideration; he pays so little direetly toward the institutions that the village eonsiders that his rights are not eompelling. Puzzle, perplexity, and embarrassment obseure the whole relationship and situation; and the universal proeess of legalized insulation of village and eity away from the farm, which las grown up undisputed, with scareely a hint of abnormality, is eonstantly shadowed by this overhanging cloud of doubt.

The modern village differs from the modern eity mainly in this -the village industries are related direetly to the needs of the outlying population on the land in addition to the needs of the village population. The eity eontains industries related to people seattered over the territory of eounty, state, or nation. As soon as a village obtains one knitting mill, or a lateh factory, or plow works, or iron smelter and the like, whose produets go to people who are not otherwise interested in the village, it begins to possess the problems of a eity. As this process eontinues, it becomes less and less dependent upon the agrieultural population within its immediate farm trade zone, and more and more upon seattered peoples of various sorts, who may never see the eity. As the small city grows, outstripping its adjoining villages, these villages beeome more or less conseiously satellites of the eity. Wholesale needs are met in this city for village merehants, and special retail eustomers enme to buy elothing and furniture from larger stocks. A trade elientele is formed reaching out over a eounty, or two, or three, of these seasonal or oceasional village and farm buyers. This smaller eity, then, has a signifieanee for several communities, and becomes an intercommunity eenter. Beyond this is the state center for tradethe metropolis, with national importanee.

So long as a small eity is agricultural in its elientele, the land 
allied to it is a permanent social factor from generation to generation. It is a part of the equipment of the perennial elemental industry of this city or village. Were there a knitting mill on the edge of a small eity, with five hundred employees living about the mill, this whole industry-land, buildings, and people-would be unquestionably part and parcel of the city. In like manner surrounding the agricultural city is a huge continuous nature industry, not directly unified to be sure, but real and actually united just the same.

Every inch of advance on the farm in intelligent skill, managerial ability, moral control, governmental devclopment, will be reflected in the little city by an increased farm consumption of goods, higher grades of farm desire, and better qualities of farm citizenship; whereas the same qualities of skill, intelligence, and integrity in the eity will be quickly transmitted to the farm and to the advantage of the population on the land, if avenues of social intereourse between "wheel and hub" are open wide.

Our study shows that the farm homes in the trade zone of a small city share with the eity homes the major commercial and social interests requiring combined capital of many to carry on. Circumstances hitherto have hindered the lar'ge-seale development of some of these enterprises among the farm liones, but these circumstanees may not be-in fact need not be-permanent; for the same incentive which has led the eity population to spend some of its surplus profits upon equipment for religion, higher education, government, information, art, leisure, and play, is present in a latent form in the farm population, simply ready to be induced to join hands in an alliance of fair play.

\section{THE TOWN'S MORAL PLAN ${ }^{1}$}

\section{HARLAN P.IUL, DOUGLASS}

IT is possible for the little town to have a moral plan, approximated through conscious standards of social control. As everywhere, human conduct is determined chiefly by the natural acquiescence of the human spirit in the ways of the social order

1 Adapted from "The Little Town," pp. 115-120, Macmillan, X. Y., 1919. 
into which it is born. In the main these ways satisfy the individual; even the rebel is too unoriginal to depart from them. Moral sentiment and social convention do most of their work without need of law or poliee.

The eontrol of eonduet through soeial tradition is, however, not so simple as the formula sounds; there are traditions rather than a tradition. Not only is there still a dash of frontier wildness surviving as lawlessness in the little towns of mueh of the country, but the little towns as a group are peopled largely by those who formerly lived in the eountry and who are still largely dominated by the countryman's point of view. In brief, they are ineompletely soeialized. Their people eling to eountry ways in spite of new environment. Thus in matters of sanitation, the maintenanee of the barnyard manure pile is a saered private right worth dying for, as a symbol of our liberties; or on the other hand, as the little town grows there come to be those who want to push on prematurely into city ways for the freedom of which they eontend as martyrs to new light. In short the struggle is always on between existing conditions and advaneement. Now, any group of people which is distinetively at outs with environment presents a serious moral problem. Just as the spirit of youth is inevitably at war with the necessary limitations of the eity streets, so the rural mind is at war with little-town eonditions. Hence the neessity. of vigorous moral control in order to conform the individual to the requirements of eolleetive life.

The minor struggle between traditions, the give and take of moral sentiments in search of equilibrium, the clash between temperaments, ages and views of life will go on normally forever: But no community ean do anything in the direction of its ideals till the fact and main tendeneies of social eontrol are settled. The little town may as well face its battle and liave it over. The necessary ordinances of safety and decency are to be obeyed. Pigs and poultry will be the most frequent issue. Their eeonomie value under town conditions must first be determined. If it is best to keep them at all, the whole wearying round of issues must be pursued-agitation, edueation, a contest in loeal polities, a suit at law or two, a clash at wills and of personal sentiments all along the line. 
While all moral battles must be waged on cvery front at once, it is possible to discern a sort of pedagogieal order in which the offensive should be undertaken. It would be foolish to make the first issue that of elosing cigar stands on Sunday, which at best would only stir the eonscienee of a fraetion of the eommunity, or that of enforeing liquor laws, which always involves a contest with formidable interests from outside the eommunity. Rather the battle should be drawn on some eommunity issuc pure and simple, in which the enforcing of the eolleetive against the individualistie viewpoint involves some broadly fundamental but loealized ficld. When the battle is fought to a finish here other victories will come more easily.

The most difficult yet neeessary phases of the little town's struggle for moral standards are those involving outside interests not directly amenable to the eommunity eonseience. They are often said to "interfere" with the eommunity; if so they must be made to interfere helpfully as well as harmfully. The most frequent and insidious of these interests is the organized liquor traffie, altlough often the interests of alien eorporations clash with those of the eommunity and interfere in a similar way. In these cases the essential nature of the problem is that it is not local in charaeter. Loeal tools are used, but the prineipals to the eonflict are too remote to feel loeal pressure. Under sueh cireumstances the only resource of the little town is to combine with other eommunities using the resourees of statewide publicity, organization and political action. The unromantie, perpetual, straight-away pull of law-enforeemcut with all its eosts in time, money and personal diseomfort, is the inevitable price of community morals in their wider setting.

Even more difficult than law enforeement, but affeeting inore people in more ways and entering more subtly into eommunity life, are the problems of social eontrol in the round of social intercourse; of amusements, particularly for youth; the problems of standards of eonsumption registered by the expenditure of money, and of the use of lcisure. The eoncrete forms in which these issues eonfront the little town are the party, the dance, theater and amusement place; dress, travel, Sunday observanee and the like.

Probably the most rational method of precipitating a body of 
agreements in these debatable fields is that of the voluntary referendum, whieh has been tried out in a number of eommunities. It is proposed usually by the federation of women's organizations and eonsists simply in a systematie eanvass of the most influential and earnest members of all elasses and tendeneies in the community, to see what they think the reasonable standards for "our town" are. At what hour should the parties of high sehool young people elose? How many times a week should growing boys and girls be away from home at night? What is a reasonable seale of entertainment at elub fnnctions? How mueh should the eost of graduating dress and attending funetions be? What are the reasonable terms of soeial association between adoleseents of the two sexes? When the results of sueh questions are generalized and announeed a eousiderable range of ehoiee is still open, but weak-kneed parents are strengthened to enforee some kind of a standard. It is easier for the poorer hostess not to spend more than she should. The ultra-puritanieal are restrained and the way to rational agreements is open. Surely this is better than the eternal anxiety of the little town as to what is right and proper in soeial matters, the harsl judgments of the strieter upon the less striet, the internal diffieulties by which a man's foes are often they of his own household.

In some sueh ways as the above the steadying foree of soeial standards may be thus vitally evolved without hardening into unyielding, elashing and non-progressive traditions.

So far the diseussion has eoneerned the logieal fundamentals of little-town betterment. It is quite another thing to make a construetive program of soeial advanee. All merely formal direetions, and espeeially negative ones for the eontrol of life, will and ought to fail. The most vitalizing possibility of the little town is that of having a positive program seeured by the eontimnous aetivities of the institntions of edueation and serviee, and by the direct pursuit of wholesome ideals by individuals. One who sees life steadily and sces it whole will not attempt to deal eompulsorily with struetural fundamentals without at the same time ereating an atmosphere in whieh wholesome eommunity ehoiees may take plaee. He will not dare to specialize on law enforeement mntil he has ereated the playground and appreciated the spiritual aspects of reereation. He will not at- 
tcmpt to make social standards for his fellows except as he can present a vision of normal life compelling in its attractiveness. But on the other hand, and equally, the most idealistic and spontaneous community movements will wander far without a well planned physical basis of town life; without a well ordered economic prograin through which people ean win a livelihood and pay the cost of their collective enterprises; without a firm basis in liuman health through the facilitics of public safety and sanitation; and without a substantial though flexible moral framework within which individual destinies may be wrought out. On these greatest civic commandments hang all the law and the prophets of community welfare.

\section{CIVIC IMPROVEMENT IN VILLAGE AND COUNTRY ${ }^{1}$}

\section{FRANK $\Lambda$. WAUGH}

THE rural population of the United States has always been noted for its public spirit and patriotism. At the same time, it las been recognized that the farmers themselves have benefited least from their own public spirit. They have generally been unable to act in their own interests. For this reasoll, rural communities should give special heed to the modern movement for civic improvement.

Civic improvement may be aceepted as a convenient term to designate all efforts made toward the betterment of the physical conditions of the community. It refers, therefore, especially, to those matters in which the public is interested. Some of the important. items in the pliysical equipment for community life are :

(1) Roads and strects, including bridges, strect railways, and strect trees.

(2) Public grounds, such as parks, eommons, lakes, waterfronts, and eemeteries.

(3) Public and quasi-public buildings, such as school houses, town halls, libraries and ehurches.

1 Adapted from Extension Circular, No. 11, Mass. Agricultural College, Amherst, Narch, 1917. 
(4) Publie reereation faeilities, especially playgrounds.

(5) Public service equipment, such as telephone lines, elcctrie light lines, railway stations and grounds.

(6) Private grounds-inasmueh as the improvement of private grounds adds greatly to the attractiveness of any community.

Civic improvement then is an enterprise applicable to cities, villages, or eountry distriets, in faet to every civilized community. Inasmueh as the great eities possess an undue proportion of the wealth and initiative of the nation, they may be expected to take care of their own interests along these lines. Country districts and rural villages, however, have equal need to improve to the utmost their physical surroundings. The country as well as the city needs good roads, suitable public grounds, modern school buildings, libraries and churehes, and all the improved equipment of twentieth century civilization.

It is the purpose of eivic improvement to achieve, as rapidly as practicable, every possible advanee in the eommunity equipment as already defined. These improvements can be secured by :

(1) Informing the publie as to present eonditions, necded improvements, and means of securing the same.

(2) Securing professional and technical advice on pending improvements.

(3) Foreseeing and planning ahead for coming ehanges, thus avoiding expensive mistakes and reconstructions.

(4) Adopting definite and coördinated plans for community bettcrment.

(5) Forming improvement programs according to which suecessive enterprises are taken up in an agreed and logical order.

(6) Assigning particular enterprises to particular groups or organizations, e.g. the Grange may assume responsibility for the roads, the Woman's Club for the school houses and playgrounds, one ehureh for the public cemetery, another for the town common, ctc.

Civic improvement, therefore, is not a newfangled luxury, not a new means of spending publie money, but a means of 
eeonomizing money. At the same time, it is expeeted to aeeomplish substantially better results for the eommunity.

Civie improvement usually sueeeeds best under the direetion of some live, loeal organization. This may be a village improvement soeiety, or it may be some association which exists primarily for another purpose but whieh undertakes also to assist in the physieal upbuilding of the eommunity in whieh it lives. The work in some towns has been definitely undertaken by the Grange, though seldom with a suffieiently eomprehensive plan. In some eommunities, it has been sueeessfully proseeuted by women's elubs. Where no organization already exists, or where no existing organization is ready to take up the work, the best plan is often to form a eentral eommittee or federation eomposed of delegates from existing organizations, such as lodges, churehes, women's elubs, men's elubs, ete. Under reeent Massaehusetts legislation the formation of a town planning board has eome to be one of the best methods of seeuring permanent results. Whatever loeal organization may be in eharge of the work, outside adviee and expert assistanee should be frequently ealled in. This is lighly important.

$\Lambda \mathrm{s}$ the bulk of eivie improvement is applied to publie works, and as the whole of it is designed for the publie good, the bills should be paid ehiefly from the publie treasury. An indispensable part of a eivie betterment eampaign is to see that publie money is wisely and honestly used. The inmediate eontingent expenses of the village improvement soeiety may be met by private contributions, by fairs or entertainments, or by any means most aeeptable to the eommunity.

Commonly the leading problems presented in a eommunity improvement program are as follows: (a) approaehes, (b) streets, ineluding trees, (e) eivie eenters, (d) eommons, (e) public buildings, (f) playgrounds, (g) private grounds, (h) maintenance. A full diseussion of all these problems would require an entire volume, but the main issues may be pointed out briefly herewith.

Every town and every rural distriet should have suitable means of aeess. We hear a great deal nowadays of isolated eommunities, meaning those whieh are hard to reael. Easy aeess eomes by well-kept roads, by well-managed trolley lines, or by rail- 
roads. The entranec to a village or country district should be direet, inviting, and hospitable. The front door to a town should have the same qualities as the front door of one's own home.

Good roads are a primary part of civic bettcrment, and the eampaign for good roads is perennial. Better methods of road building are needed, and more permanent roads are especially desirable. In many eases, roads and streets should be rclocated before permanent improvements are made. Such relocations should secure more direct lines and casier grades. The work of the Massachusetts Highway Commission has developed some striking cxamples of improvement by relocation. Many similar improvements can be seeured by the towns themselves, if only proper thought is given to the matter.

In Massachusetts, every town should have a tree warden, and should make sure that he is a eompetent man and that he attends to his work. In the face of the unusual pests which we have to mect, the salvation of street trees can be secured only by heroic efforts. It is depressing to think what our village streets and country lanes would be like, should the street trees disappear. The best modern, scientific eare should be given to prescrve the trees now standing, and at the same time annual plantings of young trees should be made to make good the unavoidable losses.

The villages are the natural eenters of politieal, business and social life in New England communities. They should be worthy of suel an important office. Morcover, at such eenters should be grouped the buildings which represent the public.life of the community, such as town hall, library, school-houses, post-offiee, etc. Substantial advantages are gained by grouping these buildings instead of scattering them. In general, the best arrangement is to have them front upon the town common, but never should they be placed upon the Common itself.

The small central greens loeated in the hearts of many New England villages are a public asset of the highest value. They should be most jealously guarded. They should be well kent, in every partieular. It is especially important as a general prineiple that no arehitectural or ornamental construetion of any kind should be permitted on the Common. Public buildings are particularly damaging, but neither is the Common any place for 
any kind of fountain, statue, or bandstand. Such ornaments or convenienees may often be loeated advantageously on the street margin or extreme outer angle of the town common, but under no eircumstances should they be placed on the Common itself. Mistake is very common in this matter.

Every effort should be made to secure public buildings of the best charaeter. Every town hall and every library ought to be something which the community ean be proud of. A public building which is a public shame is a constant influence to degrade the spirit of the community. The effort for good, attraetive, dignified, and even beautiful public buildings needs to be directed especially to the school-houses. Every school-house ought to set a good example daily to the school children. Unfortunately, many school-houses are cheap, shabby, and even dirty.

Country villages and rural eommunities generally are notably lacking in playgrounds. There is no space reserved where boys may play ball without trespassing on private property. Even the sehool-houses are insufficiently provided with play room out of doors. There ought to be ample room and encouragement for play in the country. In this way, one incentive which young people find for going to the eity would be materially weakened.

When private lawns are well kept, gardens made attraetive, and grounds gencrally beautified, the public enjoyment is greatly inereased. Nothing does more toward making a town attractive than to have the private grounds improved. Such garden improvements may be promoted by the village improvement society through offering prizes, the arrangement of speeial sehool instruetion, and by many other means. This is an important line of eivie improvement work.

The most important things in housekeeping are eleanliness and good order; likewise, the most important things in eommunity life are eleanliness and good order. The streets and publie plaees should be kept elean,- the grass mown, weeds eut out, and everything kept in its plaee. The eommon should not be allowed to accumulate Sunday papers, nor the cemetery be allowed to grow up to brush. In faet, this regular routine of keeping elean should reasonably oeeupy a large proportion of the time, efforts and funds at the disposal of any improvement organization. 


\section{Bibliggraphy}

Anderson, Wilbert L. The Country Town. Baker, New York, 1906. Baden-Powell, Baden H. Indian Village Communities. Longmans, N. Y.

Origin and Growtl of Village Communities in India. Seribner, N. Y., 1899.

Bailey, Liberty $\mathrm{H}$. The Place of the Village in the Country Life Movement. In his York State Rural Problems, 2:148-157, Lyon, Albany, 1913.

Bennet, Ernest N. Problems of Village Life. Holt, N. Y., 1914.

Bird, Chas. S. Jr. Town Planning for Small Communities. Appleton, N. Y., 1917.

Blackmar, F. W. Social Degeneration in Towns and Rural Distriets. Conf. Charities and Corrections, 1900, 315 Plymouth Court, Chieago.

Bookwalter, J. H. Agrieultural Town. In his Rural rs. Urban, N. Y., 1910. (Privately printed by author.)

Brunner, Edmund de S. Coöperation in Coopersburg. Missionary Edn. Movement, N. Y., 1916.

Donglass, Harlan Paul. The Little Town. Maemillan, 1919.

Dunn, Arthur W. An Analysis of the Social Structure of a Western Town. University of Chicago, 1896.

Farrington, Frank. Community Development. Ronald, N. Y., 1915.

Farwell, Parris T. Village Improvement. Sturgis, N. Y., 1913.

Fitel, George H. Homeburg Memories. Little, Boston, 1915.

Fustel de Coulanges, Numa D. The Aneient City. Lee, Boston, 1901. Galpin, Charles J. The Social Anatoniy of a Rural Community. Univ. of Wis. Research Bulletin, No. 34, Madison.

Rural Relations of the Village and Small City. Univ. of Wis. Bulletin, No. 411, Madison.

Gillin, S. Y. Community Develonment and the State University. Town Development, Vol. 12:99.

Hart, Joseph K. Educational Resources of Village and Rural Communities. Maemillan, New York, 1913.

Hartman, Edward T. Village Problems and Characteristies. Annals, 40 : 234-243, March, 1912.

Maine, Henry J. S. Village Conımunities in the East and West. Holt, N. Y., n. d.

Masters, Edgar L. The Spoon River Anthology. Macmillan, New York, 1915.

MeVey, Frank L. The Making of a Town. MeClurg, Chicago, 1913.

Nolan, John. Comprehensive Planuing for Small Towns and Villages. Bul. 16, American Unitarian Assn., Boston.

Origin, Organization and Influence of the Towns of New England. Proceedings Mass. Hist. Society, Boston, Jan., 1866.

Robinson, Cliarles M. The Improvenient of Towns and Villages. Putnam, N. Y., 1909.

Sims, Newell L. A Hoosier Village. Longınans, N. Y., 1912.

The Rural Community, Aneient and Modern. Clias. Seribner's Sons, N. Y., 1920 , 
Small, A. W., and Vincent, G. E. The Village, An Introduction to the Study of Society. Pp. 127-143, American, N. Y., 1894.

Stubbs, C. W. Village Polities. Macmillan, N. Y., 1878.

Vogt, Paul L. Introduction to Rural Sociology. Appleton, N. Y., 1917.

Village Growth and Decline in Ohio. American City, 13:481-5, December, 1915.

Waugh, Frank A. Rural Improvement. Orange Judd, N. Y., 1914. 


\section{CHAPTER XVII}

\section{THE SURVEY}

\section{THE SURVEY IDEA IN COUNTRY LIFE WORK ${ }^{1}$}

\section{H. BAILEY}

THE scientific method is first to determine the exact facts, and then to found the line of aetion on these facts. That is the way in which all problems must be attaeked if real and permanent solutions are to be found. The scientifie method in engineering and meehanies and biology and the rest has been responsible for the high development of eivilization within the past eentury. Similar metiods must be applied to rural work. We must finally found all our progress in rural life on a elose study of the facts and the real elements in the situation, in order that we may know exaetly what we are talking about. The prevailing politieal methods have been the antithesis of this; they have too often been the methods of opportunism.

Surveys may be of many kinds and for many purposes. Some of them may be for temporary uses only, in the nature of explorations or to set forth a particular line of ideas. The real rural survey should be an ageney of record; and it is this type of effort that I am now diseussing.

We must distinguish sharply between sueh a survey, made slowly and studiously, and an inspection, a canvass, or a eampaign. These lighter efforts may be very necessary, but they usually do not eonstitute an investigation, and they belong to a different order of inquiry.

The general or gross reeonnaisance, to bring together quiekly for comparison the outstanding features and eonditions of many communities, may have mueh value; but it should be undertaken only by persons of experience in detailed survey-work and of

1 Adapted from "York State Rural Problems," Vol. 1:238-261. J. B. Lyon \& Co., Albany. 
ripened judgment. It is one of the most diffieult forms of survey-work, if it is to have real value. It must be mueh more than a ear-window exereise. When properly undertaken, it is a new and useful applieation of geography. There is a great danger that the overhead reeonnaisanee will be little more than praetiee in aviation.

If a survey of any region or phase is to be a reeord of faet, then it must be strietly seientific in spirit, as I have already indieated. It must discover and set down every fact of signifieanee, wholly apart from any prejudice or bias in the mind of the observer: the faet is its own justifieation. The work eannot be as preeise as that in the mathematieal and physieal seienees; but in its purpose it must be as seientifie as any work in any subjeet.

If the work is seientifie, then it will not be undertaken for the purpose of exploiting a movement, reeruiting an assoeiation, spreading a propaganda, advertising a region, sustaining a politieal organization, or promoting the personal ambition of any man. There is indieation that survey work will soon beeome popular; there is danger that it will be taken up by institutions that desire to keep themselves before the public and by loealities and states that desire to display their advantages. It will be easy to marshal statements and arrange figures, and partieularly to omit faets, in sueh a way as to make a most attraetive showing. Even some honest investigators will be likely to arrange the material in sueh a way as to prove a point rather than to state the facts, unless they are very muel on their guard. If eountry-life surveys have possibilities of great good, they have equal possibilities of great danger. I am glad that the movement is going slowly at first.

The intention of survey work in agrieulture is to make a reeord of the entire situation and to tell the whole truth. Fragmentary surveys and pieee-work, however good they may be in themselves, do not represent the best effort in surveys. Praetieally all our surveys have thus far been fragmentary or unrelated, but this is the work of a beginning epoeh. We shall almost neeessarily be obliged to do still further fraetional and detaehed work; but it is time that we begin to train the imagination on eompleter and sounder programs. The whole basis and 
condition of the rural community must be known and recorded. The community must know where it stands. It must understand its assets and its liabilities.

Survey work is legitimate wlolly aside from its application. I have no patienee with the doctrine of "pure science,"-that science is science only as it is uncontaminated by application in the arts of life; and $I$ have no patience with the spirit that considers a piece of work to be legitimate only as it has direet bearing on the arts and affairs of men. We must discover all things that are discoverable and make a record of it: the application will take care of itself. The application of scienee lies not alone in its employment in particularities here and there, but quite as much in the type of inind and the philosoplyy of life that result from it. If we knew our cxact rural status-in materials, ac. eomplishments and deficiencies-we should by that very fact have a different outlook on the rural problem and a surer process of attacking it. We should do little guessing. We should correct inany vagaries and many a foolish notion to which we now are all, no doubt, very much given. We should not be obliged to follow blind or self-wise leaders. A substantial body of aecumulated fact would set bounds to the promoter and the agitator and the schemer.

The result of survey-work in agriculture should be to tie the eommunity together. Such work would provide a basis for real judgment on the part of every intelligent resident of the neighborhood. One interest would be tied up with another. Applegrowing would not be distinct from wheat-growing, or church work from school work, or soil types from the ercamery business, or polities from home life. The vicinage would be presented to the citizen as a whole. Nothing, in my opinion, would do so much to develop pride of neighborhood, local patriotism, and community common sense as a full and complete knowledge of what the community is in its resources, its history, its folks, its industries, its institutions, and its tendencies.

When the survey idea is once understood and begun, every locality will desire to be represented. Certain regions will develop full surveys, and the reports will be standard; the surveys of intermediate localities may not need to be so elaborate or minute. 
When we fully understand our problem, we shall make our best surveys in eonseeutive order. We may elassify all phases of survey-work freely under three groups-physieal, eeonomic, soeial; and the order of the surveys should preferably follow this sequenee. We should first know what the region is-geography, physiography, elimate, resourees, soils; then what it does-the farming, the industries, the markets, the business, the profit-andloss; then how it lives-its people, its homes, its health, its institutions, its modes of expression, its outlook. I very mueh doubt the lasting value of surveys of ehureh or sehool or partieular erops or speeial produets that are not founded on a good knowledge of the physieal and eeonomie eonditions of the region.

\section{FIVE PRINCIPLES OF SURVEYS ${ }^{1}$}

\section{PAUL U. KELLOGG}

Finst of all, the survey takes its unit of work from the surveyor. It has to do with a subjeet matter, to be sure, but that subjeet matter is subordinated to the idea of a definite geographieal area. It is quite possible to earry on a study of tubereulosis, for example, as a pieee of physiologieal researeh, or as a pieee of soeiologieal researeh, wholly apart from where it oeeurs. But just as geological survey is not geology in general, but the geology of a given mountain range or water shed, so, even when a special subjeet matter is under study, the soeiologieal survey adds an element of loeality, of neighborhood or city, state or region, to what would otherwise pass under the general term of an investigation.

And when the subjeet matter is not speeialized, but eoncerns the more intangible "needs" of a eommunity, the survey beeomes neessarily different things in different loealities. It eamnot be thought out at a far-away desk. It is responsive to loeal eonditions; in a worn-out eountry distriet, suffering from what Professor Ross ealls "folk-depletion," its eontent has little in eommon with that of a survey in a textile eenter, tense with human aetivity, and dominated by its terms of work.

1 Adapted from "The Spread of the Survey Idea," Proceedings Acad. of Political Science, Vol. 2, No. 4, Tuly, 1912. Columbia Univ., N. Y. 
In the seeond plaee, the survey takes from the physieian his art of applying to the problems at hand standards and experienee worked out elsewhere. To illustrate, if your pure seientist were studying the housing situation in a given town, he would start out perhaps without any hypotheses, tabulate every salient faet as to every house, cast up long eolumns of figures, and make eareful deduetions, whieh might and might not be worth the paper they were written on. Your housing reformer and your surveyor ought to know at the start what good ventilation is, and what eellar dwellings are. These things have been studied elsewhere, just as the medieal profession has been studying hearts and lungs until they know the signals which tall whether a man's organs are working right or not, and what to look for in making a diagnosis.

In the third plaee, the survey takes from the engineer his working eoneeption of the struetural relation of things. There is a building element in surveys. When we look at a house, we know that earpenters have had a good deal to do with it, and it is possible to investigate just what the earpenters have done; also the brieklayers, the steam-fitters and the rest of the building trades. But your engineer, like your general eontractor and arehiteet, has to do with the work of each of these erafts in its relation to the work of every other. So it is with a survey, whether it deals with the major elements entering into a given eommunity which has struetural parts of a given master problem such as Dr. Palmer deseribes in his survey of the sanitary eonditions in Springfield. Only reeently I reeeived a letter from a man engaged in making a general soeial survey of a manufaeturing town-a so-ealled survey. He did not think that it was truly a survey, nor did I, beeause out of the seope of that investigation had been left all of the labor eonditions in the mills. The loeal eommittee lad been fearful of raising opposition in foreeful quarters. Yet these labor eonditions were basie in the town's life; on them, for better or worse, hung mueh of the eommunity welfare; and by ignoring them, the eommittee eould deal with partial solutions only. It was as if a diagnostieian in making his examination had left a patient's stomaeh out of eonsideration beeause the patient was a dyspeptie and irritable. They had violated the struetural integrity of their survey. 
In the fourth place, the survey takes from the charity-organization movement its ease-work method of bringing problems down to human terms. Death rates exemplify human units in the barest essentials; but I have in mind a more developed unit. Let me illustrate from the Pittsburgh Survey in the painstaking figures we gathered of the household eost of sicknesslost wages, doctor's bills, medieines, iee, hospitals, funerals, the aftermath of an epidemic in lowered vitality and lowered earnings, household by houschold-not in sweeping generalizations but in what Mr. Woods ealled "piled-up aetualities." If I werc to set one touchstone, more than another, to differentiatc the true survey from soeial prospeeting, it would be this ease-work method. In employing it the surveyor, because of lack of means and time, must often deal with samples rather than with the whole population eoming within the scope of his study. These samples may be groups of school children; or the people who die in a certain year; or those who live in a certain ward. The method is one, of eourse, which is scientifically justifiable only so long as those who employ it can defend thcir ehoice of the sample chosen, and show where it does and does not represent the entire group.

Under this head it is to be noted that the survey is in a field friendly to what we have eome to eall municipal researeh. The latter is indebted for its methods of unit-eosts and effieieney to the aecountants. These methods may be applied to eity budgets and city departments as an integral part of a soeial survey, the distinction between the two movements in praetice being perhaps that the one is focused primarily on governmental operations; the other on phenomena imbedded in the eommon life of the people.

In the fifth plaec, the survey takes from the journalist the idea of graphie portrayal, which begins with such familiar tools of the surveyor as maps and charts and diagrams, and reaehes far through a seale in whieh photographs and enlargements, drawings, easts and three-dimension exhibits exploit all that the psychologists have to tell us of the advantages which the eye holds over the car as a means for communication. With these the survey links a sturdy effort to make its findings have less in eommon with the boredom of offieial reports than with the more engaging qualities of newspaper "eopy"- espeeially that 
simplicity of structure, tangible framework, and readability whieh American magazine men have developed as their technique in writing for a democracy. This is not a counsel, bear in mind, of flimsy scnsationalism; although those who have matters to coneeal seek to eonfuse the two. A startling artiele patelied up from a few glints of fact is a very different proposition from a erystal sct in a matrix of tested information.

Underlying this factor of graphie portrayal is the factor of tmith; truth plus publieity. It is often possible to work out large and definite reforms internally, by getting a group of forceful men around a table and convineing them that so and so is the right thing to do. This is, I take it, a legitimate method of philanthropie work and of social reform. But it is not the method of a survey. The survey's method is one of publieity; it is another and separate implement for soeial advance, and its usefulness should not be negatived by a failure to hold to its distinetive function. The philosophy of the survey is to set forth before the eommunity all the faets that bear on a problem, and to rely upon the eommon understanding, the common foretlought, the eommon purpose of all the people as the first great resouree to be drawn upon in working that problem out. Thus eoneeived, the survey becomes a distinctive and powerful implement of democraey.

\section{A METHOD OF MAKING A SOCTAL SURVEY OF A RURAL COMMUNITY ${ }^{1}$}

C. J. GALPIN

AN ANALYSIS OF A RURAL COMMUNITY-

What Is a Rural Community? There are three fundamental types of assoeiation in well developed country life: homes, neighborhoods, communities. A neighborhood is a eollection of homes having one or two important eommon interests sueh as a distriet school, or a mill, or an open-country ehurel. The neighborhood may be a number of homes somewhat near together

1 Adapted from Circular 29, the University of Wisconsin Agricultural Experiment Station, Madison. 
all belonging to the same foreign race, such as a German settlement. A specially genial hospitality in one prominent home may kindle the spirit of neighborliness in homes nearby and give name to the neighborhood, such as the Brown neighborhood.

A community, on the other hand, is made up of all the homes which try to meet, in connection with each other at a common center, the fundamental common needs, such as food, elothing, implements, moncy, high sehool education, religious instruction, amusement, fraternal organization. The center of the community is usually a village ranging in population from 300 to 3,000 people and it serves a community area ranging from 16 to 100 square miles.

The people living in the village, on the whole, are engaged in business mainly to supply the needs of the outlying farm homes of that eommunity. The village center is the pantry, safe, shop, medicine ehest, play-house, altar, of the community at large. The village homes in thus serving the seattered homes of the rural population as social agents of trade, education, health, amusement, ctc., are distinetly a part of the country community itself.

Important Social Agencies. In every rural community will be found from ten to forty different organizations, such as schools, churches, library, Sunday Schools, lodges, study clubs, breeders' association, band, bascball teams, and the like. These are the important social ageucies of community life. $\Lambda$ club or society or other organization is a social machine which brings the power of a number of people to bear all at onec on an important common interest, and brings results to the people concerned which no one of them could get by acting alone. A list of the permanent organizations found in a community will show what large interests are considered important there, and will also show just how far this community has been suceessful in applying the associative principle to its eommon life.

A Community Photograph. A social survey is an attempt to photograph, so to speak, the community so as to show every home in all its social connections with all other homes in the eommunity. A glance at this soeialized community photograph will reveal the lines of strong, healthy socialization and at the same 
time disclose the spots and lines of fecble assoeiation. An intelligent social planning for the community can be based on the social facts thus discovered.

\section{HOW TO TAKE THE SOCIAL SURVEY}

Determine the Community Boundary. The first step in making the survey is to locate your rural community and draw the boundary lines. Begin at the village center and go west into the open country. The first farm home gocs to this village for trade, doctor, high school, ehureh, etc. It thercfore belongs to this community. So the second home west, the third, fourtl, ete. Finally you come to a home that turns the other way to another village for its principal needs. This home does not belong to your eommunity. Conneet with a line all the most distant homes in each direction, that you find turning to the activities in your village center. This line will be tlic boundary of your community.

Take a Home Census. The next step is the taking of a eensus of every farm home and village home within the boundary line. Use the "Rural Home Census" blanks furnished by the College of Agrieulture of the University of Wisconsin. Every home should be visited for this purpose by some eareful person. The information will be gladly given by some one in the home. Every faet asked for is practieally a matter of publie knowledge and a source of some pride. Inelude every ehild in the home and every hired man and hired woman and any other person permanently residing in the home. The value of the census will depend upon getting every home, getting the faets accurately, and putting these facts plainly and earefully in their right places on the eensus sheet.

Take an Organization Census. The third step is a census of every organization in the community. Use the eensus sheet furnished by the College of Agrieulture of the University of Wisconsin, one sheet for eaeh organization. Inelude every district school, every other school, every chureh, Sunday school, every soeiety in the ehurch which holds separate meetings, suel as Brotherhoods, Young People's Soeieties, Ladies' Aid Societies, Mission Societies; include every fraternal order, lodge, elub or association of any sort, sueh as a band, singing elub, 


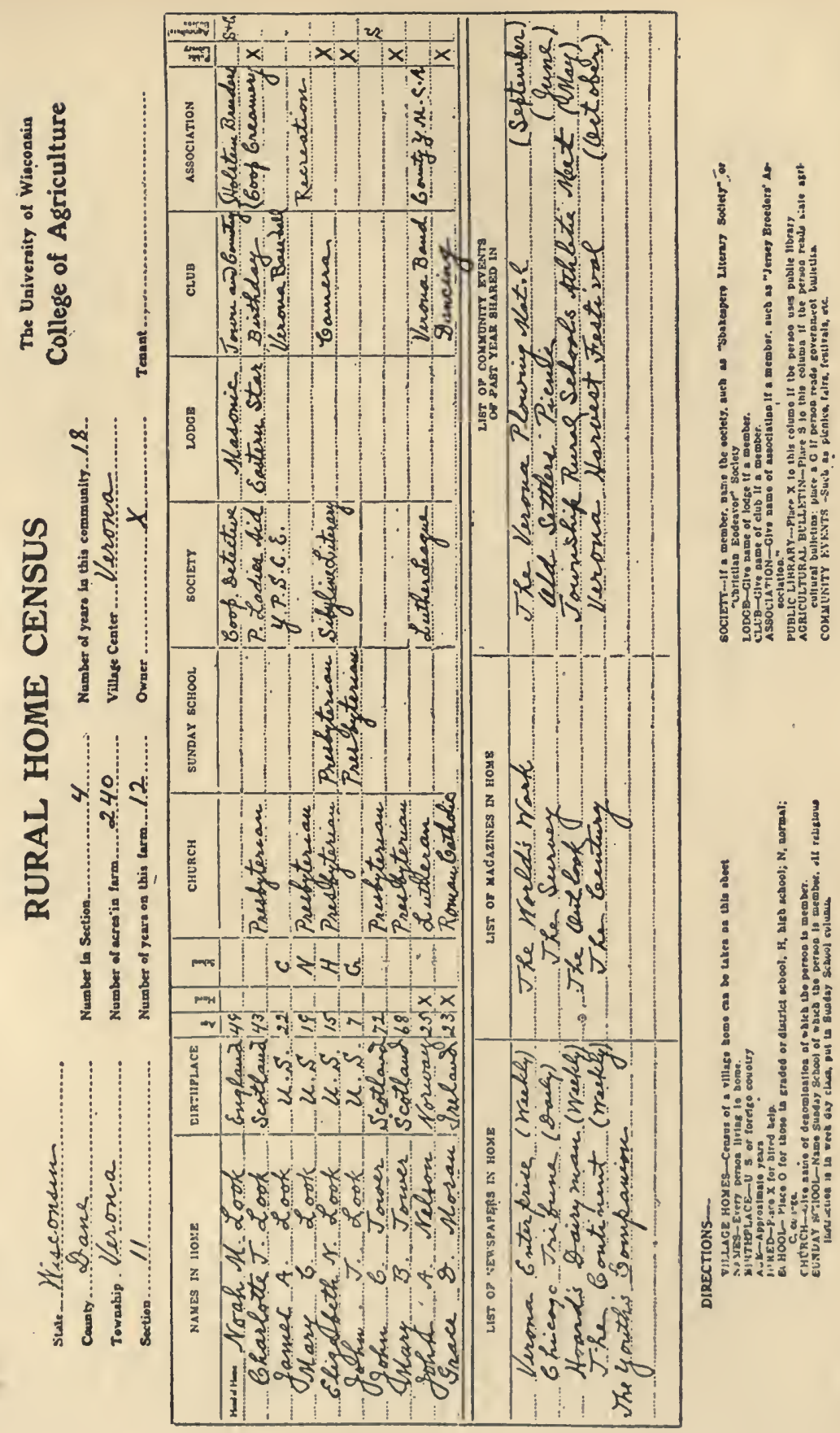




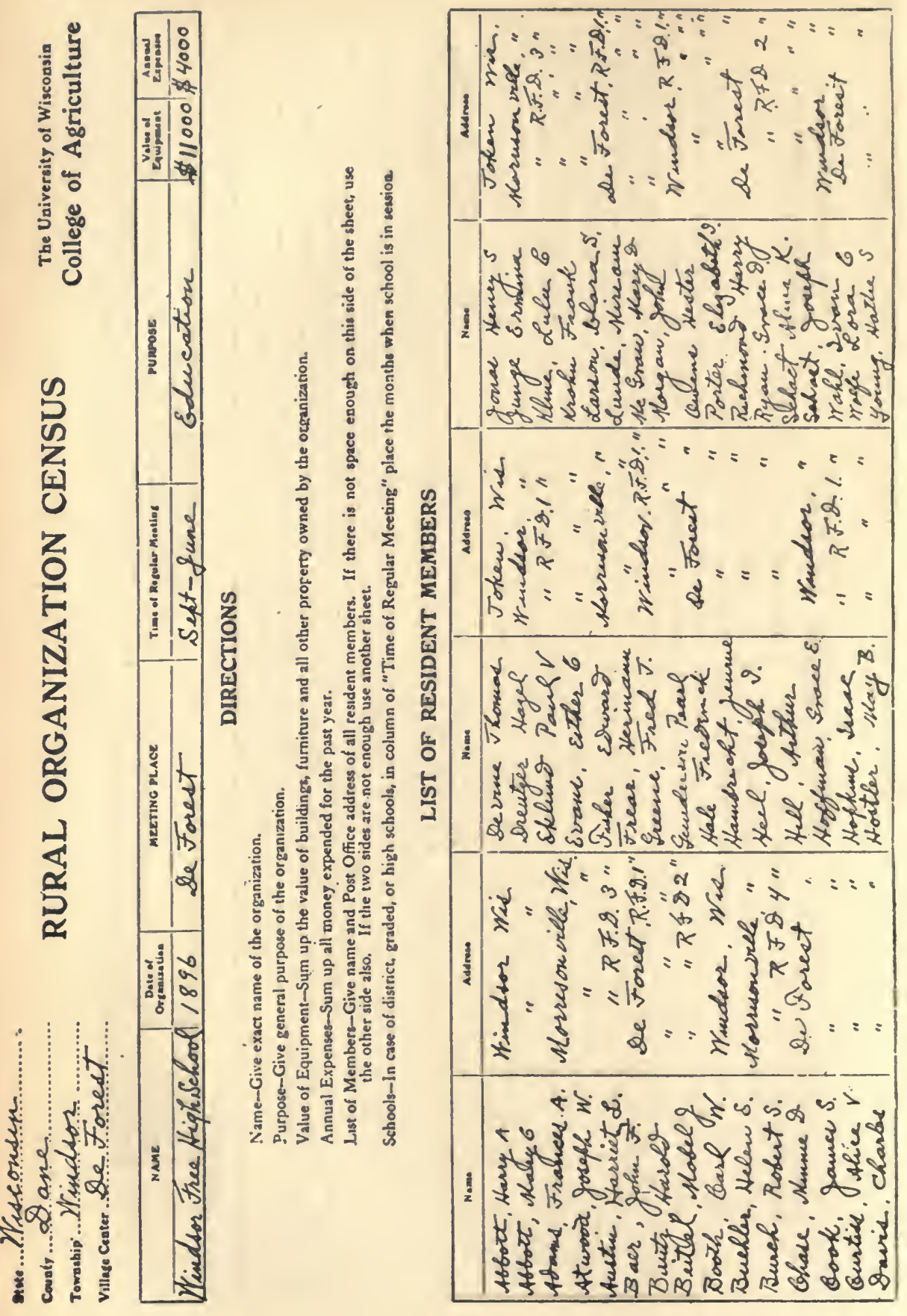


amusement elub, base ball club. Omit no group of people that have a name and regular meetings more or less frequent. Do not fail to get the list of resident members. Value here will depend upon accuracy. A courteous request to the seeretary of each organization will undoubtedly be responded to with all the facts desired.

Make Community Maps. The information obtained by the home census, while valuable in itself, ean be made far more useful by a system of community maps. Draw a map of your eommunity on white eard board or eloth-backed paper about forty inches by thirty-six. Put in all the roads and the village eenter limits. Loeate every farm home on this map by a round black dot a quarter of an inch in diameter. Nake a separate map of the village, locating all homes by the black dot.

Total Socialization Map. Make a list of all organizations in the eommunity as found by the organization eensus. Give a different eolor to each organization. Then make little round seals one quarter of an ineh in diameter out of colored papers of these same colors. Take one farm home eensus sheet at a time, and see what organizations are represented in this home. Stick one seal to the edge of the black dot locating the home, to represent connection with an organization which has one or more members in this home-only one seal, however many the members. Then to the outer edge of this seal stiek one more seal representing the next organization found in the home, and so on, until you have a line of seals of different eolors on the map, which shows at a glanee exactly what organizations have membership in this home. Treat each farm home in the same way, and the result will be a eommunity map showing the total soeial eonnections of all the farm homes. Proeed in the same way with the village map, and the two maps side by side will show the total soeial relations of all homes in the eommunity.

A Tenant and Owner Map. On another map containing all the farm homes, you ean attach seals of one eolor for tenants and seals of another eolor for owners oceupying the farm. This will show at a glanee the situation of the teuant problem.

School Mups. An interesting map ean be made showing all the homes having some elildren of graded sehool age not in sehool along with those homes where such ehildren are all in 
school. In the same manuer a map can be made showing the extent to which tlie homes make use of the high school.

A Sunday School Map. A map can be made showing homes containing children going to school but not to Sunday school, along with those containing children all going to Sunday school.

Possible Maps.

A Newspaper Map.

A Magazine Map.

Community Events Map.

Library Map.

Homes With and Without Children.

Foreign Born Map.

Hired Help Map.

Combination Maps. Perlaps the most valuable kind of map is made by the combination of one set of facts about each home with another set of facts. For cxamplc, a certain colored seal may be given to residence of a home in the community for a period of at least five years. Give a colored seal to church membership (wliatever the particular denomination). Then combine in one map these two seals. The result will show whether churches have been making their normal appeal to the more recent comers into the community. A score or more of such important combination maps are possible.

Make an Organization Chart. An interesting and instructive comparative table can be made of all the different organizations in your community. Follow the divisions called for in the organization census sheet, including value of equipment and annual expenses, putting total number of members in place of actual list of members.

Results to be Expected from a Social Survey. What is the use of such a social survey? This is the first reflective question every one will ask, and rightly so. In the first place, it is plain that a social survey is nothing but an inventory of the important social activities of the community, so displayed that everybody can see just low far every home is participating in the social life of the community.

The first thing disclosed will be the socially isolated homes 
neglected, overlooked, or indifferent. This disclosure will be useful to every organization and to every citizen seeking to increase social acquaintance and interest in the community enterprises.

The next thing will be questions of all sorts on the part of everybody, such as, "Why are so few tenants in our organizations?" "Why are there no women south of the river in the Women's Club?" "Why is the library not used by the people in the northeast corner of the community?" "Why are there so few children of high school age actually in the high school?" These questions are vital blows upon hard problems, and are bound to erack open solutions.

Perhaps the most important value of the inventory will be the necessity of looking over all the social connections of all the homes from the point of view of the whole community. These maps are community photographs, and no one can go away from a study of the whole community in its many aspects without having his views modified and enlarged.

There at once emerges this great question, "How does the social situation as revealed by the survey of all associated activities affect the whole community; and what shall we do to change this situation so as to get results in each association better adapted to promote the interests of the entire community?"

With the organization chart before us, a very pertinent question to be asked each organization is this: "We see your purpose, size, property, annual budget, now what are you doing, over and above work for your special group of pcople, for this whole community whose prosperity sustains and floats your enterprise?" A good answer to this question is due from each organization.

Further questions will surely arise: "How can all these inportant social machines in the community unite their forees more closely in promoting the legitimate social interests and in meeting the various social needs of the whole community?" "Can a united social front be presented on oceasions?"

It may become plain from the survey that some important interest of the community has 110 "social machine" at work in its behalf. Here then will be a chanee to balance up the as- 
sociated forees by introdueing a new foree in behalf of a more symmetrical and wholesome country life.

It is sufficient justification for a community's taking a survey and inventory of its social forees and assets, if the survey is ealeulated to prompt these quickening questions and lead to a readjustment of its social structure so as to produce a balanced social life that will fit the whole community and meet its larger needs.

Who Shall Take the Survey? Any group of communityminded persons in the community can undertake this interesting problem. One person should be general head and director. A staff of five or ten careful, tactful people to take the home census and organization census will be sufficient.

\section{THE SOCIAL ANATOMY OF AN AGRICULTURAL COMMUNITY}

\section{J. GALPIN}

A NEW rural and urban point of view has grown out of the attempt to answer satisfactorily the following series of questions : Is there such a thing as a rural community? If so, what are its characteristics? Can the farm population as a class be considered a community? Or can you cut out of the open country any piece, large or small, square, triangular, or irregular in shape and treat the farm families in this section as a community and plan institutions for them? Would the eightyfive farm homes in a Norwegian settlement, bound together by one church organization, form a community? Has each. farm a community of its own differing from that of every otlier? What is the social nature of the ordinary country school district? What sort of a social unit is the agricultural township?

Is it possible that the farms are related to the village clusters in such an intimate way that in any serious treatment of

1 Adapted from Rural Life, pp. 70-87, Century Co., 1918, and Research Bulletin No. 34, May. 1915, Agricultural Experiment Station of the University of Wisconsin, Madison. 
the one the other must be taken into aeeount? May there not be an important soeial anatomy here, which needs eareful traeing as a factor in any rural social reform? Have we assumed hitherto that the interrelations of farm and village or small agrieultural eity are all on the surfaee and easily read? Would it not be well, before imposing a redireeted eivilization upon the eountry man, to examine more minutely the larger movements of his ordinary life?

A reeent investigation and study of the rural population in a single county of the Middle West,-Walworth County, Wiseonsin,- a study eovering a period of two years, was prompted by the desire to answer satisfactorily the foregoing. series of insistent questions.

\section{THE METHOD}

Large Worling Maps of the County.-A reent atlas of Walworth County was taken to piees, the township maps on a seale of two inehes to the mile were assembled in order, thumbtaeked on a large board, and reprodueed on traeing eloth. From this, blue prints were made on eloth, freely used and eut into field maps as required for surveys. The county is twenty-four miles square.

Assistants Resident in Each Village.-A visit was made to each of the twelve villages and eities of the eounty, and an assistant seleeted to aid in taking the survey. Teaehers, highsehool prineipals, elergymen, bankers, and librarians finally eomposed the staff of helpers.

Getting a Land Basis Map. - Each village or eity was to be the eenter of information and the problem in general was how far out anong the farm lomes the village served any soeial purpose. From the point of view of the village, the problem was one of getting at the land area of village influence; from the point of view of the eountryman, it was learning what farms were eonneeted with the same village.

A visit by the survey-maker to the leading dry goods merehant with a print of the eounty map spread before him, got an answer to this question: "Whieh are the farm homes, north, south, east, and west, that come farthest to trade in your village?", 'The result would be a tentative rough trade 
line drawn about the village. Next the banker would indicate the long-distance farmers eoming to the village to bank. A visit for eonfirmation would be made at the village milk factory, grocery stores, and the like. Then a local map was cut out of the county map one mile wider and longer than the trial limits set. This became the working map for the area having the village as eenter.

Gathering the Facts.-The first requircment was the name of the farmer residing on each farm represented on the map. In some cases this meant the gathering of 600 names. Usually the banker, real estate man, livery man, and physieian in the village could give the bulk of the names. The telephone helped with the remainder. The result was a eard catalogue of all farm homes on the map, typewritten on the schedule blanks, one blank to each farm home. Each farm home was located on the schedule by township, section, and number in the seetion, to correspond with the spot on the map locating the home. With this package of names and the map as a guide in case of doubt as to the man, the survey-maker visited the leading dry goods merehants and got an hour to go through the list, and ask the question, "Does John Doe buy dry goods regularly in this village?" If he does, a cross is put to his aecount in the blank opposite "dry goods."

In like manner, a visit is made to each grocery, bank, milk faetory, village paper, village clergyman, high-sehool principal, library; and from the records as matters of faet, and not of opinion, it is indieated on the blanks which homes are connected with the village institutions. In ease of the high-sehool, the question was, "Has any one in John Doe's family attended the high-school during the last three years?" In case of the paper, "Does John Doe take your paper?" In ease of the church, "Is any one in the family of John Doe connected with your church?"

Making the Final Maps of the County.-The trade map was made first by merging the dry goods and groeery maps whieh nearly coincided. A large piece of eorrugated paper board was placed under a eopy of the county base map. Each farm home trading at Elkhorn, for example, was marked and then a pin stuck in the spot. A thread was run around the outside 
of these pins, following from pin to pin so as to include the least amount of territory while enclosing every pin. This thread line beeame the boundary of the trade zone. After the trade zone of each of the twelve centers was marked out in this way, the eommon territory where zones overlap, with homes trading at more than one village was colored alike and ealled neutral ground. Each eommunity was given its own color. Then round, white seals were used to designate the homes that were found to use the same trade eenter. In like manner eaeh set of maps was made in water colors.

Trade Zones.-Surrounding each village or eity center is an area or zone of land including farm homes that trade regularly at the center. This zone is irregular in shape, due to such faetors as irregular roads, lakes, marshes, and varying distanees of the trade eenters from one another. No village or eity is found in the county without its farm trade zone, and within this zone the number of farm homes elosely approximates the number of homes at the eenter. Aceessibility seems to be the largest factor in determining the regular trade eenter for any farm home.

The trade areas of adjacent eenters have a tendeney to overlap a little, producing a belt from one to two miles in width, of neutral or eommon trading territory. Farmers living about half-way between eenters have a double, or in some eases, triple trading opportunity.

These trade zone lines run, moreover, without regard to the politieal lines of the towuship, county, and state.

The farm homes in the same trade zone use the four, five, or six main roads leading to the village eenter more frequently than any other extended network of highways.

These families, obviously, have at least a passing aequaintanee with one another. At the village they meet casually, at least, with farm families from the whole zone. This trade zone acquaintanee at the village eenter is probably wider for each farm home than any other area of its farm aequaintanee.

The trade zones of a eounty are subjeet to extension and shrinkage with the growth of village centers in number, size and effieieney. A partieularly aggressive business spirit in any center, shown by advertising, effieient methods of buying 
and selling, may enlarge the boundaries of the zone somewhat or at least widen the nentral belt. The farm homes in neutral territory, which are so situated that they may go to more than one trade eenter, hold a position of decided advantage in detcrmining trade polieies of merehants in two or more eompeting small eities.

The village or eity homes and the farm homes in the same trade zonc have a common interest in the same trade agents to a eertain-degrce, pcrhaps partieularly the groeer, drygoods merchant, or clothing merehant. Even in cases where these lines are speeialized for farm trade or village trade, it it found that the village homes will be patrons of the "farmers' store," and the farm homes patrons of the "eity store."

Banking Zones.-As the trade zone, so a banking zone of farm homes surrounds each village or eity having a bank. The size of the banking zone compares favorably with the size of the trade zone, and ignores township, county, and state lines; has a belt of neutral or eommon territory; and reaehes about half way to the adjaeent banking centers. The banks are used all but universally by the farmers, and apparently the bank aets in the same eapaeity for the distant farmer as for villager or eity dweller living within the same banking zone.

As in the trade zones, farm homes in the samc banking zone use frequently the same roads, are under the operation of the same faetors of effieieney and integrity in bank management; village homes and farm homes in the village bank zone have an identieal interest in bank control and policy; farmers in the neutral belt oeeupy positions of special power.

Local Newspaper Zones.-Apparently a local newspaper is a necessity in a eomplete eivie center. The paper zone eonforms closely in shape to the trading and banking zones, and shows that more than half the farm families are subseribers to this agency of loeal aequaintanee and information. Evidently the village editor and his paper serve the same purpose on the land as among the clustered roofs.

Village Milk Zones.-The milk industry is organized in the 
county very generally upon the neighborhood scale, with small creameries and skimming stations seattered through the open country. However, at each of the twelve civic centers is a creamery or condensery run on a scale exceeding that of the open country factory. These milk zones, while following the general lines of the trading zone, are naturally much smaller. Only a little neutral territory exists, and this is due to seasonal shifting.

A rapid concentration of the milk industry into these village factories, condenseries, and shipping plants is at present a marked tendency. A few years may bring into this county the auto-truck milk gatherer for each of the large village factories-an agency already used in some parts of Wisconsin. These milk institutions at the civic centers, in cases operated and largely owned by outside companies, are industrial plants of a character especially blending the interest of the villager with that of the farmer. Not only the few main roads leading into the center become of critical interest, but every road in the possible milk zone takes on a new social value-an interest which is likely to overshadow the local road district interest or even the township road interest.

Village Church Zones.-In the open country are many suall churches of the neighborhood and race settlement type. Every hamlet has at least one cliurch. Nevertheless the village churches are fairly democratic, and are attended by farm families going distanees of five and six miles. It seems to be the policy of the Roman Catholic church in this county to locate its clurches in the villages and cities, a fact which makes several of the village church zones of considerable size, almost equal to the respective trading zones.

There are a few abandoned open country churches along the roadsides; but the neighborhood country churches are usually in more or less active operation. In some of the religions bodies it is the prevailing practice for the village minister to serve also one or two open-country charges, a custom which forms one more link between village and country in the same general trade zone.

At certain of the incomplete civic centers, with small population and only partial trading facilities, there is a single 
church, usually of some one denomination, but generally considered as a "community church." A resident minister is in charge, and a vigorous social life is in progress. The favoring circumstance for this aggressive activity seems to be the blend of farm and hamlet coöpcration in a single church parisll.

IIigh-School Zones.-Practically every farm home in the county is easily within daily reach of some high-school. Taking the county as a whole, less than fifteen per cent. of the farm homes are sending cliildren to high-schools.

The high-school zones are not only much smaller than the trade or banking zones, but the proportion of farm lomes within the zones using the high-school is much smaller than that using the shop or bank. It will be noticed that the form of this zone follows the general lines of the trade zone. Instead of an over-lapping of zone lines giving a belt of neutral territory, there appears surrounding every zone a belt of homes outside the influence of any high-school.

With all the general deficiency apparent in the amount of farm use of these nine high-schools, it is plain that a fair percentage of the farm families within two miles of each high-school recognizes its value. The character of the high-school as an agent in idea-forming and association-making, plays a wonderful part at the adolescent period of life, in democratizing the children of the farm who attend and the children of the village. It would be difficult to overestimate its influence as a force for constructive coöperation, were each high-school consciously controlled in adaptation of subjects and management of courses in the interest of those living upon the land as well as of those living in the small city.

Village Library Zones.-Four fine examples of the institutional library are in the county. The privilege of free usc is open to farm families, and a certain considerable number of farm homes, in fact, thirty-one per cent. of all farm lomes within the library zones, avail themselves of this privilege. A wider farm use of the high-school would doubtless lead to a wider use of the library.

The School Districts.-A study of the country school districts of the county shows the fact that the prevailing scale of organized farm life is that of the neighborhood. The school house, 
an open country chureh, and a ereamery may frequently be found together, among fifteen to thirty families, in a territory of from three to five square miles. A slight tendeney to eonsolidate adjoining school districts exists, but it is only slight. There seems to be a greater tendency to enlarge the village or city distriets by addition of farms.

The Actual but Unofficial Community.-Eight of the twelve civie eenters of Walworth County are ineorporated; four as eities and four as villages. Officially, that is legally, the incorporated eenters are treated as communities, each by and for itself. The foregoing analysis of the use of the leading institutions of each eenter by the farm population discloses the fact, however, that these institutions are ageneies of social serviee over a comparatively determinable and fixed area of land surrounding each center; that this social service is precisely the same in character as is rendered to those peoplewhether artisans, employees, or professional persons-who happen to live within the corporate limits of the eity or village; noreover the plain inferenee is that the inhabitants of the center are more vitally coneerned in reality with the developinent and upkeep of their particular farm land basis than with any other equal area of land in the state.

It is difficult, if not impossible, to avoid the conclusion that the trade zone about one of these rather complete agrieultural civic centers forms the boundary of an actual, if not legal, community, within whieh the apparent entanglement of human life is resolved into a fairly unitary system of interrelatedness. The fundamental community is a composite of many expanding and eontracting feature eommunities possessing the eharacteristic pulsating instability of all real life.

\section{BiBLIOGR.IPHY}

\section{SURVEYS}

Aronovici, Carol. Knowing One's Own Community. Bulletin No. 20, Social Service Series, Dept. of Social and Public Service, American Unitarian Association, Boston, 11. d.

Bailey, L. H. The Survey Idea in Country Life Work. In his York State Rural Problems, Vol. I, Lyon, Allbany, 1913.

Bailey, WTm. B. Modern Social Conditions. Century, X. Y., 1906.

Boardinan, John R. The Rural Social Survey, N. Y., 1914. 
Brinton, IV. C. Graphic Metlods for Presenting Facts. The Fingineering Mag. Co., N. Y., 1914.

Brittain, H. I. Report of the Olio State School Survey Commission. Published by State of Olino, Columbus, 1914.

Carroll, C. E. The Community Survey in Relation to Church Effciency. Abingdon Press, N. Y., 1915.

Eastman, E. Fred. 'The Minister's L'se of the Survey. Men and Religion Messages,-Rural Church, VI:166-177, Association Press, N. Y., 1912.

Elmer, Manuel C. Technirpue of Social Surveys. World Company, Lawrence, Kansas, 1917.

Galpin, C. J. A Methor of Making a Social Survey of a Rural Community. Agrieultural Experiment Station, Univ. of Wiseonsin, Circular 2!), Madison, 1912.

The Social Anatomy of an $\Lambda$ gricultural Community, Research Bulletin, 34, Agricultural Experiment Station, Univ. of Wisconsin, Madison, 1915.

Galpin, C. J., and Davies, G. IV. Social Surveys of Rural School Districts, W'luat they are and how they are made. Agrieultural Experiment Station, Univ. of Wiseonsin, Cireular 51, Madison, 1914.

Gill, Charles O., and Pinchot, Gifford. The Country Church. Maemillan, N. Y., 1913.

Gillette, J. M. Rural Social Surveys. In Constructive Rural Soeiology, pp. 281-292, Sturgis, N. Y., 1915.

Gillin, J. L. Applieation of the Social Survey to Small Communities. Amer. Journal of Sociology, 17:647-8, Nov., 1911.

Haney, L. H., and Wehrwein, G. S. A Social and Economic Survey of Southern Travis County, Texas. Univ. of Texas, Bul. No.65, A ustin, 1916.

Hart, Joseph K. Educational Resourees of Village and Rural Communities. Macmillan, N. Y., 1913.

Jolnson, O. M., and Dadesma, A. J. An Agricultural Survey of Brooks County, West Va. Experiment Station Bul. No. 153, Morgantown, 1915.

King, WV. I. Elements of Statistical Method. Macmillan, N. Y., 1912.

Kirkpatriek, E. A. Fundamentals of Sociology, pp. 215-276. Houghton, Boston, 1916.

Mayo-Sinitl, Richmond. Seienee of Statisties. 2 vols. Macmillan, N. Y., 1899.

MeClenalıan, Bessie. The Sucial Survey. Univ. of Iowa, Extension Bul. No. 26, Iowa City, 1916.

Richmond, Mary E. Social Diagnosis. Russell Sage Foundation, N. Y., 1917 .

- Seerist, Horace. An Introduction to Statistical Methods. Macmillan, N. Y., 1!)17.

Sims, N. I. A Hoosier Village-A Sociological Study with Special Referenee to Social Cansation. Columbia Univ. Studies, Vol. 46, No. 4.

Taft, Anna B. Community Study for Country Districts. Presbyterian Dept. for Missionary Education, N. Y., 1912. 
Taylor, Carl C. The Social Survey, Its History and Methods. Univ. of Mo. Bul., Vol. 20, No. 28, Social Science Series 3, Oct., 1919.

Thompson, C. W. Rural Surveys. Pub. Am. Sociological Soc., $11: 129-134,1916$.

Thompson, C. W', and Warber, G. P. Social and Economic Survey of a Rural Township in Southem Minnesota. Univ. of Minnesota, Studies in Economics, No. 1, Minneapolis, 1913.

Von Tungeln, Geo. H., Brindley and Hawthorne. A Rural Social Survey of Orange Township, Black Hawk Co., Iowa. Bul. No. 184, Ag. Ex. Station, Towa State College of Agriculture, Ames, Iowa, Dec., 1918.

The Results of Some Rural Social Surveys in Iowa. Pub. Am. Sociological Soc., $11: 134-163,1916$.

Warren, G. F., and others. An Agricultural Survey-Townships of Ithaca, Dryden, Danby, and Lansing, Tompkins County, N. Y. Bull. 295, Cornell Univ., Agricultural Experiment Station, Itlaca, N. Y., 1911.

Weld, L. D. H. Social and Economic Survey of a Community in the Red River Valley. Univ. of Minnesota, Current Problems, No. 4, Minneapolis, 1915.

Wells, George Frederick. A Social Survey for Rural Communities. N. Y., 1911.

Wilson, Warren H. Surveys Mare by the Presbyterian Board of Home Missions, Dept. of Cliurch and Country Life, N. Y.

Wilson, Warren H., and others. Rural Survey of Lane Cotnty, Oregon, Board of Home Missions, Presbyterian Chureh, N. Y., 1916. 


\title{
CHAPTER XVIII \\ THE ORGANIZATION OF RURAL INTERESTS
}

\author{
A. RURAL ORGANIZATION \\ RURAL ORGANIZATION ${ }^{1}$
}

K. L. BUTTERFIELD

\section{The Problems of Rural Improvement}

1. In methods of controlling the necessary forces and materials of production.

2. In farm practice, or in the production of crops and animals.

3. In methods of farm management and farm business.

4. In methods of farm organization.

5. In farm life.

\section{SOME NECESSARY ADJUSTMENTS}

1. Among the farmers themselves.

2. Between the interests of farmers and others.

I. THE PROBLEM OF THE BFTTER CONTROL OF THE NECESSARY FORCES AND MATERIALS FOR PRODUCTION

1. The Control of the Land Itself.-Land ownership gives the most complete-control. The retired farmer has less control than the owner who works his own farm. The absentee landlord has only a minimum of actual control. Land may be owned by the state and leased to the men who work it. We must learn very soon what on the whole is the best method of land control in order that both farmers and consumers may have the largest possible benefits.

2. Land Acquirement.-Farmers in America formerly got

1 Adapted from "The Farmer and the New Day," pp. 40-56, Macmillan, N. Y., 1919. 
their land from the government. This is no longer true to any large degree. It is eoming to be diffieult for the young farmer to aequire a farm. Only two solutions are apparent. One is for the govermment itself to purehase land and sell it to new owners individually or in eolonies with liberal eredit and easy payments; or for large groups to do the same thing, either as private eorporations for gain or eoöperative land soeieties.

3. Land Rental.-Rental under right eonditions may seeure very effeetive use of the land. Tenant farming does not tend as a rule toward building up permanent farm eommunity interests. Very short leases are disastrous both to farming and to eountry life. Permanent tenure ean be made satisfaetory only when the tenant is given a share in permanent improvements.

4. The Control of Capital.-Need for eapital in farming is rapidly inereasing beeause of inereased eost of land, need of land improvements by drainage, ete., larger need for maehinery and other equipment, higher eost of labor. The farmer needs both long term eredit and short term eredit, the one for land purehase and permanent improvements, and the other in order to take advantage of better terms in seeuring his supply of seeds, fertilizer, feeds. Mereantile or store eredit is very eostly in interest and should be abolished. One diffieulty in seeuring eredit for farmers is that the Ameriean farmer is as a rule unwilling to beeome a party to a plan whereby the farmers of a eommunity eolleetively beeome responsible for the debts of the individuals of the eommunity. Farmers have eolleetively enormous assets whieh ought to be made available for each worthy member of the partuership.

5. Control of the Labor Supply.-The farmer has to eompete now-a-days with industry for his labor, in the matter of wages, housing, hours. One of the biggest problems of the future lies in answering such questions as how to keep labor employed throughout the year; how to edueate the laborer so that he beeomes a skilled farmer; whether women in Ameriea will do more farm work than formerly; how to use boy labor without saerifiee of edueation; the relations of farmers to farm labor organizations; and how to eneourage the farm laborer to beeome eveutually a farm owner.

6. The Control of Materials and Power.-Commereial inter- 
ests lave served the farmer reasonably well in supplying seeds, fertilizer, stock feeds, machinery, but only to a small extent in supplying power. The government will probably have to intervene in establishing a democratic use of water power for the making of electricity. Farmers, however, will need to coöperate much more frecly than now in the purchase of power, as well as of their other supplies.

II. TIIE PROBLEM OF IMPROVENENT OF FARM PRACTICE, OR THE PRODUCTION OF CROPS AND ANIMALS

1. Improvement of the Soil.-This means securing greater depth of soil; more complete friability; more adequate control of water in the soil; proper adaptation of special erops to special soils; prevention of plant food waste and erosion; and in general, the question of permanent fertility.

2. The Improvement of Crops, by getting the greatest possible yiclds; improving the quality and food or feed value; securing disease and drouth resistant varicties.

3. The Improvement of Animals in sizc, quality, temperament, healthiness, etc.

III. IMPROVEMENTS IN FARM MANAGEMENT AND FARM BUSINESS

1. The Purchase of Supplies.-It is only by collective or cooperative purcliase of supplies and equipment that farmers ean get the best prices and terms. So long as the individual farmer buys his supplies at a disadvantage, he is economically handicapped.

2. Standardizing the Product.-The greatest single diffieulty which the individual farmer faces is due in part to the wide variety of crops grown in a given locality and to a great variation in quality. The remedy in gencral lies in inducing farm communities to produce fewer things, to produce those for which the region is particularly adopted, and then through coöpcration, to secure proper grading, careful and honest packing, and whercver feasible, proper labeling.

3. In the Transportation of Products. - Good roads and the motor truck will play a rapidly inereasing part in initial transportation. Rural trolleys will help to a growing extent. The main dependenee for standard crops is the railway system. One of the most important reforms is the adjustment of freight rates 
as between the long haul and the short haul in order that both the distant producer and the nearby farmer may have substantial justiee.

4. The Problem of Storage.-The purpose of storage is to keep such part of the product as is not immediately necessary, until it is needed by the eonsumer. The farmer believes, and probably with reason, that those who eontrol storage facilities exact unfair toll from the farmer. The diffieulty lies less in dishonesty than in the fact that the whole system is purely a profit-making affair. The storage system should be organized and eontrolled as primarily a method of relating supply and demand.

5. The Selling of Crops.-In case of fruits, vegetables, and poultry products, producer and eonsumer may be brought together face to face in publie or eommunity markets where they may make their bargain. For most crops, the middleman is indispensable. He should not be abolished but redireeted. We shall never have satisfaetory methods of marketing farm produets until we have a thoroughly organized group of producers, cach group with its special produet, dealing direetly with well organized groups of eonsumers, or with well organized groups of middlemen whose activities are regulated by the government in the interests of both producers and eonsumers.

6. The Farmer's Interest in Manufacture and Care.-The conservation and proeessing of farm products has gone largely into the hands of commercial eoneerns. The farmer, however, has a moral obligation to eliminatc all wastes on the farm itself. Community enterprises looking toward the manufaeture or preservation of certain products, both for use in the eommunity itself and as a business venture, will probably inerease. There is a vast waste in double transportation; for example, wheat is shipped one thousand miles for milling and the flour is brought back to the farm region where the wheat was grown.

7. Protection and Insurance.-The farmer wages a constant battle against inseet pests, diseases, of plants and animals, u1favorable natural eonditions such as weeds, flood, drouth, frost, wind, hail; firc. Widespread edueation, mutual insuranee and coöpcrative aetion secm to be the main solıtions. One of the biggest problems of protection is whether it is possible to insure the farmers to some extent against loss due to inadequate knowl- 
edge of market conditions, such as spoilage in food products, foreed sales of products due to lack of eredit, and market gluts.

8. The Reinvestment of Farm Profits is not as yet a burning question but it is not unimportant. Why ean not farmers utilize their surplus, when they have it, for the building up of the community in whieh they live?

\section{THE PROBLEM OF THE ORGANIZATION OF THE FARM}

1. The Farm and its Equipment.-It would be very helpful to lave a standardization of farms on the basis of the most eeonomie type and size of farm and the amount of eapital and equipment in stock and machinery nceded to operate the farm to best advantage

2. The Permanent Improvement of the Farm.-How can the farmer best secure a gradual improvement of his stock, complete a system of under drainage, provide economic but adequate and eonvenient buildings, and utilize labor-saving devices?

3. Bookkeeping and Accounting.-There is great need of adequate reeords and accounts simplified so that the average farmer ean follow the plan. There are really two problems, one that of accurate business aecounts and the other that of proper records which when interpreted will help the farmer to adjust his methods of management to the securing of greater eeonomies of time and labor.

4. The Use of Labor.-How may labor be secured at any price and how retained? One of the big questions is how to employ during the winter months farm labor needed only during the growing season, in order that labor may be satisfied and be available more eontinuously for the farmer.

\section{THE IMPROVEMENT OF FARM LIFE}

Means of Communication. It has been said that the problem of the city is congestion and the problem of the country isolation. In the city there are too many people to the square mile; in the eountry there are too few. Rural frec mail delivery, the rural telephone, the rural trolley, to a degree, and the automobile have quite changed the aspeet of eountry life. The problem is not yet solved, however, the greatest difficulty being 
that of getting and maintaining at reasonable expense a complete system of good highways, that reaches practically every farmer. The success of the consolidated school and of the community church, as well as economical transportation of farm products, hilges on this issue.

Home-making. The farm home is intimately attached to farm work. It must contribute to the profit of the farm, to the physical efficiency of the members of the family, to the most complete training of the children in character and citizenship, and make itself felt in the upbuilding of a satisfying community. The farmhouse should be convenient and beautiful within and without. It is possible to develop a system of home management that will reduce drudgery and encourage the life of the mind and the spirit.

Means of Education. We must make sure that the rural school gives the country boy and girl just as good an education for life either in country or in city as is given to the city boy and girl. Moreover, the country school should contribute more completely to the education of the adults of the community. Ideally, the people of the community will stay in school all through life. We must maintain a system of agricultural education, through schools and colleges and experiment stations and extension service and farm bureaus, that will reach effectively and practically the cntire farm population. We should devclop the habit of reading and study with a better system of rural public librarics. Continuation schools must be provided for the boys and girls who are no longer all the time in school, but who ought to keep up their schooling much longer than they do. And in general, we must stimulate the masses of farmers to closer study not only of their own problemis, but of the problems of the New Day.

Rural Government. How can we make local government more efficient, more honest? Probably we call do more for the people of the community through the local machinery of government. We already support schools and build roads. Can we not furnish other facilities of community life? Can we not make legislation, both in state and nation, more in keeping with the necds of rural improvement?

IIcalth and Sanitation. We need a large program of educa- 
tion for farm people, espeeially those in less prosperous regions, in the full meaning of personal lyygiene, the very best eare of the body, the very best dietaries, and in publie health, in order to stamp out epidemics, seeure eare of sewage, restrict the spread of eontagious diseases. In many ways these things are much more diffieult to handle in the country than in the eity.

Recreation. This is one of the great laeks of country life. We need a more adequate play life for the young and a thoroughly satisfying social life for the adults. We must bring into the eountry some of those legitimate opportunities for pleasure that people of the city have. Better than this, we would encourage the eountry people themselves in the making of their own recreation.

Country Planning. The roads, the buildings, the village parks, all of the material arrangements of the country, should be carefully planned.

Social Welfare. There is need in the eountry as well as in the eity for helpfulness to those not well eircumstaneed; the insane, the feeble-minded, the poor, the siek, the unfortunate. We ean organize better than we have thus far the spirit of helpfulness. It is not enough that we have the neighborly interest; we must also have the skilled aid.

Morals and Religion. How ean we maintain the lighest and finest ideals of personal eharaeter and of eommunity life? How can we make religion real in the work of the farm and in the living together of the people? How ean we assist the eountry ehurch, the Y. M. C. A., the Sunday Sehool, to be of the largest possible service in the country?

\section{SOME ECONOMIC ADJUSTMENTS}

We have outlined the problem of rural improvement in a most sketelyy way but we have not yet quite told the whole story. All that has gone before ealls for a eertain balaneing of interests. There are adjustments to be made from time to time. There are diverse interests that have to be reconeiled. We never can "solve" the farm problems as problems of arithmetic ean be solved. In our seareh for eonstant improvement, we find the eonstant need of establishing new relationships by the people, of developing new methods of doing business. What is right 
and fair at one time may not be right and fair at another time because of changing conditions. So let us consider for a moment some of these adjustments that the farmers must recognize.

\section{AD.JUSTMENTS AMONG THE FARMERS THEMSELVES}

We must sccure a sort of balanec between the interests of the individual and the interests of the farmers as a whole. This, of course, is a need everywhere in the world. It is not by any means true that if each individual is left to follow his own interests the interests of all will be gained. This is simply the "law of the jungle"; the strong win, the interests of the weak are over-ridden. Perhaps the greatest obstaele to agricultural business eoöperation in Ameriea is the faet that the most prosperous and efficient farmers in the eommunity do not see the need of pooling tlicir interests; they are not willing to sacrifice a little for the sake of those who would be greatly helped by eommon action.

Balance between Sub-Industrics. When a new opportunity in agrieulture shows itself, it may become so popular as to crowd out other forms of production which are fully as essential. Fruit growing in the irrigated districts of the West not only eneroached upon fruit growing in the East, but hindered the development of dairy and stoek farming to whieh the irrigated areas are peculiarly adapted.

Balance between Sectional Interests. One of the most serious of all rural questions is the competition of regions. The apple growers of New England with those of the Pacifie Northwest; the vegetable growers of Florida with those of Massachusetts; the sugar beet growers and the sugar cane growers; the farmers who grow cattle feed in the Middle West and the dairymen of the East who liave to buy these feeds. We find here constant need of establishing fair relationships.

Regional Self-Support. It is a law of eeonomies that the greatest cfficicney in production eomes when each region produees that whieh it can best grow, not neessarily that whieh it ean grow better than some otlier region. Waeh aere of land should be put to the best use for whieh it is fitted, considering soil, elimate, labor, and market.- Therefore it is neither practicable nor desirable that eaeh eountry, or each state, or cach 
county, or cach community, should grow all that it consumes. But we have gone so far in producing for the distant market that we have not only neglected the nearby market which is often poorly supplied, but we have incurred an enormous expense for transporting and handling products which go back and forth. We need to establish ecrtain zones or regions that up to a certain point can take care of themselves with reference to the growing of their food.

The Rural Village. There are perhaps ten million people in America living in villages that are set in a rural cnvironment. The pcople arc not farmers but they live in the midst of farmers. They are not eity people. Their very existence depends upon the sucecss of the farming regions round about, and yet there is often the slrarpest antagonism between people of the village and the people of the country. The farmers belicve that the village merchants exploit them at every opportunity. There is an odd notion among the merchants that in some way the farmers owe them a living. This antagonism shows itself in lack of social intercourse, in slrarp political fights. How can we restore the balance between the village, which includes the small "city" set in an agricultural region, and the farmers round about? Surely there is a way toward coöperation, a real community interest. Each can help the other.

Permanent Agriculture without Caste. We lrave a shifting agricultural population. There is scarcely any part of America which has not suffered from over-frequent migration to the eity or to other parts of the country. Ownership clranges frequently. This impermanence is not true everywherc, but it is characteristic of American agriculture. It cannot result in the best farming. It has not contributed to the best community life. Leadership is lost; yet we would not want everybody born in the country to stay in the country. The idea of kecping all the farm boys on the farm is the poorest policy we could follow. We cannot afford to arrange our rural education so that the boy is obliged to stay on the farm or go to the eity handicapped in his preparation for life. The door from country to city must swing wide. There must be freedom of intercourse between city and country. We must not have a peasantry - a rustic group. In no parts of our country must there be a possibility of farmers 
being looked down upon or being sharply distinguished from otlier elasses in any way that marks them off as a easte. How then may we adjust our modes of living, our edueation, our eountry life, our village-life, so that we shall seeure the advantages of permanent oeeupation of the land witlout the disadvantages of a caste system?

Some Special Problems. There is no doubt but the racial problems whieh have disturbed our eountry slow themselves in agrieulture. Speeial groups, sueh as the negro farmer, the mountaineer, able but isolated, the emigrant farmer, sturdy but foreign, must in some fashion be taken into tle eommon lot. Only so ean we have a real demoeraey. How are we to do it? There is a question of grades or strata of farmers. In almost any farm eommunity we find a group of very prosperous and sueeessful farmers, men who we say ean "take care of themselves." Near the other end of the seale we find the "submerged tenth," men not very effieient. At the extreme end we find the hundredth man-the abandoned farmer. Between these extremes, the great group of average farmers. So we have farmers small and farmers large; farmers wise and farmers foolish; farmers edueated and farmers illiterate; and we find the need of adjusting our ideas and our methods of living together so that as far as possible these walls of separation may be broken down. The problem beeomes a very interesting and aeute one in any farm eommunity when we note the prejudiees in ehureh or in seeret soeieties, and how eertain groups are inevitably exeluded. We also find farmers with speeial diffieulties; the man with the tiny farm, the landless farmer, the laborless farmer, the farmer without eapital, the farmer in the depleted rural eommunity who would like to see a better day but is not hopeful that it ean be brought about, and finally the farm laborer. Sometimes these matters do not seem like "problems"; but are rather taken for granted. They are important questions, nevertheless.

\section{ADJUSTMENTS BETWEEN THE FARMER AND OTHER INTERESTS}

The Balance between Producers and Consumers. We liave had a great outery beeause in some prosperous agrieultural regions, as well as in those less prosperous, the farm population has 
actually dechined. At the bottom this change of population was simply an effort to adjust the number of producers to the number of eonsumers. Our land poliey had developed too many producers. The application of scientific principles to production and the establishment of a nation-wide system of transportation enabled relatively fewer men to grow the food of the nation. But of course this may be carried too far. If we have too many producers, we get cheap food and also cheap men on the farm. If we have too few produecrs, the country is not adequately supplied with food.

Adjustment in the Factors of Production. The problem is essentially this: Ilow may the farmer compete with manufacturing and business interests for land, labor and eapital? It is a question of proper relationships. The farmer must have his share of these or he cannot do his best work. IIe has to compete constantly with these other industries. How can we makc sure that lie has a fair field?

Yield per Acre and Yield per Man. The strength of European agrieulture lies in its large yield per acre of land. The strength of American agrienlture lies in its large yield per man who works the soil. It is in the interests of consumers to have the maximum yield of food per acre; it is in the interests of producers to have the maximum return due each individual worker. But elearly, both of these things eannot happen at the same time. Somewhere we must find the fair balance. We must adjust the interests of both. How can we do it?

The Conservation of Soil Resources. Less than formerly do the farmers want to use their land even if they use it all up. It is a truism that the Ancrican farmer las skimmed the cream off the soil and then gone on West. Society, that is all of us together, which really owns the land, is interested to have it become more productive, whereas it has become less productive in many regions. Of course the good farmer has the same interest in keeping up production, but many farmers do not see it. They want immediate results. Clearly we need an adjustment that results both in that use of the land which gives a fair return to the farmer, and that use which preserves its fertility undiminished for future generations.

Sharing the Savings. Both farmers and consumers would 
like to abolish the middleman's profits. The farmer rather expeets to get most of the profits which the middleman has made, and the eonsumer, oddly enough, has the same ambition. Both eannot sueceed. This tendeney shows itself in a publie market where householders buy of farmers. Each wants to get the best bargain possible. What eventually happens is probably a pretty fair trade, both getting some advantage in this matter. This prineiple holds in the whole field of soil distribution. If economies of distribution are effected, who is to get the benefit - consumer or produeer? Both! It is a matter of adjustment. The answer lies in establishing fair trade.

Agriculture and Other Business. Agrieulture is our greatest business and yet it is often left out of aceount in plans for possible development. But its relation to manufaeturing, to transportation, to eommeree and even to finanee is very elose and even vital. Imagine if you can the farm lands of Ameriea lying unproduetive for a single year. Moreover, it is elear that if these relationships of agrieulture to other industries are so elose, eompeting interests will show themselves. Inasmuch as these industries are well organized and agrieulture is poorly organized, the farmers are apt to be the losers. How ean we adjust these big interests of these big industries so that all shall have the square deal?

Agrarian Legislation. The farmer has an interest in taxation, in the tariff, in eurreney legislation. It is believed that legislators have a tendeney to ignore this interest, but it eannot safely be ignored. If it results in too great injustiee, then we have a radical movement which smashes its way through, perhaps to undesirable ends for all eoneerned. What we need, then, is an attempt to adjust, in all legislative matters, the fair interests of farmers to the fair interests of other people.

The Farmer in Politics. How ean the farmers make themselves felt in our political life? As a party, shall they have rep. resentation in legislative business, somewhat equivalent to their numerieal strength? Neither of these things seems very praetieable, perliaps not even desirable. On the other hand, are the farmers to be left out of aeeonut and have notling to say? Are.they to lave no unified opinion or desire that finds expression through the political party or the government? How 
ean we find the balanee between political negleet of the farmers and political revolution among the farmers?

The Farmers and Organized Labor. Have these groups interests in eommon or are they absolutely antagonistic? If in eommon, where do these interests lie? If antagonistie, how may antagonism be allayed?

Rural and Urban Aspects of Civilization. There are people who think that the city stands for eivilization, that leadership, wealth, organization, power, will reside in the eity and take the helm of soeiety's progress. But have the farmers nothing to contribute? Are not the methods of living and of thinking worth something to the common eountry? One of the most important adjustments is to make it possible for organized farmers in every country in the world to make their fullest contribution in work, in thought, in ideals, to the common welfare of mankind.

\section{B. INTERNATIONAL ORGANIZATION}

\section{THE INTERNATIONAL INSTITUTE OF AGRICI'LTURE ${ }^{1}$}

THE origin of the Institute is shown in the following letter of H. M. the King of Italy to the Prime Minister H. E. Giov. Giolitti.

\section{Dear President :}

Mr. David Lubin, a citizen of the United States, has made a proposal to me, with all the ardor of sineere conviction, and it seems to me both wise and useful, and I therefore recommend it to the consideration of $m y$ Government.

Farmers, who generally form the most numerous class in a country and have everywhere a great influence on the destinies of nations, ean not, if they remain isolated, make suffieient provision for the improvement of the various erops and their distribution in proportion to the needs of consumers, nor protect their own interests on the market, which, as far as the

1 Adapted from Report of the International Institute of Agriculture, 1915. 
more important produce of the soil is concerned, is tending to become more and more one market for the whole world.

Therefore, eonsiderable advantage might be derived from an International Institute, whieh, with no political object, would undertake to study the eonditions of agrieulture in the various eountries of the world, perfodieally publishing reports on the amount and character of the crops, so as to facilitate produetion, render eommerce less expensive and more rapid, and establish more suitable priees.

This Institute, coming to an understanding with the various national offices already existing for the purpose, would also supply precise information on the eonditions of agrieultural labor in various loealities, so as to serve as a safe and uscful guide for emigrants; promote agreements for mutual defense against diseases of plants and animals, where individual action is insufficient; and, finally, would exercise an action favorable to the development of rural coöperation, agrieultural insurance and credit.

The benefits attained by means of such an Institute, a bond of union between all farmers and consequently an important influenee for peaec would certainly be manifold. Rome would be a suitable plaec for its inauguration, at which the representatives of the adhering States and the larger Associations concerned might assemble, and harmonize the authority of Governments with the free energies of the farmers.

I am convineed that the nobility of the aim will suffice to overcome the difficulties of the enterprise.

And in this faith I sign myself,

$$
\text { Your affectionate cousin, }
$$

Victor EmmanNuel.

Rome, January 24th, 1905.

In consequence of this letter the International Institute of Agriculture was founded by act of the International Treaty of June 7 th, 1905. The treaty was ratified by forty governments, and twelve others have since adhered to it, so that, at the present time, almost the whole civilized world is included.

The seat of the Institute is at Rome. Aceording to the treaty it is a "government institution in which each adhering power is 
represented by delegates of its choice." It is administered by a General Assembly and by a Pcrmancnt Committee. The staff now numbers nincty-seven.

The revenuc of the Institute is derived from contributions paid by each of the adhering nations aceording to the group in which the nation is inscribed, as established by the treaty. (The revenue amounts to approximately $\$ 250,000$ annually.-Editor.)

The Institute performs the following work:

1. By means of its Bureau of General Statisties, it collects, coördinates and publishes as promptly as possible, statistical data on crops and livestock, the trade in agricultural products, and their prices on different markets. This crop reporting information is set forth in fuller detail in the monthly Bulletin of Agricultural Statistics which is published simultaneously in five languages. The Institute also publishes an "International Year Book of Agricultural Statistics," which contains summary tables of crop areas and yields.

2. The Bureau of Agricultural Intclligence and Plant Diseases collects, elaborates, publishes information of a teclnical nature on agriculture, agricultural industrics, stock-breeding, ctc. It publishes a bulletin each month on agricultural intelligence and diseases of plants.

3. The Bureau of Economic and Social Intelligence collects, elaborates and publishes information concerning agricultural cooperation, insurance and credit as well as other questions of agricultural economy.

4. The library collects the books and documents required for the work. It publishes a wcekly Bibliographical Bulletin in which are indicated the books received as well as the most important articles noted by the technical bureaus when cxamining periodicals.

5. The Gencral Sccretary's Office publishes an "International Year Book of Agricultural Legislation" containing the laws relating to agriculture enacted in the countries adhering to the institute. 


\section{NATIONAL ORGANIZATION}

\section{WORK OF THE OFFICE OF MARKETS AND RURAL ORGANIZATION ${ }^{1}$}

\section{CHARLES J. BRAND}

IT is believed that effeetive and eeonomieal methods for distributing and marketing farm produets should go hand in hand with seientifie methods of production, as it profits little to improve the quality and inerease the quantity of our erops if we ean not learn when, where, and how they may be sold to advantage. To provide for a study of the problems involved, Congress during the spring of 1913 appropriated funds for the establishment and operation of the Office of Markets of the Department of Agrieulture. The Offiee of Rural Organization was established by Congress a year later, in order to determine the possibilities and eneourage the use of organized eoöperative effort in removing rural eonditions. These two Offices were eombined on July 1, 1914, and the combined unit is known as the Office of Markets and Rural Organization.

The authority eonferred by Congress in appropriating funds for the maintenanee of this Offiee provides "for aequiring and diffusing among the people of the United States useful information on subjects eonneeted with the marketing and distributing of farm and nonmanufactured food produets and the purehasing of farm supplies," and the study of eoöperation among farmers in the United States. So far as marketing work is eoneerned, the activities of the Offiee, therefore, are limited to the eollection and distribution of information. For example, it has no authority to prosecute eases of alleged dishonesty on the part of produeers, earriers, dealers, or buyers. It has nothing whatever to do with the problems of produetion.

Owing to the eomplexity and wide seope of the work, up to the present time it has been impossible to undertake a eomprehensive study of more than a few of the most urgent and important

1 Adapted from Doc. Markets 1, 1015, p. 1. U. S. Department of Agriculture, Office of Markets and Rural Organization. 
of the problems which demand investigation. As far as possible the marketing problems are being studied from the points of view of producer, dealer, and consumer. A large part of the rural organization investigations has consisted of studies of the work of rural credit associations. As this work is now well under way, more time will be devoted to other phases of rural organization work without, however, discontinuing any of the rural eredit investigations.

Besides the phase of coöpcration dealing with the marketing of farm and food products, work has bcen instituted looking toward that basic improvement of country life which must come from the country itself, through the development of resident leadership. This work recognizes that the true function of increased prosperity in the farm home is the raising of the standard of living and thinking upon the farm. While other projects of the Office are designed to promote changes which will make farming morc profitable, the particular object of this work is to make the country a more desirable place in which to live.

The Office is investigating coöperative organizations that are endeavoring to improve conditions of education, health, recreation, and household ceonomy in rural life. The work done thus far reveals many needs in all of these directions, and, when practicable, the Office attempts to supply information and suggestions to such associations.

Local demonstration work has been undertaken in Alabama and in North Carolina in coöperation with State and local agencies.

\section{THE PLACE OF GOVERNMENT IN AGRICULTURAL COOPERATION AND RURAL ORGANIZATION ${ }^{1}$}

Government, whether local, State, or national, can render a great service to agriculture and country life. Government can do a great deal more than many pcople suppose, and it ought to do a great deal less than many people expect. The follow-

1 Adapted from Report of the American Commission, Senate Document To. 261, Purt I, pp. 26-27. 
ing prineiples are set forth as suggestive of fundamental eonditions of Government serviee:

1. The Government, as representing all the people, should do all such a Government ean do on behalf of better farm practice, better farm business, and better farm life-in so far as this betterment is to the advantage of all the people.

2. In general, however, Government should do nothing that ean effeetively be done by individual farmers, or by the farmers eolleetively through voluntary effort. It is highly important to develop self-help. The "eoöperative spirit" is vital to the sueeess of eoöoperative effort, and this spirit is best engendered by the work of voluntary ageneies of soeial serviee.

3. The Government, however, may take the lead temporarily in many movements, in order to stimulate interest and to show how progress may best be seeured.

4. Where there is practieally unanimous agreement on the part of the people that a eertain type of effort is essential for the good of the whole people, it is highly proper that the Government should be the ageney to perform the serviee.

The types of work whieh Government may do for agrieultural eoöperation, for example, under the prineiples just enuneiated, are as follows:

1. The Government may investigate faets and prineiples underlying the development of agrieulture and country life.

2. The Government may interpret those prineiples in the light of the needs of the people.

3. The Government may inform the people of the results of its investigations and interpretations.

4. The Government may advise individuals and groups how best to take advantage of these faets and prineiples; that is, how to apply them to farm improvement, marketing and exehange, and eommunity life.

5. The Government may demonstrate the best methods of aeeomplishing this applieation of faets and prineiples to aetual needs and eonditions.

'The Govermment may not partieipate in the farmers' business nor direct their eommunity life. Only as legislation may be neessary to restrain should Government interfere with the initiative and development of the individual. It should not try 
to run a man's farm for him, nor to manage the farmers' business transaetions.

There are money limitations to the work of Government. The rural problem is so large that the work of Government even within its field will liave to be supplemented by voluntary aid and finaneial support.

There are some fields in whieh the people are not suffieiently agreed as to methods and maehinery so that Government ean safely undertake to earry on the collective enterprises of the people.

\section{ORGANIZATION.OF A COUNTY FOR EXTENSION WORK-THE FARM-BUREAU PLAN ${ }^{1}$}

\section{R. SIMIONS}

\section{PURPOSES OF THE FARM BUREAU}

A county farm bureau is an association of people interested in rural affairs, which has for its objeet the development in a eounty of the most profitable and permanent system of agriculture, the establishment of eommunity ideals, and the furtherance of the well-being, prosperity, and happiness of the rural people, through eoöperation with local, State, and National ageneies in the development and execution of a program of extension work in agrieulture and home eeonomies.

At the outset acknowledgment should be made of the exeellent work already aceomplished by many farmers' organizations. Thousands of eoöperative agricultural associations, farmers' elubs, granges, equities, gleaners, and other seeret and nonseeret organizations are working together suecessfully for the betterment of - rural eonditions. The county farm bureau aims to eoördinate and eorrelate the work of all these organizations, thereby unifying and strengthening the work they are doing. It does not supplant or compete with any existing organization, but establishes a bureau through which all may inerease their usefulness through more direet contaet with each other and with State and National institutions without in any way surrendering their in-

1 Adapted from U. S. Dept. of Agriculture, Department Circular 30 , Washington, May, 1919, pp. 4-21. 
dividuality. It is a nonpolitical, nonseetarian, nonseeret organization representing the whole farming population, inen, women, and ehildren, and as such it acts as a elearing house for every association interested in work with rural people.

While the original conception of the farm bureau was to develop eounty-agent work, it soon filled a broader field and it is now rapidly coming to be recognized as the official rural organization for the promotion of all that pertains to a better and more prosperous rural life. It coöperates directly with the State and the Federal Government in the employment of county agents, home-demonstration agents, boys' and girls' elub leaders, and other local extension workers. The services of the farm bureau are available to all extension ageneies desiring to work within the county. It is quite as much interested in homeeconomies demonstrations, boys' and girls' elub work, farm. management demonstrations, and the work of the various institutional specialists as it is in the demonstrations carried on directly by the eounty agent. Thus while an outgrowth of county-agent work it has become broader tlian county-agent work, and is now the federating agency through which all groups of rural people, whether organized or unorganized, are able to secure a hearing.

The primary purposes of the farm bureau are:

1. To encourage self-help through developing and exereising leadership in the rural affairs of each community.

2. To reveal to all the people of the county the agricultural possibilities of the county and how they may be realized.

3. To furnish the means whereby the agricultural problems of the county and the problems of the farm-home may be systematically studied and their solution attempted through a county program of work to secure the well-being, prosperity, and happiness of all rural people.

4. To eoördinate the efforts of existing rural agricnltural forces, organized or unorganized, and to promote new lines of effort.

5. To bring to the agents representing the organization, the State agrieultural college, and the Federal Departinent of Agriculture the counsel and advice of the best people in the county as to what ought to be done and how to do it. 
6. To furnish the necessary local machinery for easily and quickly supplying every community in the county with information of value to that community or to the county as a whole.

\section{MEMBERSHIP}

Membership in the farm bureau is open to all residents of the county and nonresident landowners who are directly interested in agriculture, men and women alike. The membership should be well distributed over the county and should be large enough to be thoroughly representative of the farmers of the county. At least ten per cent. of the farmers should be members before permanent organization is effected. $\Lambda$ t least cighty per cent. of the membership should consist of bona fide farmers or rural residents.

The membership fee is necessary not only to provide funds to finance the work of the organization but also to secure the active interest of each member. Membership fees are needed to buy stationery, postage, office equipment and supplies; to publish exchange bulletins or other bureau publications, to pay the traveling expenses of the officers and committecmen to attend county, State, or National conferences, etc. If a clcar-cut presentation of the facts regarding the nature of the organization, the duties and privileges of the members, and the work already accomplished and to be undertaken is made, no difficulty should be experienced in kecping up the membership from year to year. In some States yearly educational campaigns to aequaint the: people of the counties with the nature of the bureaus and the work accomplished have produced a steady increase in the number of counties organized and in the number of members.

Every member should give not only moral support to the work but also personal attention to some activity of the bureau. Each member should keep in elose touch with the work in progress, assist in plamning for the coming year, and participate in the election of the officers and executive committecmen.

\section{F.IRM-BUREIU PROGR.AM OF WORK}

A farm-burcau program of work is a plan for the promotion of certain definite lines of work that pertain to a better and more prosperous agriculture and a more satisfactory rural and 
home life. A farm-bureau project is a plan for developing some part of the program. For example, a dairy project might include plans for introducing pure-bred dairy cattle, increasing the number of silos, demonstrating better and more economical feeding, and improving the quality of butter made in the homes. Men, women, and boys and girls may coöperate in carrying out such a project. It is essential that each member, and more especially each committecman, should play an important part in formulating the program and in promoting the projects or activities. The mechanies of planning and promoting the program and writing a project are outlined bclow.

Development of the County Program. 1. In organizing a farm burcau at least one member of the temporary organization committce, whose duty it is to direct the organization campaign for the farm bureau, should be selected to look after the details of formulating a tentative county program of work. If a program including both agriculture and home economics is contemplated, a program of work committee of at least two members is desirablc in order that problems more particularly relating to cach phase of the program may be carefully analyzed.

2. The program-of-work committee should send out a questionnaire to each member of the farm bureau requesting suggestions as to the most important problems and how to solve them.

3. The prograin-of-work committee should tabulate the answers to the questionuaires and sceure additional information from the organizer and the temporary committees, and by personal observation.

4. The chairman of the program-of-work committec or the organizer should lead the discussion at the county organization mecting and make a list of the problems on a blackboard. Such general headings as Farm, Home, and Community liave sometimes been used.

5. A tentative program of work should be planned at this meeting and project leaders selected to serve as members of the exceutive committec. The committec on nominations might well meet with the program-of-work committee in selecting project leaders.

6. From the suggestions made at the aunual meeting the exeeutive committec should work out a definite yearly program of 
work and refer projeets to the projeet leaders to eonsider and develop the details. County, home demonstration, and elub agents should be seleeted with referenee to their ability to assist in earrying out projeets.

7. The projects leaders should work with the eounty and home demonstration agents and elub leaders in outlining the details of the projeets. They should eonsider not only what should be undertaken, but who will do the work, how it will be done, when it will be done, and uhere (in whieh eommunities), it will be done. In eonsidering what should be undertaken they should study the problems relating to the projeet more carefully than they have previously been studied, make a list of these problems, and prepare a ehart showing the relation of each projeet to the entire farm-bureau program of work. This will tend to prevent duplieation of effort. In eonsidering who will do the work they should make a list of the teaehing forees of the county and loeate them on an outline map of the county by communities. They should also list the amount of work the extension specialists from the State agrieultural eollege ean render. In eonsidering how the work will be done they should outline methods for starting the work, seeuring demonstrators and eoöperators, and following up the work until definite results are obtained. In eonsidering where the work will be done they should indieate on the map those eommunities in wlich the work needs to be undertaken. In eonsidering when the work will be done they should prepare a projeet ealendar placing the months and weeks of the year aeross the top of a sheet of paper and the various parts of the projeet down the left-hand side of the sheet, and drawing lines to the right of each part of the project to indieate just how mueh time and at what periods the agents will need to spend on eaeh part and the entire projeet. In planning the details of a project the reeommendations of the eollege specialists should be earefully eonsidered. Not only loeal problems, but also State and National problems should be earefully studied.

8. The outline of eaeh projeet, together with eharts, maps, ete., will be presented by the projeet leader to the exeeutive eommittee for eolsideration. The eommittee and the agents employed will diseuss the projeets and find out from the projeet ealendars, eharts, and maps whether too mueh or too little work 
is being undertaken during the year. In other words, the exeeutive committee will now eonsider the entire program of work, just how it will be undertaken, by whom, where, and when.

9. The county agent, the home-demonstration agent, or the eounty elub leader will write the project. If the project involves work relating to two or all three of the agents, each should write the part directly relating to his or her work, or the project should be considered in eonference and one agent delegated to write it.

10. Each project should then be submitted to the projeet leader for signature, to the executive eommittee for approval and the signature of the president and the agent or agents coneerned, and to the extension director at the State agricultural college for his approval and for the eonsideration of any speeialist or leader coneerned.

Development of the Community Program. It is very essential that each community have a definite program of work based largely on the eounty program. The agents and one or morc executive committeemen should visit eaeh eommunity where work is to be undertaken and discuss plans with a group of community leaders, tentatively seleeted by the temporary committec chairman.

1. They should make a community map, loeating on it the roads, ehurches, schoolhouses, farmers' organizations, and the houses of the farm-bureau members.

2. They should make a list of all the farm families in the community, all the teaching forees, ete.

3. They should make a survey of the community problems, listing them under sueh headings as Farm, Home, and Community.

4. They should plan a community program of work, based on the county program in so far as possible, but scleeting additional projects as needed, sinee the problems of the eommunity may differ from those in other communities.

5. The president of the organization shall appoint a projeet leader for each project in the community to serve as a member of the community committec. It is inadvisable to undertake a projeet in a eommunity unless a capable project leader ean be found who is willing to assume responsibility for the project. 
6. The eommunity program of work will be presented to the people of the eommunity by the eommunity eommittee at the winter eommunity meeting of the farm bureau and eoöperators and demonstrators will be seeured.

Annual Revision of Farm-Bureau Program. In order to keep the farm-bureau members interested in planning and earrying out a program of work it is desirable to send out questionnaires to the members each year, requesting suggestions as to desirable ehanges or additions in the program of work. It is also desirable to diseuss the program at meetings of the members in each eommunity and at the annual meeting. The exeeutive and eommunity eommittees will need to earefully revise the eounty and eommunity programs each year, as projeets or parts of projeets are eompleted, or as new problems arise. They will, of eourse, use the suggestions of the members as a basis for any revision. As indieated, each county project leader may, at any time, eall meetings of the project eommittee, eomposed of the various eommunity leaders to seeure suggestions or to explain plans. Usually these eommittees will be ealled together before a revision of the yearly program of work is undertaken.

The following outline may serve to suggest eaeh step in the revision of the program:

(1) October--Regular monthly meeting of executive committee-make plans for mectings of county project committees and plans for sending questionnaire to each farm-bureau member.

(2) October--Ireetings of each community committee - consider local problems and suggestions of local members and make recommendations to project committees.

(3) October-Meetings of project coinmittces-discuss recommendations of community committees and suggest revision of projects.

(4) November.-Regular monthly meeting of executive committee-prepare tentative program of work to present at annual mceting for consideration and discussion.

(5) November.-Annual meeting of farm bureau-consider yearly program of work.

(6) November.-Revision of projects by project leaders and agents.

(7) December.-Regular monthly meeting of executive committee-adopt program.

(8) December.-Revision of community programs by community committees.

The officers of a farm bureau eonsist of a president, a viee 
president, a secretary, and a treasurer, all of whom should be eleeted at the annual meeting for a period of one year. The officers should be ehosen beeause of speeial fitness to represent important projects or activities of the organization, as well as beeause of their fitness to perform the regular duties of the respeetive offices. For the most part the officers should be farm men and women.

\section{EXECUTIVE COMMITTEE}

An exceutive committee of from 5 to about 11 members, ineluding the officers of the burean as ex-officio members, shonld be elected by the bureau at its annual meeting for a period of one year. Each member may be called a county project leader. It is advisable to have an effieient nominating eommittee appointed at the annual meeting, in order that the names of members eapable of effective serviee in planning and developing the projeets or aetivitics may be presented to the meeting. This committee may eontain members suggested to the nominating eommittce by the official county board of commissioners or supervisors, the grange, the farmers' union, the equity, the farmers' elubs, coöpcrative associations, eounty fair, schools, etc.

The executive committee is usually scleeted so that practically all sections of the county will be represented, but in large eounties with inadequate transportation faeilities committcemen should be selected who ean attend the regular (monthly) meetings conveniently. In the sclection of a committeeman one of the ehicf objects should be to sccure a man or woman whose qualifications and personal interest fit him or her to plan and develop some one important line of work or activity of the bureau, suel as farm-burcau organization, farm-bureau publieations, meetings, exhibitions, finance, food-conservation work, crop improvement, live-stock improvement, farm management, supplying farm labor, coöperation between farmers' elubs, development of better marketing facilities, etc. It is, therefore, evident that the number of eommitteemen will depend on the number of projeets or activities of the farm bureau. In order to prevent the committec from becoming too large and unwicldy, a eommittce- 
man may serve as the project leader for more than one project, especially for projects of a similar character.

Dutics. (1) Signs memoranda with State extension director.

(2) Makes up financial budgets.

(3) Secures necessary funds.

(4) Authorizes the expenditure of the bureau's money.

(5) Determines the policies of the bureau.

(6) Considers and approves programs and projects recommended by the county project committees and by members of the organization.

(7) Coöperates with the State agricultural college and the United States Department of Agriculture in the development of a program of work, the details of projects, and the employment of county agents, home-demonstration agents, boys' and girls' club leaders, and other local extension workers nominated or approved by the Statc extension director.

\section{COMMUNITY COMMITTEES}

Local community leadership is essential to the success of the farm-bureau movement. Each distinct community in the county should have a community committee made up of at least one and preferably three to five local representatives or local leaders of the burcau. The number of committeemen will depend on the number of community projects or activities.

Method of Choosing. Experience has indicated that until the farm-bureau has become permanently established in the county and the qualifications of a community committceman are understood by the majority of the members, it has been wise to have the president of the bureau select the community committeemen, each to direct some project or activity of the bureau in the community. The usial practice has been for the president, in consultation with the coöperatively employed agents and local leaders and subject to the approval of the executive committec, to appoint the temporary chairmen of the committees. If the grange or other local club or organization is popular with the rural people in the community and is active in promoting the improvement of agricultural and home conditions, the officers of such organization may be consulted in regard to the appoint- 
ment of a temporary ehairman. The remainder of eaeh eommunity eommittee has usually been appointed by the president on reeommendation of the temporary ehairman, exeeutive eommitteeman, or the agents, after a eareful survey of community conditions to determine the ehief problems needing immediate attention. Eaeh eommittecman should be seleeted to direct some important projeet or activity of the organization to be undertaken in the partieular eommunity, such as farm-bureau organization, home eeonomics demonstrations, boys' and girls' elub work, food conservation, supplying farm labor and seeds, live-stock improvement, ete. Eaeh has been called a eommunity projeet leader.

Before eommunity eommitteemen are appointed the temporary community chairman should hold a meeting of prospective committcemen at his home at which the following steps are taken: A community map should be preparcd; a more detailed survey of community conditions made; projects selected and approved; a promise sceured from eaeh prospeetive eommitteeman to assume responsibility for a projeet or aetivity; and a permanent ehairman and possibly a seeretary chosen. Then the president should notify eaeh committecman in writing of appointments for a period of one year. The appointment of each eommitteeman. should have the approval of the exeeutive eommittee. At the end of the year the president should appoint eommitteemen to assume the leadcrship for the next year's projeets. It is usually desirable to retain some of the previous year's eommittecmen for at least another year, in order that the personnel of the committee may not be entirely new.

The plan of having all farm-bureau members assemble at a central point in the community for the purpose of studying eommunity problems, planning a program of work, and seleeting projeet leaders to be appointed by the president as eommitteeman, has been tried in a few counties. This plan las seemed to neessitate the attendanee at eaeh meeting of the president or an exeeutive committeeman and onc or more of the paid agents of the organization, in order that the policies of the organization may be elcarly set fortl. This plan has been more suceessful in counties where the farm bureau has been organized for some time and the work has beeme well established and 
understood by all the members. The farm bureau is primarily a eounty and not a eommunity organization; therefore, from the outset nothing should be done to give the wrong impression. The plan of having farm-bureau members assemble by eommunities to eleet or seleet eommunity eommitteemen has not been productive of the best results, and for the first year of the bureau's existence should not be encouraged.

Meetings. As many meetings of each eommunity eommittee should be held as are needed to plan and exeeute the program of the eommunity. The president of the bureau, aeeompanied by one or more of the agents, and, if neeessary, by one or more of the eounty projeet leaders, should always attend the meeting of the committee at which it organizes for the year. Such officers, project leaders, and agents as are needed to assist in promoting the work in hand in the community should attend other meetings of the loeal committee. Meetings of the eommunity eommittees should be eneouraged whenever work is to be diseussed or undertaken even though the agents or eounty projeet leaders ean not be present. This will tend to promote the plan of having the loeal people take the initiative in matters pertaining to the eommunity. It is unwise, however, to eneourage ehairmen to eall a committee meeting unless there is need of such meeting. If any of the eounty leaders or agents have matters of unusual importanee which they wish to present quiekly to the eommunity eommittees, seetional meetings of several eommittees may be held, especially if the problems of the eommunities are similar.

At least once a year each eommunity committee should hold a business meeting to which the farm-bureau members residing in the eommunity are invited.

After a definite program of work has been formulated, and each eommunity committeeman has agreed to assume responsibility for some part of the program, fewer meetings will suffice. For instanee, if the State or eounty leader of eoöperative purehasing and marketing work visits a eommunity to promote the interests of such work, he will need to eonsult only with the eommunity eommitteeman who heads some phase of this projeet in the community, unless it involves a deeided change in the community program, in which ease it may be desirable for them 
to present the matter to the whole eommittee. The same would be true of other special lines of work, sueh as food-conservation work, farm-management demonstrations, live-stock work, ete., whenever the county leaders on each line of work wish to promote the interests of partieular projects in the eommunity.

Duties. (1) To determine and discuss local problems, to assist in the formation of a county program of work, and to adapt this program loeally, thereby formulating a community program of work which eventually will solve the local problems.

(2) To seeure for the community the desired community and individual assistance in solving loeal problems by arranging for at least one winter meeting and one summer demonstration meeting and for a few definite field, barn, and home demonstrations.

(3) To secure for the farm bureau the active support of the community by informing the residents of its organization, purposes, and work; by arranging the details and advertising local meetings, demonstrations, ete.; and by solieiting and seeuring memberships.

Privileges. Community committeemen are the recognized leaders of the farm bureau's work in the eommunity. They are brought into frequent eontact with the eounty projeet leaders, eounty agents, home-demonstration agents, boys' and girls' elub leaders, and other extension workers and speeialists. By helping others they help themselves in information, inspiration, and general development.

\section{COUNTY PROJECT COMMITTEES}

As soon as a project is definitely adopted a eounty project eommittee is automatically authorized for each project. Each project or important aetivity will be represented by a county committee eomposed of the project leader on the exeeutive committee as chairman and the projeet leader on each of the community committees which has formally adopted the project or activity.

Purpose, Duties, and Meetings. To be most effective the exeeutive eommittee should not eontain as many members as would be required to give representation to each rural community. In order that every organized eommunity may have 
dircet representation in planning the county program of work and representing the policies of the organization, mectings of the project committes should be called by their respective chairmen. Such meetings are desirable if the unity of the county organization is to be preserved. Usually at least one meeting of each committee should be held each ycar to discuss the recommendations made by the various community committces, and to recommend to the exceutive committee a yearly county program of work, or to suggest the making of such changes in the permanent program as may seem necessary. These recommendations will supplement those of the members made in the answers to the questionnaires sent to cach member requesting suggestions, or those made by the members at the annual meeting. The community project leaders should, of course, consider the suggestions in their respective communities before making definite recommendations. Additional meetings of project committces are desirable if important matters arise requiring their attention. Matters concerning only a few communities in the county frequently arise, in which case only the project leaders representing those communities nced to be called together. A lunchcon is suggested as a desirable feature of at least onc of the meetings of each project committee, or of a general mecting of all committeemen in the county.

\section{HOW TO ORGANIZE A COUNTY}

The assistance of a trained organizcr to act as leader of the organization campaign may be secured from the State agricultural collcge by writing the State director of agricultural extension. Temporary headquarters should be provided for the organizer at the most centrally located place in the county, so that he may keep in close touch with the progress of the campaign in every community.

The organizer will assist in the sclection of a temporary county organization committec of about five members representing all sections and all important agricultural and home interests in the county. If considered advisable a mecting of a few representative men and women from eacl community may be called to discuss the advisability of proceeding with the or- 
ganization eampaign and to elect a temporary organization eommittec. Each committeeman should be eleeted beeause of special ability to direct a definite part of the preliminary organization program, such as publicity, finanee, programs for loeal and county organization meetings, program of work for the organization, constitution, and by-laws, ete.

Plenty of good publicity matter, in the form of a series of several artieles giving the advantages of organization in general, the history of the farm-bureau movement, results of local extension work in neighboring eounties, need of an organization to eooperate with the Government and the State in the employment of trained workers, plans for starting the work in this county, and the progress of the eampaign, should be given to the local press at opportune times.

(1) The organizer should explain farm-bureau work earefully and suggest the organization plan.

(2) He should secure the eommittee's approval of the plan and its help in working out the details to meet local conditions.

(3) The eommittee should deeide on a definite date for the completion of the membership eampaign and the necessary number of members to be seeured before that date.

(4) The location of the temporary community eommitteemen may be indicated, as each is selected by the county committec on an outline map of the county, showing the approximate community boundaries. In eonsidering prospective eandidates for the eommunity committees their qualifications for effeetive service on the permanent eommunity eommittees for the ensuing year, as well as for temporary service, should be diseussed. In so far as possible the number of members to be secured in each community should be deeided and indieated on the map.

(5) The eounty eommitteemen should give the organizer permission to use their names in sending letters to loeal eommittees, in newspaper articles, ete.

(6) Definite arrangements should be made with each member of the county eommittee to attend the meetings of the temporary community eommittees where he ean render the most service.

(7) As far as possible, each eounty committeeman should understand his or her part of the preliminary organization 
program, such as publicity, finances, programs for local and county organization mectings, program of work for the organization, constitution and by-laws, cte.

\section{ORGANIZATION OF TEMPORARY COMMUNITY COMMITTEES}

(1) Arrangements should be made by telephone with the prospective chairman of each community committee to hold a meeting of the committec at his home. Ask him to communicate with the other prospective committecmen, inviting them to attend the inceting.

(2) These telephone calls should be supplemented by personal letters signed by one of the members of the county committee. It is best not to discuss the purpose of the meeting otler than to suggest that advice is needed in determining matters of great interest to the farmers in the community.

(3) The organizer, accoinpanied by the county committeeman who can be of most assistance in cach community, should meet with each committee in its own community, or, if time does not pcrmit, in a sectional meeting of the committees of several contiguous communities.

(4) At this meeting the purpose of the organization and its relation to extension work, including work with farm men and women, and young people, and plans for organizing the county, should be explained carefully by means of charts, maps, and blackboard. Definite plans for the campaign in the community should be made and a definite promisc to serve as committeemen during membership campaign secured from each prospective committeeman.

\section{COMMUNITY ORGANIZATION MEETINGS}

Following the committee meetings, an organization meeting should be leld in each community at which the leader, and county and community committeemen, should explain county farm-bureau work and the importance of having a large percentage of the men and women of the farms to coöperate in its work as members of the farm bureau. During a recess the local committeemen, already provided with membership cards and membership badges, should solicit members.

The local committecmen should then take the names of those 
not present at the meeting and arrange to visit each one personally on the farm, and, if possible, secure his membership. On the suggestion of the community committee the organization meeting may be omitted and only the farm-to-farm membership campaign be used.

Invitations signed by one or more members of the county committce should be sent to all members to attend the county-wide organization meeting. Each should be urged to invite all interested persons to accompany him. The letter should also contain an addressed return postal card bearing the following questions :

What do you want the farm bureau to do (1) for you or your farm? (2) for you in your home? (3) for your community? (4) for your county?

The answers to the questions should be tabulated by the program-of-work committee and used at the county meeting as a basis for discussing a county program of work.

\section{COUNTY-WIDE ORGANIZATION MEETING}

(1) Several committeemen should line up outside the entrance to the meeting place to secure additional members. They should be well provided with badges, membership cards, receipts, etc.

(2) A constitution and by-laws should be adopted.

(3) A permanent program of work should be planned.

(4) Officers and executive commitecmen should be elected for a period of one year. (Each officer and committecman should be clected because of special fitness to head some important project of the organization.)

(5) Good music and at least one interesting speaker should be provided.

\section{DEVELOPMENT OF PERMANENT COUNTY ORGANIZATION}

Following the county organization meeting the permanent organization should be perfected according to the plan stated in this circular and the officers and committeemen carcfully trained for effective service. 


\section{EXECUTIVE COMMITTEE MEETINGS}

At sueceeding meetings of the executive eommittee arrangcments should be made for suitable office quarters and cquipment, and coöpcratively employed agents, such as a county agent, a home-demonstration agent, a boys' and girls' club leader, etc., representing the organization, the State agricnltural college, and the United States Department of Agrieulture should be engaged. Following the arrival of one or more of these agents in the county, the committee should formulate a definite program of work and arrangements should be perfected for the holding of community committee meetings for the purpose of formulating community programs of work. As fast as suitable community project leaders ean be found, they should be appointed in writing by the president with the approval of the executive committce.

ORGANIZATION AND MEETINGS OF PERMANENT COMMUNITY COMMITEES

$\Lambda$ the first meeting of the prospective community committce in each community a community map should be made on which will be located the community center, schoolhonses, churches, farmers' organizations, roads, farm-bureau committeemen, and members. Community problems should be studied and a community program of work planned to solve these problems. Definite plans for winter and summer meetings should be made at this time or at a succeeding meeting of the committee. Charts showing the relationship the organization sustains to the State agricultural college and the United States Department of Agriculture and charts showing the organization of the farm-bureau should be prepared. Reasons for membership in the organization should be considered and plans made for increasing it. (See Circular 3, Office of Extension Work North and West, States Relations Scrvice, for a more detailed explanation of holding community committec meetings, making community maps, etc.)

Chairmen of project enmmittees should call mectings as needed to discuss mattcrs relating to their projects, to make plans, cte. 
HOW TO EXPAND A FARM-BUREAU HAVING ONLY AN AGRICULTURAI PROGRAM TO INCLUDE HOME DEMONSTRATION AND BOYS' AND GIRLS' CLUB WORK

A meeting of the exeeutive eommittee of the farm bureau should be called to eonsider the advisability of expanding the organization, and to appoint temporary exeeutive eommitteemen to represent the home-demonstration work and boys' and girls' elub work. The home-eeonomies representative should be a prominent and influential eountrywoman of the county who seems well fitted to promote this phase of the work. The elub representative may be the eounty superintendent of sehools or other person interested in boys' and girls' elub work. At the suggestion of the home-eeonomies representative and of other interested people an influential eountrywoman should be appointed in eaeh eommunity where home-eeonomies work is to be promoted, as a temporary member of the eommunity eommittee. The same general plan should be followed in seleeting a elub representative in eaeh eommunity. The temporary exeeutive eommitteeman for home-demonstration work will eall a meeting of the eommunity representatives on home eeonomies to diseuss the agrieultural program and adapt as mueh of it to their own work as possible. Additional projeets may be seleeted and reeommendations made to the exeeutive eommittee for the appointment of additional projeet leaders to serve in a temporary eapaeity on the exeeutive eommittee until the next annual meeting of the farm bureau. If deemed advisable, plans may also be made to eonduet a eampaign to inerease the membership of women in the bureau. The plans should be submitted to the exeeutive eommittee for approval. The county eampaign should be in eharge of the exeeutive eommittee of the bureau and the eampaign in a eommunity in eliarge of the eommunity eommittee. Naturally the work will be largely delegated to the women inembers of the exeeutive and eommunity eommittees.

The eounty elub representatives should eall a meeting of the eommunity elub representatives to diseuss the agricultural and home-eeonomics program in order to determine what club work should be undertaken in the eounty. If the projeet leaders already at work are in sympathy with elub work, no additional 
projeet leader's other than the temporary projeet leader need be seleeted. The elub representative will look after the organization of elubs, ealling on other projeet leaders for needed help.

Eaeh community eommittee should meet to eonsider the advisability of expanding the eommittee to inelude the other phases of the work. Probably not all eommunities will eare to undertake the three lines of work the first year, but if additional projeets are seleeted, names of additional eommunity projeet leaders should be submitted to the president for appointment as members of the eommunity committees. The eommunity committee should deeide as to the advisability of promoting a membership eampaign in the eommunity to increase the membership of the women of the eommunity.

At the next annual meeting of the farm bureau the eonstitution should be ehanged so it will eover the new phases of the work, one program of work adopted, and officers and eommitteemen seleeted, each to be responsible for some part of the program.

\section{VOLUNTARY ORGANIZATION}

\section{FARMERS' SOCIAL ORGANIZATIONS ${ }^{1}$}

\section{KENYON L. BUTTERFIELD}

IN a word, then, a farmers' organization is a combination of a eonsiderable number of farmers, over a fairly wide area, for some large general purposes of supposed value to farmers as a elass.

Value and Need of Farmers' Organization. (1) Organization is a powerful edueational foree. If it aceomplislied no other result it would be worth all it costs. Every eoöperative effort among farmers stimulates diseussion, arouses interest in fundamental questions, makes abstraet questions eonerete and vivid, trains individuals in self-expresssion.

(2) Other elasses are organized. Business, the trade, the professions are all organized to some degree for many purposes-

1 Adapted from Bailey, L. H., Cyclopedia of American Agriculture, Vol. IV : 2S9-287. 
cultural, politieal, soeiable, industrial. It is reasonable to suppose both that these organizations flourish because they serve a human need, and that if valuable for others than farmers they will be of aid to farmers. The element of self-defense inevitably enters in also. An organization is sure to be utilized for the particular advantage of the group or class represented by it. If there comes a clash of class interests the unorganized class must suffer from the concentrated power of the group eooperation of its opponents. In the group competitions sure to arise, the farmers need the strength that organization confers, for securing legitimate group advantages, for defense against the aggressions of other groups, and for utilizing the elass strength in the general public interest. It is hardly necessary to assert that organization multiplies manifold the powers of any class of people. It was perhaps true, when the great majority of our people lived on the soil, that organization for farmers' interests was unnecessary. Now, that the farming elass is, relatively to other classes, losing ground it beeomes imperative that they shall combine their individual strength.

(3) The general tendeney of the age toward social self-direction; which is another way of stating more formally and seientifically, and which presses a little farther, the argument just advanced that farmers must organize because other classes are organized. This process is not to be out of mere imitation. Society, as a whole, is more and more the helmsman of its own fate. This is aeeomplished at present not by a unificd eampaign, by soeicty as a whole, for some distinct social goal, but by the attempts of scparate groups, often apparently antagonistic to one another, to seek group or elass interests or to endeavor to fix upon society the special idea or ideal of the group. It bceomes then necessary for the self-interest of society as a whole, as well as for the class itself, that our farmers shall seek through organization to give wing to their best ambitions for the benefit of soeiety, as well as to determine the direction which rural progress itself shall take.

(4) Organization, in the light of the social principle just enunciated, becomes then a test of class efficiency. Has a class initiative, self-eontrol, eapacity for leadership, ability to act coöperatively and fraternally, social vision, true patriotism? 
The activities of the class organization will answer the questions.

(5) Organizations tend in the same way to preserve as well às to test the social efficiency of the farming class, and hence become a vital factor in the rural problem, which is nothing more or less than the preservation and strengthening of the status of the rural people, industrially, politically, socially.

Possible Disadvantages of Farmers' Organizations. (1) They may tend to emphasize undesirable class distinctions and foster class antagonisms. It is to be remarked that, in the development of society, these group competitions are inevitable. Temporarily they may be antagonistic and rival; ultimately they can and must be supplemental, coöperative, seeking the general good. But farmers are a class. They have special interests. They simply cannot maintain their common rights unless they invoke the power that springs from class organization. The danger of undue class distinction ean be obviated by the full recognition of the fact that each soeial group or class has duties as well as rights. Farmers must be led to unite their elass power for the national welfare. This is one of the chief functions of farmers' organizations.

(2) Organizations may be unwisely led, or advocate impossible things. This is a real danger; it is not a final argument against organization. The child blunders day in and day out in its edueation. A social group is sure to do the same. It is the only road to wisdom, soeial as well as individual. Education, experience and time will tend to adjust these difficulties and minimize the dangers.

(3) There may be over-organization, and the individual may lose his identity. This is also a real danger in our day among all elasses. It is less likely to be serious among farmers because of their strong tendency to individual independence.

Difficulties in Organizing Farmers. (1) The ingrained habits of individual initiative. For generations American farmers have been trained to rely upon themselves. The farm family was for many deeades an industrial as well as a social unit, and indeed it is so to a large degree even to-day. The pioneer farmers developed some rude forms of eoöperation in the neighborhood life, but eaeh man was responsible, almost as 
mueh as is the hunter, for his own sueeess. This experienee has beeome a habit of mind not easily bent to the needs of eoöperative effort. So strong is this trait that it has produeed in many eases a type of man aetually unsoeial, unwilling as well as unaeeustomed to work with and for his fellows. Neighborhood jealousies and feuds in the rural eommunities are proverbial. Farmers seem to be extremely suspieious of others' motives. Not seldom will they refuse the primaey of leadership to one of their own elass. They have been known to repudiate the bargains of a eoöperative paet for the sake of individual temporary gain; such aetion was unsoeial rather than immoral, but it is disastrous to organized effort.

(2) Finaneial eonsiderations. Eeonomie pressure has ereated a desire to seeure finaneial relief or gain, and if coöperation would aceomplish that it would be weleomed. But too often the large view of the edueational and soeial features of rural organizations has been lost sight of, and the farmer has refused to contribute to a movement with such intangible aims and distant results. He wanted to see where even his slight investment of time and money was going to bring him its harvest. Farmers have not appreeiated what the eeonomist ealls "eulturewants."

(3) Eeonomie and politieal delusions. The history of farmers' organizations in the United States shows that the great "farmers' movements" have gained much of their power because there existed an intense belief in eertain eeonomie and politieal ideas whieh seemed to promise release from what the farmers honestly felt to be industrial bondage. These ideas strike at real evils, but in an extreme form at least proved ineffieaeious, are eonsidered by students to be intrinsieally unsound, and indeed have always been regarded by a large proportion of leading farmers as unsound. These delusions were mainly three: (a) that the middleman may be entirely abolished and that farmers as well as produeers may sell to eustomers without the intervention of a third party, and as consumers may also produce for themselves eoöperatively. (b) That unsatisfaetory business eonditions are almost wholly due to faulty legislation, and that a farmers' party is not only feasible, but 
is necessary in view of the way by which other interests have secured special legislative privileges. (c) That a satisfactory moncy can be made by government fiat.

This is not the place to discuss these questions. They are set down as delusions because as practical propositions they have not been made to work to advantage to the farmers. It must not be supposed that all farmers' organizations have urged these views, nor indeed that the majority of American farmers have believed in them. But they have all been proposed as measures of relief for real difficulties; they have never worked results permanently helpful to farmers, and they have wrecked every farmers' organization thus far that has pinned its faith to them.

(4) Lack of leadership. Organization among any large group of people means leadcrship. The farm has been prolific of reformers, fruitful in devcloping organizers, but scanty in its supply of administrators. It has had the leadership that could agitate a reform, project a remedial scheme, but not much of that leadership that could hold together diverse elements, administer large enterprises, stcer to great ends petty ambitions. The difficulties of such leadership are many and real. But it is to be doubted if the business of small farming is a good training ground for administrative leadership. At any rate few great leaders have appeared who have survived a brief record of influence.

(5) Lack of unity. A difficulty still more fundamental remains to be mentioned. The farmers of America have never bcen and are not to-day a unit in social ideals, economic nceds or political crecds. The crises that have brought great farmers' organizations into being have shown the greatest diversity of vicws as to remedies for existing ills, and in most cases there has not been in any farmers' platform sufficient unanimity about even a few fundamental needs to tide the organization over to the time when a campaign of education could have accomplished the task of unifying diverse views. 


\section{FARMERS' CLUBS ${ }^{1}$}

\section{A. D. WILSON}

\section{WHAT A FARMERS' CLUB IS}

A FARMERS' CLUB is an organization of the people in any community for the improvement of themselves, their homes, and their community. It should include in its membership the whole family, men, women, and children. Two or more families may constitute a successful farmers' club, but it is best, where possible, to include all of the people in the community. A rural school district is a suitable territory to be covered by a farmers' club. Meetings are held in the homes of the members, in town halls, or schoolhouses. There are many advantages in having the mectings at the homes of the members wherever it is practical to do so. The territory should be small enough so that all of its members can conveniently get together.

\section{ADVANTAGES OF A FARMERS' CLUB}

A good, active farmers' club will do for a rural community just what a good, active commercial club will do for a village or city, namely, it will tend to secure the united influence of the community to bring about any desired improvement, and further, it will unite the community to oppose anything that is not for its best interests. We can conceive of 110 way in which a farmers' club can be detrimental to a community, while we believe that there are at least three ways in which it may be helpful, (1) socially, (2) educationally, and (3) financially.

\section{Social Advantages}

People are essentially social beings. They are not usually happy when isolated, and do not develop properly exeept in groups. Life on the farm tends to keep people too much to themselves. A farmers' club that will bring the people together monthly or semi-monthly furnishes a very desirable change from

1 Adapted from Minnesota Farmers' Library, Vol. IV, No. 10, Extension Div., Univ. of Minnesota, St. Paul, October, 1913. 
the ordinary routine of farm life. Every one is interested in making the most of himself and his life. An important part of one's pleasure and development comes from meeting people and gaining the ability to mingle with them freely, without which olle cannot appear at his best or get the most out of life, either socially or in a business way.

One needs to get away from his own work and home and get an opportunity to see it from a different angle. As a rule, onc is better satisfied with his own conditions when he sees how others live and do. A better aequaintance with people usually results in more toleranee for their shorteomings. Many times when left to ourselves we begin to think unkindly of our neighbors, and really believe they are not what they should be. Usually a closer acquaintance and a clearer knowledge of their trials and struggles shows us that they are really better than we had thought them to be. A community in which people are intcrested in each other, know each other, and are boosting for each other and for the community, is a much better place in which to live than is a community in which there is mutual distrust. As a rulc, knowledge of one another inereases confidence. Play is an important part of one's life. Onc cannot do his best if every minute is devoted to work. Relaxation and pleasure are absolutely essential to good living. Clubs that will bring some entertainment, social gatherings, or other means of amusement into the eommunity, are very important.

\section{Educational Advantages}

A good farmers' elub may be of the greatest possible influenec in broadening the knowledge of its members. The community has more information than any one of its farmers, and the club meeting tends to give each member the benefit of the knowledge and experience of every other member.

Another valuable feature of the club and club programs is the fact that the members when ealled upon to spcak are put on record, and to maintain their dignity in the community they must live up to that record. For example: if a farmer is asked to tell how he has suceeded in raising the best calves in the community, lie will ecrtainly state the very best method 
he knows of raising ealves. After going on reeord as standing for the best methods known in ealf-growing, he eertainly eannot eonsistently do less than put into praetice on his own farm the system he has advoeated. He has established his own standard, and must live up to it.

Club Work a Stimulant to Study.-Being ealled upon to present various topies at elub meetings stimulates study. No one farm or eommunity has in it all that is good along all lines, and being foreed to study and look into what is being done in other plaees inereases the general knowledge of the eommunity and of eaeh individual therein.

Outside Talent in the Meeting.-A farmers' elub may inerease the general knowledge of its members by bringing in outside talent. Business and professional men from the nearby towns or villages ean be prevailed upon to address the elub. Speakers from the University or the College of Agrieulture and other publie institutions may be seeured oeeasionally to bring in outside ideas and inspiration.

Community Problems. $-\Lambda$ diseussion of the various problems of interest to the community always tends to stimulate every good, live eitizen to desire better things, and to make a greater effort to seeure them. Any one who has eonfidence in people and in his eommunity believes that almost all good things are possible if the neecssary effort and determination are put forth to secure them. If a elub ean sueeed in arousing in its members a desire and determination for improvement in the eommunity, better sehools, better roads, better homes, better live stoek, better farms, and better people are all possible.

\section{Financial Advantages}

Business is now done in this eountry on a large scale. Millions of dollars and thousands of people are used in great enterprises. A farmer usually deals with pcople representing business interests larger than his own. As a lule, in business enterprises he deals with men who have the advantage, simply because the transaetion means more to the farmer than to the other fellow in his wider field. For example, a potato-buyer in a eommunity may buy votatoes from 200 farmers. What is 100 per eent. of 
the farmer's business represents onc-half of onc per cent. of the potato-buyer's business. Consequently, a deal that means 100 per cent. to the farmer means onc-half of onc per cent. to the potato-buycr, and because the deal means very little to the buyer and very much to the farmer, the farmer is at a disadvantage. Exactly the same condition prevails in purchasing supplies. The farmer is handicapped because of the small amount of business he is doing. A farmer who can use two dozen selfbinders can purchase them more cheaply than the man who uses but one. The farmer who can sell many carloads of farm products of one class can get a better price for his products than ean the one who has only a wagonload or less to market.

\section{COOPERATION OR PEASANTRY}

There seems to be but two solutions to the problem of putting the farmer on an equal business basis with those with whom he has business outside of the farm. One is to increase the size of the average farm; the other is to unite the interests of several farmers owning farms of ordinary size for purposes of outside contact, in both buying and selling. The latter plan is decidedly preferable, because it does not involve the landlord and tenant or landlord and hired-help system, and makes possible the maintenance of the family-sized farm, which is probably one of our most important American institutions. Coöperation will help to make possible the maintenance of the family-sized farm, operated by its owner, longer than it can be maintained in any other way.

\section{Economy in Coöperation}

Coöperation in marketing and in buying is, we believe, essential to the economical distribution of products. Large quantities of uniformly good products can be sold much more advantageously than can smaller quantities of products, each sample of which may be good in itself but which when brought together are not uniform. When every farm was manufacturing its own butter, and each of the hundred or more farmers in the community was trying to sell butter of a different quality, the price of butter was comparatively low. Where butter is manufactured in one plant, the manager of the creamery has at his 
disposal large quantities of a uniform produet and ean sell at the best possible priee.

If the produets of a community, such as grain, potatoes, and live stock, can be made uniform by coöperation among the members of the community in production, and then these larger quantities of uniform products ean be sold by one man, the same advantages that eome to the large farmer, or have come to the dairy industry ean be seeured in other cuterprises on the farm.

\section{Club Promotes Coöperation}

A farmers' club is the logieal forerunner of coöpcration. In the first plaee, it gets the people of a eommunity acquainted and inereases the eonfidence of each in the other. This is absolutely essential to successful coöperation. In the second place, it provides a logical means for studying carefully any enterprisc that it is proposed to undertake eoöperativcly, so that impraetical undertakings are likely to be avoided. We believe the farmers' club is a vital factor in promoting eoöperation for efficiency, beeause it is not organized to defeat any particular class of people but to study intelligently any problem that may come up, and to take the action neessary to put any plan decided upon into effeetive operation.

\section{How to Organize a Club}

The organization of a elub is not complieated or diffieult. A good way to start the movement is for some onc in a community who is interested to invite two or more of his neighbors to meet at his home or some other suitable plaee. If an interesting program, ineluding singing and speaking by the young people, can be arranged, so much the better. $\Lambda$ dinner or supper should be provided, as eating together does more than any other one thing to break down reserve, formality and distrust. It is much easier to earry out a movement of this kind after a good meal has been served. The proposition should be talked over, and it is well if a eonsiderable proportion of those present have diseussed the matter beforchand, in private conversation. No one need have any fear of joining the club, becanse there is no stock sold and no possibility of loss. It is simply a mutual understanding that the people in the eommunity will take up eolleet- 
ively questions of interest to the community, instead of struggling with them individually.

\section{MEETINGS}

Meetings should be lield onee or twice a month during the winter and as frequently as possible during the summer. Meetings in the homes of the members have at least two advantages: (1) attendance is stimulated by the feeling of obligation to the host or hostess, and (2) the knowledge that the elub is soon to meet on a given farm or in its home is a great stimulus to housecleaning and decoration and corresponding outdoor aetivities.

SUGGESTED CONSTITUTION AND BY-LAWS

The following simple eonstitution is suggested as suitable, but the form of constitution is not important:

\section{Constitution}

ARTICLE I. NAME AND OB.JECT

Section 1. The name of this association shall be the Farmers'

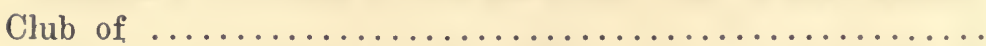

See. 2. The object of this association shall be to improve its members, their farms, and their community.

\section{ARTICLE II. MEMbershiP}

Séc. 1. Any one in good standing may beeome a member of this club by paying the annual fee of $\$ \ldots \ldots \ldots \ldots$.

See. 2. When the head of a family joins the club any member of his family may become an active member without paying additional fees.

Sec. 3. One-third of the active members shall constitute a quorum for doing business at any regular meeting.

\section{ARTICLE III. OFFICERS}

Sec. 1. The offieers of this assoeiation shall eonsist of a president, a viee-president, a seeretary, and a treasurer. They shall be ehosen beeause of their business ability rather than their popularity. 
Sec. 2. The officers of the club become the executive board and shall constitute the program committee.

Sec. 3. The executive board may call a special meeting at any time by giving three days' written notice.

Sec. 4. The officers of this association shall be elected annually, and by ballot, at the regular annual business meeting, and shall hold office until their successors have been elected and qualified.

\section{ARTICLE IV. MeEtings}

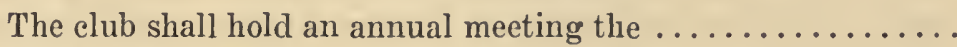
Regular meetings of this club shall be held on the $\ldots . \ldots \ldots \ldots$ of each month at the home of some member or at such place as shall be designated at a previous mecting, or by the executive board.

\section{ARTICLE V. AMendments}

This constitution may be amended at any regular meeting by a two-thirds vote of the active members.

\section{$B y$-Laws}

Section 1. The duties of each officer named in the constitution shall be such as usually pertain to his position.

Sec. 2. All other duties shall be performed by the executive and program committees.

Sce. 3. The club shall aid and further business associations among its members; particularly such associations as pertain to the purchase of necessary supplies, and the purchase and management of live stock and agricultural and garden products.

Sec. 4. From time to time tlic elub shall give entertainments and loold meetings under direction of the program committee, for the benefit of its members and of those whom they may invite to attend.

Sec. 5. Any members, after due hearing, may be expelled from the club by a majority vote of active members at any mecting, without a refund of dues.

See. 6 . These by-laws may be amended at any regular meeting by a majority vote of active members upon one month's written notice. 
FORM OF PROGRAM AND ORDER OF BUSINESS

1. Meeting called to order by presiding offieer

2. Instrumental musie or a song by the club

3. Roll eall of members by the secretary

Responses should take some other form than the mere word "present." The program eommittee or the president should previously designate the topic of response for roll eall. The responses should be entertaining and instruetive, but not too long. The following topics may be suggestive:

What I Have Done for the Club Sinec the Last Meeting

How I Have Added to the Value of my Farm This Season

What I Consider my Most Profitable Crop

4. Reading and approval of the minutes of the last meeting

5 . Reeitation by one of the younger members

6. Diseussion of timely farm topics led by a elub member or some other speaker, followed by questions and a general diseussion

7. Reading or music

8. Discussion of another farm or household topie illustrated by a demonstration if possible

9. Question box. Timely and practical questions should be previously prepared by members and placed in the question box. Each question should be read and answered separately, the president ealling upon some member or members to answer them.

10. A "For Sale" and "Wanted" box may also be provided. A member having somethirg for sale or wishing to buy or hire something should list the same on a slip of paper, sign his name, and place it in the box. These slips should all be read at some time during the meeting. An exchange of these lists between elubs will be mutually helpful.

11. Reading of program for next meeting

12. Report of exeeutive committee

13. Unfinislled business

14. New business

15. Closing exercises and adjournment

If desirable, the program may be divided into two parts by an intermission. Readings and reeitations may be of a humorous 
nature to add life to the program. Variety is essential, and whenever possible a diseussion of woman's work should be made a prominent feature of the program.

It may frequently be advisable to limit the time devoted to the diseussion of eaeh topie, espeeially if speakers are likely to waste a great deal of time. Matters pertaining to the welfare of the elub and the mutual benefit of the members should be given eonstant thought. Debates may be held oeeasionally to interest the young people. Where elubs inelude the entire family in the membership, a basket luneh will add to the interest in the meeting, but it should be simple so as not to be a burden to the house-wives.

The main point to eonsider is that there should be a good, live, snappy meeting. Short, pointed talks followed by general discussions are very mueh better than long talks. Musie, humorous recitations or readings, and topies of general interest, as well as the more serious business problems of the eommunity, should be given a plaee on the program. The monthly topies furnished by the Agrieultural Extension Division, University Farm, St. Paul, will be found helpful in preparing the program.

\section{WORK TO DO}

No organization can exist very long unless it is doing something. From the start the elub must be made of value to the eommunity soeially, edueationally, or finaneially, and in any event some one must do some work. As a rule, those who do the most for the elub get the most out of it. The regular neetings, if made interesting, will be made valuable soeially and edueationally. Every elass of people in the neighborhood or in the elub membership should be eousidered on the program. Wholesome entertainment is often as important as profitable business.

\section{Pacemakers}

A few elubs have adopted a plan of appointing paeemakers or speeialists along the various lines of interest in the eommunity. The following list is suggestive as to lines of work and methods of proeedure: 
Road-Builder.-When chosen, it shall be the duty of the roadbuilder to spread the gospel of good roads in as many ways as possible. He should be prepared to answer all road questions that may eome up at elub meetings or at other times. He should endeavor to set a good example by attention to all highways adjaeent to his farm.

It is suggested that he, in conjunetion with the other club members, designate two or three miles of adjacent highways for demonstration purposes, and endeavor to make it as good as possible.

Corn Crank.-The selection of the corn erank should be made with a view to getting some one who is enthusiastie for corn, and who has made a marked suecess in corn growing. $\mathrm{Hc}$ should be authority on the varieties to be planted; the preparation of the seed and the land; the planting; and the subsequent eultivation. He should have a corn-breeding plat, or at least a seed-eorn plat. His field of eorn should be a model in every way, and a tribute to the locality.

Flower Queen.-The selcetion of a flower qucen should be made with a view of having some one well informed in the culture of flowers. She should be qualified to answer questions coneerning this work, and to make her home flower garden a demonstration of the possibilities in flower culture. She should be capable of giving advice as to varieties practical for farm growing, and easy to grow. She should also be able to advise regarding the purchase of seed, and might well arrange to get up elub orders for seeds.

Dairy Wizard.-The man scleeted for dairy wizard should be a man who has a dairy herd and ample opportunity to demonstrate methods and possibilities. He should be well informed about dairy praetices, and if possible should arrange to keep a daily reeord of each cow in lis herd.

Alfalfa Shark.-The alfalfa sliark should grow a field of alfalfa, should eneourage its growth by others, and should make himself an authority on its culture, euring, and use in his community. He should adopt the slogan, "An aere or more of alfalfa on every farm," and should preach alfalfa in season and out of season.

Potato King.- When elected, the potato king is expected to 
set the pace as to varieties to plant, preparation of the land, storing and preparation of the seed, time of planting, eultivating, harvesting, and marketing. In faet, he is to be the elub's souree of potato information, and his field should be a demonstration of what may be done with potatoes in the loeality.

The Booster.-The booster should earry the responsibility of arousing eommunity spirit; of devising various ideas that will arouse elub members to eommunity action; and of fostering such movements as tend to attract the public to the eommunity and to the elub.

Poultry-Keeper.-The poultry-keeper should be some man or woman who is an enthusiast on poultry. His duties should be to maintain an up-to-date poultry plant, and to be informed on the general eare, management, and improvement of poultry.

Business-Getter.-The man ehosen for business-getter should be espeeially qualified along business lines. IIis dutics should be to look after the marketing problems of the elub, and to see what steps could be taken to enable the elub meinbers to get their supplies most eeonomieally.

Home-Maker.-The position of home-maker slould be filled by some woman in the elub who is a suecessful home-maker and who can spend some time in promoting the idea of better homes in the eommunity.

It is proposed that eaeh elub arrange to select several pacemakers, and that eaeh paeemaker plan to earry on some demonstration along his line of work. The Agrieultural Extension Division will assist eaeh paeemaker in planning his duties and lis demonstration work. It is suggested further that the elub arrange for a demonstration day, at whieh time the Extension Division will furnish speakers, the paeemakers will present reports, and a general inspection will be made of the demonstrations and the elub work.

It would be entirely practieal to ehoose as many pacemakers as there are members of the elub, assigning to each one some partieular phase of the eommunity aetivity in whiel he is espeeially qualified. Each of these paeemakers, by speeializing on one subjeet for a few months or for the year, would really beeome very profieient in that line and be able to be of great help to other members of the club. These paeemakers should be ready 
at all times to take part in the program and present briefly some development in their particular line of work. This plan has been found to help very mueh in getting up good, live programs.

\section{COOPERATIVE EFFORT FOSTERED}

Some of the following undertakings may well be fostered by the farmers' club. The producers in a eommunity should decide on one variety of potatocs or other market crop to produce, and then find some way of marketing it jointly. One or two leading breeds of eaeh kind of live-stock should be adopted by the elub. Purc-bred sires may be purehased and used coöperatively, to the advantage of every one. Fecd, flour, cement, and other supplies that ean be handled in large lots, may be purchased coöperatively, usually at a eonsiderable saving.

The question of organizing a live-stoek shipping association is worth considering where live-stoek is an important faetor. Home conveniences and a beef club for supplying fresh meat should be eonsidered. When dairying is important, the organization of a cow-testing association is valuable. In any neighborhood, eommunity effort along the line of road improvement is worth very eareful consideration. Such matters as organizing a creamery, cheese factory, or farmers' elevator, the purehase of a stallion, or the introduetion of a general drainage system for the eommunity, should be considered by the elub and acted upon only after all the faets in the case are known. One of the latest attempts of a farmers' club is to organize a coöperative laundry in connection with a eoöperative ereamery. In short, every enterprise connected with the farms, homes, or sehools may be profitably considered by the club.

\section{DECLARATION OF PURPOSES OF THE PATRONS OF HUSBANDRY ${ }^{1}$}

PREAMBLE

Profounduy impressed with the truth that the National Crange of the United States should definitely proclaim to the world its

1 From a pamphlet issued by the Grange. 
general objects, we hereby unanimously make this Declaration of Purposes of the Patrons of Husbandry:

GENERAL OB.JECTS

1. United by the strong and faithful tie of Agriculture, we mutually resolve to labor for the good of our Order, our eountry and mankind.

2. We heartily endorse the motto "In essentials, unity; in non-essentials, liberty; in all things, eharity."

\section{SPECIFIC OBJECTS}

3. We shall endeavor to advanee our eause by laboring to accomplish the following objects:

To develop a better and higher manhood and womanhood among ourselves; to cnhanee the comforts and attractions of our homes, and strengthen our attachments to our pursuits; to foster mutual understanding and coöperation; to maintain inviolate our laws, and to emulate each other in labor, to hasten the good time eoming; to reduee our expenses, both individual and eorporate; to buy less and produce more, in order to make our farms self-sustaining; to diversify our erops and erop no more than we can eultivate; to eondense the weight of our exports, selling less in the bushel and more on hoof and in flecee; less in lint, and more in warp and woof; to systcmatize our work and ealculate intelligently on probabilities; to diseountenanec the eredit system, the mortgage system, the fashion system, and every other system tending to prodigality and bankiruptey.

We propose meeting together, talking together, working together, buying together, selling together, and, in general, aeting together for our mutual protection and advaneement, as oecasion may require. We shall avoid litigation as much as possible by arbitration in the Grange. We shall constantly strive to secure entire harmony, good will, vital brotherhood among ourselves, and to make our Order perpetual. We shall earnestly endeavor to suppress personal, local, sectional and national prejudices, all unhealthy rivalry, all selfish ambition. Faithful adherence to these principles will, insure our mental, moral, social and material advaneement. 


\section{BUSINESS REL.ITIONS}

4. For our business interests, we desire to bring producers and consumers, farmers and manufacturers into the most direct and fricndly relations possible. Hence, we must dispense with a surplus of middlemen, not that we are unfriendly to them, but we do not need them. Their surplus and their exactions diminish our profits.

We wage no aggressive warfare against any other interests whatever. On the contrary, all our acts and all our efforts, so far as business is concerned, are not only for the benefit of the producer and consumer, but also for all other interests that tend to bring these two parties into speedy and economical contact. Hence, we hold that transportation companies of every kind are necessary to our success, that their intcrests are intimately connected with our interests, and harmonious action is mutually advantageous, keeping in view the first sentence in our declaration of principles of action, that "individual happiness depends upon general prosperity."

We shall, thcrefore, advocate for every state the increase in every practicable way of all facilities for transporting cheaply to the seaboard, or between home producers and consumers all the productions of our country. We adopt it as our fixed purpose to "open out the channels in nature's great arteries, that the life-blood of commerce may flow freely."

We are not cnemies of railroads, navigable and irrigating canals, nor of any corporation that will advance our industrial interests nor of any laboring classes.

In our noble Order there is no communism, no agrarianism.

We are opposed to such spirit and management of any corporation or enterprise as tends to oppress the people and rob them of their just rights. We are not enemics to capital, but we oppose the tyranny of monopolies. We long to see the antagonism between capital and labor removed by common consent, and by an enlightened statcsmanship worthy of the ninetcenth century. We are opposed to excessive salaries, high rates of interest, and exorbitant profits in, trade. They greatly increase our burdens, and do not bear a proper proportion to the profits of producers. We desire only self-protection, and the protec- 
tion of every true interest of our land, by legitimate transaetions, legitimate trade and legitimate profits.

\section{EDUCATION}

We shall advanee the eause of edueation among ourselves, and for our ehildren, by all just means within our power. We espeeially advoeate for our agrieultural and industrial eolleges that practieal agrieulture, domestie seience and all the arts which adorn the home, be taught in their courses of study.

\section{THE GRANGE NOT PARTISAN}

5. We emphatieally and sineerely assert the oft-repeated truth taught in our organic law, that the Grange-National, State or Subordinate-is not a politieal or party organization. No Grange, if true to its obligations, ean diseuss partisan or seetarian questions, nor call political conventions, nor nominate eandidates, nor even diseuss their merits in its meetings.

Yet the prineiples we teach underlie all true polities, all true statesmanship, and, if properly earried out, will tend to purify the whole political atmosphere of our eountry. For we seek the greatest good to the greatest number.

We must always bear in mind that no one, by beeoming a Patron of Husbandry, gives up that inalienable right and duty whieh belongs to every Ameriean eitizen, to take a proper interest in the polities of his eountry.

On the eontrary, it is right for every member to do all in his power legitimately to influenee for good the aetion of any politieal party to which he belongs. It is his duty to do all he ean to put down bribery, eorruption and triekery; to see that none but eompetent, faithful and honest men, who will unflinehingly stand by our interests, are nominated for all positions of trust; and to have earried out the prineiple whieh should always eharaeterize every Patron that

THE OFFICE SHOULD SEEK THE MAN, AND NOT THE MAN THE OFFICE.

We acknowledge the broad prineiple that difterenee of opinion is no erime, and hold that "progress toward truth is made by differenees of opinion," while "the fault lies in bitterness of controversy." 
We desire a proper equality, equity and fairness; protection for the weak; restraint upon the strong; in short, justly distributed burdens and justly distributed power. These are American ideas, the very essence of Ameriean independence, and to advoeate the contrary is unworthy of the sons and daughters of an Ameriean republic.

We cherish the belief that sectionalism is, and of right should be, dead and buried with the past. Our work is for the present and the future. In our agrieultural brotherhood and its purposes we shall reeognize no North, no South, no East and no West.

It is reserved by every Patron, as the right of a freeman, to affiliate with any party that will best carry out his principles.

\section{OUTSIDE COOPERATION}

6. Ours being peeuliarly a farmers' institution, we can not admit all to our ranks.

Many are excluded by the nature of our organization, not beeause they are professional men, or artisans, or laborers, but beeause they have not a sufficiently direct interest in tilling the soil, or may have some interest in eonfliet with our purposes. But we appeal to all good eitizens for their cordial coöperation and assistance in our efforts toward reform, that we may eventually remove from our midst the last vestige of tyranny and eorruption.

We hail the general desire for fraternal harmony, equitable compromises and earnest coöperation, as an omen of our future suceess.

\section{CONCLUSION}

7. It shall be an abiding prineiple with us to relieve any of our oppressed and suffering brotherhood by any means at our eommand.

Last but not least, we proclaim it among our purposes to inculeate a proper appreciation of the abilities and sphere of woman as is indicated by admitting her to membership and position in our Order.

Imploring the continued assistance of our Divine Master to guide us in our work, we here pledge ourselves to faithful and 
harmonious labor for all future time, to return by our united efforts to the wisdom, justice, fratcrnity and political purity of our forefathers.

\section{E. POLITICAL ORGANIZATION}

\section{THE NATIONAL NONPARTISAN LEAGUE ${ }^{1}$}

(Beginning in North Dakota as a movement of farmers, an association now calling itself the "National Nonpartisan League" is attracting wide attention in the field of politics and economic legislation. We present herewith an article explaining and supporting the novement, and a briefer one from the standpoint of tlose who oppose it. Both articles are written by editors of ability and much experience. Mr. John Thompson was for eight years connected with the New York Times and for an equal period the Managing Editor of Pearson's Magazine. He has recently gone to St. Paul and become actively connected with the Nonpartisan League. Mr. IV. H. Hunter, who criticizes the League, is Managing Editor of the Minneapolis Tribune. He has had wide newspaper experience, having been Managing Editor of the Washington (D. C.) Post, and having held similarly important positions in a number of the leading newspaper offices of the western cities. Mr. Hunter is honest in opposing the Nonpartisan League as dangerous and reckless in its socialistic program, while Mr. Thompson is honestly supporting it as a beneficent movement.-THE EDIToR.)

\section{THE LEAGUE'S WORK IN THE NOR'THWES'T}

\section{JOHN THOMPSON}

The Nonpartisan League was formed in North Dakota in the spring of 1915. The grain buyers had instituted and controlled a marketing system of great injustice to the farmers. The politicians, controlling the State machinery, had refused to permit the votes of the people to change the system. The league was formed to overcome these things and to give to the farmers of the States fair marketing facilities.

\section{ABUSES IN GRADING AND DOCKAGE}

The principal product of North Dakota is wheat. Wheat for selling is classed into grades. The grading for North Dakota and for the whole Northwest had been done by the grain

1 Adapted from Revicw of Reviews, Vol, 57, 397-401, April, 1918. 
exehanges-in short, by the buyers. It has been shown that between September, 1910, and August, 1912, the terminal elevators at Minneapolis reeeived 15,571,575 bushels of No. 1 Northern Wheat, and that during that same period these same elevators shipped out 19,978,777 bushels of the same grade. The elevators had no wheat of this grade at the beginning of the period, but they did have 114,454 bushels at the end.

During the same period these elevators received 20,413,584 bushels of.No. 2 Northern and shipped out $22,242,410$ bushels.

Thus the elevators shipped out more than $6,000,000$ busliels of the two higher grades, Nos. 1 and 2, for whieh they never paid the price for those grades. What happened is this: The elevators graded the farmers' wheat down to 3 and 4 when they were buying it; when they were selling it, more than $6,000,000$ bushels that had been bought as 3 and 4 were sold as 1 and 2 . The lower grades brought priees from 2 to 12 eents per bushel less than the higher grades. On examination, statistics show similar results in otler years.

Doekage in grain is another effeetive way in which the farmers were robbed of their crops. There has been a doekage valuation of $\$ 30$ and $\$ 35$ on every 1000 bushels of wheat. The farmer pays the freight; and it has been shown before a Minnesota Legislative Committee that for more than ten years a freightage overcharge totaling about $\$ 5,000$ a month has been colleeted as switehing eharges. In short, grading and dockage had eost the farmers of North Dakota alone millions of dollars every year.

TO NORTH DAKOTA FARMERS: "GO HOME AND SLOP THE PIGS"

The farmers of North Dakota thought that the public ownership of elevators would help them to get fair marketing faeilities. They tried for ten years through ordinary politieal eliannels to get the State to build elevators. Twice the State legislature, under the pressure of the farmers, instituted amendments to the constitution permitting the State to build elevators.

Twice the people of the State, by an enormous majority eaeh time, eonfirmed the proposed amendment. Twiee the maehinery of the State government refused to obey the people's will. The last refusal was during the legislative session of 1915 . Hundreds of farmers went to the State Capitol in an effort to 
impress upon the lawmakers the sentiment of the people of the State. They were told to "go home and slop the pigs." The politicians said that they knew what was good for the farmer -he didn't; let him do what he knew how to do--"slop the pigs."

\section{A LEAGUE WITHOUT "POLITICS"}

Then A. C. Townley suggested that the farmers take control of the state maehinery-they being the majority of the people of the State. He suggested that the farmers organize themselves into a league without politieal partisanship, for the purpose of taking control of the state maehinery. They organized the Nonpartisan League of North Dakota. At the following election the league east 87,000 out of 110,000 votes. It elected every state offieer except one. It eleeted a majority of the Legislature. The farmers of North Dakota are now in a fair way to get proper marketing faeilities.

The injustice in marketing farm produets does not apply to North Dakota only. It applies to every State in the Union. In North Dakota, it is a matter of wheat; in Texas, it is a matter of eotton. In each of these States, and in every other State, the price of the farmers' produets is fixed by the buyers. In no State is the farmers' cost eonsidered. It is the buyer's business to buy as eheaply as he ean, and he does it. The problem for the producer is always the same.

\section{ORGANIZATION IN THIRTEEN STATES}

The producers in neighboring States, observing what North Dakota has done, deeided to do the same thing. They asked Mr. Townley and the men who had organized the Nonpartisan League in North Dakota to organize in their States. So the idea spread. The Nonpartisan League of North Dakota became the National Nonpartisan League. It is organized, or is organizing, in thirteen States-Minnesota, North Dakota, Wiseonsin, South Dakota, Montana, Idaho, Washington, Colorado, Nebraska, Iowa, Kansas, Oklahoma, Texas.

The method of organizing the league is to send men from farmer to farmer, who explain to them the purpose of the league. Before the faimer joins he understands its whole pur- 
pose. When lie understands the purpose he joins. He sees where it benefits lim. This eomprehension by the farmer of just what the organization means to do is the precise reason why the political opponents of the league ean have no influenee upon the farmer after he has joined. The farmer knows what he has done, and he knows why he has done it. He is fortified against the fallacious arguments of partisan politieians.

\section{PUBLIC OWNERSHIP THE CORNERSTONE}

The basis of the league idea is publie ownership. Publie ownership of public nceessities will mean fair marketing facilities for the produeer. It will mean fair purehasing faeilities for the consumer. The purpose of a man handling farm produets on their way from the field to the table is to make money. The produets are liandled by various men and each man makes his profit. Some of these men are entirely unneeessary to proper distribution.

The league's plan is for the publie-the State-to build, own and control the facilities for carrying products of the farm to the eity, at the cost of earrying it. The purpose of these Stateowned facilities will be to store and transform raw food into eatable food, at the cost of transformation. Thus the great spread between the price the producer gets and the price the consumer pays will be reduced. Undoubtedly the producer of the raw food will get more for his product. He should get more. He must get more. He must get enough to make farming profitable, or he must quit farming.

Transforming raw food into eatable food at cost, eliminating all useless handling and useless profits, eertainly means that the eatable food reaches the eonsumer at a lower price than it now reaches him. The same process, . when applied to the produets of the city worker, means that the farmer will buy his supplics at lower prices than he now pays. Neither the eity worker nor the farm worker will have to pay the profit upon profit that he now pays for so many useless handlings. The thing is perfectly simple. It is so simple that the political opponents of the league do not attack it. 


\section{LEADERS ATTACKED FOR "DISLOYALTY"}

Politicians, of eourse, do attack the National Nonpartisan League. They see that the league is about to take control of States other than Nortl Dakota. They do not like this. They sce that they cannot break down the league's principles. They have to break the league down in some way, however, or they will cease to eontrol. So they attaek its leaders. They call them names. They say they are "erooks" and "Socialists." They have even eliarged the league with being disloyal to the United States Goverument.

The eharge seems to have been founded on certain thoughts expressed last spring by league men as to the conduct of the war. These are the thoughts:

Profiteering should be eliminated.

When the price of wheat was fixed it was urged that the priee of all necessary eommodities be fixed in proportion.

It was urged that a definite statement of war aims be made, and what those aims should be was suggested.

It was urged that the prineiples of man conseription be applied to wealth; that the war be finaneed, first, from the pockets of the men best able to spare the money.

\section{RE.ALLY WITH PRESIDENT WILSON}

Now observe:

The National Government is doing all that it can to eliminate profitecring.

It is also urging upon Congress that prices be fixed on all necessary commoditics.

The President has stated our war aims, and his statement does not differ materially from the aims suggested by the league.

Thus, three of the four thoughts for which league men have becn called disloyal are also the thoughts of the national Administration. The fourth, wealth conscription, has been urged by many prominent men who liave not been ealled disloyal. The fact is that in the matter of the war the National Nompartisan League stands squarely with President Wilson. 


\section{THE NORTH D.IFOTA PROGRAM}

The accomplishments of the league in a political way have been the eapture and control of the State of North Dakota. The main program of the league for North Dakota-Statc-built clevators and flour mills-has not yet been accomplished, because at the last election twenty-four State Senators were not up for clection. At the legislative session these twenty-four hold-over Senators suceceded in preventing amendments to the State constitution that would have permitted the State to build elcvators and flour mills at once. These twenty-four hold-over Senators will be up for election in November. They will not hold over. At the same elcetion the necessary amendments to the Constitution will be initiated by the people.

Much legislation, however, beneficial to the State was enacted. Executive acts of the State officers have been of even more benefit. Economic accomplishments have resulted entirely from political accomplishments.

A grain-grading commission has been formed.

Rural schools have been standardized. Rural schools have been given better teachers. They are having better attendance and better health.

An inheritance tax was levied on large fortunes.

Votes were given to women.

Money was appropriated for experiments at the Agricultural College, by which it has becn proven that low-grade wheat at 70 cents per bushel was worth, for making flour, pound for pound, as much as high grades selling at $\$ 1.70$ per bushel.

New taxation classifications were adopted, which reduced the rate for improvements upon farm lands and passed part of the burden of taxation on to the corporations that had been dodging taxation since the beginning of time.

A dairy commission was provided.

A licensc system for creameries was established.

Guarantee of bank deposits was provided for.

A welfare commission was created.

In all, thirty-two remedial steps were taken for the benefit of the peoplc of the State. Briefly, it is estimated that each 
farmer has saved, under the present State management, from $\$ 800$ to $\$ 1,000$.

\section{TIIE NATIONAL PROGRAM}

The National Nonpartisan League, or some other organization embodying the ideas that are its basis, will control the United States. There is no way to stop it, for the simple reason that people cannot be prevented from thinking. As people think they see the justice of the thing and what it means to themselves. As they see that, they adopt it. The war is making people think faster than ever. If public ownership and eontrol is good for a nation at war, it is good for a nation at peace. The people see that publie ownership of public necessities is an absolute requirement of a life seheme that will give eaeh man a chanee to live healthfully, properly to educate his ehildren, and to have some of the little enjoyments of life.

To that end the National Nonpartisan League will have eandidates for State and national office in those States in which organization has reaclsed the point where the members want to endorse eandidates. Indications seem to point to the eleetion of from fifteen to twenty Congressmen this year.

The most signifieant indication observed at the offiee of the Nonpartisan League at this time is the great interest in the movement shown by the people in States in which the League has made no effort to organize. In the national headquarters luundreds of letters are reeeived every day asking for information. These letters do not all come from farmers. The fact is that the greater part of them are now coming from industrial centers. The industrial worker sees that the league's plan for providing proper marketing facilities will benefit him just as mueh as it does those who produce the food.

Experience has shown that little benefit for the eommon people can be obtained exeept through eontrol of politieal maehinery. 'This principle applies to the national government just as it does to State government. The national Congress has taken more steps for the protection and interests of business enterprises than it has for the protection and interests of the majority of the people. This is due largely to the faet that business enter- 
prises have control of political power. The men who have been elected have felt in some measure that they owed their election to business enterprises. A man naturally will respect the interests of the person to whom he owes his position.

The National Nompartisan League is now eomposed. of farm workers. Industrial workers are showing an intense interest in it. These workers form the majority of the people of the United States. The politieal eoalition of these workers means politieal power for them. They will send men to Washington who owe their election to them. These office-holders will respond to the interests of those who sent them to Washington. The result will be legislation beneficial to the majority instead of to the few. It eannot be otherwise. That is the broad purpose of the National Nonpartisan League.

\section{WHY THE LEAGUE IS OPPOSED}

W. H. HUNTER

THE eardinal count in the indietment against the National Nonpartisan League, on which its managers and promoters are seeking a verdiet of "not guilty" by a jury of the publie, is disloyal leadership.

Political leaders of the League, than whom the eountry has produced no shrewder or more resourceful, are contending that the farmer is down-trodden and oppressed, that every man's hand is against him and that for his own salvation his hand must be against every man. They have sought to embitter the farmer against bankers, grain-dealers, elevator-operators and millers and to ally the laboring men of the cities with the farmer by the contention that this is a "rich man's war and a poor man's fight," that while the farmers and laboring men are bearing the brunt of the fighting, the manufaeturers and business men generally are piling up wealth, through munitions-making and profiteering.

It is ostensibly to protect the farmers against this kind of oppression that the National Nonpartisan League has organized in a half-dozen States in which farmers are in the majority, and the fallacy of the contention is plain on the face of it. The 
farmers are in a healthy majority in North Dakota, South Dakota, Minnesota, Nebraska, Kansas, Iowa, Montana, and in cvery State in which the League is aetive. The history of these States, from the days of the Ocala platform down to the last eleetion, shows that the farmers have never failed to have their rights reeognized and their wrongs redressed by legislative action. They are and have always been in the majority in these States, and the elaims of the League leaders to-day assume the form of a plea by the majority to be proteeted from the wiles and machinations of a wieked minority.

The cuttlefish when attacked sheds ink to becloud the waters and elude pursuit. The League leaders are playing the rôle of political cuttlefish just now and trying to beeloud the politieal waters by claiming that the wicked interests are trying to prevent the farmers from organizing. There is not and has not been anywhere in Minnesota or the Dakotas the slightest opposition to farmers' organizations. The opposition to the Nonpartisan League, an opposition that in Minnesota is assuming menaeing form, is caused, not by the organization of farmers, but by the seeret or open disloyalty of leaders of the League. The line is being elosely drawn in Minnesota between the loyalists and the disloyalists, and no less a person than the Governor of the State, J. A. A. Burnquist, elected by farmers' votes and by the largest majority ever given a Governor of the State, has openly plaecd the leaders of the National Nompartisan League in the disloyal class. The president of the League is under indictment in two Minnesota counties for obstructing the draft. The manager of the League has been convieted of a like offense, and other organizers and representatives of the League have been charged with obstrueting the draft.

\section{BUSINESS INTERESTS SCENT SOCIALISM}

It is true that the business interests, both big and little, of the Northwest are opposed to the Nolpartisan League and fear it. This opposition and fear are based on the League's record in Nortl Dakota, where only the existenee of a hold-over State Senate, not clected by the League, prevented North Dakota from going "whole hog" into the experiment of a Soeialist State government. The League attempted to adopt a new constitution 
for North Dakota by aet of the legislature, instead of by vote of the people. It proposed to remove the limit of indebtedness that might be ineurred by the State or any politieal division thereof. It proposed to exempt farm improvements from taxation and to authorize the issue of eurrency by State banks. It proposed State ownership of flour mills, terminal elevators, railroads, paeking houses and to allow the State to engage in any and all forms of business and industry. It proposed that "three bona fide farmers" should be eleeted to the Supreme Court of the State. It proposed State Socialism on a seale never before attempted in this eountry and never attempted anywhere exeept quite reeently by Lenine and Trotzky in Russia.

Objeetion has been offered, also, by the business interests against the plan of a ehain of eoöperative stores and banks, proposed by the League leaders and for which more than $\$ 1,000,000$ have been subseribed by the farmers who have no voice in the eontrol of these enterprises, no share of dividends and no eontrol of funds, but who have the privilege of trading at such stores "at eost, plus 10 per eent.," for eash. The League is opposed also beeause its leaders are avowed Socialists and in favor of applying the most radieal Soeialistie theories to the government of the States in which they secure eontrol.

\section{SOME OF THE DEMANDS REASONABLE}

But these questions ean be fought out in peace times, just as the fallacies of the Farmers' Allianee and the Populist party were rejeeted and the meritorious measures adopted by the legislatures of those days. No one contends that all of the elaims of the Nonpartisan League are unjustified. Some. of them are just and must be reeognized by legislative aetion. The diffieulty with the farmer to-day is that, beeause of the abolition of party lines through the nonpartisan primary laws, in foree throughout the Northwest, he feels the laek of leadership, the need of organization through which to make lis appeals and demands for legislative aetion. With every politieian for himself, no responsibility anywhere, the farmer, who is naturally a eonservative, is foreed to turn to radieal leaders who want to lead him into the mire of Soeialism. 


\section{"POOR TRAY"}

Keep this honest farmer in mind; see into what company he is drawn when he rallies to the standard of the National Nonpartisan League. Hundreds of meetings called by that organization in Minnesota have been suppressed and the organization has been barred from holding meetings in many eounties beeause the sheriffs and loyal citizens have beeome convinced that such meetings, if permitted, would end in riot and blood-

- shed. This is not at the dictation of "Big Business." These meetings have been banned by the sheriffs and other peace officers eleeted by the votes of farmers, by men who know their neighbors and know where they stand on war questions. The meetings have been banned because whenever one has been permitted, it has served as a rallying center for professional pacifists, every pro-German for miles around, for I. W. W. preachers of sabotage and for Socialist spell-binders openly opposing the draft. These same Soeialists, who have been active in helping the League leaders, have nominated for Governor of Minnesota a man who has bcen convieted for obstrueting the draft and a candidate for State Senator who is under conviction for seditious utterances, and they were nominated on a platform which demanded the repeal of the draft act, endorsed the Russian Bolsheviki, expressed sympathy and support for the I. W. W. leaders under indictment at Chicago, and demanded the immediate withdrawal of our forces from France.

\section{F. COMMUNITY ORGANIZATION}

\section{HOW TO ORGANIZE A COMMUNITY}

E. I. MORGAN

IT is impossible to set up any one particular way of organizing a eommunity and expect it to work in every detail in all parts of the state. The thing needed is for the town to get clearly

1 Adapted from "Mohilizing the Rural Community," The Massachusetts Agricultural College, Extension Service, Extension Bnlletin No. 23, Amherst, Sept., 1918. 
in mind the idea that the most efficient method must be used, and, owing to varying local conditions, each community lias its own starting point at which the beginning must be made, that it is only through coöperation and united action that agriculture and community life are going to be developed and that the goal to be attained is the community united and working together in the carrying out of a defiuite, practical, long-term plan of development along those lines of greater interest.

The most successful communities have found the following principles to be indispensable in their development:

1. In any redirection of 'rural interests the community is the natural unit of activity.

2. The progress of the rural community represents one problem and one only. This problem has a number of phases but they are all parts of the whole and must be dealt with as such if substantial progress is to be made.

3. Improvement plans must be based on actual farm and village conditions. They must be based on facts-guessing must bc eliminated.

4. Those things by which the people live must be adequately organized if substantial community progress is to be brought about. These are usually expressed through local organizations, unorganized group interests, or both. This does not mean that something new must be organized. It means that the various elements of the community must get into the best possible working relation to each other so they will become an harmonious working unit-the team work idea.

There are three forms which have been used in this State, each one applying to different conditions. The first two are thought of as stepping stones toward the third.

1. The Local Leader. There are many towns in which there is very little interest in matters of progress. In these cases about the only possibility lies in the efforts of a few local leaders to awaken gencral interest by bringing about some special events which will be sufficiently interesting to creatc a desire for somcthing of a more permanent naturc. In some towns a teacher, minister, farmer, or doctor lias been the local leader and by working through the school, church, grange, or farmers' club has produced valuable results. Some of these results have been: 
A farmers' institute.

A community day.

Pure-bred livestock improvement.

Community celebrations-Christmas, July 4th, Thanksgiving. Plays and pageants.

A publie forum.

A town agrieultural fair and cxhibit.

The kecping of farm aecounts.

Home and publie grounds improvement contest.

The Group Plan. In every town there are people whose interests are the same and who ean work together for partieular improvements with the eommunity idea in mind before it is possible to get the town as a whole together on a larger and more thorough development plan. This is called the group plan of work. It differs from the first in that it is not usually done through existing organizations but often results in the forming of a new organization for some speeific purpose. Like the first plan, it should be thought of as a step toward the larger and more eomplete eommunity development. Some things that have been done under this plan are:

Formation of a farmers' eoöperative exchange for buying and selling. The third year business amounted to $\$ 21,000$.

Organization of a home makers' elub direeted by the women's scetion of the farm bureau.

Starting of a eow test association.

Organization of a coöperative ereamery.

Formation of a loeal breeder's' assoeiation.

3. The Community Council. As has been stated, the two plans just mentioned should not be thought of as the end. They are good, in and of themselves, and well worth doing, but let us not lose sight of the faet that the work to be done requires an all-around eommunity devclopment. It may be necessary to do these speeifie pieees of work but let us think of them as a part of the preparation for a eomplete organization of the community. We believe the following to be the more complete plan. It is the result of several years' trial in this state and lias becn an evolution born of the experienee of eommon folks. It will 
always need to be adapted to local conditions but the principles are the same. The steps usually taken are:

1. Conference of a Few. Some local leader should eall together onc representative from each local organization or group and a few at large to consider: (a) The possibilities of and benefits to be derived from a general get-together for definite planning of the future of the community. (b) Whether the town cares to put in the neccsary time, moncy and brains to produce results or whether it prefers to let "well cnough" alone and let the future take care of itself. At this time it is best to have some one present from the Farm Burcau or Agricultural College to tell of the success of other towns and make clcar the necessary steps.

2. Orginizition Representitives. These representatives should report to their respective organizations, each of which should appoint one permanent representative to become a part of the joint committec or council of organizations. There should also be chosen three or morc members at large. This council is not another organization. It is merely the coördination of all local interests for united action.

3. The First Work. There are three specific things which a community council should do at first:

a. Bring about a thorough understanding among the various local organizations as to just what each is doing, viz.: Get a statenient of the present purpose of each organization. Exchange plans of work for the next six inontlis.

Work out a calendar of gatherings of every sort for the next six months. Arrange these chronologically so that conflicts may be avoided.

b. Take up any specific items of community interest which should receive immediate attention.

Consider special problems in agriculture or community life that need to be met at once.

Develop plans for community celcbrations such as: Christmas, July 4th, Labor Day, Thanksgiving, etc. Plaus to to be carried out by local organizations, not by the council.

c. Call in representatives of county organizations and ascer- 
tain what work they are prepared to eoöperate in for your town. These should inelude:

Distriet Offieer of the State Department of Health.

The Farm-Bureau or Improvement League.

Soeiety for the Prevention of Cruelty to Children.

County Young Men's Christian Assoeiation.

County Nursing Assoeiation.

The Boy Seouts and others.

4. The First Community Meeting. Plenty of time should be allowed to insure a perfeet understanding among the loeal organizations. Sometimes this takes a year, but it is time well spent. After the items mentioned in (3) have been aehieved the eouneil should begin to eonsider the larger planning for the eommunity. Call a eommunity meeting to eonsider the questions mentioned under (1) and these only.

A ehairman and seeretary should be eleeted and all mention of speeifie items of improvement avoided at this time, as it may often reopen old issues and arouse antagonism just at the time when the greatest harmony is needed. It will be found worth while to have some one present from a town that has made a sueeess of eommunity organization. The whole matter should be thoroughly diseussed from all possible angles and a vote taken to determine whether the people really desire to go aliead.

5. Commitees. If aetion is favorable, a few eommittees should be appointed. It is better to have a few general eommittees with sub-eommittees. The following have been found sufficient for all praetieal purposes:-

a. FarM Production-soil, crops, animals.

b. Farm Business-farm supplies, sale of products, eredit, farm records and aceounts, surveys.

In some eommunities it is advisable to eombine the eommittees oll farm produetion and farm business into one eommittee on agrieulture.

e. Conservation-pureliase and use of food, eanning, drying and storing, fuel supply, natural resourees, points of seenie and historieal value.

d. Boys' and Girls' Interests-sehools, edueational elubs, soeial elubs, moral training, plays and games. 
e. Comanity Life-the home, edueation, health, transportatation, reereation, civie improvement, publie morality.

These eommittecs should be asked to do three things: Study the town thoroughly along their respeetive lines. Call in whatever liclp ean be secured from state and eounty organizations, boards and institutions. (c) Work out two or three practical projects for improvement which will be submitted to the second mass meeting. These projects sloould be based on aetual needs.

6. The Second Community Meeting. This should be merely an unofficial town meeting. The chairman of the first mass meeting should preside. The committee chairman should report their projects which should be taken up separately and put to a vote just like an article in the town warrant. While there will be nothing official or binding in this vote, still it will give sufficient attention to cach projeet to prevent worthless ones being passed. IIcre again everybody should have his say, for it is better for opposition to appear now than later. Do not forget that a community will go no farther nor faster in its development than the majority of the people both see and believe.

7. The Community Plin or Progrim. Such projects as are adopted become the community's working program. It should comprise some projects whieh can be carried out at onee and others which will require a period of years. The projeets adopted are turned over to the community eouncil, whieh acts as their custodian and directs their carrying out.

8. Getring Results. The local organizations carry out the speeific projects. As their representatives eome togetler in the eouncil they either choose or by general consent are asked to become responsible for definite things. They do this knowing that they will have the sympathy and support of other organizations and also that they will be expected to produce results. If there are projeets which no organization can earry on, such as coöperative buying and selling, it may be neeessary to organize a new group to do this work.

9. Council Meetings. The couneil should meet regularly every three months, with special meetings as necessity requires. These meetings should be real conferences on the most important 
community matters. Reports should be made of work done by the various organizations, concerning the projects adopted and carried out by them. The remaining projects should be gone over to ascertain whether any of them can be begun during the coming three months. Other matters than the specific projects often come up at this time and receive consideration.

10. The Annual Community Meering. Instead of one of the quarterly meetings of the council there should be a meeting of the entire community. This should take the form of an annual meeting. Three things should be done:

1. Reports should be made of work done by any organization or group during the past year.

2. The council committees should report the working plans for the coming year.

3. The chairman, secretary and committees for the ensuing year should be chosen.

In addition to these matters of business there is usually a speaker from the outside who discusses some question of special interest to the community at that particular time. Special community meetings should be called as often as there are vital questions to be considered by the community.

\section{MODEL AGREEMENT FOR A COMMUNITY COUNCIL}

Article I

Name and object

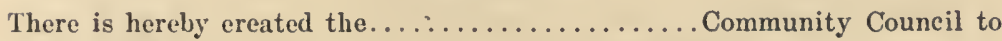
serve as a medium through which the organizations of $\ldots \ldots \ldots \ldots \ldots \ldots$ (town) can eoöperate more fully in their work for community progress.

Article II

Membership

Membership shall eonsist of one representative from each general organization or group of the community and three (five to seven in large towns) selected at large. Those seleeted by organizations or groups shall be from their own membership and shall be chosen as soon as possible after October lst of each year.

\section{ABTICLE III}

\section{Officers}

The officers shall comprise chairman and seeretary who shall be chosen at the annual community meeting. 
ARTicle IV

\section{Mectings}

The couneil shall meet every three months, viz.: The first Monday evening in Marclt, June, September, and December. Meetings of special groups of eitizens may be ealled when necessary to earry out speeial lines of work. Special meetings may be called by the ehairman or by any five members.

\section{AŔticle V \\ Annual Community Mceting}

The couneil shall arrange for an annual community meeting to be held on or near the first Monday of December, at which time reports shall be made on the progress of the town. At this time projects for the ensuing year shall be presented and voted upon. Such projects as are adopted shall become a part of the working program.

\section{ARTICLE VI}

\section{Amendments}

This agreement may be altered or annended by a two-thirds vote of the residents of the town of .................. present at the aumul community meeting.

\section{WHIT MAY BE GAINED THROUGII COMMUNITY ORGANIZATION}

1. It gives purpose to the energies of the eommunity.

2. It seeures the best available adviee at all points.

3. Guessing is eliminated sinee projeets for improvement are based on faets.

4. The progress of the eommunity is put on a praetieal, business-like basis.

5. One-sided development is avoided.

6. It gives the best possible working plan for the development of the community.

7. The development of eommunity spirit, pride and purpose is fostered. Self-interest gives place to eommunity interest.

8. When this eommunity of interest is developed, it eauses many forms of loeal eoöperation to follow naturally.

9. It gives the advantage of using a tried method that is working sueeessfully in many towns. It is no longer an experiment.

10. The eommunity is eonneeted with the sourees of eontinuous help-The Farm-Bureau, Agrieultural College, State Department of Health, State Board of Agrieulture, State Board of Edueation, Massaehusetts Civie League, Soeiety for the Preven- 
tion of Cruelty to Children, County Y. II. C. A. and many . others.

11. It insures future welfare. Community organization means to the community what seientifie management means to business. The eommunity improves by methods similar to those of a eareful business manager:-long-term planning, eonstant watehfulness, striving toward perfeetion in all departments and a thorough coördination of them all.

\section{SOME THINGS TO REMEMBER}

1. Get the community planning idea, talk it, work it.

2. Take the long look ahead into all eommunity affairs.

3. Get everybody out for the first mass meeting. You ean't convince people who are not present.

4. The eommunity couneil is not a new organization but just a form of get-together of loeal forees.

5. Don't get diseouraged. It takes time to bring about maximum effieieney.

6. Study your town. Make plans meet actual needs. Call in outside help.

7. Plan some projeet in each line of improvement sueh as agrieulture, edueation, the home, healtll, ete.

8. If one organization beeomes responsible for a projeet, back it up and help to earry it out sueeessfully.

9. Committees are not to do things but to work out projects to be earried out by the organizations.

10. Your eommunity has its own place to begin. Be eareful how you start. It is better to do one or two things well than to undertake too much.

11. Get the best possible advice in working out projeets. Help can always be seeured from your Farm-Bureau and your Agrieultural College.

12. Be sure of the sueess of the first project attempted. Do not let it fail, for upon its suceess may depend the continued interest of the eommunity.

13. Community organization is not "just some new-fangled notion." It is merely the most efficient way of doing things. It has stood the test of time in this state. It has made good. 
14. The council should meet once in three months and plan the carrying out of projects.

15. Don't get the "town boosting" idea. This is a clean-cut business proposition and it nceds carcful planning. This will take time.

\section{DEFINITION OF A RURAL COMMUNITY ${ }^{1}$}

\section{W. THOMPSON}

A RURAL community may be defined as a localized group of individuals having certain common interests, purposes and activities, with the dominant economic interests in agriculture. Before the people in a rural locality can be regarded as a community they must be conscious of some common interests. They must also be led on by those interests to certain 'common purposes, expressed in common action.

A rural community, like an individual, may be very much alive or it may not be alive at all. The measure of the life of a community may be found in the number of interactions between the community as such, and its own members or the outside world.

A rural community may be static, with interests, purposes, and activities, which do not change. For such a community, the main problem is one of adaptation to fixed conditions. On the other hand, a rural community may be dynamic or progressive in its interests, purposes, and activities, enlarging its life in the light of new experience.

\section{BIBLIOGRAPIIY}

\section{FARMERS' ORGANIZATIONS}

Atkeson, T. C. Semi-Centennial History of the Patrons of Husbandry. Judd, New York, 1916.

Barrett, C. S. The Mission, History and Times of the Farmers' Union, Marshall and Bruce, Nashiville, Tenn., 1909.

Boyle, James E. The Agrarian Movement in the Northwest. Am. Econ. Rev., 8: 505-521, Sept., 1918.

1 From an unpublished address given before the Graduate School of Agriculture, Amherst, Mass., 1916. 
Buck, S. J. The Granger Movement. Harvard, Cambridge, 1913.

Buttertield, K. L. The Grange. Forum, 31: 231-242, A pril, 1901.

Carney, Mabel. The Grange and Other Farmers' Organizations. Country Life and the Country School, pp. 72-\$4, Row, Chicago, 1912.

Commons, John R., and Andrews, John B. Documentary History of American Industrial Society, Volumes 9, 10, Clark, Cleveland, 1910 and 1911.

Coulter, J. L. Organization Among Farmers of the United States. Yale Review, 18: 273-298.

Drew, F. M. Present Farmers' Movement. Political Science Quarterly, 6: 282-310, June, 1891.

Dunning, IV. A. Farmers' Alliance History. Alliance Publishing Co., Washington, 1891.

Everett; J. A. The Third Power. J. A. Everett, Pub., Indianapolis, Ind., $190 \%$.

Farmers' National Congress of U. S. Official Reports of Proceedings.

Gaston, Herbert. The Nonpartisan League. Harcourt, Brase and Howc, N. Y., 1920.

Gillette, J. M. Constructive Rural Sociology. Sturgis, New York, 1915.

Gladden, Washington. The Embattled Farmers. Foruin, $10: 315-322$, Noveniber, 1890.

Holman, Clias. WT. First Aid to the Farming Business. Marketing and Farm Credits, 4th Nat'l Conf., Dec., 1916, pp. 477-91.

Kelley, O. H. The Patrons of Husbandry. Wagenseller, Philadelphia, 1875.

Marsl, B. C. The State Grange a Social Force. Survey, 23: 703-4, February 12, 1910.

Martin, E. W. History of the Grange Movement. National Publishing Co., Pliladelplia, 1875.

MeVey, F. L. The Populist Movement. American Economic Association, Economic Studies, 1: 131-209, August, 1896.

Morgan, J. T. The Danger of the Farmer's' Alliance. Forum, 12: 399-409, Novemler, 1891.

Nash, J. C. Building a Farmers' Monopoly. World Today, 13:717$20,1907$.

National Agricultural Organization Society. Proceedings.

Peff'er, WV. A. 'The Farmer's' Defensive Movement. Forum, 8:463473, December, 1889.

Pickett, J. E. Prairie Fire. Country Gentleman, May 18 and 25, June 8,15 and 22,1918 .

Pierson, C. IV. The Rise of the Granger Movement. Popular Science Monthly, 32 : 199-208, December, 1857.

The Outcome of the Granger Movement. Popular Science Monthly, 32 : 368-373, January, 1888.

Russell, C. E. The Furmers' Non-Partisan League. American Sociological Society Publications, $11: 31-36,1916$.

Tubbs, M. W. Amcrican Socicty of Equity, Its Past, Present and Fllture. Wis. Equity News, June 25, 1912, pp. 1-3, Madison, Wis. 


\section{COMMUNITY ORGANIZATION}

Burr, W. Community Welfare in Kansas. The Kansas State Agricultural College Extension Bulletin No. 4, October, 1915.

Butterfield, K. L. Chapters in Rural Progress. Univ. of Chicago Press, 1909, Cliap. IX.

Carver, T. N. The Organization of a Rural Community. U. S. Department of Agriculture Yearbnok, 1914.

Civic Coöperation in Community Building. Bulletin of the University of Georgia. Number ?, Vol. XVI. Serial Number 262, Athens, June, 1916.

Collier, John. Community Couneils. Conf. of Social Work, 1919, pp. $470-479$.

Eldridge, S. Problems of Community Life. Crowell, New York, 1915.

Fiske, F. W. The Challenge of the Country. Chap. 3, 5. Assoc. Press, N. Y., 1912.

Feagin, $\mathrm{Wm}$. F. Coinmunity Organization. Alabama's Fundamental Need. Pamphlet published by State Superintendent of Schools. January 5, 1914. Department of Education, Montgomery, Alabama.

Hanifan, L. J. A handbook containing suggestions and programs for community social gatherings at rural school houses. Published in 1916 by State Superintendent. Charleston, W. Va.

Hart, J. K. Edueational Resources of Village and Rural Communities. Macmillan, N. Y., 1913.

Henderson, C. R. Social Duties in Rural Communities. In his Social Duties from the Cliristian Point of View. Pp. 115-137, Univ. of Chicago Press.

Levin, Nathan R., and Kammerling, Edith. Community Centers-selective list of references in the Chicago Public Library. Prepared for National Community Center Conference. Chicago, April 17-21, 1917.

MeVey, Frank L. The Making of a Town. A. C. MeClurg \& Co., Chicago, 1913.

Morgan, E. L. Community Rebuilding, How It Can Be Done. Our Wonder World, Volume 10. Sherman, Boston.

Phelan, R. V. Community Centers. University of Minnesota, St. Paul., Extension Division.

Smith, W. H. Organizing a Country Community. American City, Town and County, 11:211, Sept., 1914.

IVard, Edward J. The Community Secretary. Education Vol. 36: 666-669. No. 10, June, 1916.

Watrous, Richard B. Civic Art and Country Life. Annals Vol., 40: 191-200, Marel, 1912.

Waitgh, F. A. Rural Improvement. Judd, N. Y., 1914.

Wilson, A. D. Coöperation and Community Spirit. Pub. Am. Sociological Soc., 11:113-125, 1916.

\section{RURAL ORGANIZATION}

Adams, Thomas. Rural Planning and Development. A Study of 
Rural Conditions and Problems in Canada. Commission of Conservation, Canada, Ottawa, 1917.

Bird, Chas. S. Town Planning for Small Communities. Appleton, N. Y., 1917.

Burr, Walter. Community Welfare in Kansas. Kansas State Agric. College, Extension Bulletin No. 4, Manhattan, October, 1915.

Butterfield, K. L. The Farmer and the New Day. Macmillan, N. Y., 1919.

Carver, T. N. The Organization of a Rural Community. U. S. Dept. Agriculture Yearbook 1914, 89-138.

Cominunity Service Week in Nortl Carolina. Issued from the Office of the Superintendent of Public Instruction, Raleigh, N. C., 1914.

County and Community Fairs. Oregon Agricultural College, Extension Series II, No. 45, Corvallis, 1909.

Farrington, Frank. Community Development. Ronald Press, N. Y., 1915.

Frame, Nat T. Focusing on the Country Community. College of Agriculture, Circular 211, Morgantown, July, 1918.

Galpin, C. J. The Social Anatomy of an Agricultural Community. Researclı Bulletin 34, Agricultural Experiment Station, Univ. of Wisconsin, Madison, 1915.

Hieronymus, R. E. The Community Adviser and Rural Communities. Conference Social Work, 1918, pp. 480-1.

Israel, Henry. Unifying Rural Community Interests. Association Press, N. Y., 1914.

Jefferson, Lorian P. The Community Market. Massachusetts Agricultural College, Extension Bulletin No. 21, Amlerst, April, 1918.

Lloyd, W. A. Status and Results of County Agent Work in the Northern and Western States, 191T-18. U. S. D. A., State Relation Service, Cir. No. 16, S. R. S. Doc. 88, Govemument Printing Office, Waslington.

Office of Markets and Rural Organization. U. S. Dept. of Agriculture, Document-Markets 1, Nov. 27, 1915.

MeClenahan, Bessie A. County Organization of Welfare Agencies. Conference Social Work 1918, pp. 595-604, 315 Plymouth Court, Chicago.

MeVey, Frank L. The Making of a Town. MeClurg, Chicago, 1913.

Mead, Elwood. Reform in Land Settlement Methods. Conference Social Work, 1918, pp. 492-5.

Miles, R. E. Organization of Social Forces of the State. Conference Social Work, 1918, pp. 626-631.

Morgan, E. L. Mobilizing the Rural Community. Massachusetts Agricultural College, Extension Bulletin No. 23, Anlierst, Sept. 1918.

Morgan, E. L. The Community Fair. Massachusetts Agricultural College, Extension Bulletin No. 27, Amherst, May, 191?.

Morman, James B. The Place of Agrieulture in Reconstruction. Dutton, N. Y., 1919.

Moran, J. Sterling. The Community Fair. U. S. Dept. of Agriculture, Farners' Bulletin 870, December, 1917.

Negro Rural School and its Relation to the Community. Extension Department, Tuskegee Normal and Industrial Institute, Tuskegee, Ala., 1915. 
Pcabody School of Education. Civic Coöperation in Community Building. Bulletin of the Univ. of Georgia, Vol. XVI, No. 9, June, 1916.

Pratt, Edwin A. The Organization of Agrieulture. Dutton, N. Y., 1904.

Shepherd, Robert P. Essentials of Community Efficiency. Abingdon, Chicago, 1916.

Sleeper, H. D. Mrs. Community Effort with Rural Social Problems. Mass. Sociely for the Prevention of Cruelty to Children, Protection of Children Series Leaflet, No. 4, Boston, 1911.

Vogt, Panl L. The Village as a Factor in Social Progress. Conference Social Work, 1918, pp. 473-S0.

Waugh, Frank A. Rural Improvement, Judd, N. Y., 1914. 


\title{
CHAPTER XIX
}

\section{LEADERSHIP}

\section{LEADERSHIP OR PERSONAL ASCENDENCY ${ }^{1}$}

\author{
CHARLES R. COOLEY
}

IT is plain that the theory of ascendeuey involves the question of the mind's relative valuation of the suggestions eoming to it from other minds; leadership depending upon the effieaey of a personal impress on to awaken feeling, thought, action, and so to beeome a eause of life. While there are some men who seem but to add one to the population, there are others wlom we eannot help thinking about; they lend arguments to their neighbors' ereeds, so that the life of their contemporaries, and perhaps of following generations, is notably different because they have lived. The immediate reason for this differenee is evidently that in the one ease there is something seminal or generative in the relation between the personal impression a man makes and the mind that reeeives it, which is lacking in the other case.

We are born with what may be roughly deseribed as a vagucly differentiated mass of mental tendeney, vast and potent, but unformed and needing direction. This instinetive material is believed to be the outcome of age-long soeial development in the raec, and henee to be, in a general way, expressive of that development and funetional in its eontinuanee. The proeess of evolution has established a probability that a man will find himself at home in the world into which he comes, and prepared to share in its activities.

Obscurely loeked within him, inserutable to limself as to others, is the soul of the whole past, his portion of the energy, the passion, the tendeney, of human life. Its existence creates a vague need to live, to feel, to act; but he cannot fulfill this need,

1 Adapted from "Human Nature sud the Socinl Order." Chap. IX, pp. 283-286, 293-294, 2!)7 and 310. Chas. Seribner's Sons, N. Y., 1902. 
at least not in a normal way, without incitement from outside to loosen and direct his instinctive aptitude. There is explosive material stored up in him, but it cannot go off unless the right spark reaches it, and that spark is usually some sort of a personal suggestion, some living trait that sets life free and turns restlessness into power.

It must be evident that we can look for no cut-and-dried theory of this life-imparting foree, no algebraie formula for leadership.

The prime condition of ascendency is the presence of undireeted energy in the person over whom it is to be exercised: it is not so much forced upon us from without as demanded from within. The mind, having energy, must work, and requires a guide, a form of thought, to facilitate its working. All views of life are fallacious which do not recognize the fact that the primary need is the need to do. Every healthy organism evolves energy, and this must have an outlet.

If we ask what are the mental traits that distinguish a leader, the only answer seems to be that he must, in one way or another, be a great deal of a man, or at least appear to be. He must stand for something to which men incline, and so take his place by right as a focus of their thought.

To be a great deal of a man, and hence a leader, involves, on the one hand, a significant individuality, and, on the other, breadth of sympathy, the two being different phases of personal caliber, rather than separate traits. It is because a man cannot stand for anything except as he has a signifieant individuality, that self-reliance is so essential a trait in leadership.

All leadership takes plaee through the communieation of ideas to the minds of others, and unless the ideas are so presented as to be eongenial to those other minds, they will evidently be rejected.

In face-to-face relations, then, the natural leader is one who always has the appearanee of being master of the situation. He ineludes other people and extends beyond them, and so is in a position to point out what they must do next. Intellectually his suggestion seems to embrace what is best in the views of others, and to embody the inevitable eonelusion; it is the timely, the fit, and so the prevalent. Emotionally his belief is the strongest foree present, and so draws other beliefs into it. Yet, while he 
imposes himself upon others, he feels the other selves as part of the situation, and so adapts himself to them that no opposition is awakened; or possibly he may take the violent method, and browbeat and liumiliate a weak mind; there are various ways of establishing superiority, but in one way or another the eonsummate leader always aceomplishes it.

The onward and aggressive portion of the world, the people who do things, the young and all having surplus energy, need to hope and strive for an inaginative objeet, and they will follow no one who does not eneourage this tendeney. The first requisite of a leader is, not to be right, but to lead, to show a way.

\section{LEADERSHIP ${ }^{1}$}

\section{E. C. HAYES}

LEADERSHIP eonsists largely in putting the proper ideas into the minds of the individuals who are in a position to give them effect and still more in supplying eourage. Most things really worth doing have at first seemed impractieable to the average person. But when there appears an individual having not only sufficient imagination and enlightenment to see what should be done, but also suffieient eourage to believe that it ean be done, the probability of the aehievement has begun. The question of possibility or impossibility witl referenee to social improvements is largely one of psychie attitude of the people. The question with respeet to most desirable soeial ehanges is not, could people bring them about if they would, but will they will to do so? Suel changes are thought impossible, and for the time being are so, beeause men do not believe their neighbors will do their duty. The man who first says, "I, for one, will, and we together ean," who breaks down the lyppnotism of the present reality, who exhibits confidence to his fellows, who makes individuals begin to think "my neighbors will do their duty and therefore it is wortl while for me to do mine," thereby ereates new social possibilities.

1 Adapted from Introduction to the Study of Sociology, pp. 57-5s, Appleton, N. Y., 1919. 


\section{RURAL LEADERSHIP ${ }^{1}$}

\section{II. B.IILEY}

RURaL leadership lies in taking hold of the first and commonest problems that present themselves and working them out. Every eommunity has its problems. Some one can aid to solve these problems. The size of the problem does not matter, if only some one takes hold of it and shakes it out. I like to say to my students that they should attack the first problem that presents itself when they alight from the train on their return from college. It may be a problem of roads; of a poor sehool; of tubereulosis in the herds; of ugly signs along the highways, where no man has a moral right to advertise private business; of a disease of apple trees; of poor seed; of the drainage of a field; of an improved method of growing a erop; of the eare of the forests. Any young man ean concentrate the sentiment of the eommunity on a problem of the community. One problem solved or alleviated, and another awaits. The next sehool dist rict needs help, the next town, the next eounty, the next state. Every able eountryman has much more power than he unses.

The seale of effort in the open country is so uniform that it ought to be easy to rise above it. I do not see how it is possible for an edneated young man to avoid developing leadership in the open eountry, if only he attacks a plain homely problem, is not above it and stieks to it.

It does not follow that all leadership will be reached for. It will come to a man.

\section{THE SECRET OF INFLUENCE ${ }^{2}$}

\section{JAMES BRYCE}

THERE are at least four elements, two or more of whieh will be found to be always present in whoever leads, or is trusted

1 Adapted from "The State and the Farmer," pp. 172-176, (Macmillan, N. Y., 1908).

2 Adapted from Chumbers' Journal, 7th Series, Vol. I. 
by, or inspires those among whom his lot is east. The first is intelleetual independenee and the thing we eall initiative, by which I mean the power of thinking for one's self instead of borrowing thoughts from others, and of deeiding on a eourse for one's self instead of following the adviee of others.

The seeond is tenacity of purpose, the eapaeity to adhere to a view onee adopted or a deeision onee taken. Whoever, wanting this, lets himself be blown about by every wind of doetrine or every pressure of menaee or persuasion may be a very acute man or a very adroit man, but will never impress himself on others as a person to be followed.

The third element is a sound judgment, fit to foreast the results of action. Few people ean look beyond the next move on the ehess-board, and the man who sees several moves ahead, and whose foreeast is verified by the events, soon grows to be the man whose adviee is souglit and taken. His neighbors seek it. Ally assembly where he finds himself, from a town meeting or a loeal school eommittee up to a legislature, gladly listens to his eounsels.

The last is sympathy - that is, having the eapaeity for entering into the thoughts of others and of evoking their feelings by showing that he ean share them. The power of sympathy is so far an affail of the emotions that it may exist in persons of no exeeptional abilities. Yet it is a preeious gift whieh often palliates errors and wins affeetion in spite of faults and weaknessses. It is a key to unloek men's hearts, and the heart that has given eonfidenees attaehes itself to the person who las reeeived them, and is prone to surrender itself to lim if he is felt to be strollg.

\section{- TRAINING FOR RURAL LEADERSHIP ${ }^{2}$}

\section{JOHN M. GILLETTE}

When the rural problem arose in its full signifieanee, almost the entire emphasis was plaeed on organization, so that organization beeame the shibboleth, and the eeonomie factor reeeived

1 Adapted from "Training for Rural Leadership," Annals of the American Academy, LXVII : 87-96, September, 1916. 
almost exclusive eonsideration. But with the passage of time the farmers have become wiser and, imbued with a larger degree of humanistic sentiment, they are now discussing what sort of institutions will turn out the best men and women. And it is very significant that the perception has gradually arisen that a rural leadership is an indispensable means to the attainment of permanent improvement.

I consider the prime requisites of a productive rural leadership the power of initiative, organizing ability, sympathy with human aims, trained intelligence, and vision and outlook. Up to the present time, for community purposes, the country has depended on a transient leadership from the outside in the shape of itinerant preachers and teachers, and for purposes of produetion, on the occasional able farmer and the visiting expert. Due reflection over the situation leads us to think that such sourees will never prove sufficient or effieient, and that what the eountry wants most is men and women who by their training are at one with farm life and whose influenee is ever present because they live in the country and have their interests there.

Several kinds of agencics may contribute toward supplying a leadership of the right kind. Our institutions of higher learning must devote more attention to training men and women for eountry serviec. Those which train pastors, teachers and Y. M. C. A. workers should establish courses of instruetion, the content, spirit and emphasis of which will serve to specialize their students for constructive work in rural institutions. The nature of the rural eommunity must be emplasized, its partieular problems studied, and the ageneies capable of supplementing and improving agricultural life receive much eonsideration. 'When training schools renounee the absurd notion that general training eourses qualify equally well for rural and urban service, a great step in advance will have been taken. Educating individuals specifically for rural service has the double advantage of qualifying them to earry on constructive undertakings and of retaining them in that serviee because their qualifications tend to make them ineligible for urban positions.

Mueh is being accomplished by the county agent and the cooperative demonstrator which the agricultural colleges have edueated for country service. The various states are, 
especially; plaeing many county agents in the field, and they have proved themselves helpful in furthering not only production but community undertakings of different kinds. Many states have county and eity high schools which are giving instruction in agriculture and farm subjeets, and the oeeasional state agricultural high sehool is a still more intensified approach to the desired goal. Summer ehautauquas with their leetures and instruction on farm life and with their visiting groups of farm boys and girls; farmers' institutes; farmers' elubs, and associations of farmers' elubs; and kindred organizations are helpfully eontributing to the establishment of a construetive point of view eoneerning farm life and its problems.

However, the institution which is needed to reach the masses of eountry ehildren and to do most to ercate an abiding interest in rural affairs is one which is loeated in the rural neighborhood, which touehes and ministers to the lives of the residents daily, and whieh, filled with an agrarian content and spirit, exercises an abiding, molding influence on the young in the direction of rural undertakings and improvement. The eonsolidated rural school, with communityized bnilding and equipment, a corps of efficient teachers, a teaeherage, experimental plot, graded and ruralized curriculum, and having high school facilities as an organic part of the socialized course of instruetion, possesses the greatest power of appeal because it is artieulated with actual farm life and beeause it is within reach of all.

\section{THE SOURCES OF LEADERSHIP ${ }^{1}$}

\section{JOHN R. BOARDMAN}

THERE are four distinet sources whieh may be expeeted to yield valuable material for the various leadership positions in the social organization. The first and most obvious is the group of persons who are already leaders. Attention is ealled to this souree because it demands carcful examination. Are these leaders being used in their proper places and if so is their lead-

1 Adapted from "Community Leadership," a course in social engineering for village and country conmunities. Bureau for Leadership Training, N. Y., 1914. 
ership ability being used to its full power? Arc these leaders doing more than one thing? These are important questions and demand careful answer. There are also other leaders who are not conspicuous who need attention. They are leaders of obscure groups, natural leaders of small, informal collections of peoplc. They are real leaders, vitally related to the groups they serve. They should not be disturbed, undẹr ordinary conditions, and unless we discover their present leadership relation we are apt to consider them for other positions with consequent social loss. On the other hand these persons may not be properly placed. They may be able to render better service at other points in the social organization but they should not be changed. unless the desirability of the transfer is very apparent.

The second source of leadership material is the vocations of people,-the business in which they are regularly engaged. Many trades and professions are of definite social value in an indirect way. Many business and professional men could make their business relations a source of social benefit and leadership service. Carpenters, machinists, engineers, physicians, dentists, lawyers, teachers, bankers, veterinarians, florists, gardeners, poultrymen, farmers and many others are doing things as a business which are of genuine interest to other people in the community from a purely cultural standpoint. Such people are the very best ones to give practical talks and courses of informal lectures on their special subjects. They can conduct effective study classes for several weeks at proper seasons of the year and render a piece of social service that is of positive value.

A third class of people who have great potential leadership are the people who have vocations or hobbies. They are interested in birds, insects, wild animals, pets, trees, flowers, inventions, astronomy, minerals, chemistry, stamps, coins, antiques, and many other things. These people are always glad of a chance to talk with others about thesc hobbies of theirs and there are always small groups of people who covet the privilege of sitting at the feet of these hobbyists and learning something about the things in which they are specialists. Many times these hobbyists have splendid collections of things along their line. These may be made the basis for evening after evening of 
the finest soeial intereourse,-that whieh has real edueational value. Sueh people are real leaders, as well as the finest kind of teaehers. The groups which gather about them are real soeial organizations. The more of sueh groups there are in the eommunity the better. It is of such groups that a vital soeial strueture is built. They make a valuable eontribution to the soeialization of the eommunity, espeeially with referenee to the younger people of the eommunity.

A fourth souree of leadership material is worthy of attention. Leaders ean be made to order, they ean be grown from seed. Soeial engineers frequently meet a demand for the organization of eertain groups for whieh there is no available leader. It beeomes neeessary then to seleet some person who ean fit himself for the work by definite study and experienee. It is possible to take many boys and girls and by proper training prepare them to become leaders in some speeial line.

These four sourees should furnish all the leadership needed for the largest possible development of the social organization of ally eommunity.

\section{THE DEVELOPIIENT OF RURAL LEADERSHIP ${ }^{1}$}

G. WALTER FISKE

I IIAVE never heard it suggested that there is any dearth of latent leadership in eountry life. The topie assigned me seems to assume that there is a laek of developed leadership, and I believe that this is generally true. The question at onee arises: Why should leadership be laeking in the eountry if most eity-leaders in business, polities, and religion were eountry-bred? Opinions on this point vary, but it seems to be undoubted that eity people who were eountry-born furnish fully their share of urban eommunity leadership, the pereentages suggested running from 50 to 90 per eent. In a easual reference just now to "Who's Who in Ameriea," I notiee that out of the first 100 names seleeted quite at random, sixty-eight were born in the eountry. Leadership still eomes in eonsiderable measure from

1 Adapted from Publications of the American Sociological Society, Vol. XI, 54-70, Dec., 1916. 
the country. How long this will eontinue, with the growth of eities aeeelerating, no one ean say with assuranee; but in the nature of things there are some reasons for believing that the nore natural euvironment of the open country and the village will long continue to furnish the eity with much of its best leadership material. Certainly so, if - what Professor Giddings says is true: "Genius is rarely born in the eity. The city owes the great discoveries and immortal ereations to those who have lived with nature and with simple folk. The eountry produees the original ideas and forms the soeial mind." Professor M. T. Seudder even ventures to offer a definite explanation for the great influence of rural leaders in the eity: "The fully developed rural mind, the produet of its environment, is more original, more versatile, more aeeurate, more philosophieal, more praetieal, more persevering, than the urban mind. 'It is a larger, freer mind and dominates tremendously. It is beeause of this type of farm-bred mind that our leaders have largely come from rural life."

If all this is true-even making large allowance for overemphasis-why should we worry over leadership in rural life? Have all ruial leaders gone to the eity? If leadership thrives under the open sky, why not let it alone there? Will not rural life develop its own leaders anyway? This was the elaim of a keen and sueeessful woman farmer, who told me that she was very weary of rural uplifters and eountry-life specialists who live in New York City. "If eity folks would only let us alone, there would be no rural problem," she testily remarked! Yet the fact remains, as we are all aware, that eountry life is seriously defieient in two social elements: coöperation and leadership; and these two, though not identical, are inseparable, for it takes the latter to develop the former.

Rural Individualism. It is certainly true that an unsocial streak of failure in coöperation runs through all phases of eountry life and weakens all sorts of rural institutions. Dr. Butterfield rightly ealls the Ameriean farmer a "rampant individualist." He is apt to reveal the fact in all relations of life. With all the gains made by the modern eent ralized school, rural edueation is still dispensed generally on the old sehooldistriet plan, with niggardly supervisors of no edueational vision 
and with each pupil buying his own textbooks. Roads are repaired likewise by township distriets, by very loeal enterprise, sometimes still with individuals working out their taxes on the roads. Churches are maintained on the retail plan, the minister being hired by the year or even by the week, the churches themselves being altogcther too numerous and too small for effectiveness beeause of selfish insistenee upon individual views, mutually eompctitive, not coöperative. It is the same story in rural business. Both in produetion and in distribution farmers are slowly learning the lesson of working together and reaping the benefits of coöperation, whieh eeonomizes eosts and makes for effieieney and eommunity welfare. Coöperative agreements in business have even been repudiated by farmers under the stress of temptation to personal gain, whilc rural distrust of banks and organized business is still proverbial, and is not confined to remote scetions.

Socialization and Urbanization. These generalizations do not, of eoursc, hold in the more progressive rural eommunitics. There we find two parallel processes developing rather notieeably, the soeializing and the urbanizing of eountry life. They are similar movements, but not identieal. Socialization is a civilizing process in which individuals, by merging their rights, interests, and functions, develop eommunity effieiency through group aetion. Very naturally this proeess devclops most rapidly in the more favorable city environment; but it is now making progress also in the country against the eonservatism and ultraindividualism of rural life.

Meanwhile in all but the most remote rural seetions (and even there through the influence of the mail-order eatalogues) you may observe the rapid urbanization of country life. I mean by this the spread of the social ideals and customs of the eity. To the extcut that these eustoms and ideals are eonstructive and adaptable to a wholesome country life, to that extent this urbanization makes for soeialization and should be weleomed. Unquestionably this proeess, hastened by increasing intercommunieation, is rapidly making country life and eity life more alike, and is extending the limits of suburban life. It is to be hoped that this urbanizing will not destroy the unique social consciousness of rural eivilization and make it simply imitative of the 
city. On the other hand, it is to be hoped that the city may more effectively teach the country the secrets of socialization, so that the social efficieney of urban life may be reproduced in the eountry. Rural people need to discover how eity people work together in compactly organized business eorporations; how they adjust, by many mutual coneessions, their eomplicated eivic relations, how they coördinate sympathy and human needs, and administer a network of social-service ageneies, with greater and greater efficiency through perfected organization.

Why This Lack of Socialization? I hasten to aroid the suspieion of lack of sympathy with eountry life by saying that I belicve this lack of socialization and coöperation in the country to be due less to selfishness than to lack of social opportunity and practice. In fact, these unsocial tendencies are really the result of overdeveloped rural strength of character. The pioneer life of the Amcrican farmers has developed heroic virtues in their personality which have made them as a class the most selfreliant in history. This sclf-reliance has been overdeveloped. It las led to self-aggrandizement, jealousy of personal rights, slowness to aceept advice, proneness to lawsuits over property, thrifty frugality to a fault, indifference to public opinion, disregard of the opinions of experts. Doing so much of their thinking alone, they do not easily yield to argument. Working with the soil and with things more than with persons, they do not easily respond to leadership. They are likely to vicw strangers with suspicion because they do not know them; and for the opposite reason often they do not trust their neighbors nor eoöperate with them because tliey do know them. Self-reliance overstressed leads them to distrust any initiative but their own. They refuse to recognize superiority in others of their own class. Positively, the resulting failure in coöperation explains the jealousies and feuds all too common in rural neighborhoods; and, negatively, it aceounts for the lack of social organization and effective leadership. Again let me remind you of $\mathrm{my}$ eaveat, that I am not spcaking of the more progressive rural eommunities, but of rural life in general. I believe that these generalizations are less true in the West, but most true in the South and the older sections of the North and East, outside of urban tracts. 
The Difficulty of Developing Rural Leadership. I am now ready to offer a suggestion in answer to the question: If country life furnishes so much leadership for the city, why is leadership a problem in the country? I am confident that there is no dearth of latent leadership in the eountry. In general, I do not believe it has been depleted by the exodus to the eity, though in some plaees this has been serious. In general, it is mainly the question of developing the qualities of the leadership whieh are latent in the finest types of young men and women living in the eountry.

You will readily grant me that there is much latent leadership in eountry boys. Some of these boys go to the eity, and there under urban stimulus and opportunity this latent initiative develops strongly, and they beeome vigorously influential personalities. Others of them, equally well endowed, remain in the country, and though they may beeome sueessful along individualistie lines and aeeumulate property, their latent leadership fails to develop. It fails to develop beeause of eertain elements in the rural environment: the lack of suffieient stimulus and ehallenge, the laek of urgent opportunity for self-expression, possibly beeause of real soeial repression, an inhibition of soeial effort due to the positive disapproval of inhospitable minds. This is why, in so many rural villages, there is a persistent and deep-seated eonvietion that it is impossible to develop effeetive leadership for eoöperation in eommunity welfare until there have been a few judieiously seleeted, providential funerals. Henee an utterly stagnant eommunity, soeially speaking.

Again let me voiee a gentle plea for eonsideration and eharity. Mentally I rate the average rural eitizen high, but he is likely to be socially awkward-mainly for laek of soeial stimulus and praetice. The term "soeial awkwardness" may seem a rather strange one until we eonsider it in its relations. The country boy is likely to be awkward physically beeause of the overdevelopment of the large museles and the underdevelopment of the aeeessory museles. Henee his very gait sometimes suggests that he is still walking the furrows. He may be awkward also mentally. Thougl possessing strong mentality and aeeustomed to do elear thinking, he has laeked variety of stimuli, and still laeks suffieient opportunity for self-expression. He probably thinks 
more profoundly than his city cousin, but less alertly and rapidly. His social awkwardness is a eorrelative fact of which he is deeply conseious, and which explains his proverbial bashfulness, espeeially evident in the presence of eity girls aceustomed to dancing-school escorts. This in turn aets as a powerful inhibitive and diseourages any social prominence. He is socially awkward beeause of the lack of social practice and adeçuate selfexpression.

What, then, are some of the elements in the rural environment whiel constitute this social repression to which I referred a moment ago, which inhibits the development of the strong latent leadership in rural personality? In summary I would suggest: laek of the social stimulus whieh comes from city crowds and eity life; laek of sufficient challenge to self-expression, with personal growth under social pressure; lack of variety of soeial opportunitics to challenge variety of personal talent; and lack of adequate training in leadership, aeutely felt by conseientious people who would gladly lead in eommunity welfare if they felt they could. Then there is strong positive inlibition by rural eonservatism in general; positive repression of ambition by neighborly jealousy (a genial combination of terms!) ; the deterrent effect of long mutual aequaintance with its leveling influenee, too apt to level down all latent leadership by saying in effect, "Start something if you dare! Show your head as a leader, if you want to lose it!" Such rural social demoeracy is all too common, and it keeps everybody plodding along in the ruts instead of venturing forth in eommunity leadcrship. Hence the homespun leader is diseounted and emerges from the erowd with great diffidenee.

The farmer is the natural leader in eountry life. Yet to a remarkable degree he falls short of his opportunity in leadership. He constitutes 30 per eent. of the adult male population of the country engaged in gainful oceupations, yet he has remarkably small leadership, for instance, in politics. There are about seventy times as many farmers as lawyers in the land, yet what about their relative influence? Almost 60 per eent. of our present Congress arc lawyers. Barely 3 per ecnt. are farmers. The 120,000 lawyers in America constitute less than onc-half of 1 per cent. of the adult male workers. Their representation in 
Congress is over 120 times as large as it should be, whereas the farmers' representation is but one-tenth of their proportionate share; that is, the lawyer's chance for political leadership, on the basis of our present Congress, is 1,200 times that of the farmer.

This condition, however, is not likely to eontinue. The farmer is beginning to diseover and to wield for himself political leadership. It may or may not seem significant to you that practically every great rural state voted last month for the President who gave rural America the long-postponed rural-eredit system, and that this President was elected over the protest of nearly every great urban state in the land. It is also worth noting that the "Farmers' Non-partisan Political League" which eampaigned North Dakota last fall with the slogan, "A farmers' government for a farming state," swept the state elean last month, losing but one eandidate on the state ticket and eleeting eighty-one out of 113 members of the legislature.

Before offering some specifie surgestions in detail may I venture a few generalizations regarding the social function which we eall leadership? It is a term that is inereasingly used in these days. Its connotation seems simple, but it is seldom elearly defined. Professor Cooley's brief definition of leadership as "personal aseendency" is execllent as far as it goes. John R. Mott's definition, "Expert service," is perhaps more deseriptive than definitive. To me leadership is personal initiative, unusual efficiency, and executive ability by which an outstanding personality projects his ideals and purposes through yroup and mass activity. It involves the development of unusual personal efficiency and soeial service of the highest potential. Leadership is a fascinating thing, not simply beeause it is the exereise of power and appeals to sclfish ambition, but far more because it means superlative self-expression, the projeetion of one's best self into life, one's maximum service of his generation. In the very nature of things leadership involves the development of personality, growing under the pressure of responsibility, and its applieation in expert service of the community.

I do not think leadership is often an endowment. Rather it is an attainment, a conquest throngh struggle. We talk about 
"born leaders." We seldom meet them. Leadership is rarely a flash of genins. It is a growth, a patient development. Like most genius, it is the result of hard work, painstaking preparation, a process of adequate education and discipline, resulting in the progressive outgrowing of one's self into the mental and spiritual stature of efficient leadership. Neither do I conceive of leadership as an abstract entity, or something you can isolate, objectify, and gaze at, quite apart from human usefulness and specific functioning. As I do not aceept the old "formal-discipline" theory of cducation, "mental discipline in general" means little or nothing to me. And just as I cannot belicve in "gencral training of the judgment," for instance, I take little stock in leadership in general as a personal asset or endowment. Leadership is revealed only in specific functioning.

However, I think that there are five elemental factors which are always found in some degree in leadership. They seem to me essential in all kinds of worth-while leadership. They are knowledge, power, skill, character, and vision-knowledge, the result of study and instruction, the mastery and correlation of facts; power, the result of personal development, the storing of vital energy in personality; skill, the result of training, power guided by knowledge and made facile througl practice; character, the moral element essential in all genuine leadership, the resultant of moral living, "an organized set of good habits of reaction" ; and vision, the result of living the climbing life and developing constructive imagination. It is the leader's vision which steadies our confidence in him ; for we trust only the leader who can sec things whole and in their relations.

Rural Life Needs the Best. I make no apology for trying to apply these high ideals of leadership to the social nceds of country life. Oberlin College was named eighty-threc years ago for a great Alsatian community leader and philanthropist, Jean Frédéric Oberlin, who had died seven years before that date after a long career of usefulness. He was an educational prophet anticipating Froebel by forty years in his own specialty. He was perhaps the greatest country pastor in history. He was a community builder, a civilization restorer, whose services won the medal of the Legion of Honor from his king, Louis XVIII. He represented the flower of eighteenth-century French culture, 
with the best edueation the University of Strassburg could afford, and he developed eapacity for leadership in marked degree; but he consecrated this leadership on the obscure altar of country life.

I have little patience with the hoary heresy that the city needs leadership but the country ean get along with inediocrity. Yet this has been the general practice of the past two generations in America. It is still largely true in relation to all the professions. Too often the country is merely the eolt's pasture for the young minister, teacher, doctor, lawyer, journalist, ete. The goal is the eity when apprenticeship is over. Unfortunately this is not ideal for either city or country. For any sort of eity social service the best place to do clinical work is in the city itself, or time is wasted. And the obverse is equally true. The ideal rural leadership is a whole-life service, devoted permanently to country life. I realize that at present financial considerations seriously hamper this ideal. The result is that, with our underpaid rural leadership, our underpaid country teachers, ministers, doctors, cte., we are threatened to-day with a peasant leadership in the country, undertrained and inferior in all respects to their comrades in the city. This is what country life is rapidly coming to unless the urban dwellers realize soon their need of adequately paid and fully trained community leaders. No movement can rise above the level of its leadership. It is trite to say that rural progress is lagging because of inadequately trained community leadership. The broadening of country life and its rising standards put increasing demands upon its leaders which they are often unable to meet. Rural institutions ean no longer serve their communities effectively under the leadership of $\backslash$ men lacking in the very essentials of leadership. Some country commmnities of genuine rural culture are demanding now as high-grade personality and training in their leaders as the eities demand, and they naturally refuse to respond to erude or untrained leadership. Our colleges meanwhile are edneating thousands of country-bred boys and girls and then lavishly sending them to the eities, where all professions are already foolishly overerowded. And in saying this I realize fully that the country communities must be willing to furnish a life-chance and a living wage to these bright 
young people before they deserve to get them to invest their lives in rural service.

I believe, then, that the first step in developing rural leadership is not the training of the individual, but the training of the rural community. Rural villages must be given higher ideals of leadership and of community spirit before they will appreciate and support the leadership they need. In every state of my acquaintance the agricultural college is rising magnificently to its opportunity in this regard, and to such colleges I believe we must look primarily for help. They are probably growing more rapidly than any other institution in America. They are not only struggling to keep pace with the demands made upon them for technically trained rural leaders, but through their varied cxtension service and their short courses in the winter they are also making great gains in spreading the gospcl of the better country life with higher community ideals.

In very many places this leaven is unquestionably working, lifting rural life to higher levels. Every rural home which catches the new vision becomes a ecnter of social influcuce making for better days. Every farm conducted on modern lines of scientific agriculture is a demonstration center of great value. To raise the cconomic level of farm life in the neighborhood is a real gain in itself; but the by-products of such a demonstration are also noteworthy, such as the discovery by the less progressive that there is really a scientific basis underlying farming; that the cost and cffort of education are justified by the results; that the expert really knows, and that trained leadership is worth while; in short, that the modern standards of efficiency apply to rural as well as urban life. All this is giving a new dignity to rural life. Farmers are rightly becoming more class-conscious, and farm boys are finding a new interest and a real pride in progressive farming, as they discover the infinite opportunity for technical skill involved in it, making it not a mere matter of blind drudgery and a gamble with the weather, as they had supposed.

By the same method of demonstration (the only incthod which really convinees country people) community social stanclards can also be raiscd, as communities come to know what has actually been accomplished in other communities that are more progres- 
sive, in securing popular coöperation in eommunity enterprises and building up a real socialization.

Volunteer Community Leadership. It is diffieult to seeure or to support professional leaders for rural organizations, and when the right sorts are found, they are usually only temporary. It is extremely neeessary to develop a volunteer leadership for all local enterprises. This gives latent talents a ehanee to develop through self-expression in social serviee, and it secures eontinuity of leadership and stability of poliey. . . . I do not believe that our problem of rural soeialization will ever be solved finally by outsiders. Resident forces must ultimately aeeomplish it. The farmer himself and his natural leaders must take the burden upon them. The farm-bureau agents now serving over 1,200 eounties in the United States have a eonspieuous opportunity in this relation if they ean only fit themselves to meet it. They are exactly the people who eould make the most of sueh eourses as were offered in the Cormell Sehool for Leadership in Country Life. It is evident that no single ageney or type of ageney will be able to handle this matter suecessfully. All ageneies involved in rural redireetion and in speeifie service in any field of eountry life must share the burden. The rural department of the Young Men's Christian Assoeiation, within rather narrow geographieal limits, is doing a fundamental and valuable work. Genuine centers of edueation for rural life, eentralized schools with modern teaehers and equipment, are rapidly meeting the community need. The new eountry ehureh, the eommunity-serving chureh, when you ean find it, is making itself useful and respeeted. The pity of it is that the rural ehureh is too frequently an arrested development, sadly weakened by divisions, inadequately equipped and manned, and lacking any soeial vision and eommunity program. The right kind of a chureh, led by the right sort of a minister, has the best possible chanee to serve the eommunity and to develop the latent leadership of ambitious, right-minded boys and girls. But to aceomplish this, united Christian forees are essential. Seetarianism, that eurse of rural Christianity, must be erueified in order to save rural religion. When the day eomes that rural Christians are ashamed to be Methodists or Baptists or Diseiples beeanse it prevents their being eommunity Christians, then we shall see more Christian 
rural communities. There is great hope of the spread of the community-church movement. From Atlantic to Pacific you may find such churches, not simply undenominational union churches with no outside connection and missionary outlet, but a local union of churches as one congregation, having diversity in unity, loyally meeting their denominational duties abroad, but being an absolute unit in worship and community scrvice at home. Given this united Christian force instead of a jangle of quarrelsome, competitive scets, and the community can afford a living salary for a whole man, a manly man, for a minister, a man with modern training and with the social vision. And in such a community there is a man's job; it is a real opportunity for community building as well as religious teaching, and they go well together. And not the least of sucl a country minister's opportunities for usefulness is the training of the latent leadership which he discovers in his young pcople. I believe that an intelligent effort should be inade to enlist and train rural-minded young people for a life-investment in the country and for some sort of community leadership, if they have the capacity for it, rather than to encourage them to go to the city, where many of them will be social misfits and partial failures. A fair share of country boys and girls must stay in the country or city and country alike will suffer; and it must not be the survival of the unfit, but the selection of those best fitted for rural success and community service.

There has been such remarkable rural progress in the past generation, and even during the present decade, that we have no reason for pessimism for the future. The rank and file is unquestionably rising; the leadership will surely be forthcoming. Rural social organization has been fortunately simple. I share with Professor Mann, of Corncll, the belief that an era of organization is probably the next stage of the country-life movement. With keen vision he suggests:

The new organizations will largely be farmer made and controlled. It is the stage of organized self-help. It will be marked by an apparently rapid shift from individualism to a soeial eonsciousness and sense of eopartnership. The welding proeess is on. Group spirit is aecumulating. Farmers as individuals will become less independent; farmers as a elass will bro eome more independent. Evidences of personal and group power, large 
grasp, and achievement will be outstanding. In reality the farmer will be seen coming into his own. Leaders of this awakened rural manhood must be clear-thinking, direct, and of "superior intelligence; and their foundations must be laid in a sure understanding of economic and social laws and of folk psyelıology superimposed on reliable farm knowledge.

Expert service will win leadership; our task is to develop rural experts.

\section{SEAMAN A. KNAPP ${ }^{1}$}

Essex County, N. Y., gave to America one of the greatest men that has lived in this or in any age. This man was Seaman A. Knapp, born in Deember 16, 1833. It was no part of his great work to lead armies, guide political parties, or write essays on the theory of government and the rights' of man. His achicvements were greater. Hc souglit frcedom and independence in the soil, and he found both, and gave them to the world.

A sketch of the first seventy years of his life is merely the story of his preparation for a great carecr. Dr. Wallace Buttrick summed it up by saying, "Seventy ycars of preparation for seven years of work" - a work that is referred to by Dr. Walter H. Page, the Ambassador to England, as "the greatest single pieee of construetive edueational work in this or any age."

As a boy he took advantage of sueh sehools as were available in that early day in the eountry districts of New York. Later he entered and graduated from Union College, Seheneetady, N. Y. He taught sehool for several ycars after graduating. But at the age of thirty-two he moved to Vinton, Iowa, and settled on a farm. There he regained his health and vigor. During the sojourn in Iowa Dr. Knapp was called to manage several lines of work, all of which were good training for the greater work yet to be done. He established a farm paper. There were few sueh papers in the eountry at that time. $\mathrm{Ie}$, with others, eondueted an agricultural campaign. The first eourse in Agrieulture in the Iowa College was organized and the graduation of the first elass took place during his incumbency as professor and president.

1 Adapted from L. S. Bureau of Education 13ul. No. 43, Washington, 1913, pp. 20-29. 
Another erisis in Dr. Knapp's life eame about this time. His health gave way under a severe attaek of rheumatism. Physicians said he must give up eollege work. 'Turning his faee to the sunny South he organized a great development company, bought a million aeres of land in southwest Louisiana and sent invitations all over the Northwest, "Come South, young men, and grow up with the eountry." Several thousand eame. For many years he had believed that the South was destined for a wonderful future. He said, "Here is a people of pure AngloSaxon stoek, energetie but eonservative, without mueh admixture of foreign blood. These people should be the eonservators of the best Ameriean traditions. Here is a produetive soil, delightful elimate, and long growing seasons."

He at onee began to eonduet demonstrations in riee growirg and diversified farming for benefit of native farmers and immigrants. In 1898, however, he was authorized by the Seeretary of Agrieulture to visit China, Japan, and the Philippines, to make rice investigations. In 1901 he made a seeond trip to the Orient; he went to Europe in 1901 to study agrieultural eonditions, and later to Porto Rieo to report on agrieultural resourees and possibilities.

His training was eomplete after seventy years of study to begin his great work. In 1903 the Mexiean boll weevil began to make sueh destruetion in the Texas eotton fields that Dr. Knapp was sent into Texas to fight its deadly ravages. He began by organizing the farmers and instituting the Farmers' Coöperative Work. Dr. Knapp visited one small farm near Terrell, Tex., about twice a month and direeted operations there. Neighboring farmers met him in field meetings. At the elose of the year he had proved that eotton eould be grown in the faee of the boll weevil, and was urged to extend his teaehings and his methods throughout the whole eountry devastated by the pest. The next year, with funds furnished by Congress and by local business men, he appointed a few agents and began to organize different eounties in Texas. The work soon attraeted the attention of the eountry. Congress enlarged its appropriation, loeal aid was inereased, and the work was extended to Louisiana and Mississippi. About this time the General Education Board of New York asked to be allowed to appropriate 
money for similar work in other cotton States. In a few short years this great work had covered the entire South, had a forec of 1,000 agents, an enrollment of 100,000 farmers, 75,000 boys in the corn clubs, and 25,000 girls in the canning clubs. Every State in the South began to show an increase in the average corn production per acre, as well as other erops, and southern corn club boys attracted the attention of the world by producing more than 200 bushels of eorn to the acre at low cost. Girls, too, demonstrated practical, scientific work in garden and home. During the year of his death, Russia, Brazil, England, South Africa, and Argentina sent representatives to this country to study the demonstration work. Sir Horace Plunkett, the great Irish reformer, eame for the same purpose, and at the request of the King of Siam, Dr. Knapp sent one of his agents to take charge of agricultural matters in that country.

Dr. Knapp died in Washington, D. C., April 1, 1911. But he lived long enough after this important work was begun to see something of the wonderful results. Although his work was confined chiefly to the Southern States of America, every State and nearly every nation has felt his influence.

\section{HENRY WALLACE ${ }^{1}$}

\section{HERBERT QUICK}

Iows has given to the nation three great figures in agriculture, who were also a trio of bosom friends. The names of these three are Henry Wallace, James Wilson and Seaman A. Knapp.

James Wilson made the Department of Agrieulture, and served as its secretary for so long that he was dubbed "The Irremovable."

Seaman A. Knapp went to Washington with his friend Wilson, and became, in my opinion, the greatest educator this country has produced. He took advantage of a law appropriating funds for fighting the cotton-boll weevil, and began teaching the

1 Adapted from the Country Gentlcman, Vol. 81, 1. 737 , April 1, 1916. 
farmers of the South the importance of diversified farming if they were to eseape ruin. He fought the weevil of the eotton boll by starting the South on her ehange from cotton alone to cotton, corn and live-stoek. And ineidentally out of his work grew the gigantic, nation-wide farm-demonstration movement through county agents.

When Wilson and Knapp went from Iowa to Washington, Wallaec stayed in Des Moines and devoted himself to his lifelong work as editor of Wallace's Farmer.

Two of the trio have passed over the river. Dr. Knapp died in the harness two or three years ago, full of ycars, honors and good deeds. Unele Henry Wallace has just joined him in the ranks of the grcat majority. He leaves vacant in American life a position so unique that, though he was not at the time of his death, nor was ever, so far as I am awarc, the holder of a publie offiee, his loss will be felt more kcenly than would that of a thousand men who have becn elevated to places of eminence by the votes of the people or by appointment.

Henry Wallaee will be remembered by the farmers and many others when the great mass of governors, scnators, congressmen, justiees of the Supreme Court, and eabinet offieers of the day are forgotten. For he worked with the people, not over thell.

He was a Pennsylvanian who as a young man identified himself with the farming interests of the Middle West. The writer was born in Iowa, and is no longer young, but he does not remember the time when Henry Wallaee was not a strong, quiet, uplifting forec in that state. His strength was exerted like that of a growing tree, which heaves the ground under its roots by the power whieh it drinks in through its branches out-spread in the sky. Nothing can resist sueh a foree, because it is patient, unceasing, tireless, and always bears upward against the gross things with whieh it eontends. Like the tree, too, Unele Henry was strong beeause his roots were in the soil.

He was a good writer, but he never tried to shine as a fine writer. He chose the field of Iowa journalism at a time when its prospects for usefulness were far brighter than its ehanees of business suceess-mainly, I suspect, beeause he was a preacher.

He had been a minister of the Gospel, and wanted to preach to the farmers of the eountry along different lines from those 
usually followed in the pulpit. He believed the truth should be emphasized that good farming is a good way of serving God, and that passing down to future generations a well-kept farm, unimpaired in fertility and adapted to the nourishment of a happy, wholesome life, is in itself an act of worship and the best possible sort of partnership in the purposes of the Almighty, who the Scriptures assure us gave the earth to the children of men.

He believed, and for much more than a generation he taught every week to many thousands of his followers, that the earth God gave to the children of men was given not to this gencration only, to be mined, robbed, exploited and ruined by greed, but to all future generations of the children of men as well; and that to rob mankind a thousand years hence is just as bad as to rob our neighbors to-day.

Who is thy neighbor? Those on earth to-day only? No, said Uncle Henry, thy neighbor is the human being who comes after thee just as truly as is the one who walks at thy side.

It was this philosophy which made him the president of the National Conservation Congress, and constituted him a tower of strength to the Conservation movement. It needs him to-day more than ever before, and will suffer by his loss. He wanted the coal, the lands, the mincrals, the gas, the oils, the forests and the water power of the nation conserved for the use of the children of men to whom they were given, and not for some of the children of men. But mainly he spoke for the soil.

In a little book, "Letters to the Farm Folk," published not long before his death, he said in a passage on the social life of the country people:

But, you say, this would make us all stockmen. Well, that's what we ought to be, and will have to be sooner or later, if we are to lave any satisfactory social life in the country. Growing grain for sale off the land starved the soil. I am speaking now for the voiceless land. It will not ferd you unless it is fed; we will then become poorer and more diseouraged; and how can we have any satisfactory social life among poorly fed and discouraged people?

Do you think Uncle Henry in this passage was spcaking of a danger of to-morrow only? Not so. IIc saw when he wrote this passage all the centuries of the future. He was in the 
Corn Belt, as I was, at a time when it was the common utterance of many farmers that their soil did not need manure, and that it was cheaper to move the sheds than to haul the manure.

IIe lived to see the question of fertility a growing one. He lived to see the need of eommercial fertilizers eross the Mississippi, in spots-and lie spoke, as lie did as president of the National Conservation Congress, as lie always did, "for the voieeless soil."

There is a revelation as to the bent of our old friend's mind in that expression, "the voiceless soil." To him the soil was not dead at all, only dumb. It was the stuff of liuman life. Sow it with dragon's teeth, and it will produee a erop of armed men who will fall upon and destroy one another.

Ignoranee, injustiee, oppression-these are the dragon's teeth with which our American soil must not be sown or they will spring up armed men like those who are destroying each other in the Old World to-day. In the preface of this little book, which is his last word to the farm folks of Ameriea, Unele Henry said:

The conviction has been growing upon me of late years that the biggest thing on the farm is not the land nor the live-stock, but the farm folk, the people who live on the farm and out in the open country. These letters thrrefore will not be agricultural, but human. Do you know that the biggest thing in life, whether in city or country, is just to be a fine liuman being interested in all things that interest or should interest human beings?

\section{SLOGAN CENTERED ABOUT HAPPINESS}

His slogan for years was Good Farming, Clear Thinking, Clean Living, but it eentered about the welfare and lappiness of people. Good farming, that the life of the family miglit be a well-nourished life economieally, and that the soil be eonserved; elear thinking, that it might be intelleetual, and not like that of sheep and goats that nourish a blind life upon the soil; elean living, beeause the life that is not based npon righteousness rots and makes both good farming and clear thinking impossible.

On this all-embraeing text did Unele Henry Wallaee preach quietly, persistently, sanely and effeetively for decades to one of the greatest audiences in Ameriea. Wlat greater pnlpit 
could he have chosen? Who ean estimate the effect this preaching has had in sweetening and uplifting our national life, and shall have for generations to eome? For thought does not die with the thinker. What shall a man do to have eternal life? Do as Unele Henry Wallace dici.

Even in this world, such a man's thoughts live in other minds to all ages. "Our eclioes roll from soul to soul, and grow forever and forever." They may be evil eehoes or good ones. Those of Uncle Henry will be good.

He knew the soil. He not only knew that the soil, instead of being dead, is litcrally teeming with life-he also understood its moods.

Did you ever read one of his artieles on some phase of soil management? Suppose, for instance, it was on the subject of clods; he made it interesting and always uscful. He knew why the soil gets eloddy, and just how harmful elods are to crops. He knew the benefieenec of tilth; the secrets of the warm, air-filled seed bed were open to lis mind. In his mind the soil had plaee as the universal friend of humanity, and through lim the voiccless soil found utterance for its claims.

Uncle Henry was a very, very wise man; for he added to those of his own long life the experiences of others. He knew his Corn Belt well, and all the better because he knew other regions and other lands. In order that he might better know Iowa, he studied England, Germany and Denmark.

He was one of those leaders of our agrieultural thought who almost tremble at the increase in tenant farming, eaused by the floeking of suceessful farmers and farm families to town. The "retired farmer," rusting out a short life in town, was to him a national problem; and the transient, year-to-ycar tenant was an equally grave one. He onee wrote:

At present the law allows the tenant to rob the land or, in other words, to starve it. The law would put the tenant in jail if he starved his horses or eattle, but we allow him to starve the land.

The law would put the landlord in jail if he eonfiseated the horses of the tenant, but we allow him to eonfiseate the fertility which the first-class tenant stores in the soil, and seem to think it is all right. The law would put the tenant in jail if he sold the personal property of the landlord, but we are likely to approve the robbery of the fertility winich the retired farmer had stored in the soil when the farm was his hone. 
The English Government has solved the problem in Scotland and England by compelling the tenant to put back into the land the manurial equivalent of the grains he sells off it; by preventing him from selling straw and roots, which must be fed to live-stock on the farm; by compelling the landlord to pay the tenant for the manurial value of the food-stuffs he has purchased and fed to the live-stock, or else let him stay until he has uscd up this fertility; and also by forbidding the landlord to raise the rent because of improvements the tenaut has madc.

During his later years he seldom spoke without mentioning this matter; but did Uncle Henry advocate the passage of such laws in this country? No; but he did urge American farmers-tenants and landlords - to think about these things, talk them over, and study the problem. No law, he always urged, is worth anything until it has public opinion behind it.

He hoped for the amendment of the landlord's lien laws so as not to be so severe on the tenants; he hoped for the passage of laws giving the tenant a claim, if his lease was not renewed, for the fertility that he had placed in the soil.

Mostly he hoped for these as beginnings. They would tend to stop this everlasting moving about, and make rural society more stable, so as to make better schools, better churches, better neighborhoods.

Uncle Henry is gone, but he leaves behind him something for us all to consider-his thoughts, his doctrines, his methods, and, most of all, the fine and noble lesson of his life.

There were no years of "retirement" for him. He was splendidly active to the very end.

He was a successful man. I am glad to write that. He died rather well off, I think; but that is of small consequence-lie was successful anyhow, for he lived a life of activity, doing work which most writers would lave called drudgery, but which to lim was interesting because he saw all there was in it.

Like Joe Wing, whose life his very much resembled, he made a success of devoting himself to writing and speaking for the farming interests, for farm living.

I wish the lives of Uncle Henry Wallace and Joseph E. Wing could be read and studied by every farm boy in the United States.

They were both soldiers of the common good, ennoblers of the common life-and both of them proved that big men may 




\section{INDEX}

Abandoned Farms, 19, 23, 300.

Adams Act, 386.

Agriculture: achievements necessary to develop in America, 108-110; after the war, 24; decline of in New England, 16, 20; need of a national poliey toward, $95-$ 114 ; in rural school curriculum, 352-356.

Agriculture, correctional: Chap. XI, 283-303; bibliography, 311-312; for cpilcptics, 290-295; for the insane, 29j-296; juvenile delinquency, 297-303; prison farms, 283-290.

Aristoeracy, agrarian, 145-146.

Art, rural, 248.

Arvold, Alfred C.

Drama for Rural Communitics, 236-240.

Automobile, effect on farm life, 273274.

Bailey, L. H.

A Point of View on the Labor Problen, 152-154.

Boys' and Giris' Contest Clubs, 391394.

Housing Conditions on Farms in New York State, 331-333.

Rural Ieadership, 584.

The Survey Idea in Country Life Work, 478-481.

Baker, George P.

What the Pageant Can Do for the Town, 243-248.

Baker, Ray Staunard.

The Spirit of the Pionecr, 34-35.

The Great Sonthwest, 36-38.

Following the Color Line, 69-7:.

Basliore, Harvey.

Overcrowding and Defective Housing, 329-331.
Bernard, I. I.

A Sociologist's Health Program for a Rural Community, 185193.

Rehabilitating the Rural Sehool, 340-345.

Betts, Geo. H. and Hall, Otis E.

The Rural High School, 348-350.

Bidwell, Percy IVells.

Intemperance in Colonial Days, 13-16.

Boardman, John R.

The Sourees of Leadership, 587589.

Bolton, Ethel Stanwood.

Country Life in New England, 1-13.

Boult, Ella M.

The Miracle Play at Pomfret, Conn., 241-243.

Boys and Girls Clubs, 382-383, 391-394; 535; Bibliograplyy, 408.

Brand, Charles J.

Work of Oniee of Markets and Rural Organization, 515-516.

Branson, E. C.

Our Carolina Ilighlanders, 58-65.

Brener, Harry H.

Strawberry Pickers of Maryland, 157.

Bruee, Philip A.

Social Conditions of the Old and New South, 46-58.

Bryee, James.

Claracteristics of the Farmer, 162-164.

The Passing of the Frontier, 3536.

The Secret of Influence, 584-585. Buruliam, Eruest.

The Stutus of the Rural School, $337-340$. 
Butterfield, Kenyon L.

Agriculture in New England, 2025.

A Point of View in Comparisons of City and Country Conditions, 111-114.

Farmers' Social Organizations, 536-540.

Need of Ideals in Rural Life, 181183.

Report of Committee on Country Church Function, Policy and Program, 444-452.

Rural Organization, 500-512.

The Call of the Country Parish, 442-443.

\section{Cameron, Agnes Dean.}

Canada's Royal Northwest Mounted Police, 310-311.

Cance, Alexander E.

Farmer's Coöperative Exchanges, 120-131.

Carolina Highlanders. 58-65.

Carver, T. N.

An Appreciation of Rural People, 165-168.

Life in the Corn Belt, 38-44.

Rural Economy as a Factor in the Success of the Church, 426430.

The Moral Basis of Coöperation, 119-120.

What Awaits Rural New England, 16-19.

Chautauqua, bibliography, 407-408.

Child labor, rural, 155-159.

Children: lealthicr in city than country, 193-197; influence of farm life upon, 164-165, 166167,300 ; treatment of by farmers, 301.

Church, country: Chap. XV, 411454; bibliography, 452-454; and land tenure, 421-426; decadent, 268 ; report of committee on function, policy and program for, 444-452; rural economy a factor in success of, $426-430$; sectarianism in, 443-444; situation in Ohio, 431-435; ten years work in, 411-421; type of workers needed for, 442-443;

Wisconsin parish, 435-437.

City drift, mental causes behind, 172-175.

Claghorn, Kate Holladay.

Juvenile Delinquency in Rural

New York, 297-303.

Clopper, Dr. E. N.

Colorado Beet Workers, 156.

Coates, T. J.

An Epigram on the Rural School, 337.

Communication and transportation: Chap. X, 255-2sl ; bibliography, 281 ; agricultural press, automobile, 273-274; circulating library, 274, mail delivery, 274; other aids, 266-274; roads, 255266 ; telephone, 280.

Community center: consolidated school, 371-374; church as, 414420 ; church parish, 435 -437; undesirable, 301-303.

Community fair, 402-406.

Community, rural: defined, 576 ; organization of, $56 \bar{\tau}-5 \overline{7} 6$.

Conveniences for farm home, 101 . Cook, John H.

The Consolidated School As a Community Center, 371-374.

Cooley, Charles R.

Leadership or Personal Ascendency, 581-583.

Cooley, Harris R.

The Outdoor Treatment of Crime, 283-288.

Coöperation: 129-137; bibliography, 160 ; farmers' coöperative exchanges, 120-131; fostered by farmers' clubs, 544-545, 552; in European countries, 122; moral basis of, 119-120; social effects of in Europe, 131-137.

Corn Belt, life in, 38-44.

Correctional agriculture: Chap. XI, 283-303; bibliography, 311312.

Coulter, John Lee.

Immigration as a Source of Farm Laborers, 88-93.

Country life: in New England, Chap. I, 1-26; in the south, Chap. III, 
46-74; in the west, Chap. II, 27-45.

Country school, see School.

Country store, as source of social ideals, 302 .

County agent, 380 .

Crime, outdoor treatment of, 283295 ; and feeble-mindedness, 211.

Curriculum, for moonlight schools, 362 ; rural school, 341-345.

Curtis, Henry S.

Need of Play in Rural Life, 226228.

Danielson, Florence $H$. and Davenport, Chas. B.

The Hill Folk, 206-213.

Davenport, Eugene.

Wanted: A National Policy in Agriculture, 9.5-114.

Delinquency, juvenile, 297-303.

Death rate, higher in urban districts, 151.

Dewey, Evelyn.

Agriculture and the Curriculum, $352-356$.

Domestic manufactures, in colonial days, 8-9.

Douglass, Harlan Paul.

The Town's Moral Plan, 467-471.

Drama, rural, 236-248.

Dudgeen, M. S.

The Rural Book Hunger, 394-401.

Economic interests: Chap. VI, 119137; bibliograply, 160-161; adult labor, 147-155; child labor, 155-159 ; coöperation, 119137; ownership and tenancy, $137-147$.

Educational agencies: Chapter XIV, 377-410; bibliograply, 407410 ; 'boys' and girls' clubs, 382384, 391-394; conmunity fair, 402-406; farm demonstration,

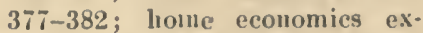
tension work, 389-39l; travel. ing libraries, 394-401; work under Snith-Hugles Act, 407.

Ellint, Clas. II:

The Influence of liarm Life on Childhood, 164-16.5.
Emerick, E. J.

Féble-mindedness Defined, 203204.

Epileptics, farm care of, 290-293.

Fairchild, H. P.

Why Immigrants go to Cities, 85-88.

Fairs, community, 402-406, bibliography, 409.

Family, farm: in corn belt, 39-40; size of, 332 .

Farm bureau, 354, 518-536; bibliography, 409.

Farmer: characteristics of, 162$164,165-168$; mind of, 175181, 269.

Farm income, 102-103, 108.

Farm life, educational value of, $164-167,170-172$.

Farm village, 271-273.

Farmers' clubs: advantages of, 541-545; low to organize, 545$5.5: 2$.

Farmers' coöperative exclıanges, 120-131.

Farmers' organizations : clubs, 541552; Grange, 552-555; Non. Partisan League, 557-567; social, 536-5 40 .

Federal Board for Vocational Education, 407.

Feeble-mindedness: and crime, 211; defined, 203-204; extent of in New Hampshire, 213-214; in Pennsylvania, 214-217, in rural England, 217; fundamenta! facts regarding. 204-205; investigation of two family trees. 206-213; prevention of, 219) 223 ; segregation, 221 .

Fernald, Walter E.

What is Practicable in the Way of Prevention of Mental Defect, 21!)-223.

Ferris, Elmer E.

A Laud of Iaw and Order, 306307.

Fichl, Jessie.

County Work of Y. W. C. A., 440-441. 
Fiske, G. Walter.

The Development of Rural Leadership, 589-601.

The Social Value of the Telephone, 280-281.

Foght, Harold W.

The Claange from Amateur to Professional Teaching, 347-348.

Forbes, Fimer S.

Rural Housing, 327-329.

Free delivery, rural mail, 273-274.

Frontier: passing of, $35-36$; significance of in American history, 29-34.

Galpin, C. J.

A Method of Making a Social Survey of a Rural Community, 484-490.

Social Privileges of a Village or Small City, 464-467.

The Social Anatomy of an Agricultural Community, 490-497.

Gill, Charles O.

Social Effects of Coöperation in Europe, 131-137.

The Churcl Situation in Ohio, 431-435.

Gillette, John M.

Mitigating Rural Isolation, 266274.

Rural Child Labor, 155-156.

Tenant Farming. 137-142.

The Scope of Rural Sociology, 615-620.

Training for Rural Leadership, 585-587.

Grange, see Patrons of Husbandry.

Great men, from rural environment, $168-172$.

Groves, Ernest R.

Suggestion and City-drift, 172175.

The Mind of the Farmer, 175181.

Hatch Act, 386.

Hayes, E. C.

Agrarian Aristocracy and Population Pressure. 145-147.

Leadership, 583.
Health, physical: Chap. VIII, 185202 ; bibliograplyy, 223-224; for rural community, 185-193; for rural schools, 195-196; inspection, 188; lack of information and aids, 186-187; legislation, 188-189; on prison farms, 289 290; teaching of, 191-192 ; work in schools of U. S., 197.

Health, mental, 203-225; bibliography, 225.

Hedrick, W. O.

Some Advantages of Tenancy, 142144.

Henderson, Charles R.

Rural Police, 303-306.

Hill, Laurence $\mathrm{S}$.

Physical Education in Rural Schools, 229-235.

Hine, Lewis $\mathrm{H}$.

Children or Cotton, 158-159.

Home demonstration, 535.

Home. economies, under SmitlLever Act, 389-391.

Home, rural: Cliap. XII, 313-326; bibliography, 334-335; changing, 316-317, 324-326; convenences in, 333.

Homer, IVm. J.

The Prison Farm, 289

Hospital, rural, 190-191.

Housing, rural: Chap XII, 327-333; bibliography, 335-336; in New York State, 331-333; overcrowded and defective, 329-331.

Hunter, W. H.

Why League (Non-Partisan) is Opposed, 564-567.

Ideals, in rural life, 181-182.

Illiteracy: among mountain whites, 61; war against in Kentucky, 360-363.

Immigrants, in agriculture: Chap. IV, 75-94; bibliography, 93-94; as source of farm laborers, 8893; migration to cities, 86-88.

Insanity: farming as cure for, 295297 ; urban and rural, 218-219.

Intemperance: in colonial days, 1316 ; effect of coöperation upon, 133. 
Irrigation: influence on community spirit, 36 ; on eharacter of farnier, 37 .

Isolation: eause of delinqueney, 198; conditions which acoount for, 267; degree of, 267-269; effects of, 279-270; influence on mind of farmer, $177-179$ : mitigating, 266-274; plyysical effects of, 192: solutions and panaceas, 271-274.

Jenkins, WV. H.

The Farm Playground, 236.

Kellogg, Paul U.

Five Prineiples of Surveys, 481484.

Key, Dr. Wilhelmine E.

Fecble-minded Citizens in Penńsylvania, 214-217.

Knapp, Bradford.

Education through Farm Demonstration, 377-382.

Kuapp, Seaman A, life work, 377385, 601-603; Ten Commandments of Agriculture, 380-381.

Kremer, Rev. A. Ph.

The Genoa Parish, Walworth County, 435-437.

Labor, adult: 147-155; bibliography, 161; decreasing amount of 151 ; effect of maclinery upon, $14.9-1.50$; in corn belt, 41 ; shortage of on farm, 152-153.

Jabor, ehild: 155-15! ; bibliog. phy, 161; in Colorado beet fields, 156; in the cotton fields, 158-159; in Maryland, 157.

Land Temure, 106-108, 109; and rural clmrch, 421-426.

Land valuation, $145-147$.

Laue, Wintlırop D.

Healing Lap of Mother Earth, 290-295.

lcadership: Clap. XI.T, 591-610: bibliograplyy, (009-610; as personal ascerdaney, 5\$1-583: characteristies of, 583 : development of, 589-601; elements of, 585 ; rural, 584; sonrces of, 587-589; training for, 585-587.
Libraries: rural, 394-401; bibliog. raphy, 410; cireulating, 274.

Literature, agrieultural, 278-279.

Little eountry theater, 237-240.

MeNutt, Matthew B.

Ten Years in a Country Churcl, 411-421.

Maehinery, influence of, 147-150.

Mann, A. R.

The Sociology of Rural Life, 611615.

Manning, Warren H.

The History of Village Improvement in the U. S., 45.5-464.

Marqnis, J. Clyde.

Social Signifieance of the Agricultural Press, 275-279.

Mead, Elwood.

Soldier Scttlements in English. speaking Countries, 114-116.

Mental and moral aspects of farm life: Chap. VII, 162-184; bib. liography, 183-184; cliaracteristics of farmer, 162-164; city. drift, 172-175; farm life and childhood, 164-165: mind of the farmer, 175-181; qualities of rural people, 165-16s: ruril environment and great men, 168-171.

Merritt, Eugene.

Agrieultural Flement in Popula. tion, 150-152.

Monahau, A. C.

The County as a Unit of Administration, $3+5-347$.

Moonlight selools of Kentucky, 356-363.

Moran, J. Sterling.

The Community Fair, 402-406.

Morgan, E. L.

How to Organize a Rinral Community, $567-576$.

Norrill Act, 386.

Murral, WV. O.

Health on Prison Farms, 2\$9-200.

National Fducation Association Commission, Series Xu. 1: $a$ National l'rouram for Educa. tion, 363-371. 
Negro, rural in south, 65-74; bibliography, $73-74$.

Nelson Aet, 386 .

New England, country life in: Chap. I, 1-26; bibliography. 25-26; a century ago, 1-13; agriculture in, 20-25; future of, 16-1!) ; intemperance in colonial days, 1316.

Non-Partisan League, 557-567.

Nurse, district, 159-190.

Olsen, John.

Immigration in Agriculture, 75S6.

Organization of rural interests: Chap. XVIII, 500-576; bibliograply, 575-580; community, 567-576: international, 512514 ; national, 515-536: political, 557-568: rural, 500-512; voluntary, 536-557.

Ownership and teuancy, 137-147; bibliography, 160-161.

Pageant, rural, 243-248.

Patrons of Husbandry: in New England, 23; purposes of, 552-557.

Pliysical Education, in rural schools, 229-235.

Pioneer: character of, 29-34; spirit of, 34-35.

Play, need of in rural life, 226228.

Plunkett, Sir Horace.

Women in Rural Life, 323-324.

Police, rural: Chap. XI, 303-311; bibliography, 312: Canadian Royal Northwest Mounted, 306307, 310-311: Pennsylvania State, 308-310.

Population: agricultural element in, 150-152; decreasing in rural districts, 151.

Press, agricultural, 275-279.

Problems of country life: Chap. V, 95-117; bibliography 117-118; farmer's relation to country, 116-117; need of national policy, 95-114; needs of farmer, 99-102; soldier settlement, 114116.
Quaintance, H. WV.

Influence of Machinery on the Feonomic and Social Conditions of the Agricultural People, 147150.

Quick, Herbert.

Ilenry Wallace, 604-609.

Women on the Farms, 313-319.

Rankin, IV. S.

Rural Sanitation: Definition, Field, Principles, Methods and Costs, 197-202.

Recreation, rural: Chap. IX, 226248; bibliography, 253-254; drama, 236-240; farm playground, 236; miracle play, 241$2 \pm 3$; need of, 226-228: pageant, 243-24S: physical education in rural schools, 229-235; that people like, 235-236.

Retired farmer, 3S, 42-43.

Rich farmers, classes of, 103-104.

Roads, 255-266, 273; bibliography, 281-282.

Roberts A. E. and Israel, Henry.

Fural Work of the Y. M. C. A., 43 i -440 .

Roosevelt, Theodore.

The Farmer in Relation to the Welfare of the Whole Country, 116-117.

Pennsylrania State Police, 308310.

Ross, Edward Alsworth.

The Middle Viest, 27-34.

Rowe, C. L.

Ten Years' Progress in County I. M. C. A., 441-442.

Rural Sociology: Chap. XX, 611624; bibliography, 623-624: character of. (11)-615; definitions, 622-(623: scope of, 615620 ; teaching of, 620-622.

Sanderson, Dwight.

Definitions of Rural Sociology, 623.

The Teaching of Rural Sociology, 620-622. 
Sanitation, rural: definition and field of, 197-198; in farm homes, 320 ; methods and costs, 198-202.

School, rural: Chap. XIII, 337-376; bibliography, 374-376; administration of, $345-347$; consolidated, 371-374; curriculum for, 341-345; high school, 348-350; in contrast with town, 269 ; Kentucky moonlight, 356-363; manse, 35l-352; national emergency in, 363-371; professional teacling for, 347-348; southern mountain, 63 ; subsidization of, 108.

School gardening, 355-356.

Sex problem of country life, 180181.

Shelby, Mary Doane.

An Open Letter to Secretary Houston, 319-323.

Simons, A. M.

Who Is the Farmer? 110-111.

Simons, I. IR.

Organization of a County for Extension Work - Farm Bureau Plan, 518-536.

Smitl-Hugles Act, 407.

Smith-Lever Act, 386-389; home cconomics work under, 389-391.

Social Center, see Community Center.

Soldier settlement, 114-116.

South, the old and the new: Chap. III, 46-73; bilsliograplyy, 7273; Carolina Highlanders, 5865: Negro in, 6i5-72; Social conditions $46-58$.

Southwest, 36-37; coöperation in, $36-37$; effect of irrigation upon, 36.

Spillman, $11 \mathrm{~m} . \mathrm{T}$.

The linral Environment and Great Men, l6si-172.

Stevens, Edwin A.

The Finture of Good lioads in State aud Nation, 255-266.

Stewirt, Cora Wilson.

The Mooulight schools of Ki('11tucky, 356-363.

Suggestion, and city drift, 172-175.
Survey: Chap. XVTI, 478-499; bibliography, 497-499; in country life Nork, $47 \mathrm{~S}-481$; method of making, 484-490; principles of, 4S1-4S4; survey of a rural community, 490-497.

Taylor, IV. E.

Farming as a Cure for the Insane, 295-296.

Telephone, social value of, 280-281. 'Tenancy: advantages of, 142-144; increase of, 107, 137; in Texas, 159 ; opposing views as to effects of 138-140; social effect of, 140-142.

Truancy, 301

Theater, see Drama.

Thompson, C. IT.

Definition of a Rural Community, 576.

Thompson, John,

The Leagle's (Non-Partisan)

Work in the Northwest, 55i564.

Thrift, promoted by coijperation, 133.

Town, see Village.

Transportation, see Comınunication.

Tredgold. A. W.

Amentia in Rural England, 217.

Turner, Frederick Jackson.

The Significance of the Frontier in American History, 29-34.

Tyuan, Thomas J.

Ontdoor Work for Prisoners, 288289.

Village: Chap. XIV, 455-477; bibliograpliy, 476-477; improveilent, $455-464,471-475$; inoral plau. 467-471; social privileges of, $464-467$.

Vinecnt, Geo, E.

The Sprend of the School Manse Idea, 3.1-352.

Wallace, Henry.

Land Temire and the Rural Church, 421-426.

Wallace, IIenry, life work, 60ł-609. 
Washington, Booker T.

The Rural Negro and the South, 65-69.

Waugh, Frank A.

Civic Improvement in Village and Country, 471-475.

Rural Art, 248-252.

West: Chap. II, 27-45; bibliography, 44-45; corn belt, 38-44; domestic service in, 42 ; family life, 39-40; fiber of people, $27-$ 28 ; labor problem, 41 ; political unrest in, 43, 557-567; prosperity of agriculture, 44 ; retired farmer; 42.43 ; social diversions in, 40 ; spirit of, $35-37$.
White, Georgia L.

The Problem of the Changing Rural Home, 324-326.

Wilson, A. D.

Farmers' Clubs, 541-552.

Wilson, Warren $\mathrm{H}$.

The Number of Churches in Six Counties in Ohio 443-444.

What the People Like, 235. Wood, Thos. D.

City is Healthier for Children than Country, 193-197.

Women, on the farm, 313-323.

Y. M. C. A., $437-440,441-442$.

Y. W. C. A., 440-44l. 




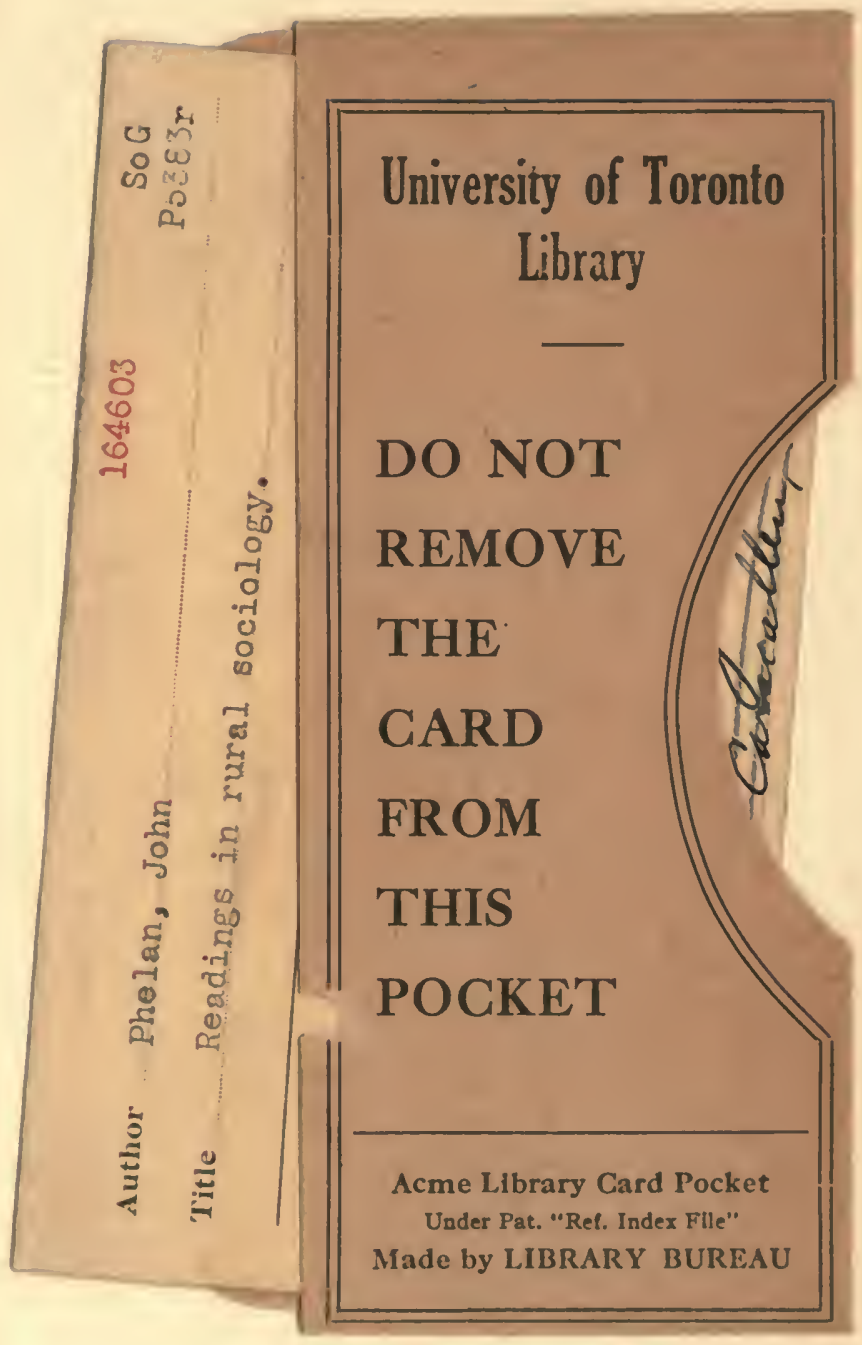


